\title{
ŚWIADCZENIE UBEZPIECZYCIELA W UMOWIE UBEZPIECZENIA MIENIA
}

Bartosz Kucharski

MONOGRAFIE

G. Wolters Kluwer 



\section{ŚWIADCZENIE UBEZPIECZYCIELA W UMOWIE UBEZPIECZENIA MIENIA}

Bartosz Kucharski

MONOGRAFIE 
Stan prawny na 1 stycznia $2019 r$.

\title{
Recenzent
}

Dr hab. Marcin Orlicki, prof. UAM

Wydawca

Małgorzata Stańczak

Redaktor prowadzący

Kinga Zając

Opracowanie redakcyjne

Violet Design Wioletta Kowalska

Łamanie

Wolters Kluwer Polska

Redaktor inicjujący WUŁ

Monika Borowczyk

\begin{abstract}
Ta książka jest wspólnym dziełem twórcy i wydawcy. Prosimy, byś przestrzegał przysługujących im praw. Książkę możesz udostępnić osobom bliskim lub osobiście znanym, ale nie publikuj jej w internecie. Jeśli cytujesz fragmenty, nie zmieniaj ich treści i koniecznie zaznacz, czyje to dzieło. A jeśli musisz skopiować część, rób to jedynie na użytek osobisty.

(C) Copyright by Bartosz Kucharski

(C) Copyright for this edition by Wydawnictwo Uniwersytetu Łódzkiego, 2019

(c) Copyright for this edition by Wolters Kluwer Polska Sp. z o.o., 2019

ISBN 978-83-8160-342-3 (WKP)

ISBN 978-83-8142-327-4 (WUŁ)

ISSN $1897-4392$

ISBN PDF- $a$ : 978-83-8160-518-2

https://doi.org/10.18778/8142-327-4

ISBN PDF-a: 978-83-8142-328-1

Dział Praw Autorskich

01-208 Warszawa, ul. Przyokopowa 33

tel. 225358219

e-mail: ksiazki@wolterskluwer.pl

www.wolterskluwer.pl

księgarnia internetowa www.profinfo.pl 


\section{SPIS TREŚCI}

Wykaz ważniejszych skrótów

Wprowadzenie

\section{Rozdział 1}

Charakter prawny odpowiedzialności ubezpieczeniowej .

1.1. Odpowiedzialność ubezpieczeniowa a odpowiedzialność prawna

1.2. Odpowiedzialność ubezpieczeniowa a odpowiedzialność odszkodowawcza i odpowiedzialność cywilna

1.3. Klasyfikacja odpowiedzialności odszkodowawczej.......... 42

1.4. Reżim odpowiedzialności ubezpieczeniowej..................... 51

1.5. Zasada odpowiedzialności ubezpieczeniowej.................... 65

1.6. Typ odpowiedzialności ubezpieczeniowej ......................... 84

1.6.1. Kryterium sprawstwa ............................................... 84

1.6.2. Kryterium ekonomicznego rozkładu ciężaru odpowiedzialności .................................................. 93

1.6.3. Kryterium pełności odszkodowania....................... 99

\section{Rozdział 2}

Treść świadczenia ubezpieczyciela ............................................... 105

2.1. Wprowadzenie...................................................................... 105

2.2. Przepisy Kodeksu cywilnego a świadczenie ubezpieczyciela .................................................................... 108

2.3. Koncepcja jednorodnego świadczenia ubezpieczyciela..... 116 
2.4. Zobowiązanie do ponoszenia ryzyka a zobowiązanie naturalne.

2.5. Świadczenie ubezpieczyciela a charakter prawny umowy ubezpieczenia .

\section{Rozdział 3}

Przesłanki odpowiedzialności ubezpieczeniowej

3.1. Katalog przesłanek odpowiedzialności ubezpieczeniowej

3.2. Zawarcie umowy ubezpieczenia ......................................... 156

3.3. Zajście wypadku ubezpieczeniowego ............................... 162

3.4. Szkoda ubezpieczeniowa................................................... 172

3.4.1. Wprowadzenie ........................................................... 172

3.4.2. Teoria lokalizacji szkody........................................... 184

3.4.3. Uszczerbki niepodlegające naprawieniu w prawie cywilnym

3.5. Związek przyczynowy między wypadkiem a szkodą....... 211

\section{Rozdział 4}

Ograniczenia odszkodowania ubezpieczeniowego.................... 233

4.1. Wartość ubezpieczenia......................................................... 233

4.2. Suma ubezpieczenia.............................................................. 251

4.3. Systemy odpowiedzialności ubezpieczycieli..................... 271

4.4. Techniczne ograniczenia odpowiedzialności ubezpieczyciela ............................................................... 299

4.5. Ubezpieczenie podwójne ................................................... 306

4.5.1. Pojęcie ubezpieczenia podwójnego

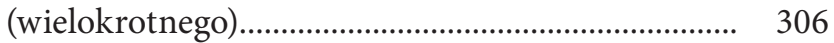

4.5.2. Ewolucja polskiej regulacji........................................ 312

4.5.3. Systemy rozliczeń między ubezpieczycielami......... 318

4.5.4. Zawarcie ubezpieczenia podwójnego w złej wierze... 323

4.5.5. Postanowienia umowne dotyczące ubezpieczenia podwójnego

\section{Rozdział 5}

Ustalanie odszkodowania ubezpieczeniowego ............................ 331

5.1. Wprowadzenie....................................................................... 331 
5.2. Elementy odszkodowania $\mathrm{z}$ ubezpieczenia mienia

5.2.1. Koszty przywrócenia do stanu poprzedniego i kosztorysowa metoda wyliczania odszkodowania

5.2.2. Kwalifikacja szkody jako całkowitej i zwrot różnicy między wartością mienia sprzed szkody a pozostałościami

5.2.3. Podatek VAT

5.2.4. Ubytek wartości handlowej i wynagrodzenie pełnomocnika

5.3. Wyrównanie korzyści z uszczerbkiem i miarkowanie odszkodowania ubezpieczeniowego.

5.3.1. Wyrównanie korzyści z uszczerbkiem.

5.3.2. Miarkowanie odszkodowania

z ubezpieczenia mienia - wzmianka

5.4. Koszty ratowania jako składnik odszkodowania ubezpieczeniowego 374

5.4.1. Zagadnienia wstępne 374

5.4.2. Uwagi prawnoporównawcze 378

5.4.3. Czasowy zakres kosztów podlegających zwrotowi... 381

5.4.4. Przedmiotowy i kwotowy zakres kosztów podlegających zwrotowi

5.5. Termin spełnienia świadczenia pieniężnego ubezpieczyciela

5.5.1. Wprowadzenie. 394

5.5.2. Charakter prawny terminu i konsekwencje jego niedochowania

5.5.3. Pojęcie zawiadomienia o wypadku

5.5.4. Okoliczności uzasadniające przekroczenie terminu podstawowego

\section{Rozdział 6}

Wyłączenia odpowiedzialności ubezpieczyciela

6.1. Wprowadzenie

6.2. Umyślne wyrządzenie szkody przez ubezpieczającego...

6.3. Wyrządzenie szkody przez ubezpieczającego wskutek rażącego niedbalstwa 
6.4. Wyrządzenie szkody umyślnie przez osoby pozostające z ubezpieczającym we wspólnym gospodarstwie domowym................................................. 435

6.5. Umowne wyłączenia odpowiedzialności ubezpieczyciela

6.5.1. Umowne wyłączenia odpowiedzialności a powinności prewencyjne

6.5.2. Skuteczność oraz interpretacja umownych wyłączeń odpowiedzialności

\section{Rozdział 7}

Naprawienie szkody przez ubezpieczyciela w drodze restytucji naturalnej

7.1. Wprowadzenie. 507

7.2. Sposoby naprawienia szkody w prawie cywilnym 510

7.3. Dopuszczalność naprawienia szkody przez ubezpieczyciela $\mathrm{w}$ drodze restytucji naturalnej.....

7.4. Zapłata odszkodowania w celu przywrócenia stanu poprzedniego a restytucja naturalna

7.5. Charakter świadczenia ubezpieczyciela w ubezpieczeniach assistance i ubezpieczeniu ochrony prawnej

7.6. Dopuszczalny zakres pomocy świadczonej przez ubezpieczyciela

Podsumowanie

Bibliografia 581

Spis orzeczeń sądowych 601 


\title{
WYKAZ WAŻNIEJSZYCH SKRÓTÓW
}

\author{
Akty prawne oraz prawo umowne \\ BGB \\ - Bürgerliches Gesetzbuch (niemiecki kodeks cywil- \\ ny) \\ dawny k.m. \\ - ustawa z 1.12.1961 r. - Kodeks morski (Dz.U. Nr 58, \\ poz. 318 ze zm.) \\ k.c. \\ - ustawa z 23.04.1964 r. - Kodeks cywilny (Dz.U. \\ z 2018 r. poz. 1025 ze zm.) \\ k.k. \\ - ustawa z 6.06.1997 r. - Kodeks karny (Dz.U. z 2018 r. \\ poz. $1600 \mathrm{ze} \mathrm{zm}$.) \\ k.k. z 1969 r. \\ - ustawa z 19.04.1969 r. - Kodeks karny (Dz.U. Nr 13, \\ poz. 94 ze zm.) \\ k.m. \\ - ustawa z 18.09.2001 r. - Kodeks morski (Dz.U. \\ z 2018 r. poz. 2175 ze zm.) \\ k.p.a. \\ - ustawa z 14.06.1960 r. - Kodeks postępowania ad- \\ ministracyjnego (Dz.U. z 2018 r. poz. 2096 ze zm.) \\ k.p.c. \\ - ustawa z 17.11.1964 r. - Kodeks postępowania cy- \\ wilnego (Dz.U. z 2018 r. poz. 1360 ze zm.) \\ k.s.h. $\quad-\quad$ ustawa z 15.09 .2000 r. - Kodeks spółek handlowych \\ (Dz.U. z 2017 r. poz. 1577 ze zm.) \\ nowelizacja z 2007 r. $\quad$ - ustawa z 13.04.2007 r. o zmianie ustawy - Kodeks \\ cywilny oraz o zmianie niektórych innych ustaw \\ (Dz.U. Nr 82, poz. 557) \\ OWU \\ - ogólne warunki umów \\ p.r.d. \\ - ustawa z 20.06.1997 r. - Prawo o ruchu drogowym \\ (Dz.U. z 2018 r. poz. 1990 ze zm.) \\ pr. przew. \\ - ustawa z 15.11.1984 r. - Prawo przewozowe (Dz.U. \\ z 2017 r. poz. 1983 ze zm.)
}


PEICL

u.d.u.

u.d.u. z 1990 r.

u.d.u. z 2003 r.

u.d.u.r.

u.k.w.h.

u.u.o.

VVG

\section{Czasopisma}

AUWr
EPS
KPP
LMCLQ
M. Prawn.
MU
NP
OSA
OSNC
OSNCP
OSP
OSPiKA
PA
Pal.
PiP
PPH

- Principles of European Insurance Contract Law (Zasady Europejskiego Prawa o Umowie Ubezpieczenia)

- ustawa z 15.12.2017 r. o dystrybucji ubezpieczeń (Dz.U. z 2018 r. poz. 2210 ze zm.)

- ustawa z 28.07.1990 r. o działalności ubezpieczeniowej (Dz.U. z 1996 r. Nr 11, poz. 62 ze zm.)

- ustawa z 22.05.2003 r. o działalności ubezpieczeniowej (Dz.U. z 2015 r. poz. 1206 ze zm.)

- ustawa z 11.09.2015 r. o działalności ubezpieczeniowej i reasekuracyjnej (Dz.U. z 2018 r. poz. 999 ze zm.)

- ustawa z 6.07.1982 r. o księgach wieczystych i hipotece (Dz.U. z 2018 r. poz. 1916 ze zm.)

- ustawa z 22.05.2003 r. o ubezpieczeniach obowiązkowych, Ubezpieczeniowym Funduszu Gwarancyjnym i Polskim Biurze Ubezpieczycieli Komunikacyjnych (Dz.U. z 2018 r. poz. 473 ze zm.)

- Versicherungsvertragsgesetz (niemiecka ustawa o umowie ubezpieczenia z 23.11.2007 r.)

- Acta Universitatis Wratislaviensis

- Europejski Przegląd Sądowy

- Kwartalnik Prawa Prywatnego

- Lloyd's Maritime and Commercial Law Quarterly

- Monitor Prawniczy

- Monitor Ubezpieczeniowy

- Nowe Prawo

- Orzecznictwo Sądów Apelacyjnych

- Orzecznictwo Sądu Najwyższego - Izba Cywilna

- Orzecznictwo Sądu Najwyższego - Izba Cywilna i Pracy

- Orzecznictwo Sądów Polskich

- Orzecznictwo Sądów Polskich i Komisji Arbitrażowych

- Prawo Asekuracyjne

- Palestra

- Państwo i Prawo

- Przegląd Prawa Handlowego 


$\begin{array}{ll}\text { PS } & - \text { Przegląd Sądowy } \\ \text { PUG } & - \text { Przegląd Ustawodawstwa Gospodarczego } \\ \text { PUSiG } & - \text { Przegląd Ubezpieczeń Społecznych i Gospodar- } \\ & \text { czych } \\ \text { RPEiS } & - \text { Ruch Prawniczy, Ekonomiczny i Socjologiczny } \\ \text { RU } & - \text { Rozprawy Ubezpieczeniowe } \\ \text { SI } & - \text { Studia Iuridica } \\ \text { SPE } & - \text { Studia Prawno-Ekonomiczne } \\ \text { SPP } & - \text { Studia Prawa Prywatnego } \\ \text { SC } & - \text { Studia Cywilistyczne } \\ \text { SU } & - \text { Studia Ubezpieczeniowe } \\ \text { WU } & - \text { Wiadomości Ubezpieczeniowe } \\ \text { ZNUMK } & - \text { Zeszyty Naukowe Uniwersytetu Mikołaja Kopernika } \\ & \end{array}$

\section{Organy orzekające i instytucje}

GKA

KNF

SA

$\mathrm{SN}$

SOKiK

TK

TSUE

UOKiK
- Główna Komisja Arbitrażowa

- Komisja Nadzoru Finansowego

- sąd apelacyjny

- Sąd Najwyższy

- Sąd Ochrony Konkurencji i Konsumentów

- Trybunał Konstytucyjny

- Trybunał Sprawiedliwości Unii Europejskiej

- Urząd Ochrony Konkurencji i Konsumentów 



\section{WPROWADZENIE}

We współczesnej polskiej literaturze istnieją opracowania monograficzne dotyczące ubezpieczeń w ogólności ${ }^{1}$, ubezpieczeń obowiązkowych ${ }^{2}$, ubezpieczeń komunikacyjnych ${ }^{3}$, ubezpieczeń osobowych, w szczególności życiowych ${ }^{4}$, i ubezpieczeń odpowiedzialności cywilnej ${ }^{5}$. Powstały też bardziej specjalistyczne prace dotyczące ubezpieczeń ekologicznych ${ }^{6}$, ubezpieczeń grupowych ${ }^{7}$, a ostatnio nawet kosmicznych ${ }^{8}$, wciąż brakuje jednak opracowania obejmującego ubezpieczenia określone w tytule mianem ubezpieczeń mienia. Ubezpieczenia tymczasem powstały na morzu i początkowo dotyczyły właśnie mienia. Można też powiedzieć, że podstawowy aparat pojęciowy, jakim posługuje się cała nauka o ubezpieczeniach prywatnych, został wypracowany w odniesieniu do ubezpieczeń mienia. Opracowania dotyczące innych ubezpieczeń czerpią z tego aparatu, w niektórych przypadkach zastępują określone pojęcia nowymi,

1 E. Kowalewski, Prawo ubezpieczeń gospodarczych. Ewolucja i kierunki przemian, Bydgoszcz 1992, M. Orlicki, Umowa ubezpieczenia, Warszawa 2002.

2 M. Orlicki, Ubezpieczenia obowiązkowe, Warszawa 2011.

3 A. Wąsiewicz, Ubezpieczenia komunikacyjne, Bydgoszcz-Poznań 2001; K. Ludwichowska, Odpowiedzialność cywilna i ubezpieczeniowa za wypadki samochodowe, Toruń 2008; Ubezpieczenia komunikacyjne, red. S. Rogowski, Warszawa 2008.

${ }^{4}$ M. Szczepańska, Ubezpieczenia na życie. Aspekty prawne, Warszawa 2008; M. Szczepańska, Ubezpieczenie na życie z ubezpieczeniowym funduszem kapitałowym, Warszawa 2011.

5 E. Kowalewski, Ubezpieczenie odpowiedzialności cywilnej. Funkcje i przemiany, Toruń 1981; M. Krajewski, Ubezpieczenie odpowiedzialności cywilnej według kodeksu cywilnego, Warszawa 2011.

6 D. Maśniak, Ubezpieczenia ekologiczne, Kraków 2003.

7 M. Fras, Umowa ubezpieczenia grupowego. Aspekty prawne, Warszawa 2015.

8 K. Malinowska, Space Insurance: International Legal Aspects, Kluwer Law International 2017. 
bardziej adekwatnymi. Mając to na uwadze, w zasadzie każdy prawnik piszący o ubezpieczeniach zajmuje się ubezpieczeniami mienia. Mogłoby się również wydawać, że z tego względu materia ubezpieczeń mienia powinna być najlepiej zbadana. Nawet jeżeli tak jest, przy bliższym spojrzeniu okazuje się, że zupełnie podstawowe kwestie ubezpieczeń mienia budzą wątpliwości i kontrowersje. Być może taki stan rzeczy jest nieunikniony. Nie bez powodu za jedną z podstawowych zdobyczy greckiej filozofii uważa się wszak obserwację Sokratesa, że wiedza rodzi kolejne wątpliwości, a mądrość polega często na przyznaniu się do niewiedzy. Niezależnie od tego w pracy podjęto próbę wyjaśnienia najistotniejszych problemów dotyczących umowy ubezpieczenia mienia.

Przedstawienie kwestii wątpliwych wypada rozpocząć od określenia umowy ubezpieczenia mienia jako umowy niebędącej umową ubezpieczenia odpowiedzialności cywilnej, na mocy której ubezpieczyciel zobowiązuje się wobec ubezpieczającego do zapłaty odszkodowania za szkodę powstałą wskutek przewidzianego w umowie wypadku, natomiast ubezpieczający zobowiązuje się do zapłaty składki. Przytoczona definicja ubezpieczenia mienia, oparta oczywiście na sformułowaniu kodeksowym (art. 805 k.c.), sugeruje prima facie, że ubezpieczyciel ponosi względem ubezpieczającego odpowiedzialność odszkodowawczą mającą charakter umowny. Jednakże już samo założenie, że sytuacja, w jakiej znajduje się ubezpieczyciel po zawarciu umowy ubezpieczenia, przybiera postać odpowiedzialności w sensie prawnym, jest przedmiotem kontrowersji. Łatwo zauważyć, że nawet jeżeli podstawą odszkodowania ubezpieczeniowego jest umowa, ubezpieczyciel ma je wypłacić jako świadczenie główne, żeby wywiązać się ze zobowiązania, nie zaś jako świadczenie zastępcze, płacone wobec niewykonania zobowiązania. Do tego dochodzą zupełnie podstawowe kontrowersje związane z funduszem ubezpieczeniowym jako źródłem odszkodowania ubezpieczeniowego, niepełnym charakterem tego odszkodowania,

9 T. Dybowski, Naprawienie szkody [w:] System Prawa Cywilnego, t. 3, cz. 1, Prawo zobowiązań. Część ogólna, red. Z. Radwański, Ossolineum 1981, s. 173-174; S. Byczko, Świadczenie pieniężne ubezpieczyciela na tle pojęcia odpowiedzialności cywilnej [w:] Prawo prywatne wobec wyzwań współczesności. Księga pamiątkowa dedykowana Profesorowi Leszkowi Ogiegle, red. M. Fras, P. Ślęzak, Warszawa 2017, s. 18. 
relacji między odpowiedzialnością sprawczą za dług własny i odpowiedzialnością za dług cudzy, a także zasadą odpowiedzialności ubezpieczeniowej określaną niekiedy mianem absolutnej ${ }^{10}$. Opisywanych, najbardziej podstawowych zagadnień dotyczy pierwszy rozdział pracy. Ma on w dużej mierze charakter teoretyczny, a wnioski z niego płynące wykorzystywane są w toku dalszych rozważań. Większość wątpliwości związanych z odpowiedzialnością ubezpieczyciela jak soczewka skupia spór toczący się co do tych kwestii w prawie angielskim ${ }^{11}$, który również został opisany w tym rozdziale.

Świadczenie określane jest najczęściej w cywilistyce jako zachowanie dłużnika służące zaspokojeniu interesu wierzyciela, stanowiące przedmiot stosunku cywilnoprawnego. Jak wiadomo, co do tego, jakie zachowanie ubezpieczyciela jest przedmiotem stosunku ubezpieczenia, w doktrynie toczy się dyskusja między zwolennikami teorii świadczenia pieniężnego oraz zwolennikami teorii ponoszenia ryzyka. Obydwie teorie występują w wielu wariantach. Zwykle z rozwiązaniem tego sporu łączy się konsekwencje co do kwalifikacji ubezpieczenia jako umowy wzajemnej. Kontrowersje dotyczące tych zagadnień są dobrze widoczne w orzecznictwie polskiego Sądu Najwyższego. Sam spór ma jednak źródło w prawie niemieckim (Geldleistungtheorie i Gefahrtragungtheorie) ${ }^{12}$, gdzie od pewnego czasu wyrażane są poglądy, że ma on charakter, po pierwsze - nierozstrzygalny, a po drugie - jałowy, jego konsekwencje praktyczne są bowiem znikome ${ }^{13}$. Ustawodawca niemiecki postanowił w końcu pogodzić obydwie strony w nowej ustawie o umowie ubezpieczenia z 2008 r. przez nawiązanie w określeniu umowy ubezpieczenia zarówno do ponoszenia ryzyka, jak i spełniania świadczenia pieniężnego

10 W. Warkałło, Odpowiedzialność odszkodowawcza. Funkcje, rodzaje, granice, Warszawa 1972, s. 191 i n.

11 N. Campbell, The nature of insurer's obligation, „Lloyd's Maritime Commercial Law Quarterly" 2000/42.

12 Zob. przykładowo M. Dreher, Die Versicherung als Rechtsprodukt. Die Privatversicherung und ihre rechtliche Gestaltung, Tubingen 1991, s. 88-89; E. Deutsch, Versicherungsvertragsrecht. Ein Grundi $\beta$, Karlsruhe 2000, s. 126-127; K. Sieg, Allgemeines Versicherungsvertragsrecht, Wiesbaden 1994, s. 26-27.

13 P. Schimikowski, Versicherungsvertragsrecht, München 2017, s. 25-26; M. Wandt, Versicherungsrecht, München 2016, s. 9-10. 
w razie zajścia wypadku, co i tak wszystkich nie przekonało ${ }^{14}$. Ustawodawca polski tego nie uczynił, kontrowersja zatem jest tym bardziej aktualna. Chociaż uwagi autorów niemieckich co do niemożności rozstrzygnięcia oraz jałowości sporu również wydają się aktualne, kwestii tej nie można było pominąć w pracy dotyczącej świadczenia ubezpieczyciela. Z uwagi na jej temat zagadnienie to ma charakter przynajmniej tak samo istotny, jak charakter prawny odpowiedzialności ubezpieczyciela. Z tych względów treści świadczenia ubezpieczyciela poświęcono drugi rozdział pracy. Kontynuując rozważania podjęte w pracy doktorskiej, próbowałem wypracować koncepcję kompromisową, mam jednak świadomość, że stanowczych zwolenników Geldleistungtheorie zapewne nie przekonam, tym bardziej że podobne próby były podejmowane w polskiej doktrynie już wcześniej ${ }^{15}$.

Opowiedzenie się po którejkolwiek ze stron sporu dotyczącego treści świadczenia ubezpieczyciela bynajmniej nie wyczerpuje zagadnienia, wręcz przeciwnie, rodzi kolejne pytania i wątpliwości. Ustawa wskazuje wprawdzie, że ubezpieczyciel ma zapłacić odszkodowanie za szkodę powstałą w następstwie określonego w umowie wypadku, nie wyjaśnia jednak, jakie znaczenie ma sam termin „wypadek”" ${ }^{16}$. W związku z powyższym niejasne są przesłanki odpowiedzialności odszkodowawczej ubezpieczyciela. Interesujące jest przy tym, że doktryna w zasadzie nie podejmuje zagadnienia wyodrębnienia tychże przesłanek. Prezentowany bywa w szczególności pogląd utożsamiający szkodę z wypadkiem ubezpieczeniowym, niebędącym samodzielną przesłanką odpowiedzialności, oraz pogląd, że ukształtowanie przesłanek odpowiedzialności pozostawiono stronom, de facto zaś ubezpieczycielowi ${ }^{17}$. W nauce dosyć powszechnie powtarzane jest ponadto stwierdzenie, że samo pojęcie szkody

${ }_{14}$ Zob. M. Krajewski, Przydatność i tresśc pojęcia ochrony ubezpieczeniowej [w:] Kierunki rozwoju ubezpieczeń gospodarczych $w$ Polsce. Wybrane zagadnienia prawne, red. B. Gnela, M. Szaraniec, Warszawa 2013, s. 141 oraz wskazana tam literatura.

15 W szczególności M. Orlicki, Umowa ubezpieczenia, 2002, s. 131 i n., a także B. Kucharski, Przeniesienie praw z umowy ubezpieczenia, Warszawa 2010, s. 50-55.

16 Por. E. Kowalewski, Prawo ubezpieczeń gospodarczych. Ewolucja..., s. 147.

17 Zob. w szczególności M. Krajewski, Wypadek ubezpieczeniowy. Przyczyna czy skutek? [w:] Z badań nad prawem prywatnym. Ksiega pamiątkowa dedykowana Profesorowi Andrzejowi Kochowi, red. A. Olejniczak, M. Orlicki, J. Pokrzywniak, Poznań 2017, s. 141 i n. 
w ubezpieczeniach ma znaczenie identyczne z pojęciem przyjmowanym na gruncie prawa cywilnego. Jednocześnie jednak z jednej strony zwraca się uwagę na tzw. teorię lokalizacji szkody, z drugiej zaś wskazuje na bardzo szerokie możliwości indemnizacji, jakie w ubezpieczeniach stwarza zastąpienie teorii mienia teorią interesu ubezpieczeniowego, który zdaje się odrywać od prawa podmiotowego. Niezależnie od wyodrębnienia wypadku oraz szkody jako samodzielnych przesłanek jasne jest, że nie są one wystarczające do powstania obowiązku zapłaty odszkodowania przez ubezpieczyciela. Inne kontrowersyjne kwestie dotyczące przesłanek odpowiedzialności obejmują: początek i koniec okresu, w którym ubezpieczyciel może ponosić odpowiedzialność, przede wszystkim zaś różnie rozwiązywane w prawodawstwach obcych zagadnienie związku przyczynowego między wypadkiem a szkodą, w szczególności zaś kryterium, według którego przebiegać ma selekcja następstw. W doktrynie polskiej prezentowane są w tej mierze bardzo różne poglądy: od aprobujących ogólne kryterium adekwatności ${ }^{18}$, poprzez zastąpienie go kryterium bezpośredniości ${ }^{19}$, aż do odrzucających jakiekolwiek dodatkowe kryteria poza testem conditio sine qua non ${ }^{20}$. Przesłanki odpowiedzialności ubezpieczeniowej, a ściślej odpowiedzialności odszkodowawczej ubezpieczyciela starano się wyodrębnić i omówić w rozdziale trzecim.

Dla ubezpieczeń mienia charakterystyczne są pojęcia wartości oraz sumy ubezpieczenia. Pomimo że pojęcia te i relacje między nimi mają podstawowe znaczenie dla ustalenia wysokości odszkodowania ubezpieczeniowego, wiele kwestii pozostaje niewyjaśnionych albo przynajmniej bardzo wątpliwych. Jest to zrozumiałe, szczególnie wziąwszy pod uwagę, że Kodeks cywilny tym pierwszym pojęciem w zasadzie się nie posługuje. Problemy dotyczą między innymi obowiązywania w ubezpieczeniu zasady odszkodowania w kontekście możności zawarcia ubezpieczenia w wartości nowej lub otaksowanej, dopuszczalności waloryzacji sumy

18 Z. Brodecki, Kilka refleksji na temat związku przyczynowego, PA 1995/3, s. 4; M. Krajewski, Umowa ubezpieczenia. Art. 805-834 KC. Komentarz, Warszawa 2016, s. 225-227.

19 E. Kowalewski, Odszkodowanie ubezpieczeniowe za utracone korzyści, PA 1996/3, s. 47.

20 A. Cudna-Wagner, Odpowiedzialność odszkodowawcza ubezpieczyciela, Warszawa 2002, s. 79-86. Nieco ostrożniej A. Koch, Związek przyczynowy w ubezpieczeniach, PA 1993/5, s. 7. 
ubezpieczenia w jakimkolwiek trybie, ograniczeń dotyczących przyjęcia tzw. systemu odpowiedzialności proporcjonalnej oraz związanych z tym konsekwencji. Szczególną wagę tego ostatniego zagadnienia ukazuje orzecznictwo Sądu Najwyższego z ostatnich lat. Nienormowane przez kodeks są również pojęcia tzw. technicznych ograniczeń odpowiedzialności, tj. franszyzy i udziału własnego. Znaczenie tych ograniczeń, ich wzajemne relacje i konsekwencje ich wprowadzenia do umowy ubezpieczenia budzą wątpliwości nie tylko w Polsce, ale również w prawodawstwach obcych, które niekiedy pojęcia te normują. Konsekwencją zasady odszkodowania jest zagadnienie tzw. ubezpieczenia podwójnego albo wielokrotnego. Jak wiadomo, regulacja w tej mierze uległa zmianie w 2007 r. Nowelizacja nie wyjaśniła wszelkich wątpliwości, tym bardziej że przyjęty system rozliczeń między ubezpieczycielami w proporcji do sumy ubezpieczenia zdaje się odbiegać od preferowanego w reprezentatywnych obcych systemach prawnych. Prawnoubezpieczeniowym konstrukcjom powodującym ograniczenie odszkodowania ubezpieczeniowego oraz relacjom między nimi poświęcono czwarty rozdział pracy.

Nakładanie się zasady lokalizacji szkody, wyżej opisanych, ściśle ubezpieczeniowych konstrukcji oraz ogólnych reguł prawa odszkodowawczego przyjmowanych w prawie cywilnym rodzi cały szereg dodatkowych problemów. Dotyczą one przede wszystkim poszczególnych składników odszkodowania ubezpieczeniowego oraz sposobu ustalania tego odszkodowania. Bogactwo problemów jest tutaj olbrzymie. Wskazać można między nimi kwestie: kosztów przywrócenia do stanu poprzedniego, związane z tym zagadnienia tzw. kosztorysowej metody likwidacji szkody, rozróżnienia szkody całkowitej oraz szkody częściowej, objęcia odszkodowaniem ubezpieczeniowym: podatku VAT, utraty wartości handlowej pojazdu oraz kosztów wynagrodzenia pełnomocnika w postępowaniu likwidacyjnym. W zakresie samego ustalania odszkodowania rodzą się przede wszystkim problemy uwzględnienia w ubezpieczeniach reguły compensatio lucri cum damno oraz dopuszczalności sądowego miarkowania odszkodowania ubezpieczeniowego. Odrębnym, kontrowersyjnym, ściśle ubezpieczeniowym zagadnieniem jest objęcie odszkodowaniem tzw. kosztów ratowania. Również w tej kwestii zmiana z 2007 r. nie wyjaśniła wszystkich wątpliwości, prawodawstwa obce przyjmują zaś rozmaite rozwiązania, różniąc się przede 
wszystkim co do samej zasady uwzględnienia kosztów ratowania oraz co do limitowania tych kosztów sumą ubezpieczenia. Wątpliwości dotyczą także terminu spełnienia świadczenia $\mathrm{z}$ umowy ubezpieczenia. Niejasne są w szczególności: pojęcie zawiadomienia o wypadku oraz jego relacja do zgłoszenia roszczenia, jak również zakres staranności, jakiej można wymagać od ubezpieczyciela w wyjaśnieniu okoliczności koniecznych dla ustalenia odpowiedzialności i wysokości należnego świadczenia. Pomimo ugruntowanej linii orzecznictwa Sądu Najwyższego wciąż powszechne są przypadki, w których zakłady ubezpieczeń uzależniają wypłatę świadczenia od zakończenia postępowań sądowych i administracyjnych mogących mieć związek z wypadkiem² ${ }^{21}$.

Odrębnym zagadnieniem od granic odszkodowania ubezpieczeniowego są granice ryzyka przejmowanego przez ubezpieczyciela. Druga kwestia ma w pewnym zakresie znaczenie szersze i bardziej podstawowe niż pierwsza, dotyka bowiem samego pojęcia wypadku ubezpieczeniowego. Wypadek omówiony jest w rozdziale trzecim wśród przesłanek odpowiedzialności ubezpieczeniowej. Związane z tym kwestie wyłączeń odpowiedzialności ubezpieczyciela zdecydowano się jednak rozważyć dopiero w rozdziale szóstym, ulegając intuicyjnemu wrażeniu, że wyłączenia nie tyle dotyczą istoty samej odpowiedzialności ubezpieczyciela, ile doprecyzowują jej zakres. Rozdział dotyczący tych zagadnień obejmuje wyłączenia ustawowe, w szczególności zaś zasadę nieodpowiedzialności ubezpieczyciela za winę umyślną ubezpieczającego, mającą związek z podstawową zasadą odpowiedzialności odszkodowawczej, jaką jest zasada bezwzględnej odpowiedzialności za winę umyślną ${ }^{22}$. W bezpośrednim związku z tymi zasadami pozostaje zasada względnej nieodpowiedzialności ubezpieczyciela za rażące niedbalstwo. Zakres omawianych wyłączeń oraz ich stosunek do zasady przyczynienia poszkodowanego obowiązującej w ogólnym prawie cywilnym wciąż bywają niejasne. To samo dotyczy tzw. klauzuli reprezentantów, którą reguluje obecnie art. $827 \$ 3$ k.c. i której zakres był szeroko dys-

21 B. Kucharski, Termin spetnienia świadczenia przez ubezpieczyciela w orzecznictwie sądowym [w:] Kierunki rozwoju ubezpieczeń gospodarczych w Polsce. Wybrane zagadnienia prawne, red. B. Gnela, M. Szaraniec, Warszawa 2013.

22 W. Warkałło, Odpowiedzialność..., s. 84. 
kutowany przede wszystkim $\mathrm{w}$ toku prac przygotowujących reformę kodeksowej regulacji umowy ubezpieczenia z $2007 \mathrm{r}$. Reforma jednak nie wyjaśniła wszystkich pojawiających się problemów, rodząc przy okazji, jak to często bywa, nowe niejasności. Drugą część rozdziału szóstego stanowią rozważania dotyczące wyłączeń umownych, w szczególności zaś ich relacji do powinności prewencyjnych. Problem ten nigdy nie był precyzyjnie uregulowany w polskim prawie, a jego złożoność ukazuje dobrze reforma przeprowadzona w prawie niemieckim, będąca jedną z zasadniczych przyczyn uchwalenia w 2008 r. nowej ustawy o umowie ubezpieczenia. Można śmiało powiedzieć, że zagadnienie to należy wciąż do najbardziej spornych w prawie ubezpieczeń. W polskiej doktrynie i orzecznictwie wypowiadane są stanowiska przeciwstawne, a linia orzecznictwa Sądu Najwyższego jest nieustalona. Odrębne kwestie pojawiają się w związku z dopuszczalnym zakresem postanowień kreujących wyłączenia odpowiedzialności oraz interpretacją tych postanowień, także przy uwzględnieniu przepisów o nieuczciwych klauzulach w umowach $\mathrm{z}$ konsumentami. Oczywiście, umowne wyłączenia odpowiedzialności obejmują nie tylko problem relacji między wyłączeniami a powinnościami prewencyjnymi. Powszechną i uświęconą tradycją praktykę ubezpieczycieli stanowią inne wyłączenia dotyczące przede wszystkim: wojny, zamieszek, ubytków naturalnych ubezpieczonych rzeczy itp. Zagadnienia te jednak przynajmniej dotąd na polskim gruncie nie były choćby w połowie tak wątpliwe jak zagadnienie relacji między klauzulami wyłączającymi ryzyko i powinnościami prewencyjnymi, i dlatego pozostawiono je poza zakresem rozważań.

Problem natury prawnej świadczenia ubezpieczyciela nie ogranicza się do zagadnienia, czy ubezpieczyciel świadczy także, gdy wypadek ubezpieczeniowy nie zachodzi, które stanowi przedmiot sporu między zwolennikami teorii świadczenia pieniężnego oraz zwolennikami teorii ponoszenia ryzyka. Kontrowersyjny jest również sam sposób spełnienia świadczenia odszkodowawczego w razie zajścia wypadku. Zagadnienie streszcza się w pytaniu, czy ubezpieczyciel, zamiast wypłacając odszkodowanie, może naprawić szkodę w drodze restytucji naturalnej. Jest dosyć interesujące, że w prawie angielskim taka możliwość niemal nigdy nie była przedmiotem wątpliwości, podczas gdy w kontynentalnych porządkach prawnych kwestia spełnienia świadczenia w formie niepieniężnej 
powstała dopiero stosunkowo niedawno, przede wszystkim w związku z rozwojem ubezpieczeń assistance. Znalazło to w szczególności wyraz w uchwaleniu dyrektywy z 1984 r. (84/641/EWG) ${ }^{23}$, której unormowania przejęto następnie w dyrektywie Wypłacalność $\mathrm{II}^{24}$. Do chwili obecnej widoczna wydaje się zresztą różnica między germańskim systemem prawnym, który choć dopuszcza taką formę spełnienia świadczenia ubezpieczeniowego, widzi w niej margines działalności ubezpieczeniowej, oraz systemem romańskim, gdzie w świadczeniach spełnianych w formie niepieniężnej upatruje się przyszłości ubezpieczeń. Jest charakterystyczne, że we Francji celem dopuszczenia takiej formy naprawienia szkody zmieniono Kodeks ubezpieczeń, a ubezpieczeniom assistance poświęca się całe opracowania naukowe ${ }^{25}$. Skrajnie odmienne zapatrywania dotyczące tej kwestii wyrażane w polskiej doktrynie stanowią odbicie tych różnic. Klasyk polskich ubezpieczeń W. Warkałło zdawał się jeszcze nie dostrzegać wagi problemu. Współcześnie stanowczym przeciwnikiem takiej formy spełnienia świadczenia jest przede wszystkim, pozostający pod wpływem doktryny niemieckiej, M. Orlicki ${ }^{26}$. Inni autorzy wyrażają jednak często bardziej liberalny punkt widzenia ${ }^{27}$. Zgodnie z poglądem prezentowanym w pracy pieniężny lub niepieniężny sposób spełnienia świadczenia odszkodowawczego w ogóle nie dotyczy istoty ubezpieczenia jako instytucji prawnej i samej dopuszczalności takiego sposobu naprawienia szkody nie należy kwestionować. Zagadnienie

23 Dyrektywa Rady z 10.12.1984 r. (84/641/EWG) zmieniająca, szczególnie w zakresie ubezpieczenia świadczenia pomocy turystycznej, pierwszą dyrektywę (73/239/EWG) w sprawie koordynacji przepisów ustawowych, wykonawczych i administracyjnych odnoszących się do podejmowania i prowadzenia działalności w dziedzinie ubezpieczeń bezpośrednich innych niż ubezpieczenia na życie (Dz.Urz. UE L 339, s. 21).

24 Dyrektywa Parlamentu Europejskiego i Rady 2009/138/WE z 25.11.2009 r. w sprawie podejmowania i prowadzenia działalności ubezpieczeniowej i reasekuracyjnej (Wypłacalność II) (wersja przekształcona) (Dz.Urz. UE L 335, s. 1, ze zm.).

25 Zob. w szczególności S. Beaugendre, Contrat d'assistance et activite d’assurance, Paris 2000 .

26 M. Orlicki, Umowa ubezpieczenia [w:] System Prawa Prywatnego, red. Z. Radwański, t. 8, Prawo zobowiązań. Część szczegółowa, red. J. Panowicz-Lipska, Warszawa 2008, s. 730.

27 B. Balas-Noszczyk, K. Malinowska, W sprawie dopuszczalności spetnienia świadczenia $z$ umowy ubezpieczenia $w$ formie restytucji naturalnej (przywrócenia stanu poprzedniego), PA 1998/4; J. Nawracała, Nie tylko zapłata. Charakter prawny świadczenia zakładu ubezpieczeń w razie zajścia wypadku ubezpieczeniowego, WU 2006/9-10; M. Krajewski, Umowa ubezpieczenia. Art. 805-834 KC..., 2016, s. 59-60. 
umów ubezpieczenia oraz umów podobnych do ubezpieczenia, w których świadczenie zdaje się przybierać formę niepieniężną, jest jednak niezmiernie skomplikowane. W pracy poświęcono mu ostatni rozdział przy świadomości, że zasługuje ono na zupełnie odrębne opracowanie.

Mając na uwadze, że świadczenie ubezpieczyciela jest świadczeniem charakterystycznym w umowie ubezpieczenia, ze świadczeniem tym wiążą się niemal wszystkie zagadnienia ubezpieczeń mienia. Praca nie ma jednak za przedmiot ubezpieczenia mienia jako takiego, ale właśnie świadczenie ubezpieczyciela. Dlatego pominięto w niej cały szereg zagadnień, które z samym świadczeniem ubezpieczyciela pozostają w związku nieco dalszym. Dotyczy to w szczególności kwestii subrogacji i regresu ubezpieczyciela, jak również przedawnienia roszczeń ubezpieczającego. Wskazane dwa zagadnienia także zdają się zasługiwać na odrębne opracowanie, tym bardziej że prace T. Sangowskiego i A. Szpunara o regresie ubezpieczeniowym ${ }^{28}$ oraz A. Szpunara o przedawnieniu roszczeń ubezpieczeniowych ${ }^{29}$ obecnie straciły w pewnym zakresie na aktualności. Każda z dwóch wymienionych kwestii może stanowić odrębną „kopalnię problemów”, które wiążą się z zagadnieniami poruszanymi w pracy, ale wykraczają poza jej zakres.

Innym spornym zagadnieniem, które nie zostało omówione, jest kulancja ubezpieczeniowa. W doktrynie dominuje stanowisko, wedle którego świadczenie kulancyjne stanowi z prawnego punktu widzenia świadczenie nienależne, a jego podstaw należy szukać w art. 411 pkt 2 k.c. ${ }^{30}$ Wyrażono również pogląd, że kulancja jest w istocie świadczeniem należnym, a jej podstaw należy szukać w umowie ubezpieczenia oraz przepisach umożliwiających jej wykonanie z powołaniem się na zasady współżycia społecznego, w szczególności w art. 354 oraz 827 \$ 2 k.c. ${ }^{31}$

28 T. Sangowski, Regres ubezpieczeniowy, Warszawa 1977; A. Szpunar, Roszczenie regresowe zakładu ubezpieczeń [w:] Ubezpieczenia w gospodarce rynkowej, t. 2, red. A. Wąsiewicz, Bydgoszcz 1994, s. 90 i n.

29 A. Szpunar, Przedawnienie roszczeń ubezpieczeniowych, PA 1994/1.

30 M. Orlicki, Instytucja kulancji w polskim prawie ubezpieczeniowym, PA 1998/4, s. 29; E. Kowalewski, M. Serwach, Kulancja ubezpieczeniowa, PA 2008/3, s. 5-7.

31 P. Sury, Świadczenie kulancyjne jako świadczenie należne, RU 2011/2, s. 58. Nieco ostrożniej D. Fuchs, Implikacje spetnienia świadczenia kulancyjnego przez ubezpieczyciela w szczególności dla jego prawa regresu wobec sprawcy szkody, PPH 2009/7, s. 26-27. 
Odwołanie się do tego drugiego przepisu wydaje się wątpliwe, zastosowana w nim klauzula generalna kreuje bowiem zaskarżalne roszczenie, podczas gdy kulancja polega na spełnieniu przez ubezpieczyciela świadczenia pieniężnego, mimo braku roszczenia po stronie osoby, która je otrzymuje $e^{32}$. Autorzy piszący o kulancji zgodni są co do tego, że chociaż musi być ona powiązana $\mathrm{z}$ konkretną umową ubezpieczenia i wynikającym z niej stosunkiem prawnym, jej cechą charakterystyczną jest pozytywna wiedza ubezpieczyciela o braku obowiązku zapłaty i kwestionowanie obowiązku spełnienia świadczenia, a mimo to jego wypłata $^{33}$. Ubezpieczyciel świadczy zatem, twierdząc jednocześnie, że czyni to nie dlatego, że jest zobowiązany, ale wyłącznie z dobrej woli, i uzasadnia swoje działanie szczególnym interesem po stronie beneficjanta lub chęcią utrzymania dobrej z nim współpracy. Innymi słowy, obowiązek spełnienia świadczenia kulancyjnego nie wynika wprost z warunków wiążącej strony umowy ubezpieczenia ani $z$ ustawy ${ }^{34}$ i trudno go w ogóle określić mianem zobowiązania, choćby naturalnego. Właśnie to ostatnie stwierdzenie pozwala pozostawić kulancję poza zakresem pracy, która dotyczy świadczeń mających swoją podstawę w warunkach zawartej umowy ubezpieczenia mienia, nie zaś świadczeń spełnianych ex gratia, choćby w związku z zawartą umową. Dodać można, że świadczenia kulancyjne nie mają wyraźnej podstawy również w ustawie z 11.09.2015 r. o działalności ubezpieczeniowej i reasekuracyjnej ${ }^{35}$ i stanowią niewielki odsetek wypłacanych świadczeń.

Praca nie obejmuje w zasadzie odpowiedzialności ubezpieczyciela za niewykonanie zobowiązania z umowy ubezpieczenia. Świadczeniem ubezpieczyciela $\mathrm{z}$ umowy ubezpieczenia mienia jest przede wszystkim świadczenie pierwotne, jakie wynika z samego jej zawarcia i rozpoczęcia okresu ochrony ubezpieczeniowej. Natura prawna odpowiedzialności ubezpieczeniowej sprawia, że również to świadczenie ma co do zasady charakter odszkodowawczy. Świadczenie polegające na konieczności naprawienia szkody, będącej następstwem niewykonania umowy ubez-

32 M. Krajewski, Umowa ubezpieczenia. Art. 805-834 KC..., 2016, s. 85.

33 Tak również, M. Sury, Świadczenie..., s. 53.

34 E. Kowalewski, M. Serwach, Kulancja..., s. 10. Zdaniem autorów świadczenia kulancyjne są spełniane causa donandi.

35 Dz.U. z 2018 r. poz. 999 ze zm. 
pieczenia, ma charakter wtórny. Nie wynika z samego zawarcia umowy, ale stanowi dopiero następstwo jej niewykonania. Zdaniem autora ubezpieczyciel ponosi tego rodzaju odpowiedzialność na ogólnych zasadach, co oczywiście nie wyklucza wprowadzania umownych modyfikacji oraz ograniczeń w granicach dozwolonych przez prawo. Konstatacja ta stanowi konsekwencję poglądów na naturę odpowiedzialności ubezpieczeniowej, które zostały zaprezentowane w pierwszym rozdziale pracy, i pojawia się w kilku miejscach, przede wszystkim przy okazji kwestii terminu zapłaty odszkodowania ubezpieczeniowego.

Praca dotyczy ubezpieczeń majątkowych niebędących ubezpieczeniami odpowiedzialności cywilnej. Przyjęcie tytułu Świadczenie ubezpieczyciela $w$ umowie ubezpieczenia mienia podyktowane zostało zwartością sformułowania, ugruntowaniem w praktyce rynkowej oraz w literaturze, a także nawiązaniem do pojęcia mienia zdefiniowanego w Kodeksie cywilnym. Tytuł odwołujący się do interesu jako przedmiotu ubezpieczenia sugerowałby objęcie zakresem pracy ubezpieczenia odpowiedzialności cywilnej, co nie stanowi zamiaru autora. Ubezpieczenie to, jak wiadomo, ma szereg cech szczególnych tak dalece odróżniających je od innych ubezpieczeń majątkowych, że często traktuje się je jako odrębny rodzaj ubezpieczenia od ubezpieczeń majątkowych oraz osobowych, postulując nawet odpowiednią zmianę systematyki unormowania umowy ubezpieczenia $^{36}$. Proponowane ostatnio w literaturze zastąpienie terminu „ubezpieczenia mienia” terminem „ubezpieczenie aktywów” nawiązywałoby z kolei do nieznanego prawu cywilnemu i niemającego definicji ustawowej pojęcia z zakresu księgowości, nieużywanego również przez obce systemy prawne ${ }^{37}$. Jeszcze bardziej mylący, a nadto archaiczny byłby termin „ubezpieczenia rzeczowe”. Zawężałby on zakres pracy wyłącznie do ubezpieczeń dotyczących rzeczy oraz nawiązywał wprost do odrzuconej przez ustawodawcę teorii majątku upatrującej przedmiotu ubezpieczenia jedynie w materialnych tworach przyrody. Z opisanych względów, pomimo zmiany art. 821 k.c. w 2007 r., postanowiłem pozostać przy terminie „ubezpieczenia mienia”, mając świadomość, że interes

36 E. Kowalewski, Prawo ubezpieczeń gospodarczych. Ewolucja..., s. 151 i n.

37 Takie zastąpienie sugeruje S. Byczko, Prawo ubezpieczeń gospodarczych. Zarys wykładu, Warszawa 2013, s. 172. 
majątkowy mogący stanowić przedmiot ubezpieczenia występuje także w sytuacjach, gdy zainteresowanemu nie przysługuje ani własność, ani jakiekolwiek prawo ${ }^{38}$. Zagadnienie objęcia ubezpieczeniem interesów czysto gospodarczych nieobjętych prawem podmiotowym jest zresztą kwestyjne, stanowi i może stanowić przedmiot odrębnych opracowań w przyszłości ${ }^{39}$. W pracy jest poruszane przy okazji rozważań dotyczących zakwalifikowania jako szkody ubezpieczeniowej tzw. szkody czysto ekonomicznej (pure economic loss).

Rozważania nie pretendują do roli analizy historycznej ani tym bardziej filozoficznej. Wątki historyczne związane z wzajemnym wpływem odpowiedzialności odszkodowawczej i ubezpieczeniowej pominięto, uznając, że zostały one w naszej literaturze dobrze opisane ${ }^{40}$. Uwagi prawnoporównawcze ograniczają się przede wszystkim do trzech najbardziej reprezentatywnych europejskich porządków prawnych, to jest: niemieckiego, francuskiego i angielskiego. Ten ostatni, choć obcy polskiej tradycji prawniczej, ma szczególną rolę w rozwoju ubezpieczeń, co uzasadnia poświęconą mu uwagę. Rozważania prawnoporównawcze mają przy tym charakter pomocniczy. Pominąwszy wyjątkowe sytuacje, nie wyodrębniam podrozdziałów komparatystycznych, nawiązując do obcych porządków jedynie wtedy, gdy wydaje mi się to pomocne dla rozwiązania problemów pojawiających się w polskiej doktrynie i judykaturze.

Praca dotyczy najbardziej kontrowersyjnych oraz stanowiących przedmiot licznych sporów sądowych zagadnień prawa ubezpieczeniowego. Polskie orzecznictwo dotyczące omawianych zagadnień jest niezmiernie bogate i choć starałem się je wykorzystywać na bieżąco, zapew-

38 S. Byczko, Interes ubezpieczeniowy. Aspekty prawne, Warszawa 2013, s. 251-264; E. Kowalewski, Wprowadzenie do teorii interesu ubezpieczeniowego [w:] Ubezpieczenia w gospodarce rynkowej, t. 3, red. A. Wąsiewicz, Bydgoszcz 1997, s. 85.

39 S. Byczko, Interes..., s. 251-264 oraz 209-221; B. Kucharski, Przeniesienie..., s. $110-112$.

40 Zob. przede wszystkim W. Warkałło, Ubezpieczenie a odpowiedzialność odszkodowawcza, SC 1970, t. 16, s. 133 i n.; W. Warkałło, Odpowiedzialność..., passim; E. Kowalewski, Prawo ubezpieczeń gospodarczych. Ewolucja..., s. 196 i n.; B. Lewaszkiewicz-Petrykowska, Odpowiedzialność na zasadzie ryzyka a ubezpieczenie, SPE 1968, t. 1. 
ne nie zdołałem uwzględnić wszystkich istotnych judykatów. W każdym razie mam nadzieję, że praca w znacznie większym zakresie niż większość typowych monografii naukowych może zainteresować praktyków. Nie jest ona jednak adresowana wyłącznie do nich i ma być podstawą habilitacji. Między innymi dlatego rozpoczyna ją teoretyczny wywód dotyczący charakteru odpowiedzialności ubezpieczeniowej. Z podobnych względów w podsumowaniu podjęto próbę wytyczenia niektórych kierunków, w których powinna zmierzać w przyszłości ewolucja świadczenia ubezpieczyciela w ubezpieczeniu mienia. Próba ta jest wyrazem moich poglądów na istotę ubezpieczenia mienia, w pewnej mierze podsumowuje wcześniejsze rozważania, nie pretenduje jednak do roli żadnej profetycznej ani zupełnej wizji i dlatego znalazła się w krótkim zakończeniu.

Pragnę wyrazić wdzięczność wszystkim osobom, które w jakikolwiek sposób przyczyniły się do powstania tej pracy, przede wszystkim zaś Koleżankom i Kolegom z Katedry Prawa Gospodarczego i Handlowego Uniwersytetu Łódzkiego za gorące dyskusje na seminariach. Pan Profesor Richard Giessen z Uniwersytetu w Monachium pomógł mi w zebraniu bibliografii niemieckiej. Dwie osoby, a mianowicie Pani Mecenas Alicja Bień - konsul honorowy Francji w Łodzi, oraz moja kuzynka dr Agnieszka Godzisz z Instytutu Filologii Germańskiej Uniwersytetu Łódzkiego, udzieliły mi nieocenionej pomocy przy tłumaczeniu literatury obcej. Szczególne podziękowania należą się trzem osobom. Pan Profesor Eugeniusz Kowalewski zainspirował mnie przy wyborze tematu oraz zweryfikował plan zagadnień. Pani Profesor Biruta Lewaszkiewicz-Petrykowska nauczyła mnie prawa cywilnego, a przy pisaniu pracy poświęciła sporo czasu i udzieliła szeregu cennych wskazówek. Panu Profesorowi Wojciechowi J. Katnerowi dziękuję za życzliwość, wieloletnią opiekę naukową oraz wnikliwe i krytyczne uwagi, które bardzo pomogły przy ostatecznym opracowaniu pracy. Dziękuję też mojemu recenzentowi wydawniczemu Profesorowi Marcinowi Orlickiemu, Celne uwagi zawarte w jego recenzji starałem się uwzględnić, przygotowując pracę do druku. 
Rozdział 1

\section{CHARAKTER PRAWNY ODPOWIEDZIALNOŚCI UBEZPIECZENIOWEJ}

\subsection{Odpowiedzialność ubezpieczeniowa a odpowiedzialność prawna}

Wyjaśnienie charakteru prawnego odpowiedzialności ubezpieczeniowej wymaga rozważenia wzajemnego stosunku pojęć: „odpowiedzialność”, „odpowiedzialność cywilna” i „odpowiedzialność odszkodowawcza”. W pierwszym rzędzie pojawia się problem objęcia sytuacji ubezpieczyciela zobowiązanego do świadczenia w wykonaniu zawartej umowy ubezpieczenia pojęciem odpowiedzialności prawnej. Kwestie te są ze względu na temat pracy istotne, ponieważ od ich rozstrzygnięcia zależy zastosowanie do odpowiedzialności ubezpieczeniowej ogólnych reguł odpowiedzialności cywilnej i odszkodowawczej.

Zagadnienie objęcia instytucji prawnej ubezpieczenia terminem „odpowiedzialność” budzi kontrowersje. W przedmiotowej sprawie zarysowały się dwa odmienne stanowiska. Zdaniem W. Warkałły obowiązek naprawienia szkody obciążający ubezpieczyciela jest wyrazem szczególnego rodzaju odpowiedzialności zwanej odpowiedzialnością ubezpieczeniową. Odpowiedzialność ubezpieczeniowa stanowić ma przy tym 
najwyższy szczebel rozwojowy odpowiedzialności odszkodowawczej ${ }^{1}$. Według W. Warkałły wszędzie tam, gdzie przedmiotem stosunku prawnego jest świadczenie odszkodowawcze, zachodzi odpowiedzialność podmiotu obowiązanego do naprawienia szkody. Autor ten zwraca również uwagę, że w języku prawnym oraz prawniczym powszechnie używa się terminu „odpowiedzialność” w powiązaniu z instytucją ubezpieczenia. Nadto jego zdaniem sprawę rozstrzygnął sam ustawodawca, określając w przepisach Kodeksu cywilnego o umowie ubezpieczenia obowiązek świadczenia odszkodowania przez ubezpieczyciela mianem odpowiedzialności².

Według stanowiska przeciwnego nie można mówić o odpowiedzialności ubezpieczeniowej, ponieważ obowiązek spełniania świadczenia ubezpieczeniowego nie odpowiada modelowi konstrukcyjnemu odpowiedzialności prawnej. W szczególności odpowiedzialność nie występuje tam, gdzie chodzi o skutki wydarzeń, które nie mogą być przypisane jakiemukolwiek podmiotowi prawa, w sytuacjach tych bowiem brakuje naruszenia porządku prawnego. W polskiej cywilistyce pogląd ten prezentował przede wszystkim T. Dybowski. Według niego trudno uznać za przejaw odpowiedzialności spełnianie świadczeń będących wyrazem normalnej działalności gospodarczej zakładu ubezpieczeń, który - pokrywając szkody zgodnie z warunkami ubezpieczeniowymi - wykonuje swoje zadania planowe i statutowe oraz otrzymuje za to wynagrodzenie w postaci składki ubezpieczeniowej.

1 W. Warkałło, Odpowiedzialność..., s. 105 i n. oraz 305; W. Warkałło, Ubezpieczenie a odpowiedzialność..., s. 109-110.

2 Podobnie jak się zdaje M. Krajewski. Autor stwierdza, że na gruncie art. 822 k.c. termin „odpowiedzialność” wydaje się równoznaczny z istnieniem określonego długu, a konieczność istnienia negatywnych konsekwencji wiążę z samym obowiązkiem zapłaty odszkodowania. Analizując pojęcie odpowiedzialności odszkodowawczej stwierdza ostatecznie, że zachodzi ona, ilekroć ustawodawca tak dany przypadek określa. Samo objęcie sytuacji ubezpieczyciela mianem „odpowiedzialności” traktuje zaś jako pewną oczywistość - M. Krajewski, Ubezpieczenie odpowiedzialności cywilnej według kodeksu cywilnego, Warszawa 2011, s. 30-33 oraz 44 i n.. M. Krajewski, Pojęcie odpowiedzialności odszkodowawczej (uwagi na marginesie art. 299 k.s.h.) [w:] Prawo handlowe XXI wieku. Czas stabilizacji, ewolucji czy rewolucji? Księga jubileuszowa Profesora Józefa Okolskiego, red. M. Modrzejewska, Warszawa 2010, s. 468 oraz 470-471. 
Do wniosku, że instytucja ubezpieczenia nie daje się zamknąć w ramach odpowiedzialności prawnej, doprowadził T. Dybowskiego następujący wywód. Pojęcie odpowiedzialności w prawie ma charakter interdyscyplinarny. Wyróżnia się przede wszystkim odpowiedzialność cywilną, karną, dyscyplinarną. Poza prawem cywilnym i karnym odpowiedzialność występuje również w innych gałęziach prawa, w szczególności w prawie konstytucyjnym, administracyjnym, finansowym oraz prawie pracy. Próby konstruowania ogólnego pojęcia odpowiedzialności podejmowane były przede wszystkim przez przedstawicieli teorii prawa.

Zdaniem T. Dybowskiego konstrukcjom cywilnoprawnym najbardziej odpowiada definicja odpowiedzialności autorstwa W. Langa, wedle której odpowiedzialność to zasada ponoszenia przez podmiot przewidzianych prawem ujemnych konsekwencji za zdarzenia lub stany rzeczy podlegające ujemnej kwalifikacji normatywnej i przypisywane prawnie określonemu podmiotowi w danym porządku prawnym ${ }^{3}$. Definicja odpowiedzialności cywilnej przedstawia się w tym ujęciu odpowiednio jako ponoszenie przez podmiot stosunków cywilnoprawnych ujemnych konsekwencji przewidzianych przez prawo cywilne za fakty podlegające ujemnej kwalifikacji normatywnej i przypisywane temu podmiotowi przez prawo cywilne. Tomasz Dybowski podkreślał przy tym, że ujemne konsekwencje, o których mowa w prawie cywilnym, inaczej niż w prawie karnym, nie zawsze zawierają elementy moralnego i prawnego potępienia, co dotyczy w szczególności znanej prawu cywilnemu odpowiedzialności oderwanej od winy. Niezbędny jest jednak istotny element ujemnej kwalifikacji normatywnej zdarzeń lub określonych stanów rzeczy przypisywanych określonym osobom. Już prima facie widać, że element ten uniemożliwia objęcie pojęciem odpowiedzialności sytuacji wykonania istniejącego zobowiązania zgodnie z jego treścią ${ }^{4}$.

W ostatnim czasie pogląd T. Dybowskiego łączący samo pojęcie odpowiedzialności z ujemnymi konsekwencjami pewnego zachowania

3 Tak T. Dybowski, Naprawienie..., s. 166. Co do samej koncepcji zob. W. Lang, O strukturze odpowiedzialności prawnej, ZNUMK 1968/31, Prawo VIII, s. 10, oraz W. Lang, Spór o pojęcie odpowiedzialności prawnej, ZNUMK 1969/37, Prawo IX, s. 68.

4 T. Dybowski, Naprawienie..., s. 166. 
zaaprobował S. Byczko5. Zdaniem tego autora, skoro odpowiedzialność obejmuje jedynie sytuacje, w których zachowanie osoby odpowiedzialnej można poddać ujemnej kwalifikacji normatywnej, sytuacji ubezpieczyciela płacącego odszkodowanie, ponieważ zobowiązał się do tego na mocy umowy, a nie dlatego, że wyrządził szkodę, nie można objąć terminem „odpowiedzialność”'. Do takiego wniosku prowadzą również spostrzeżenia, że świadczenia pieniężne w ubezpieczeniach osobowych mają charakter nieodszkodowawczy, a odszkodowanie ubezpieczeniowe wypłacane w innych ubezpieczeniach ma cechy szczególne, zwłaszcza jest ograniczone oraz nie stosuje się do niego reguł dotyczących przyczynienia do powstania szkody oraz miarkowania ${ }^{7}$. Szymon Byczko nie uzasadnia jednak początkowych założeń o bezwzględnym związku pojęcia odpowiedzialności z pojęciem szkody oraz z ujemną kwalifikacją normatywną zachowania podmiotu odpowiedzialnego. Trudno przyjąć, że szczególne cechy odszkodowania ubezpieczeniowego przesądzają o tym, że sytuacji ubezpieczyciela po zawarciu umowy ubezpieczenia w ogóle nie można określić mianem odpowiedzialności. Liczne wyjątki od zasad ogólnych nie mogą też a limine przesądzać o niestosowaniu tych zasad w ogóle.

W istocie przytaczane wyżej stanowisko, że świadczenie spełniane w wykonaniu umowy ubezpieczenia nie może być określane mianem odpowiedzialności, wydaje się być sprzeczne z poglądami wyrażanymi wcześniej w polskiej cywilistyce. Wieloznaczność odpowiedzialności cywilnej mieszczącej się w ramach odpowiedzialności prawnej była dostrzegana już przez R. Longchampsa de Bériera. Autor ten wskazywał, że termin „odpowiedzialność” służyć może jako określenie:

1) rozmiaru świadczenia (np.: odpowiedzialność ograniczona rachunkowo),

2) subiektywnego warunku powstania zobowiązania (np.: odpowiedzialność za winę),

3) obowiązków w ramach zobowiązania (np.: odpowiedzialność z tytułu rękojmi),

\footnotetext{
5 S. Byczko, Świadczenie..., s. 18-19.

6 S. Byczko, Świadczenie..., s. 19-20.

7 S. Byczko, Świadczenie..., s. 21-23.
} 
4) właściwości, że majątek dłużnika jest gwarancją spełnienia przezeń świadczenia.

Roman Longchamps de Bérier za zasadnicze uważał to czwarte znaczenie, będące podstawą odróżnienia długu, tj. powinności świadczenia, oraz odpowiedzialności, tj. gotowości majątku dłużnika do zaspokojenia wierzyciela ${ }^{8}$. Podkreślić należy jednak, że obowiązki w ramach zobowiązania również określał mianem odpowiedzialności.

Na wieloznaczność pojęcia odpowiedzialności cywilnej zwracał również uwagę A. Stelmachowski. Wychodząc od rozróżnień dokonanych przez R. Longchampsa de Bériera, uznał on, że odpowiedzialność cywilną można rozumieć szerzej, a mianowicie jako sytuację prawną, w której rodzi się zobowiązanie określonego podmiotu zagrożone sankcją cywilną. Zobowiązaniu temu odpowiada po stronie uprawnionego możliwość domagania się przymusowego zaspokojenia za pomocą organów państwowych lub przez samopomoc w wypadkach przewidzianych przepisami szczególnymi.

Takie stanowisko zaaprobował ostatnio M. Kaliński, podkreślając, że jest ono koherentne z wywodzącą się jeszcze z prawa rzymskiego strukturą zobowiązania, gdzie po stronie dłużnika występuje dług oraz odpowiedzialność ${ }^{9}$. Według M. Kalińskiego nie ma wystarczających podstaw, by wyłączać z zakresu odpowiedzialności cywilnej przymusowe wykonanie zobowiązania, a nawet wykonanie dobrowolne, jeżeli zobowiązaniu towarzyszy możliwość uruchomienia sankcji. Dłużnik, świadcząc zgodnie z treścią zobowiązania, realizuje swoją odpowiedzialność. Dlatego zamieszczanie w definicji pojęcia odpowiedzialności prawnej kwalifikatorów wskazujących na negatywną ocenę jakichś zdarzeń lub rzeczy wydaje się nieprawidłowe. Za stanowiskiem odmiennym, pozwalającym objąć terminem „odpowiedzialność” świadczenie ubezpieczyciela spełniane w wykonaniu umowy, przemawia również stosowanie przez ustawodawcę określenia „odpowiedzialność” w przepisach Kodeksu cy-

8 R. Longchamps de Bérier, Polskie prawo cywilne. Zobowiązania, wydanie anastatyczne, Poznań 1999, s. 19.

9 M. Kaliński, Szkoda na mieniu i jej naprawienie, Warszawa 2011, s. 4. 
wilnego regulujących umowę ubezpieczenia ${ }^{10}$.W przedstawionym sporze należy opowiedzieć się po stronie W. Warkałły i M. Kalińskiego, według których powinność ubezpieczyciela spełnienia świadczenia $\mathrm{z}$ umowy ubezpieczenia jest odpowiedzialnością. Także T. Dybowski dostrzega, że ustawodawca niejednokrotnie, między innymi w przepisach o umowie ubezpieczenia, używa terminu „odpowiedzialność” w znaczeniu każdej powinności opatrzonej sankcją prawną. Autor ten jednak, moim zdaniem niesłusznie, kwestionuje możliwość objęcia spełnienia świadczenia zgodnie z treścią zobowiązania terminem „odpowiedzialność”.

Błąd w rozumowaniu T. Dybowskiego wydaje się leżeć w apriorycznym przyjęciu założenia, że określenie odpowiedzialności prawnej opracowane w teorii prawa przez W. Langa najlepiej odpowiada konstrukcjom cywilistycznym. Sam W. Lang przed sformułowaniem swojej definicji odpowiedzialności prawnej analizuje odpowiedzialność na gruncie różnych gałęzi prawa. W prawie cywilnym wyróżnia trzy jej postaci, a mianowicie 1) odpowiedzialność dłużnika za wykonanie zobowiązania, 2) odpowiedzialność kontraktową z tytułu niewykonania zobowiązania, 3) odpowiedzialność deliktową za szkodę wyrządzoną czynem niedozwolonym. Pierwszą z postaci odpowiedzialności W. Lang określa jako pierwotną, wynikającą bezpośrednio z treści czynności prawnej będącej źródłem zobowiązania i przeciwstawia odpowiedzialności kontraktowej za szkodę spowodowaną niewykonaniem lub nienależytym wykonaniem zobowiązania $^{11}$. W Lang wskazuje wprawdzie, że odpowiedzialność dłużnika z przyjętego zobowiązania polega na możliwości zastosowania wobec dłużnika środków egzekucyjnych w razie nienależytego wykonania albo niewykonania świadczenia dłużnego, nie kwestionuje jednak, że odpowiedzialność istnieje jeszcze, zanim dłużnik nie wykona zobowiązania.

Jak łatwo zauważyć, ostatecznie sformułowana przez W. Langa definicja odpowiedzialności prawnej nie obejmuje podstawowej wyróżnianej przez niego kategorii odpowiedzialności cywilnej. Trudno zatem zgodzić się, że definicja ta odpowiada najlepiej konstrukcjom cywilistycz-

10 M. Kaliński, Szkoda..., s. 5.

11 W. Lang, O strukturze..., s. 10. 
nym. Przeciwnie, wydaje się, że konstrukcjom cywilistycznym bardziej odpowiada znacznie szersza definicja wiążąca kategorię odpowiedzialności prawnej z istnieniem zobowiązania oraz z sankcją. Można się zastanawiać, czy skonstruowanie interdyscyplinarnego pojęcia odpowiedzialności w prawie jest w ogóle celowe i możliwe. W każdym razie próbę pozostawiającą poza nawiasem podstawową kategorię odpowiedzialności cywilnej trudno uznać za udaną.

Próbując ekstrapolować na inne dziedziny prawa definicję A. Stelmachowskiego, za odpowiedzialność można uznać powinność określonego podmiotu prawa, $\mathrm{z}$ którą prawo wiąże określone sankcje ${ }^{12}$. Definicja taka, choć bardzo szeroka, wydaje się odpowiadać intuicji językowej, która określenie „odpowiedzialność” wiąże ze słowem „odpowiedź”. Można upatrywać w terminie „odpowiedzialność” odpowiedzi, jaką daje prawo na określoną sytuację danego podmiotu prawa, czyli powinności opatrzonej sankcją. Takie ujęcie w pewien sposób koresponduje również z budową normy prawnej składającej się z hipotezy, dyspozycji i sankcji. Hipoteza opisuje pierwotną sytuację podmiotu, dyspozycja - powinny sposób zachowania, sankcja - konsekwencje niezachowania się zgodnie z powinnością. Wbrew jednak twierdzeniom Langa odpowiedzialność pojawia się już wtedy, gdy podmiot stosunku cywilnoprawnego zachowuje się zgodnie ze zobowiązaniem, nie zaś dopiero wtedy, gdy zobowiązania nie wykonuje.

Także znaczenie potoczne słowa „odpowiedzialność” skłania do przyjęcia szerokiego znaczenia terminu „odpowiedzialność prawna”. Zgodnie ze słownikiem języka polskiego PWN odpowiedzialność to obowiązek moralny lub prawny odpowiadania za swoje lub czyjeś czyny, ewentualnie przyjęcie na siebie obowiązku zadbania o kogoś lub o $\cos ^{13}$. Zgodnie z „Wikisłownikiem” odpowiedzialność to obowiązek odpowiadania za swoje działanie, bycia odpowiedzialnym za coś, ewentualnie cecha

12 Por. A. Stelmachowski, Wstęp do teorii prawa cywilnego, s. Warszawa 1984, s. 308-309.

13 Internetowy Słownik Języka Polskiego PWN (https://sjp.pwn.pl/sjp/;2493511). 
kogoś, kto jest odpowiedzialny, dojrzały, rozsądny ${ }^{14}$. Z kolei w myśl Słownika języka polskiego pod red. W. Doroszewskiego odpowiedzialność to obowiązek moralny odpowiadania za własne czyny, ewentualnie obowiązek prawny ponoszenia konsekwencji cywilnych lub karnych za działanie lub zaniechanie ${ }^{15}$. Żadna z powyższych definicji słownikowych nie łączy terminu „odpowiedzialność” wyłącznie z działaniami lub zaniechaniami ocenianymi negatywne.

Podsumowując, nie wydaje się, by termin „odpowiedzialność" musiał zakładać naruszenie szeroko rozumianego porządku prawnego, choć bardzo często tak jest. Na marginesie można dodać, że cytowane wyżej poglądy autorów, według których odpowiedzialność w prawie cywilnym, podobnie jak w prawie karnym $\mathrm{i}$ innych gałęziach prawa, musi zawsze stanowić sankcję za naruszenie określonych obowiązków, wypowiadane były w minionej epoce społeczno-gospodarczej z powołaniem się na przedstawicieli radzieckiej teorii prawa, w szczególności O.S. Joffego i M. Szargorodskiego, które obecnie nie są już tak nośne. W cywilistyce niemieckiej oraz francuskiej powszechnie używa się sformułowania „odpowiedzialność" w odniesieniu do wykonania umowy ubezpieczenia.

Powyższe uwagi pozwalają na rozstrzygnięcie, że powinność spełnienia świadczenia przez ubezpieczyciela w wykonaniu zawartej umowy ubezpieczenia jest postacią odpowiedzialności prawnej. Pozostaje zastanowić się nad stosunkiem odpowiedzialności ubezpieczeniowej do odpowiedzialności odszkodowawczej oraz cywilnej.

${ }^{14}$ http://pl.wiktionary.org/wiki/odpowiedzialno\%C5\%9B\%C4\%87 (dostęp: 30.10.2018 r.).

${ }^{15} \mathrm{http} / / /$ doroszewski.pwn.pl/haslo/odpowiedzialno\%C5\%9B\%C4\%87/ (dostęp: 30.10.2018 r.). 


\subsection{Odpowiedzialność ubezpieczeniowa a odpowiedzialność odszkodowawcza i odpowiedzialność cywilna}

Zwykle przyjmuje się, że odpowiedzialność odszkodowawcza występuje wszędzie tam, gdzie dłużnik w ramach sankcji przewidzianej przez prawo zobowiązany jest do świadczenia polegającego na naprawieniu uszczerbku, jakiego doznała inna osoba na skutek tego, że prawnie chronione dobra i interesy tej drugiej osoby zostały naruszone ${ }^{16}$. W prawie cywilnym sankcja odszkodowawcza ma znaczenie podstawowe. Inne sankcje, jak sankcja nieważności, bezskuteczności czynności prawnej, ewentualnie odpowiednie ukształtowanie stosunku prawnego, mają znaczenie drugoplanowe. Podkreślić należy, że sankcja odszkodowawcza w ramach odszkodowawczego stosunku prawnego polegać może nie tylko na zapłacie odszkodowania w pieniądzu, ale również na naprawieniu szkody w drodze przywrócenia stanu poprzedniego ${ }^{17}$.

Charakterystyczne jest, że wątpliwości autorów wypowiadających się w kwestii kwalifikacji odpowiedzialności ubezpieczeniowej jako postaci odpowiedzialności odszkodowawczej koncentrowały się jedynie na możności objęcia instytucji ubezpieczenia ogólną kategorią odpowiedzialności. Nie wysuwano natomiast zastrzeżeń co do umiejscowienia ubezpieczeń w obrębie odpowiedzialności odszkodowawczej z uwagi na samo istnienie bądź brak istnienia obowiązku naprawienia szkody przez ubezpieczyciela lub też specyfikę takiego obowiązku. Kwestia może wydawać się oczywista, wypada jednak przytoczyć kilka argumentów wskazujących na obarczenie ubezpieczyciela obowiązkiem odszkodowawczym.

Rozważania dotyczą ubezpieczeń majątkowych, odnotować jednak należy, że niektóre świadczenia z ubezpieczeń osobowych mają charakter

16 A. Stelmachowski, Wstęp..., s. 314. Podobnie M. Krajewski, stwierdzając wyrażnie, że nie wystarcza, by przesłanką odpowiedzialności była szkoda, konieczne jest również, by spełniane świadczenie miało charakter odszkodowawczy - M. Krajewski, Ubezpieczenie..., s. 44 i n. Jeszcze wyraźniej M. Krajewski, Pojęcie odpowiedzialności..., s. 465.

17 W. Warkałło, Odpowiedzialność..., s. 13-14, 77 i n.; T. Dybowski, Naprawienie..., s. 167. 
odszkodowawczy. Występuje również teoria, reprezentowana głównie przez autorów włoskich (Donati, Buttero) i hiszpańskich (Uria, Caballero), o odszkodowawczym charakterze ubezpieczeń na życie. Jak wskazuje W. Warkałło, abstrakcyjne określenie wysokości świadczeń kapitałowych w ubezpieczeniach osobowych samo przez się nie wyłącza możliwości dopatrywania się elementów odszkodowania w wypłacie sumy ubezpieczenia na wypadek śmierci lub dożycia. Właśnie te poglądy leżą u podstaw tzw. teorii odszkodowawczej ubezpieczenia, która dąży do stworzenia jednolitej koncepcji ubezpieczenia obejmującej zarówno ubezpieczenia majątkowe, jak i osobowe ${ }^{18}$. Podobny wydźwięk mają wyrażane ostatnio w polskiej doktrynie poglądy o potrzebie występowania także w ubezpieczeniach na życie interesu ubezpieczeniowego ${ }^{19}$.

Odszkodowawczy charakter świadczenia ubezpieczeniowego wiąże się $\mathrm{z}$ istotą instytucji ubezpieczenia. Warto w tym miejscu przytoczyć poglądy E. Kowalewskiego, który zwraca uwagę, że ubezpieczenie w odróżnieniu od gry i zakładu, bazujących na tzw. ryzyku spekulatywnym tworzonym w celu wzbogacenia się, opiera się na ryzyku czystym - istniejącym niezależnie od woli człowieka. Ubezpieczenie jest w tym sensie antylosowe, stanowi zabezpieczenie ubezpieczonego przed skutkami zdarzeń przyszłych niepewnych co do samego ich zajścia bądź terminu, czasem mających nawet charakter dla ubezpieczonego pomyślny, zawsze łączących się jednak dla ubezpieczonego lub uposażonego z uszczerbkiem majątkowym ${ }^{20}$.

Niezależnie od poprawności odszkodowawczej teorii ubezpieczenia jako instytucji ogólnej, o odszkodowawczym charakterze świadczeń pieniężnych z ubezpieczenia majątkowego świadczy cały szereg unormowań Kodeksu cywilnego. W ubezpieczeniu majątkowym świadczenie ubezpieczyciela polega na zapłacie określonego odszkodowania jako naprawienia szkody powstałej wskutek przewidzianego w umowie wypadku

18 W. Warkałło, Zasada odszkodowania w ubezpieczeniach, SC 1969, t. XIII-XIV, s. 451.

19 B. Kucharski, Przeniesienie..., s. 121; S. Byczko, Interes..., s. 287.

20 Zob. przykładowo E. Kowalewski, Wprowadzenie do teorii ryzyka ubezpieczeniowego [w:] Ubezpieczenia w gospodarce rynkowej, t. 2, red. A. Wąsiewicz, Bydgoszcz 1994, s. 25-26. 
(art. $805 \$ 2$ pkt 1 k.c.). Przez umowę ubezpieczenia odpowiedzialności cywilnej, będącą szczególną postacią ubezpieczenia majątkowego, ubezpieczyciel zobowiązuje się do zapłacenia określonego w umowie odszkodowania za szkody wyrządzone osobom trzecim, wobec których odpowiedzialność za szkodę ponosi ubezpieczający lub ubezpieczony (art. $822 \$ 1$ k.c.).

Suma wypłacona przez ubezpieczyciela $\mathrm{z}$ tytułu ubezpieczenia majątkowego nie może być wyższa od poniesionej szkody (art. $824 \$ 1$ k.c.). Ubezpieczający nie może żądać świadczenia przenoszącego wysokość szkody także wtedy, gdy ten sam przedmiot ubezpieczenia w tym samym czasie jest ubezpieczony od tego samego ryzyka u dwóch lub więcej ubezpieczycieli na sumy, które łącznie przewyższają jego wartość ubezpieczeniową (art. $824^{1} \$ 2$ k.c.). Ubezpieczyciel wolny jest od odpowiedzialności, gdy ubezpieczający wyrządził szkodę umyślnie (art. $827 \$ 1$ k.c.). Roszczenie ubezpieczającego wobec sprawcy szkody przechodzi na ubezpieczyciela do wysokości zapłaconego odszkodowania (art. $828 \$ 1$ k.c.).

Jedynymi przepisami Kodeksu cywilnego o ubezpieczalniach majątkowych, które nie odwołują się wyraźnie do pojęć szkody lub odszkodowania, są art. 821 k.c. - dotyczący interesu ubezpieczeniowego, oraz art. 823 k.c. - dotyczący zbycia przedmiotu ubezpieczenia. Ten pierwszy przepis wskazuje przy tym, że przedmiotem ubezpieczenia może być wyłącznie interes, który daje się ocenić w pieniądzu, co ściśle wiąże się $\mathrm{z}$ wynikającą $\mathrm{z}$ art. $824^{1} \$ 1$ k.c. zasadą odszkodowania. Ten drugi zaś również dotyczy zasady interesu, wyrażając regułę, że prawa $z$ ubezpieczenia mogą być przenoszone wyłącznie na osoby zainteresowane.

Argumentów na rzecz możliwych odstępstw od odszkodowawczego charakteru świadczeń z ubezpieczeń majątkowych można szukać w następujących sformułowaniach. Przepis art. $805 \$ 2$ k.c., wyjaśniający, na czym może polegać świadczenie ubezpieczyciela, zawiera sformułowanie „W szczególności”. Przepis art. $824^{1} \$ 1$ k.c. wyrażający expressis verbis zasadę odszkodowania rozpoczyna się od słów: „O ile nie umówiono się inaczej”. Przepis art. $823 \$ 4$ k.c. wskazuje natomiast, że wcześniejszych reguł dotyczących przenoszenia praw $\mathrm{z}$ ubezpieczenia nie stosuje się 
przy przenoszeniu wierzytelności, jakie powstały lub mogą powstać wskutek zajścia przewidzianego w umowie wypadku.

Należy podkreślić, że żadne z przytoczonych powyżej unormowań nie przewiduje wyraźnie możliwości wypłacania przez ubezpieczyciela świadczeń niemających związku z poniesioną przez ubezpieczającego szkodą. Zawierają one jedynie sformułowania otwierające pole do poszukiwania odstępstw od reguł ogólnych, nie wskazując jednak, czy może chodzić o odstępstwa od zasady, że rolą świadczenia $\mathrm{z}$ ubezpieczenia majątkowego jest wyrównanie poniesionej przez ubezpieczającego lub ubezpieczonego szkody.

Przepis art. $805 \$ 2$ k.c. stanowi, że świadczenie ubezpieczyciela polega w szczególności na zapłacie, a następnie wymienia świadczenia pieniężne z dwóch rodzajów ubezpieczeń znanych Kodeksowi cywilnemu. Sformułowanie „w szczególności” podkreśla jedynie, że chodzi o uszczegółowienie reguły ogólnej wynikającej z definiującego istotę ubezpieczenia art. $805 \$ 1$ k.c. Ponadto słowa „w szczególności” występują przed słowami „na zapłacie” i używane są jako argument przez zwolenników teorii ryzyka czy też ochrony ubezpieczeniowej jako możliwego świadczenia ubezpieczyciela. Nawet jednak zwolennicy tej teorii twierdzą, że kluczowe jest ryzyko czy też ochrona przed szkodą ${ }^{21}$.

Początek art. $824^{1} \$ 1$ k.c. komentowany jest jako dopuszczenie ubezpieczenia w wartości nowej oraz ubezpieczenia w wartości otaksowanej. Wskazane rodzaje ubezpieczenia nie stanowią wyjątku od zasady odszkodowania, ale jej potwierdzenie. Pozwalają bowiem na przywrócenie ubezpieczonego mienia do stanu sprzed wypadku ubezpieczeniowego (restitutio in integrum) w sensie gospodarczym bez troszczenia się o to, czy wysokość kosztów takiego przywrócenia odpowiadać będzie dokładnie wartości uszkodzonego mienia, wziąwszy pod uwagę jego naturalne zużycie $^{22}$. Ujmując rzecz praktycznie, chodzi o to, że nie można odbudować identycznego domu jak ten, który spłonął, ani kupić identycznego

21 M. Orlicki, Umowa ubezpieczenia, 2002, s. 141-143.

22 W. Warkałło, Ubezpieczenie utraconych korzyści, ubezpieczenie w wartości nowej i ubezpieczenie $w$ wartości otaksowanej a zasada odszkodowania, SU 1975, t. 2, s. 72. 
samochodu co ten, który uległ wypadkowi. Można wybudować podobny nowy dom albo kupić nowy samochód tego samego typu. Wartość nowego domu lub samochodu będzie oczywiście większa niż domu lub samochodu sprzed wypadku, jednak z gospodarczego punktu widzenia dla ubezpieczającego taka sytuacja bliższa będzie przywróceniu stanu poprzedniego niż kupno używanego niepodobnego domu lub samochodu. Kwestie te będą jeszcze przedmiotem analizy.

Artykuł $823 \$ 4$ k.c. miał wskazywać, według intencji jego twórców, na odróżnienie między przeniesieniem prawa do świadczenia w postaci ochrony ubezpieczeniowej oraz prawa do świadczenia mającego charakter stricte pieniężny, czyli właśnie świadczenia odszkodowawczego. Przepis ten został nadto poddany zdecydowanej krytyce. Zwrócono uwagę, że prawa $\mathrm{z}$ umowy ubezpieczenia będącej umową obligacyjną nie mogą mieć innego charakteru niż wierzytelności. Przeniesienie wierzytelności w postaci ochrony ubezpieczeniowej ma sens jedynie, jeżeli towarzyszy jej perspektywa prawa do uzyskania świadczenia pieniężnego. Zdająca się zaś wynikać z przepisu możliwość dowolnego przenoszenia wierzytelności o świadczenie pieniężne przed zajściem wypadku jest nie do przyjęcia jako sprzeczna $\mathrm{z}$ istotą ubezpieczenia ${ }^{23}$.

W ujęciu odpowiedzialności ubezpieczeniowej jako odpowiedzialności odszkodowawczej pomaga również szersze spojrzenie na kwestie zasad ustalenia odszkodowania obowiązujących dla różnych reżimów odpowiedzialności. Adam Szpunar zwrócił uwagę, że w odniesieniu do tego zagadnienia w Europie występują trzy systemy:

1) prawo niemieckie tworzy wspólne rozwiązania dla różnych systemów odpowiedzialności;

2) prawo francuskie wyznacza jedynie reguły odpowiedzialności za niewykonanie zobowiązania. Stosowanie tych reguł do odpowiedzialności ex delicto jest źródłem wielu kontrowersji;

3) prawo szwajcarskie kładzie nacisk na unormowanie zasad odpowiedzialności z tytułu czynów niedozwolonych. Zasady te stosuje się również do odpowiedzialności z tytułu niewykonania zobowiązania.

${ }^{23}$ B. Kucharski, Przeniesienie..., s. 353; M. Krajewski, Przydatność..., s. 143. 
Dawny Kodeks zobowiązań ${ }^{24}$ przyjmował trzecie rozwiązanie, co stwarzało szereg trudności. Obecny Kodeks cywilny idzie za wzorem niemieckim. Przyjęte stanowisko zostało przez A. Szpunara stanowczo zaaprobowane ${ }^{25}$. Z wywodów A. Szpunara wynika wyraźnie, że zasady wynikające $z$ art. 361-363 k.c. uważał on za wspólne zasady ustalania odszkodowania w stanach faktycznych, w których powstaje obowiązek naprawienia szkody, tzn. nie tylko w przypadku odpowiedzialności z tytułu czynów niedozwolonych i odpowiedzialności z tytułu niewykonania zobowiązania, ale również w odpowiedzialności ubezpieczeniowej oraz w pozostałych sytuacjach przewidywanych przez Kodeks cywilny. Takie ujęcie wspiera między innymi systematyka Kodeksu cywilnego.

Oczywiście konstatacja, że ogólne reguły dotyczące ustalenia odszkodowania są wspólne we wszystkich sytuacjach, w których występuje obowiązek naprawienia szkody, nie oznacza, że przepisy szczególne dotyczące obowiązku naprawienia szkody w konkretnej sytuacji nie mogą ich modyfikować. W odniesieniu do świadczenia ubezpieczyciela w ubezpieczeniu mienia modyfikacje te są wyraźne już prima facie. Zachowując kolejność wynikającą z art. 361-363 k.c. i uprzedzając tok dalszych rozważań, łatwo wskazać, że na gruncie ubezpieczeń modyfikacje dotyczyć mogą wszystkich reguł ogólnych:

- zasady adekwatnego związku przyczynowego w związku z określeniem wypadku ubezpieczeniowego w umowie ubezpieczenia,

- zasady pełnego odszkodowania w związku z określeniem w umowie ubezpieczenia jego zakresu,

- przyczynienia do powstania szkody, wobec treści art. 827 k.c., który zwalnia ubezpieczyciela od odpowiedzialności, jedynie gdy ubezpieczający wyrządził szkodę umyślnie,

- zasady wyboru między restytucją naturalną oraz odszkodowaniem pieniężnym wobec wynikającego z wielu przepisów Kodeksu cywilnego prymatu w ubezpieczeniach tego drugiego sposobu naprawienia szkody.

24 Rozporządzenie Prezydenta Rzeczypospolitej Polskiej z 27.10.1933 r. - Kodeks zobowiązań (Dz.U. Nr 82, poz. 598 ze zm.).

25 A. Szpunar, Odszkodowanie za szkodę majątkową. Szkoda na mieniu i osobie, Bydgoszcz 1998, s. 20. 
Przesłanki odpowiedzialności ubezpieczeniowej oraz inne wyżej poruszone kwestie będą przedmiotem dalszych wywodów. Na obecnym etapie wypada dostrzec, że modyfikacje reguł ogólnych są z pewnymi zastrzeżeniami dopuszczalne również w innych umowach. Sam fakt, że świadczenie odszkodowawcze ubezpieczyciela jest świadczeniem podstawowym wynikającym z umowy, nie zaś świadczeniem zastępczym należnym w razie jej niewykonania, nie implikuje ani nieistnienia odpowiedzialności ubezpieczeniowej, ani braku szkody jako jej niezbędnej przesłanki. Sprawę można zatem zamknąć, konstatując, że odpowiedzialność ubezpieczeniowa jest postacią odpowiedzialności odszkodowawczej, a ogólne reguły, choć mogą doznawać wyjątków, powinny stanowić punkt wyjścia rozważań dotyczących ubezpieczenia.

Ostatnie postawione zagadnienie, a mianowicie wzajemny zakres odpowiedzialności odszkodowawczej oraz odpowiedzialności cywilnej nie wymaga w zasadzie rozważenia. Niezależnie od zakresu pojęcia odpowiedzialności cywilnej nie sposób bowiem zaprzeczyć, że odpowiedzialność ubezpieczeniowa mająca swoje źródło w umowie obligacyjnej jest postacią odpowiedzialności cywilnej. W moim przekonaniu wniosku tego nie zmienia okoliczność, że w ubezpieczeniu OC odpowiedzialność ubezpieczyciela jest akcesoryjna wobec odpowiedzialności sprawcy szkody, co do której można niekiedy rozważać rodowód pozacywilistyczny.

Dla porządku wypada jednak wskazać, że w doktrynie dominuje stanowisko, zgodnie z którym odpowiedzialność odszkodowawcza jest zawsze odpowiedzialnością cywilną. Innymi słowy, termin „odpowiedzialność odszkodowawcza” jest węższy niż „odpowiedzialność cywilna”. Jak wykazał A. Szpunar, ogólne zasady rządzące określeniem odszkodowania za szkodę majątkową są te same bez względu na to, jakie było źródło powstania tego obowiązku².

Takie ujęcie jest przekonujące również zdaniem M. Kalińskiego. Wprawdzie normy prawne dotyczące obowiązku naprawienia szkody rozsiane są po aktach prawnych zaliczanych do różnych dziedzin prawa, jed-

26 A. Szpunar, Odszkodowanie..., s. 13. 
nakże ustalenie treści stosunku odszkodowawczego powinno następować zawsze z uwzględnieniem zawartych w art. 361-363 k.c. ogólnych norm dotyczących zapłaty odszkodowania. Z tych względów stosunek odszkodowawczy ma charakter cywilnoprawny, a odpowiedzialność odszkodowawczą należy uznać za element odpowiedzialności cywilnej ${ }^{27}$.

Dodać można, że istotny argument na rzecz braku zróżnicowania obowiązku odszkodowawczego $\mathrm{w}$ ramach różnych gałęzi prawa polega na wzajemnej zaliczalności świadczeń orzekanych w postępowaniach należących do tych gałęzi. Argument ten znalazł ostatnio oddźwięk bezpośrednio na gruncie prawa ubezpieczeń, kiedy to Sąd Najwyższy w uchwale z 13.07.2011 r. stwierdził, że „Sprawca wypadku komunikacyjnego, wobec którego zastosowano środek karny polegający na obowiązku naprawienia szkody (...) może domagać się od ubezpieczyciela - na podstawie umowy ubezpieczenia odpowiedzialności cywilnej posiadaczy pojazdów mechanicznych (...) - zwrotu świadczenia zapłaconego na rzecz pokrzywdzonego" 28 .

\subsection{Klasyfikacja odpowiedzialności odszkodowawczej}

Większość polskich cywilistów wyodrębnia odpowiedzialność ubezpieczeniową jako odpowiedzialność odszkodowawczą o charakterze szczególnym. Proponowane są jednak różne kryteria oraz określenia dokonywanej klasyfikacji.

Roman Longchamps de Bérier pozostawał przy klasycznym podziale na odpowiedzialność wynikającą z niewykonania zobowiązania (ex contractu) oraz odpowiedzialność wynikającą z popełnienia czynu niedozwolonego (ex delicto). Według tego autora na gruncie Kodeksu zobowiązań obowiązek odszkodowania powstawał wówczas, gdy szkoda wynikła z przyczyny, za którą prawo czyniło kogoś odpowiedzialnym.

27 M. Kaliński, Szkoda..., s. 9. Inaczej jednak M. Krajewski, Ubezpieczenie..., s. 35.

28 Uchwała z 13.07.2011 r., III CZP 31/11, OSNC 2003/12, poz. 29, z glosą aprobującą M. Krajewskiego, OSP 2012/4, poz. 43. 
Przyczyny te autor dzielił na dwie grupy. Pierwsza obejmowała przypadki wyrządzenia szkody przez niewykonanie zobowiązania, określane nazwą szkody kontraktowej, druga grupa zaś przypadki wyrządzenia szkody poza stosunkiem zobowiązaniowym, obejmowane nazwą szkody deliktowej. Przywoływany autor obydwa określenia uważał za nieściśle, wskazując, że pierwsza grupa przypadków obejmowała zobowiązania wynikające nie tylko $\mathrm{z}$ umowy, ale również $\mathrm{z}$ innych zdarzeń, a druga grupa dotyczyła zarówno sytuacji, gdy szkodę wyrządzono czynem niedozwolonym w ścisłym znaczeniu, czyli niedozwolonym działaniem lub zaniechaniem człowieka, jak również sytuacji wyrządzenia szkody przez zwierzęta, rzeczy, siły przyrody lub dozwolone działania ludzkie ${ }^{29}$.

Fryderyk Zoll również wychodził od podziału zobowiązań odszkodowawczych na powstające niezależnie od istniejącego stosunku obligacyjnego oraz wskutek niewykonania lub nienależytego wykonania zobowiązań już istniejących. Wskazywał, że Kodeks zobowiązań określał pierwszą grupę mianem zobowiązań z czynów niedozwolonych, każąc stosować reguły ich dotyczące również do grupy drugiej. $Z$ tych względów F. Zoll kompleksowo omawiał jedynie zobowiązania z czynów niedozwolonych, zastrzegając, że termin ten jest nieprecyzyjny, obejmuje bowiem nie tylko szkody będące następstwem zawinionych działań ludzkich. Zdaniem tego autora fakty niebędące niewykonaniem albo nienależytym wykonaniem zobowiązania, z których powstają obowiązki odszkodowawcze, można w istocie podzielić na cztery grupy: 1) czyny zawinione, 2) czyny (zdarzenia lub stany) niezawinione, łączące się z pewnym niebezpieczeństwem wyrządzenia szkody innym, 3) czyny przez ustawodawcę dozwolone, ale powodujące szkody podlegające naprawieniu, 4) repartycję odpowiedzialności za szkody rodzące zobowiązania odszkodowawcze uzasadnioną umową lub ustawą publiczno-prawną.

Omawiając ostatnią grupę, F. Zoll wskazywał, że zasada odpowiedzialności za winę oraz zasada odpowiedzialności za stworzenie niebezpieczeństwa, z którego ma się korzyści (jak np. wprawianie w ruch fabryk siłami przyrody), rodzą ujemne konsekwencje. Konsekwencje te po-

29 R. Longchamps de Bérier, Polskie..., s. 230-231. 
legają z jednej strony na rujnujących skutkach odpowiedzialności dla osób odpowiedzialnych, a z drugiej strony na nikłym znaczeniu odpowiedzialności dla poszkodowanego. Celem uchylenia, a przynajmniej osłabienia tych skutków, wprowadzone zostały środki polegające na tzw. repartycji, tj. rozłożeniu odpowiedzialności za szkody na wielką liczbę osób w drodze ubezpieczeniowej ${ }^{30}$.

Powołany autor opisywał repartycję jako system polegający na tym, że wielkie instytucje finansowe przejmują na siebie obowiązki płacenia odszkodowań, jakie w przyszłości mogą powstać. Osoby, które ponosiłyby ciężary naprawienia przyszłych szkód, uiszczają bez względu na to, czy szkody rzeczywiście nastąpią, pewne, zwykle periodyczne, opłaty na rzecz tych instytucji, zwane premiami (składkami). Opłaty te są w stosunku do wysokości ewentualnych szkód niewielkim ciężarem dla osób zwalniających się od groźnej dla nich ewentualnej odpowiedzialności. Instytucje finansowe, które naprawiają szkody zamiast osób odpowiedzialnych, mogą, wobec wielkiej liczby zawieranych umów i statystycznych, dających się przewidzieć sum potrzebnych na odszkodowania, traktować te sumy jako normalne pozycje bierne swych przedsiębiorstw pokrywane $\mathrm{w}$ całości, a nawet $\mathrm{z}$ nadwyżką z pozycji czynnych, pochodzących z inkasowanych premii. Umowy, przez które następuje takie przerzucenie odpowiedzialności na instytucje finansowe, nazywają się umowami ubezpieczenia, gdyż ubezpieczają poszkodowanym uzyskanie odszkodowania, natomiast osoby, które musiałyby ponosić obowiązki naprawienia szkód, uwalniają od bardzo groźnej nieraz dla nich odpowiedzialności ${ }^{31}$.

Również A. Ohanowicz podkreślał, że podział na dwa klasyczne systemy odpowiedzialności ex delicto i ex contractu stanowił uproszczenie już na gruncie Kodeksu zobowiązań. Istniały bowiem poza tym kodeksem pewne przypadki, wykazujące właściwości specyficzne i w znakomitej większości niedające się zamknąć do żadnego ze znanych Kodeksowi zobowiązań systemów odpowiedzialności. Dotyczyło to przede wszystkim umów ubezpieczeniowych, odszkodowań z tytułu wywłaszczenia

\footnotetext{
30 F. Zoll, Zobowiązania w zarysie, Warszawa 1945, s. 81, 83-84.

31 F. Zoll, Zobowiązania...
} 
oraz odszkodowań z tytułu szkód wyrządzonych przy wykonywaniu uprawnień $^{32}$. Następnie, na gruncie Kodeksu cywilnego, A. Ohanowicz przeciwstawiał przypadki odpowiedzialności za szkodę wynikające z umowy (np. umowy ubezpieczenia albo gwarancyjnej), przypadkom opartym na przepisie ustawowym. Przypadki odpowiedzialności ustawowej mogły być jego zdaniem bardzo różnorodne i bazowały przede wszystkim na zasadzie winy, w mniejszym stopniu na zasadzie ryzyka, wyjątkowo zaś na zasadzie słuszności. Do ważniejszych przypadków obowiązku wynagrodzenia szkody powstających z mocy ustawy zaliczał:

a) czyny niedozwolone,

b) naruszenie obowiązków wynikających ze zobowiązania przez niewykonanie lub nienależyte wykonanie świadczenia,

c) ustawowe gwarancje, np. istnienia wierzytelności przy jej zbyciu (art. 516 k.c.) lub gwarancje pełnomocnika co do istnienia i zakresu jego upoważnia (art. 103 k.c.),

d) dozwolone wtargnięcie w cudzą sferę prawną celem odwrócenia grożącego niebezpieczeństwa (art. 142 k.c.),

e) nadużycie pomocy własnej (art. 343 k.c.),

f) nielojalne zachowanie przy zawarciu umowy (culpa in contrahendo), np. zawarcie umowy przy świadomości niemożliwości świadczenia (art. $387 \$ 2$ k.c.) ${ }^{33}$.

Podstawowy charakter, gdy chodzi o klasyfikacje odpowiedzialności, miały prace W. Warkałły. Autor ten dokonał rozróżnienia typów, rodzajów i reżimów odpowiedzialności. Wśród typów odpowiedzialności ze względu na kryterium sprawstwa rozróżniał odpowiedzialność sprawczą i gwarancyjną. Zważywszy na to, z czyich środków naprawiana jest szkoda, wyróżniał kolejne dwa typy, tj. odpowiedzialność indywidualną i repartycyjną. Następnie wyodrębniał rodzaje odpowiedzialności, a mianowicie: ze względu na pełność kompensacji - odpowiedzialność pełną i niepełną, oraz ze względu na pewność kompensacji - odpowiedzialność za winę, z tytułu ryzyka, absolutną oraz odpowiedzialność na

32 A. Ohanowicz, Rodzaje odpowiedzialności za szkodę wedle Kodeksu zobowiązań i ich wzajemny stosunek [w:] A. Ohanowicz, Wybór prac, Warszawa 2007, s. 1103.

33 A. Ohanowicz [w:] A. Ohanowicz, J. Górski, Zarys prawa zobowiązań, Warszawa 1970, s. 49-50. 
zasadach współżycia społecznego. Witold Warkałło wskazywał także na reżimy odpowiedzialności ze względu na jej źródło, tj. odpowiedzialność z tytułu czynów niedozwolonych (ex delicto), odpowiedzialność za szkodę wynikłą z niewykonania zobowiązania (ex contractu) oraz odpowiedzialność za szkodę wynikłą z innych źródeł. Podsumowując, w ujęciu W. Warkałły odpowiedzialność ubezpieczeniowa stanowiła typ odpowiedzialności gwarancyjnej oraz repartycyjnej, rodzaj odpowiedzialności niepełnej, ale absolutnej, i wreszcie, reżim odpowiedzialności odrębny od odpowiedzialności ex delicto i ex contractu, wynikający $\mathrm{z}$ innych źródeł ${ }^{34}$.

Do proponowanego przez W. Warkałłę podziału odpowiedzialności na typy krytycznie odniósł się T. Dybowski. Pierwszy przeprowadzony przez W. Warkałłę podział, zakładający wyróżnienie odpowiedzialności sprawczej i gwarancyjnej ze względu na kryterium sprawstwa szkody, skrytykował z uwagi na swoiste pojmowanie sprawstwa, kolidujące jego zdaniem z tradycją i poczuciem językowym. Drugi podział, zakładający wyróżnienie odpowiedzialności indywidualnej oraz gwarancyjno-repartycyjnej na podstawie pochodzenia środków, ma zdaniem T. Dybowskiego znaczenie raczej ekonomiczne, a nie prawne. Od strony stosunków prawnych obowiązek świadczenia obciąża bowiem nie ogół podmiotów opłacających składki, ale zakład ubezpieczeńn ${ }^{35}$.

Tomasz Dybowski wskazał również na podstawy odpowiedzialności, wyróżniając przede wszystkim odpowiedzialność ex delicto i ex contractu. Przyznał jednak, że chociaż klasyczne rozróżnienie podstaw odpowiedzialności zachowało swój walor, to jednak we współczesnym systemie prawa cywilnego wyłącznie dychotomiczny podział odpowiedzialności odszkodowawczej jest nie do utrzymania. Jego zdaniem wśród sytuacji, w których powstaje obowiązek naprawienia szkody, można wyróżnić następujące grupy przypadków:

a) obowiązek odszkodowawczy wynika z zawartej umowy lub zastępującej tę umowę normy prawnej,

34 W. Warkałło, Odpowiedzialność..., passim, oraz W. Warkałło, Ubezpieczenie a odpowiedzialność..., s. 98.

35 T. Dybowski, Naprawienie..., s. 174-175. 
b) obowiązek odszkodowawczy jest następstwem wyrządzenia szkody na skutek niewykonania lub nienależytego wykonania zobowiązania (odpowiedzialność kontraktowa),

c) obowiązek odszkodowawczy jest następstwem wyrządzenia szkody czynem niedozwolonym lub przez zdarzenia zbliżone do czynów niedozwolonych (odpowiedzialność deliktowa),

d) obowiązek naprawienia szkody związany jest z faktem wyrządzenia szkody na skutek wykonywania określonych praw podmiotowych lub rozwijania określonej działalności na skutek upoważnienia ustawowego,

e) obowiązek odszkodowawczy jest następstwem szkody wyrządzonej w wyniku legalnego wykonywania funkcji władczych przez organy państwowe,

f) obowiązek odszkodowawczy jest następstwem poniesienia szkody w interesie drugiej osoby lub w interesie wspólnym.

Pozostając wierny ograniczaniu pojęcia odpowiedzialności odszkodowawczej do sytuacji, w których obowiązek naprawienia szkody jest następstwem przypisania określonemu podmiotowi naruszenia porządku prawnego, T. Dybowski stwierdzał, że o odpowiedzialności w ścisłym rozumieniu można mówić jedynie w przypadkach wymienionych w lit. b) i c), ewentualnie, przy szerokim ujmowaniu bezprawności, również w przypadkach wymienionych w lit. d). Obowiązek wymieniony w lit. a) na pewno nie mieści się w pojęciu odpowiedzialności. Sytuacje wymienione w lit. e) i f) wykazują natomiast cechy szczególne ${ }^{36}$.

Witold Czachórski z kolei odróżniał trzy grupy przypadków, w których przedmiotem świadczenia jest odszkodowanie. Poza szkodą wyrządzoną czynem niedozwolonym oraz szkodą wyrządzoną przez niewykonanie lub nienależyte wykonanie zobowiązania autor ten wskazuje na przypadki, gdy ktoś w drodze umowy zobowiązuje się wobec kontrahenta do świadczenia odszkodowawczego z tytułu szkody, którą temu kontrahentowi wyrządzi on sam, osoba trzecia lub zajście jakiegoś zdarzenia. Świadczenie odszkodowawcze staje się wtedy głównym świadczeniem na rzecz wierzyciela, jakkolwiek wyrządzenie szkody nie stwarza samo

36 T. Dybowski, Naprawienie..., s. 185-197. 
w sobie nowego i samoistnego zobowiązania odszkodowawczego między stronami. Typowym przykładem są tu niektóre umowy ubezpieczenia i tzw. umowy gwarancyjne ${ }^{37}$.

Podobne rozróżnienie przeprowadził A. Szpunar. Wyróżnił cztery grupy stanów faktycznych, w których powstaje obowiązek świadczenia odszkodowania. Pierwsze dwie grupy to odpowiedzialność ex delicto i ex conractu. Trzecia grupa to odpowiedzialność ubezpieczeniowa, w ramach której to samo zdarzenie może jednocześnie rodzić odpowiedzialność sprawcy szkody oraz uzasadnia powstanie obowiązku zakładu ubezpieczeń do określonych świadczeń, zwykle odszkodowawczych. Czwarta grupa obejmuje mozaikę różnorodnych stanów faktycznych, w szczególności działanie podjęte w interesie cudzym lub wspólnym, wykonywanie praw podmiotowych oraz odpowiedzialność za legalne działanie administracji publicznej (art. 161 k.p.a.) ${ }^{38}$.

Według Z. Radwańskiego o odpowiedzialności odszkodowawczej można mówić, jeżeli uszczerbek powstał w związku z faktami wskazanymi w systemie prawnym i jakaś osoba zostaje zobowiązana do naprawienia uszczerbku poszkodowanemu. Autor ten wyróżniał zasady odpowiedzialności, tj. reguły decydujące o tym, komu przypisać odpowiedzialność za zdarzenie powodujące szkodę, oraz rodzaje odpowiedzialności, tj. wskazany przez system prawny zespół reguł określających odpowiedzialność odszkodowawczą. Wśród zasad Z. Radwański wskazywał na: zasadę winy, zasadę ryzyka, zasadę słuszności oraz zasadę gwarancyjno-repartycyjną, której klasycznym przykładem są ubezpieczenia. Jedynym uzasadnieniem dla tej odpowiedzialności jest współuczestnictwo potencjalnych sprawców szkód lub osób nimi zagrożonych w tworzeniu ogólnego funduszu, z którego wypłaca się odpowiednie odszkodowania. W tym przypadku funduszem zarządza zakład ubezpieczeń. Zbigniew Radwański zauważał, że kiedyś fundamentalną zasadę odpowiedzialności stanowiła wina. Obecnie dostrzec należy postępujące zaostrzenie odpowiedzialności i nie wydaje się, by którejkolwiek ze wskazanych

37 W. Czachórski, A. Brzozowski, M. Safjan, E. Skowrońska-Bocian, Zobowiązania. Zarys wykładu, Warszawa 2009, s. 85-86.

38 A. Szpunar, Odszkodowanie..., s. 17. 
zasad można było przyznać walor nadrzędny w tym sensie, by stosować ją zawsze wtedy, gdy brakuje rozstrzygnięć ustawowych. Nie należy więc przepisów wyrażających inne zasady niż zasada winy interpretować restryktywnie ${ }^{39}$.

Wśród rodzajów odpowiedzialności Z. Radwański wyróżniał odpowiedzialność deliktową, odpowiedzialność kontraktową, inne rodzaje odpowiedzialności, szczególnie odpowiedzialność gwarancyjno-repartycyjną, wyrażającą się zwłaszcza w ubezpieczeniach, i wreszcie odpowiedzialność państwa za szkody wyrządzone przy dozwolonym wykonywaniu funkcji władczych oraz przy wykonywaniu przez jakiekolwiek osoby praw podmiotowych lub za szkody poniesione w cudzym lub wspólnym interesie. Świadczenie ubezpieczyciela w ramach odpowiedzialności gwarancyjno-repartycyjnej ma - w odróżnieniu od osoby odpowiadającej ex contractu - charakter świadczenia pierwotnego, a nie zastępczego. Natomiast w przeciwieństwie do odpowiedzialności ex delicto zobowiązanym do świadczenia nie jest sprawca szkody, lecz inna osoba (zakład ubezpieczeń) $)^{40}$.

Wyczerpującą klasyfikację odpowiedzialności za szkodę przedstawia również M. Kaliński, wyróżniając typy, reżimy oraz zasady odpowiedzialności. Według tego autora celowość wyróżnienia szczególnych typów odpowiedzialności odszkodowawczej wynika z jej rosnącego znaczenia we współczesnych systemach prawnych, co sprawia, że kryteria, źródła oraz zasady odpowiedzialności stają się niewystarczające. Wśród typów M. Kaliński wyróżnia: ze względu na kryterium pełności kompensacji - odpowiedzialność pełną i niepełną, ze względu na kryterium ekonomicznego rozkładu ciężaru odpowiedzialności - odpowiedzialność indywidualną oraz repartycyjną, oraz ze względu na kryterium sprawstwa - odpowiedzialność sprawczą i gwarancyjną.

W obrębie podziału na reżimy ze względu na źródło powstania poza odpowiedzialnością z tytułu niewykonania lub nienależytego wykonania

39 Z. Radwański, A. Olejniczak, Zobowiązania - część ogólna, Warszawa 2016, s. $84-85$.

40 Z. Radwański, A. Olejniczak, Zobowiązania..., s. 85-86. 
zobowiązania przez dłużnika (ex contractu), z tytułu czynów niedozwolonych (ex delicto) oraz odpowiedzialnością gwarancyjną obejmującą m.in. ubezpieczenia gospodarcze, M. Kaliński wyróżnia jeszcze odpowiedzialność przy wykonywaniu funkcji publicznych, odpowiedzialność z tytułu szkody przy wykonywaniu praw podmiotowych, a także odpowiedzialność z tytułu poniesienia szkody w cudzym lub wspólnym interesie. Jeżeli chodzi o zasady odpowiedzialności, M. Kaliński wyróżnia natomiast zasadę winy, zasadę bezprawności, zasadę ryzyka, zasadę odpowiedzialności absolutnej oraz zasadę słuszności.

Prezentację własnego stanowiska wypada rozpocząć od uporządkowania terminologii. Być może kwestia ta ma znaczenie drugorzędne, nie należy jej jednak zupełnie pomijać. Porównując wypowiedzi doktryny, trudno pozbyć się wrażenia dowolności i chaosu. Większość autorów nie przywiązuje do terminologii wagi, wyróżniając określone grupy stanów faktycznych, w których może wystąpić obowiązek naprawienia szkody. Tak czynią autorzy przedwojenni, a także A. Ohanowicz, A. Szpunar, W. Czachórski i w zasadzie T. Dybowski.

Słowo „reżim” wywodzi się z łacińskiego regimen - kierownictwo. Oznacza po pierwsze, system rządów, w którym władza stosuje wobec społeczeństwa przemoc i ucisk polityczny, a także: rząd stosujący takie metody, po drugie, ściśle ustalony tryb postępowania. Niekiedy używa się go również w znaczeniu zespołu zasad wyznaczających postępowanie. To trzecie znaczenie jest istotne ze względu na przedmiot rozważań. Sformułowania "rodzaj” i "typ” to jednostki klasyfikacyjne używane często zamiennie, przy czym intuicyjnie „rodzaj” wydaje się być jednostką szerszą. Nie jest tak jednak zawsze, przykładowo w taksonomii rodzaj jest jednostką klasyfikacyjną znacznie węższą od typu. W prawie cywilnym powszechnie przyjęło się również sformułowanie „zasada odpowiedzialności”. Używa się go, poszukując odpowiedzi na pytanie, komu należy przypisać odpowiedzialność za zdarzenie powodujące szkodę oraz w jaki sposób osoba potencjalnie odpowiedzialna może się od tej odpowiedzialności zwolnić.

Mając to wszystko na uwadze, wydaje się, że można zaakceptować terminologię zaproponowaną przez M. Kalińskiego, który wyróżnia 
typy, reżimy i zasady odpowiedzialności. Nomenklatura używana przez W. Warkałłę, który wyodrębnia typy, rodzaje i reżimy, wywołuje wątpliwości odnośnie do wzajemnej hierarchii rodzajów oraz typów, a także nieuwzględnienia zasad odpowiedzialności, co wydaje się sprzeczne ze stanowiskiem upowszechnionym obecnie w doktrynie. Propozycja Z. Radwańskiego, który wyróżnia rodzaje i zasady odpowiedzialności, została sformułowana na potrzeby podręcznika i wydaje się mieć charakter nieco uproszczony. Wyodrębnienie rodzajów zamiast reżimów odpowiedzialności odpowiada polskiej tradycji językowej, jednak nie uwzględnia, że reżim w odróżnieniu od rodzaju wskazuje nie tylko na kryterium źródła odpowiedzialności, ale również na pewne reguły rządzące odpowiedzialnością odszkodowawczą ze względu na jej źródło.

Wstępnie zatem na potrzeby niniejszych rozważań można zastanowić się nad usytuowaniem odpowiedzialności ubezpieczeniowej w obrębie typów odpowiedzialności wyróżnianych ze względu na trzy kryteria, a mianowicie: 1) sprawstwa, 2) pełności kompensacji oraz 3) ekonomicznego rozkładu ciężaru odpowiedzialności, w obrębie reżimów odpowiedzialności, ze względu na źródło powstania odpowiedzialności i reguły obowiązujące przy jej ustalaniu, oraz wreszcie, w obrębie zasad odpowiedzialności wyróżnianych ze względu na kryterium, komu można przypisać odpowiedzialność i w jaki sposób osoba, której odpowiedzialność próbuje się przypisać, może uniknąć odpowiedzialności. Pierwszorzędne znaczenie zdaje się mieć jednak, mające tradycje jeszcze w prawie rzymskim, odróżnienie reżimów odpowiedzialności, od niego więc wypadnie rozpocząć. Następnie omówione zostanie zagadnienie zasad odpowiedzialności ubezpieczeniowej. Usytuowanie odpowiedzialności ubezpieczeniowej w obrębie typów odpowiedzialności będzie rozważane na końcu.

\subsection{Reżim odpowiedzialności ubezpieczeniowej}

Celem autora jest odpowiedź na pytanie, do którego z reżimów odpowiedzialności należy zakwalifikować odpowiedzialność ubezpieczeniową, w szczególności zaś, czy stanowi ona odrębny reżim od odpowiedzialności ex conractu oraz ex delicto. Autor nie zamierza zaś wikłać się w spory 
doktrynalne dotyczące wyróżnienia innych jeszcze reżimów. Chcąc rozstrzygnąć zasadniczy problem, trudno jednak zupełnie pominąć tę ostatnią kwestię. Najbardziej rozbudowana klasyfikacja reżimów odpowiedzialności, poza odpowiedzialnością ex delicto, ex contractu oraz odpowiedzialnością gwarancyjną, wyróżnia jeszcze odpowiedzialność:

1) z tytułu wyrządzenia szkody przy wykonywaniu funkcji publicznych,

2) z tytułu wyrządzenia szkody przy wykonywaniu praw podmiotowych,

3) z tytułu poniesienia szkody w cudzym lub wspólnym interesie,

4) z tytułu nadużycia pomocy własnej (art. 343 k.c.),

5) odpowiedzialność z tytułu culpa in contrahendo.

Dwa ostatnie reżimy wyróżniane przez A. Ohanowicza i W. Górskie$\mathrm{go}^{41}$ obecnie przez większość przedstawicieli doktryny uważane są za odpowiedzialność z tytułu czynów niedozwolonych. Poszerzanie o nie klasyfikacji wydaje się zatem zbędne. Według W. Czachórskiego oraz W. Warkałły reżim deliktowy stanowi kategorię zbiorczą i obejmuje także odpowiedzialność z tytułu wyrządzenia szkody przy wykonywaniu funkcji publicznych, z tytułu wyrządzenia szkody przy wykonywaniu praw podmiotowych i z tytułu poniesienia szkody w cudzym lub wspólnym interesie. Z kolei A. Szpunar oraz Z. Radwański łączą wszystkie te sytuacje w jedną grupę, tworząc swoisty worek, do którego wrzucają przypadki odpowiedzialności niedające się łatwo przyporządkować do odpowiedzialności ex ontractu, ex delicto oraz odpowiedzialności gwarancyjnej ${ }^{42}$.

Maciej Kaliński, początkowo wyodrębniając jako oddzielne kategorie odpowiedzialność za szkody wyrządzone przy wykonywaniu funkcji publicznych oraz odpowiedzialność za szkody wyrządzone przy wykonywaniu praw podmiotowych, ostatecznie jednak dochodzi do wniosku, że przynajmniej tę pierwszą można objąć reżimem ex delicto. Za takim zabiegiem przemawia, po pierwsze, fragmentaryczne uregulowanie omawianej odpowiedzialności oraz konieczność stosowania do

41 Zob. A. Ohanowicz, J. Górski, Zarys...

42 A. Szpunar, Odszkodowanie...; Z. Radwański, A. Olejniczak, Zobowiązania..., s. 86. 
niej przepisów o czynach niedozwolonych. Po drugie, nie stoi temu na przeszkodzie okoliczność, że źródłem szkody jest zachowanie zgodne z prawem, bezprawność nie stanowi bowiem immanentnej cechy czynu niedozwolonego. Powoływany autor twierdzi natomiast, że nie można reżimem ex delicto objąć przypadków wyrządzenia szkody w związku $\mathrm{z}$ wykonywaniem praw podmiotowych, które stanowią odrębny reżim ${ }^{43}$. Argumentem na poparcie tej ostatniej tezy ma być okoliczność, że gdy uprawniony wyrządza szkodę, korzystając z określonej w prawie przedmiotowym sfery możności postępowania, nie da się powiedzieć, że do wyrządzenia szkody doszło poza stosunkiem zobowiązaniowym.

Argument ten wydaje się dosyć wątpliwy. Z tego, że komuś przysługuje jakieś prawo podmiotowe, będące zresztą pochodną lub fragmentem prawa własności, nie wynika, że pomiędzy nim a osobami, które mają jego własność respektować, powstaje stosunek zobowiązaniowy. Stosunek taki powstanie moim zdaniem dopiero, gdy uprawniony, wykonując swoje prawo, wyrządzi szkodę. Na gruncie Kodeksu cywilnego odpowiedzialność za szkodę wyrządzoną w wykonywaniu praw podmiotowych dotyczy dwóch sytuacji o marginalnym znaczeniu praktycznym, a mianowicie wejścia przez właściciela gruntu na grunt sąsiedni celem usunięcia zwieszających się z jego drzew gałęzi i owoców (art. 149 k.c.) oraz pościgu za rojem pszczół (art. 182 k.c.). Tworzenie dla tych dwóch sytuacji odrębnego reżimu odpowiedzialności wydaje się nie mieć większego sensu; nie odpowiada choćby na pytanie, jakie przepisy stosować do tych przypadków w zakresie nieuregulowanym, przykładowo gdy chodzi o naprawienie szkody na osobie albo o przedawnienie roszczeń.

Podobne racje można, jak się zdaje, wysunąć wobec wyodrębnienia jako odrębnego reżimu przypadków naprawienia szkody poniesionej w cudzym lub wspólnym interesie. Na gruncie Kodeksu cywilnego dotyczy to przypadków wskazanych w art. 438 oraz 142, przy czym kwalifikacja tego drugiego przepisu jest sporna. Poza Kodeksem cywilnym wskazuje się na przepisy Kodeksu morskiego o awarii wspólnej (art. 250, 252 $\$ 1$ k.m.), których zakres stosowania jest zresztą ograniczony choćby dlatego, że przewóz morski niemal zawsze zawiera elementy trans-

43 M. Kaliński, Szkoda..., s. 27-28. 
graniczne. W realiach współczesnego handlu dosyć trudno wyobrazić sobie zagranicznego kontrahenta godzącego się na stosowanie prawa polskiego. Dodać można, że art. 438 k.c., mający relatywnie największe znaczenie, usytuowany jest wśród przepisów o odpowiedzialności deliktowej, wobec czego zasadne wydaje się stosowanie w odniesieniu do niego przynajmniej odpowiednio reguł dotyczących tej odpowiedzialności ${ }^{44}$. Odnośnie do szkód wyrządzonych przy usuwaniu zwieszających się gałęzi lub owoców (art. 149 k.c.), w pościgu za rojem pszczół (art. 182 k.c.) lub uszkodzenia cudzej rzeczy dla odwrócenia grożącej komuś szkody (art. 142 k.c.) najrozsądniejsza wydaje się zatem propozycja stosowania per analogiam przepisów o czynach niedozwolonych, co dotyczyłoby art. 440-449 k.c.

Podsumowując powyższy wywód, wydaje się, że wydzielenie jako odrębnych reżimów odpowiedzialności przypadków odpowiedzialności: 1) z tytułu poniesienia szkody w cudzym lub wspólnym interesie, 2) z tytułu nadużycia pomocy własnej (art. 343 k.c.)

wydaje się zbędne, a w każdym razie niewiele wnosi. Jak wcześniej wskazano, zastosowanie słowa „reżim” zamiast „rodzaj” miało na celu zwrócenie uwagi, że podział ze względu na źródło powstania zobowiązania wywołuje również konsekwencje w sferze reguł ustalania odpowiedzialności. Innymi słowy, wszystkie przypadki wyrządzania znajdujące się poza reżimem ex contractu oraz reżimem gwarancyjnym można zakwalifikować do reżimu deliktowego. Tak czynili autorzy przedwojenni, przyznając, że termin „odpowiedzialność z tytułu czynów niedozwolonych" jest terminem nieścisłym, obejmującym również sytuacje, które trudno określić mianem czynu niedozwolonego sensu stricto, podobnie zresztą jak reżim odpowiedzialności z tytułu niewykonania umowy obejmuje wszystkie sytuacje wyrządzenia szkody w ramach istniejącego stosunku zobowiązaniowego.

${ }_{44}$ W. Czachórski, A. Brzozowski, M. Safjan, E. Skowrońska-Bocian, Zobowiązania..., s. 270. Trudno wskazać opracowanie poświęcone wyłącznie art. 438 k.c. Zob. przede wszystkim A. Kubas, Wynagrodzenie szkody poniesionej w cudzym interesie, SC 1979, t. XXX, s. 91 i n. Na szczególny charakter unormowania z art. 438 k.c. zwraca uwagę m.in. A. Śmieja. A. Śmieja, Czyny niedozwolone [w:] System Prawa Prywatnego, red. Z. Radwański, t. 6, Prawo zobowiązań - część ogólna, red. A. Olejniczak, Warszawa 2014, s. 773-774. 
Pozostaje odpowiedzieć na pytanie zasadnicze ze względu na temat pracy, a mianowicie, czy istnieje potrzeba wyodrębniania odrębnego reżimu odpowiedzialności gwarancyjnej poza reżimami odpowiedzialności ex delicto oraz ex contractu. Podkreślić należy, że wszyscy powoływani wyżej autorzy wypowiadający się na gruncie przepisów Kodeksu cywilnego są zgodni co do potrzeby wyodrębniania takiego reżimu. Na gruncie Kodeksu zobowiązań reżim taki wyróżniali przynajmniej F. Zoll oraz A. Ohanowicz. Zgodnie ze stanowiskiem doktryny reżim odpowiedzialności gwarancyjnej ma charakteryzować się na tle odpowiedzialności ex delicto tym, że doznanie szkody nie stwarza samo w sobie nowego i samoistnego zobowiązania między stronami, jej źródło stanowi bowiem zawarta wcześniej umowa, oraz na tle odpowiedzialności ex contractu tym, że obowiązek świadczenia odszkodowawczego ma charakter pierwotny ${ }^{45}$.

Ze spostrzeżeniami tymi, jak również samym wyodrębnieniem odpowiedzialności gwarancyjnej nie sposób chyba polemizować, konkluzję wypada jednak opatrzyć pewnymi zastrzeżeniami. Dotyczyć one muszą raz jeszcze kwestii terminologicznych. Jak wiadomo, pojęcia odpowiedzialności ex contractu nie można utożsamiać z odpowiedzialnością z tytułu niewykonania umowy. Odpowiedzialność ex contractu to odpowiedzialność realizująca się w obowiązku świadczenia odszkodowania $\mathrm{z}$ tytułu niewykonania lub nienależytego wykonania zobowiązania mogącego mieć źródło umowne, jak i pozaumowne. Odpowiedzialność gwarancyjna nie jest w tym sensie odpowiedzialnością ex contractu, nie jest bowiem odpowiedzialnością z tytułu niewykonania zobowiązania ani nawet odpowiedzialnością z tytułu niewykonania umowy. Nie znajdują do niej zatem zastosowania reguły zawarte w art. 471-486 k.c. Z drugiej strony odpowiedzialność ubezpieczeniowa jest odpowiedzialnością umowną w tym sensie, że u podstaw jej powstania leży niewykonanie umowy obligacyjnej, na mocy której dłużnik zobowiązuje się zapłacić odszkodowanie za szkodę wyrządzoną przez osobę trzecią albo wynikającą z działania okoliczności niezależnych od człowieka. Do wykonania tej umowy znajdują zastosowanie ogólne reguły wykonywania zobowiązań, a zdaniem niektórych przedstawicieli doktryny,

45 Tak również M. Orlicki, Umowa ubezpieczenia [w:] System..., t. 8, s. 721-722. 
choć ten pogląd jest wątpliwy, również reguły dotyczące wykonania oraz skutków niewykonania zobowiązań wzajemnych. W razie zaś niewykonania wynikającego z umowy świadczenia głównego polegającego na zapłacie odszkodowania ubezpieczyciel będzie odpowiadał również za niewykonanie zobowiązania na zasadach ogólnych wskazanych w art. 471-486 k.c.

Reżim odpowiedzialności gwarancyjnej nie podlega regułom odpowiedzialności z tytułu niewykonania ani nienależytego wykonania zobowiązania umownego, ani tym bardziej regułom odpowiedzialności deliktowej ( $\mathrm{z}$ wyjątkiem odpowiedzialności ubezpieczyciela $\mathrm{z}$ tytułu zawartej umowy ubezpieczenia OC, która ma charakter akcesoryjny wobec odpowiedzialności sprawcy szkody i w tym sensie może podlegać, zależnie od zakresu ubezpieczenia, zarówno regułom odpowiedzialności ex delicto, jak również ex contractu). Reguły odpowiedzialności gwarancyjnej wynikają przede wszystkim z treści umowy będącej jej podstawą, jak również z przepisów prawa regulujących tę umowę, ewentualnie z zasad współżycia społecznego oraz ustalonych zwyczajów (art. 56 oraz 65 k.c.).

Odpowiedzialności gwarancyjnej nie można oczywiście utożsamiać z odpowiedzialnością ubezpieczeniową. Reżim odpowiedzialności gwarancyjnej poza odpowiedzialnością wynikającą z zawartej umowy ubezpieczenia obejmuje również odpowiedzialność z tytułu innych umów, na podstawie których ktoś zobowiązuje się wobec kontrahenta do naprawienia szkody powstałej wskutek zdarzeń określonych w umowie. Spośród uregulowanych w Kodeksie cywilnym wchodzą w grę umowa o świadczenie przez osobę trzecią (art. 391 k.c.), umowa o zwolnienie dłużnika z obowiązku świadczenia (art. 392 k.c.), klauzula del credere w umowach pośrednictwa (art. $761^{7}$ k.c.) oraz umowa poręczenia (art. 876 k.c. $)^{46}$. Indywidualne umowy gwarancyjne mają jednak niepomiernie mniejsze znaczenie praktyczne niż umowy ubezpieczenia ${ }^{47}$.

46 Dotyczy to sytuacji, gdy obowiązek świadczenia, o którym mowa w art. 392 k.c., albo zobowiązanie, o którym mowa w art. 872 k.c., mają charakter odszkodowawczy, to jest polegają na naprawieniu szkody.

47 T. Dybowski, Naprawienie..., s. 186; M. Kaliński, Szkoda..., s. 47. 
Wydaje się, że należy tu również zakwalifikować sytuacje, w których zobowiązanie do naprawienia szkody przed jej doznaniem istnieje z mocy ustawy, a świadczenie odszkodowawcze ma charakter pierwotny ${ }^{48}$.

Brak wyróżnienia reżimu odpowiedzialności gwarancyjnej jako reżimu odrębnego od odpowiedzialności ex contractu, ewentualnie brak zrozumienia relacji między obydwoma reżimami prowadzi często do błędnych wniosków wykluczających możliwość domagania się odszkodowania z tytułu nienależytego wykonania przez ubezpieczyciela umowy ubezpieczenia w szczególności za zwłokę. Zagadnienie to doskonale ilustruje spór o naturę odpowiedzialności ubezpieczeniowej toczący się w prawie angielskim. Spór ten, choć dotyczy reguł wypracowanych na gruncie common law, skupia ważniejsze problemy odnoszące się do odpowiedzialności ubezpieczeniowej w prawie polskim.

Finałem prowadzonej w Anglii dyskusji stało się dodanie w maju 2017 r. do ustawy o ubezpieczeniu z 2015 r. (Insurance Act) art. 13a. Przepis zostanie szerzej omówiony w rozdziale dotyczącym terminu spełnienia świadczenia ubezpieczyciela. Na obecnym etapie istotny jest jego ostatni fragment (art. 13a ust. 5), zgodnie z którym środki służące ubezpieczającemu w razie niewywiązania się przez ubezpieczyciela $\mathrm{z}$ obowiązku zapłaty świadczenia w terminie, w szczególności odszkodowanie za niewykonanie umowy, są niezależne od uprawnień do wyegzekwowania samej płatności z umowy, jak również należnych ubezpieczającemu odsetek i służą ubezpieczającemu oprócz tych uprawnień.

Wprowadzenie wskazanej reguły było reakcją ustawodawcy brytyjskiego na wykształcenie się w orzecznictwie lat 90. poprzedniego wieku koncepcji mówiącej, że odszkodowanie ubezpieczeniowe jest odszkodowaniem z tytułu niewykonania umowy, wobec czego nie można żądać odszkodowania za zwłokę w jego zapłaceniu ${ }^{49}$. Koncepcja ta powiązana

48 M. Kaliński, Szkoda..., s. 48.

49 Rozważania opieram na artykule N. Campbella, The nature..., cytowanym przez innych autorów angielskich. Zob. również J. Birds, Birds' Modern Insurance Law, London 2016, s. 301-302; M. Clarke, The Law of Insurance Contract, London 2009, § 70 A; J. Lowry, P. Rawlings, R. Merkin, Insurance Law. Doctrines and Principles, Oxford and Portland, Oregon 2011, s. 337. 
była z tezą, według której na mocy umowy ubezpieczenia ubezpieczyciel zobowiązuje się przeciwdziałać szkodzie albo zapewnia, że szkoda nie zajdzie, a zatem do niewykonania umowy (breach of contract) dochodzi wraz z zajściem szkody. Teza taka została wywiedziona z wypowiedzi Lorda Goffa w sprawie The Fanti ${ }^{50}$ odnoszącej się do tzw. klauzuli pay to be paid w ubezpieczeniu odpowiedzialności cywilnej. Najogólniej mówiąc, Lord Goff stwierdził, że świadczenie ubezpieczyciela w ubezpieczeniu odpowiedzialności cywilnej co do zasady polega na zwolnieniu ubezpieczającego z długu wobec osoby trzeciej i jest należne już wtedy, gdy taki dług powstaje.

Pomimo że Lord Goff miał na myśli ubezpieczenie odpowiedzialności cywilnej, w doktrynie angielskiej jego twierdzenia zaczęto odnosić do innych rodzajów ubezpieczeń. W sprawie The Italia Express (No 2) ${ }^{51}$, dotyczącej odszkodowania za zatonięcie statku, ubezpieczyciel przewlekał moment zapłaty, wskazując, że ubezpieczający sam zatopił statek. Ubezpieczający obaliwszy ten zarzut, wystąpił z roszczeniami za szkody pośrednie poniesione w związku ze zwłoką w wypłacie odszkodowania. Sąd oddalił te roszczenia, wskazując, że odszkodowanie ubezpieczeniowe jest odszkodowaniem z tytułu niewykonania umowy, a common law nie zna odszkodowania za niewypłacenie w terminie odszkodowania. Nadto według sądu suma ubezpieczenia pełni w ubezpieczeniu rolę zbliżoną do kwotowego ograniczenia odszkodowania.

Najczęściej cytowanym precedensem jest sprawa Sprung v. Royal Ins. (UK) Ltd ${ }^{52}$, w której ubezpieczający zawarł ubezpieczenie chroniące przed nagłymi i nieprzewidzianymi wypadkami wywołującymi konieczność natychmiastowej naprawy albo wymiany maszyn dla przywrócenia ich normalnej pracy. Maszyny zostały zniszczone przez wandali. Ubezpieczyciel przez prawie cztery lata upierał się, że akty wandalizmu nie były objęte ochroną ubezpieczeniową, by w końcu zmienić zdanie i wypłacić odszkodowanie obejmujące wartość uszkodzonych maszyn

50 Fanti C-Trade SA v. Newcastle Protection \& Indemnity Association (The Fanti) [1991] 2 AC 1.

51 Ventouris v. Mountain, The Italia Express (No 2) [1992] 2 Lloyd's Rep. 281.

52 [1999] Lloyd's Rep. IR 111 (CA). 
wraz z odsetkami. Ubezpieczający domagał się ponadto odszkodowania związanego $\mathrm{z}$ przestojem produkcji, jednak $\mathrm{w}$ tym zakresie roszczenie zostało oddalone z powołaniem się na sprawę The Italia Express (No 2).

Ujmowanie odszkodowania ubezpieczeniowego jako odszkodowania z tytułu niewykonania umowy, poza niemożnością domagania się szkód poniesionych w związku ze zwłoką, rodzi jeszcze jeden trudny do zaakceptowania rezultat. Dotyczy on terminu wymagalności roszczenia względem ubezpieczyciela oraz biegu terminu przedawniania. Problem ilustruje wcześniejsza od wyżej przytaczanych sprawa Chandrix v. Argo Insurance Co. Ltd $^{53}$. W sprawie tej sześciu armatorów pozwało ubezpieczycieli o odszkodowanie za szkody związane z uszkodzeniami statków. Ubezpieczyciele powoływali się na przedawnienie, wskazując, że do uszkodzeń doszło przed ponad sześciu laty. Armatorzy argumentowali, że wysokość szkód była znana dopiero po opracowaniu raportów rzeczoznawców. Sąd stwierdził, że roszczenie ubezpieczeniowe nie jest roszczeniem o odzyskanie istniejącego długu ściśle pieniężnego, ale roszczeniem odszkodowawczym. Skoro tak, ma ono naturę roszczenia $z$ tytułu niewykonania umowy. Do niewykonania umowy przez ubezpieczycieli doszło już z chwilą zajścia wypadków i z tą chwilą roszczenia ubezpieczających stały się wymagalne, wobec tego roszczenia są przedawnione.

Stanowisko sądów angielskich w przedmiocie natury odpowiedzialności ubezpieczeniowej było dosyć powszechnie kontestowane w literaturze. Jego dogłębną krytykę przeprowadził przede wszystkim, podnosząc cały szereg argumentów, N. Campbell. Po pierwsze, zdaniem tego autora ze stwierdzenia, że ubezpieczyciel wypłaca odszkodowanie ubezpieczeniowe, nie płynie wniosek, że zobowiązanie ubezpieczyciela od zajścia wypadku ubezpieczeniowego polega na zapłacie odszkodowania z tytułu niewykonania umowy. W sytuacji gdy zobowiązanie wynikające z umowy polega na zapłacie określonej sumy pieniężnej, nie ma wielkiej różnicy w domaganiu się wykonania umowy oraz odszkodowania $z$ tytułu jej niewykonania, bo w obu wypadkach żądanie dotyczy przede wszystkim zapłaty sumy pieniężnej, która wbrew treści zobowiązania nie została

53 [1963] 2 Lloyd's Rep. 65. 
uiszczona. Z okoliczności, że odszkodowanie ubezpieczeniowe nie jest od początku oznaczone co do kwoty, nie wynika jednak, że ubezpieczyciel od zajścia wypadku odpowiada z tytułu niewykonania umowy ani że już z chwilą wypadku, zanim ubezpieczający sformułował jakiekolwiek roszczenia, popada w zwłokę. Argumentacja w sprawach Chandrix, The Italia Express (No 2) oraz Sprung pomija zasadnicze rozróżnienie między pierwotnym i wtórnym zobowiązaniem ubezpieczyciela, sprawiając wrażenie, że wierzytelność ubezpieczającego ogranicza się do prawa żądania odszkodowania z tytułu niewykonania umowy.

Po drugie, rozstrzygnięcia, o których mowa, nie mają oparcia w precedensach. Powoływanie się na słowa Lorda Goffa w sprawie Fanti jest chybione, ponieważ dotyczyły one wyłączenia ubezpieczenia OCi umów o podobnym skutku, w których wierzyciel rzeczywiście ma prawo oczekiwać, że sam nie będzie musiał płacić długu. Ponadto poglądy, które znalazły wyraz w sprawach The Italia Express (No 2) oraz Sprung, są sprzeczne z wcześniejszym rozstrzygnięciem w sprawie Jabbour v. Custodian Israeli Absentee Property dotyczącej ubezpieczenia mienia, w której sąd wyraźnie odrzucił koncepcję ujmującą świadczenie ubezpieczyciela jako zapobiegania szkodzie, stwierdzając, że ubezpieczyciel obiecuje zapłacić odszkodowanie w razie zajścia szkody. Linia orzecznictwa wyznaczona przez sprawę Sprung jest również sprzeczna z poglądami wyrażanymi przez autorytety w literaturze ubezpieczeniowej, a także $\mathrm{z}$ orzecznictwem w innych krajach common law.

Po trzecie, koncepcja przyjęta w sprawach The Italia Express (No 2) oraz Sprung jest sprzeczna $\mathrm{z}$ naturą prawną i celem ubezpieczenia mienia. $\mathrm{W}$ ubezpieczeniu tym zarzut braku należytej dbałości o własne mienie przez ubezpieczającego zwalnia ubezpieczyciela z odpowiedzialności. Przyjęcie, że obowiązek przeciwdziałania szkodzie ciąży również na ubezpieczycielu, prowadzi do absurdalnej konkluzji, że w razie zajścia wypadku każdej ze stron można zarzucić niewykonanie umowy, a ich odpowiedzialność wzajemnie się znosi. Nadto w ubezpieczeniu mienia obowiązkiem ubezpieczającego jest zgłoszenie szkody w określonym czasie. $\mathrm{Z}$ istnieniem takiego obowiązku po stronie ubezpieczającego trudno pogodzić twierdzenie, że ubezpieczyciel nie wykonuje umowy, zanim ubezpieczający zgłosił szkodę. Dodatkowo obciążanie ubez- 
pieczyciela obowiązkiem zapobiegania szkodzie jest równoznaczne z nałożeniem na niego obowiązku, którego nie chce on i zwykle nie potrafi wykonać. Ubezpieczyciele w praktyce nie zajmują się bowiem działaniami prewencyjnymi, ale wypłacaniem odszkodowań, stojąc nie przed, ale za ubezpieczającym. Akceptacja podobnego poglądu, że ubezpieczyciel nie tyle zobowiązuje się do zapobiegania szkodzie, ile udziela gwarancji, że szkoda nie zajdzie, również nie oddaje istoty ubezpieczenia, bo tego rodzaju gwarancja bardziej przypomina zakład niż ubezpieczenie. Wobec powyższego najwłaściwsze jest rozumienie zobowiązania ubezpieczyciela jako zobowiązania do naprawienia szkody w razie jej zajścia. Inaczej jest w ubezpieczeniu odpowiedzialności cywilnej, gdzie ubezpieczyciel może zapobiec poniesieniu uszczerbku przez ubezpieczającego na przykład poprzez zapłatę odszkodowania bezpośrednio osobie trzeciej.

Po czwarte, pogląd, według którego ubezpieczyciel przyjmuje na siebie obowiązek zapobiegania szkodzie, ewentualnie udziela gwarancji, że szkoda nie zajdzie, nie daje się pogodzić z powszechnie spotykanym $\mathrm{w}$ angielskich umowach ubezpieczenia mienia prawem zwolnienia się przezeń ze zobowiązania poprzez przywrócenie do stanu poprzedniego. Orzecznictwo niezmiennie traktuje wykonanie tego prawa jako spełnienie zobowiązania pierwotnego, podobnie jak w kontynentalnym upoważnieniu przemiennym. Sytuacja ubezpieczyciela jako dłużnika jest taka sama, jak gdyby od początku zobowiązywał się tylko do spełnienia tego świadczenia, które ostatecznie wybrał. W szczególności odpowiada on za zwłokę w przywróceniu do stanu poprzedniego. Według N. Campbella uprawnienie ubezpieczyciela do zwolnienia się ze zobowiązania przez przywrócenie do stanu poprzedniego może być wyjaśnione w satysfakcjonujący sposób jedynie przy założeniu, że stanowi ono facultas alternativa w zobowiązaniu pierwotnym.

Po piąte, wynikająca z uzasadnienia w sprawie The Italia Express (No 2) interpretacja wartości i sumy ubezpieczania jako ograniczenia odszkodowania $z$ tytułu niewykonania umowy jest nietrafna. Marine Insurance Act 1906 w ogóle nie dotyczy praw ubezpieczającego w razie niewykonania przez ubezpieczyciela umowy ubezpieczenia morskiego, ale jedynie pierwotnych zobowiązań stron, nie pretendując do roli wyczerpującego 
kodeksu ubezpieczeń morskich. Artykuł 1 tej ustawy określa umowę ubezpieczenia morskiego jako umowę, na mocy której ubezpieczyciel zobowiązuje się naprawić szkodę poniesioną przez ubezpieczającego w uzgodniony sposób. Z przepisu tego wynika zatem, że pierwotnym zobowiązaniem ubezpieczyciela jest naprawienie szkody, która zaistniała, nie zaś przeciwdziałanie szkodzie. Podobny wniosek płynie z szeregu innych artykułów wskazanej ustawy.

Jak wskazano na wstępie, w angielskim sporze o charakter odpowiedzialności ubezpieczeniowej wybrzmiewają nuty dobrze znane z polskiej literatury i orzecznictwa. Koncepcja, zgodnie z którą świadczenie ubezpieczyciela w ubezpieczeniu odpowiedzialności cywilnej polega na zwolnieniu ubezpieczającego lub ubezpieczonego z długu względem osoby trzeciej była analizowana również w Polsce (dominuje ona w literaturze niemieckiej, a ostatnio znalazła wyraz w tekście VVG). Pomimo że w bardziej pogłębionych polskich opracowaniach jest zwykle odrzucana, wciąż przewija się w wypowiedziach wielu autorów i można ją uznać za jedną z podstawowych koncepcji tłumaczących istotę ubezpieczenia odpowiedzialności cywilnej ${ }^{54}$.

Argumentacja sądów angielskich, że odszkodowanie ubezpieczeniowe nie ma z góry określonej wysokości, wobec czego nie można go traktować jako zapłaty długu pieniężnego z umowy, przypomina toczącą się w Polsce dyskusję co do tego, czy zobowiązanie ubezpieczyciela jest zobowiązaniem pieniężnym sensu stricto, czy też ma naturę typowo odszkodowawczą. Druga odpowiedź wyłącza w zasadzie stosowanie do odszkodowania ubezpieczeniowego przepisów o zobowiązaniach pieniężnych, w szczególności możliwość zmiany sumy ubezpieczeniowej w drodze waloryzacji sądowej (art. $358^{1} \$ 3$ k.c.). Kwestia będzie przedmiotem analizy również w niniejszej pracy.

54 Zob. w szczególności E. Kowalewski, Teoretyczny model świadczenia ubezpieczeniowego w ubezpieczeniu odpowiedzialności cywilnej, „Acta Universitatis Nicolai Copernici” 1990, z. XXVIII, s. 136 i n.; M. Krajewski, Ubezpieczenie..., s. 247-250 oraz wskazana tam literatura. 
Samo rozróżnienie między zapłatą długu wynikającego z umowy oraz zapłatą odszkodowania kieruje myśli w stronę rozważanego na samym wstępie tego rozdziału problemu, czy odpowiedzialność ubezpieczeniowa jest w ogóle odpowiedzialnością. Sądy angielskie w istocie przyjęły, że skoro ubezpieczyciel płaci odszkodowanie, to odpowiada za szkodę wyrządzoną przez siebie na skutek niewykonania umowy. Takie rozumowanie oraz nawiązania do wypowiedzi Lorda Goffa na gruncie charakteru zobowiązania ubezpieczyciela w ubezpieczeniu OC doprowadziły do wykształcenia się dosyć zaskakującej koncepcji mówiącej, że zobowiązanie ubezpieczyciela w ubezpieczeniu mienia polega na przeciwdziałaniu wystąpieniu wypadku ubezpieczeniowego, ewentualnie na udzieleniu gwarancji, że taki wypadek w ogóle nie zajdzie.

Błędy dotyczące rozróżnienia między wykonaniem pierwotnego zobowiązania wynikającego z umowy oraz wtórnym zobowiązaniem będącym następstwem jej niewykonania były popełniane również przez polskie sądy. Teza, że ubezpieczyciel nie odpowiada za zwłokę w spełnieniu swojego świadczenia, także pojawiała się w rodzimym orzecznictwie $^{55}$. To samo dotyczy nieprawidłowości polegającej na traktowaniu sumy ubezpieczenia jako bezwzględnego ograniczenia odpowiedzialności ubezpieczyciela. Przykładem orzeczenia zawierającego uchybienia, o których mowa, jest w szczególności wyrok Sądu Apelacyjnego w Łodzi z 29.01.1997 r., I ACa 59/9656, w którym stwierdzono, że „w przypadku opóźnienia w wypłacie odszkodowania za szkodę w mieniu objętym umową ubezpieczenia, ubezpieczającemu nie przysługuje w stosunku do ubezpieczyciela żądanie wyrównania na podstawie art. 471 k.c. w związku z art. $361 \$ 1$ k.c. utraconych w okresie opóźnienia korzyści, w postaci zysku, jaki rzecz ubezpieczona przyniosła ubezpieczającemu”.

55 Szerzej co do tych kwestii zob. B. Kucharski, Odpowiedzialność ubezpieczyciela za niewykonanie umowy ubezpieczenia [w:] Ubezpieczenia gospodarcze. Wybrane zagadnienia prawne, red. B. Gnela, Warszawa 2011, s. 47 i n.; S. Byczko, Roszczenia uprawnionego w przypadku nienależytego wykonania umowy przez ubezpieczyciela [w:] Ubezpieczenia gospodarcze. Wybrane zagadnienia prawne, red. B. Gnela, Warszawa 2011, s. 60 i n.

56 OSA 1997/6, poz. 37, s. 21, wraz z glosą krytyczną P. Szyszki, PS 1998/11-12, s. 192. Krytycznie co do ww. wyroku wypowiedział się również W.J. Katner. Zob. W.J. Katner [w:] Prawo gospodarcze i handlowe, t. 5, Prawo umów w obrocie gospodarczym, red. S. Włodyka, Warszawa 2001, s. 234. 
W sprawie chodziło o kradzież ciągnika IVECO. Ubezpieczyciel nie wypłacił $\mathrm{w}$ terminie odszkodowania z ubezpieczenia OC, powołując się na niezakończenie postępowania karnego. Ubezpieczający prowadzący przedsiębiorstwo transportowe pozwał ubezpieczyciela o wypłatę pieniędzy, które należały mu się na mocy umowy. Ponadto domagał się jednak wynagrodzenia szkody, jaką poniósł, nie mogąc realizować dalszych zleceń przewozowych. Sąd Apelacyjny w Łodzi, odwrotnie niż sądy angielskie, przyjął, że odpowiedzialność ubezpieczyciela ograniczona jest wyłącznie do pierwotnego świadczenia wynikającego z umowy. Odszkodowanie ubezpieczeniowe obejmuje jedynie damnum emergens, chyba że utracone korzyści zostały objęte warunkami ubezpieczenia. Następstwa wypadku ubezpieczeniowego uwzględniane przy ustaleniu odszkodowania określają warunki ubezpieczenia. Do odpowiedzialności ubezpieczeniowej nie mają zastosowania przepisy o odpowiedzialności z powodu niewykonania lub nienależytego wykonania zobowiązania (art. 471 i n. k.c.).

Inaczej wypowiedział się Sąd Najwyższy w wyroku z 2.07.2004 r., II CK 412/03, stwierdzając, że ubezpieczyciel ponosi odpowiedzialność za szkodę poniesioną przez ubezpieczającego wskutek zwłoki w spełnieniu świadczenia z umowy ubezpieczenia (art. 471 k.c.) ${ }^{57}$. Wypłata odszkodowania uzgodnionego w umowie ubezpieczenia jest spełnieniem świadczenia będącego pierwotnym przedmiotem zobowiązania istniejącego między stronami. Niespełnienie tego świadczenia (odmowa wypłaty zagwarantowanego w umowie odszkodowania) lub nienależyte jego spełnienie (np. zwłoka w wypłacie odszkodowania) uprawnia poszkodowanego do wtórnego świadczenia odszkodowawczego, które zastępuje lub uzupełnia pierwotny przedmiot zobowiązania.

Zdaniem Sądu Najwyższego odpowiedzialność gwarancyjną ubezpieczyciela należy oddzielić od jego odpowiedzialności opartej na podstawie art. 471 i n. k.c. Mimo że obie są odpowiedzialnością kontraktową, pierwsza z nich ma charakter gwarancyjny i dlatego oparta jest na związku normatywnym, natomiast druga ma charakter sprawczy i oparta jest na konstrukcji normalnego związku przyczynowego (art. 361 k.c.).

57 LEX nr 121694. 
W pierwszej z nich ubezpieczyciel gwarantuje naprawienie szkody, która wyrządzona zostaje przez zdarzenie od niego niezależne, w drugiej zaś występuje jako sprawca szkody. Nieterminowe spełnienie świadczenia przez pozwanego ubezpieczyciela należy oceniać jako nienależyte wykonanie zobowiązania. Za szkodę spowodowaną wskutek opieszałości mającej w świetle bezspornych ustaleń wszelkie cechy zwłoki w spełnieniu świadczenia ubezpieczyciel ponosi odpowiedzialność na podstawie art. 471 k.c.

Pogląd Sądu Najwyższego jest oczywiście trafny. Można zauważyć, że chociaż samo stanowisko Sądu Apelacyjnego w Łodzi na naturę zobowiązania ubezpieczyciela było krańcowo odmienne od przyjmowanego w orzecznictwie angielskim, to jego konsekwencje okazały się podobne. W obu przypadkach źródeł nieporozumienia należy upatrywać w braku zrozumienia relacji między odpowiedzialnością gwarancyjną ubezpieczyciela wynikającą z samego zawarcia umowy a odpowiedzialnością z tytułu jej niewykonania. Wskazanych reżimów odpowiedzialności nie można ze sobą mieszać ani przyjmować, że wykluczają się wzajemnie.

\subsection{Zasada odpowiedzialności ubezpieczeniowej}

Przez zasady odpowiedzialności rozumie się zwykle reguły decydujące o tym, komu przypisać odpowiedzialność za zdarzenie powodujące szkodę $^{58}$. Według W. Czachórskiego zasady odpowiedzialności mają wyjaśnić sens społeczny i mechanizm działania przepisów, w myśl których odpowiedzialność za szkodę obciąża ten, a nie inny podmiot prawa ${ }^{59}$. Katalog zasad odpowiedzialności formułowany jest różnie i w najbogatszej bodaj wersji obejmuje: 1) zasadę winy, 2) zasadę bezprawności, 3) zasadę ryzyka, 4) zasadę odpowiedzialności absolutnej, 5) zasadę słuszności ${ }^{60}$.

58 Z. Radwański, A. Olejniczak, Zobowiq̨zania..., s. 83.

59 W. Czachórski, A. Brzozowski, M. Safjan, E. Skowrońska-Bocian, Zobowiązania..., s. 211.

60 W. Warkałło, Odpowiedzialność..., s. 220; T. Dybowski, Naprawienie..., s. 201; M. Kaliński, Szkoda..., s. 90 i n.; Z. Radwański, A. Olejniczak, Zobowiązania..., s. 83-85; W. Czachórski, A. Brzozowski, M. Safjan, E. Skowrońska-Bocian, Zobowiązania..., s. 212. 
Przedmiotem kontrowersji jest przede wszystkim wyodrębnienie zasad bezprawności oraz odpowiedzialności absolutnej.

Zasada winy oraz zasada ryzyka jawią się jako podstawowe. Zasada winy zastąpiła rozwiązanie najstarszych prawodawstw, które wiązały odpowiedzialność odszkodowawczą ze skutkiem zewnętrznym wywołanym przez dany czyn bez względu na jego subiektywną stronę. Zasada winy została powszechnie przyjęta w Europie z prawa rzymskiego w dużej mierze pod wpływem prawa kanonicznego, a następnie na przełomie XVIII i XIX w. ugruntowały ją wielkie kodyfikacje. Jej filozoficzne motywy są proste i polegają na przyjęciu, że jedynie czyn sprzeczny z prawem oraz subiektywnie zarzucalny może rodzić odpowiedzialność sprawcy ${ }^{61}$. W europejskiej tradycji kontynentalnej zasada winy ma charakter naczelny, na niej oparta jest zarówno odpowiedzialność za szkody wyrządzone czynem niedozwolonym, jak też odpowiedzialność za szkodę wyrządzoną niewykonaniem zobowiązania ${ }^{62}$. Taki model przyjmuje również prawodawstwo polskie.

Zasada ryzyka stanowi owoc wyzwań, jakie przyniosła rewolucja przemysłowa XIX w. Działalność przedsiębiorstw wprawianych w ruch siłami przyrody, niepodlegającymi całkowitej kontroli człowieka, okazała się generować zarówno wielkie zyski, jak i wielkie szkody. Pomimo głosów moralistów sprzeciwiających się oderwaniu odpowiedzialności od winy przyjęto zatem, że ryzyko szkód związanych z prowadzeniem takich przedsiębiorstw winno spoczywać na barkach osób odnoszących $\mathrm{z}$ tego korzyści, zgodnie z paremią cuius commodum eius periculum, zaś wina nie stanowi koniecznej przesłanki ich odpowiedzialności. Dla uwolnienia się od odpowiedzialności opartej na zasadzie ryzyka nie wystarcza wykazanie braku winy, konieczne jest udowodnienie jednej ze wskazanych przez ustawę okoliczności egzoneracyjnych. Zwykle okoliczności egzoneracyjne ograniczają się do trzech: wyłącznej

${ }^{61}$ Co do zasady winy zob. B. Lewaszkiewicz-Petrykowska, Wina jako podstawa odpowiedzialności z tytułu czynów niedozwolonych, SPE 1969, t. 2, s. 87 i n.

$62 \mathrm{~W}$ prawie francuskim zasada winy dotyczy odpowiedzialności za niewykonanie umów starannego działania. W prawie anglosaskim odpowiedzialność za szkodę wywołaną niewykonaniem zobowiązania jest odpowiedzialnością niezależną od winy. 
winy poszkodowanego, wyłącznej winy osoby trzeciej, za którą osoba prowadząca działalność generującą wzmożoną odpowiedzialność nie odpowiada, oraz siły wyższej. Wyłączność winy postrzegana jest w kategoriach związku przyczynowego i oznacza, że wina samego sprawcy lub osoby trzeciej stanowi wyłączną przyczynę szkody ${ }^{63}$. Siła wyższa ma mieć postać zdarzenia zewnętrznego nadzwyczajnego, nieuchronnego i niemożliwego do przewidzenia ${ }^{64}$.

Typowe przykłady odpowiedzialności na zasadzie ryzyka w polskim prawie cywilnym to odpowiedzialność za szkody wywołane ruchem przedsiębiorstwa wprawianego w ruch siłami przyrody (art. 435 k.c.) oraz odpowiedzialność za szkody wywołane ruchem pojazdu mechanicznego poruszanego siłami przyrody (art. 436 k.c.). Ponadto na zasadzie ryzyka oparte są: odpowiedzialność za wyrzucenie, wylanie i spadnięcie czegoś z pomieszczenia (art. 433 k.c.), odpowiedzialność za zawalenie się budowli lub oderwanie się jej części (art. 434 k.c.), odpowiedzialność za produkt (art. $449^{1}$ k.c.), odpowiedzialność osób utrzymujących hotele i podobne zakłady za utratę lub uszkodzenie rzeczy wniesionych przez gości (art. 846 k.c.), a także odpowiedzialność organizatora turystyki za niewykonanie lub nienależyte wykonanie umowy o świadczenie usług turystycznych (art. 48-50 ustawy z 24.11.2017 r. o imprezach turystycznych i powiązanych imprezach turystycznych ${ }^{65}$ ). Nie we wszystkich przytoczonych przykładach przesłanki egzoneracyjne kształtują się jednolicie. Odrębności wyraźne są szczególnie w odniesieniu do odpowiedzialności za zawalenie się budowli lub oderwanie się jej części oraz odpowiedzialności za produkt.

Zasada słuszności jest zasadą w pewnym sensie wyjątkową, uzupełniającą dwie poprzednie. Przede wszystkim łagodzi ona mankamenty zasady winy. W pewnych wypadkach sprawcy nie można przypisać winy,

63 Zob. przykładowo B. Lewaszkiewicz-Petrykowska, Odpowiedzialność cywilna prowadzacego na własny rachunek przedsiębiorstwo wprawiane $w$ ruch za pomoca sit przyrody, Warszawa 1967, s. 179; A. Śmieja, Czyny..., s. 602-603.

64 Tak przykładowo B. Lewaszkiewicz-Petrykowska, A. Rembieliński, Uwagi o zasadzie ryzyka jako podstawie odpowiedzialności z tytułu czynów niedozwolonych w kodeksie zobowiązań, NP 1959/10, s. 1171.

65 Dz.U. z 2017 r. poz. 2361 ze zm. 
a brakuje osób odpowiadających zamiast niego, ewentualnie sprawca lub osoba, która mogłaby za niego odpowiadać, jest w stanie uwolnić się od odpowiedzialności, przeprowadzając dowód braku winy. Jednocześnie słuszność zdaje się wymagać, by określona osoba zapłaciła odszkodowanie poszkodowanemu. Przemawiać za tym może przede wszystkim porównanie stanu majątkowego tej osoby oraz poszkodowanego. Obecnie najistotniejsze przykłady odpowiedzialności opartej na zasadach słuszności stanowią: odpowiedzialność osób poddanych nadzorowi (art. 428 k.c.), odpowiedzialność osób chowających lub posługujących się zwierzęciem, którym nie można przypisać odpowiedzialności za winę w nadzorze (art. $431 \$ 2$ k.c.), oraz odpowiedzialność Skarbu Państwa za szkody na osobie spowodowane zgodnym z prawem wykonywaniem władzy publicznej (art. $417^{2}$ k.c.).

Wyróżnienie zasad bezprawności oraz odpowiedzialności absolutnej stanowi, jak wskazano, przedmiot sporu. Zasada bezprawności polega na przypisaniu sprawcy odpowiedzialności za działanie sprzeczne z prawem niezależnie od tego, czy można mu postawić zarzut umyślności lub nieumyślności w postaci lekkomyślności lub niedbalstwa. Od zasady ryzyka odróżnia ją zatem przede wszystkim konieczność oceny zachowania ludzkiego jako źródła szkody z punktu widzenia kryteriów normatywnych. Odpowiedzialność sprawcy w porównaniu do odpowiedzialności na zasadzie ryzyka jest złagodzona, ponieważ dla zwolnienia z obowiązku naprawiania szkody wystarczy wykazanie zgodności działania z prawem i nie jest wymagane udowodnienie konkretnej okoliczności egzoneracyjnej. Zwolennicy wyróżnienia zasady bezprawności jako najważniejsze przypadki jej zastosowania wskazują odpowiedzialność Skarbu Państwa i jednostek samorządu terytorialnego za szkody wywołane niezgodnym z prawem wykonywaniem władzy publicznej (art. $417^{1}$ k.c.), odpowiedzialność z tytułu niesłusznego skazania, tymczasowego aresztowania i zatrzymania (art. 552 i n. k.p.k.) oraz odpowiedzialność komornika i Skarbu Państwa na podstawie art. 23 ustawy o komornikach sądowych i egzekucji ${ }^{66}$. 
Wydaje się, że wyodrębnienie zasady bezprawności jest zbędne. Przytaczane przykłady dotyczą w istocie odpowiedzialności za cudze czyny. Kwestia dotyczy zatem tego, na jakiej zasadzie oparta jest odpowiedzialność osoby zobowiązanej do naprawienia szkody, nie zaś bezpośredniego sprawcy. Należy raczej zgodzić się z poglądem wyróżniającym odpowiedzialność na zasadzie ryzyka w czystej postaci, oderwaną zarówno od winy osoby zobowiązanej do naprawienia uszczerbku, jak i winy podmiotu, za którego działania osoba ta odpowiada, oraz odpowiedzialność na zasadzie ryzyka w złagodzonej postaci obejmującą właśnie niektóre przypadki odpowiedzialności za cudze czyny i dla przypisania obowiązku odszkodowawczego wymagająca winy lub bezprawności bezpośredniego sprawcy ${ }^{67}$.

Zasada odpowiedzialności absolutnej z kolei, zdaniem jej zwolenników, idzie w swej surowości jeszcze dalej od zasady ryzyka, mając tę właściwość, że nie pozwala na uwolnienie się przez zobowiązanego od obowiązku naprawienia szkody nawet po udowodnieniu okoliczności egzoneracyjnych. Typowy przykład odpowiedzialności absolutnej stanowić ma właśnie - będąca przedmiotem rozważań - odpowiedzialność ubezpieczyciela. Wśród innych przykładów wymienia się odpowiedzialność z tytułu nieuzyskanych świadczeń w innych umowach gwarancyjnych (art. 391-392 k.c.), odpowiedzialność z tytułu rękojmi (art. 557 i n. k.c.), odpowiedzialność za podwładnego (art. 430 k.c.), odpowiedzialność fałszywego negotiorum gestor (art. 754 k.c.). Kolejna grupa przykładów odpowiedzialności absolutnej obejmować ma: odpowiedzialność osoby, która dla odwrócenia niebezpieczeństwa uszkodziła lub zniszczyła cudzą rzecz (art. $142 \$ 1$ k.c.), odpowiedzialność właściciela, który w celu usunięcia zwieszających się z jego drzew gałęzi lub owoców wszedł na grunt sąsiedni i wyrządził szkodę sąsiadowi (art. 149 k.c.), odpowiedzialność właściciela roju pszczół, który wszedł na cudzy grunt w pościgu za rojem (art. 182 k.c.) ${ }^{68}$. W skazuje się również na szereg pozakodek-

67 Tak w szczególności A. Śmieja, Czyny..., s. 372-373. Podobnie SN w wyroku z 27.11.2015 r., I CSK 28/15, LEX nr 1976873.

68 Z. Gawlik, Odpowiedzialność absolutna w polskim prawie odszkodowawczym [w:] Prace cywilistyczne. Ksiegga pamiątkowa dla uczczenia 40-lecia pracy naukowej profesora Jana J. Winiarza, red. S. Wójcik, Warszawa 1990, s. 45-51. 
sowych przykładów odpowiedzialności absolutnej, w szczególności: odpowiedzialność za szkody łowieckie (art. 46 Prawa łowieckiego ${ }^{69}$ ), górnicze (art. 144-145 Prawa geologicznego i górniczego ${ }^{70}$ ), wyrządzone wskutek wykonywania pozwolenia wodno-prawnego (art. 469 Prawa wodnego $^{71}$ ), jądrowe (art. 101 Prawa atomowego ${ }^{72}$ ), lotnicze (art. II i IV ust. 2 konwencji montrealskiej ${ }^{73}$ ), kosmiczne (art. II Konwencji o odpowiedzialności za szkody wyrządzone przez obiekty kosmiczne ${ }^{74}$ ).

Witold Warkałło, będący głównym propagatorem koncepcji odpowiedzialności absolutnej w prawie polskim, opracował ją przede wszystkim w związku z ubezpieczeniami ${ }^{75}$. Również M. Kaliński wskazuje, że jej początków należy szukać w ubezpieczeniach oraz że główny czynnik wpływający na jej rozwój stanowiła rygorystyczna odpowiedzialność ubezpieczyciela obejmująca naprawienie szkód doznanych przez ubezpieczonego w jego mieniu, także wskutek działania siły wyższej ${ }^{76}$. Poza W. Warkałłą za wyróżnieniem zasady odpowiedzialności absolutnej wypowiedzieli się m.in. J. Łopuski ${ }^{77}$, Z. Gawlik ${ }^{78}$ i J. Rajski ${ }^{79}$. W nauce polskiej potrzebę wyróżnienia odpowiedzialności absolutnej stanowczo

69 Ustawa z 13.10.1995 r. - Prawo łowieckie (Dz.U. z 2018 r. poz. 2033).

70 Ustawa z 9.06.2011 r. - Prawo geologiczne i górnicze (Dz.U. z 2017 r. poz. 2126 ze zm.).

71 Obecnie kwestię tę reguluje art. 469 ustawy z 20.07.2017 r. - Prawo wodne (Dz.U. z 2018 r. poz. 2268).

72 Ustawa z 29.11.2000 r. - Prawo atomowe (Dz.U. z 2018 r. poz. 792).

73 Konwencja o ujednoliceniu niektórych prawideł dotyczących międzynarodowego przewozu lotniczego, sporządzona w Montrealu dnia 28 maja 1999 r. (Dz.U. z 2007 r. Nr 37, poz. 235).

${ }^{74}$ Konwencja o międzynarodowej odpowiedzialności za szkody wyrządzone przez obiekty kosmiczne, sporządzona w Moskwie, Londynie i Waszyngtonie dnia 29 marca 1972 r. (Dz.U. z 1973 r. Nr 27, poz. 154).

75 W. Warkałło, Odpowiedzialność..., s. 191 i n.

76 M. Kaliński, Szkoda..., s. 125.

77 J. Łopuski, Charakter prawny odpowiedzialności z tytułu szkód atomowych, $\mathrm{PiP}$ 1967/4-5, s. 758 i n.

78 Z. Gawlik, Odpowiedzialność..., s. 54.

79 J. Rajski, Odpowiedzialność cywilna przewoźnika lotniczego w prawie międzynarodowym i krajowym, Warszawa 1968, s. 92 i n.; J. Rajski, Odpowiedzialność międzynarodowa za szkody wyrządzone przez obiekty kosmiczne, Warszawa 1974, s. 89. 
zanegował jedynie W. Czachórski, wskazując, że zasada ryzyka obejmuje zarówno ryzyka znające, jak i nieznające egzoneracji ${ }^{80}$.

Wśród przedstawicieli stanowiska umiarkowanego można wymienić R. Longchampsa de Bériera, J. Winiarza, A. Stelmachowskiego oraz B. Lewaszkiewicz-Petrykowską. Roman Longchamps de Bérier nie wyróżniał odpowiedzialności absolutnej. Zaliczając do odpowiedzialności na zasadzie ryzyka m.in. odpowiedzialność za szkody wyrządzone przy wykonywaniu praw prywatnych lub funkcji publicznych, zaznaczał jednak, że w tych przypadkach okoliczności egzoneracyjne nie spełniają takiej samej roli jak przy klasycznej odpowiedzialności na zadzie ryzy$\mathrm{ka}^{81}$. Jan Winiarz dla niektórych postaci odpowiedzialności współcześnie klasyfikowanych jako odpowiedzialność absolutna używał nazwy „odpowiedzialność bezwzględna""2. Andrzej Stelmachowski początkowo mówił o odpowiedzialności ex lege, ostatecznie zaś o odpowiedzialności prewencyjnej ${ }^{83}$. Biruta Lewaszkiewicz-Petrykowska, pisząc o odpowiedzialności za szkody jądrowe, określa ją jako odpowiedzialność obiektywną, zdając się przy tym odróżniać odpowiedzialność obiektywną od odpowiedzialności na zasadzie ryzyka ${ }^{84}$.

Zwolennicy zasady odpowiedzialności absolutnej przyznają, że przypadki ujmowane w jej ramy są bardzo różnorodne. Jak wskazano, wszyscy upatrują przyczyny odróżnienia tej zasady od odpowiedzialności na zasadzie ryzyka w niemożności zwolnienia się od obowiązku świadczenia poprzez wykazanie okoliczności egzoneracyjnych, ewentualnie w istotnym zawężeniu ich zakresu. Poza tym różni autorzy wyróżniają

80 W. Czachórski, Zasady i funkcje odpowiedzialności cywilnej według kodeksu cywilnego - ich ewolucja [w:] Studia z prawa zobowiązań. Ksiega pamiątkowa ku czci Profesora Alfreda Ohanowicza, red. Z. Radwański, Warszawa-Poznań 1979, s. 66.

81 R. Longchamps de Bérier, Polskie..., s. 281.

82 J. Winiarz, Obowiazek naprawienia szkody, Warszawa 1970, s. 61.

83 A. Stelmachowski, Wstęp..., s. 308 i n.

84 B. Lewaszkiewicz-Petrykowska, Cywilna odpowiedzialność za szkodę jądrowa $w$ polskim prawie atomowym, PiP 1987/4, s. 33-34. Umiarkowanym zwolennikiem zasady odpowiedzialności absolutnej, z omówionym wyżej zastrzeżeniem, że obowiązku naprawienia szkody przez ubezpieczyciela co do zasady nie należy określać mianem odpowiedzialności, wydaje się być również T. Dybowski. Por. T. Dybowski, Naprawienie..., s. 206. 
odmienne cechy dodatkowe, charakterystyczne dla odpowiedzialności absolutnej. Wśród tych dodatkowych cech można wymienić w szczególności:

- istnienie wynikającej z umowy lub ustawy gwarancji zapłaty odszkodowania,

- okoliczność, że szkoda jest następstwem czynu dozwolonego, niekiedy zaś działania niezbędnego lub podyktowanego przez potrzeby społeczno-gospodarczo, wreszcie zaś

- wąski zakres funkcji tej odpowiedzialności sprowadzający się do funkcji kompensacyjnej, przy braku funkcji represyjnej oraz prewencyjno-wychowawczej.

Ze względu na zakres pracy analizowanie wszystkich przypadków kwalifikowanych w ramach odpowiedzialności absolutnej nie jest konieczne. Celowe wydaje się natomiast wyeliminowanie przypadków, które już prima facie nie spełniają podstawowych kryteriów takiej kwalifikacji. W dalszej kolejności należy zaś odpowiedzieć na pytanie, czy odpowiedzialność ubezpieczeniowa ma cechy odpowiedzialności absolutnej. Chybiony w szczególności wydaje się pogląd, że cechy odpowiedzialności absolutnej ma odpowiedzialność za zapłatę kary umownej ${ }^{85}$. Odpowiedzialność ta, będąc szczególnym przypadkiem odpowiedzialności za niewykonanie istniejącego zobowiązania, jest oparta na zasadzie winy ${ }^{86}$. Nie jest również odpowiedzialnością odszkodowawczą kwalifikowany przez niektórych jako odpowiedzialność absolutna obowiązek zapłaty odsetek za opóźnienie (art. 481 k.c.) $)^{87}$.

Przy okazji odpowiedzialności za zapłatę kary umownej oraz odpowiedzialności z tytułu odsetek nasuwa się również uwaga, że nie wszystkie przypadki odpowiedzialności kwalifikowane w ramach odpowiedzialno-

85 Tak Z. Gawlik, Odpowiedzialność..., s. 46-47. Słuszna krytyka tego poglądu u M. Kalińskiego, Szkoda..., s. 129. Odpowiedzialność za zapłatę kary umownej, będąc szczególnym przypadkiem odpowiedzialności za niewykonanie istniejącego zobowiązania, jest oparta na zasadzie winy. Zgodnie z art. 473 k.c. można jej nadać kształt oderwany od winy, ale taka możliwość istnieje niezależnie od zastrzeżenia kary umownej.

${ }^{86}$ Zgodnie z art. 473 k.c. można jej nadać kształt oderwany od winy, ale taka możliwość istnieje niezależnie od zastrzeżenia kary umownej.

87 Przykładowo M. Kaliński, Szkoda..., s. 128. 
ści absolutnej należą do odpowiedzialności odszkodowawczej, a właśnie w odniesieniu dla tej ostatniej czynione są przecież rozróżnienia. Samą odpowiedzialność za zapłatę kary umownej można zapewne kwalifikować jako odpowiedzialność odszkodowawczą. Nawet jeżeli szkoda nie jest konieczną jej przesłanką, to jednak kara umowna stanowi surogat odszkodowania, nadto wykazanie przez dłużnika nieponiesienia szkody przez wierzyciela lub jej znikomej wysokości pozwala na skuteczne domaganie się miarkowania kary umownej z uwagi na jej rażące wygórowanie ${ }^{88}$. Trudno jednak twierdzić, że charakter odszkodowawczy ma odpowiedzialność z tytułu rękojmi, podstawowe roszczenia z rękojmi przysługują bowiem niezależnie od samego faktu poniesienia szkody ${ }^{89}$.

Wątpliwości budzi kwalifikowanie jako odpowiedzialności absolutnej tych wszystkich przypadków odpowiedzialności, w których istnieje możliwość zwolnienia się z obowiązku zapłaty odszkodowania przez wykazanie choćby bardzo ograniczonych przesłanek egzoneracyjnych. Dotyczy to przykładowo odpowiedzialności za szkody jądrowe, od której można się uwolnić przez wykazanie, że szkoda nastąpiła bezpośrednio wskutek działań wojennych lub konfliktu zbrojnego ${ }^{90}$. Rozstrzygnięcie wydaje się uzależnione od przyjętego kryterium wyróżnienia odpowiedzialności absolutnej. Jak wskazano, twierdzi się niekiedy, że odpowiedzialność taka obejmuje nie tylko przypadki odpowiedzialności, od której nie można się uwolnić, ale również sytuacje, w których zakres okoliczności egzoneracyjnych jest węższy niż w przypadku odpowiedzialności na zasadzie ryzyka. W takim ujęciu jednak granica między odpowiedzialnością absolutną oraz odpowiedzialnością na zasadzie ryzyka bardzo się zamazuje. Jak wspomniano, przesłanki egzoneracyjne nie są ukształtowane jednolicie nawet w odniesieniu do przypadków obowiązku naprawienia szkody powszechnie kwalifikowanych jako odpowiedzialność na zasadzie ryzyka.

${ }^{88}$ Odmiennie M. Krajewski, Pojęcie odpowiedzialności..., s. 463.

89 Zastrzeżenie to nie dotyczy oczywiście odpowiedzialności z tytułu rękojmi w granicach negatywnego interesu umowy (art. $566 \$ 1$ zdanie drugie k.c.).

90 Zastrzeżenia w odniesieniu do kwalifikowania odpowiedzialności za szkody jądrowe jako absolutnej zgłasza m.in. J. Łopuski, Charakter..., s. 776. 
Zgodnie z tym, co wcześniej napisano, nie jest również odpowiedzialnością na zasadzie ryzyka odpowiedzialność przełożonego za podwładnego z art. 430 k.c. Odpowiedzialność ta jest w istocie łagodniejsza od typowych przykładów odpowiedzialności na zasadzie ryzyka, ponieważ jej przypisanie przełożonemu wymaga udowodnienia winy bezpośredniego sprawcy szkody. W skazana dodatkowa przesłanka pełni w istocie podobną rolę do okoliczności egzoneracyjnych w przypadkach odpowiedzialności na zasadzie ryzyka w postaci surowszej. Jej złagodzenie względem tych ostatnich przejawia się zarówno samym odwołaniem do zasady winy przypisywanej wszakże innej osobie niż odpowiedzialna za szkodę, nierozpatrywanej w kategoriach wyłącznej przyczyny szkody, jak również obciążeniem poszkodowanego ciężarem jej udowodnienia.

Twierdzi się natomiast, że możność powołania się przez zobowiązanego na przesłanki egzoneracyjne nie wyklucza kwalifikowania jako odpowiedzialności absolutnej sytuacji, w której od obowiązku naprawienia szkody uwalnia wykazanie kwalifikowanej winy poszkodowanego. Wina poszkodowanego może być bowiem traktowana nie jako przesłanka egzoneracyjna, ale jako okoliczność wyłączająca możliwość dochodzenia odszkodowania przez osobę, której taki zarzut można uczynić, zgodnie z rzymską zasadą volenti non fit iniuria ${ }^{91}$. Uwagę tę należy opatrzyć dwoma zastrzeżeniami. Po pierwsze, walor rozróżnienia między okolicznościami egzoneracyjnymi oraz wyłączającymi możliwości dochodzenia odszkodowania może być kwestionowany, skoro odpowiedzialność odszkodowawcza polega na realizacji roszczenia naprawienia szkody ${ }^{92}$. Po drugie, wyłączność winy jako przesłanki zwalniającej od odpowiedzialności oceniania jest przede wszystkim przez pryzmat związku przyczynowego, nie zaś przez pryzmat stopnia zawinienia.

Przechodząc do odpowiedzi na pytanie, czy odpowiedzialność ubezpieczeniowa stanowi przykład odpowiedzialności absolutnej, należy natomiast wskazać, co następuje. Kwalifikacja odpowiedzialności ubezpieczeniowej jako absolutnej zależy oczywiście od kryteriów wyróżnienia oraz zakresu pojęcia odpowiedzialności absolutnej. Istota

91 Z. Gawlik, Odpowiedzialność..., s. 52.

92 M. Kaliński, Szkoda..., s. 127. 
odpowiedzialności absolutnej polegać ma przede wszystkim na jej wynikaniu $\mathrm{z}$ samego faktu wyrządzenia szkody oraz pozbawieniu elementu niepewności, jaki wiąże się zwykle z możnością uwolnienia się przez osobę potencjalnie zobowiązaną od obowiązku jej naprawienia wskutek udowodnienia braku winy lub określonych okoliczności egzoneracyjnych. Samo określenie „odpowiedzialność absolutna” ma wskazywać na absolutną pewność kompensacji w przypadkach objętych tą odpowiedzialnością.

W sytuacji gdy obowiązek naprawienia szkody wynika z ustawy i podyktowany jest interesem osób potencjalnie poszkodowanych utożsamianym przez ustawodawcę $\mathrm{z}$ ważnym interesem społecznym, preponderancja tego interesu wobec interesu osoby zobowiązanej skłania niekiedy ustawodawcę do ukształtowania odpowiedzialności w sposób bardzo surowy, tak że kompensacja jest pewna lub niemal pewna. Istota odpowiedzialności ubezpieczeniowej sprowadza się jednak do tego, że ubezpieczyciel gwarantuje zapłatę odszkodowania w okolicznościach precyzyjnie określonych w umowie ubezpieczenia. Działalność ubezpieczeniowa jako działalność gospodarcza prowadzona jest zarobkowo. W skali makro przychód, na który składają się środki pieniężne ze składek oraz obracania nimi, w zamierzeniu ubezpieczyciela ma być większy niż straty łączące się z wypłacanymi odszkodowaniami. Ustawodawca nie wskazuje na preponderancję interesu osób zagrożonych szkodą wobec interesu majątkowego ubezpieczyciela, pominąwszy może wyjątkową odpowiedzialność tego ostatniego za szkody będące wynikiem rażącego niedbalstwa.

Prima facie ubezpieczyciel nie może zwolnić się z odpowiedzialności ubezpieczeniowej przez udowodnienie wskazanych w ustawie okoliczności egzoneracyjnych. Dotyczy to przede wszystkim przypadków siły wyższej mających charakter różnego rodzaju zdarzeń żywiołowych oraz wyłącznej winy osoby trzeciej. Istota ubezpieczenia polega przecież na tym, że chroni ono przed niekorzystnymi skutkami zdarzeń losowych wywoływanych siłami przyrody (np.: piorun, trzęsienie ziemi, powódź, zjawiska klimatyczne o szczególnym nasileniu, takie jak wicher, śnieżyca, mróz itp.), choćby można było im przypisać charakter siły wyższej, przed niekorzystnymi skutkami zawinionego działania lub zaniechania osób 
trzecich (np.: kradzież lub podpalenie), ale również przed skutkami niestaranności samego ubezpieczającego.

Istnieje jednak cały szereg okoliczności, które zmniejszając pewność uzyskania odszkodowania ubezpieczeniowego, przemawiają przeciwko kwalifikowaniu odpowiedzialności ubezpieczyciela jako absolutnej. Wśród nich można wymienić po pierwsze, możliwość zwolnienia się przez ubezpieczyciela $\mathrm{z}$ odpowiedzialności z uwagi na niedochowanie powinności ubezpieczeniowych. Naruszenie powinności ustawowych może uchylać odpowiedzialność ubezpieczyciela, chociaż ze swej istoty nie stanowi wyłącznej przyczyny wypadku, ale jedynie jego współprzyczynę. Naruszenie powinności deklaracji i notyfikacji nie musi być nadto wynikiem winy umyślnej lub rażącego niedbalstwa, wystarczy związek przyczynowy między nieujawnioną okolicznością a wypadkiem. Dodatkowo ubezpieczyciel może nakładać na ubezpieczającego dodatkowe powinności prewencyjne, których naruszenie według części doktryny i judykatury skutkuje zwolnieniem od odpowiedzialności niezależnie od stopnia zawinienia ${ }^{93}$.

Po drugie, pewność odszkodowania ubezpieczeniowego zmniejsza również możliwości uchylenia się przez ubezpieczyciela od odpowiedzialności z uwagi na niewykonanie przez ubezpieczającego głównych obowiązków umownych. Ubezpieczyciel w zamian za przyjęcie odpowiedzialności ryzyka zajścia wypadku pobiera składkę. Jeżeli ubezpieczyciel ponosi odpowiedzialność przed zapłaceniem składki, jej niezapłacenie w terminie upoważnia go do natychmiastowego wypowiedzenia umowy ubezpieczenia (art. $814 \$ 2$ k.c.). Nieco bardziej skomplikowane, ale również możliwe jest uchylenie się przez ubezpieczyciela od odpowiedzialności w razie nieopłacenia kolejnej raty składki. Skutek taki przewidywać musi umowa, nadto ubezpieczyciel winien udzielić ubezpieczającemu dodatkowego terminu i uprzedzić o skutkach jego niedochowania (art. $814 \$ 3$ k.c.).

93 Por. M. Krajewski, Umowa ubezpieczenia. Art. 805-834 KC..., 2016, s. 254 i n. Stanowisko autora w tym zakresie zostanie przedstawione w rozdziale dotyczącym wyłączeń odpowiedzialności. 
Po trzecie, ujemy wpływ na pewność kompensacji ubezpieczeniowej ma sama konstrukcja wypadku ubezpieczeniowego, który musi być z mocy ustawy zdarzeniem przyszłym i niepewnym, i niezależnym od woli ubezpieczającego, i może być kształtowany co do zakresu przez ubezpieczyciela. Wprawdzie kwestie związane z granicami wypadku i działaniem umyślnym ubezpieczającego można zgodnie z powyższymi uwagami zakwalifikować jako okoliczności wyłączające możliwość domagania się odszkodowania, nie zaś jako okoliczności egzoneracyjne, jednak bezsprzecznie mają one wpływ na pewność kompensacji. To samo dotyczy wyłączenia odpowiedzialności za umyślne działania osób, z którymi ubezpieczyciel pozostaje we wspólnym gospodarstwie domowym. Zupełnie nie przystaje do konstrukcji odpowiedzialności absolutnej słusznościowa odpowiedzialność ubezpieczyciela za szkody spowodowane rażącym niedbalstwem ubezpieczającego.

Po czwarte, wysokość odszkodowania ubezpieczeniowego jest ograniczona wysokością sumy ubezpieczania, jej relacją do wartości ubezpieczenia, ukształtowaniem odpowiedzialności jako odpowiedzialności w systemie proporcjonalnym lub na pierwsze ryzyko. Dodatkowo umowa lub ogólne warunki bardzo często przewidują udział własny ubezpieczającego w szkodzie, ewentualnie franszyzę integralną lub redukcyjną. Chociaż wymienione mechanizmy nie stanowią przesłanek egzoneracyjnych, a jedynie ograniczają wysokość odszkodowania, bardzo często mają skutek podobny, prowadząc do tego, że poniesiona przez ubezpieczającego szkoda w ogóle nie podlega kompensacji ${ }^{94}$.

Można oczywiście powiedzieć, że ubezpieczyciel odpowiada na zasadzie odpowiedzialności absolutnej, jednak w granicach oraz na warunkach wskazanych w umowie i w ogólnych warunkach ubezpieczenia, natomiast odszkodowanie ubezpieczeniowe jest ze swej istoty limitowane i ta ostatnia kwestia nie ma nic wspólnego z zasadą odpowiedzialności. Problem w tym, że zwykle potencjalna liczba pretekstów umożliwiających ubezpieczycielowi zwolnienie się z odpowiedzialności jest, oględnie

94 Z tej przyczyny sprzeciwia się traktowaniu odpowiedzialności ubezpieczeniowej Ł. Węgrzynowski, Dopuszczalność sądowej modyfikacji sumy gwarancyjnej w ubezpieczeniu OC na żądanie poszkodowanego, PS 2009/2. 
mówiąc, znaczna. Dlatego też nawet przy bardzo dużej dozie życzliwości dla samego pojęcia zasady odpowiedzialności absolutnej oraz bardzo liberalnych kryteriów jej wyróżnienia odpowiedzialność ubezpieczeniową, mającą być przecież pierwowzorem oraz sztandarowym przykładem odpowiedzialności absolutnej, trudno określać tym mianem. Dla przeciętnego prawnika praktyka, który chociaż kilka razy spotkał się z odmową wypłaty odszkodowania przez ubezpieczyciela oraz miał okazję zapoznać się z argumentami przytaczanymi w uzasadnieniu, określenie odpowiedzialności ubezpieczeniowej jako absolutnej, mające przecież wskazywać na niezachwianą pewność kompensacji, jawić się może wręcz jako humorystyczne.

Rozpatrując odpowiedzialność ubezpieczeniową pod kątem występowania innych niż niemożność powoływania się na okoliczności egzoneracyjne cech odpowiedzialności absolutnej, wskazać trzeba, co następuje. Cecha udzielenia gwarancji zapłaty odszkodowania jawi się w odniesieniu do ubezpieczenia szczególnie wyraźnie. Gwarancja wynika w omawianym przypadku z umowy i należy do samej istoty ubezpieczenia jako instytucji prawnej. Cecha występowania wynikającej z umowy gwarancji naprawienia szkody wiąże się jednak przede wszystkim z wyróżnieniem odrębnego od zasady odpowiedzialności ex contractu oraz ex delicto reżimu odpowiedzialności określanego mianem odpowiedzialności gwarancyjnej, do którego poza odpowiedzialnością ubezpieczeniową zaliczyć można odpowiedzialność poręczyciela oraz odpowiedzialność wynikającą z umów gwarancyjnych przewidzianą w art. 391 i 392 k.c., który to reżim został wcześniej omówiony. Gwarancja naprawienia szkody wynikająca $\mathrm{z}$ ustawy jest dobrze widoczna przykładowo w odniesieniu do odpowiedzialności za szkody łowieckie (art. 46 Prawa łowieckiego) oraz odpowiedzialności za podwładnego (art. 430 k.c.).

Wymieniana jako szczególna cecha odpowiedzialności absolutnej okoliczność, że szkoda jest następstwem czynu dozwolonego, niekiedy zaś działania niezbędnego, jest nieadekwatna do odpowiedzialności ubezpieczyciela. Zakres jego odpowiedzialności kształtowany jest przez umowę ubezpieczenia i może obejmować zarówno odpowiedzialność za szkody wywołane czynem dozwolonym, jak też działaniem niezbędnym. Bardziej typowy dla odpowiedzialności ubezpieczeniowej jest 
przy tym właśnie obowiązek naprawienia szkód wynikających z czynów niedozwolonych łączących się z działaniem lub zaniechaniem osób trzecich (kradzież, podpalenie, akty wandalizmu), ewentualnie wynikających ze zdarzeń niezależnych od człowieka, w szczególności zjawisk przyrodniczych (uderzenie pioruna, powódź, nadzwyczajne zjawiska klimatyczne).

Wątpliwa jest również cecha dotycząca pełnienia przez odpowiedzialność ubezpieczeniową funkcji prewencyjnej. Wskazuje się, że odpowiedzialność absolutna, dotycząc sytuacji wyrządzenia szkody działaniem legalnym lub niezależnym od człowieka, nie może pełnić tej funkcji, skoro szkoda wywołana zostaje działaniem legalnym albo jest nieuchronna ${ }^{95}$. W odniesieniu do funkcji prewencyjnej odpowiedzialności ubezpieczeniowej na myśl przychodzą oczywiście wypowiedzi z poprzedniej epoki społeczno-gospodarczej próbujące w tejże funkcji upatrywać podstawowej, obok funkcji kompensacyjnej, funkcji ubezpieczeńn ${ }^{96}$. Pierwszorzędne znaczenie funkcji prewencyjnej w ubezpieczeniach socjalistycznych miało przemawiać za ich wyższością wobec ubezpieczeń kapitalistycznych według koncepcji radzieckich teoretyków ${ }^{97}$. Jak się zdaje, w literaturze polskiej poglądów dotyczących priorytetowego znaczenia funkcji prewencyjnej nigdy nie traktowano zupełnie poważnie. Przykładowo W. Warkałło, który bywa postrzegany jako główny propagator funkcji prewencyjnej odpowiedzialności ubezpieczeniowej, podkreślał, że to funkcja kompensacyjna stanowi rację bytu oraz podstawową funkcję społeczno-gospodarczą ubezpieczeń ${ }^{98}$.

Z przytoczonym ostatnio poglądem oczywiście nie sposób polemizować. Wydaje się jednak, że odpowiedzialność ubezpieczeniowa nie jest pozbawiona funkcji prewencyjnej również współcześnie. Względy

95 Z. Gawlik, Odpowiedzialnośćc.., s. 53.

96 Przykładowo w klasycznym podręczniku W. Warkałły, W. Marka i W. Mogilskiego, Prawo ubezpieczeniowe, Warszawa 1983, prewencyjnej funkcji ubezpieczeń poświęcono cały rozdział (s. 61-80), omawiając ją przed funkcją kompensacyjną.

97 Zob. przykładowo poglądy W. Rajcher, Społeczno-historyczne typy ubezpieczeń, Warszawa 1951, passim, oraz autorzy przywoływani przez Z. Szymańskiego, Prawo ubezpieczeniowe, Łódź 1978, s. 123-124.

98 Zob. W. Warkałło [w:] W. Warkałło, W. Marek, W. Mogilski, Prawo..., s. 80. 
ideologiczne nie mają $\mathrm{w}$ tej kwestii znaczenia. Jednym $\mathrm{z}$ aspektów zarządzania przedsiębiorstwem lub nawet gospodarstwem domowym jest bowiem tzw. zarządzanie ryzykiem (risk management). Stanowi ono proces wieloetapowy, obejmując przynajmniej trzy etapy, tj. identyfikację ryzyka, wybór metody obchodzenia się z ryzykiem oraz wdrożenie programu obchodzenia się z ryzykiem w konkretnym przypadku. Wśród metod obchodzenia się z ryzykiem wyróżnia się metody negatywne, zaliczając do nich: unikanie ryzyka, zatrzymanie ryzyka oraz kontrolę ryzyka, jak również metody pozytywne obejmujące transfer ryzyka, repartycję strat i dyspersję ryzyka oraz właśnie ubezpieczenie będące $\mathrm{w}$ istocie kombinacją obu wymienionych wcześniej pozytywnych metod obchodzenia się z ryzykiem $^{99}$.

Ubezpieczenie jest zdaniem niektórych najbardziej praktyczną metodą radzenia sobie z ryzykiem, może się również jawić jako metoda najnowocześniejsza i najbardziej wyspecjalizowana. Wybór tej metody łączy się z koniecznością zapłacenia składki, której wysokość zależy od prawdopodobieństwa zaistnienia szkody i jej ewentualnych rozmiarów. W niektórych sytuacjach ubezpieczenie po prostu może się nie opłacać. Tańsze mogą okazać się inne metody obchodzenia się z ryzykiem, w tym jego unikanie oraz kontrola. Ponadto nawet wybór ubezpieczenia jako metody zarządzania ryzykiem bardzo często łączy się z koniecznością zastosowania określonych przez ubezpieczyciela sposobów kontroli ryzyka - od zupełnie trywialnych, jak kraty w oknach, przez bardziej zaawansowane, jak ochrona obiektu, alarm przeciwwłamaniowy, instalacja przeciwpożarowa, ewentualnie użycie bezpiecznych materiałów i technologii budowlanej czy też opracowanie określonych reguł postępowania oraz weryfikacja ich przestrzegania. Dodatkowo wśród celów zastrzegania tzw. technicznych ograniczeń odpowiedzialności ubezpieczeniowej, tzn. franszyzy i udziału własnego, wymienia się właśnie prewencje ubezpieczeniową.

99 Por. przykładowo E. Kowalewski, Wprowadzenie do teorii ryzyka..., s. 11 i n., oraz E. Kowalewski, Co psychologia behawioralna dać może teorii ryzyka ubezpieczeniowego? [w:] Ryzyko ubezpieczeniowe. Wybrane zagadnienia teorii i praktyki, red. M. Serwach, Łódź 2013, s. 36-41. 
W tym sensie ubezpieczenia i odpowiedzialność ubezpieczeniowa pełnią funkcję prewencyjną także współcześnie. Dopatrywać się można w ubezpieczeniu, a konkretnie w regresie ubezpieczeniowym nawet funkcji penalnej. Spostrzeżenia te nie podają w wątpliwość znaczenia funkcji kompensacyjnej, wskazują jedynie, że odpowiedzialność ubezpieczeniowa pełni również funkcje dodatkowe, podobnie jak odpowiedzialność oparta na zasadzie winy lub ryzyka.

Nie można nie dostrzegać, że pogląd upatrujący w ubezpieczeniu najbardziej rozbudowanego, najczystszego i stojącego na najwyższym stadium rozwojowym przykładu odpowiedzialności absolutnej został sformułowany w innych realiach społeczno-gospodarczych, w dobie monopolu Państwowego Zakładu Ubezpieczeń oraz ubezpieczeń ustawowych. Ubezpieczenie socjalistyczne, organizowane, a częściowo wykonywane przez państwo, nastawione na interes ogólnospołeczny zamiast na zysk ubezpieczyciela, miało zapewniać najwyższy stopień pewności uzyskania należnych świadczeń w odróżnieniu do ubezpieczenia kapitalistycznego $^{100}$. Współcześnie ubezpieczenie jako kamień węgielny czy fundament odpowiedzialności absolutnej zdaje się nieco chwiać, wpływając na stabilność całego gmachu takiej odpowiedzialności.

Jak wskazano, samo odróżnienie odpowiedzialności absolutnej od odpowiedzialności na zasadzie ryzyka może budzić kontrowersje. Okoliczności egzoneracyjne nie zawsze kształtują się jednolicie dla różnych przypadków odpowiedzialności na zasadzie ryzyka. Niektórzy twierdzą, że odpowiedzialność na zasadzie ryzyka obejmuje również ryzyka nieznające egzoneracji. Tym bardziej można argumentować jak R. Longchamps de Bérier, że okoliczności egzoneracyjne w różnych przypadkach odpowiedzialności na zasadzie ryzyka nie zawsze pełnią taką samą rolę. Nadto mianem tzw. odpowiedzialności absolutnej określa się wiele różnych przypadków odpowiedzialności. Sporny może być zarówno zakres tej zasady, jak też jej podstawowe cechy. Co do zakresu zasady odpowiedzialności absolutnej, wątpliwe może być w szczególności, czy obejmuje ona jedynie przypadki odpowiedzialności odszkodowawczej, czy również przypadki odpowiedzialności niezależnej od szkody.

100 W. Warkałło, Odpowiedzialność..., s. 193. 
To drugie rozwiązanie wydaje się prima facie właściwsze, pozwala bowiem objąć mianem odpowiedzialności absolutnej odpowiedzialność z tytułu rękojmi.

Odnośnie do samej konstrukcji i cech odpowiedzialności absolutnej kontrowersje wyłaniają się na tle szeregu kwestii, w szczególności co do katalogu cech konstrukcyjnych przemawiających za wyróżnieniem odpowiedzialności absolutnej jako odrębnej zasady odpowiedzialności. Nawet przyjmując, że jedyną cechą charakterystyczną odpowiedzialności absolutnej odróżniającą ją od odpowiedzialności na zasadzie ryzyka jest niemożność zwolnienia się od obowiązku naprawienia szkody przez wykazanie okoliczności egzoneracyjnych, napotyka się problem kwalifikacji przypadków odpowiedzialności, w których okoliczności egzoneracyjne występują, mają jednak mniej lub bardziej ograniczony zakres.

Z kolei gwarancja naprawienia szkody, charakterystyczna zdaniem niektórych dla odpowiedzialności absolutnej, może mieć różne źródła. Gwarancji wynikającej z ustawy można dopatrywać się również w przypadkach odpowiedzialności opartej na zasadzie ryzyka. Gwarancja wydaje się być w istocie pochodną niemożności lub bardzo ograniczonej możności uwolnienia się od obowiązku naprawienia szkody. Z gwarancją udzielaną umownie immanentnie wiąże się możliwość umownego kształtowania przesłanek gwarancję wyłączających, co każe wątpić w możliwość odnoszenia odpowiedzialność absolutnej do stosunków umownych, w zakresie których ustawodawca nie wykluczył zupełnie swobody stron.

Zdzisław Gawlik twierdzi, że zasada ryzyka odnosi się do stanów faktycznych mieszczących się w przedziale od deliktu do czynu dozwolonego, podczas gdy odpowiedzialność absolutna dotyczy odpowiedzialności za działania legalne i społecznie użyteczne. Jak łatwo zauważyć, nie dotyczy to wszystkich przypadków, które próbuje się kwalifikować jako odpowiedzialność absolutną. Deliktowy charakter ma z pewnością odpowiedzialność za podwładnego, ubezpieczyciel w ubezpieczeniu mienia, jak była już mowa, odpowiada przede wszystkim za szkody wywołane siłami przyrody oraz deliktowymi działaniami osób trzecich. Odpowiedzialność za szkody geologiczne i górnicze, lotnicze, kosmiczne oraz 
atomowe również wydaje się zahaczać o odpowiedzialność deliktową. Prowadzenie elektrowni atomowej jawi się jako szczególny przypadek prowadzenia przedsiębiorstwa wprawianego w ruch siłami przyrody.

Nawet ogólna teza, że odpowiedzialność absolutna pozbawiona jest funkcji prewencyjnej, ponieważ dotyczy przede wszystkim szkód, które mają charakter nieuchronny i którym nie można zapobiec za pomocą jakichkolwiek zmian technicznych lub organizacyjnych, również budzi zastrzeżenia. Trudno bowiem wśród szkód, których naprawienie podlegać ma zasadzie odpowiedzialności absolutnej, wskazać szkody, które są absolutnie nieuchronne w tym sensie, że nie można im zapobiec przez jakiekolwiek działanie prewencyjne. Przeciwnie, wydaje się, że właśnie tam, gdzie szkoda o katastrofalnych rozmiarach może zostać spowodowana przez bardzo drobne uchybienie, potrzeba najdalej posuniętych środków prewencyjnych, wprowadzania zmian organizacyjnych, dbałości o stan techniczny urządzeń oraz najogólniej rzecz biorąc, szczególnie wysokiego stopnia staranności osób zaangażowanych w przedsięwzięcie.

Podsumowując, zasadność samego wyróżnienia odpowiedzialności absolutnej jako odrębnej od ryzyka zasady odpowiedzialności jest wątpliwa. Określenie to może ewentualnie służyć do opisania niektórych szczególnie surowych przypadków odpowiedzialności na zasadzie ryzyka, gdzie okoliczności egzoneracyjne są bardzo ograniczone albo w ogóle nie występują. Opisywanie za pomocą tego określenia odpowiedzialności ubezpieczeniowej budzi jeszcze dalej idące zastrzeżenia. Z całą pewnością zaś kwalifikowanie odpowiedzialności ubezpieczeniowej jako odpowiedzialności absolutnej nie ogranicza swobody ubezpieczyciela do kształtowania przesłanek, zakresu odpowiedzialności oraz możliwości uwolnienia się od niej. Odpowiedzialność ubezpieczeniową wypada zatem zakwalifikować do odpowiedzialności na zasadzie ryzyka. 


\subsection{Typ odpowiedzialności ubezpieczeniowej}

\subsubsection{Kryterium sprawstwa}

Klasyfikowanie odpowiedzialności odszkodowawczej według kryterium sprawstwa ma sens przy założeniu, że można w sensie cywilistycznym odpowiadać za szkodę, której się nie wyrządziło. Kwestia była już przedmiotem rozważań. Autorzy klasyfikujący odpowiedzialność odszkodowawczą według tego kryterium zgadzają się, że nie pokrywa się ono z kryterium źródła odpowiedzialności. O ile w ostatnim przypadku chodzi o odpowiedź na pytanie, czy źródłem odpowiedzialności za szkodę jest delikt, niewykonanie umowy czy inne zdarzenie, o tyle pierwsze pytanie dotyczy tego, czy odpowiedzialność ponosi sam sprawca szkody, czy też inna osoba.

Rozróżnienie jednak zamazuje się, ponieważ ten sam termin „odpowiedzialność gwarancyjna” używany jest zarówno na określenie reżimu odpowiedzialności wyodrębnionego ze względu na źródło czy podstawę odpowiedzialności, jak również na określenie typu odpowiedzialności wyodrębnianego ze względu na kryterium sprawstwa szkody. W pierwszym znaczeniu wskazuje się na odpowiedzialność gwarancyjną jako na odpowiedzialność niebędącą odpowiedzialnością z tytułu czynu niedozwolonego ani odpowiedzialnością z tytułu niewykonania zobowiązania. W drugim znaczeniu wskazuje się na odpowiedzialność gwarancyjną, odróżniając ją od odpowiedzialności za szkodę wyrządzoną przez podmiot zobowiązany do jej naprawienia.

Zamęt potęguje okoliczność, że szczególnie w nowszej literaturze i orzecznictwie używa się określenia „odpowiedzialność gwarancyjna” na określenie odpowiedzialności niebędącej odpowiedzialnością za szkodę w ścisłym znaczeniu tego ostatniego terminu. Ponadto, co jest dobrze widoczne szczególnie w sporze o charakter odpowiedzialności członków zarządu spółki z o.o. z art. 299 k.s.h., odpowiedzialność gwarancyjną przeciwstawia się odpowiedzialności odszkodowawczej, 
rozumianej jako odpowiedzialność sprawcy szkody wobec poszkodowanego $^{101}$.

Autorzy wyróżniający typy odpowiedzialności sprawczej oraz gwarancyjnej stwierdzają obrazowo, że w pierwszym przypadku ustawodawca koncentruje się na szkodzie wyrządzonej, podczas gdy w drugim na szkodzi doznanej, nie zgadzają się jednak co do zakresu przypadków objętych obydwoma typami. Zdaniem W. Warkałły w obrębie odpowiedzialności sprawczej, tj. odpowiedzialności za spowodowanie szkody, mieszczą się niemal wszystkie przypadki odpowiedzialności odszkodowawczej z tytułu czynów niedozwolonych z uwzględnieniem odpowiedzialności na zasadzie ryzyka oraz odpowiedzialności za cudze czyny, nadto wszystkie przypadki szkody wynikłej z niewykonania lub nienależytego wykonania zobowiązania $\mathrm{z}$ uwzględnieniem odpowiedzialności za pomocników i zastępców dłużnika, a także niektóre przypadki odpowiedzialności z tytułu niedotrzymania jednostronnych oświadczeń woli. Autor ten nie wyliczał przy tym przykładów odpowiedzialności gwarancyjnej, jednak podawane przezeń przypadki dotyczą umów ubezpieczenia oraz poniesienia szkody w cudzym interesie ${ }^{102}$.

Rozróżnienie zaproponowane przez W. Warkałłę skrytykował T. Dybowski, wskazując, że rozciąganie pojęcia sprawstwa na przypadki odpowiedzialności za szkody powstałe w związku z użyciem sił przyrody oraz za cudze czyny, gdzie między działaniem zobowiązanego zachodzi jedynie związek pośredni i niekoniecznie przyczynowy, koliduje z tradycją i poczuciem językowym. Według T. Dybowskiego tak szerokie i sztuczne ujmowanie sprawstwa stworzone zostało tylko po to, aby móc przeciwstawić wszelkim innym rodzajom odpowiedzialności tzw. odpowiedzialność ubezpieczeniową.

Pod wpływem tej krytyki M. Kaliński, starając się uniknąć zarzutu, że wyróżnienie typów odpowiedzialności sprawczej i gwarancyjnej jest nieoperatywne, ujmuje przypadki odpowiedzialności sprawczej znacznie

101 Por. A. Kappes, Odpowiedzialność członków zarządu za zobowiązania spółki z o.o., Warszawa 2009, s. 155 oraz 160-161.

102 W. Warkałło, Odpowiedzialność..., s. 109. 
węziej. Według jego zdania o sprawstwie można mówić jedynie w razie istnienia adekwatnego związku przyczynowego między zachowaniem podmiotu odpowiedzialnego a naruszeniem jakiegoś dobra. Takie ujęcie prowadzi do wyłączenia poza obręb odpowiedzialności sprawczej przypadków odpowiedzialności za cudze czyny z art. 429, 430 i 431 k.c., przypadków odpowiedzialności na zasadzie ryzyka z art. 434-436 k.c., jak również w obrębie odpowiedzialności ex contractu odpowiedzialność za pomocników i osoby, którym powierzono wykonanie zobowiązana. Wszystkie te przypadki M. Kaliński zalicza do odpowiedzialności gwarancyjnej, a poza nimi także odpowiedzialność z art. 391 i 392 k.c. z tytułu umowy ubezpieczenia oraz odpowiedzialność z art. 91, 93, 96 i 100 dawnego Prawa geologicznego i górniczego ${ }^{103}$.

Kwestia zakresu pojęcia sprawstwa w prawie cywilnym nie jest pozbawiona wątpliwości. Ewolucja odpowiedzialności cywilnej sprawia, że karnoprawne rozumienie sprawstwa jako sytuacji, w której sprawcy można zarzucić subiektywną winę, to jest zły zamiar albo zarzucalną nieumyślność, przestało być w prawie cywilnym odpowiednie. W przypadkach dotyczących odpowiedzialności na zasadzie ryzyka oraz odpowiedzialności za cudze czyny w istocie można doszukać się sprawstwa, tyle że rozumianego inaczej niż w prawie karnym. Ustawa przypisuje odpowiedzialność za szkodę osobom, które odnoszą korzyści, ale jednocześnie wywołują zagrożenie dla otoczenia przez posługiwanie się innymi osobami albo określonymi urządzeniami. Przypisanie osobie prowadzącej przedsiębiorstwo wprawiane w ruch siłami przyrody sprawstwa szkód wywołanych ruchem tego przedsiębiorstwa nie kłóci się ze współczesnym poczuciem językowym. Dodatkowo w przypadku odpowiedzialności za małoletnich, zwierzęta oraz za powierzenie czynności podmiot odpowiedzialny ponosi odpowiedzialność za własną winę, określaną mianem winy w nadzorze albo w wyborze. Przyznać jednak trzeba, że Kodeks cywilny w rzadkich przypadkach posłużenia się określeniem „sprawca” odnosi je do osób, między których działaniem lub zaniechaniem a szkodą istnieje adekwatny, a nawet bezpośredni związek przyczynowy (por. 428 i 429 k.c.). Sam W. Warkałło zdawał się zresztą odczuwać niedostatki używanego przez siebie określenia sprawstwa,

103 M. Kaliński, Szkoda..., s. 20-23. 
pisząc, że związek między działaniem a zaniechaniem sprawcy „słusznie czy niesłusznie zwany przyczynowym zazębia się o zachowanie osoby odpowiedzialnej lub osoby, za którą ona ponosi odpowiedzialność"104.

Niezależnie od powyższego wypada zauważyć, że określanie przez M. Kalińskiego koncepcji W. Warkałły jako nieoperatywnej wynika zapewne stąd, że pomijając art. 438 k.c. (poniesienie szkody w cudzym interesie), ogranicza ona typ odpowiedzialności gwarancyjnej do przypadków sytuowanych w reżimie odpowiedzialności gwarancyjnej, co sprawia, że wątpliwe staje się wyróżnienie typu odpowiedzialności gwarancyjnej oprócz reżimu takiej odpowiedzialności. Problem w dużej mierze wynika stąd, że obydwaj cytowani autorzy zacieśniają swe rozważania wyłącznie do odpowiedzialności odszkodowawczej. Wyróżnienie typów odpowiedzialności gwarancyjnej i odpowiedzialności sprawczej staje się bardziej operatywne, gdy odnieść je również do przypadków odpowiedzialności wykraczających poza sferę wąsko rozumianej odpowiedzialności odszkodowawczej ${ }^{105}$. Spośród przypadków przewidzianych przez Kodeks cywilny najistotniejsze znaczenie ma oczywiście odpowiedzialność nabywcy przedsiębiorstwa lub gospodarstwa rolnego za zobowiązania związane $\mathrm{z}$ prowadzeniem tego przedsiębiorstwa lub gospodarstwa (art. $55^{4}$ k.c.). Poza tym można wskazać choćby odpowiedzialność nabywcy spadku za długi spadkowe (art. $1055 \$ 1$ k.c.).

Liczne przypadki ustawowego przystąpienia do długu zasługujące na miano odpowiedzialności gwarancyjnej przewidziane są w Kodeksie spółek handlowych. Dotyczy to w szczególności odpowiedzialności wspólników spółki osobowej za jej długi (art. $22 \$ 1$ w zw. z art. 31 k.s.h.), odpowiedzialność wspólnika przystępującego do spółki osobowej za zobowiązania powstałe przed jego przystąpieniem (art. 32 k.s.h.), odpowiedzialność osoby zawierającej umowę spółki osobowej z przedsiębiorcą jednoosobowym wnoszącym do tej spółki przedsiębiorstwo za długi tego przedsiębiorstwa (art. 33 k.s.h.), odpowiedzialność nabywcy

104 W. Warkałło, Odpowiedzialność..., s. 169.

105 M. Jastrzębski zwraca uwagę, że odszkodowawczy charakter nie należy do istoty odpowiedzialności odszkodowawczej także w znaczeniu jej reżimu. Por. M. Jastrzębski, Nieubezpieczeniowe umowy gwarancyjne, PPH 2018/7, s. 5. 
udziału w spółce osobowej za zobowiązania zbywcy związane z udziałem oraz zobowiązania spółki (art. $10 \$ 3$ k.s.h.), odpowiedzialność nabywcy udziału w spółce z o.o. za niespełnione świadczenia należne spółce ze zbytego udziału (art. $186 \$ 1$ k.s.h.) i odpowiedzialność członków zarządu spółki z o.o. za jej długi (art. 299 k.s.h.).

Jak zaznaczono, przykład tego ostatniego przepisu najlepiej wskazuje, jak bardzo wieloznaczne są określenia „odpowiedzialność odszkodowawcza” oraz „odpowiedzialność gwarancyjna”. Oczywiście nie ma zgody co do tego, że odpowiedzialność z art. 299 k.s.h. ma charakter gwarancyjny, w orzecznictwie Sądu Najwyższego zwyciężyła teoria odszkodowaw$\mathrm{cza}^{106}$. Można zresztą odnieść wrażenie, że uczestnicy sporu, powołując się na W. Warkałłę, od początku używają terminu „odpowiedzialność gwarancyjna” w zupełnie innym rozumieniu niż autor tego określenia. Kwestię dostrzega m.in. A. Kappes, rozpoczynając jednak swój wywód od nieprecyzyjnego wskazania, że W. Warkałło przez odpowiedzialność gwarancyjną rozumiał rodzaj odpowiedzialności deliktowej ${ }^{107}$.

Wydaje się, że w sporze o charakter odpowiedzialności z art. 299 k.s.h. odróżnienie odpowiedzialności sprawczej od gwarancyjnej nałożyło się na odróżnienie odpowiedzialności za szkodę i odpowiedzialności niemającej takiego charakteru, ostatecznie przybierając postać przeciwstawienia odpowiedzialności odszkodowawczej i odpowiedzialności gwarancyjnej. Istota zagadnienia sprowadza się natomiast do tego, że wśród przypadków odpowiedzialności gwarancyjnej mieszczą się zarówno przypadki odpowiedzialności za szkodę, jak i przypadki niemające takiego charakteru, podobnie jak wśród przypadków odpowiedzialności odszkodowawczej są zarówno przypadki odpowiedzialności sprawczej, jak i przypadki niemające takiego charakteru.

W istocie zatem w sporze o charakter odpowiedzialności z art. 299 k.s.h. polemizują ze sobą przedstawiciele teorii sprawczej i gwarancyjnej oraz odszkodowawczej i nieodszkodowawczej, mieszając obydwa kryteria

106 Uchwała SN (7) z 7.11.2008 r., III CZP 72/08, OSNC 2009/9, poz. 20. Tak również M. Krajewski, Pojęcie odpowiedzialności..., s. 472-473.

107 Por. A. Kappes, Odpowiedzialność członków..., s. 155 oraz 160-161. 
rozróżnienia. Różnice ujęć wynikają oczywiście z różnych zainteresowań autorów zajmujących się charakteryzowaniem typów odpowiedzialności. Obserwacja T. Dybowskiego, że W. Warkałło widzi szerokie zagadnienie odpowiedzialności odszkodowawczej przez pryzmat odpowiedzialności ubezpieczyciela, jest z pewnością słuszna. Zupełnie inne jest spojrzenie autorów zajmujących się prawem spółek, w szczególności próbujących scharakteryzować odpowiedzialność członków zarządu spółki z o.o. za jej długi. Kolokwialnie można powiedzieć, że punkt wyjścia wyznacza w tym przypadku punkt dojścia.

Cytowany już A. Kappes próbuje naświetlić problem z innej strony, analizując pojęcie odpowiedzialności za dług cudzy. Wśród przypadków określanych mianem odpowiedzialności za dług cudzy sensu largo umieszcza sytuację ponoszenia przez daną osobę odpowiedzialności w związku z innym zobowiązaniem (długiem głównym), a więc obok zobowiązania innej osoby. Dla lepszego zobrazowania można powiedzieć, że dług główny jest długiem pierwotnym, za który wtórnie odpowiedzialność ponosi inna osoba, przy czym odpowiedzialność tej osoby pełni funkcję gwarancyjną. Cytowany autor wskazuje, że przypadki odpowiedzialności za cudzy dług sensu largo różnią się co do źródła (ustawa czy czynność prawna), akcesoryjności lub jej braku, możliwości regresu lub subrogacji, solidarnego charakteru lub jego braku, osobistego bądź rzeczowego charakteru, ograniczonego lub nieograniczonego charakteru, odpłatności lub jej braku, związku z profesjonalną działalnością podmiotu odpowiedzialnego lub braku takiego związku ${ }^{108}$.

Następnie A. Kappes przedstawia znany problem dotyczący charakteru odpowiedzialności poręczyciela, zastanawia się nad rozróżnieniem odpowiedzialności oraz długu, konkludując, że w każdym przypadku odpowiedzialności za cudzy dług mamy jednak do czynienia nie tylko z odpowiedzialnością, ale również z długiem, tyle że cudzym. Ostatecznie cytowany autor dochodzi do wniosku, że właściwym kryterium wyróżnienia odpowiedzialności za cudzy dług jest kryterium woli jej ponoszenia przez podmiot odpowiedzialny i do przypadków odpowie-

108 A. Kappes, Odpowiedzialność za cudzy dług. Próba analizy pojęcia [w:] Europeizacja prawa prywatnego, red. M. Pazdan i in., Warszawa 2008, s. 532-533. 
dzialności za cudzy dług sensu stricto zalicza jedynie przypadki, w których brakuje oświadczenia woli osoby ponoszącej odpowiedzialność wyrażającego zamiar ponoszenia odpowiedzialności zamiast lub obok innej osoby. Takie ujęcie prowadzi do zakwalifikowania jako przypadków odpowiedzialności za cudzy dług jedynie sytuacji, gdy wynika ona z przepisu ustawy ${ }^{109}$. Odpowiedzialność ubezpieczyciela jest oczywiście odpowiedzialnością za cudzy dług tylko w pierwszym szerokim znaczeniu. Aleksander Kappes umieszcza zresztą w tej grupie jedynie odpowiedzialność ubezpieczyciela w ubezpieczeniu OC. Można jednak wskazać, że we wszystkich przypadkach, gdy ubezpieczyciel odpowiada za szkodę wyrządzoną działaniem ludzkim, nie zaś niezależnymi od człowieka siłami przyrody, chodzi w istocie o szeroko rozumianą odpowiedzialność za cudzy dług.

Charakteryzowanie odpowiedzialności ubezpieczyciela jako odpowiedzialności za cudzy dług napotyka generalnie na dwie przeszkody. Po pierwsze, jak już wskazano, ubezpieczyciel odpowiada nie tylko za szkody wyrządzone działaniem ludzkim, ale również wynikające z przyczyn niezależnych od człowieka. W niektórych przypadkach zatem nie będzie żadnego pierwotnego długu, za który ubezpieczyciel odpowiadałby jedynie wtórnie. Można dodatkowo wskazać, że z tego powodu nie da się generalnie określić odpowiedzialności ubezpieczyciela mianem odpowiedzialności wtórnej, występującej obok lub zamiast odpowiedzialności pierwotnej. Po drugie, co również wskazano, nawet w tych przypadkach, gdy ubezpieczyciel odpowiada za szkodę wyrządzoną przez osobę trzecią, jego odpowiedzialność wynika z zawarcia umowy ubezpieczenia, której istotą jest dobrowolne przejęcie odpowiedzialności za szkody wynikające z działania innych osób lub sił przyrody. Nie sposób w tej sytuacji twierdzić, że ubezpieczyciel nie zaciąga własnego długu. W tych przypadkach, gdy doznana przez ubezpieczonego szkoda wynika z działania człowieka, można co najwyżej powiedzieć, jak w przypadku odpowiedzialności poręczyciela, że ubezpieczyciel odpowiada za dług formalnie własny, ale materialnie cudzy, Takie ujęcie również jednak nasuwa zastrzeżenia, choćby z tego powodu, że w przypadku odpowiedzialności ubezpieczyciela w ubezpie-

109 A. Kappes, Odpowiedzialność za cudzy dług..., s. 534-539. 
czeniu mienia, inaczej niż w ubezpieczeniu OC, brakuje akcesoryjności między zakresem odpowiedzialności sprawcy a odpowiedzialnością ubezpieczyciela, ewentualnie akcesoryjność ta jest modyfikowana przez cały szereg typowych dla ubezpieczeń ograniczeń odpowiedzialności dotyczących nie tylko zakresu odszkodowania pieniężnego wypłacanego przez ubezpieczyciela.

Ewentualne trzecie zastrzeżenie wiąże się z samym pojęciem odpowiedzialności za cudzy dług. Właściwie do wszystkich przypadków odpowiedzialności charakteryzowanych jako odpowiedzialność za cudzy dług można odnieść wywodzące się od Longchampsa de Bériera, a przejęte przez A. Szpunara powiedzenie o odpowiedzialności za dług formalnie własny, a materialnie cudzy. Dług odpowiada przecież wierzytelności w zobowiązaniu, a źródłem zobowiązania może być nie tylko własne działanie lub czynność prawna, ale również sam przepis ustawy. Nawet w sytuacjach, gdy podmiot odpowiedzialny nie zaciąga własnego zobowiązania, ale dług obciąża go z mocy ustawy, często obok lub zamiast innej osoby, dług jest zatem w istocie długiem podmiotu odpowiedzialnego. Jak trafnie zauważa A. Kappes, prawo polskie w zasadzie nie zna konstrukcji odpowiedzialności bez długu. Konkludując, powiedzieć można, że wyróżnienie oprócz odpowiedzialności sprawczej i gwarancyjnej odpowiedzialności za własny i cudzy dług niewiele wnosi, gdy chodzi o charakterystykę odpowiedzialności ubezpieczyciela, chociaż sama okoliczność, że dług pierwotnie obciążał inną osobę, rzeczywiście rzutuje na kwestie regresu oraz w zakresie ubezpieczenia OC na kwestię przedawnienia roszczeń (por. art. $828 \$ 1$ oraz art. $819 \$ 3$ k.c.).

Wydaje się zatem, że należy pozostać przy zaproponowanym przez W. Warkałłę odróżnieniu odpowiedzialności gwarancyjnej od odpowiedzialności sprawczej, odnosząc, jak sam twórca odróżnienia, sprawstwo także do przypadków, w których odpowiada się za winę w wyborze, winę w nadzorze, a także posłużenie się urządzeniami, których podmiot odpowiedzialny nie jest w stanie kontrolować. Dodać można, że zastrzeżenia samego W. Warkałły, według których związek między działaniem sprawcy jest nie całkiem słusznie zwany przyczynowym, jak również zastrzeżenia jego krytyków dotyczące braku adekwatności w wielu przypadkach klasyfikowanych przezeń jako odpowiedzialność 
sprawcza, nie są zupełnie trafione. Pomiędzy posłużeniem się siłą, rzeczą albo osobą, której sprawca nie jest w stanie kontrolować, a szkodą istnieje w istocie związek przyczynowy, i to mający cechy normalności następstw, bardzo często brakuje bezpośredniości następstw, jednakże tego kryterium polska ustawa cywilna nie wymaga, ograniczając się do kryterium adekwatności. Użycie przez Kodeks cywilny w art. 428 i 429 określenia „sprawca” jedynie do osób, które bezpośrednio wyrządziły szkodę, zamiast do osób odpowiedzialnych za ich działanie, nie powinno być decydujące, szczególnie że przynajmniej gdy chodzi o osoby nieodpowiedzialne z uwagi na wiek lub stan psychiczny, określenie „sprawca” również może nasuwać zastrzeżenia. Przykładowo określenie to w odniesieniu do rocznego dziecka, które potrąca świeczkę, ucząc się chodzić, jest niewiele bardziej odpowiednie niż w odniesieniu do psa lub kota, który czymś przestraszony taką świeczkę potrąca.

Zarzutu nieoperatywności odróżnienia łatwo się unika, zauważając, że odróżnienie odpowiedzialności sprawczej i gwarancyjnej krzyżuje się z odróżnieniem odpowiedzialności odszkodowawczej i nieodszkodowawczej. Odpowiedzialność gwarancyjną należy zatem odnieść nie tylko do przypadków odpowiedzialności za wyrządzoną przez kogoś szkodę, określanych tradycyjnie mianem odpowiedzialności odszkodowawczej, ale również do przypadków odpowiedzialności określanych niekiedy mianem odpowiedzialności za cudzy dług w szerokim znaczeniu, do których dochodzi zwykle w wyniku przystąpienia do długu z mocy ustawy albo czynności prawnej. Precyzyjnie rzecz ujmując, można powiedzieć, że odpowiedzialność gwarancyjna ubezpieczyciela w ubezpieczeniu mienia wynika z czynności prawnej, ma charakter osobisty, a nie rzeczowy, jest odpłatna, ilekroć dotyczy szkody wyrządzonej przez osobę trzecią, wiąże się z możliwością regresu lub subrogacji i ponoszona jest in solidum ze sprawcą szkody, a nadto co do zasady nie ma charakteru akcesoryjnego. 


\subsubsection{Kryterium ekonomicznego rozkładu ciężaru odpowiedzialności}

Drugie kryterium wyróżnienia różnych typów odpowiedzialności dotyczy ekonomicznego rozkładu ciężaru odpowiedzialności i wiąże się ze wskazaniem odpowiedzialności typu indywidualnego oraz odpowiedzialności typu repartycyjnego. W przypadkach odpowiedzialności indywidualnej odszkodowanie musi zostać pokryte ze środków podmiotu odpowiedzialnego, najczęściej samego sprawcy. W przypadkach odpowiedzialności repartycyjnej ciężar odszkodowania rozkłada się na liczne grono osób wchodzących w skład określonej wspólnoty. Granice rozróżnienia również są nieostre. Łatwo wskazać, że odpowiedzialność ubezpieczyciela odpowiadającego za stłuczoną szybę różni się w sposób zasadniczy od odpowiedzialności jednostki, która wybiła szybę. Istnieją jednak liczne sytuacje, w których ciężar naprawienia szkody rozkłada się na krąg podmiotów wchodzących w stosunki kontraktowe z dłużnikiem, tradycyjnie podaje się tu przykład monopolisty przerzucającego wydatki na ogół odbiorców za pomocą odpowiednich narzutów na cenę dostarczanych dóbr i usług.

Nie budzi większych wątpliwości, że nie ma charakteru repartycyjnego odpowiedzialność spółki lub spółdzielni, lub innych korporacji. Odpowiedzialność za wyrządzoną przez korporację szkodę rozkłada się na jej członków, wynika to jednak w sposób naturalny ze struktury tej korporacji, jej statutu oraz zasad rachunkowości. Dopatrywanie się w tych przypadkach odpowiedzialności repartycyjnej trudno pogodzić z teorią osób prawnych przyznającą takim osobom odrębny byt prawny, i to zupełnie niezależnie od tego, czy można upatrywać w osobach prawnych odrębnych bytów rzeczywistych ${ }^{110}$. Do odpowiedzialności repartycyjnej zalicza się natomiast odpowiedzialność Skarbu Państwa oraz jednostek samorządu terytorialnego. System budżetowy musi uwzględniać konieczność realizacji zobowiązań odszkodowawczych, co odbija się negatywnie na możliwości realizacji przez wskazane podmioty odpowiedzialne interesów ich członków. Jak wskazywał W. Warkałło, wiąże się to z zadaniami akumulacyjno-dystrybucyjnego systemu budżetowego.

110 Por. W. Warkałło, Odpowiedzialność..., s. 112-113. 
Cytowany autor upatrywał w odpowiedzialności repartycyjnej wyższej formy odpowiedzialności, wskazując, że w większym stopniu zapewnia ona pokrycie uszczerbku w całości. Kompensacja indywidualna polega bowiem na tym, że wypełnienie wyrwy w majątku poszkodowanego kompensowane jest na skutek uczynienia wyrwy w indywidualnym majątku konkretnego dłużnika, a zatem w ujęciu globalnym niewiele się zmienia. Przy repartycji ubezpieczeniowej albo budżetowej sprawa przedstawia się inaczej, wyrwa w majątku poszkodowanego naprawiana jest bowiem przez doprowadzenie majątku pochodzącego, obrazowo mówiąc, ze znacznie większej powierzchni. Stosunkowo drobny udział każdego z uczestników zbiorowości w pokryciu szkody stanowi dla nich ofiarę ledwie odczuwalną. Wprowadzenie odpowiedzialności repartycyjnej może być zatem traktowane jako przejaw ekonomizacji odpowiedzialności cywilnej. Ekonomizacja polega tu na wykorzystaniu instytucji cywilnoprawnej odpowiedzialności do zaspokojenia gospodarczej potrzeby pokrywania szkód zagrażających procesom produkcji ${ }^{111}$.

Rozróżnienie to zaaprobował, jak się zdaje, również A. Szpunar, wskazując, że pełna realizacja systemu roszczeń regresowych oznaczałaby przesunięcie ciężaru odszkodowań z powrotem na osoby ponoszące odpowiedzialność indywidualną. Jego zdaniem przemawia to za przyjęciem w wielu przypadkach rozwiązania, wedle którego osoba odpowiedzialna za szkodę zostaje przynajmniej częściowo zwolniona z obowiązku jej naprawiania ${ }^{112}$. Jak wiadomo, rozwiązanie takie rzadko jest stosowane w ubezpieczeniach majątkowych. Przeciwko niemu przemawia art. 828 k.c. przewidujący podstawienie ubezpieczyciela, który spłacił dług w miejsce ubezpieczającego, co do roszczeń wobec sprawcy szkody. Zwrócić wypada jednak uwagę, że przepis ten jest względnie obowiązujący, a nadto odpowiedniej regulacji brakuje w ubezpieczeniach osobowych.

Zaproponowany przez W. Warkałłę podział na odpowiedzialność indywidualną i repartycyjną skrytykował T. Dybowski. Zdaniem tego

111 W. Warkałło, Odpowiedzialność..., s. 114.

112 A. Szpunar, Ustalenie odszkodowania w prawie cywilnym, Warszawa 1975, s. 99; A. Szpunar, Odszkodowanie..., s. 77. 
ostatniego autora omawiany podział nie ma charakteru prawnego, ale wyłącznie ekonomiczny. Z punktu widzenia treści stosunku odszkodowawczego odpowiedzialność zawsze obciąża konkretny podmiot, nie zaś zbiór o trudnym nieraz do określenia składzie osobowym ${ }^{113}$. W prawie polskim dotychczas brak uregulowań nakładających ciężar naprawienia szkody na zbiorowość, co wiąże się z koniecznością związku przyczynowego między zachowaniem szkodzącym a skutkiem szkodowym, względnie związku normatywnego, na mocy którego przepisy nakładają odpowiedzialność na konkretny podmiot, nie zaś na grupę podmiotów ${ }^{114}$.

Krytykę nieco łagodzi M. Kaliński, wskazując, że możliwe jest wprowadzenie odpowiedzialności repartycyjnej na mocy normy prawnej. Przykładem takiego rozwiązania mają być rozwiązania stosowane w przypadku pozornego zbiegu przyczyn (przyczynowość alternatywna), gdy nie można jednoznacznie ustalić sprawstwa i w grę wchodzi wiele podmiotów podejmujących działania prowadzące do konkretnego uszczerbku. Ma to istotne znaczenie przede wszystkim w przypadku odpowiedzialności za produkt niebezpieczny, kiedy produkt, np. lek, wytwarzany jest przez wiele podmiotów i nie można wskazać, kto był producentem leku, który zażył poszkodowany. Nałożenie odpowiedzialności solidarnej na szerszy krąg podmiotów można w tych sytuacjach uznać za przejaw odpowiedzialności repartycyjnej, i to w sensie prawnym, a nie tylko ekonomicznym ${ }^{115}$.

Wydaje się, że poglądy wskazujące na wyłącznie ekonomiczny charakter podziału na odpowiedzialność indywidualną oraz repartycyjną pomijają szczególny aspekt ubezpieczeń polegający na bezpośrednim związku świadczenia ubezpieczyciela w konkretnym stosunku ubezpieczeniowym z działalnością ubezpieczeniową w makroskali. Nawet przyjąwszy tzw. teorię świadczenia pieniężnego, nie sposób pominąć, że spełnienie świadczenia w formie pieniężnej jest możliwe jedynie dzięki prowadzeniu przez ubezpieczyciela działalności w określony sposób. Związek,

\footnotetext{
113 T. Dybowski, Naprawienie..., s. 175.

114 M. Kaliński, Szkoda..., s. 113-114.

115 M. Kaliński, Szkoda..., s. 19 oraz 405 i n.
} 
o którym mowa, akcentuje teoria ponoszenia ryzyka w zmodyfikowanej postaci, upatrująca w świadczeniu ubezpieczyciela zespołu czynności składających się na prowadzenie działalności ubezpieczeniowej ${ }^{116}$. Omawiane kwestie będą przedmiotem szczegółowych rozważań w drugim rozdziale pracy dotyczącym treści świadczenia ubezpieczyciela.

W tym miejscu warto zauważyć, że we włoskiej i niemieckiej nauce ubezpieczeniowej stworzono szereg koncepcji łączących świadczenie ubezpieczeniowe w konkretnym indywidualnym stosunku ubezpieczeniowym z działalnością ubezpieczeniową. Teorie te upatrują w instytucji ubezpieczenia stosunku wieloosobowego. Zarzuca się im wprawdzie właśnie, że ujmują ubezpieczenie od strony ekonomicznej, nie można im jednak odmawiać jakichkolwiek walorów prawnych. Wskazane koncepcje oparte są na obserwacji, że składki wpłacane przez wszystkich ubezpieczonych służą pokryciu strat, które dotknęły niektórych spośród nich. Ubezpieczeni pozostają zatem ze sobą w związku, tworząc otwarty krąg wykazujący tendencję do włączania możliwie wielkiej liczby osób, tak by mogło działać prawo wielkich liczb.

Obserwacja, że repartycja ryzyka grożącego jednostce na krąg osób tworzących związek dokonuje się dzięki istnieniu przedsiębiorcy ubezpieczeniowego, który przejmuje organizację tej repartycji, leży u podstaw tzw. teorii przedsiębiorstwa stworzonej przez C. Vivante. Według tego autora istota ubezpieczenia polega na utworzeniu przedsiębiorstwa służącego powiązaniu ryzyk i kapitałów poprzez stałe i systematyczne zawieranie umów ubezpieczenia ${ }^{117}$. Meinrad Dreher zarzuca tej teorii, że koncentruje się ona na kolektywnym elemencie ubezpieczenia oraz istnieniu przedsiębiorstwa zamiast na konkretnym umownym stosunku, który jest esencją ubezpieczenia i przynajmniej w obcych systemach prawnych może powstawać także na mocy umowy zawartej $\mathrm{z}$ indywidualnym ubezpieczycielem niebędącym przedsiębiorcą. W tym ostatnim przypadku M. Dreher ma zapewne na myśli umowy zawiera-

116 Ostatnio w tym kierunku również J. Jastrzębski, Nieubezpieczeniowe..., s. 15.

117 M. Dreher, Die Versicherung..., s. 34; H. Möller, Wspótczesne teorie o pojęciach ubezpieczenia i umowy ubezpieczenia, referat wygłoszony na Kongresie AIDA w 1969 r., którego tłumaczenie opublikowano w WU 1969/6, s. 4 i n. 
ne w ramach Lloyd's of London ${ }^{118}$. Wskazany argument krytyczny jest słuszny jedynie częściowo. Po pierwsze, ani w Niemczech, ani w Polsce nie można zawrzeć ubezpieczenia $\mathrm{z}$ indywidualną osobą. Po drugie, również w ramach rynku Lloyd's tzw. underwriterzy akceptują ryzyko nie w imieniu indywidualnych osób, ale w imieniu syndykatów, w które zorganizowane są te osoby ${ }^{119}$. Nadto w związku z kryzysem finansowym Lloyd's z początku lat 90. ubiegłego wieku, związanym przede wszystkim z tzw. long-tail claims, stworzono cały system centralnych zabezpieczeń na poziomie korporacji Lloyd's.

Zdaniem E. Brucka związek ubezpieczonych, w którym C. Vivante widział przedsiębiorstwo, prowadzi do powstania rzeczywistej wspólnoty ryzyk. Dlatego teoria E. Brucka określana jest mianem teorii wspólnoty ryzyk. Jego zdaniem wspólnota ryzyka istnieje nie tylko w instytucjach samopomocy, takich jak towarzystwa ubezpieczeń wzajemnych, ale również w spółkach akcyjnych. Wieloczłonowość wspólnoty ryzyka powoduje podobieństwo warunków ubezpieczenia oraz ich obiektywną interpretację, jak również ograniczenie wolności umowy w stosunku ubezpieczenia, wymaga ona także równego traktowania ubezpieczonych. Teoria E. Brucka czyni założenie techniczne sprowadzające się do tworzenia homogenicznych klas ryzyka oraz planowego działania ubezpieczyciela cechą charakterystyczną ubezpieczenia w ujęciu prawnym ${ }^{120}$.

Z podobnych założeń wychodzi teoria upatrująca w ubezpieczeniu umowy o załatwienie interesu broniona przede wszystkim przez $\mathrm{H}$. Eichlera. Według tego autora działalność ubezpieczycieli polega na swego rodzaju powiernictwie. Ubezpieczyciel tworzy wspólnotę ryzyka, w skład której wchodzą ubezpieczający, i zarządza tą wspólnotą. Właśnie za przyjęcie do istniejącej wspólnoty ryzyka płacona jest składka. Składka uiszczana jest zatem ubezpieczycielowi jako powiernikowi, który zarządza pieniędzmi ubezpieczających oraz całej wspólnoty tak, by z pieniędzy tych

118 M. Dreher, Die Versicherung..., s. 34.

119 Ponadto, jak wskazuje przykładowo M. Clarke, udział tzw. names w rynku Lloyd’s stale maleje. W 2004 r. wynosił tylko 13\%, podczas gdy 80\% udziałowców stanowiły inne korporacje. M. Clarke, Policies and Perceptions of Insurance Law in The Twenty-First Century, Oxford 2005, s. 41.

120 M. Dreher, Die Versicherung..., s. 35; H. Möller, Współczesne..., s. 4 i n. 
sfinansować świadczenia wypłacane tym spośród ubezpieczających, których dotknęły zdarzenia losowe. Za administrowanie wspólnotą ryzyka ubezpieczycielowi należne jest wynagrodzenie, które uwzględnione jest w wysokości składek. Ubezpieczyciel, przejmując ryzyko, wyświadcza ubezpieczającemu usługę, prowadzi jego interesy majątkowe, pełniąc rolę powiernika i opiekuna, umowa między nimi oparta jest na szczególnym zaufaniu ${ }^{121}$.

W prawie angielskim R. Merkin i J. Steele podkreślają, że zasada repartycji rodzi konflikt między samą ideą odpowiedzialności a ubezpieczeniem. Ubezpieczenie jako instrument umożliwiający rozproszenie ryzyka prowadzi do rozcieńczenia odpowiedzialności. W tym ujęciu ubezpieczenia stoją w opozycji do prawa deliktowego, które opiera się na odpowiedzialności osobistej. Autorzy wywodzą jednak, że prawo ubezpieczeń nie neguje pojęcia odpowiedzialności w obrębie prawa prywatnego, ale zmienia jego sens przynajmniej w dwóch aspektach. Pierwszy aspekt polega na propagowaniu przez ubezpieczenia idei odpowiedzialności za samego siebie, ponieważ, zawierając ubezpieczenie, jednostka unika bycia ciężarem dla innych. Drugi aspekt polega na propagowaniu przez ubezpieczenia idei odpowiedzialności za innych, ponieważ, zawierając ubezpieczenie, jednostka dostarcza środków na pokrycie wypłacanych im odszkodowań ${ }^{122}$.

Problem z wyróżnieniem odpowiedzialności indywidualnej i repartycyjnej, jeszcze w większym zakresie niż odróżnienie odpowiedzialności sprawczej i gwarancyjnej, polega na nieoperatywności odróżnienia z uwagi na fakt, że jedynymi przypadkami typowej odpowiedzialności repartycyjnej wydają się właśnie odpowiedzialność ubezpieczeniowa oraz ewentualnie odpowiedzialność Skarbu Państwa i jednostek samorządu terytorialnego. Wprawdzie W. Warkałło jako odpowiedzialność repartycyjną traktuje również odpowiedzialność nuklearną (odpowiedzialność za szkodę jądrową), wynika to jednak z objęcia tej odpowiedzialności obowiązkowym ubezpieczeniem odpo-

121 P. Schimikowski, Versicherungsvertragsrecht, s. 25-26; M. Dreher, Die Versicherung..., s. 74-75; M. Wandt, Versicherungsrecht, s. 9.

122 R. Merkin, J. Steele, Insurance and the Law of Obligations, Oxford 2013, s. 30-31 i n. 
wiedzialności cywilnej. Innymi słowy, moment repartycji nie dotyczy wcale odpowiedzialności osoby eksploatującej urządzenia jądrowe, która jest odpowiedzialnością indywidualną. Zarzut nieoperatywności można oczywiście złagodzić, wskazując, że ustawy atomowe nie zadowalają się repartycją ubezpieczeniową, ale ponadto przewidują odpowiedzialność państwa, do którego należy reaktor, w przypadku szkód o rozmiarze katastrofalnym, wyższym od pułapu osiąganej w danym kraju ochrony ubezpieczeniowej. W tym sensie da się powiedzieć, że odpowiedzialność atomowa rozkłada się na wszystkich obywateli, stanowiąc przykład odpowiedzialności Skarbu Państwa, którą jak wyżej wskazano, traktować można jako drugi poza ubezpieczeniami przykład odpowiedzialności repartycyjnej.

\subsubsection{Kryterium pełności odszkodowania}

Ostatnim zaproponowanym rozróżnieniem typów odpowiedzialności odszkodowawczej jest podział ze względu na kryterium pełności odszkodowania. Kwestie zakresu odszkodowania ubezpieczeniowego będą omówione dalej. Na obecnym etapie można przypomnieć, że zasadą prawa odszkodowawczego jest pełność odszkodowania. Wymiar odszkodowania wyznacza przede wszystkim teoria różnicy mówiąca najogólniej o tym, że należy porównać stan majątkowy osoby, która doznała szkody, ze stanem przed szkodą oraz doprowadzić do postawienia poszkodowanego w takiej samej sytuacji, w jakiej był przed szkodą. Kodeks cywilny wyróżnia przy tym tylko dwie składowe szkody, a mianowicie szkodę efektywnie poniesioną (damnum emergens) oraz utracone zyski (lucrum cessans).

Efektywnie poniesiona szkoda obejmuje przy tym również wydatki poniesione z woli poszkodowanego, ale pozostające w adekwatnym związku przyczynowym z doznaną szkodą, jak również niektóre przypadki tzw. szkody czysto handlowej, w szczególności utratę wartości handlowej rzeczy na skutek konieczności dokonania naprawy. Inną kwestią, która wykracza poza zakres niniejszego opracowania dotyczącego jedynie ubezpieczeń mienia, jest objęcie pojęciem szkody tzw. krzywdy, czyli szkody niemajątkowej obejmującej uszczerbek w zakresie dóbr osobi- 
stych $^{123}$. Utracony zysk obejmuje z kolei: 1) utracony zarobek z własnej działalności (lucrum cessans sensu stricto), 2) utratę spodziewanego zysku z przyszłych transakcji (lucrum speratum, np.: korzyści ze zbycia przewożonych towarów po dostarczeniu ich do miejsca przeznaczenia), 3) utratę pożytków i przychodów z rzeczy, 4) utratę możności korzystania $z$ rzeczy ${ }^{124}$.

Kwestią sporną jest kwalifikacja oraz możliwość naprawienia tzw. szkody przyszłej (damnum futurum) ${ }^{125}$ oraz szkody ewentualnej ${ }^{126}$. Należy zgodzić się z M. Kalińskim, że tzw. szkody przyszłe, o ile są rzeczywiście przyszłe, tzn. w żadnym zakresie nie istnieją w chwili orzekania, jak również szkody ewentualne, tzn. polegające na utracie szansy i nadziei o trudnym do ustaleniu prawdopodobieństwie realizacji, wedle zasad ogólnych Kodeksu cywilnego nie podlegają naprawieniu. Jeszcze mniej wątpliwe jest wyłączenie $\mathrm{z}$ zakresu szkody podlegającej naprawieniu uszczerbków na mieniu mających charakter ubytków naturalnych materiałowo-towarowych wywołanych przemianami fizyko-chemicznymi (np.: wysuszka, ewaporacja) lub fizjologicznymi (zwykły ubytek masy zwierząt rzeźnych w trakcie transportu i przetrzymywania) czy mechanicznymi (rozkurcz, rozsyp przy składowaniu, ładowaniu, transporcie itp.), jeżeli ubytki te nie przekraczają norm empirycznie ustalonych ${ }^{127}$.

Na gruncie prawa cywilnego występuje cały szereg przypadków odpowiedzialności niepełnej lub ograniczonej. Ich omawianie, a nawet wyczerpujące wyliczanie wykracza oczywiście poza tematykę pracy. Wypada jednak przedstawić choćby ogólne rodzaje wchodzących w grę ograniczeń celem porównania z nimi odpowiedzialności ubezpieczy-

${ }^{123}$ W polskiej doktrynie zwyciężyła, jak się zdaje, koncepcja, że szkoda obejmuje również szkodę niemajątkową. Co do tej kwestii, zob. A. Szpunar, Ustalenie odszkodowania w prawie...; A. Szpunar, Odszkodowanie... Kwestia ta jednak nie jest zupełnie pozbawiona wątpliwości. Por. W. Warkałło, Odpowiedzialność..., s. 125-129.

124 M. Kaliński, Szkoda..., s. 275-276.

125 M. Kaliński, Szkoda..., s. 262, 276 oraz 453-458.

126 M. Kaliński, Szkoda..., s. 262, 276, 453-458 (co do szkody przyszłej) oraz s. 253-260 (co do szkody ewentualnej).

127 W. Warkałło, Odpowiedzialność..., s. 135-136. 
ciela. Wśród ogólnych czynników wpływających na wysokość odszkodowania można wskazać:

- sposoby ustalenia szkody prawnie relewantnej (art. $361 \S 2$ k.c.) z ograniczeniami dotyczącymi przede wszystkim przyjęcia kryteriów obiektywnych zamiast subiektywnych, naprawienia szkody jedynie $\mathrm{w}$ granicach damnum emergens albo $\mathrm{w}$ granicach ujemnego interesu umowy,

- kwestię selekcji następstw, za które ponoszona jest odpowiedzialność, przez wprowadzenie kryterium ich normalności lub bezpośredniości (art. $361 \$ 1$ k.c., art. 250 i 320 k.m.),

- przyczynienie poszkodowanego do powstania szkody (art. 362 k.c.),

- miarkowanie odszkodowania (art. 440 k.c.),

- umowne modyfikacje odpowiedzialności za szkodę wynikającą z niewykonania zobowiązania (art. 473 k.c.).

Ponadto wskazać można cały szereg szczególnych ograniczeń odszkodowania mogących wynikać z ustawy, a wśród nich uregulowania, według których odszkodowanie nie może przekroczyć:

- zwykłej wartości rzeczy lub przesyłki (odpowiedzialność przewoźnika - art. $788 \$ 1$ k.c., spedytora - art. $801 \$ 1$ k.c., przedsiębiorcy składowego - art. $855 \$ 4$ k.c., hotelarza (art. $849 \$ 1$ k.c.),

- wartości wynikającej z rachunku dostawcy lub sprzedawcy albo z cennika (art. 80 ust. 1 pr. przew.),

- wartości zadeklarowanej (art. $166 \$ 3$ k.m., art. 80 ust. 3 pr. przew.),

- wartości limitowanej określoną wielokrotnością wynagrodzenia przysługującego usługodawcy (art. $849 \$ 1$ k.c., art. 245 k.m., art. 88 Prawa pocztowego $\left.{ }^{128}\right)$,

- wartości limitowanej określoną wielkością specjalnych praw ciągnienia (art. 22 konwencji montrealskiej),

- wartości limitowanej pewną wielkością wyliczaną w określonej walucie (art. 22 konwencji warszawskiej) ${ }^{129}$.

128 Ustawa z 23.11.2012 r. - Prawo pocztowe (Dz.U. z 2017 r. poz. 1481 ze zm.).

129 Przypadki te omawia, przedstawiając nieco inną ich klasyfikację, M. Kaliński. Por. M. Kaliński, Szkoda..., s. 555-567. 
Wyprzedzając tok dalszych rozważań, można wskazać, że chociaż pojęcie szkody w prawie ubezpieczeniowym jest bliskie ogólnemu, cywilistycznemu pojęciu szkody, to jednak odszkodowanie ubezpieczeniowe podlega całemu szeregowi ograniczeń wynikających z umowy ubezpieczenia. Jak już wskazywano, zakwalifikowanie odpowiedzialności ubezpieczyciela jako odrębnego reżimu odpowiedzialności gwarancyjnej obok odpowiedzialności ex delicto oraz ex contractu oraz odrębnego typu odpowiedzialności gwarancyjno-repartycyjnej obok odpowiedzialności sprawczej otwiera drzwi do wyłączeń w zakresie będących punktem wyjścia, ogólnych zasad naprawienia szkody z art. 361-363 k.c. Wątpliwości zostaną szczegółowo omówione w dalszym toku rozważań.

Odnosząc się do podanych wyżej czynników wpływających na wysokość odszkodowania oraz ograniczeń odszkodowania w ramach wstępu do dalszych rozważań, wypada zwrócić uwagę na następujące kwestie. Przedmiotem ubezpieczenia jest określony interes ucieleśniony zwykle w określonej rzeczy. Wynikająca stąd tzw. zasada lokalizacji szkody ogranicza już sam sposób ustalenia szkody prawnie relewantnej. Nie bierze się pod uwagę różnicy między stanem całego majątku poszkodowanego sprzed i po szkodzie, ale co najwyżej różnicę między stanem przedmiotu ubezpieczenia sprzed i po szkodzie. Już prima facie jawią się wobec tego wątpliwości co do objęcia odszkodowaniem ubezpieczeniowym lucrum cessans.

Wobec faktu, że ubezpieczyciel może i powinien oznaczyć w umowie wypadki oraz następstwa, za które odpowiada, kontrowersje dotyczą również zastosowania w ubezpieczeniach kryterium normalności następstw w odniesieniu do związku przyczynowego między wypadkiem ubezpieczeniowym a szkodą, a nawet samego kryterium związku przyczynowego ${ }^{130}$. Z kolei okoliczność, że ubezpieczenie chronić ma ubezpieczonego nie tylko przed skutkami działań osób trzecich czy sił przyrody, ale również przed skutkami własnych zaniedbań, ogranicza zastosowanie przyczynienia poszkodowanego do powstania szkody. Wątpliwości te wyraża art. 827 k.c. wyłączający odpowiedzialność ubezpieczyciela

${ }^{130}$ A. Koch, Związek przyczynowy w ubezpieczeniach, s. 8 i n.; M. Krajewski, Wypadek..., s. 141 i n. 
jedynie za szkody wyrządzone przez ubezpieczonego umyślnie lub powstałe w wyniku jego rażącego niedbalstwa. Zagadnienia te zostaną omówione w rozdziałach dotyczących przesłanek odpowiedzialności odszkodowawczej ubezpieczyciela.

Mechanizmy zbliżone do ustawowych limitów odszkodowania stanowią w prawie ubezpieczeniowym nie wyjątek, ale zasadę, co wynika $\mathrm{z}$ umownego ustalania wartości ubezpieczeniowej, przede wszystkim zaś z zastosowania sumy ubezpieczenia (w ubezpieczeniu OC sumy gwarancyjnej) jako limitu odpowiedzialności wynikającego z samej istoty ubezpieczenia, w proporcji do którego ustalana jest zresztą wysokość świadczenia wzajemnego ubezpieczającego, to jest składki. Dodatkowo w praktyce ubezpieczeniowej powszechne są tzw. techniczno-ubezpieczeniowe ograniczenia odpowiedzialności, w szczególności zaś udział własny, franszyza redukcyjna oraz franszyza integralna. Ta ostatnia przypominać może rozwiązanie zastosowane przez ustawodawcę w zakresie odpowiedzialności za produkt niebezpieczny, według którego odszkodowanie nie przysługuje, jeżeli szkoda na mieniu nie przekracza równowartości 500 euro (art. $449^{7}$ k.c.).

Z drugiej strony należy nadmienić, że w niektórych przypadkach odszkodowanie ubezpieczeniowe może obejmować składniki, których objęcie zakresem odszkodowania na zasadach ogólnych mogłoby być wątpliwe albo niemożliwe. Dotyczyć to może wydatków związanych $\mathrm{z}$ ratowaniem rzeczy, których zwrot w pewnym zakresie przewiduje art. 826 k.c., a także zagadnień związanych z odszkodowaniem z ubezpieczenia w wartości nowej i otaksowanej. To ostatnie rozwiązanie przyrównać można do znanego przede wszystkim z szeroko rozumianego prawa transportowego limitowania odpowiedzialności zadeklarowaną wartością przesyłki, które jak się zdaje, również w niektórych wypadkach prowadzić może do wypłaty odszkodowania przekraczającego wysokość rzeczywiście poniesionej szkody.

Wskazane powyżej czynniki wpływające na wysokość odszkodowania oraz ograniczenia wysokości odszkodowania sensu stricto odróżnić należy od ograniczeń odpowiedzialności ubezpieczyciela mających zakres jeszcze szerszy od tych pierwszych. Odróżnienie to wiąże się 
przy tym nie tylko z rozdzieleniem pojęć długu i odpowiedzialności oraz ograniczeniem tej drugiej do określonych przedmiotów majątkowych lub pewnej wyodrębnionej masy majątkowej dłużnika czy to do pewnej wysokości oznaczonej liczbowo. Chodzi przede wszystkim o wyłączenia pewnych kategorii szkód będących szkodami z zakresu kompensacji ubezpieczeniowej przez ograniczenie zakresu wypadku ubezpieczeniowego (zakresu ryzyka przejętego przez ubezpieczyciela), wprowadzenie wyraźnych wyłączeń odpowiedzialności oraz nałożenie na ubezpieczającego określonych powinności z zagrożeniem utraty prawa do odszkodowania ubezpieczeniowego. Wszystkie wyżej zasygnalizowane kwestie będą omawiane w kolejnych rozdziałach pracy. 
Rozdział 2

\section{TREŚĆ ŚWIADCZENIA UBEZPIECZYCIELA}

\subsection{Wprowadzenie}

Umowa ubezpieczenia, w odróżnieniu od innych umów uregulowanych w Kodeksie cywilnym, rodzi wątpliwości co do podstawowych elementów ją charakteryzujących. Dotyczy to przede wszystkim treści oraz natury prawnej świadczenia ubezpieczyciela, co z kolei, zdaniem większości autorów, wpływa na naturę prawną samej umowy ubezpieczenia przede wszystkim w zakresie jej wzajemności i losowości. Jak wiadomo, spór ma swoje źródła w doktrynie niemieckiej i toczy się między zwolennikami teorii świadczenia pieniężnego (Geldleistungstheorie) oraz zwolennikami teorii ponoszenia ryzyka (Gefarhrtragungstheorie) ${ }^{1}$.

Według teorii świadczenia pieniężnego jedynym świadczeniem ubezpieczyciela jest świadczenie pieniężne spełniane w razie zajścia wypadku ubezpieczeniowego. W prawie polskim podstawowym argumentem zwolenników tej teorii jest art. 805 k.c. wskazujący, że świadczenie ubezpieczyciela spełniane jest w razie zajścia wypadku i polega w szczególności przy ubezpieczeniu majątkowym - na zapłacie odszkodowania oraz przy ubezpieczeniu osobowym umówionej sumy pieniężnej, renty lub innego świadczenia. Zwolennicy teorii świadczenia pieniężnego twierdzą, że ubezpieczyciel nie spełnia żadnego świadczenia, jeżeli wypadek

1 Dyskusję toczącą się w naturze niemieckiej opisuje szerzej Z. Szymański, O definicji umowy ubezpieczenia, WU 1963/9, s. 20-21. Z nowszej literatury M. Orlicki, Umowa ubezpieczenia, 2002. 
ubezpieczeniowy nie zachodzi. W związku z tym uważają, że nie można traktować umowy ubezpieczenia jako umowy wzajemnej. Ponoszenie ryzyka nie daje się zakwalifikować do któregokolwiek z rodzajów świadczeń znanych prawu cywilnemu i można w nim upatrywać co najwyżej zespołu czynności przygotowawczych do spełnienia świadczenia pieniężnego.

Teorii świadczenia pieniężnego zarzuca się, że nie oddaje ona gospodarczej istoty ubezpieczenia. W ubezpieczeniach majątkowych wypadek ubezpieczeniowy jest zdarzeniem w pewnym sensie niepożądanym i zachodzi jedynie wyjątkowo. Ujmując rzecz z ekonomicznego punktu widzenia, trudno twierdzić, że w normalnej sytuacji, gdy wypadek nie zachodzi, świadczenie ubezpieczającego w postaci składki nie ma żadnego ekwiwalentu. Dlatego zwolennicy teorii ponoszenia ryzyka uważają, że ubezpieczający płaci za samo przejęcie przez ubezpieczyciela ryzyka zajścia określonych zdarzeń. Korelatu pojęcia ponoszenia ryzyka można ich zdaniem szukać w szeregu czynności, które sprawiają, że gwarancja wypłaty odszkodowania lub świadczenia w razie zajścia wypadku jest realna.

Argumentem na rzecz teorii ponoszenia ryzyka jest zawarte w art. 805 k.c. sformułowanie, według którego świadczenie ubezpieczyciela polega w szczególności na zapłacie odszkodowania, umówionej sumy pieniężnej, renty lub innego świadczenia, co nie wyklucza świadczeń odmiennego rodzaju niepolegających na zapłacie. Dodatkowo przepis art. 813 k.c. w nowym brzmieniu ${ }^{2}$ posługuje się wyraźnie pojęciem ochrony ubezpieczeniowej w kontekście wskazującym, że stanowi ona ekwiwalent płaconej przez ubezpieczającego składki. Również ustawa o działalności ubezpieczeniowej i reasekuracyjnej wskazuje, że działalność ubezpieczeniowa polega na udzielaniu ochrony ryzyka na wypadek zajścia określonych zdarzeń losowych ${ }^{3}$. Skoro ekwiwalentu składki można upatrywać w samym udzieleniu ochrony ubezpieczeniowej, nie sposób odmawiać umowie ubezpieczenia cechy wzajemności.

\footnotetext{
2 W brzmieniu ustalonym nowelizacją z $2007 \mathrm{r}$.

3 Art. 4 ust. 1 u.d.u.r.
} 
Spór, o którym mowa, jest w polskiej literaturze utrwalony. Można powiedzieć, że zwolennicy obydwu teorii okopali się na swoich pozycjach. Teorię świadczenia pieniężnego zdawał się przyjmować W. Warkałło. Współcześnie broni jej konsekwentnie M. Krajewski ${ }^{4}$. Poparł ją również Sąd Najwyższy w wyroku z 20.10.2006 r. ${ }^{5}$ Za teorią ponoszenia ryzyka opowiadał się natomiast A. Wąsiewicz ${ }^{6}$. Następnie poparł ją D. Fuchs7. Najszerzej teorię tę uzasadnił M. Orlicki ${ }^{8}$. Obecnie, poza wyżej wymienionymi, opowiadają się za nią również K. Malinowska ${ }^{9}$ oraz S. Byczko ${ }^{10}$.

Argumenty obydwu stron sporu są znane. Powyżej zaprezentowano je jedynie skrótowo.

Autor niniejszych rozważań szerzej zreferował spór o naturę prawną świadczenia ubezpieczyciela w pracy pt.: Przeniesienie praw $z$ umowy ubezpieczenia i tam zaproponował własne stanowisko. Celem bieżących uwag nie jest powtarzanie wywodów zawartych w wyżej wymienionej pracy, ale raczej rozwinięcie wcześniejszej koncepcji oraz pokazanie jej konsekwencji. W tym celu niezbędne będzie jednak zrekapitulowanie podstawowych tez stanowiska sformułowanego przed laty i dlatego rozważania w pewnym zakresie będą się powtarzać ${ }^{11}$.

${ }^{4}$ M. Krajewski, Świadczenie ubezpieczyciela w umowie ubezpieczenia, PS 2011/11-12, s. 7 i n.; M. Krajewski, Umowa ubezpieczenia. Art. 805-834 KC..., 2016, s. 36-37.

5 Wyrok SN z 20.10.2006 r., IV CSK 125/06, OSNC-ZD 2008/1, poz. 7, z glosą B. Kucharskiego, „Glosa” 2009/1, s. 56-64.

6 A. Wąsiewicz, Umowa ubezpieczenia [w:] Ubezpieczenia $w$ gospodarce rynkowej, t. 3, red. A. Wąsiewicz, Bydgoszcz 1997, s. 110-111.

7 D. Fuchs, Umowa ubezpieczenia - umowa wzajemna czy tylko dwustronnie zobowiązująca??, WU 1995/7-9; D. Fuchs, Wybrane cechy umowy ubezpieczenia majątkowego, PA 1999/4, s. 42; D. Fuchs, Ochrona ubezpieczeniowa jako świadczenie główne ubezpieczyciela, PA 2006/2, s. 40 i n.

8 M. Orlicki, Umowa ubezpieczenia, 2002, s. 133 i n.

9 K. Malinowska, Wzajemność umowy ubezpieczenia $w$ świetle orzecznictwa ustawodawstwa i doktryny, PA 2009/3, s. 29.

10 S. Byczko, Prawo..., s. 89-90 oraz 128.

11 Szeroko: B. Kucharski, Przeniesienie..., s. 38 i n. 


\subsection{Przepisy Kodeksu cywilnego a świadczenie ubezpieczyciela}

Zgodnie z artykułem $805 \$ 1$ k.c. ubezpieczyciel zobowiązuje się spełnić określone świadczenie $\mathrm{w}$ razie zajścia przewidzianego w umowie wypadku, co zdaje się wykluczać przyjęcie tezy, że świadczenie ubezpieczyciela polega na ponoszeniu ryzyka. Można przyjąć, że $\$ 2$ art. 805 k.c., wyliczając świadczenia ubezpieczyciela w ubezpieczeniach majątkowych i osobowych, odnosi sformułowanie „W szczególności” do świadczeń spełnianych w razie zajścia wypadku. Jak wspomniano, brzmienie art. 805 k.c. jest podstawowym argumentem zwolenników teorii świadczenia pieniężnego ${ }^{12}$.

Teorię świadczenia pieniężnego można również wesprzeć sformułowaniami zawartymi w art. 817, $822 \$ 1$ i art. $824^{1} \$ 1$ k.c. Artykuł 817 k.c. każe ubezpieczycielowi spełnić świadczenie w terminie 30 dni od zajścia wypadku. Według art. $822 \$ 1$ k.c. przez umowę ubezpieczenia odpowiedzialności cywilnej ubezpieczyciel zobowiązuje się do zapłacenia określonego w umowie odszkodowania. Z kolei zgodnie $\mathrm{z}$ art. $824^{1} \$ 1$ k.c. suma pieniężna wypłacana przez ubezpieczyciela $z$ tytułu ubezpieczenia nie może być wyższa od poniesionej szkody.

Inne przepisy Kodeksu cywilnego o umowie ubezpieczenia dostarczają jednak szeregu argumentów na rzecz teorii ponoszenia ryzyka. Zgodnie $\mathrm{z}$ art. $812 \$ 4$ in fine k.c. odstąpienie od umowy ubezpieczenia nie zwalnia ubezpieczającego z obowiązku zapłacenia składki za okres, w jakim ubezpieczyciel udzielał ochrony ubezpieczeniowej. Artykuł $813 \$ 1$ k.c. wskazuje, że składkę oblicza się za czas trwania odpowiedzialności ubezpieczyciela, i dalej stanowi o zwrocie składki za okres niewykorzystanej ochrony ubezpieczeniowej. W myśl art. $814 \$ 2$ k.c., jeżeli ubezpieczyciel podnosił odpowiedzialność przed zapłaceniem składki, a składka nie została zapłacona w terminie, ubezpieczyciel może wypowiedzieć umowę i żądać zapłaty składki za okres, w którym ponosił odpowiedzialność. Trzy ostatnio powołane przepisy w sposób jednoznaczny wskazują,

12 M. Krajewski, Świadczenie... Wyrok SN z 20.10.2006 r., IV CSK 125/06, z glosą B. Kucharskiego. 
że ekwiwalentem składki jest udzielanie ochrony ubezpieczeniowej niezależnie od tego, czy ubezpieczyciel wypłaca świadczenie pieniężne.

Argumentów na poparcie teorii ponoszenia ryzyka można szukać również w art. 806 i 816 k.c. Artykuł $806 \$ 2$ k.c. wyjaśnia, kiedy skuteczne jest objęcie ubezpieczeniem okresu poprzedzającego zawarcie umowy. Zakładając, że można zobowiązać się do spełnienia świadczenia w okresie przed zawarciem umowy, przepis odnosi się jedynie do ponoszenia ryzyka zajścia określonych zdarzeń, nie zaś do świadczenia pieniężnego wypłacanego w razie zajścia wypadku. Artykuł 816 k.c. pozwala każdej ze stron zgłosić żądanie obniżenia albo podwyższenia składki ubezpieczeniowej stosownie do ujawnionej zmiany prawdopodobieństwa zaistnienia wypadku. Regulacja nie odnosi się do realizacji wypadku, a jedynie prawdopodobieństwa jego potencjalnego zajścia w przyszłości i byłaby niezrozumiała, gdyby jedynym świadczeniem ubezpieczyciela miało być świadczenie pieniężne.

W przepisach o ubezpieczeniach majątkowych również można odnaleźć sformułowania wspierające teorię ponoszenia ryzyka. Artykuł 821 k.c. wskazuje, że przedmiotem ubezpieczenia jest interes majątkowy. Sformułowanie to odnoszone jest przez doktrynę jednomyślnie do przedmiotu ochrony ubezpieczeniowej $j^{13}$. Umieszczony w strukturze stosunku prawnego ubezpieczenia interes okazuje się być zatem przedmiotem świadczenia ubezpieczyciela, polegającego na udzielaniu ochrony ubezpieczeniowej ${ }^{14}$.

Artykuł $824 \$ 2$ k.c. pozwala żądać zmniejszenia sumy ubezpieczeniowej $\mathrm{w}$ razie zmniejszenia wartości ubezpieczeniowego mienia, co zgodnie $\mathrm{z}$ art. $824 \S 3$ k.c. pociąga za sobą odpowiednie zmniejszenie składki. Ten ostatni przepis zawiera $\mathrm{w}$ istocie regułę podobną do zawartej w art. 816 k.c., który przyznaje stronom prawo żądania zmiany składki

13 M. Orlicki, J. Pokrzywniak, Umowa ubezpieczenia. Komentarz do nowelizacji kodeksu cywilnego, Warszawa 2008, s. 97; S. Byczko, Interes..., s. 85.

14 A. Klein, Elementy zobowiazzaniowego stosunku prawnego, Wrocław 2005, s. 57-59; T. Dybowski, A. Pyrzyńska, Świadczenie [w:] System Prawa Prywatnego, red. Z. Radwański, t. 5, Prawo zobowiązań - część ogólna, red. E. Łętowska, Warszawa 2012, s. 189. 
w razie zmiany prawdopodobieństwa zaistnienia wypadku. Istota obydwu przepisów sprowadza się do zmiany wysokości składki stosownie do zmiany zakresu ryzyka ponoszonego przez ubezpieczyciela niezależnie od zajścia wypadku ubezpieczeniowego. W przypadku art. 816 k.c. modyfikacja wynika ze zmiany prawdopodobieństwa zaistnienia wypadku, natomiast w odniesieniu do art. 824 k.c. ze zmiany rozmiarów potencjalnej szkody. W doktrynie podnoszone jest słusznie, że art. $824 \$ 2$ k.c. powinien analogicznie do art. 816 k.c. przyznawać prawo dostosowania sumy, a co za tym idzie, również składki nie tylko do zmniejszonej, ale również zwiększonej wartości sumy ubezpieczenia ${ }^{15}$.

Z kolei art. 823 k.c. odnosi się do przeniesienia przedmiotu ubezpieczenia, a zatem przeniesienia interesu ubezpieczeniowego, i wskazuje, że w takiej sytuacji prawa $\mathrm{z}$ umowy ubezpieczenia mogą być pod pewnymi warunkami przeniesione na nabywcę interesu. Ostatni paragraf art. 823 k.c. zastrzega, że reguł wynikających z wcześniejszych trzech paragrafów nie stosuje się przy przenoszeniu wierzytelności, jakie powstały lub mogą powstać wskutek zajścia przewidzianego w umowie wypadku. Przepis ten wskazuje zatem jednoznacznie, że podlegające przeniesieniu prawa $z$ umowy ubezpieczenia, a zatem wierzytelności istnieją już przed zajściem wypadku ${ }^{16}$. Jak wiadomo, wierzytelność to prawo domagania się od dłużnika spełnienia świadczenia. Świadczenie ubezpieczyciela przed zajściem wypadku polegać może wyłącznie na ponoszeniu ryzyka.

Podsumowując powyższy wywód, w przepisach Kodeksu cywilnego można odnaleźć przynajmniej tyle samo, jeżeli nie więcej, argumentów na poparcie teorii ponoszenia ryzyka co na poparcie teorii świadczenia pieniężnego. Podstawowy problem sprowadza się zatem do pogodzenia z teorią ponoszenia ryzyka art. 805 k.c., który określa umowę ubezpieczenia. Właśnie sformułowanie tego przepisu skłoniło Sąd Najwyższy do opowiedzenia się za teorią świadczenia pieniężnego w jedynym orzeczeniu, którego ratio decidendi skupia się na charakterze umowy

15 Tak przykładowo S. Byczko, Interes..., s. 160.

16 B. Kucharski, Przeniesienie..., s. 352-353; M. Krajewski, Przydatność..., s. 143. 
ubezpieczenia ${ }^{17}$. Interpretacja art. 805 k.c. zmierzająca do pogodzenia go z teorią ponoszenia ryzyka może przebiegać kilkoma drogami.

Po pierwsze, można wskazać, że art. 805 k.c. nie zawiera definicji umowy ubezpieczenia ${ }^{18}$. Przepis określa jedynie niejako zarys kształtu umowy, nieostry kontur, jednak dokładne wyrysowanie konturu oraz wypełnienie pola nim wyznaczonego możliwe jest dopiero po przeanalizowaniu wszystkich przepisów składających się na regulację umowy. Dodać można, że nierzadko zakwalifikowanie umowy jako umowy nazwanej nie jest możliwe na podstawie jednego tylko przepisu o charakterze, zdawałoby się, definicyjnym ${ }^{19}$.

Po drugie, art. 805 k.c. traktuje o spełnieniu określonego świadczenia na wypadek zajścia przewidzianego w umowie wypadku, ponieważ zakres świadczenia w postaci ponoszenia ryzyka jest bardzo trudny do wyznaczenia. Zakres ten nie jest zresztą określany w konkretnej umowie, ale w przepisach ustawowych regulujących działalność ubezpieczeniową. Przedstawia się on podobnie w każdej umowie ubezpieczenia, niezależnie od praw i obowiązków stron wynikających $\mathrm{z}$ jej treści. Ubezpieczający nie musi nawet dokładnie znać konkretnych obowiązków, które spoczywają na ubezpieczycielu z mocy ustawy oraz mają źródło w samej istocie umowy ubezpieczenia, ponieważ i tak nie jest w stanie zweryfikować tego, czy ubezpieczyciel wywiązuje się z tych obowiązków. Kwestia zostanie szerzej omówiona. Z tych samych względów jedynie do konkretnego świadczenia pieniężnego wypłacanego w razie zajścia wypadku odnoszą się art. $822 \$ 1$ oraz art. $824^{1} \$ 1$ k.c. i dlatego nie przesądzają one o trafności teorii świadczenia pieniężnego.

Po trzecie, art. 805 k.c. wskazuje, że ubezpieczyciel spełnia świadczenie w razie zajścia wypadku w zakresie działalności swego przedsiębiorstwa. Działalność leżąca w zakresie przedsiębiorstwa ubezpieczyciela to dzia-

17 Wyrok SN z 20.10.2006 r., IV CSK 125/06, z glosą B. Kucharskiego.

18 Tak stanowczo w odniesieniu do art. 1 niemieckiej VVG z 2008 r. M. Wandt, Versicherungsrecht, s. 9-10.

19 W.J. Katner, Pojęcie umowy nienazwanej [w:] System Prawa Prywatnego, red. Z. Radwański, t. 9, Prawo zobowiązań - umowy nienazwane, red. W.J. Katner, Warszawa 2015, s. 7, 10. 
łalność ubezpieczeniowa, określona w art. 4 u.d.u.r. jako wykonywanie czynności związanych z oferowaniem i udzielaniem ochrony na wypadek ryzyka wystąpienia skutków zdarzeń losowych. Dodatkowo, zgodnie $\mathrm{z}$ art. 15 u.d.u.r., zakład ubezpieczeń udziela ochrony ubezpieczeniowej na podstawie umowy ubezpieczenia zawartej z ubezpieczającym. Zdefiniowanie umowy ubezpieczenia wymaga zatem dokonania syntezy art. 805 k.c. z przepisami ustawy o działalności ubezpieczeniowej i reasekuracyjnej, co prowadzi do przyjęcia, że świadczenie ubezpieczyciela polega na udzielaniu ochrony ubezpieczeniowej na wypadek ryzyka wystąpienia zdarzeń losowych oraz na spełnieniu świadczenia pieniężnego $\mathrm{w}$ razie zajścia przewidzianego $\mathrm{w}$ umowie wypadku ${ }^{20}$.

Odnosząc powyższe uwagi do zagranicznych regulacji umowy ubezpieczenia, warto wskazać, że zgodnie z art. 1 VVG z 2008 r. przez zawarcie umowy ubezpieczenia ubezpieczyciel zobowiązuje się pokryć określone ryzyko ponoszone przez ubezpieczającego lub osobę trzecią, poprzez zapłacenie określonego świadczenia w razie zajścia wypadku ubezpieczeniowego. Określenie to odnosi się zatem wprost do dwóch postaci świadczenia ubezpieczyciela, a mianowicie do pokrycia ryzyka, czy inaczej udzielenia ochrony ubezpieczeniowej, oraz do świadczenia pieniężnego spełnianego w razie zajścia wypadku. Tym samym ustawodawca próbował rozstrzygnąć toczony od lat w niemieckim piśmiennictwie spór o naturę świadczenia pieniężnego przez pogodzenie obydwu stanowisk ${ }^{21}$.

$\mathrm{W}$ prawie angielskim zwraca się uwagę na kłopoty w zdefiniowaniu ubezpieczenia ${ }^{22}$. Jako leading case, $\mathrm{w}$ którym podjęto próbę określenia ubezpieczenia, traktowana jest sprawa Prudential Insurance Co v. IRC. W sprawie tej sędzia Channel opisał ubezpieczenie jako umowę, na mocy której ubezpieczyciel zobowiązuje się w zamian za zapłatę składki uiścić

20 Por. M. Orlicki, Uwagi o nowelizacji przepisów dotyczących umowy ubezpieczenia na tle nowych przepisów niemieckich, PA 2008/1, s. 63-64.

21 P. Schimikowski, Versicherungsvertragsrecht, s. 25; por. M. Orlicki, Uwagi..., s. 64. Zob. jednak M. Krajewski, Przydatność..., s. 141 i wskazana tam literatura.

22 R.W. Hodgin, Problem in defining insurance contract, LMCLQ 1980, s. 14 i n. Malcolm Clark swoje monumentalne dzieło o umowie ubezpieczenia zaczyna od rozdziału zatytułowanego: „Definition or Description?”; M. Clarke, The Law..., s. 1 i n. 
na rzecz drugiej strony (ubezpieczającego) sumę pieniężną albo spełnić świadczenie stanowiące jej ekwiwalent w razie wystąpienia określonego zdarzenia. Dalej wskazał na kilka koniecznych elementów ubezpieczenia, a mianowicie: po pierwsze, obietnicę korzyści majątkowej na rzecz ubezpieczającego w razie zajścia określonego zdarzenia, niekoniecznie przybierającej postać świadczenia pieniężnego w zamian za consideration w postaci składki płaconej często okresowo, po drugie, niepewność zdarzenia, od którego uzależniona jest korzyść majątkowa ubezpieczającego. Po trzecie, według sędziego, zdarzenie niepewne powinno być prima facie niekorzystne dla ubezpieczającego ${ }^{23}$.

Określenia wywodzone z tej wypowiedzi w doktrynie bardzo się różnią ${ }^{24}$. John Birds, powołując się dodatkowo na sprawy Gould v. Curtis oraz Medical Defence Union v. Department of Trade, ujmuje ubezpieczenie jako umowę, na podstawie której ubezpieczyciel przyjmuje ryzyko zajścia w przyszłości zdarzenia niepewnego, znajdującego się poza jego kontrolą, oddziałującego na interes drugiej strony, oraz zobowiązuje się zapłacić pieniądze albo spełnić świadczenie stanowiące ich ekwiwalent w razie zajścia niepewnego zdarzenia. Według J. Birdsa każdy, kto regularnie zawiera takie umowy jako strona ponosząca ryzyko, prowadzi działalność ubezpieczeniową w rozumieniu ustaw regulujących sposób prowadzenia tej działalności ${ }^{25}$.

Podobnie sprawę stawiają R. Merkin i J. Steele, wskazując, że na ubezpieczenie można patrzeć z perspektywy wspólnoty ryzyka zapewniającej rozproszenie ryzyka albo z perspektywy relacji oraz interesów stron umowy. W tym drugim ujęciu elementem definiującym ubezpieczenie z punktu widzenia ubezpieczającego jest zmniejszenie niepewności, natomiast z punktu widzenia ubezpieczyciela przejęcie ryzyka w zamian za zapłatę składki. Cytowani autorzy zdają się jednak dalej nie dostrzegać

23 Prudential Insurance Co v. IRC, [1904] 2 KB, s. 658.

${ }^{24}$ MacGillivray on Insurance Law, red. J. Birds, B. Lynch, S. Milnes, London 2012, s. 3; Colinvaux's Law of Insurance, red. R. Merkin, London 2006, s. 4-5; A. McGee, The Modern Law of Insurance, London 2006, s. 3-12; J. Lowry, P. Rawlings, R. Merkin, Insurance Law..., s. 3-9.

25 J. Birds, Birds'..., s. 8-9. 
rozróżnienia między obietnicą przejęcia ryzyka oraz obietnicą zapłaty odszkodowania w razie zajścia wypadku ubezpieczeniowego ${ }^{26}$.

Paul Collinvaux jako świadczenie ubezpieczyciela traktuje świadczenie odszkodowawcze płacone w razie zajścia wypadku, ale w ramach innych elementów niezbędnych dla umowy ubezpieczenia wskazuje m.in. składkę szacowaną w zależności od stopnia ryzyka, a także transfer ryzyka. Zdaniem tego autora, choć w sprawie Prudential ten ostatni element nie był omawiany, nie ma wątpliwości, że bez transferu ryzyka nie ma ubezpieczenia ${ }^{27}$. Na konieczność transferu ryzyka zwracają też uwagę redaktorzy MacGillivray, wskazując, że w orzecznictwie amerykańskim przeniesienie ryzyka z ubezpieczającego na ubezpieczyciela oraz redystrybucja kosztów szkody pomiędzy większą wspólnotę traktowane są jako podstawowe elementy umowy ubezpieczenia ${ }^{28}$.

Francuski Code des assurances nie zawiera przepisu określającego umowę ubezpieczenia. Zgodnie $\mathrm{z}$ art. $113.5 \mathrm{w}$ razie realizacji ryzyka określonego w umowie albo nadejścia terminu wynikającego $\mathrm{z}$ umowy ubezpieczyciel ma spełnić świadczenie określone w umowie, nie przekraczając wynikającego z niej terminu. Zapewne dlatego M. Piccard i A. Besson definiują umowę ubezpieczenia jako umowę, na mocy której jedna strona, zwana ubezpieczycielem, obiecuje drugiej stronie, zwanej ubezpieczającym, w zamian za wynagrodzenie w postaci składki ubezpieczeniowej, spełnienie świadczenia $w$ razie realizacji ryzyk ${ }^{29}$. Bliższe teorii świadczenia pieniężnego zdają się być również sformułowania art. 1 belgijskiej ustawy o ubezpieczeniach lądowych oraz art. 2389 Kodeksu cywilnego prowincji Quebec ${ }^{30}$.

Jean Bigot w trzecim tomie współczesnego Traktatu o prawie ubezpieczeń, zatytułowanym Umowa ubezpieczenia, zestawia wszystkie te określenia,

26 R. Merkin, J. Steele, Insurance..., s. 26-27.

${ }_{27}$ Colinvaux's..., s. 9.

28 MacGillivray..., s. 8.

29 M. Picard, A. Besson, Les assurances terrestres en droit français, t. 1, Le contrat d'assurance, Paris 1982, s. 66.

30 Traité de Droit des Assurances, t. 3, Le Contrat d'Assurance, red. J. Bigot, Paris 2002, s. 26. 
przedstawiając dyskusję nad definicją umowy ubezpieczenia w ujęciu historycznym. Ostatecznie krytykuje definicję przytaczaną przez M. Picarda i A. Bessona właśnie za pomijanie aspektu działalności ubezpieczeniowej w postaci szeroko rozumianego ponoszenia ryzyka i formułuje własną. Według tego autora ubezpieczenie to umowa, na mocy której jedna strona, zwana ubezpieczycielem, zobowiązuje się względem drugiej, zwanej ubezpieczającym, w zamian za zapłatę składki, do pokrycia ryzyka oraz spełniania na rzecz ubezpieczającego lub osoby trzeciej świadczenia w razie realizacji ryzyka ${ }^{31}$. Definicja ta, podobnie jak definicja niemiecka, odwołuje się zatem do dwóch postaci świadczenia ubezpieczyciela.

Kończąc rozważania prawnoporównawcze, wypada podkreślić, że również Zasady Europejskiego Prawa o Umowie Ubezpieczenia (PEICL), mające stanowić wspólny punkt odniesienia dla państw członkowskich Unii Europejskiej, odwołują się wprost do ponoszenia ryzyka, i to nawet nie wspominając o wypłacie świadczenia w razie zajścia wypadku. W myśl art. 1:201 PEICL umowa ubezpieczenia oznacza umowę, na podstawie której jedna strona, zwana ubezpieczycielem, obiecuje drugiej stronie, zwanej ubezpieczającym, ochronę przed oznaczonym ryzykiem w zamian za zapłatę składki. W uzasadnieniu projektodawcy przepisu wskazują na dwa niezbędne elementy umowy ubezpieczenia, a mianowicie przejęcie ryzyka przez ubezpieczyciela oraz zapłatę składki przez ubezpieczającego ${ }^{32}$. W ostatnim słowie warto nadmienić, że określenie zawarte w PEICL jest niejako powrotem do określenia Grocjusza sformułowanego w słynnym traktacie „O wojnie i pokoju”. Według Grocjusza przez umowę ubezpieczenia ubezpieczyciel zobowiązuje się do wzięcia na siebie określonego ryzyka w zamian za zapłatę umówionej składki. Do definicji tej odwoływał się zresztą także projekt polskiej międzywojennej komisji kodyfikacyjnej ${ }^{33}$. Powojenne unormowania były bliższe teorii świadczenia pieniężnego ${ }^{34}$.

31 Traité..., red. J. Bigot, s. 29.

32 Principles of European Contract Law (PEICL), red. J. Basedow, J. Birds, M. Clarke, H. Cousy, H. Heiss in cooperation with L.D. Loacker, Munich 2009, s. 49.

33 Za Z. Szymańskim, O definicji..., s. 22.

34 Poza art. 805 k.c. zob. art. 2 ust. 2 ustawy z 28.03.1952 r. o ubezpieczeniach państwowych (Dz.U. poz. 130 ze zm.) oraz art. 8 ustawy z 2.12.1958 r. o ubezpieczeniach majątkowych i osobowych (Dz.U. poz. 357 ze zm.). 


\subsection{Koncepcja jednorodnego świadczenia ubezpieczyciela}

Zgodnie z koncepcją autora niniejszej pracy ubezpieczyciel spełnia swoje świadczenie także w sytuacji, gdy nie zachodzi wypadek ubezpieczeniowy $^{35}$. Koncepcja ta wpisuje się zatem w założenia teorii ponoszenia ryzyka. Według teorii ponoszenia ryzyka przejęcie przez ubezpieczyciela ryzyka zajścia określonego zdarzenia jest dla ubezpieczającego korzyścią samą w sobie, tym bardziej że ubezpieczający, chcąc zabezpieczyć się przed tym ryzykiem, we własnym zakresie zwykle musiałby poczynić określone wydatki ${ }^{36}$. Zwolennicy teorii świadczenia pieniężnego w trosce o czystość doktryny prawa zdają się tracić z pola widzenia gospodarczą istotę ubezpieczenia oraz zdrowy rozsądek. W istocie nie jest bowiem tak, że ubezpieczyciel pojawia się na firmamencie zdarzeń dopiero w chwili zajścia wypadku ubezpieczeniowego.

Trafna jest obserwacja, że rola ubezpieczyciela staje się wyraźnie dostrzegalna dopiero z chwilą zajścia wypadku. Wcześniej ubezpieczyciela nie widać, pozostaje on niejako pod powierzchnią zdarzeń. Jego roli na tym etapie nie można jednak zupełnie ignorować ani też bagatelizować, wskazując, że podejmuje on wyłącznie czynności przygotowawcze do spełnienia właściwego świadczenia. Rolę ubezpieczyciela można porównać do roli agencji ochrony mienia, która spełnia świadczenie nie tylko wtedy, gdy włącza się sygnał alarmowy i w miejsce, skąd pochodzi sygnał, zostaje wysłany patrol interwencyjny. Agencja ochrony mienia spełnia swoje świadczenie, pobierając w zamian wynagrodzenie, również wtedy, gdy jedynie pośrednio sprawuje stały dozór obiektu, śledząc sygnały przesyłane drogą elektroniczną do stacji monitorowania.

Propagatorzy teorii świadczenia pieniężnego zwracają uwagę, że zachowanie ubezpieczyciela będące świadczeniem nie może być pojmo-

35 Wśród ostatnich wypowiedzi opowiadających się za stanowiskiem, że świadczenie tzw. ochrony ubezpieczeniowej jest świadczeniem ekwiwalentnym względem zapłaty składki ubezpieczeniowej, zob. przede wszystkim Ł. Węgrzynowski, Ekwiwalentność świadczeń w umowie wzajemnej, Warszawa 2011, s. 423 i n.

36 M. Orlicki, Umowa ubezpieczenia, 2002, s. 135. 
wane jako ponoszenie ryzyka samo w sobie. Potoczne stwierdzenie, że w zamian za składkę ubezpieczający kupuje święty spokój albo bardziej oględnie - pewne poczucie bezpieczeństwa ${ }^{37}$, nie w pełni oddaje istotę świadczenia ubezpieczyciela i nie pozwala na opisanie jego zachowania w kategoriach dare, facere, non facere, pati ${ }^{38}$. Ochrona ubezpieczeniowa może być uznana za świadczenie ubezpieczyciela jedynie wtedy, gdy przypisze się jej określoną treść znaczeniową, wskazując czynności kryjące się za tym pojęciem.

Zastrzeżeniu temu można jednak przeciwstawić szereg argumentów. Po pierwsze, opisując treść świadczenia ubezpieczyciela, nie należy tracić z pola widzenia okoliczności, że umowa ubezpieczenia majątkowego zawierana jest na określony, zwykle roczny okres. Proporcjonalnie do okresu ponoszenia ryzyka ustalana jest również składka. Będące świadczeniami ciągłymi świadczenia najemcy lub dzierżawcy także rzadko przybierają postać konkretnych czynności. Dzieje się tak przykładowo dopiero wtedy, gdy konieczne jest dokonanie określonych napraw albo ochrony praw najemcy względem osób trzecich. Zachowań będących przedmiotem konkretnych obowiązków, które mogą, ale nie muszą się pojawić, nie można utożsamiać ze świadczeniem, które ma zakres znacznie szerszy. Dotyczy to, jak się zdaje, w szczególności wszystkich świadczeń ciągłych.

Po drugie, stwierdzenie M. Krajewskiego, że ponoszenie ryzyka, czyli stan wystawienia na niebezpieczeństwo lub też bycia zagrożonym, nie mieści się w klasycznej definicji świadczenia akceptowanej w prawie cywilnym, jest co najmniej nieścisłe. Klasyczna definicja świadczenia nie określa bowiem świadczenia wyłącznie w kategoriach dania lub czynienia. Poza dare, fecere zwykle wymienia się przecież non facere oraz pati. Właśnie to ostatnie określenie, a mianowicie pati, czyli znoszenie, wydaje się być określeniem najbardziej odpowiadającym charakterowi

37 Zob. np.: S. Byczko, Prawo..., s. 89; Z. Szymański, O definicji..., s. 20. W prawie angielskim na ten aspekt zwraca uwagę M. Clarke, Policies and Perceptions of Insurance Law..., s. 3 i 4.

38 M. Krajewski, Umowa ubezpieczenia. Art. 805-834 KC..., 2016, s. 36-37; Z. Szymański, $O$ definicji..., s. 21. 
świadczenia ubezpieczyciela. Ubezpieczyciel w zamian za zapłatę składki zgadza się w okresie ubezpieczenia znosić stan bycia wystawionym na niebezpieczeństwo czy też stan bycia zagrożonym. Podobnie najemca lub dzierżawca lokalu mają umożliwić najemcy korzystanie z lokalu, co zwykle sprowadzać się będzie do znoszenia obecności najemcy w należącym do niego lokalu, bez konieczności podejmowania jakichkolwiek konkretnych działan' ${ }^{39}$. Zauważyć należy nadto, że stan wystawienia na niebezpieczeństwo, w jakim znajduje się ubezpieczyciel, nie oznacza, że niebezpieczeństwo zagraża bezpośrednio rzeczy należącej do ubezpieczyciela, ale na tym, że w razie realizacji niebezpieczeństwa ubezpieczyciel zapłaci odszkodowanie.

Ujęciu świadczenia ubezpieczyciela jako pati można przeciwstawić spostrzeżenie, że przykładowo świadczenie wynajmującego ma korelat w postaci zaprzestania działań przeszkadzających w korzystaniu z rzeczy przez najemcę. Podobnego korelatu trudno doszukać się w znoszeniu stanu ponoszenia ryzyka przez ubezpieczyciela. Wypada jednak odpowiedzieć, że ubezpieczenie, jak każda umowa nazwana, ma swoją specyfikę, właśnie dlatego ustawodawca rozróżnia poszczególne umowy nazwane. Nie jest zresztą tak, że między znoszeniem przez ubezpieczyciela stanu ponoszenia ryzyka a świadczeniami w innych umowach nazwanych nie można doszukać się analogii. Podobnie niektórzy ujmują świadczenie poręczyciela oraz świadczenie gwaranta. Gdy chodzi o umowy nienazwane, znów nasuwa się analogia do umowy o zapewnienie ochrony fizycznej. W odniesieniu do ubezpieczyciela w porównaniu $\mathrm{z}$ umowami poręczenia i gwarancji istnieje nadto dodatkowy argument w ujmowaniu świadczenia jako znoszenia określonej sytuacji, a mianowicie okoliczność, że ubezpieczenie zawierane jest na oznaczony czas.

Po trzecie, we współczesnej doktrynie wyrażane są poglądy, że świadczenie dłużnika polegać może na samej gotowości do spełnienia świadczenia. Jak już wskazano, podobna koncepcja broniona jest nie tylko w odniesieniu do umowy ubezpieczenia, ale również w odniesieniu do poręczenia oraz gwarancji bankowej, choć prawdą jest, że dominuje

39 Por. R. Longchamps de Bérier, Polskie..., s. 28. 
stanowisko przeciwne ${ }^{40}$. Łukasz Węgrzynowski zajmuje stanowisko jeszcze dalej idące, stwierdzając, że świadczeniem może być oddziaływanie na płaszczyźnie społeczno-gospodarczej powodujące skutek zaspokajający interes wierzyciela, przy czy związek tego skutku z faktycznymi zachowaniami dłużnika może być jedynie pośredni, niekiedy zaś może go nie być $w$ ogóle ${ }^{41}$. Zdaniem cytowanego autora z przepisów prawa cywilnego, w szczególności z art. 353 k.c., nie płynie konieczność namacalności świadczenia, czyli zapewnienia mu jakiegoś desygnatu w postaci konkretnego działania lub zaniechania, tym bardziej zaś zaskarżalności ${ }^{42}$.

Marcin Krajewski polemizuje z Ł. Węgrzynowskim, wskazując, że u źródeł jego poglądu leży koncepcja świadczenia A. Kleina, jednak ostateczny rezultat rozumowania wydaje się z tą koncepcją sprzeczny. Wbrew tym zastrzeżeniom A. Klein ujmuje świadczenie nie w kategoriach składających się na nie konkretnych zachowań, ale właśnie przez pryzmat skutków albo ściślej pożądanego efektu gospodarczego zachowania dłużnika. Przykładowo świadczenie sprzedawcy A. Klein określa jako postawienie kupującego w pewną sytuację prawną i faktyczną przysługującą dotąd sprzedawcy, świadczenie wynajmującego jako danie najemcy rzeczy do używania lub też jako znoszenie używania rzeczy przez najemcę.

${ }^{40} \mathrm{~W}$ odniesieniu do gwarancji bankowej tak przede wszystkim G. Tracz. Zdaniem tego autora świadczenie gwaranta polega na tym, że wykazuje on stałą gotowość do zapłaty sumy gwarancyjnej w przypadku określonym w umowie, za co m.in. otrzymuje w stosunku zlecenia udzielania gwarancji prowizję. G. Tracz, Umowa gwarancji ze szczególnym uwzględnieniem gwarancji bankowej, Kraków 1998, s. 289-290. Również A. Koch twierdzi, że świadczenie gwaranta - poza ewentualnym aktem zapłaty sumy gwarancyjnej - realizowane jest przez samo zgłoszenie takiej gotowości. Zob. A. Koch, Umowa gwarancji bankowej [w:] System Prawa Prywatnego, red. Z. Radwański, t. 8, Prawo zobowiązań - część szczegółowa, red. J. Panowicz-Lipska, Warszawa 2011, s. 618. Poglądy te, jak również poglądy przeciwne przytacza M. Krajewski, Świadczenie..., s. 9. Ogólniejszy zakres ma pogląd F. Zolla, wedle którego także w umowach aleatoryjnych zabezpieczenie ryzyka należy uznać za świadczenie. Zob. F. Zoll, Wykonanie i skutki niewykonania zobowiązań przez spetnienie świadczenia [w:] System Prawa Prywatnego, red. Z. Radwański, t. 6, Prawo zobowiązań - część ogólna, red. A. Olejniczak, Warszawa 2014, s. 1053, przypis 143. Co do stanowiska przeciwnego zob. przede wszystkim T. Dybowski, A. Pyrzyńska, Świadczenie, s. 187-188 oraz wskazana tam literatura.

41 Ł. Węgrzynowski, Ekwiwalentność..., s. 269, 287.

42 Ł. Węgrzynowski, Ekwiwalentność..., s. 432-433. 
Po czwarte, nawet obstając przy konieczności przypisania świadczeniu konkretnych zachowań, we współczesnej doktrynie wskazuje się, że ochrona ubezpieczenia polega $\mathrm{w}$ istocie na podjęciu przez ubezpieczyciela całego kompleksu działań ${ }^{43}$. Przejęcie ryzyka zajścia określonego w umowie ubezpieczenia zdarzenia losowego polega na tym, że ubezpieczający w zamian za składkę przyjmuje ubezpieczającego do utworzonej wcześniej wspólnoty ryzyka. Nadto ubezpieczyciel zobowiązuje się tą wspólnotą administrować w sposób stwarzający realną gwarancję wypłaty odszkodowania w razie zajścia objętego umową zdarzenia. Odwołać się tu należy do nauk ekonomicznych, wedle których ubezpieczenie polega na repartycji ryzyka grożącego jednostce na grupę jednostek zagrożonych jednakowym ryzykiem ${ }^{44}$. Przykładowo według J. Łazowskiego ubezpieczenie w ujęciu ekonomicznym jest urządzeniem społeczno-gospodarczym zapewniającym pokrycie przyszłych potrzeb majątkowych wywołanych u poszczególnych jednostek przez odznaczające się pewną prawidłowością zdarzenia losowe w drodze rozłożenia pokrycia na wiele jednostek, którym te same zdarzenia losowe zagrażają.

Na ten ekonomiczny aspekt umowy ubezpieczenia zwracały uwage opisywane w poprzednim rozdziale starsze koncepcje umowy ubezpieczenia, w szczególności teoria wspólnoty ryzyk reprezentowana w literaturze niemieckiej przez E. Brucka ${ }^{45}$, a we francuskiej, jak się wydaje, przez P. Sumien ${ }^{46}$, w mniejszym stopniu zaś teoria potrzeby A. Manesa oraz teoria przedsiębiorstwa C. Vivante ${ }^{47}$. Wyżej wymienione teorie w mniejszym lub większym stopniu kładły nacisk na zorganizowanie we wspólnotę przez ubezpieczyciela zagrożonych podobnym ryzykiem ubezpieczających, którzy przez zawieranie umów i opłacanie składek

43 W polskiej doktrynie tak w szczególności M. Orlicki, Umowa ubezpieczenia, 2002, s. 136-137. W doktrynie niemieckiej przykładowo K. Sieg, Allgemeines..., s. 27.

44 J. Łazowski, Wstęp do nauki o ubezpieczeniach, adaptacja i red. W.W. Mogilski, Sopot 1998, s. 13-14. W polskiej literaturze ostatnio w tym kierunku J. Jastrzębski, który właśnie w uwzględnieniu elementu wspólnoty ryzyka upatruje odróżnienia ubezpieczenia od nieubezpieczeniowych umów gwarancyjnych. Zob. J. Jastrzębski, Nieubezpieczeniowe..., s. 5 i 15.

45 H. Möller, Współczesne..., s. 5.

46 P. Sumien, Traité théorique et pratique des assurances terrestres et des operations de capitalisation et d'epargne, Paris 1948, s. 41.

47 H. Möller, Wspótczesne..., s. 4 i 5. 
finansują odszkodowania wypłacane przez ubezpieczyciela osobom, wobec których ryzyko zrealizowało się na skutek zajścia wypadku.

Opisanie wszystkich czynności składających się na administrowanie wspólnotą ryzyka wymaga odrębnej rozprawy, i to niemającej charakteru prawniczego, a ekonomiczny. Ujmując rzecz skrótowo, ponoszenie przez ubezpieczyciela ryzyka polega:

- na zapewnienie udziału we wspólnocie odpowiednio dużej grupy ubezpieczających, w szczególności przez podejmowanie działań marketingowych,

- na ustalaniu wysokości składek ubezpieczeniowych przy uwzględnieniu wielkości grupy, prawdopodobieństwa wystąpienia zdarzenia losowego oraz wielkości potencjalnej szkody,

- na egzekwowaniu od ubezpieczających składek umożliwiających zgromadzenie rezerw ubezpieczeniowych oraz utrzymanie tych rezerw na właściwym poziomie,

- na lokowaniu zgromadzonych środków w sposób przynoszący zyski,

- na zawarciu odpowiednich umów reasekuracji,

- na utrzymywaniu na odpowiednim poziomie płynności finansowej $^{48}$.

Marcin Krajewski krytykuje takie ujęcie świadczenia ubezpieczyciela, twierdząc, że w istocie ubezpieczyciel nie otrzymuje składki za podjęcie czynności składających się na ochronę ubezpieczeniową. Według tego autora, gdyby ubezpieczyciel wynagradzany był za podejmowanie opisywanych wyżej czynności, nie miałby prawa żądać składki w sytuacji, gdy czynności tych nie podjął, będąc nieświadomym zawarcia ważnej umowy ubezpieczenia przez agenta, i odwrotnie: winien mieć prawo żądać składki, gdyby opisywane czynności podjął, pozostając w błędnym przeświadczeniu, że zawarto ważną umowę ${ }^{49}$. Obydwie konkluzje M. Krajewski uważa za wykluczone z aksjologicznego punktu widzenia, co jego zdaniem każe przyjąć, że ubezpieczający płaci za samo pozostawanie w stanie niebezpieczeństwa spełnienia świadczenia, natomiast

48 Por. w szczególności M. Orlicki, Umowa ubezpieczenia, 2002, s. 137.

49 M. Krajewski, Świadczenie..., s. 15-16. 
w art. $812 \$ 4$, art. $813 \$ 1$ oraz art. $814 \$ 2$ k.c. mowa o udzielaniu ochrony czy ponoszeniu odpowiedzialności w innym znaczeniu niż podejmowanie konkretnych czynności składających się na tę ochronę.

Argumenty powyższe nie przekonują. Teza, że ubezpieczyciel nieświadomy zawarcia umowy, która jednak została zawarta, może domagać się składki, wydaje się słuszna. W opisanej sytuacji ubezpieczający został przecież w istocie włączony do stworzonej i administrowanej przez ubezpieczyciela wspólnoty ryzyka. Ubezpieczyciel taki spełniał zatem swoje świadczenie, nawet jeżeli o tym nie wiedział. Teza, że ubezpieczyciel pozostający w błędnym przekonaniu o przejęciu ryzyka zajścia wypadku określonego w umowie, która następnie okazała się nieważna, nie ma prawa domagać się od ubezpieczającego czegokolwiek, ponieważ ten ostatni nie odniósł żadnej korzyści i nie jest bezpodstawnie wzbogacony, może być już wątpliwa. Teoria ponoszenia ryzyka pozwala przynajmniej rozważyć przyznanie ubezpieczycielowi w drugiej sytuacji roszczenia o zapłatę sumy odpowiadającej składce za okres, w którym ubezpieczyciel pozostawał w błędnym przekonaniu o ponoszeniu ryzyka zajścia wypadku. Aksjologia, którą M. Krajewski uzasadnia odmienną tezę, płynie z teorii świadczenia pieniężnego, tymczasem właśnie słuszność tej teorii ma być udowodniona.

Podobne rozważania można snuć w odniesieniu do umowy najmu nieruchomości. Osoba wprowadzająca się do lokalu bez zgody wynajmującego, który błędnie sądził, że nie doszło do zawarcia ważnej umowy, będzie zobowiązana zapłacić czynsz. Można argumentować, że roszczenie o zapłatę czynszu będzie przysługiwać wynajmującemu niezależnie od tego, czy najemca wprowadzi się, jeżeli tylko lokal pozostawał do jego dyspozycji, pomimo niewiedzy wynajmującego o zawarciu umowy. Osoba wprowadzająca się do lokalu za zgodą wynajmującego, który błędnie sądził, że zawarto ważną umowę, również będzie zobowiązana do zapłacenia sumy odpowiadającej wysokości czynszu za okres korzystania z lokalu. W tej ostatniej sytuacji podstawą roszczeń będą jednak przepisy o bezpodstawnym wzbogaceniu, nie zaś przepisy o umowie najmu. Różnica między najmem a ubezpieczeniem sprowadza się do postaci świadczenia charakterystycznego, które w przypadku najmu zwykle jest bardziej uchwytne, co wynika ze specyfiki obydwu umów. 
Problem przy ujmowaniu ponoszenia ryzyka jako szeregu czynności łączących się z włączeniem ubezpieczającego do tworzonej i administrowanej przez ubezpieczyciela wspólnoty leży przede wszystkim w braku związku podejmowanych przez ubezpieczyciela czynności z konkretną umową ubezpieczenia. Jedynie w razie zawarcia umowy ubezpieczenia, w której niebezpieczeństwo zajścia wypadku jest szczególnie duże, biorąc pod uwagę jego prawdopodobieństwo, wysokość potencjalnej szkody oraz zakres działalności prowadzonej przez ubezpieczyciela, ten ostatni podejmie dodatkowe czynności bezpośrednio w związku z tą konkretną umową. W takim przypadku nie ma zresztą żadnych kłopotów aksjologicznych z przypisaniem ubezpieczającemu obowiązku zapłaty składki, gdy umowa została zawarta mimo braku wiedzy ubezpieczyciela, ani z obciążeniem ubezpieczającego kosztami odpowiadającymi wartości składki za okres ponoszenia ryzyka, gdy zawarta umowa okaże się nieważna.

W innych sytuacjach - teorii, według której na ponoszenie ryzyka składają się czynności związane z utworzeniem i administrowaniem wspólnotą ryzyka, można zarzucać spojrzenie na ubezpieczenie w makroskali zamiast z perspektywy konkretnej umowy ${ }^{50}$. Równie dobrze można by twierdzić, że na świadczenie banku w umowie kredytu lub rachunku bankowego składa się prowadzenie szeroko rozumianej działalności bankowej, w szczególności odpowiednio gromadzenie środków pieniężnych i utrzymywanie infrastruktury umożliwiającej efektywne prowadzenie rozliczeń pieniężnych. Poszerzając punkt widzenia, można by twierdzić, że świadczeniem przedsiębiorcy w każdej umowie handlowej jest prowadzenie przedsiębiorstwa konkretnego rodzaju (np. komisanta - prowadzenie komisu, a spedytora - przedsiębiorstwa spedycyjnego itd.).

Rozważając te analogie, warto jednak odnotować, że związek między końcowym rezultatem świadczenia ubezpieczyciela w postaci wypłaty odszkodowania ubezpieczeniowego a czynnościami składającymi się na

50 Podobne argumenty wysuwane są pod adresem zwolenników poglądu o braku losowości ubezpieczenia, którzy argumentują, że działalność ubezpieczeniowa opiera się na regułach prawdopodobieństwa. Kwestia będzie omówiona w kolejnym podrozdziale. 
ponoszenie ryzyka ubezpieczeniowego jest daleko większy niż w przypadku komisanta lub nawet banku. Łatwo zauważyć, że świadczenie komisanta mogłoby być spełnione bez związku z prowadzeniem jakiegokolwiek przedsiębiorstwa. Podobnie w odniesieniu do umów bankowych można by zobowiązać się do przechowania cudzych pieniędzy oraz prowadzenia cudzych rozliczeń pieniężnych, nie prowadząc przedsiębiorstwa ${ }^{51}$. Można by również, nie prowadząc przedsiębiorstwa, udzielić kredytu, mając pieniądze z innego źródła niż działalność bankowa, podobnie jak jest to możliwe w odniesieniu do udzielenia pożyczki. Spełnienie świadczenia pieniężnego ubezpieczyciela nie byłoby natomiast możliwe bez wcześniejszej gotowości jego spełnienia przybierającej postać określonych czynności. Także osoba, która zobowiązałaby się do zapłacenia odszkodowania za szkodę wyrządzoną przez kogoś innego bez związku z prowadzonym przedsiębiorstwem, chcąc, by obietnica przez nią dana była realna, musiałaby utrzymywać środki przeznaczone na ten cel lub zapewnić sobie dopływ takich środków przed zajściem szkody. Wśród umów bankowych najwięcej podobieństwa do umowy ubezpieczenia wykazuje umowa gwarancji bankowej, w odniesieniu do której, jak również wskazano, prezentowana jest teoria, że świadczenie gwaranta polega na przejęciu ryzyka gospodarczego związanego z niewystąpieniem określonego rezultatu oraz pozostawaniu w stałej gotowości do zapłaty sumy gwarancyjnej ${ }^{52}$.

Istnieje jednak daleko idące podobieństwo między działalnością ubezpieczeniową oraz działalnością bankową. Obydwa rodzaje czynności wiążą się bowiem z zarządzeniem pieniędzmi powierzonymi przez inne osoby. Jak wskazano w nauce niemieckiej, w umowie ubezpieczenia upatrywano postaci umowy o prowadzenie cudzych interesów. Zgodnie $\mathrm{z}$ tą teorią ubezpieczenie jest postacią powiernictwa polegającą na gromadzeniu składek ubezpieczających, tworzeniu wspólnoty ryzyk oraz przeznaczaniu części składek na wypłatę odszkodowań. Krytycy tej teorii wskazują, że zakłada ona masowość zawieranych umów, tworzenie

51 W odniesieniu do rozliczeń pieniężnych możliwość taka wydaje się jednak raczej teoretyczna. Odnieść by ją można co najwyżej do niektórych postaci rozliczeń w oderwaniu od regulacji prawa bankowego.

52 G. Tracz, Umowa..., s. 299-300; A. Koch, Umowa..., s. 618. 
wspólnot niebezpieczeństwa spośród osób występujących w charakterze kontrahentów ubezpieczyciela, dzielenie składki na część przypadającą na wypłatę świadczeń oraz na koszty i zysk ubezpieczyciela, oraz implikuje konieczność dopłat w razie niedoboru, jeżeli środki ze składek nie wystarczają na pokrycie odszkodowań, jak również roszczenie o zwrot nadwyżki w sytuacji przeciwnej. Według zwolenników teorii świadczenia pieniężnego założenia te nie znajdują odzwierciedlania w obowiązujących przepisach i są prawdziwe jedynie w odniesieniu do ubezpieczeń wzajemnych, gdzie zachodzi sprzężenie dwóch stosunków prawnych, tj. stosunku ubezpieczenia oraz stosunku członkostwa, i nie można przenosić ich na grunt ubezpieczeń wzajemnych ${ }^{53}$. W świetle wcześniejszych uwag krytyka ta wydaje się słuszna jedynie częściowo, nie sposób bowiem zaprzeczyć, że również komercyjne zakłady ubezpieczeń działają, opierając się na wspólnocie ryzyka, a prawo ubezpieczeniowe stara się zapewnić ich sprawne działanie oraz gwarancje w razie zagrożenia tej sprawności.

Aprobując pogląd, że pozostawanie w stanie niebezpieczeństwa spełniania określonych obowiązków oraz że czynności składające się na ponoszenie ryzyka mogą stanowić zachowanie będące świadczeniem ubezpieczyciela, nie należy jednak tracić z pola widzenia świadczenia pieniężnego spełnianego przez ubezpieczyciela w razie zajścia wypadku. Zwracają na to uwagę zwolennicy teorii ponoszenia ryzyka, której w jej ortodoksyjnej postaci właściwie nikt nie broni ${ }^{54}$. Połączeniem obydwu teorii miała być teoria świadczenia o zmiennej treści mówiąca, że świadczenie polegające na ponoszeniu ryzyka zmienia się i aktualizuje w postaci obowiązku wypłaty sumy pieniężnej. Teorii tej zarzucono, że jest ona stworzona wyłącznie na użytek ubezpieczenia, trudno bowiem znaleźć inną umowę, w której świadczenie zmienia się w podobny sposób ${ }^{55}$.

W wielu umowach spełnienie przez dłużnika świadczenia wymaga wykonania szeregu obowiązków. Niektórzy autorzy wskazują na istnienie

53 M. Krajewski, Świadczenie..., s. 24-26 oraz cytowana tam literatura niemiecka.

54 Por. M. Orlicki, Umowa ubezpieczenia, 2002, s. 140.

55 Z. Szymański, O definicji..., s. 21. 
kilku świadczeń, co nie wydaje się słuszne ${ }^{56}$. Przykładowo w umowie sprzedaży sprzedawca ma wydać rzecz kupującemu i przenieść na niego własność rzeczy. W umowie najmu wynajmujący ma wydać rzecz najemcy i umożliwić mu niezakłócone korzystanie z niej, dokonując poważniejszych napraw oraz chroniąc go przed roszczeniami osób trzecich. Spełnienie jednego albo kilku obowiązków nie przesądza o zadośćuczynieniu interesowi wierzyciela oraz o spełnieniu świadczenia. Kwestia ta będzie wyjaśniona w kolejnym podrozdziale. Podobnie świadczenie ubezpieczyciela tworzone jest przez szereg działań zmierzających do wypłaty świadczenia pieniężnego $w$ razie zajścia wypadku. Różnicowanie charakteru tego świadczenia zależnie od tego, czy wypadek ubezpieczeniowy nastąpił, nie wydaje się słuszne ${ }^{57}$.

Wziąwszy pod uwagę losowy charakter umowy ubezpieczenia, świadczenie ubezpieczyciela winno być rozpatrywane przy uwzględnieniu obydwu możliwych scenariuszy; pierwszego, w którym wypadek ubezpieczeniowy nie zachodzi, oraz drugiego, w którym wypadek zachodzi. Według pierwszego świadczenie wyczerpuje się w ponoszeniu ryzyka, według drugiego świadczenie polega przede wszystkim na wypłacie świadczenia pieniężnego. Wbrew pozorom jednak pogląd, że świadczenie ubezpieczyciela ma treść dwupostaciową i zmienną zależnie od rozwoju wydarzeń, byłby uproszczeniem. W istocie obie postaci świadczenia można porównać do dwóch stron medalu.

Świadczenie ubezpieczyciela to monolit, ma ono jednorodny charakter. Wypłata świadczenia pieniężnego $\mathrm{w}$ razie zajścia wypadku stanowi wprawdzie jedynie ewentualną konkretyzację wcześniejszych czyn-

56 Tak. S. Grzybowski, Zobowiązania w systemie prawa cywilnego [w:] System Prawa Cywilnego, t. 3, cz. 1, Prawo zobowiązań. Część ogólna, red. Z. Radwański, Ossolineum 1981, s. 44-45 oraz 86; T. Dybowski, A. Pyrzyńska, Świadczenie, s. 86. Przeciwnie A. Klein, Elementy..., s. 42-51. Niezupełnie jasno W. Czachórski, który z jednej strony wskazuje, że spełnienie świadczenia może wymagać od dłużnika nie jednej, lecz wielu czynności i postaw, z drugiej natomiast wśród obowiązków dłużnika wyróżnia zasadnicze i pomocnicze (główne i uboczne), a wśród nich jako najważniejszy obowiązek świadczenia. Por. W. Czachórski [w:] W. Czachórski, A. Brzozowski, M. Safjan, E. Skowrońska-Bocian, Zobowiązania...., s. 44 i 54. Co do uzasadnienie przyjęcia poglądu A. Kleina, zob. B. Kucharski, Przeniesienie..., s. 49, przypis 123.

57 B. Kucharski, Przeniesienie..., s. 48-50. 
ności składających się na ponoszenie ryzyka, ale jednocześnie jest ich zwieńczeniem. Jego spełnienie nie byłoby możliwe, gdyby czynności te nie zostały podjęte. Niezależnie od tego, jakie czynności składają się na ponoszenia ryzyka przed zajściem wypadku, nie mają one dla ubezpieczającego znaczenia same w sobie, ale jedynie przez wzgląd na obowiązek ubezpieczyciela wypłaty odszkodowania, aktualizujący się jedynie w razie zajścia wypadku, ale podlegający realizacji właśnie dlatego, że został poprzedzony przez odpowiednie czynności określane mianem ponoszenia ryzyka. Czynności te nie mają jednocześnie charakteru wyłącznie czynności przygotowawczych do spełniania właściwego świadczenie. Ich ciężar gatunkowy jest znacznie większy, a nadto przeważnie przy realizacji zwykłego scenariusza pożądanego przez obie strony umowy świadczenie ubezpieczyciela wyczerpuje się w tych czynnościach.

Według koncepcji zaprezentowanej wcześniej przez autora niniejszej pracy, pomimo że wierzytelność ubezpieczeniowa istnieje również przed zajściem wypadku, roszczenie ubezpieczającego pojawia się dopiero z jego zajściem. Szersze przedstawienie tej koncepcji wymaga odwołania się do podstawowych w cywilistyce pojęć wierzytelności oraz roszczenia. Jak wiadomo, wierzytelność jest prawem podmiotowym względnym, tj. skutecznym jedynie wobec określonych podmiotów, polegającym na możliwości domagania się od dłużnika spełnienia świadczenia. Świadczenie zaś to zachowanie dłużnika mające na celu zaspokojenie interesu wierzyciela ${ }^{58}$.

Według tzw. monistycznej (zwanej inaczej globalną) koncepcji wierzytelności mianem wierzytelności określać należy całość sytuacji prawnej wierzyciela, tak jak mianem długu całość sytuacji dłużnika. Spełnienie świadczenia wymaga zwykle od dłużnika spełnienia całego szeregu obowiązków umożliwiających zaspokojenie interesu wierzyciela. Dopiero łączne spełnienie wszystkich obowiązków funkcjonalnie związanych

58 Zob. przykładowo W. Czachórski, A. Brzozowski, M. Safjan, E. Skowrońska-Bocian, Zobowiązania..., s. 62; T. Dybowski, Świadczenie [w:] System Prawa Cywilnego, t. 3, cz. 1, Prawo zobowiązań. Część ogólna, red. Z. Radwański, Ossolineum 1981, s. 71; T. Dybowski, A. Pyrzyńska, Świadczenie, s. 186 oraz wskazana tam literatura, P. Szyszka, Analiza stosunku ubezpieczenia z punktu widzenia monistycznej koncepcji przedmiotu prawa, WU 1996/10-11, s. 17-18. 
z długiem przesądza o wykonaniu świadczenia. Konkretnym obowiązkom dłużnika odpowiadają roszczenia wierzyciela. Tak zwana pluralistyczna (syngularna) koncepcja wierzytelności, zgodnie z którą każdy obowiązek dłużnika stanowi po stronie wierzyciela odrębną wierzytelnośći każdej wierzytelności musi odpowiadać roszczenie w taki sposób, że poszczególne wierzytelności wyczerpują się w odpowiadających im roszczeniach, ma niewielu zwolenników w doktrynie ${ }^{59}$.

Poza roszczeniami wierzycielowi służą uprawnienia niemające charakteru roszczeń, a mianowicie uprawnienia kształtujące, chroniące jego interes $\mathrm{w}$ ukształtowaniu poszczególnych roszczeń lub nawet całości stosunku zobowiązaniowego. Mocą tych uprawnień wierzyciel swym własnym działaniem doprowadza do powstania określonych skutków prawnych. Tym uprawnieniom nie odpowiadają żadne obowiązki dłużnika. Do uprawnień kształtujących należą w szczególności uprawnienia do wyboru świadczenia przemiennego (art. 365 k.c.), do odstąpienia od umowy (art. 395 i 396 k.c.), do wypowiedzenia (np. art. 672-674 k.c.). Pogląd S. Grzybowskiego, że uprawnienia te nie wchodzą w skład wierzytelności jako prawa podmiotowego, wydaje się dyskusyjny, skoro są one bezpośrednio powiązane funkcjonalnie z zachowaniem lub zachowaniami, jakich wierzyciel ma prawo oczekiwać od dłużnika ${ }^{60}$.

Zakres znaczeniowy pojęcia roszczenia jest w literaturze cywilistycznej określany w różny sposób, pomimo że należy ono do zupełnie podstawowych kwestii, poruszanych w ramach wstępu wykładu o zobowiązaniach. Alfred Klein zdaje się utożsamiać roszczenie z możliwością przymusowej realizacji niektórych obowiązków składających się na wierzytelność ${ }^{1}$. Inni autorzy, m.in. A. Wolter i Z. Radwański, akcentują podmiotową i przedmiotową konkretyzację roszczenia jako możliwo-

59 Zwolennikiem syngularnej koncepcji wierzytelności w skrajnej postaci jest J. Kuropatwiński. Por. J. Kuropatwiński, Umowne rozporządzenie wierzytelnością przyszła, Toruń 2007, s. 40-46. Takie ujęcie zdaje się być podporządkowane nadrzędnemu celowi autora, który we wszystkich sytuacjach, gdy uprawnionemu nie przysługuje jeszcze roszczenie i roszczenie takie może powstać w przyszłości, chce widzieć wierzytelność przyszłą.

60 S. Grzybowski, Zobowiązania..., s. 43.

61 A. Klein, Elementy..., s. 44. 
ści dochodzenia od określonej osoby konkretnego obowiązku ${ }^{62}$. Z kolei zdaniem P. Machnikowskiego o roszczeniu, czyli o prawie żądania spełnienia obowiązku, należy mówić bez odwoływania się do kwestii zaskarżalności oraz skonkretyzowania obowiązku. Autor ten zwraca uwagę, że przepisy o przedawnieniu traktują o roszczeniu rozumianym szeroko, przyznając wierzycielowi roszczenie, zanim obowiązek jest skonkretyzowany, ale również gdy odpada możliwość jego przymusowej realizacji ${ }^{63}$.

Poza tym w literaturze cywilistycznej rozróżnia się roszczenie materialnoprawne od roszczenia procesowego. Małgorzata Pyziak-Szafnicka definiuje roszczenie materialnoprawne za A. Wolterem jako skonkretyzowane uprawnienie domagania się określonego zachowania, natomiast roszczenie procesowe za W. Broniewiczem jako twierdzenie powoda o istnieniu albo nieistnieniu określonej normy indywidualno-konkretnej przedstawione sądowi celem wiążącego ustalenia tego istnienia lub nieistnienia. Autorka ta podkreśla odrębność obu pojęć oraz ich samodzielny byt ${ }^{64}$. Nie negując wskazanego rozróżnienia, wypada zwrócić uwagę, że nawet P. Machnikowski, wskazujący na istnienie odrębnej od roszczenia kategorii w postaci kompetencji przymusowej realizacji tego roszczenia znajdującej się na styku prawa cywilnego oraz procesowego, aprobuje uwzględnianie tej kompetencji przy omawianiu stosunków zobowiązaniowych i jej regulowanie w przepisach o charakterze materialnoprawnym ${ }^{65}$.

Autorzy dostrzegający rozróżnienie między roszczeniem oraz jego przymusową realizacją obydwie kategorie traktują często łącznie. Przykładowo S. Grzybowski pisze, że w odniesieniu do zobowiązań naturalnych prawo nie oddaje do dyspozycji wierzyciela całego arsenału roszczeń oraz możności przymusowej realizacji ${ }^{66}$. Zdaniem autora niniejszych rozważań wyróżnianie na gruncie prawa cywilnego, które służy ochro-

62 Z. Radwański, A. Olejniczak, Zobowiązania..., s. 14.

63 P. Machnikowski, Struktura zobowiązania [w:] System Prawa Prywatnego, t. 5, Prawo zobowiązań - część ogólna, red. E. Łętowska, Warszawa 2012, s. 141.

64 M. Pyziak-Szafnicka, Prawo podmiotowe, SPP 2006/1, s. 60.

65 P. Machnikowski, Struktura..., s. 143.

66 S. Grzybowski, Zobowiązania..., s. 62. 
nie wierzyciela, roszczeń niepodlegających przymusowej realizacji wydaje się wątpliwe. Przepisy o przedawnieniu rzeczywiście mówią o roszczeniach przedawnionych, jednak w tym przypadku jest to o tyle uzasadnione, że roszczenia takie mogą być przedmiotem potrącenia i odnowienia, a także uznania, co przywraca im zaskarżalność. Nadto niezaskarżalność roszczeń przedawnionych brana jest pod uwagę na zarzut $^{67}$. Można zatem powiedzieć, że są one jedynie względnie niezaskarżalne.

Konkludując, można raz jeszcze podkreślić, że roszczenie ściśle wiąże się z wierzytelnością. Jednakże wierzytelność, czyli prawo wierzyciela domagania się od dłużnika spełnienia świadczenia, jest czym innym niż roszczenie pełniące rolę służebną i będące środkiem umożliwiającym przymusową realizację konkretnego obowiązku składającego się na wierzytelność. Niektóre spośród obowiązków składających się na wierzytelność nie nadają się do przymusowego wykonania i nie mają odpowiedników w postaci roszczeń. Wierzytelność nie wyczerpuje się zatem w roszczeniu ani nawet roszczeniach materialnoprawnych będących jedynie elementem umożliwiającym realizację niektórych obowiązków za pomocą przymusu państwowego.

Specyfika umowy ubezpieczenia, łącząca się z jej losowością, polega na tym, że roszczenie dotyczy jedynie obowiązku spełnienia świadczenia pieniężnego, który aktualizuje się dopiero wraz z zajściem wypadku ubezpieczeniowego. Obowiązki składające się na ponoszenie ryzyka ubezpieczeniowego nie nadają się do przymusowego wykonania, pominąwszy końcowy, ewentualny i stanowiący ich zwieńczenie obowiązek wypłaty odszkodowania ubezpieczeniowego. Trudno wyobrazić sobie, by ubezpieczający występował $\mathrm{z}$ roszczeniem o podjęcie przez ubezpieczyciela kampanii marketingowej reklamującej usługi tego ostatniego, o ulokowanie w określony sposób przez ubezpieczyciela środków ze składek ubezpieczeniowych albo o zawarcie umowy reasekuracji. Przyznanie ubezpieczającemu roszczenia przed zajściem wypadku stwarzałoby

${ }^{67}$ Po zmianie przepisów o przedawnieniu dokonanej ustawą z 13.04.2018 r. o zmianie ustawy - Kodeks cywilny oraz niektórych innych ustaw (Dz.U. poz. 1104) przedawnienie roszczenia w odniesieniu do konsumentów brane jest przez sąd pod uwagę z urzędu. 
możliwość ingerowania przezeń w działalność ubezpieczeniową, która jest przecież zastrzeżona dla ultraprofesjonalnych instytucji zwanych zakładami ubezpieczeń, podlegających ścisłej reglamentacji i nadzorowi ze strony państwa. Ubezpieczający nie ma dostępu do informacji ani nie dysponuje wiedzą pozwalającą podważać realność gwarancji stwarzanej przez działania ubezpieczyciela.

Zwolennicy tzw. zmodyfikowanej teorii ponoszenia ryzyka, zgodnie z którą pojęciem tym należy objąć cały szereg czynności sprawiających, że ochrona ubezpieczeniowa jest realna, często upatrują w umowie ubezpieczenia umowy o świadczenie usług ${ }^{68}$. Nie przesądzając trafności tej koncepcji, można wskazać, że umowy o świadczenie usług profesjonalnych charakteryzują się tym, że zleceniobiorca ma pewien zakres swobody w wykonaniu zlecenia, a zleceniodawca działa w zaufaniu do jego profesjonalnych umiejętności. Podobnie ubezpieczający niebędący profesjonalistą musi działać w zaufaniu do ubezpieczyciela, który świadczy wysoko wyspecjalizowaną usługę finansową. Zaufanie ubezpieczającego względem ubezpieczyciela wzmacnia nadzór ze strony państwa nad działalnością tego ostatniego oraz szczególny system ochrony ubezpieczających na wypadek jego niewypłacalności.

Rekapitulując podstawowe tezy wyżej przedstawionej koncepcji świadczenia ubezpieczyciela, koncepcja ta stara się godzić teorię ponoszenia ryzyka z teorią świadczenia pieniężnego. Zespół działań ubezpieczyciela przed zajściem wypadku ubezpieczeniowego, określany mianem ponoszenia ryzyka, może być traktowany jako świadczenie. Działania te nie mają jednak charakteru czynności przygotowawczych, ale same w sobie przybierają postać świadczenia, a nawet, jeżeli nie dochodzi do realizacji wypadku ubezpieczeniowego, wyczerpują jego zakres. Z drugiej strony tak rozumiane świadczenie ubezpieczeniowe ma sens jedynie ze względu na obowiązek zapłaty sumy pieniężnej, który aktualizuje się jedynie w razie zajścia wypadku. Świadczenie ubezpieczyciela, choć jego treść pozornie jest zróżnicowana, winno być traktowane jako jednorodne. Działaniom ubezpieczyciela składającym się na ponoszenie ryzyka,

${ }_{68}$ Tak w szczególności A. Wąsiewicz, Umowa..., s. 109, oraz M. Orlicki, Umowa ubezpieczenia, 2002, s. 143. 
pomimo że wypełniają one często treść jego świadczenia, przed zajściem wypadku nie odpowiadają żadne roszczenia po stronie ubezpieczającego. Ten ostatni ma jedynie roszczenie o zapłatę odszkodowania ubezpieczeniowego, powstanie tego roszczenia uzależnione jest od zajścia wypadku ubezpieczeniowego.

\subsection{Zobowiązanie do ponoszenia ryzyka a zobowiązanie naturalne}

Przedstawiona koncepcja zobowiązania z umowy ubezpieczenia przed zajściem wypadku ubezpieczeniowego przypomina w wielu aspektach konstrukcję zobowiązania naturalnego. Jak wiadomo, zobowiązania naturalne, zwane również zobowiązaniami niezupełnymi albo zobowiązaniami o osłabionej sankcji, charakteryzują się dwiema podstawowymi cechami, a mianowicie niezaskarżalnością oraz brakiem obowiązku zwrotu spełnionego świadczenia. Niezaskarżalność zobowiązań naturalnych wyjaśnia się przy uwzględnieniu odróżnienia długu rozumianego jako powinność spełnienia świadczenia oraz odpowiedzialności rozumianej jako gotowość majątku dłużnika do zaspokojenia wierzyciela albo inaczej jako możność przymusowej realizacji roszczenia. W odniesieniu do zobowiązań naturalnych istnieje jedynie dług, nie istnieje natomiast odpowiedzialność, wobec czego wierzytelności z nich wynikające nie mogą być dochodzone na drodze przymusu państwowego. Nieistnienie odpowiedzialności nie oznacza przy tym jedynie, że zobowiązania naturalne nie nadają się do egzekucji komorniczej. Z uwagi na brak odpowiedzialności za dług w zobowiązaniu naturalnym świadczenie w tym zobowiązaniu nie podlega w ogóle zasądzeniu w wyroku sądowym, wierzyciel nie ma zatem roszczenia umożliwiającego przymusową realizację świadczenia ${ }^{69}$.

Przypomnieć należy, że do zobowiązań naturalnych zalicza się zwykle trzy kategorie zobowiązań: zobowiązania przedawnione, zobowiązania z gry i zakładu oraz zobowiązania spełniane zgodnie z zasadami

69 Zob. przykładowo M. Tenenbaum, Zobowiązania naturalne [w:] Odpowiedzialność w prawie cywilnym, red. P. Machnikowski, AUWr 2897, Wrocław 2006, s. 242. 
współżycia społecznego. Doktryna nie jest jednak w pełni zgodna co do zaliczenia wszystkich wymienionych kategorii do zobowiązań naturalnych. Przykładowo S. Grzybowski, a za nim P. Machnikowski twierdzą, że sytuacje, w których spełniono świadczenie czyniące zadość zasadom współżycia społecznego, nie należą do zobowiązań naturalnych. Artykuł 411 k.c. wylicza jedynie sytuacje, w których spełnione świadczenie nie podlega zwrotowi, wobec czego nie można $\mathrm{z}$ niego wnosić o istnieniu stosunku prawnego. Wyraźne wymienienie wśród tych sytuacji świadczeń czyniących zadość zasadom współżycia społecznego było niezbędne właśnie dlatego, że w sytuacjach tych zobowiązanie po prostu nie istnieje, ustawowe wyłączenie obowiązku zwrotu byłoby zbędne, gdyby zobowiązanie istniało ${ }^{70}$. Z poglądem tym należy się zgodzić.

Marcin Krajewski zwraca uwagę, że sytuacja zbliżona do zobowiązania naturalnego, ale nie identyczna, występuje w odniesieniu do umowy przedwstępnej o słabszym skutku. Uprawniony z umowy przedwstępnej nie ma roszczenia o zawarcie umowy przyrzeczonej, pomimo że zobowiązany ma obowiązek jej zawarcia. Różnica w odniesieniu do zobowiązań naturalnych polega na tym, że odmowa spełnienia przez dłużnika świadczenia w postaci zawarcia umowy przyrzeczonej rodzi przynajmniej obowiązek odszkodowawczy, który podlega realizacji przy użyciu przymusu państwowego i może być egzekwowany. W przypadku zobowiązań naturalnych wierzyciel nie ma możliwości konstruowania nawet zastępczych obowiązków podlegających przymusowej realizacji. Z powyższych względów M. Krajewski kwalifikuje zobowiązanie z umowy przedwstępnej o słabszym skutku jako kategorię pośrednią między zobowiązaniami w pełni zaskarżalnymi oraz zobowiązaniami naturalnymi ${ }^{71}$.

Można zaryzykować stwierdzenie, że koncepcja zobowiązania naturalnego, podobnie jak koncepcja roszczenia, chociaż zupełnie podstawowa, nie jest we współczesnej cywilistyce w pełni opracowana. W istocie konstrukcja ta stanowi kalkę z prawa rzymskiego, gdzie do zobowiązań naturalnych zaliczano przede wszystkim zobowiązania osób podlegają-

70 P. Machnikowski, Struktura..., s. 177-178.

71 M. Krajewski, Umowa przedwstępna, Warszawa 2000, s. 146. 
cych czyjejś władzy, w szczególności: niewolników, dzieci, kobiet i innych osób podlegających władzy pater familiae, a nadto długi hazardowe oraz w prawie poklasycznym zobowiązania moralne ${ }^{72}$. Powszechnie wskazuje się, że kategorie zobowiązań klasyfikowanych jako naturalne różnią się między sobą zależnie od przyczyn, dla których ustawodawca odmawia im zaskarżalności. O odmowie ochrony interesu wierzyciela w odniesieniu do zobowiązań przedawnionych przesądza upływ czasu. W przypadku zobowiązań z gier i zakładów prowadzonych bez zezwolenia interes wierzyciela w ogóle nie jest uważany za godny ochrony, a porządek prawny jedynie je toleruje. Zobowiązania spełnione zgodnie z zasadami współżycia społecznego stanowią kategorię pośrednią między wyżej wymienionymi - z jednej strony widoczny jest brak niechęci ustawodawcy do ochrony obowiązków zaledwie podciągniętych do rangi ustawowych, z drugiej strony jednak nie ma podstaw do zbytniego ich popierania $^{73}$.

Nawet dwie bezsporne w polskiej cywilistyce kategorie zobowiązań naturalnych, tzn. zobowiązania przedawnione i zobowiązania z gry i zakładu, nie mają charakteru jednorodnego. Niezaskarżalność zobowiązania przedawnionego uwzględniana jest na zarzut, natomiast niezaskarżalność zobowiązana z gry lub zakładu - z urzędu. Zarzutu przedawnienia dłużnik może się zrzec, przywracając zobowiązaniu zaskarżalność. Obecnie nie dotyczy to jednak konsumentów ${ }^{74}$. Niezaskarżalność roszczeń z gry i zakładu jest niezależna od woli zobowiązanego. Ponadto zobowiązanie przedawnione w pewnych sytuacjach podlega potrąceniu, co jest niedopuszczalne w odniesieniu do innych kategorii

72 W. Litewski, Rzymskie prawo prywatne, Warszawa 1990, s. 260; Z. Rozwadowski, Prawo rzymskie, Poznań 1992, s. 151; C. Kunderewicz, Rzymskie prawo prywatne, Łódź 1995, s. 122; Wikipedia, hasło „zobowiązanie naturalne”, https://pl.wikipedia.org/wiki/ Zobowi\%C4\%85zania_naturalne (dostęp: 1.11 .2018 r.).

73 W. Czachórski, A. Brzozowski, M. Safjan, E. Skowrońska-Bocian, Zobowiązania..., s. 60 .

74 Wykładnia systemowa art. 117 k.c. w brzmieniu ustalonym ustawą z 13.04.2018 r. o zmianie ustawy - Kodeks cywilny oraz niektórych innych ustaw (Dz.U. poz. 1104), zgodnie z którą możliwość zrzeczenia się zarzutu przedawnienia nie dotyczy konsumentów. Zob. przykładowo M. Krajewski, Zmiany regulacji przedawnienia roszczeń, PPH 2018/12, s. 15-16; P. Machnikowski, Nowelizacja przepisów Kodeksu cywilnego o przedawnieniu roszczeń, PS 2018/9, s. 11. 
zobowiązań niezaskarżalnych. Podobnie oceniać należy odnowienie, które jest dopuszczalne w odniesieniu do zobowiązań przedawnionych i wyłączone w odniesieniu do zobowiązań z gry i zakładu ${ }^{75}$.

Powyższe przypomnienie podstawowych wiadomości o zobowiązaniach naturalnych nie wystarcza, aby jednoznacznie odpowiedzieć na pytanie, czy zobowiązanie ubezpieczyciela $z$ umowy ubezpieczenia przed zajściem wypadku ubezpieczeniowego można kwalifikować jako zobowiązanie naturalne. Zgodnie z tym, co napisano powyżej, dwie wspólne cechy tej kategorii zobowiązań to niezaskarżalność oraz brak roszczenia o zwrot spełnionego świadczenia. Zobowiązanie ubezpieczyciela, pomimo że nie jest wymieniane wśród zobowiązań naturalnych, zdaje się spełniać obydwie wyżej wskazane cechy: ubezpieczający nie ma prawa domagać się podejmowania przez ubezpieczyciela działań składających się na ochronę ubezpieczeniową, $\mathrm{z}$ drugiej strony ubezpieczyciel nie ma roszczenia o zwrot ochrony, która została już udzielona. Brak tego drugiego roszczenia wynika zresztą poniekąd ze szczególnego charakteru umowy ubezpieczenia oraz świadczenia ubezpieczyciela, które ma charakter ciągły ${ }^{76}$. Ubezpieczyciel nie może przecież wycofać ochrony ubezpieczeniowej, której wcześniej udzielił, podobnie jak bank nie może wycofać rozliczeń, których wcześniej dokonał na zlecenie posiadacza rachunku, operator telefoniczny połączeń, których nawiązanie umożliwił, a wynajmujący nie może ze skutkiem wstecznym uniemożliwić używania rzeczy będącej przedmiotem najmu.

Porównując zobowiązania naturalne do zobowiązania ubezpieczyciela przed zajściem wypadku ubezpieczeniowego, można wskazać, że we wszystkich przypadkach kwalifikowanych jako zobowiązania naturalne chodzi o świadczenia, które ze swej istoty nadają się do przymusowego wykonania i są niezaskarżalne jedynie z woli ustawodawcy. Przykłady świadczeń w zobowiązaniach naturalnych dotyczą zwykle zapłaty określonej sumy pieniężnej. Wynikający z umowy przedwstępnej obowiązek świadczenia polegającego na zawarciu umowy przyrzeczonej również

75 P. Machnikowski, Struktura..., s. 165 oraz wskazana tam literatura. Podobnie Z. Radwański, A. Olejniczak, Zobowiązania..., s. 22.

${ }^{76}$ M. Orlicki, Umowa ubezpieczenia, 2002, s. 251. 
nadaje się do przymusowego wykonania i podlega takiemu wykonaniu w odniesieniu do umowy o skutku silniejszym.

W przypadku umowy ubezpieczenia sprawa przedstawia się inaczej. O niezaskarżalności zobowiązania ubezpieczyciela przed zajściem wypadku przesądza właśnie charakter wierzytelności. Niewłaściwe wykonanie świadczenia ubezpieczyciela przed zajściem wypadku polegać będzie najogólniej na niewłaściwym zarządzaniu wspólnotą ryzyka lub popadnięciu w zły stan finansowy w taki sposób, że wypłata odszkodowania w razie zajścia wypadku jest niepewna. Sposoby zarządzania wspólnotą ryzyka oraz kryteria oceny sytuacji finansowej zakładu ubezpieczeń, w szczególności w zakresie kapitału gwarancyjnego oraz marginesu wypłacalności, zostały sprecyzowane w przepisach ustawy o działalności ubezpieczeniowej i reasekuracyjnej oraz w rozporządzeniach wykonawczych do tej ustawy. Dokonywanie oceny prawidłowości zarządzania wspólnotą ryzyka oraz spełniania przez zakład ubezpieczeń wymagań finansowych powierzono natomiast na mocy odrębnej ustawy specjalnemu organowi państwa w postaci Komisji Nadzoru Finansowego ${ }^{77}$. Ponadto $z$ istoty ponoszenia ryzyka ubezpieczeniowego jako świadczenia wynika, że ubezpieczający zwykle dowie się o jego niewykonaniu dopiero po zajściu wypadku ubezpieczeniowego, kiedy ubezpieczyciel rzeczywiście nie wypłaci odszkodowania ${ }^{78}$. Ubezpieczający nie ma kompetencji ani możliwości bieżącego nadzorowania stanu finansowego ubezpieczyciela.

Opisywaną różnicę między zobowiązaniami naturalnymi a zobowiązaniem ubezpieczyciela przed zajściem wypadku można wyjaśnić inaczej, wracając do rozróżnienia roszczenia oraz jego zaskarżalności, ewentualnie kompetencji do dochodzenia roszczenia. Rozróżnienie to zostało powyżej zanegowane jako sprawdzające się częściowo jedynie w odniesieniu do zobowiązań przedawnionych. W odniesieniu do innych kategorii tzw. zobowiązań naturalnych roszczenie wydaje się po prostu nie istnieć pomimo istnienia wierzytelności. Dłużnik karciany ma dług

77 Ustawa z 21.07.2006 o nadzorze nad rynkiem finansowym (Dz.U. z 2018 r. poz. $621 \mathrm{ze} \mathrm{zm}$.).

78 Por. M. Orlicki, Umowa ubezpieczenia, 2002, s. 146-147. 
honorowy, wierzyciel może domagać się od niego zaspokojenia swej pretensji, jednak określanie tej pretensji czy żądania mianem roszczenia ma wątpliwy walor. Podobnie osoba, która domaga się środków utrzymania od kogoś, kto moralnie poczuwa się do jej alimentowania przy jednoczesnym braku obowiązku prawnego, może jedynie prosić, jednak nazywanie takiej prośby roszczeniem jest co najmniej dyskusyjne. Inna rzecz, że przynajmniej w tym ostatnim przypadku brak prawnego obowiązku wynika z nieistnienia wierzytelności, co już zaznaczono, sprzeciwiając się określaniu świadczeń spełnianych z dobroci serca mianem zobowiązań.

Koncepcja o istnieniu roszczenia przy jednoczesnym braku kompetencji do jego dochodzenia, kontrowersyjna w odniesieniu do zobowiązań przedawnionych, zobowiązań z gry i zakładu oraz świadczeń spełnianych zgodnie z zasadami współżycia społecznego, jest jeszcze trudniejsza do utrzymania, gdy chodzi o świadczenie ubezpieczeniowe. Przyczyna jest przy tym inna niż w przypadku zobowiązań z gry i zakładu oraz świadczeń spełnianych zgodnie z zasadami współżycia społecznego. W przypadku tych pierwszych dług jest tzw. długiem honorowym, w przypadku drugich nie ma zobowiązania, a zatem i wierzytelności. Niektórzy mówią, że roszczenia istniejące w obu przypadkach są niezaskarżalne albo dłużnik nie ma kompetencji ich dochodzenia ${ }^{79}$. W odniesieniu do wierzytelności ubezpieczeniowej przed zajściem wypadku brak roszczenia znów wynika z natury prawnej stosunku ubezpieczenia. Trudno bowiem przyznać ubezpieczającemu choćby namiastkę roszczenia o ochronę ubezpieczeniową przybierającą $\mathrm{w}$ istocie postać roszczenia o poprawę sytuacji finansowej zakładu ubezpieczeń. Poprawa sytuacji finansowej jakiegokolwiek uczestnika obrotu, w szczególności zaś instytucji ubezpieczeniowej, jest procesem skomplikowanym i długotrwałym. Nawet gdyby ubezpieczający takie roszczenie posiadał, byłoby ono trudne do zrealizowania.

Marcin Orlicki twierdzi wprawdzie, że wywodzone przez niego z przepisów o wykonaniu zobowiązań wzajemnych uprawnienia ubezpieczającego na wypadek złej sytuacji finansowej ubezpieczyciela, a mianowicie:

79 Zob. rozważania w poprzednim podrozdziale. 
uprawnienie do powstrzymania się z zapłatą składki, uprawnienie do żądania odszkodowania obejmującego koszty tworzenia i utrzymywania własnych rezerw na pokrycie skutków majątkowych zdarzeń losowych oraz uprawnienie do zawarcia zastępczej umowy ubezpieczenia na koszt ubezpieczyciela stanowią sposoby realizacji roszczenia o ochronę ubezpieczeniową. Z przytoczonym poglądem trudno jednak się zgodzić. Nawet przyjąwszy, że ubezpieczający opisane uprawnienia posiada, należy upatrywać w nich nie sposobów realizacji roszczenia, ale raczej sposobów realizacji wierzytelności o ochronę ubezpieczeniową przyznanych ubezpieczającemu właśnie $\mathrm{z}$ uwagi na brak roszczenia przed zajściem wypadku.

Prawo powstrzymania się ze spełnieniem świadczenia oraz prawo do odstąpienia od umowy z uwagi na jej niewykonanie traktowane są zwykle jako odrębne od roszczeń uprawnienia wierzyciela i przynajmniej to drugie zalicza się do uprawnień kształtujących ${ }^{80}$. Prawo do żądania odszkodowania z uwagi na niewykonanie umowy albo prawo do zawarcia zastępczej umowy ubezpieczenia są roszczeniami. Nawet jednak gdyby przyznać je ubezpieczającemu, nie byłyby roszczeniami o ochronę ubezpieczeniową skierowanymi względem pierwotnego dłużnika. Obydwa są roszczeniami zastępczymi, pierwsze roszczeniem o odszkodowanie przyznanym zamiast roszczenia o ochronę ubezpieczeniową, drugie roszczeniem o pokrycie kosztów ochrony ubezpieczeniowej zapewnionej przez innego ubezpieczyciela, znów przyznanym w braku roszczenia o ochronę względem pierwotnego dłużnika.

Niezależnie od prawnej kwalifikacji wszystkich opisywanych uprawnień, zgodnie z tym, co napisano powyżej, w istocie uprawnienia te ubezpieczającemu nie służą z uwagi na brak po jego stronie informacji, wiedzy i kompetencji potrzebnych do oceny sytuacji finansowej ubezpieczyciela. Jak wspomniano, M. Orlicki, opowiadając się za wzajemnością ubez-

80 Zob. P. Machnikowski, Struktura..., s. 162-163. Autor ten, zdaje się, jednak nie traktuje prawa powstrzymania się ze spełnieniem świadczenia jako uprawnienia kształtującego, ale jako uprawnienie wierzyciela o odrębnych charakterze. Zob. P. Machnikowski, Uprawnienia kształtujące w zobowiązaniowych stosunkach prawnych [w:] O źródłach i elementach stosunków cywilnoprawnych. Księga pamiątkowa ku czci Prof. Alfreda Kleina, red. E. Gniewek, Kraków 2000, s. 243. 
pieczenia, wywodzi opisane uprawnienia przede wszystkim z przepisów o wykonaniu i skutkach niewykonania umów wzajemnych. Kwestia kwalifikacji umowy ubezpieczenia jako wzajemnej oraz możliwości stosowania do niej przepisów o wykonaniu i skutkach niewykonania umów wzajemnych zostanie omówiona w kolejnym podrozdziale.

Na obecnym etapie można wskazać, że środków ochrony ubezpieczających w sytuacji, gdy zakład ubezpieczeń nie spełnia wymaganych standardów finansowych (co stawia pod znakiem zapytania wypłatę odszkodowania ubezpieczeniowego w razie zajścia wypadku, a zatem samo świadczenie przez zakład ochrony ubezpieczeniowej), nie należy widzieć w uprawnieniach indywidualnych osób będących członkami zarządzanej przez zakład ubezpieczeń wspólnoty ryzyka, ale w szczególnych rozwiązaniach wprowadzonych ustawowo. Przepisy ustawy o działalności ubezpieczeniowej i reasekuracyjnej nakazują zakładom ubezpieczeń wdrożenie specjalnych procedur wewnętrznych mających na celu stałe monitorowanie sytuacji finansowej (por. art. 64-65, 234-235 u.d.u.r.).

Na złą sytuację finansową zakładu ubezpieczeń, poza samym zakładem, powinien reagować organ nadzoru, który w świetle ustawy o nadzorze nad rynkiem finansowym ma prawo wydawać stosowne zalecenia w drodze decyzji. Dodatkowo zła sytuacja finansowa zakładu ubezpieczeń może być przesłanką wdrożenia w odniesieniu do niego planu naprawczego, a w skrajnym przypadku procedury restrukturyzacyjnej lub upadłościowej. Prawo upadłościowe zawiera szczególne przepisy dotyczące upadłości zakładów ubezpieczeń oraz zakładów reasekuracji.

\section{5. Świadczenie ubezpieczyciela a charakter prawny umowy ubezpieczenia}

Jak wspomniano, spór o świadczenie ubezpieczyciela tradycyjnie łączy się ze sporem o naturę prawną samej umowy ubezpieczenia. Zwolennicy teorii świadczenia pieniężnego odmawiają ubezpieczeniu cechy wzajemności, podczas gdy zwolennicy teorii ponoszenia ryzyka widzą w ubezpieczeniu umowę wzajemną. Wbrew powszechnie wyrażanym poglądom spór o treść świadczenia ubezpieczyciela nie powinien rodzić 
konsekwencji ani w zakresie wzajemności umowy ubezpieczenia, ani jej losowości. Teorię świadczenia pieniężnego również można pogodzić $\mathrm{z}$ wzajemnym charakterem umowy. W nauce niemieckiej przeciwnicy teorii ponoszenia ryzyka twierdzą nawet, że właściwą przyczyną powstania teorii ponoszenia ryzyka były tendencja kwalifikowania umowy ubezpieczenia jako umowy wzajemnej. Zdaniem M. Drehera wobec odkrycia możliwości pogodzenia teorii świadczenia pieniężnego z wzajemnością ubezpieczenia teoria ponoszenia ryzyka traci rację bytu ${ }^{81}$.

Zgodnie z tradycyjnym stanowiskiem ubezpieczenie nie jest wzajemne, ponieważ ubezpieczający niczego nie uzyskuje w zamian za składkę, jeżeli nie zajdzie wypadek ubezpieczeniowy. Wadą tego rodzaju koncepcji jest dokonywanie oceny wzajemności umowy ubezpieczenia niejako ex post. Rozumując w ten sposób, w braku zajścia wypadku można mieć wątpliwości nawet, gdy chodzi o kwalifikację ubezpieczenia jako umowy dwustronnie zobowiązującej. Uboczne obowiązki ubezpieczyciela polegające na powinności doręczenia dokumentu ubezpieczenia, ogólnych warunków ubezpieczenia, protokołu rozbieżności między umową oraz OWU, pisemnym zwróceniu uwagi na niekorzystne w stosunku do złożonego wniosku postanowienia dokumentu ubezpieczenia i wyznaczeniu terminu do złożenia sprzeciwu, nie wydają się bowiem składać na treść jego świadczenia. Z drugiej strony, jeżeli wypadek ubezpieczeniowy zajdzie, umowa ubezpieczenia jawi się jako wzajemna oraz dwustronnie zobowiązująca.

Wbrew opisanym tendencjom oceny charakteru prawnego umowy ubezpieczenia nie należy jednak dokonywać ex post na etapie jej wykonania, ale ex ante, w chwili zawierania umowy, kiedy nie wiadomo jeszcze, czy dojdzie do realizacji ryzyka objętego ubezpieczeniem, a strony wymieniają obietnice. Obietnica ubezpieczającego polega na bezwarunkowym przyrzeczeniu zapłaty składki ubezpieczeniowej w uzgodnionym ter-

81 M. Dreher, Die Versicherung..., s. 84-89. Inaczej K. Sieg, Allgemeines..., s. 26-27. Ten drugi autor opowiada się za teorią ponoszenia ryzyka, głosząc klasyczny pogląd, że tylko ona umożliwia kwalifikowanie ubezpieczenia jako umowy wzajemnej, na poparcie swoich tez przywołując orzeczenie Sądu Rzeszy z 20.06.1902 r. (RG.20.6.1902, RGZ Gd. 52, s. 52-53). 
minie. Obietnica ubezpieczyciela polega natomiast na warunkowym przyrzeczeniu wypłaty świadczenia pieniężnego w razie zajścia przewidzianego w umowie wypadku. Wartość świadczenia pieniężnego ubezpieczyciela jest relatywnie bardzo duża w porównaniu do uiszczanej przez ubezpieczającego składki. Obietnice wymieniane przez strony są wzajemnie ekwiwalentne właśnie dlatego, że spełnienie świadczenia pieniężnego przez ubezpieczyciela jest niepewne i uzależnione od zajścia wypadku.

Kwalifikacja umowy ubezpieczenia jako umowy wzajemnej zależy oczywiście w pewnej mierze od samego pojęcia wzajemności oraz rozumienia ekwiwalentności świadczeń w umowie wzajemnej. Obecnie trudno wskazać autorów broniących koncepcji obiektywnej ekwiwalentności świadczeń w umowie wzajemnej. Nowsze teorie odchodzą nawet od ekwiwalentności rozumianej subiektywnie. Przykładowo według Ł. Węgrzynowskiego świadczenia w umowie wzajemnej mają być swoimi odpowiednikami w tym sensie, że mają pozostawać w stosunku bezpośredniej wymiany, co polega na spełnieniu świadczeń jedno w zamian za drugie ${ }^{82}$. Świadczenia stron w umowie ubezpieczenia pozostają wobec siebie w stosunku bezpośredniej wymiany niezależnie od natury prawnej świadczenia ubezpieczyciela. Nawet opowiadając się za teorią świadczenia pieniężnego, łatwo zauważyć, że składka jako świadczenie pewne stanowi odpowiednik niepewnego, ale relatywnie wysokiego odszkodowania ubezpieczeniowego ${ }^{83}$. Kwalifikacja ubezpieczenia jako umowy wzajemnej pozostaje zatem w ścisłym związku z jej losowością.

Według tradycyjnego poglądu zwolenników teorii świadczenia pieniężnego ubezpieczenie jest umową losową, w której spełnienie świadczenia przez jedną ze stron zależy od ziszczenia się wypadku. Propagatorzy koncepcji ponoszenia ryzyka wskazują natomiast, że ubezpieczenie nie jest umową losową, bo obydwie strony spełniają swoje świadczenie niezależnie od zajścia wypadku. Ich zdaniem o losowości można mówić

82 Ł. Węgrzynowski, Ekwiwalentność..., s. 287, 305, 307.

83 Dostrzegają to autorzy niemieccy i francuscy. Cytowany $Ł$. Węgrzynowski zdaje się jednak łączyć wzajemność ubezpieczenia z teorią ponoszenia ryzyka; Ł. Węgrzynowski, Ekwiwalentnośćc..., s. 431-437. 
jedynie w tym znaczeniu, że od zajścia wypadku uzależniona jest wypłata świadczenia pieniężnego ${ }^{84}$. Jeszcze inny pogląd niepowiązany ze sporem dotyczącym wzajemności mówi, że umowa ubezpieczenia nie jest umową losową, działalność ubezpieczeniowa opiera się bowiem na regułach prawdopodobieństwa i prawie wielkich liczb ${ }^{85}$.

Poglądy odmawiające ubezpieczeniu cechy losowości należy odrzucić. Okoliczność, że według teorii ponoszenia ryzyka samo spełnienie świadczenia nie zależy od wypadku, nie jest przesądzająca, ponieważ dla uznania umowy za losową wystarcza, by od wypadku zależał rozmiar świadczenia lub jego postać ${ }^{66}$. Pogląd odwołujący się do reguł statystyczno-matematycznych i przewidywania przez ubezpieczycieli prawdopodobieństwa zajścia wypadku ujmuje ubezpieczenie w makroskali, nie zaś w kontekście konkretnego stosunku ubezpieczenia, którego wynik ekonomiczny jest niepewny. Ekonomiczna niepewność zależna od zajścia wypadku ubezpieczeniowego wystarcza, by uznać ubezpieczenie za umowę losową. Nie ma przy tym znaczenia, że wypadkiem ubezpieczeniowym nie może być każde zdarzenie losowe, ale jedynie zdarzenie odznaczające się określonymi cechami. Istotne jest jedynie to, że postać świadczenia ubezpieczyciela, w szczególności zaś powstanie roszczenia o wypłatę świadczenia pieniężnego zależy od wypadku ${ }^{87}$.

Dla ubezpieczyciela oczywiście ekonomicznie korzystniejsza jest sytuacja, gdy wypadek ubezpieczeniowy nie zachodzi, ewentualnie w ubezpieczeniu na życie, gdy wypadek następuje po wielu latach opłacania składek ubezpieczeniowych. Odwrotnie sytuacja przedstawia się z punktu widzenia ubezpieczającego. Trafnie wskazuje M. Krajewski, że działalność kasyn gry też opiera się na regułach statystyczno-matematycznych, a nikt nie odmawia cechy losowości umowie gry lub zakładu ${ }^{88}$. Oczywiście losowość gier i zakładów różni się od ubezpieczenia, ponieważ u podstaw

84 M. Orlicki, Umowa ubezpieczenia, 2002, s. 42.

85 W. Warkałło, W. Marek, W. Mogilski, Prawo..., s. 255; A. Wąsiewicz, Umowa..., s. 109.

${ }^{86}$ W. Czachórski, A. Brzozowski, M. Safjan, E. Skowrońska-Bocian, Zobowiązania..., s. 140-141.

${ }^{87}$ Losowość ubezpieczenia nie budzi wątpliwości w prawie francuskim; por. S. Beaugendre, Contrat..., s. 23.

88 M. Krajewski, Umowa ubezpieczenia. Art. 805-834 KC..., 2016, s. 42. 
tych pierwszych leży ryzyko spekulatywne lub subiektywne, sztucznie wytwarzane przez uczestników po to, by na nim skorzystać, podczas gdy idea ubezpieczenia opiera się na istnieniu ryzyk niezależnych od człowieka, tzw. ryzyk obiektywnych, przed których niekorzystnymi skutkami finansowymi człowiek chce się zabezpieczyć, aby nie stracić ${ }^{89}$. Z tych względów ubezpieczenie przeciwstawia się umowom hazardowym, wskazując, że ma ono w istocie charakter antylosowy ${ }^{90}$.

Można odnieść wrażenie, że podejmowane przez niektórych autorów próby wykazania, że ubezpieczenie nie jest umową losową, wiąże się z przypisywaniem umowom losowym zabarwienia pejoratywnego czy też lekceważącym traktowaniem umów losowych przez doktrynę prawa cywilnego. Podobne konotacje emocjonalne odnoszą się jednak przede wszystkim do umów gry i zakładu jako umów hazardowych. System prawa traktuje umowy hazardowe $z$ dużą rezerwą, a zobowiązania $z$ nich wynikające mają charakter zupełnych jedynie wtedy, gdy gra lub zakład prowadzone są na podstawie określonego zezwolenia przede wszystkim ze względu na społeczne reperkusje hazardu. Wprawdzie prowadzenie działalności ubezpieczeniowej również wymaga zezwolenia, jednak przyczyny takiego stanu rzeczy są inne niż w odniesieniu do umów hazardowych i wiążą się z okolicznością, że ubezpieczyciel, podobnie jak bank, dysponuje i zarządza środkami finansowymi powierzonymi mu przez jednostki.

Jak już wskazano, ryzyko w umowie ubezpieczenia ma zupełnie innych charakter niż w umowach hazardowych, z czym wiąże się będąca jednym $\mathrm{z}$ fundamentów prawa ubezpieczeń teoria interesu. W odniesieniu do ubezpieczenia rozumowanie prowadzące do umniejszania roli umów hazardowych można nawet odwrócić, wskazując na społecznie korzystne skutki przezorności przejawiającej się w zawieraniu umów ubezpieczenia. Umowy te chronią jednostki przed wydatkami wynikającymi z ryzyk istniejących niezależnie od tych jednostek, w szczególności ryzyk związanych z działaniem sił natury, ogół społeczeństwa chronią zaś przed wydatkami związanymi z likwidacją skutków klęsk dotyka-

89 E. Kowalewski, Wprowadzenie do teorii ryzyka..., s. 26.

90 M. Picard, A. Besson, Les assurances..., s. 67. 
jących jednostki nieprzezorne. Stąd między innymi wynika obowiązek ubezpieczenia w niektórych dziedzinach. Kwestię ilustruje choćby sytuacja związana z powodziami, które dotknęły rolników w połowie lat 90. ubiegłego wieku. Niezależnie od powyższego raz jeszcze przyznać należy rację M. Krajewskiemu, który wskazuje, że kwalifikacja umowy ubezpieczenia jako umowy losowej nie pociąga za sobą żadnych konsekwencji umniejszających jej rolę w systemie prawa czy też osłabiających roszczenia $\mathrm{z}$ tej umowy wynikające ${ }^{91}$. Kodeks cywilny nie zawiera zresztą szczególnych przepisów o umowach losowych, a wyróżnienie tych umów jest kwestią tradycji.

Dodać należy, że losowość nie była dla Sądu Najwyższego przeszkodą do uznania za wzajemne szeregu innych umów. Przykładowo w wyro-

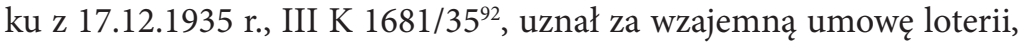
stwierdzając przy tym: „Loterja czy to pieniężna czy też fantowa jest to stosunek prawny, polegający na dwustronnej - wzajemnej - umowie, przy której urządzający loterję pod pewnemi oznaczonemi, od przypadku zależnemi warunkami zobowiązuje się do wypłacenia pewnej sumy pieniężnej lub do świadczenia pewnego przedmiotu osobom, biorącym udział w grze, te zaś, ze swej strony zobowiązują się bezwarunkowo do wzajemnego świadczenia przedsiębiorcy pewnej sumy pieniężnej - stawki". Jak z powyższego wynika, niepewne, ale wysokie świadczenia urządzającego loterie stanowiło według SN ekwiwalent pewnej, ale relatywnie niskiej stawki już w okresie międzywojennym ${ }^{93}$.

W związku z zakwalifikowaniem umowy ubezpieczenia do umów wzajemnych rodzi się pytanie, czy do umowy ubezpieczenia znajdują zasto-

91 M. Krajewski, Umowa ubezpieczenia. Art. 805-834 KC..., 2016, s. 43.

92 LEX nr 373363.

93 Por. również orzeczenie SN z 28.12.1934 r., II C 2032/34, OSNC 1935/6, poz. 252, w którym SN uznał, że losowość nie przeczy wzajemności kontraktu naftowego, w którym przedsiębiorca, przystępujący do założenia i uruchomienia kopalni nafty, nie może przewidzieć, czy i w jakiej ilości uzyska minerały żywiczne, w jakiej głębokości i jakie będą koszty ich wydobycia, wobec czego bierze na siebie wszelkie ryzyko w tej mierze i dlatego nie może przerzucać na uprawnionego do udziałów brutto rosnących kosztów oczyszczania ropy, nawet jeśli wysokość tych kosztów z biegiem czasu wzrosła ponad miarę zwyczajną w chwili zawarcia kontraktu naftowego. 
sowanie szczególne przepisy Kodeksu cywilnego o wykonaniu umów wzajemnych. Większość autorów przeczy takiej możliwości, a niektórzy z nieadekwatności przepisów o umowach wzajemnych do umowy ubezpieczenia wywodzą nawet brak jej wzajemności. Przeciwko stosowaniu do ubezpieczenia przepisów o umowach wzajemnych wypowiadają się także autorzy aprobujący koncepcję o wzajemności ubezpieczenia. Stanowisko to nie jest przy tym szczegółowo uzasadniane. Zwykle twierdzi się po prostu, że przepisy o umowach wzajemnych nie nadają się do zastosowania w odniesieniu do umowy ubezpieczenia. Poza zdecydowanymi przeciwnikami tezy o wzajemności ubezpieczenia pogląd o braku zastosowania do tej umowy przepisów o umowach wzajemnych reprezentował w szczególności W. Warkałło ${ }^{94}$.

Dariusz Fuchs, pisząc o ubezpieczeniu, odwołuje się do przepisów o umowach wzajemnych, nie przesądza jednak, czy przepisy te znajdują zastosowanie do ubezpieczenia. Wskazuje on, że dzięki opłacaniu składki zakład ubezpieczeń spełnia swoje świadczenie w postaci ponoszenia ryzyka zaistnienia wypadku oraz że odpowiedzialność zakładu nie występuje przed zapłatą składki. Uzależnienie odpowiedzialności ubezpieczyciela od zapłacenia składki ma być szczególnie zrozumiałe w świetle art. 488 k.c., zgodnie z którym świadczenia z umowy wzajemnej winny być spełnione jednocześnie. Kolejnym argumentem za wzajemnością ubezpieczenia jest, według D. Fuchsa, porównanie art. 814 $\$ 2$ k.c. (w starym brzmieniu), który pozwalał ubezpieczycielowi ponoszącemu odpowiedzialność przed zapłaceniem składki odstąpić od umowy ze skutkiem natychmiastowym w razie niezapłacenia składki w terminie, z art. 491 k.c. regulującym skutki zwłoki w wykonaniu świadczenia z umowy wzajemnej ${ }^{95}$.

Wypada zwrócić uwagę, że w praktyce zakład ubezpieczeń bardzo często odpowiada przed zapłaceniem składki, a przepisy o umowie ubezpieczenia zawierają szczególne uregulowania takiej sytuacji, czego przykładem był wcześniej powołany art. $814 \$ 2$ k.c. w dawnym brzmieniu. Przepis zdawał się przy tym wykluczać zastosowanie ogólnego art. 491 k.c., który

94 W. Warkałło, W. Marek, W. Mogilski, Prawo..., s. 254.

95 Zob. D. Fuchs, Umowa... 
przed odstąpieniem od umowy nakazuje wyznaczyć dodatkowy termin na wykonanie zobowiązania. Nota bene nowy przepis, regulując kwestie inaczej, również wyklucza zastosowanie art. 491 k.c.

Omawianej kwestii dotyczył wspominany już wyrok SN z 20.10.2006 r., IV CSK $125 / 06^{96}$. Zakład ubezpieczeń nie wypłacił odszkodowania $\mathrm{z}$ ubezpieczenia autocasco $\mathrm{z}$ uwagi na niezapłacenie przez ubezpieczającego raty składki, powołując się przy tym na postanowienie OWU, zgodnie z którym niezapłacenie w terminie kolejnej raty składki miało być traktowane jako odstąpienie od umowy przez ubezpieczyciela bez konieczności składania odrębnego oświadczenia woli w tym zakresie.

Sąd okręgowy uznał postanowienie OWU za sprzeczne z art. 491 k.c., zgodnie z którym, jeżeli jedna ze stron dopuszcza się zwłoki w wykonaniu zobowiązania z umowy wzajemnej, druga strona może odstąpić od umowy dopiero po bezskutecznym upływie uprzednio wyznaczonego odpowiedniego terminu dodatkowego. Sąd apelacyjny zmienił wyrok, odmawiając ubezpieczeniu cechy wzajemności. Sąd Najwyższy zgodził się z poglądem sądu apelacyjnego dotyczącym braku wzajemności, uwzględnił jednak skargę kasacyjną, uznając postanowienie OWU przewidujące, że zaniechanie ubezpieczającego będzie traktowane jako oświadczenie woli ubezpieczyciela za sprzeczne z regułami dotyczącymi składania oświadczeń woli.

Kwestia rozpatrywana przez Sąd Najwyższy w powyższej sprawie obecnie nie powstałaby ze względu na zmianę art. $814 \$ 3$ k.c. W myśl aktualnego brzmienia przepisu $\mathrm{w}$ razie opłacania składki w ratach niezapłacenie w terminie kolejnej raty składki może powodować ustanie odpowiedzialności ubezpieczyciela tylko wtedy, gdy skutek taki przewidywała umowa lub ogólne warunki ubezpieczenia, a ubezpieczyciel po upływie terminu wezwał ubezpieczającego do zapłaty z zagrożeniem, że brak zapłaty w terminie 7 dni od dnia otrzymania wezwania spowoduje ustanie odpowiedzialności. Przytoczona regulacja stanowi niewątpliwie lex specialis względem art. 491 k.c.

96 Z glosą częściowo krytyczną B. Kucharskiego. 
Stanowisko o stosowalności do umowy ubezpieczenia przepisów o umowach wzajemnych w doktrynie prezentuje wyraźnie jedynie M. Orlicki. Autor ten nie przyznaje ubezpieczającemu roszczenia o podjęcie określonych czynności kryjących się pod pojęciem ochrony ubezpieczeniowej wprost. Zamiast tego próbuje, jak już wskazano, wykorzystać przepisy o wykonaniu umów wzajemnych dla realizacji wierzytelności przed powstaniem roszczenia o wypłatę świadczenia pieniężnego. Twierdzi w szczególności, że w sytuacji, gdy składka lub jej rata mają być zapłacone po rozpoczęciu ochrony ubezpieczeniowej, ubezpieczający może na podstawie art. 490 k.c. powstrzymać się z zapłatą składki lub jej raty albo zażądać zabezpieczenia, jeżeli uzna, że ubezpieczyciel faktycznie nie świadczy ochrony ubezpieczeniowej ze względu na złą sytuację finansową ${ }^{97}$.

Marcin Orlicki dopuszcza również skorzystanie przez ubezpieczającego z uprawnień służących stronie umowy wzajemnej na wypadek zwłoki, tzn. z prawa do odstąpienia od umowy po bezskutecznym upływie terminu dodatkowego oraz prawa żądania naprawienia szkody, jaką ubezpieczający poniósł na skutek tego, że ochrona ubezpieczeniowa nie była prawidłowo świadczona (art. 491 k.c.). Nadto jego zdaniem ubezpieczający może na postawie przepisów ogólnych o niewykonaniu zobowiązań, a dokładnie art. 480 k.c., zachowując roszczenie o naprawienie szkody, żądać upoważnienia przez sąd do wykonania czynności na koszt dłużnika. W konkretnym przypadku miałoby to polegać na zawarciu umowy ubezpieczenia $\mathrm{z}$ innym ubezpieczycielem oraz obciążeniu składką ubezpieczyciela pozostającego w zwłoce.

Wyżej przytoczone stanowisko M. Orlickiego wydaje się wątpliwe ze względów wcześniej opisywanych. Ubezpieczającemu nie służą żadne uprawnienia wiążące się z oceną stanu finansowego ubezpieczyciela i spełnieniem przez niego ustawowych kryteriów prowadzenia działalności ubezpieczeniowej ani tym bardziej uprawnienia pozwalające w tę działalność ingerować przede wszystkim z uwagi na brak po jego stronie dostępu do informacji, brak wiedzy ubezpieczeniowej oraz brak usta-

97 M. Orlicki, Umowa ubezpieczenia, 2002, s. 149-152. 
wowych kompetencji do ingerowania w działalność ubezpieczeniową, które to kompetencje przyznane są organowi nadzoru ${ }^{98}$.

Wśród przeciwników kwalifikowania ubezpieczenia jako umowy wzajemnej niestosowalność przepisów o wykonaniu i skutkach wykonania umów wzajemnych szczegółowo uzasadnia przede wszystkim M. Krajewski. Argumentacja tego autora zmierza w kierunku wykazania, że przepisy o wykonaniu umów wzajemnych nie nadają się do zastosowania do umowy ubezpieczenia ze względu na specyfikę tej umowy. Według zdania M. Krajewskiego wyjątek dotyczy art. $492^{1}$ k.c., który przewiduje prawo do odstąpienia od umowy na wypadek oświadczenia przez drugą stronę, że świadczenia nie spełni. Stojąc konsekwentnie na stanowisku o braku wzajemności ubezpieczenia, M. Krajewski wyklucza jednak zastosowanie tego przepisu, nadmieniając, że odstąpienie odnosiłoby się jedynie do nieuprawnionego $\mathrm{w}$ świetle treści ubezpieczenia umowy oświadczenia o niespełnieniu świadczenia pieniężnego w razie zajścia wypadku, co byłoby trudne do pogodzenia z teorią ponoszenia ryzyka. Cytowany autor rozważa również zastosowanie do umowy ubezpieczenia przepisów o wyzysku, słusznie jednak konkluduje, że ze względu na zinstytucjonalizowany charakter działalności ubezpieczeniowej mało prawdopodobne wydaje się spełnienie przesłanek wyzysku9

Reasumując powyższe wypowiedzi, wypada zgodzić się z nieco intuicyjnym spostrzeżeniem doktryny, że przepisy o wykonaniu i skutkach niewykonania umów wzajemnych nie nadają się do zastosowania do umowy ubezpieczenia. Przyjmując wzajemność ubezpieczenia, nie można a limine wykluczyć ich zastosowania, trudno jednak wyobrazić sobie praktyczną sytuację, w której ubezpieczający mógłby sięgnąć po którekolwiek z wynikających z tych przepisów uprawnień. Dotyczy to również uprawnienia do odstąpienia od umowy na wypadek oświadczenia ubezpieczyciela, że świadczenia nie spełni. Przed zajściem wypadku ubezpieczeniowego ubezpieczyciel nie będzie raczej składał takich oświadczeń, natomiast po zajściu prawo odstąpienia mogłoby mieć znaczenie jedynie w rzadkiej sytuacji, gdy wypadek nie unicestwia

98 M. Dreher, Die Versicherung..., s. 89-90; B. Kucharski, Przeniesienie..., s. 54.

99 M. Krajewski, Umowa ubezpieczenia. Art. 805-834 KC..., 2016, s. 41-42. 
przedmiotu ubezpieczenia i jednocześnie ubezpieczającemu pozostają do zapłaty kolejne raty składki.

Pojawiają się w związku z tym dwa pytania. Pierwsze, czy niestosowalność przepisów o umowach wzajemnych do umowy ubezpieczenia przemawia za brakiem jej wzajemności oraz drugie, jaki jest sens kwalifikowania umowy ubezpieczenia jako wzajemnej, skoro przepisy o wykonaniu i skutkach niewykonania umów wzajemnych i tak do ubezpieczenia się nie stosują. Odnosząc się do odpowiedzi na pierwsze pytanie, trzeba wskazać, że stosowanie do określonej umowy przepisów o wykonaniu albo niewykonaniu umów wzajemnych nie stanowi warunku jej wzajemności. Przeciwnie, stosowanie tych przepisów do określonej umowy jest konsekwencją uznania jej za wzajemną. Z niestosowalności przepisów o umowach wzajemnych nie można zatem wnioskować o braku wzajemności określonej umowy ${ }^{100}$.

Ponadto uprawnienia przyznane przez przepisy o wykonaniu i niewykonaniu zobowiązań wzajemnych wiążą się przede wszystkim z regułą jednoczesności świadczeń. Dotyczą one prawa powstrzymania się ze spełnieniem świadczenia w braku zaoferowania świadczenia drugiej strony, prawa odstąpienia na wypadek zwłoki oraz niemożliwości świadczenia oraz wzajemnego zwrotu świadczeń w wykonaniu prawa odstąpienia. Uprawnienia te nie przystają nie tylko do umowy ubezpieczenia, ale do wszystkich umów zawieranych na pewien okres, w których świadczenie choćby jednej ze stron przybiera postać świadczenia ciągłego. W umowach tego rodzaju trudno mówić o regule jednoczesności świadczeń, ewentualnie trzeba postrzegać ją w sposób swoisty, prawo odstąpienia od umowy zastępowane jest prawem jej wypowiedzenia, natomiast wzajemny zwrot świadczeń z istoty swej nie jest możliwy, nie może bowiem dotyczyć części świadczenia ciągłego spełnionej w okresie obowiązywania umowy.

Przykładem mogą być przede wszystkim umowy o odpłatne korzystanie z rzeczy lub praw, w przypadku których świadczenie jednej ze stron

100 Co do tej kwestii, zamiast wielu zob. Ł. Węgrzynowski, Ekwiwalentność..., s. $166-168$. 
(wynajmującego, wydzierżawiającego, leasingodawcy) polega na ciagłym zachowaniu lub obowiązku znoszenia, natomiast świadczenie drugiej strony jest świadczeniem okresowym (czynsz najmu lub dzierżawy) lub jednorazowym, które może być rozkładane na raty (opłata leasingowa). Zamiast odstąpienia od umowy jednej ze stron przyznaje się prawo wypowiedzenia, regulując tak w sposób szczególny konsekwencje niewykonania zobowiązania przez drugą stronę, natomiast wzajemny zwrot świadczeń nie wchodzi w grę, co wynika $\mathrm{z}$ istoty świadczenia ciągłego. Pomimo tego nikt nie neguje wzajemności umów najmu, dzierżawy czy leasingu.

Drugie postawione pytanie dotyczyło znaczenia kwalifikacji ubezpieczenia jako umowy wzajemnej przy jednoczesnym przyznaniu, że ogólne przepisy Kodeksu cywilnego o wykonaniu oraz skutkach niewykonania umów wzajemnych nie znajdują do ubezpieczenia zastosowania. Otóż szczegółowa analiza umowy wzajemnej wykazuje, że siła oddziaływania umowy wzajemnej wykracza daleko poza art. 488-496 k.c. Jak dowodzi Ł. Węgrzynowski, kwalifikacja umowy jako wzajemnej nie pociąga za sobą jedynie dopuszczalności stosowania do tej umowy wprost norm prawnych sięgających w swych hipotezach do wzajemności. Oznacza również nałożenie na umowę szeregu postulatów aksjologicznych i społeczno-gospodarczych, określanych łącznie jako ekwiwalentność świadczeń ${ }^{101}$.

Wzajemny charakter umowy ubezpieczenia może mieć wpływ na kontrolę jej treści. Dotyczyć to może w szczególności postanowień OWU ograniczających zakres wypadku ubezpieczeniowego albo zakres odszkodowania ubezpieczeniowego, wprowadzających określone wyłączenia odpowiedzialności ubezpieczyciela, nakładających na ubezpieczającego lub ubezpieczonego określone powinności lub przyznających ubezpieczycielowi jednostronnie określone uprawnienia. Podstawą sądowej kontroli będzie w tym zakresie art. $353^{1}$ k.c. pozwalający w określonych sytuacjach dopatrywać się zwichnięcia ekwiwalentności świadczeń nie w wyniku zastrzeżenia zbyt wysokiego lub niskiego świadczenia, ale raczej w wyniku naruszenia struktury zobowiązania. Instrumentami

101 Ł. Węgrzynowski, Ekwiwalentność..., s. 357 i 361. 
prawnymi chroniącymi ekwiwalentność świadczeń będą właściwość (natura) stosunku prawnego ubezpieczenia oraz klauzula zasad współżycia społecznego ${ }^{102}$.

Przykładowo w kilku niedawnych wyrokach ${ }^{103}$ Sąd Najwyższy, uznając umowę ubezpieczenia za umowę wzajemną, stwierdził, że w przypadku ubezpieczeń majątkowych składka ta co do zasady odpowiada ryzyku ubezpieczeniowemu wyrażającemu się sumą ubezpieczenia. Skoro zatem ubezpieczyciel pobrał składkę odpowiadającą ryzyku ubezpieczeniowemu do określonej kwoty, to w razie wystąpienia szkody na skutek zdarzenia objętego ubezpieczeniem powinien ponosić odpowiedzialność będącą równowartością świadczenia, które otrzymał od ubezpieczającego. W konkluzji Sąd Najwyższy uznawał za niedopuszczalną klauzulę proporcjonalności zastrzeżoną w ogólnych warunkach ubezpieczenia od ognia ${ }^{104}$.

Podobną argumentacją posłużył się J. Nawracała, wskazując, że zasadę ekwiwalentności świadczeń narusza odniesienie tzw. klauzuli odpowiedzialności proporcjonalnej ubezpieczyciela do wysokości należnego odszkodowania zamiast do wysokości szkody, za którą odpowiada ubezpieczyciel. W tym pierwszym przypadku co do szkód przekraczających sumę ubezpieczenia proporcjonalne umniejszenie dotyczyłoby w praktyce sumy ubezpieczenia. Opisany rezultat jest, zdaniem cytowanego autora, sprzeczny z zasadą, że składka obliczana jest w proporcji do sumy ubezpieczenia. Co za tym idzie, konstrukcja odnosząca zasadę proporcji do wysokości należnego odszkodowania nie daje się pogodzić $z$ naturą stosunku prawnego ubezpieczenia, a także z dobrymi obyczajami ${ }^{105}$.

102 Ł. Węgrzynowski, Ekwiwalentność..., s. 195-196.

103 Wyrok SN z 16.10.2014 r., III CSK 302/13, OSNC 2015/10, poz. 121; wyrok SN z 15.05.2015 r., V CSK 470/14, OSNC 2016/4, poz. 48; wyrok SN z 10.06.2016 r., IV CSK 624/15, LEX nr 2067079; wyrok SN z 9.08.2016 r., II CSK 743/15, LEX nr 2095937.

104 Wyroki szerzej omawiam w rozdziale dotyczącym zakresu odszkodowania ubezpieczeniowego.

105 J. Nawracała, Odpowiedzialność proporcjonalna ubezpieczyciela $w$ przypadku niedoubezpieczenia mienia, PA 2016/3, s. 44. 
Do wzajemności ubezpieczenia odwołał się również M. Orlicki, uznając za niedopuszczalne, spotykane w dawniejszej praktyce, klauzule upoważniające ubezpieczyciela do natychmiastowego wypowiedzenia umowy ubezpieczenia, w której postanowiono, że składka płatna jest jednorazowo za cały okres ubezpieczenia, w sytuacji wypłaty odszkodowania ubezpieczeniowego lub odmowy jego wypłaty. Według M. Orlickiego odpowiednikiem zapłaconej składki jest świadczenie ubezpieczyciela w postaci ponoszenia ryzyka ubezpieczeniowego przez okres, na jaki zawarto umowę. Upoważnienie jednej ze stron do wypowiedzenia umowy przed upływem okresu, na który tę umowę zawarto, w braku zajścia wyjątkowych i istotnych przewidzianych w umowie przyczyn jest zatem sprzeczne z cechą wzajemności tej umowy, która stanowi o jej naturze ${ }^{106}$.

Kwalifikacja umowy ubezpieczenia jako wzajemnej może mieć również znaczenie dla wykładni określonych postanowień umowy albo OWU, dla rozstrzygnięcia kwestii związanych $\mathrm{z}$ dalszym funkcjonowaniem stosunku prawnego ubezpieczenia, a więc zagadnień związanych z jego wykonaniem lub niewykonaniem oraz ochroną stron przed wystąpieniem nadzwyczajnych okoliczności. Jeżeli chodzi o pierwsze z zagadnień, postulat ekwiwalentności świadczeń stanowić może uzasadnienie stosowania reguł odpowiedzialności kontraktowej, ale również limitować jej zakres ${ }^{107}$, jeżeli natomiast chodzi o drugie, szczególnego znaczenia nabrać może sprawa waloryzacji świadczenia pieniężnego ubezpieczyciela przy uwzględnieniu roli sumy ubezpieczenia ${ }^{108}$.

Wzajemność umowy ubezpieczenia stanowiła w istocie argument w orzeczeniach dotyczących waloryzacji świadczeń z ubezpieczeń osobowych. Przykładowo w uchwale z 10.04.1992 r., III CZP 126/91 109, Sąd Najwyższy podkreślił, że w umowach ubezpieczenia zachodzi ekwiwalentność świadczeń między globalnymi kwotami składek a kwotami wypłacanych świadczeń, a celem obu stron jest uzyskanie świadczeń

\footnotetext{
106 M. Orlicki, Umowa ubezpieczenia, 2002, s. 253.

107 Ł. Węgrzynowski, Ekwiwalentność..., s. 201 i n. oraz 373 i n.

108 Ł. Węgrzynowski, Ekwiwalentność..., s. 201 i n. oraz 363 i n.

109 OSNC 1992/7-8, poz. 121.
} 
w wysokości zakładanej w momencie zawarcia umowy. To z jednej strony uzasadnia żądanie waloryzacyjne, ale jednocześnie zmusza do poszukiwania adekwatnych i wyważonych kryteriów uwzględniających interesy obu stron ${ }^{110}$.

110 Ł. Węgrzynowski, Ekwiwalentność..., s. 205. 



\section{Rozdział 3 \\ PRZESŁANKI ODPOWIEDZIALNOŚCI UBEZPIECZENIOWEJ}

\subsection{Katalog przesłanek odpowiedzialności ubezpieczeniowej}

W doktrynie wskazuje się zwykle, że dla powstania obowiązku świadczenia odszkodowawczego po stronie ubezpieczyciela wystarczy spełnienie dwóch przesłanek, a mianowicie zawarcia umowy ubezpieczenia oraz powstania szkody ${ }^{1}$. Ujęcie takie, prezentowane m.in. przez A. Szpunara, W. Warkałłę, a ostatnio również M. Kalińskiego, nie jest uzasadniane i już prima facie wydaje się uproszczeniem. Nawet wychodząc od ujednoliconego zestawu przesłanek odpowiedzialności odszkodowawczej, według którego dla powstania zobowiązania odszkodowawczego konieczne jest zaistnienie szkody, faktu, z którym ustawa wiąże obowiązek jej naprawienia oraz związku przyczynowego między tym faktem a szkodą, łatwo dostrzec, że zawarcie umowy ubezpieczenia samo przez się nie jest zdarzeniem nakładającym na ubezpieczyciela obowiązek naprawienia powstałej szkody.

Wynikające z art. $805 \$ 1$ i 2 k.c. określenie ubezpieczenia majątkowego jako umowy, na podstawie której ubezpieczyciel, w zamian za zapłatę

1 A. Szpunar, Ustalenie odszkodowania w prawie..., s. 48. W. Warkałło [w:] W. Warkałło, W. Marek, W. Mogilski, Prawo..., s. 95; M. Kaliński, Zasada odszkodowania w ubezpieczeniach gospodarczych, cz. 1, PA 2002/1, s. 54. 
składki, zobowiązuje się zapłacić określone odszkodowanie za szkodę powstałą wskutek przewidzianego w umowie wypadku, pozwala sformułować szerszy zestaw przesłanek odpowiedzialności ubezpieczeniowej. $\mathrm{W}$ świetle przytoczonej regulacji obowiązek zapłaty odszkodowania ubezpieczeniowego pojawia się, jeżeli spełnione są następujące warunki. Po pierwsze, istnieje ważnie zawarta umowa ubezpieczenia. Po drugie, zachodzi przewidziany w umowie wypadek ubezpieczeniowy. Po trzecie, w majątku ubezpieczonego powstaje szkoda. Po czwarte, między wypadkiem ubezpieczeniowym a szkodą zachodzi związek przyczynowy².

Wskazane przesłanki zostaną omówione po kolei. Uprzednio należy zastrzec, że niniejsze uwagi odnoszą się jedynie do odpowiedzialności ubezpieczeniowej ujmowanej jako obowiązek zapłaty odszkodowania w razie zajścia wypadku. Jak była mowa, zdaniem autora niniejszej pracy, ubezpieczyciel świadczy również przed zajściem wypadku ubezpieczeniowego, a nawet, jeżeli wypadek ubezpieczeniowy w ogóle nie zachodzi. W takiej sytuacji trudno jednak mówić o odpowiedzialności ubezpieczyciela jako korelacie długu, ponieważ ubezpieczający nie dysponuje roszczeniem umożliwiającym przymusową realizację służącej mu wierzytelności.

\subsection{Zawarcie umowy ubezpieczenia}

Pierwsza przesłanka określona została wstępnie jako zawarcie umowy ubezpieczenia. Witold Warkałło wskazuje natomiast na istnienie stosunku ubezpieczenia ${ }^{3}$. Obydwa określenia wydają się niewystarczająco precyzyjne wobec tradycyjnego rozróżnienia formalnego i materialnego okresu ubezpieczenia ${ }^{4}$. Formalny okres ubezpieczenie to okres,

2 Jak się zdaje, zwolennikiem podobnej koncepcji jest M. Krajewski. Zob. M. Krajewski, Umowa ubezpieczenia. Art. 805-834 KC..., 2016, s. 62.

3 W. Warkałło [w:] W. Warkałło, W. Marek, W. Mogilski, Prawo..., s. 95.

4 Co do tego rozróżnienia, zob. przykładowo Z. Szymański, Prawo..., s. 92; W. Warkałło [w:] W. Warkałło, W. Marek, W. Mogilski, Prawo..., s. 266; Prawo ubezpieczeń gospodarczych, red. E. Kowalewski, Bydgoszcz-Torun 2006, s. 192. Po zmianie art. 813 k.c. materialny okres ubezpieczenia jest tożsamy z tzw. technicznym okresem ubezpieczenia, tzn. okresem, za jaki pobiera się składkę. 
w którym istnieje ważnie zawarta umowa ubezpieczenia. Materialny okres ubezpieczenia natomiast to okres, w którym ubezpieczyciel ponosi odpowiedzialność za skutki wypadku ubezpieczeniowego. Okresy te nie muszą być tożsame, zgodnie bowiem $\mathrm{z}$ art. $814 \$ 1$ k.c., jeżeli nie umówiono się inaczej, odpowiedzialność ubezpieczyciela rozpoczyna się od dnia następującego po zawarciu umowy, nie wcześniej jednak niż od dnia następnego po zapłaceniu składki lub jej pierwszej raty. Zawarcie umowy ubezpieczenia może zatem nie być wystarczające, jeżeli materialny okres ubezpieczenia rozpoczyna bieg w późniejszym terminie.

Można również wyobrazić sobie ustanie ochrony ubezpieczeniowej pomimo trwania stosunku ubezpieczenia. Wprawdzie ustawa wiąże obydwa te skutki, wydaje się jednak, że umowa lub ogólne warunki ubezpieczenia mogą stanowić, że w określonych sytuacjach, w szczególności w braku zapłacenia składki lub jej raty w umówionym terminie, ochrona ubezpieczeniowa ulega wstrzymaniu, by ulec przywróceniu po zapłaceniu składki lub spełnieniu innego warunku ${ }^{5}$. Podsumowując ten wywód, wydaje się, że pierwszą przesłankę należy doprecyzować, wskazując na konieczność trwania stosunku ubezpieczenia, na podstawie którego ubezpieczyciel ponosi odpowiedzialność za skutki określonych w umowie wypadków, albo inaczej, na trwanie tzw. materialnego okresu ubezpieczenia.

Konkluzja powyższa każe postawić następne pytanie, a mianowicie kiedy stosunek ubezpieczenia musi trwać. Zagadnienie to wiąże się oczywiście bezpośrednio z kolejną przesłanką odpowiedzialności ubezpieczyciela, jaką jest zajście wypadku ubezpieczeniowego, ale dla zachowania proporcji wywodów można je omówić w tym miejscu. Największe bogactwo problemów pojawia się na gruncie ubezpieczeń odpowiedzialności cywilnej, gdzie ogólne warunki mogą kształtować zakres ubezpieczenia różnorodnie przez określenie tzw. triggerów, czyli zdarzeń, których zaistnienie w okresie ubezpieczenia jest konieczne dla powstania obowiązku wypłaty odszkodowania ubezpieczeniowego ${ }^{6}$. Trigger act commited

${ }^{5}$ W świetle art. $813 \$ 1$ k.c. ubezpieczyciel nie mógłby jednak pobierać składki za okres wstrzymania ochrony ubezpieczeniowej.

6 M. Krajewski, Ubezpieczenie..., s. 185. 
oznacza, że ubezpieczyciel ponosi odpowiedzialność, gdy zdarzenie będące źródłem szkody wystąpiło w okresie ubezpieczenia. Trigger loss occurrence oznacza, że ubezpieczyciel odpowiada, jeżeli szkoda wystąpiła w okresie ubezpieczenia. Trigger loss manifestation oznacza, że ubezpieczyciel odpowiada, jeżeli szkoda ujawniła się w okresie ubezpieczenia. Wreszcie, trigger claims made oznacza, że ubezpieczyciel odpowiada, jeżeli w okresie ubezpieczenia zgłoszono roszczenie ${ }^{7}$.

Zagadnienia ubezpieczeń odpowiedzialności cywilnej wykraczają poza zakres pracy, jednak uwaga dotycząca triggerów pozwala spojrzeć w odpowiednim świetle na ubezpieczenia mienia. Na gruncie tych ubezpieczeń również może pojawić się pytanie, czy ubezpieczyciel odpowiada wtedy, gdy w okresie ubezpieczenia wystąpiło zdarzenie szkodzące, czy wtedy, gdy w okresie ubezpieczenia wystąpiła szkoda, czy może wtedy, gdy w okresie ubezpieczenia szkoda ujawniła się. Ewentualny odstęp czasowy między wystąpieniem szkody a jej ujawnieniem w ubezpieczeniach mienia nie będzie miał oczywiście takiego znaczenia jak w ubezpieczeniu odpowiedzialności cywilnej, gdzie występuje zagadnienie triggerów, lub w ubezpieczeniach osobowych, gdzie zdrowotne następstwa wypadku ujawniają się nierzadko po dłuższym okresie. Wydaje się jednak, że również w odniesieniu do ubezpieczeń mienia nie należy a priori wykluczać odstępstwa czasowego między zajściem wypadku, wystąpieniem szkody oraz jej ujawnieniem.

W literaturze S. Reps i J. Reps wskazują, że sformułowanie art. 805 k.c., według którego ubezpieczyciel obowiązany jest spełnić świadczenie w razie zajścia przewidzianego w umowie wypadku $(\$ 1)$ i świadczeniem tym w ubezpieczeniu majątkowym jest odszkodowanie za szkodę powstałą wskutek przewidzianego w umowie wypadku (\$2), przemawia za tym, że wypadkiem ubezpieczeniowym jest nie samo doznanie szkody, lecz zdarzenie losowe będące jego przyczyną ${ }^{8}$. Aprobując to stanowisko, należałoby przyjąć, że dla powstania odpowiedzialności ubezpieczenio-

7 Por. przykładowo M. Serwach [w:] Prawo ubezpieczeń gospodarczych, red. E. Kowalewski, s. 398-402; M. Krajewski, Ubezpieczenie..., s. 185 i n.

8 S. Reps, J. Reps, Ubezpieczenia majątkowe przedsiębiorców, Warszawa 2000, s. $195-196$. 
wej materialny okres ubezpieczenia ma co do zasady trwać w chwili zajścia wypadku, nie zaś w chwili powstania szkody.

Jego potwierdzeniem może być spostrzeżenie, że art. $822 \$ 2$ k.c., stanowiący lex specialis wobec przepisów ogólnych, zawiera wyraźne zastrzeżenie, że umowa ubezpieczenia OC obejmuje szkody będące następstwem przewidzianego w umowie zdarzenia, które miało miejsce w okresie ubezpieczenia, o ile strony nie umówiły się inaczej. Podobnego zastrzeżenia pozwalającego stronom na inne ukształtowanie okresu ochrony ubezpieczeniowej nie zawierają przepisy ogólne. Dodać można, że w literaturze nie budzi większych sporów, że przepisy Kodeksu cywilnego o umowie ubezpieczenia, w odróżnieniu od przepisów dotyczących innych umów, co do zasady stanowią ius cogens. W ostatnim czasie pojawił się wprawdzie postulat, by w nowym Kodeksie cywilnym umowę ubezpieczenia uregulować przepisami dyspozytywnymi, jednak spotkał się on ze zdecydowaną krytyką w doktrynie?

Kwestię tę można zilustrować dwoma wyrokami Sądu Najwyższego. Wyrok z 10.10.2000 r., V CKN 97/00, dotyczył ubezpieczenia kosztów leczenia ${ }^{10}$. Ubezpieczenie to zwykle kwalifikowane jest jako ubezpieczenie osobowe, w którym świadczenie ma charakter odszkodowawczy. W świetle dotychczasowych uwag ubezpieczenie to, chroniąc interes majątkowy, należy w istocie do ubezpieczeń majątkowych, ściślej zaś do ubezpieczeń mienia, więc przykład może być instruktywny. W stanie faktycznym sprawy zawarto ubezpieczenie na czas wycieczki zagranicznej. Ostatniego dnia wycieczki powód doznał nagłego krwotoku, co pociągnęło za sobą kilkudniowy pobyt w szpitalu oraz związane z tym koszty. Ubezpieczyciel odmówił wypłaty odszkodowania, wskazując, że szkoda powstała po zakończeniu okresu ubezpieczenia. Pobyt w szpitalu rozpoczął się ostatniego dnia wycieczki, a zatem koszty tego pobytu powstały w okresie nieobjętym ubezpieczeniem. Sądy dwóch instancji podzieliły stanowisko ubezpieczyciela, jednak Sąd Najwyższy uznał

9 M. Orlicki, Regulacja umowy ubezpieczenia: imperatywna, dyspozytywna czy semiimperatywna [w:] ubezpieczeń kierunki rozwoju ubezpieczeń gospodarczych $w$ Polsce, red. B. Gnela, M. Szaraniec, Warszawa 2013, s. 47 i n.

10 OSNC 2001/3, poz. 46. 
to stanowisko za nietrafne. Zdaniem SN właściwa wykładnia OWU prowadzi do wniosku, że zdarzeniem objętym ubezpieczeniem było zachorowanie lub nieszczęśliwy wypadek, nie zaś poniesienie związanych z tym kosztów leczenia. Według SN inna interpretacja $\mathrm{z}$ uwagi na bardzo krótki okres ubezpieczenia powodowałaby iluzoryczność ochrony ubezpieczeniowej.

Z kolei w wyroku z 6.12.1995 r., I CRN 224/95 ${ }^{11}$, chodziło o ubezpieczenie domu, który został oceniony jako nadający się do rozbiórki wskutek osuwania się terenu. Zjawisko osuwania się terenu miało charakter postępujący i wieloletni. Dom objęty był ubezpieczeniem bez przerwy od lat 60. do 90., kiedy pojawiła się konieczność rozbiórki. W lipcu 1991 r. ubezpieczyciel ocenił dom jako nadający się do ubezpieczenia. Powódka wystąpiła z roszczeniem o wypłatę odszkodowania we wrześniu 1992 r. Ubezpieczyciel powołał się na zarzut przedawnienia, twierdząc, że pierwsze pęknięcia związane $z$ osuwaniem terenu powstały wiele lat wcześniej. Sąd pierwszej instancji podzielił stanowisko powódki. Sąd drugiej instancji zmienił rozstrzygnięcie na korzyść ubezpieczyciela i powództwo oddalił, uznając roszczenie za przedawnione.

Sąd Najwyższy uchylił wyrok sądu drugiej instancji i przekazał sprawę do ponownego rozpoznania. Według tezy wyroku SN w sprawie o odszkodowanie za zniszczenie domu objętego ubezpieczeniem od ognia i innych zdarzeń losowych zdarzeniem objętym ubezpieczeniem (uchylony obecnie art. $819 \$ 2$ k.c.) nie jest pojawienie się pierwszych pęknięć, lecz wystąpienie fazy destrukcji, uzasadniającej ocenę, że dom nadaje się do rozbiórki. Adam Szpunar w glosie do tego orzeczenia zaaprobował stanowisko Sądu Najwyższego, stwierdzając, że jest obojętne, kiedy rozpoczął się proces pękania. Dopiero w 1992 r. powstała, stanowiąca kroplę przepełniającą czarę, szkoda na mieniu ubezpieczonego ${ }^{12}$.

O ile samo rozstrzygnięcie jest trafne, o tyle teza orzeczenia SN, rozłożenie akcentów w uzasadnieniu, jak również argumentacja glosatora budzą wątpliwości. Wydaje się, że istota zagadnienia sprowadza się do stwier-

11 OSNC 1996/4, poz. 60.

12 A. Szpunar, Glosa do wyroku SN z 6.12.1995 r., I CRN 224/95, PA 1996/3, s. 81. 
dzenia, że wypadek ubezpieczeniowy, tj. zjawisko osuwania się terenu było procesem powolnym i postępującym. Zjawisko to rozpoczęło się jeszcze w latach 60. i trwało wciąż w lipcu 1991 r., kiedy ubezpieczyciel ponownie zgodził się ubezpieczyć budynek. Wcześniej powódka próbowała przedsiębrać różne środki zaradcze przeciwdziałające zaistnieniu szkody, jednak roszczenie nie obejmowało związanych z tym kosztów. Skoro kolejne ubezpieczenie zawarto w 1991 r., a niecały rok później postępujące zjawisko osuwania się terenu doprowadziło do konieczności rozbiórki budynku, nie sposób było uznać roszczenia za przedawnione.

Powyższa argumentacja zmierzająca do wykazania, że przesłanką odpowiedzialności ubezpieczyciela jest trwanie okresu ubezpieczenia w chwili wypadku, nie zaś w chwili powstania lub ujawnienia się szkody, koresponduje z uchyleniem art. $819 \$ 2$ k.c., w myśl którego bieg przedawnienia roszczenia o świadczenie od zakładu ubezpieczeń rozpoczynał się w dniu, w którym nastąpiło zdarzenie objęte ubezpieczeniem. Gdyby przesłanką odpowiedzialności ubezpieczyciela było trwanie stosunku ubezpieczenia w chwili, gdy ujawniła się szkoda, nie zaś w chwili zajścia zdarzenia będącego jej przyczyną, zmiana przepisu byłaby zbędna, samo zajście zdarzenia będącego przyczyną szkody nie skutkowałoby bowiem wymagalnością roszczenia.

Ustawodawca zdecydował się zmienić regulację właśnie dlatego, że poprzednie unormowanie mogło prowadzić do sytuacji, w której ubezpieczony dowiadywał się o szkodzie, gdy roszczenie było już przedawnione, ewentualnie gdy do upływu terminu przedawnienia pozostawał bardzo krótki okres ${ }^{13}$. Obecne rozwiązanie jest zbieżne z ogólną regułą $\mathrm{z}$ art. 120 k.c. Innymi słowy, ubezpieczyciel odpowiada jedynie za szkody wywołane zdarzeniami, które miały miejsce w okresie ubezpieczenia. Dopóki jednak szkoda nie powstała i nie ujawniła się z całą mocą wymagalność roszczenia nie powstaje. Określenie chwili, w której powinien zajść wypadek ubezpieczeniowy dla powstania odpowiedzialności ubezpieczyciela, pozwala płynnie przejść do omówienia kolejnej przesłanki tej odpowiedzialności, jaką jest właśnie zajście wypadku.

13 Por. M. Orlicki, J. Pokrzywniak, Umowa..., s. 93-94. 


\subsection{Zajście wypadku ubezpieczeniowego}

Wystąpienie przewidzianego w umowie wypadku jest drugą w kolejności niezbędną przesłanką odpowiedzialności ubezpieczyciela. W odniesieniu do wypadków ubezpieczeniowych w ubezpieczeniu mienia A. Koch postawił tezę, że mogą one mieć postać kauzalną albo niekauzalną. W tej drugiej sytuacji wypadkiem ubezpieczeniowym ma być sama szkoda niezależnie od jej przyczyn. Przy takim ujęciu przesłanką odpowiedzialności ubezpieczyciela przestaje być związek przyczynowy. Szkoda tożsama z wypadkiem ubezpieczeniowym stawałaby się samoistną przesłanką odpowiedzialności ${ }^{14}$. Przy przyjęciu tej koncepcji sformułowany wcześniej katalog przesłanek odpowiedzialności ubezpieczeniowej nie byłby zatem zawsze prawidłowy.

Jako przykład ubezpieczeń, w których wypadek sformułowany jest w postaci niekazualnej, A. Koch podaje ubezpieczenia na życie, będące poza zakresem rozważań niniejszej pracy, ale również ubezpieczenia kradzieżowe będące klasycznym przykładem ubezpieczeń mienia. Według M. Kalińskiego z kolei, który aprobuje stanowisko A. Kocha, wypadek w postaci niekauzalnej może występować również w ubezpieczeniu od ognia i innych zdarzeń losowych. Przykładem wypadku ubezpieczeniowego w postaci kauzalnej ma być „zniszczenie budynku wskutek pożaru”, natomiast przykładem wypadku w postaci niekauzalnej „zniszczenie budynku”.

Rozróżnienie, o którym mowa, akceptuje również M. Krajewski. Jako typowy przykład wypadku w postaci niekauzalnej wskazuje ubezpieczenie na życie. Wyklucza natomiast takie ukształtowanie wypadku w ubezpieczeniu następstw nieszczęśliwych wypadków. W odniesieniu do innych rodzajów ubezpieczeń autor ten daje stronom umowy ubezpieczenia swobodę co do sposobu określenia wypadku ubezpieczeniowego. Przykładem ubezpieczenia mienia, w przypadku którego wypadek określony jest w sposób niekauzalny, ma być ubezpieczenie od wszystkich ryzyk.

14 A. Koch, Związek przyczynowy w ubezpieczeniach, s. 8 oraz 12 i 13; M. Kaliński, Szkoda..., s. 362; M. Orlicki [w:] System Prawa Prywatnego, red. Z. Radwański, t. 8, Prawo zobowiązań - część szczegółowa, red. J. Panowicz-Lipska, Warszawa 2011, s. 808. 
Marcin Krajewski przyznaje jednak, że w zdecydowanej większości ubezpieczeń majątkowych wypadki ubezpieczeniowe określone są w postaci kauzalnej, a ubezpieczyciel ponosi odpowiedzialność tylko w razie spowodowania szkody przez przyczynę wskazaną w umowie ${ }^{15}$.

Wypowiedź M. Krajewskiego stanowi najpełniejszą w polskiej literaturze analizę omawianej kwestii. Autor ten zwraca uwagę, że polski ustawodawca używa pojęcia wypadku w różnych znaczeniach. Wypadek jako przyczyna szkody ujmowany jest w art. $805 \$ 2$ pkt 1, według którego ubezpieczyciel obowiązany jest spełnić świadczenie w razie zajścia przewidzianego w umowie wypadku, oraz odczytywanym dosłownie art. 826 $\$ 1$ k.c. dotyczącym obowiązku ratowania. Wśród przepisów, które wyraźnie utożsamiają lub przynajmniej zdają się utożsamiać wypadek ze szkodą, M. Krajewski wymienia art. 805 k.c. uzależniający obowiązek świadczenia ubezpieczyciela od zajścia wypadku, art. 806 k.c. proklamujący nieważność umowy ubezpieczenia, jeżeli zajście wypadku nie jest możliwe, art. $808 \$ 3$ i art. $822 \$ 5$ wiążące $z$ nadejściem wypadku ustabilizowanie sytuacji osoby trzeciej niebędącej stroną umowy, przede wszystkich zaś przepisy dotyczące zawiadomienia ubezpieczyciela o zajściu wypadku (art. 817 i 818 k.c.).

Wydaje się, że analiza przepisów ogólnych o umowie ubezpieczenia nie może dać odpowiedzi na pytanie, czy wypadek ubezpieczeniowy może być utożsamiany ze szkodą, ponieważ przepisy te z założenia dotyczyć mają również ubezpieczeń osobowych, w których świadczenia ubezpieczeniowe co do zasady nie mają charakteru odszkodowawczego. Trudno również odnosić się do przepisów o umowie ubezpieczenia odpowiedzialności cywilnej. W tym ubezpieczeniu ubezpieczyciel zobowiązuje się zapłacić odszkodowanie za szkody wyrządzone osobom trzecim, wobec których odpowiedzialność za szkodę ponosi ubezpieczający albo ubezpieczony, a zatem szkoda, niezależnie od przyjętego triggera, stanowi element wypadku ubezpieczeniowego ${ }^{16}$.

15 M. Krajewski, Wypadek..., s. 141 i n.

16 Szerzej M. Krajewski, Ubezpieczenie..., s. 185 i n. 
W ubezpieczeniach mienia upatrywanie w szkodzie samoistnej przesłanki odpowiedzialności wydaje się kontrowersyjne przynamniej z kilku przyczyn. Po pierwsze, zgodnie z cytowanym już poglądem S. Repsa i J. Repsa, językowa wykładnia art. 805 k.c., według którego ubezpieczyciel obowiązany jest spełnić świadczenie w razie zajścia przewidzianego w umowie wypadku ( $\$ 1)$ i świadczeniem tym w ubezpieczeniu majątkowym jest odszkodowanie za szkodę powstałą wskutek przewidzianego w umowie wypadku $(\$ 2)$, przemawia za tym, że wypadkiem ubezpieczeniowym jest nie samo doznanie szkody, lecz zdarzenie losowe będące jej przyczyną ${ }^{17}$. Do podobnych wniosków prowadzi treść art. 826 $\$ 1$ k.c., który równie wyraźnie odróżnia wypadek i szkodę ${ }^{18}$.

Cytowany wyżej M. Krajewski opisuje dyskusję toczącą się w prawie niemieckim na kanwie przepisów będących odpowiednikami art. 805 i 826 polskiego k.c. Artykuł 1 VVG z 1906 r. stanowił, że po zajściu wypadku ubezpieczeniowego ubezpieczyciel zobowiązany jest, stosownie do postanowień umowy, naprawić szkodę majątkową ubezpieczającego powstałą wskutek tego wypadku. Na tle tego sformułowania Federalny Trybunał Sprawiedliwości w wyroku z 18.12.1954 r. uznał, że chociaż ubezpieczyciel ma obowiązek spełnić świadczenie dopiero z chwilą powstania szkody, samo jej powstanie nie jest elementem wypadku ubezpieczeniowego. Pogląd ten dominował także w literaturze. Wyrażono jednak również stanowisko przeciwne, zgodnie z którym przez szkodę powstałą wskutek wypadku w rozumieniu wskazanego przepisu można rozumieć także szkodę stanowiącą element stanu faktycznego, którym jest wypadek ubezpieczeniowy. Taka interpretacja miałaby być bliższa regułom znaczeniowym języka potocznego, zgodnie z którymi pojęcie wypadku ubezpieczeniowego obejmuje również szkodę. Pogląd o odrębności wypadku ubezpieczeniowego i szkody dominował również na gruncie $₫ 62$ VVG w wersji obowiązującej do 31.12.2007 r., który stanowił, że w razie zajścia wypadku ubezpieczający jest zobowiązany

17 S. Reps, J. Reps, Ubezpieczenia majątkowe przedsiębiorców, s. 195-196.

18 Wyrażany niekiedy w literaturze pogląd, że obowiązek ratowania wynikający z tego przepisu aktualizuje dopiero zajście szkody, uważam za nietrafny. Co do tej kwestii, zob. rozważania dotyczące kosztów ratowania jako odrębnego składnika odszkodowania ubezpieczeniowego. 
w miarę możliwości i zgodnie ze wskazówkami ubezpieczyciela podjąć kroki w celu zapobieżenia szkodzie i jej ograniczenia ${ }^{19}$.

Aktualnie obowiązujący \$1 VVG z 2008 r. wskazuje, że zadaniem ubezpieczyciela jest zabezpieczenie ubezpieczającego lub osoby trzeciej przed skutkami ryzyka, co następuje poprzez spełnienie świadczenia przy zajściu ustalonego wypadku ubezpieczeniowego ${ }^{20}$. W nowszej literaturze wydaje się dominować pogląd, zgodnie z którym jakkolwiek szkoda nie jest koniecznym elementem wypadku, to ostatecznie rozstrzygnięcie, czy wypadek ubezpieczeniowy obejmuje również szkodę, zależy od stron umowy. Odpowiednikiem dawnego $\$ 62$ niemieckiej ustawy o umowie ubezpieczenia jest obecnie $\$ 82$, którego redakcja nie różni się w istotny sposób od redakcji jego poprzednika. Nowością jest natomiast wprowadzenie do ustawy samodzielnego przepisu ( $\$ 90 \mathrm{VVG}$ ) przewidującego zwrot na rzecz ubezpieczającego kosztów działań podjętych w celu odwrócenia bezpośredniego niebezpieczeństwa wypadku, który to obowiązek ma wyraźnie odrębny charakter od obowiązku zwrotu kosztów działań podjętych na podstawie $\$ 82$ VVG. Stanowi on dodatkowy argument na rzecz tezy, że dla powstania obowiązku ratowania wystarczy, że rozpocznie się realizacja stanu faktycznego, którym jest wypadek. Wątpliwe jest natomiast, czy musi także rozpocząć się proces powstawania szkody ${ }^{21}$.

Niezależnie od wniosków mogących płynąć ze sformułowań konkretnych przepisów ustawowych, dosyć trudno wyobrazić sobie wypadki w postaci niekauzalnej. Andrzej Koch podaje przykłady ubezpieczeń na życie oraz ubezpieczeń kradzieżowych. Te pierwsze, jak wskazano, nie są przedmiotem zainteresowania niniejszej pracy, a świadczenia z nich wynikające nie mają charakteru odszkodowawczego, szkoda nie jest więc przesłanką odpowiedzialności ubezpieczyciela. Na marginesie wypada jednak wskazać, że również w ubezpieczeniach na życie ubezpieczyciel zobowiązuje się wypłacić świadczenie na wypadek śmierci zależnie od

19 M. Krajewski, Wypadek..., s. 147-149 oraz wskazana tam literatura.

20 M. Krajewski, Wypadek..., s. 147-149 oraz wskazana tam literatura.

21 Zob. rozbieżne poglądy wyrażane w literaturze niemieckiej przytaczanej przez M. Krajewskiego, Wypadek..., s. 147-149. 
jej przyczyny. Przynajmniej prima facie wydaje się zatem, że problem związku przyczynowego może mieć podstawowe znaczenie także na gruncie ubezpieczeń na życie ${ }^{22}$.

Odnośnie do ubezpieczeń mienia w literaturze podkreśla się, że wypadek ubezpieczeniowy zwykle skonstruowany jest w postaci kauzalnej ${ }^{23}$. Wbrew intencjom A. Kocha i M. Kalińskiego przykłady ubezpieczenia od pożaru oraz ubezpieczenia od kradzieży pokazują to zresztą wyraźnie. W ubezpieczeniu od ognia wypadkiem ubezpieczeniowym nie jest szkoda niezależnie od przyczyn, ale pożar skutkujący zniszczeniem budynku, czyli szkodą. Podobnie w ubezpieczeniu od kradzieży wypadkiem ubezpieczeniowym nie jest szkoda jako taka, ale będąca jej przyczyną kradzież rozumiana w sposób wskazany w ogólnych warunkach ubezpieczenia, ewentualnie w znaczeniu określonym przez przepisy prawa karnego. Znana powszechnie praktyka ubezpieczycieli odmawiających wypłaty odszkodowania, dopóki postępowanie karne nie wykaże, że $\mathrm{w}$ istocie kradzież miała miejsce, jest tego widocznym dowodem.

Dodać można, że powszechnym standardem ubezpieczenia nieruchomości jest obecnie tzw. FLEXA obejmująca ryzyka elementarne, to jest ogień (fire), uderzenie pioruna (lighting), wybuch (explosion), upadek statku powietrznego (aircraft crash landing). W języku polskim mówi się o ubezpieczeniu od ognia i innych zdarzeń losowych. Wbrew stanowisku M. Krajewskiego nawet w przypadku ubezpieczenia o bardzo szerokim zakresie nie sposób wyobrazić sobie, by obejmowało ono wszystkie szkody powstałe w nieruchomości niezależnie od przyczyn ${ }^{24}$. Każde ubezpieczenie ma określony zakres przedmiotowy, zawiera wymienione wyłączenia oraz zakres czasowy. Nawet w trudnej do wyobrażenia sytuacji braku jakichkolwiek wyłączeń trzeba będzie rozstrzygnąć, czy szkoda nie jest wynikiem winy umyślnej bądź rażącego niedbalstwa ubezpieczonego, co wyłącza odpowiedzialność ubezpieczyciela z mocy ustawy

22 Nie dotyczy to zapewne tzw. ubezpieczeń na dożycie.

23 M. Krajewski, Umowa ubezpieczenia. Art. 805-834 KC..., 2016, s. 227.

24 Przykładowo OWU ubezpieczenia mienia od wszystkich ryzyk PZU SA zawierają dwie strony wyłączeń odpowiedzialności precyzujących rzeczywisty zakres wypadku ubezpieczeniowego. 
(art. 827 k.c.). Można zatem postawić ostrożną tezę, że tzw. wypadki w postaci niekauzalnej w istocie nie istnieją. Sformułowany wcześniej zestaw przesłanek wydaje się zatem prawidłowy.

W literaturze wypadek ubezpieczeniowy definiuje się zwykle, wyliczając jego konieczne cechy jako zdarzenie przyszłe, niepewne, niezależne od woli ubezpieczonego, z którego zajściem umowa wiąże obowiązek wypłaty odszkodowania lub świadczenia ubezpieczeniowego. Niektórzy dodają ponadto, że wypadek ubezpieczeniowy jest zdarzeniem losowym oraz zdarzeniem prawnym ${ }^{25}$. Omawiając wypadek ubezpieczeniowy jako przesłankę odpowiedzialności, należy przynajmniej krótko omówić wskazane cechy.

Określenie wypadku ubezpieczeniowego jako zdarzenia przyszłego wiąże się z koniecznością zawarcia umowy ubezpieczenia przed wystąpieniem wypadku. Zasada dotycząca następczości wypadku względem rozpoczęcia formalnego okresu ubezpieczenia doznaje wyjątku określonego w art. 806 k.c. W myśl tego przepisu możliwe jest objęcie ubezpieczeniem okresu poprzedzającego zawarcie umowy ubezpieczenia, jeżeli żadna ze stron nie wiedziała i przy zachowaniu należytej staranności nie mogła się dowiedzieć, że wypadek zaszedł bądź odpadła możliwość jego zajścia w tym okresie.

Niepewność wypadku ubezpieczeniowego oznacza, że zdarzenie określone jako wypadek może, ale nie musi zajść. Innymi słowy, nie da się przewidzieć, czy zdarzenie zajdzie, czy też nie. W odniesieniu do ubezpieczeń majątkowych mowa jest przy tym o niepewności w postaci incertitudo an, tzn. nie wiadomo, czy zdarzenie w ogóle wystąpi, ewentualnie w incertitudo effectus, tzn. nie wiadomo, jakie będą następstwa zdarzenia. W odniesieniu do ubezpieczeń życiowych na wypadek śmierci zachodzi natomiast niepewność w postaci incertitudo quando, tzn. wiadomo, że zdarzenie wystąpi, jednak nie wiadomo kiedy.

25 Por. przykładowo W. Warkałło, W Marek, W. Mogilski, Prawo..., s. 176-178, Prawo ubezpieczeń gospodarczych, red. E. Kowalewski, s. 56; A. Wąsiewicz, Z.K. Nowakowski, Prawo ubezpieczeń gospodarczych, Warszawa-Poznań 1980, s. 43-47; Z. Łabno, Prawo ubezpieczeń gospodarczych. Zarys wykładu, Katowice 1975. 
Dwie wymienione wyżej cechy wypadku ubezpieczeniowego (przyszłość i niepewność) upodabniają go do warunku. Podkreśla się jednak, że wypadek ubezpieczeniowy warunkiem nie jest, stosunek prawny ubezpieczenia trwa bowiem niezależnie od zajścia wypadku ${ }^{26}$. Zajście wypadku warunkuje jedynie powstanie roszczenia o wypłatę świadczenia pieniężnego $\mathrm{z}$ ubezpieczenia. Wbrew communis opinio cecha ta nie przesądza jednak o niemożności kwalifikowania wypadku ubezpieczeniowego jako warunku. $Z$ art. 89 k.c. nie wynika bowiem wyraźnie, czy warunkiem w rozumieniu prawnym może być jedynie zdarzenie, od którego uzależniono powstanie lub ustanie wszystkich skutków czynności prawnej, czy również zdarzenie, od którego uzależniono powstanie jedynie niektórych skutków takiej czynności. Stanowisko, wedle którego warunkiem jest wyłącznie zdarzenie, od którego zajścia uzależniono powstanie lub ustanie całego stosunku prawnego ze wszystkimi jego skutkami, nie wydaje się zasadne. Trudno zaprzeczyć temu, że zaistnienie zdarzenia określonego w umowie jako wypadek ubezpieczeniowy jest warunkiem niezbędnym powstania roszczenia o wypłatę odszkodowania ubezpieczeniowego, wpływa zatem na wystąpienie istotnego skutku stosunku prawnego ubezpieczenia, w pewnym sensie zatem prowadzi do przekształcenia tego stosunku ${ }^{27}$.

Wypadek ubezpieczeniowy nie jest warunkiem w rozumieniu art. 89 k.c. $z$ innych przyczyn. Warunek jest dodatkowym postanowieniem umownym należącym do typowych postanowien podmiotowo istotnych (accidentalia negotii), a jego dodanie ma charakter wyjątkowy. Postanowienie umowy uzależniające obowiązek zapłaty odszkodowania od zajścia wypadku ubezpieczeniowego decyduje natomiast o kwalifikacji danej umowy jako umowy ubezpieczenia. Postanowienie to należy zatem do elementów przedmiotowo istotnych (essentialia negotii) ${ }^{28}$. Można zatem stwierdzić, że konieczność występowania w umowie ubezpieczenia wypadku ubezpieczeniowego wynika z ustawy, która określa niezbędną treść tej umowy. Panuje zgoda, że wynikające z ustawy wymagania do-

26 W. Warkałło [w:] W. Warkałło, W. Marek, W. Mogilski, Prawo..., s. 177.

27 Inaczej H. Ciepła [w:] Kodeks cywilny. Komentarz. Ksiega trzecia. Zobowiązania, Lex Polonica, komentarz do art. 805, teza 6.

28 M. Krajewski, Umowa ubezpieczenia. Art. 805-834 KC..., 2016, s. 55-56. 
tyczące ważności i skuteczności czynności prawnej warunkami nie są ${ }^{29}$. $\mathrm{Na}$ omawianą kwestię zwracał uwagę już A. Ohanowicz, wskazując, że warunek jest klauzulą umowną dodaną przez strony do umowy, która może być zawarta również bez jego dodania, natomiast niepewność umowy losowej tkwi w jej istotnej treści i bez tego elementu niepewności nie mogłaby ona w ogóle dojść do skutku lub przynajmniej nie w tej postaci, w jakiej strony chciałyby ją zawrzeć ${ }^{30}$. Konieczność wskazania w umowie ubezpieczenia wypadku ubezpieczeniowego mającego określone cechy wiąże się zatem immanentnie z losowością tej umowy ${ }^{31}$.

Ostatnia cecha, a mianowicie niezależność wypadku od woli osoby ubezpieczonej, nie dotyczy ubezpieczeń OC, w przypadku których można umówić się, że spowodowanie wypadku umyślnie lub wskutek rażącego niedbalstwa ubezpieczonego objęte będzie ochroną ubezpieczeniową (art. $827 \$ 2$ k.c.) ${ }^{32}$. Umyślne spowodowanie wypadku przez ubezpieczonego nie zwalnia ubezpieczyciela z odpowiedzialności również w niektórych obowiązkowych ubezpieczeniach OC, w szczególności w ubezpieczeniu posiadaczy pojazdów mechanicznych, jest jednak przesłanką tzw. regresu niewłaściwego ze strony ubezpieczyciela ${ }^{33}$. Ponadto w ubezpieczeniach na życie samobójstwo ubezpieczonego nie zwalnia ubezpieczyciela z odpowiedzialności, jeżeli nastąpi po upływie 2 lat od zawarcia umowy ubezpieczenia.

Z powyższego wynika, że wypadek ubezpieczeniowy nie musi być zdarzeniem niezależnym od człowieka, z zasady zaś powinien być niezależny od woli człowieka. Wśród rodzajów wypadków wyróżnić można zdarzenia wynikające z działania siły przyrody lub inne niezależne od

29 Tak przykładowo S. Rudnicki [w:] Kodeks cywilny. Komentarz. Ksiega pierwsza. Część ogólna, komentarz do art. 89, teza 1, Lex Polonica.

30 A. Ohanowicz, J. Górski, Zarys..., s. 83.

31 Por. rozdział o przesłankach odpowiedzialności ubezpieczyciela.

32 Umowa obowiązkowego ubezpieczenia OC obejmuje również szkody wyrządzone umyślnie lub wskutek rażącego niedbalstwa ubezpieczonego lub osób, za które ponosi on odpowiedzialność (art. 9 ust. 2 u.u.o.). W ubezpieczeniu OC posiadaczy pojazdów mechanicznych szkoda umyślna ubezpieczonego umożliwia ubezpieczycielowi wystąpienie wobec ubezpieczonego z tzw. regresem niewłaściwym (art. 43 u.u.o.).

33 Por. art. 43 pkt 1 u.u.o. 
człowieka, jak również zdarzenia od człowieka zależne. W obrębie tych ostatnich wskazuje się zdarzenia wywołane działaniem osób trzecich, w przypadku których wina umyślna sprawcy nie jest przesłanką zwalniającą z odpowiedzialności, oraz zdarzenia wywołane przez ubezpieczonego, których dotyczy cecha niezależności od woli ludzkiej, a w każdym razie nastąpienie bez winy umyślnej (art. $827 \$ 1$ k.c.) ${ }^{34}$. Podsumowując ten wątek, wypada stwierdzić, że o ile wina sprawcy stanowi co do zasady przesłankę pozytywną odpowiedzialności ex delicto lub ex contractu, o tyle wina umyślna ubezpieczonego stanowi co do zasady negatywną przesłankę odpowiedzialności gwarancyjnej ubezpieczyciela. Wypadkiem ubezpieczeniowym może być natomiast zdarzenie wywołane przez człowieka na skutek lekkomyślności lub niedbalstwa.

W doktrynie dodaje się również, że wypadkiem ubezpieczeniowym może być wyłącznie zdarzenia losowe, tj. zdarzenie przyszłe, niepewne, niezależne od woli dotkniętej nim jednostki oraz charakteryzujące się dodatkowymi jeszcze cechami, a mianowicie statystyczną prawidłowością występowania, nadzwyczajnością i losowością. Statystyczna prawidłowość rozumiana jest jako tendencja do stałości w pojawianiu się zdarzeń losowych, powtarzalność ich w czasie i w przestrzeni oraz możliwość matematycznego ustalenia stopnia prawdopodobieństwa. Nadzwyczajność polega na tym, że choć zdarzenia losowe zagrażają szerokiej grupie osób, realizują się jedynie względem niektórych spośród nich (będąc dla konkretnych jednostek nadzwyczajnymi). Losowość zdarzeń rozumiana jest natomiast jako niemożność przewidzenia, które z jednostek zagrożonych jednakowym typem zdarzenia losowego zostaną przez to zdarzenie dotknięte. Innymi słowy, choć można w przybliżeniu ustalić liczbę zdarzeń, nie można przewidzieć, które jednostki zostaną nimi dotknięte, o tym bowiem decyduje $\operatorname{los}^{35}$.

Rola zdarzeń losowych w prawie ubezpieczeniowym ma obecnie podstawę normatywną. Zgodnie z art. 4 ust. 1 u.d.u.r. przez działalność ubezpieczeniową rozumie się wykonywanie czynności ubezpieczeniowych związanych z oferowaniem i udzielaniem ochrony na wypadek

34 W. Warkałło [w:] W. Warkałło, W. Marek, W. Mogilski, Prawo..., s. 178.

35 A. Wąsiewicz, Z.K. Nowakowski, Prawo..., s. 45. 
ryzyka wystąpienia skutków zdarzeń losowych. Przepis art. 3 ust. 1 pkt 57 u.d.u.r. definiuje zdarzenie losowe jako niezależne od woli ubezpieczającego lub ubezpieczonego zdarzenie przyszłe i niepewne, którego nastąpienie powoduje uszczerbek w dobrach osobistych lub w dobrach majątkowych albo zwiększenie potrzeb majątkowych po stronie ubezpieczającego lub innej osoby objętej ochroną ubezpieczeniową ${ }^{36}$.

W odniesieniu do wypadków ubezpieczeniowych, ewentualnie również w odniesieniu do zdarzeń losowych, zwraca się uwagę na jeszcze jedną ich cechę, a mianowicie, że muszą one stanowić zdarzenia prawne. Rodzą się jednak kontrowersje co do skutków prawnych wywoływanych przez zajście wypadku. Zdaniem niektórych autorów skutek prawny wywoływany przez zajście wypadku polegać ma na przekształceniu ekspektatywy prawa do świadczenia ubezpieczeniowego w prawo istniejące $^{37}$. O ile sama kwalifikacja wypadków ubezpieczeniowych jako zdarzeń prawnych nie budzi wątpliwości, o tyle do poglądu dotyczącego ich skutków można mieć zastrzeżenia.

Po pierwsze, zgodnie $\mathrm{z}$ wywodami zawartymi w drugim rozdziale, ubezpieczającemu służy wobec ubezpieczyciela wierzytelność jeszcze przed zajściem wypadku ubezpieczeniowego. Zajście wypadku sprawia jedynie, że pojawia się roszczenie, tj. instrument pozwalający na przymusową realizację wierzytelności, która jednocześnie przybiera postać wierzytelności pieniężnej. Po drugie, trudno określać ewentualne prawo do uzyskania w przyszłości odszkodowania ubezpieczeniowego mianem ekspektatywy, ponieważ powstanie tego prawa uzależnione jest od zdarzenia nadzwyczajnego, co do zasady rodzącego dla ubezpieczającego następstwa negatywne, w związku z czym ubezpieczający pozbawiony jest jakichkolwiek środków ochrony pozwalających na nabycie prawa ${ }^{38}$.

${ }^{36}$ Co do zdarzeń losowych, ze starszej literatury zob. Z. Lichniak, Zastosowanie teorii zdarzeń losowych w prawie o umowie ubezpieczenia, WU 1963/3; Z. Lichniak, Ryzyko a wypadki i niebezpieczeństwa oraz wypadek ubezpieczeniowy, WU 1969/11.

37 W. Warkałło [w:] W. Warkałło, W. Marek, W. Mogilski, Prawo..., s. 177; Prawo ubezpieczeń gospodarczych, red. E. Kowalewski, s. 56.

38 Co do tych kwestii, K. Gandor, Prawa podmiotowe tymczasowe. Ekspektatywy, Ossolineum 1968, passim; J. Kuropatwiński, Ekspektatywa powstania wierzytelności w polskim prawie cywilnym, Bydgoszcz 2006, passim. 


\subsection{Szkoda ubezpieczeniowa}

\subsubsection{Wprowadzenie}

Zgodnie z powyższymi uwagami obowiązek wypłaty odszkodowania ubezpieczeniowego powstaje, jeżeli wypadek ubezpieczeniowy doprowadzi do szkody. Rodzi się zatem pytanie, jak rozumiany jest termin „szkoda” w prawie ubezpieczeniowym. W literaturze cywilistycznej podkreśla się, że samo znaczenie tego pojęcia na gruncie ubezpieczeń nie odbiega od jego ogólnego znaczenia w prawie cywilnym ${ }^{39}$. Spostrzeżenie to niczego nie wyjaśnia, tym bardziej że ustawodawca nie daje ogólnej definicji szkody. Język prawniczy czerpie z języka potocznego, a tam szkoda ma wiele znaczeń. Jak obrazowo wskazuje A. Szpunar, jedynie rdzeń znaczeniowy terminu „szkoda” jest jasny, natomiast kontury pozostają zamazane ${ }^{40}$. W języku prawniczym szkodę definiuje się zwykle jako każdy uszczerbek w dobrach prawnie chronionych. Często czynione są dodatkowe zastrzeżenia, w szczególności przez wskazanie, że chodzi o uszczerbek, który nastąpił wbrew woli poszkodowanego ${ }^{41}$.

Ostatnie zastrzeżenie jest przedmiotem kontrowersji co do swej użyteczności, przede wszystkim z uwagi na objęcie mianem szkody także wydatków ponoszonych przez poszkodowanego z własnej woli w związku ze zdarzeniem szkodzącym ${ }^{42}$. Wydaje się jednak, że sformułowanie „zajście szkody wbrew woli ubezpieczonego" może stanowić istotną dyrektywę interpretacyjną przy odpowiednim jego rozumieniu. Wydatki poniesione dobrowolnie przez samego poszkodowanego należy traktować jako poniesione wbrew jego woli, jeżeli tylko potrzeba ich dokonania

39 Tak przykładowo W. Warkałło, Zasada...; W. Warkałło, Ubezpieczenie a odpowiedzialność..., s. 128; W. Warkałło, Ubezpieczenie utraconych korzyści..., s. 52-53; W. Wąsiewicz, Odszkodowanie ubezpieczeniowe, jego ograniczenia i wyłączenia, PA 1996/4, s. 23; M. Kaliński, Zasada..., cz. 1, s. 41. Kłopoty z określeniem szkody w prawie cywilnym podkreśla M. Krajewski, Ubezpieczenie..., s. 45 i n. oraz Pojęcie odpowiedzialności..., s. 465.

40 A. Szpunar, Odszkodowanie..., s. 22.

${ }^{41}$ Zob. przykładowo R. Longchamps de Bérier, Polskie..., s. 229-230; A. Szpunar, Odszkodowanie..., s. 312; Z. Radwański, A. Olejniczak, Zobowiązania..., s. 91; A. Sinkiewicz, Pojęcie i rodzaje szkody w polskim prawie cywilnym, „Rejent” 1998/2, s. 62.

${ }^{42}$ M. Kaliński, Szkoda..., s. 178 i wskazana tam literatura. 
pojawiła się w wyniku zdarzenia szkodzącego celem przywrócenia stanu poprzedniego albo choć stanu doń zbliżonego w sensie gospodarczym. Dotyczy to również szkód poniesionych w cudzym interesie, w odniesieniu do których art. 438 k.c. expressis verbis stanowi, że mogą być poniesione choćby dobrowolnie. Istotna jest $\mathrm{w}$ tej mierze prognoza ex ante - sprzed zdarzenia szkodzącego, uzasadniająca wniosek, że zaistniała sytuacja niejako zmusiła poszkodowanego do poświęcenia pewnych dóbr celem ratowania innych, mających znaczenie nadrzędne $e^{43}$.

W prawie cywilnym powszechnie wyróżnia się szkodę majątkową i niemajątkową oraz szkodę na mieniu i szkodę na osobie. Temat pracy pozwala zawęzić rozważania do szkód majątkowych, a w ich obrębie do szkód na mieniu, pozostawiając pozostałe rodzaje szkody bez omówienia. Szkodę niemajątkową określa się mianem krzywdy, natomiast kwotę stanowiącą jej naprawienie jako zadośćuczynienie. Jak wiadomo, obecnie ustawodawca stosuje tę terminologię niekonsekwentnie. W odniesieniu do podziału szkody na szkodę niemajątkową - krzywdę, oraz majątkową, dodać można za W. Warkałłą, że w ubezpieczeniach, z wyjątkiem ubezpieczeń odpowiedzialności cywilnej, zadośćuczynienie za krzywdę nigdy nie jest przyrównywane do naprawienia szkody albo ujmowane łącznie z nią. Niepozbawione racji są natomiast próby sprowadzenia niektórych świadczeń z ubezpieczenia osobowego do świadczeń odszkodowawczych w celu zaliczenia ich na poczet należnego poszkodowanemu odszkodowania za szkodę na osobie. Kwestie te zostaną pokrótce omówione w rozdziale dotyczącym zakresu odszkodowania ubezpieczeniowego.

Przyjmowana powszechnie w prawie polskim teoria różnicy prowadzi do określenia szkody jako uszczerbku w dobrach poszkodowanego, którego wielkość wyraża się w różnicy między stanem tych dóbr powstałym wskutek zdarzenia szkodzącego a stanem, jaki istniałby, gdyby do zdarzenia nie doszło. Wcześniejsze uwagi dotyczące wypadku ubezpieczeniowego jako źródła szkody pozwalają zawęzić definicję szkody w prawie ubezpieczeniowym do różnicy w zakresie wartości przedmiotu ubezpieczenia sprzed wypadku ubezpieczeniowego oraz po jego zajściu.

43 A. Szpunar, Odszkodowanie..., s. 32. 
Ostatnie zastrzeżenie wypada podkreślić. O ile w prawie odszkodowawczym teoria różnicy odnosi szkodę majątkową do zmniejszenia się ogólnego stanu praw i obowiązków majątkowych, o tyle w prawie ubezpieczeniowym prawnie relewantna jest szkoda dotycząca konkretnego przedmiotu ubezpieczenia (interesu ubezpieczeniowego). Innymi słowy, na zasadach ogólnych prawa cywilnego należy brać pod uwagę uszczerbek we wszystkich dobrach poszkodowanego chronionych przez prawo, czyli w całym jego majątku. Dla odmiany na gruncie ubezpieczeń chodzi o uszczerbek w dobrach chronionych konkretnym ubezpieczeniem, często nawet $w$ indywidualnie oznaczonym przedmiocie majątkowym. Z tego względu mówi się, że w prawie ubezpieczeń obowiązuje tzw. teoria lokalizacji szkody ${ }^{44}$. Wstępnie można postawić tezę, że właśnie lokalizacja szkody stanowi najistotniejszą różnicę między szkodą w rozumieniu prawa ubezpieczeniowego a szkodą na gruncie reguł ogólnych. Kwestia zostanie omówiona w dalszej części rozdziału.

Druga istotna korekta ogólnego pojęcia szkody w prawie ubezpieczeń może wynikać z odejścia od teorii mienia na rzecz teorii interesu jako przedmiotu ubezpieczania. Jak wiadomo, w prawie cywilnym przedmiotem ochrony są prawa podmiotowe przysługujące jednostce. Przedmiotem ochrony ubezpieczeniowej jest natomiast po zmianie art. 821 k.c. interes majątkowy, o ile jest zgodny z prawem i daje się wycenić w pieniądzu. Omawianą zmianę często tłumaczy się właśnie potrzebą ochrony interesów czysto gospodarczych, które mieściły się w kategorii mienia zdefiniowanej w kodeksie jako własność oraz inne prawa. Ta korekta przynajmniej prima facie zdaje się prowadzić w inną stronę, tzn. zamiast zawężać, rozszerza pojęcie szkody ubezpieczeniowej w porównaniu ze szkodą w prawie cywilnym. Kwestia szkody ubezpieczeniowej jako szkody wynikającej z naruszenia interesu ubezpieczeniowego również zostanie szerzej przeanalizowana w dalszej części rozdziału.

Do dzisiaj najbardziej dogłębną analizę szkody ubezpieczeniowej zawierają pionierskie prace W. Warkałły. Autor ten wypowiadał się na gruncie teorii mienia. Poza zwróceniem uwagi na teorię lokalizacji szkody, podkreślał dodatkowo, że ogólne prawo odszkodowawcze przerzuca

44 W. Warkałło, Zasada..., s. 425. 
na sprawcę ciężar naprawienia szkody przezeń wyrządzonej, natomiast prawo ubezpieczeniowe koncentruje się na przejęciu przez ubezpieczyciela ciężaru naprawienia szkody doznanej przez ubezpieczonego. Podkreślana przez W. Warkałłę różnica: szkoda wyrządzona a szkoda doznana, pozornie nieistotna i wynikająca z przyjęcia różnych punktów widzenia, w zasadniczy sposób wpływa na określenia desygnatów samego pojęcia szkody w ogólnym prawie cywilnym oraz $\mathrm{w}$ prawie ubezpieczeniowym, z pewnością zaś rzutuje na zakres szkody w obydwu dziedzinach. Uwzględniając przykłady podawane w różnych publikacjach przez W. Warkałłę, można podjąć próbę omówienia różnic między szkodą w ogólnym prawie odszkodowawczym oraz szkodą w prawie ubezpieczeniowym ${ }^{45}$.

Po pierwsze, prawa cywilnego co do zasady nie interesują szkody, które poszkodowany sam sobie wyrządził, podczas gdy prawo ubezpieczeniowe odnosi termin „szkoda” również do uszczerbków spowodowanych przez poszkodowanego, pod warunkiem że powstały bez jego winy umyślnej lub rażącego niedbalstwa. Warto przy tym zwrócić uwagę, że wcześniejsze zastrzeżenie dotyczące powstania szkody wbrew woli poszkodowanego pozostaje aktualne również w prawie ubezpieczeniowym. Szkody wyrządzone wskutek lekkomyślności lub niedbalstwa nie są bowiem objęte wolą ubezpieczonego.

Po drugie, prawo odszkodowawcze zwykle nie wiąże skutków odszkodowawczych ze szkodami wynikającymi z działania sił przyrody, w szczególności klęsk żywiołowych, np.: pożarów, powodzi, gradobicia, uderzenia pioruna itp., oraz innych zdarzeń mających cechy siły wyższej. Zdarzenia te stanowią natomiast jeden z podstawowych obszarów zastosowania prawa ubezpieczeniowego.

Po trzecie, przepisy prawa odszkodowawczego wiążą skutki ze wszystkimi szkodami niezależnie od ich wysokości, podczas gdy prawo ubezpieczeniowe często wyłącza z pola objętego kompensacją szkody nieprzekraczające określonego minimum. Stosowane są w tym zakresie

45 Zob. w szczególności W. Warkałło, Zasada..., s. 417 i n., oraz W. Warkałło, Ubezpieczenie a odpowiedzialność..., s. 128 i n. 
przeróżne ograniczenia określane mianem franszyzy integralnej oraz udziału własnego ubezpieczonego. Same pojęcia franszyzy integralnej oraz udziału własnego, jak również różnice między nimi zostaną przedstawione w odrębnym rozdziale poświęconym zakresowi odszkodowania ubezpieczeniowego.

Po czwarte, prezentowany m.in. przez E. Kowalewskiego tradycyjny pogląd mówi, że o ile szkoda na zasadach ogólnych obejmuje zarówno damnum emergens, jak i lucrum cessans, o tyle odszkodowanie ubezpieczeniowe przede wszystkim nie obejmuje utraconych zysków (lucrum cessans), chyba że zostały one odrębnie ubezpieczone ${ }^{46}$. Pogląd ten ma stanowić właśnie konsekwencję teorii lokalizacji szkody. Skoro ubezpieczenie obejmuje jedynie konkretne dobro lub dobra, to utrata zysków związanych z utratą lub uszkodzeniem tych dóbr nie może podlegać naprawieniu. Kwestia zostanie szerzej omówiona w związku z analizą teorii lokalizacji szkody.

Po piąte, tradycyjne na gruncie prawa odszkodowawczego rozróżnienie szkody na osobie i szkody na mieniu oraz w obrębie szkody majątkowej rozróżnienie poniesionych strat (damnum emergens) i utraconych zysków (lucrum cessans) nie wystarczają w prawie ubezpieczeniowym. Koszty wydatkowane przez ubezpieczonego w związku z zaistniałym wypadkiem, dotyczące zarówno szkody na osobie, jak i szkody na mieniu, mogą stanowić odrębny przedmiot ubezpieczenia. Wskazać tu można na różnego rodzaju ubezpieczenia assistance, ubezpieczenie kosztów leczenia oraz ubezpieczenie kosztów pomocy prawnej. Zagadnienia te będą omawiane w ostatnim rozdziale pracy dotyczącym dopuszczalności naprawienia przez ubezpieczyciela szkody w drodze restytucji naturalnej.

Po szóste, inaczej przedstawia się kwestia ciężaru dowodu w zakresie szkody i jej wysokości. W ogólnym prawie odszkodowawczym udo-

46 W. Warkałło, Ubezpieczenie a odpowiedzialność..., s. 127; W. Warkałło, Zasada odszkodowania..., s. 429; W. Warkałło, Ubezpieczenie utraconych korzyści..., s. 56; E. Kowalewski, Odszkodowanie ubezpieczeniowe za utracone korzyści, s. 49; M. Kaliński, Zasada odszkodowania w ubezpieczeniach gospodarczych, cz. 2, PA 2002/2, s. 37, 42-43. 
wodnienie wysokości szkody należy do poszkodowanego. W ubezpieczeniach ustalenie wysokości szkody wymaga reguł szczegółowych i zróżnicowanych według przedmiotu ubezpieczenia. W zasadzie wysokość szkody ustala zakład ubezpieczeń w ramach postępowania likwidacyjnego, bazując na danych uzyskanych od ubezpieczonego. Często szkoda nie jest dokumentowana bezpośrednio przez ubezpieczonego ani nawet określana przez samego ubezpieczyciela, ale ustalana przez osoby trzecie (w szczególności przez profesjonalnych rzeczoznawców).

Po siódme, w doktrynie twierdzi się również, że badając wysokość szkody na zasadach ogólnych, należy brać pod uwagę wartość szczególnej użyteczności rzeczy dla poszkodowanego (premium singulare) - ustalając szkodę według kryteriów subiektywnych, podczas gdy w prawie ubezpieczeniowym decydująca jest zwykła wartość rynkowa (premium commune) - szkodę należy ustalać według kryteriów obiektywnych. Raz jeszcze przyczyną takiego stanu rzeczy na gruncie ubezpieczeń ma być zlokalizowanie szkody w konkretnej rzeczy stanowiącej przedmiot ubezpieczenia $^{47}$.

Pomimo przedstawionych różnic W. Warkałła stawia tezę, że pojęciowo szkoda w prawie ubezpieczeniowym i prawie zobowiązań jest identyczna. Różnice dotyczą raczej zakresu szkody podlegającej naprawieniu, innymi słowy, wysokości odszkodowania należnego według ogólnych reguł odpowiedzialności i według prawa ubezpieczeniowego ${ }^{48}$. Odnosząc się do pierwszych trzech przykładów, można zauważyć, że szkoda wyrządzona samemu sobie albo wynikająca z klęski żywiołowej jest szkodą również na gruncie ogólnego prawa zobowiązań, tyle że w prawie zobowiązań nie podlega naprawieniu, podobnie jak szkoda objęta franszyzą integralną lub udziałem własnym jest szkodą na gruncie ubezpieczeń, tyle że nie podlega naprawieniu zgodnie $\mathrm{z}$ warunkami ubezpieczenia.

47 Zob. m.in. A. Szpunar, Odszkodowanie..., s. 60-61; A. Wąsiewicz, Ustalenie wysokości szkody i odszkodowania w ubezpieczeniu pojazdów samochodowych autocasco, Pal. 1973/12, s. 39; E. Kowalewski, Odszkodowanie ubezpieczeniowe za utracone korzyści, s. 50.

48 W. Warkałło, Ubezpieczenie a odpowiedzialność..., s. 130. 
To samo dotyczy różnicy czwartej, mającej polegać na nieobjęciu odszkodowaniem ubezpieczeniowym utraconych zysków (lucrum cessans). Tradycyjny pogląd mówiący, że odszkodowanie ubezpieczeniowe przede wszystkim z uwagi na zasadę lokalizacji szkody nie obejmuje utraconych zysków, chyba że zostały one odrębnie ubezpieczone, bywa kontestowany jako niewynikający z przepisów ustawowych. Według M. Kalińskiego i M. Krajewskiego utracone zyski podlegają naprawieniu, chyba że ogólne warunki ubezpieczenia stanowią inaczej ${ }^{49}$. Oczywiście zwykle suma ubezpieczenia obejmuje jedynie wartość ubezpieczonej rzeczy, a OWU wyraźnie wyłączają utracone zyski z zakresu odszkodowania. Nie wynika stąd jednak zasada dogmatyczna, że odszkodowanie ubezpieczeniowe nie obejmuje lucrum cessans. Wszystko zależy od przedmiotu ubezpieczenia oraz uregulowań konkretnej umowy i OWU. Pogląd ten wymaga głębszej analizy, która zostanie przeprowadzona w związku z omawianiem teorii lokalizacji szkody.

Odnośnie do przykładu piątego, W. Warkałło konsekwentnie wyróżnia wydatki, nakłady i koszty jako odrębny od efektywnie poniesionej straty (damnum emergens) oraz utraconych zysków (lucrum cessans) składnik odszkodowania na ogólnych zasadach i jednocześnie podkreśla istotność tej pozycji w ubezpieczeniach. Na wydatki jako składnik szkody wskazuje się przede wszystkim w kontekście omówionej wcześniej cechy szkody, polegającej na powstaniu szkody wbrew woli poszkodowanego. Biorąc pod uwagę teorię różnicy oraz treść art. $361 \$ 2$ k.c., który wymienia jedynie dwa składniki szkody, wydaje się jednak, że wydatki poniesione w związku z zaistniałym zdarzeniem szkodzącym należy kwalifikować jako szkodę efektywnie poniesioną (damnum emergens).

Wyróżnienie wydatków jako odrębnego składnika odszkodowania ubezpieczeniowego ma znaczenie przede wszystkim, gdy chodzi o szczególne wydatki mające na celu zapobieżenie powstaniu szkody lub zwiększeniu się jej zakresu, które nie zawsze będą podlegać indemnizacji na ogólnych zasadach. Artykuł 826 k.c. nakłada na ubezpieczającego obowiązek ratowania przedmiotu ubezpieczenia oraz zapobieżenia szkodzie

49 M. Kaliński, Zasada..., cz. 2, s. 37, 42-43; M. Krajewski, Umowa ubezpieczenia. Art. 805-834 KC..., 2016, s. 563-565. 
i zmniejszenia jej rozmiarów, zobowiązując jednocześnie ubezpieczyciela do zwrotu w granicach sumy ubezpieczenia kosztów wynikłych z zastosowania celowych środków, zmierzających do wykonania tego obowiązku, choćby środki te okazały się bezskuteczne. Prawo ubezpieczeń zna jeszcze inne przypadki objęcia ochroną wydatków. Wskazać można w szczególności ubezpieczenia ochrony prawnej oraz ubezpieczenia assistance. Objęcie ubezpieczeniem wydatków wymaga jednak szczególnego przepisu ustawy albo umowy ubezpieczenia. W tym zakresie można ewentualnie upatrywać trzeciej korekty pojęcia szkody w porównaniu do ogólnych zasad prawa cywilnego. W istocie jednak różnica ta, podobnie jak różnica dotycząca lucrum cessans, jest pochodną teorii lokalizacji szkody. Kwestie te również zostaną omówione dalej. Koszty ratowania jako składnik odszkodowania ubezpieczeniowego będą przedmiotem bardziej pogłębionych rozważań w rozdziale dotyczącym sposobu ustalania tego odszkodowania. Ubezpieczenia assistance oraz ochrony prawnej zostaną natomiast poddane szerszej analizie $\mathrm{w}$ ostatnim rozdziale dotyczącym naprawienia przez ubezpieczyciela szkody w drodze restytucji naturalnej.

Kwestii szóstej, to jest powinności ustalenia szkody przez ubezpieczyciela, nie należy moim zdaniem przeceniać. Nie sposób kwestionować obowiązku aktywności ubezpieczyciela w postępowaniu likwidacyjnym $^{50}$, wskazać jednak trzeba, że ubezpieczyciel będzie ustalał wysokość szkody przede wszystkim na podstawie dowodów przedstawionych przez ubezpieczającego. Pomijając zaangażowanie rzeczoznawców, jeżeli ubezpieczający dowodów nie przedstawi, ubezpieczyciel ma prawo uznać szkodę z nieudowodnioną. Dodać można, że w obecnych realiach społeczno-gospodarczych jest oczywiste, że ubezpieczyciele działają dla zysku, nie zaś w interesie ogólnospołecznym, więc nieudowodnienie wysokości szkody leży w interesie ubezpieczyciela. W ewentualnym procesie, który wymagał będzie od ubezpieczającego nakładów finansowych, ciężar udowodnienia szkody spocznie właśnie na nim.

50 Por. S. Byczko, Proces likwidacji szkody w kontekście świadczenia ubezpieczyciela [w:] Kierunki rozwoju ubezpieczeń gospodarczych $w$ Polsce. Wybrane zagadnienia prawne, red. B. Gnela, M. Szaraniec, Warszawa 2013, s. 175 i 178. 
Ostatnia różnica polegająca na ustalaniu szkody w prawie ubezpieczeń przy uwzględnieniu pretium commune zamiast pretium singulare znów polega $\mathrm{w}$ istocie na ustaleniu zakresu odszkodowania, nie zaś na określeniu desygnatów samego pojęcia szkody. Nadto należy zwrócić uwagę, że także na gruncie ogólnych reguł prawa cywilnego różnica między wartością rynkową i wartością szczególnej użyteczności często się zaciera, natomiast stosowana terminologia - kryteria subiektywne (pretium singulare) oraz kryteria obiektywne (pretium commune) - jest w istocie sprawą konwencji językowej wywodzącej się z tradycji prawa rzymskiego. W zasadzie konsekwentne stosowanie teorii różnicy prowadzi do wniosku, że jeżeli tylko istnieje rynek, wedle którego można w miarę precyzyjnie ustalić wartość konkretnej rzeczy, decydujące znaczenie powinna mieć wartość szkody poniesionej wskutek utraty rzeczy przy uwzględnieniu specyfiki konkretnego rynku oraz relacji uszczerbku do całego majątku poszkodowanego. Ustalanie szkody przy uwzględnianiu tzw. pretium singulare nie odbywa się zatem wcale przy uwzględnieniu kryteriów subiektywnych ${ }^{51}$.

Podawane zwykle przykłady mające na celu przedstawienie różnicy między pretium singulare a pretium commune dotyczą utraty lub zniszczenia elementu pewnego zbioru, np. kolekcji znaczków lub filiżanki z zabytkowego serwisu oraz rzeczy, które posiadają cechy mające znaczenie dla konkretnej osoby, niemające natomiast takiego znaczenia dla innych osób, np. psa przewodnika osoby niewidomej. Poddanie tych przykładów analizie wskazuje w moim przekonaniu, że generalny pogląd o odrzuceniu na gruncie prawa ubezpieczeń pretium singulare jest niewłaściwy. W rzeczywistości raz jeszcze wszystko zależy od przedmiotu ubezpieczenia oraz jego warunków, przy czym w braku wyraźnych zastrzeżeń decydująca powinna być wartość szczególnej użyteczności dla ubezpieczonego.

Zaczynając od przykładu kolekcji znaczków, jeżeli przedmiotem ubezpieczenia jest sama kolekcja i zaginięcie lub zniszczenie jednego ze znaczków obniża jej wartość, odszkodowanie ubezpieczeniowe w braku odmiennych zastrzeżeń powinno obejmować zmniejszenie wartości ca-

51 Zwraca na to uwagę M. Kaliński, Szkoda..., s. 424-427. 
łej kolekcji. Podobnie rzecz przedstawia się, gdy ubezpieczenie obejmuje ruchomości domowe. Zniszczenie jednego znaczka wpływa na wartość kolekcji i również nie ma powodów, dla których odszkodowanie miałoby zostać ograniczone tylko do wartości skradzionego lub zniszczonego znaczka. Jedynie w wyjątkowej sytuacji, gdy przedmiotem ubezpieczenia będzie właśnie konkretny znaczek, teoria lokalizacji szkody nakazuje ograniczyć odszkodowanie do wartości rynkowej samego znaczka ${ }^{52}$.

W przykładzie psa przewodnika osoby niewidomej sytuacja przedstawia się analogicznie, a nawet jeszcze wyraźniej wskazuje na konieczność uwzględniania pretium singulare przy ustalaniu szkody w prawie ubezpieczeniowym. Nawet jeżeli przedmiotem ubezpieczenia jest sam pies, którego w tym wypadku należy traktować podobnie jak rzecz, a suma ubezpieczenia jest odpowiednio wysoka, utrata psa wywołuje dla niewidomego szkodę, która nie ogranicza się do wartości psa podobnej rasy i w podobnym wieku, ale obejmuje również koszty odpowiedniego przeszkolenia drugiego psa. Sytuacja przedstawia się podobnie jak przy ubezpieczeniu samochodu. Kradzież lub zniszczenie samochodu posiadającego szczególne dodatkowe wyposażenie wywołuje szkodę bardziej dotkliwą niż kradzież samochodu posiadającego wyposażenie standardowe. Do psa przewodnika osoby niewidomej najłatwiej porównać samochód przystosowany w specjalny sposób dla osoby niepełnosprawnej. W razie utraty samochodu przez taką osobę odszkodowanie ubezpieczeniowe, $w$ braku odmiennych ustaleń, powinno obejmować nie tylko wartość samochodu podobnego typu, ale również koszt przystosowania samochodu dla jej potrzeb. Sprawa sprowadza się w istocie do ustalenia sumy ubezpieczenia na odpowiednim poziomie.

Powyższe uwagi pozwalają w moim przekonaniu stwierdzić, że szkoda na gruncie prawa ubezpieczeń nie różni się od szkody w ogólnym prawie ubezpieczeniowym również co do kwestii, czy należy brać pod uwagę pretium singulare, czy pretium commune. Podkreślić należy zresztą, że podobnie jak w innych przypadkach ewentualna różnica w tym zakresie nie byłaby w istocie różnicą dotyczącą samego pojęcia szkody, ale jedynie różnicą dotyczącą sposobu ustalania odszkodowania. Nawet jeżeli

${ }^{52}$ Por. uwagi M. Kalińskiego, Zasada..., s. 39-40. 
umowa lub ogólne warunki ubezpieczenia ograniczałyby wartość odszkodowania do zwykłej wartości psa podobnej rasy lub standardowego samochodu podobnego typu, koszty odpowiedniego przeszkolenia psa lub doposażenia samochodu wciąż stanowiłyby szkodę, tyle tylko, że na mocy uzgodnień umownych szkoda w tym zakresie nie podlegałaby naprawieniu. Uwzględnienie pretium singulare byłoby wyłączone wtedy, gdyby opierało się na porównaniu całego stanu majątku ubezpieczonego sprzed i po zajściu wypadku, zamiast na porównaniu stanu mienia objętego ubezpieczeniem. Metoda dyferencyjna musi zatem w ubezpieczeniu mienia zostać ograniczona do objętego ubezpieczeniem interesu ${ }^{53}$.

Podsumowując, wydaje się, że rozważania dotyczące różnic w zakresie pojęcia szkody na gruncie ogólnego prawa zobowiązań oraz prawa ubezpieczeniowego nie prowadzą do konstruktywnych wniosków. Jak wskazano, pojęcie szkody jest jedno, inną zaś kwestię stanowi zakres obowiązku odszkodowawczego. Podkreśla to m.in. B. Lewaszkiewicz-Petrykowska, stwierdzając, że spory dotyczące zakresu pojęcia szkody nie mają większego praktycznego znaczenia. Punkt ciężkości leży bowiem w pytaniu, jaka szkoda podlega wyrównaniu ${ }^{54}$. Istota rzeczy sprowadza się do tego, że ubezpieczenie majątkowe jako instytucja prawna jest umową, na mocy której ubezpieczyciel zobowiązuje się naprawić szkodę doznaną przez ubezpieczonego na skutek oznaczonego w umowie wypadku. Zgodnie z art. 361 k.c. naprawienie szkody obejmuje poniesione straty i utracone zyski, o ile z ustawy lub umowy nie wynika nic innego. Umowa ubezpieczenia może zatem kształtować zakres obowiązku odszkodowawczego w zasadzie dowolnie, byleby jej treści nie sprzeciwiały się właściwości (naturze) stosunku prawnego ubezpieczenia, ustawie ani zasadom współżycia społecznego (art. $353^{1}$ k.c.).

W takim duchu wypowiedział się Sąd Najwyższy w uchwale z 18.03.1994 r., III CZP 25/9455. Według uzasadnienia tego wyroku:

53 Por. M. Kaliński, Zasada..., cz. 2, s. 40.

54 B. Lewaszkiewicz-Petrykowska, Zasada pełnego odszkodowania (mity i rzeczywistość) [w:] Rozprawy prawnicze. Księga pamiątkowa Profesora Maksymiliana Pazdana, red. L. Ogiegło, W. Popiołek, M. Szpunar, Kraków 2005, s. 1071.

${ }_{55}$ OSNC 1994/10, poz. 188. 
„Nie ma różnic pojęciowych pomiędzy szkodą w rozumieniu przepisów prawa ubezpieczeniowego a ogólnymi przepisami prawa zobowiązaniowego, gdyż w obu wypadkach chodzi bądź to o utratę lub zmniejszenie aktywów, bądź też o powstanie lub zwiększenie pasywów osoby poszkodowanej. Ze względu jednak na to, że w prawie ubezpieczeniowym mamy do czynienia z przejęciem przez zakład ubezpieczeń ciężaru wyrównania ściśle określonej szkody na zasadach wskazanych w warunkach ubezpieczenia, a nie z naprawieniem przez sprawcę szkody doznanej przez poszkodowanego, zachodzą pewne rozbieżności, w szczególności wtedy gdy chodzi o zakres szkody podlegającej naprawie. Ta pojęciowa identyczność szkody w prawie ubezpieczeniowym i w ogólnych przepisach prawa zobowiązań powoduje, że ustalając - w kontekście konkretnego ubezpieczenia - szkodę, można się kierować zasadami ogólnymi prawa odszkodowawczego".

Odwołując się raz jeszcze do obrazowego stwierdzenia A. Szpunara, można skonstatować, że rdzeń pojęcia szkody w ubezpieczeniu mienia wyznaczają ogólne zasady prawa cywilnego. Gdy chodzi natomiast o zamazujące się kontury, prima facie widoczne są dwie korekty. Określając uszczerbek w prawie cywilnym, należy uwzględnić zgodnie z teorią różnicy całokształt stosunków majątkowych poszkodowanego. W prawie ubezpieczeniowym właściwsze jest konkretne ujęcie szkody określonej jako naruszenie interesu majątkowego będącego przedmiotem ubezpieczenia. Odszkodowanie stanowi zatem surogat konkretnego objętego ubezpieczeniem interesu ubezpieczonego. Nie oznacza to jednak, by przyjęta w prawie cywilnym teoria różnicy zawodziła w ubezpieczeniach, gdzie przedmiotem ochrony jest konkretne dobro lub interes objęty ubezpieczeniem zamiast ogólnej sfery majątkowej ubezpieczonego. Teoria ta będzie stosowana, tyle że w odniesieniu do interesu objętego ubezpieczeniem, zamiast do całej sfery majątkowej ubezpieczającego ${ }^{56}$.

Druga korekta w zakresie konturów szkody ubezpieczeniowej zdaje się, jak już wskazano, przebiegać w przeciwnym kierunku, rozszerzając zakres szkody podlegającej kompensacie w ubezpieczeniach w porów-

56 Por. uwagi A. Szpunara dotyczące konkretnego ujęcia szkody. A. Szpunar, Ustalenie odszkodowania w prawie..., s. 39-40. 
naniu do zasad prawa cywilnego. Wynika ona z art. 821 k.c., który pozwala objąć ubezpieczeniem każdy interes majątkowy, byle był zgodny $\mathrm{z}$ prawem oraz dawał się wycenić w pieniądzu, co zdaje się stanowić różnicę w porównaniu do ogólnych zasad prawa cywilnego odnoszących szkodę do naruszenia interesu prawnego, nie zaś czysto gospodarczego. Pytanie o zakres owych korekt stanowi przedmiot dalszych rozważań.

\subsubsection{Teoria lokalizacji szkody}

Zgodnie z poglądem wyrażonym przez W. Warkałłę oraz powtarzanym w polskiej literaturze zasadnicza cecha odróżniająca odszkodowanie ubezpieczeniowe od odszkodowania na zasadach ogólnych polega na tym, że szkoda, za którą odpowiada ubezpieczyciel, jest zlokalizowana w określonym przedmiocie ubezpieczenia ${ }^{57}$. Koncepcja ta, zwana teorią lokalizacji szkody, została sformułowana na gruncie dawnego art. 821 k.c., zakładającego zdaniem niektórych, że przedmiot ubezpieczenia mogły stanowić wyłącznie rzeczy materialne. Teoria lokalizacji szkody dotyczyć miała w szczególności ubezpieczeń rzeczowych i zakładała, że odszkodowanie za konkretną rzecz będącą przedmiotem ubezpieczenia nie może przekraczać wartości tej rzeczy. Od strony negatywnej uzasadniało ją stwierdzenie, że celem odszkodowania ubezpieczeniowego jest zrekompensowanie utraty lub zniszczenia konkretnej rzeczy, nie zaś wyrównanie całego uszczerbku w majątku właściciela, np. szkód pośrednich wynikłych z utraty lub zniszczenia tej rzeczy ${ }^{58}$.

Oczywiście można doszukiwać się pewnych analogii między omawianym ograniczeniem odszkodowania ubezpieczeniowego a ograniczeniami odszkodowania w ogólnym prawie cywilnym. Wskazać można w szczególności, że odszkodowanie należne od przewoźnika oraz spedytora limitowane jest zwykłą wartością przesyłki (art. $788 \$ 1$ i art. 801 $\$ 1$ k.c.). Inną kwestią jest przychodzący również na myśl, a wynikający z odróżnienia długu oraz odpowiedzialności, związek między granica-

57 W. Warkałło [w:] Ubezpieczenia majątkowe. Ochrona ubezpieczeniowa mienia społecznego, red. W. Warkałło, Warszawa 1971, s. 168-169.

58 W. Warkałło, Prawo ubezpieczeniowe, Warszawa 1974, s. 71-72. 
mi obowiązku odszkodowawczego oraz granicami odpowiedzialności. Ograniczenie odpowiedzialności do oznaczonych rzeczy (odpowiedzialność ograniczona rzeczowo), do pewnej masy majątkowej (odpowiedzialność ograniczona cum viribus patrimonii) lub do pewnej oznaczonej liczbowo wysokości (odpowiedzialność ograniczona pro viribus patrimonii), a więc ograniczenie tego, czym dłużnik odpowiada, bądź tego, do jakiej kwoty odpowiada, nie pozostaje oczywiście bez wpływu na realność czy zakres stosowalności zasady pełnego odszkodowania ${ }^{59}$.

Pozostawiając powyższe rzeczywiste i pozorne analogie, na uboczu należy zastanowić się, czy zmiana art. 821 k.c. oraz zastąpienie teorii majątku teorią interesu nie dezaktualizuje teorii lokalizacji szkody. W pierwszej kolejności trzeba wskazać, że twierdzenie jakoby przedmiot ubezpieczenia stanowiła konkretna rzecz, stanowił uproszczenie również na gruncie teorii majątku ${ }^{60}$. Zgodnie z art. 821 k.c. przed zmianą z 2007 r. przedmiotem ubezpieczenia mogło być mienie, czyli własność oraz inne prawa majątkowe. W orzecznictwie dostrzegano przy tym różnicę między interesem właściciela rzeczy oraz interesami osób trzecich, którym służyły określone prawa w stosunku do cudzej rzeczy ${ }^{61}$. Obserwacja, że prawo ma określony substrat, zwykle w postaci rzeczy materialnej, nie upoważniała do utożsamiania przedmiotu ubezpieczenia $z$ tymże substratem. Uściślając, przed zmianą art. 821 k.c. przedmiotem ubezpieczenia były prawa mające określony substrat, zwykle rzeczowy, podobnie jak obecnie przedmiot stanowi interes majątkowy, który nie musi mieć odpowiednika w postaci prawa, ale również ma określony substrat, ujmując rzecz obrazowo: nie może być zupełnie zawieszony w próżni ${ }^{62}$.

Powyższa uwaga wskazuje, że teoria lokalizacji szkody wiąże się ze skoncentrowaniem szkody w określonym prawie lub interesie i tak ujmowana wydaje się wciąż aktualna. Jeżeli przedmiotem ubezpieczenia jest przykładowo interes właściciela samochodu, wartość i suma ubezpieczenia odpowiadać będą co do zasady rzeczywistej wartości samochodu

\footnotetext{
59 W. Warkałło, Odpowiedzialność..., s. 139-140.

60 B. Kucharski, Przeniesienie..., s. 176-177.

61 Uchwała SN z 30.11.2005 r., III CZP 96/05, OSNCP 2006/10, poz. 164.

62 Szerzej co do interesu S. Byczko, Interes..., s. 208-209.
} 
stanowiącego substrat prawa własności. Jeżeli natomiast przedmiotem ubezpieczenia jest interes pożyczkodawcy lub kredytodawcy związany z ryzykiem niespłacenia długu w terminie, wartość i suma ubezpieczenia odpowiadać będą co do zasady wartości pożyczki lub kredytu wraz $\mathrm{z}$ oprocentowaniem. Kwestie związane $\mathrm{z}$ wartością ubezpieczenia oraz sumą ubezpieczenia zostaną omówione dalej. Uprzedzając tok dalszych rozważań, należy zaznaczyć, że odszkodowanie ubezpieczeniowe nie może co do zasady przekraczać sumy ubezpieczenia ani wartości przedmiotu ubezpieczenia, niezależnie od tego, jak kształtują się relacje między nimi.

Odnosząc się do przytoczonych przykładów, właściciel uszkodzonego samochodu może ponieść wydatki związane z jego holowaniem oraz utracić zyski osiągane przy użyciu samochodu, natomiast pożyczkodawca, który nie odzyskał pożyczonej kwoty w terminie spłaty, może utracić zyski, jakie mógłby osiągnąć, gdyby oddaną mu na czas kwotę zainwestował. Przykłady te unaoczniają problem objęcia odszkodowaniem ubezpieczeniowym wydatków oraz nakładów pośrednio związanych z realizacją ryzyka ubezpieczeniowego, przede wszystkim zaś objęcia tym odszkodowaniem utraconych zysków. Jak wskazano wyżej, zwykle przyjmuje się, że odszkodowanie ubezpieczeniowe nie obejmuje lucrum cessans, a wyłączenie to jest prostą konsekwencją teorii lokalizacji szkody ${ }^{63}$.

Uzasadnienia poglądu zawężającego zakres odszkodowania ubezpieczeniowego do damnum emergens poszukuje się również w art. $805 \$ 2$ k.c., według którego świadczenie ubezpieczeniowe polega w szczególności na zapłacie określonego odszkodowania, a więc odszkodowania, którego zakres wyznacza umowa lub OWU ${ }^{64}$. Eugeniusz Kowalewski powołuje również art. $824 \$ 3$ k.c. wprowadzający możliwość żądania zmiany wysokości składki w razie obniżenia wartości ubezpieczonego mienia

63 Podobne stanowisko jest przyjmowane również w obcych porządkach prawnych. Por. M. Wandt, Versicherungsrecht, s. 299. W prawie francuskim zasadę tę wyraża art. 121-1 Code des assurances rozpoczynający tytuł II o ubezpieczeniu szkodowym. Zob. również: Y. Lambert-Faivre, L. Leveneur, Droit des assurances, Paris 2011, s. 407.

${ }^{64}$ W. Warkałło, Ubezpieczenie utraconych korzyści..., s. 72; W. Warkałło, Zasada..., s. 428 . 
po zawarciu umowy i argumentuje, że z przytoczonej reguły wynika bezwzględne ograniczenie wartości odszkodowania ubezpieczeniowego do wartości ubezpieczonego mienia, a tym samym wyłączenie utraconych zysków z zakresu odszkodowania ubezpieczeniowego ${ }^{65}$.

Oczywiście nikt nie kwestionuje możliwości objęcia odszkodowaniem ubezpieczeniowym utraconych zysków, wskazuje się jednak na konieczność zawarcia odrębnej umowy ubezpieczenia. Używając jeszcze jednego przykładu - czym innym jest ubezpieczenie maszyn stanowiących składniki zakładu produkcyjnego od zniszczenia na skutek pożaru, czym innym zaś ubezpieczenie przedsiębiorcy od utraty zysków związanych z przestojem zakładu wywołanego spaleniem maszyn. Pogląd o nieobjęciu odszkodowaniem ubezpieczeniowym utraconych zysków przyjmowany w doktrynie dosyć powszechnie ${ }^{66}$, został jednak zakwestionowany przez M. Kalińskiego oraz M. Krajewskiego. Argumentację wskazanych autorów wypada przeanalizować.

Maciej Kaliński kontestuje tradycyjne stanowisko, wedle którego wartość przedmiotu ubezpieczenia determinuje górną granicę należnego poszkodowanemu odszkodowania, w związku z czym nawet w wypadku szkody całkowitej nie jest możliwe objęcie tym odszkodowaniem lucrum cessans. Cytowany autor twierdzi, że suma ubezpieczenia przekraczać może wartość ubezpieczonego mienia i w takim wypadku nic nie stoi na przeszkodzie, by odszkodowanie ubezpieczeniowe objęło utratę korzyści, które poszkodowany mógłby osiągnąć, gdyby ubezpieczone mienie nie uległo wypadkowi ubezpieczeniowemu. Zdaniem M. Kalińskiego w omawianej sytuacji nie dochodzi do nadubezpieczenia, chyba że z postanowień umowy ubezpieczania lub OWU wynika wyraźnie, że odszkodowanie nie obejmuje utraconych zysków.

65 E. Kowalewski, Odszkodowanie ubezpieczeniowe za utracone korzyści, s. 49-50.

66 Np. W. Warkałło, Ubezpieczenie a odpowiedzialność..., s. 127; A. Wąsiewicz, Z.K. Nowakowski, Prawo..., s. 51-52; A. Wąsiewicz, Ubezpieczenia..., s. 144; E. Kowalewski, Odszkodowanie ubezpieczeniowe za utracone korzyści, passim; M. Orlicki [w:] System Prawa Prywatnego, red. Z. Radwański, t. 8, Prawo zobowiązań - część szczegółowa, red. J. Panowicz-Lipska, Warszawa 2011, s. 178, 723; S. Reps, J. Reps, Ubezpieczenia majątkowe przedsiębiorców, s. 159-160; S. Byczko, Interes..., s. 247. 
Cytowany autor powołuje również art. $361 \S 2$ k.c., który w braku odmiennego przepisu ustawy albo umowy stron obejmuje zakresem obowiązku odszkodowawczego zarówno straty, które poszkodowany poniósł, jak i korzyści, które mógł osiągnąć, gdyby mu szkody nie wyrządzono. Jego zdaniem obecnie brak jest przepisów wykluczających zastosowanie w ubezpieczeniach ogólnej reguły wyrażającej pozytywny aspekt zasady odszkodowania. Nie można również mówić o istnieniu takich cech konstrukcyjnych odszkodowania ubezpieczeniowego, które przesądzałyby o jego odmiennym charakterze w porównaniu z art. 361 i n. k.c. Pojęciu odszkodowania nie należy zatem przypisywać w prawie ubezpieczeniowym innego znaczenia, jedynie zakres skutków szkodowych, za które odpowiada ubezpieczyciel, może zostać ograniczony na mocy umowy lub OWU. To ostatnie zastrzeżenie wynika z natury gospodarczej ubezpieczenia oraz działalności ubezpieczeniowej, która prowadzona jest dla zysku. W braku odmiennych postanowień zastosowanie znajdują więc ogólne zasady z art. 361 i 363 k.c. ${ }^{67}$

Podobną argumentację przytacza M. Krajewski, twierdząc, że z dyspozytywnego charakteru art. $361 \$ 2$ k.c. oraz powszechnie spotykanego wyłączenia utraconych zysków spod zakresu odszkodowania ubezpieczeniowego w umowie lub OWU nie wynika odwrócenie ogólnej reguły na gruncie ubezpieczeń. Płynące z art. $805 \$ 2$ k.c. upoważnienie do umownego określenia skutków odszkodowania ubezpieczeniowego nie oznacza, że w braku skorzystania z takiej możliwości przez strony nie znajdują zastosowania reguły ogólne. Odnosząc się do argumentacji E. Kowalewskiego dotyczącej art. 824 k.c., M. Krajewski wskazuje, że przepis ten można interpretować inaczej. Pierwsza $z$ alternatywnych wersji wykładni zakłada, że ustawodawca chciał objąć art. 824 k.c. jedynie najbardziej typowe przypadki, gdy umowa ogranicza odszkodowanie do wartości ubezpieczenia. Zgodnie z drugą wersją szkoda w postaci utraconych zysków pojawia się w praktyce znacznie rzadziej niż szkoda rzeczywista, w związku z czym wysokość sumy ubezpieczenia powinna być powiązana wyłącznie ze szkodą rzeczywistą. Możliwe jest jednak zachowanie pewnego marginesu obejmującego lucrum cessans.

${ }^{67}$ M. Kaliński, Zasada..., cz. 2, s. 36-38. 
Przedstawione wyżej rozumowanie zwolenników objęcia odszkodowaniem ubezpieczeniowym w ubezpieczeniu aktywów utraconych zysków nie przekonuje. Podejmowane przez nich próby wykazania, że w prawie ubezpieczeń powinny znajdować zastosowanie ogólne reguły dotyczące zakresu szkody podlegającej naprawieniu, w istocie abstrahują od teorii lokalizacji szkody. W sytuacji gdy umowa ani ogólne warunki ubezpieczenia nie wyłączają wyraźnie utraconych zysków z zakresu odszkodowania, zasadnicze znaczenie musi mieć wskazany w umowie przedmiot ubezpieczenia. Regułą jest, że przedmiot ten określony jest w nawiązaniu do rzeczy lub prawa stanowiącego substrat interesu majątkowego. Jeżeli umowa i OWU wyraźnie wskazują na korelacje między interesem ubezpieczeniowym oraz konkretną rzeczą lub prawem i nie odnoszą tego interesu do ogólnej sytuacji majątkowej ubezpieczającego, brak jest podstaw dla objęcia ubezpieczeniem utraconych zysków. Wydaje się, że sama istota ubezpieczenia majątkowego w powiązaniu z przepisami wskazującymi na zamierzony przez strony cel umowy jako kryterium przesądzającym o kierunku wykładni oświadczeń woli (art. $65 \$ 2$ k.c.) oraz sposobie wykonania zobowiązania (art. 354 k.c.) wykluczają przyjęcie, że ewentualna różnica między sumą ubezpieczenia a wartością ubezpieczenia ma obejmować utracone przez ubezpieczającego zyski.

Argumentacja M. Kalińskiego oraz M. Krajewskiego wydaje się nadto wewnętrznie sprzeczna. Ustawodawca nie definiuje pojęcia wartości ubezpieczenia, ale posługuje się nim w art. $824^{1}$ k.c., wskazując na korelację między wartością i sumą ubezpieczenia. Wyprzedzając nieco tok dalszych szczegółowych rozważań dotyczących wartości oraz sumy ubezpieczenia, wypada wskazać, że wartość ubezpieczenia odnosi się do przedmiotu ubezpieczenia, tj. do ubezpieczonego interesu. Ustawodawca nie jest w tej mierze zupełnie konsekwentny, w art. 821 k.c. definiuje bowiem przedmiot ubezpieczenia jako interes, natomiast w art. 824 k.c. mówi o zmniejszeniu się wartości ubezpieczonego mienia zamiast interesu. Niezależnie jednak od tej niekonsekwencji, teza M. Kalińskiego oraz M. Krajewskiego, wedle której margines między wartością ubezpieczenia oraz sumą ubezpieczenia w razie wątpliwości obejmuje utracone zyski, w związku z czym w opisanej sytuacji nie występuje nadubezpieczenie, prowadzi do stwierdzenia, że zakres ubezpieczenia wykracza 
poza jego przedmiot, tj. poza interes lub mienie, do którego odnosi się wartość ubezpieczenia.

Proponowana przez M. Krajewskiego wykładnia art. 824 k.c. zdaje się również pomijać okoliczność, że przepisy Kodeksu cywilnego o umowie ubezpieczenia mają z wyraźnymi zastrzeżeniami charakter bezwzględnie obowiązujący. Wykładnia celowościowa art. $824 \$ 2$ k.c. pozwalającego wystąpić z żądaniem obniżenia składki w razie obniżenia wartości ubezpieczonego mienia odnosi do przedmiotu ubezpieczenia i jego wartości nie tylko składkę, ale również świadczenie ubezpieczyciela. Dodatkowo twierdzenie, że margines między wysokością wartości ubezpieczenia oraz sumy ubezpieczenia w razie wątpliwości obejmuje utracone zyski, nie uwzględnia okoliczności, że wysokość utraconych zysków niejednokrotnie może być zbliżona do poniesionej przez ubezpieczającego szkody rzeczywistej albo nawet ją przekraczać. Trudno mówić o „pewnym marginesie” zamierzonym przez strony w sytuacji, gdy puste pole brzegowe ma zakres bliżej nieoznaczony i potencjalnie przekraczający zakres pola tekstowego.

Marcin Krajewski wskazuje też, że pomimo brzmienia art. 824 k.c. w doktrynie powszechnie przyjmuje się, że utracone korzyści są ubezpieczalne, z tym że dla objęcia tych korzyści ubezpieczeniem konieczne jest wyraźne postanowienie umowne. Nawiązując do tej tezy, wskazać trzeba, że pozostawienie w obecnym art. 824 k.c. sformułowania „mienie" wydaje się wynikać jedynie z braku staranności ustawodawcy, który wyraźnie postanowił w art. 821 k.c., że ubezpieczalne są także interesy niemające związku z istnieniem konkretnego prawa. Dla objęcia ubezpieczeniem interes musi jednak podlegać wycenie w pieniądzu, po to by dało się ustalić wartość i sumę ubezpieczenia. Przepis art. 824 k.c. pozwala oczywiście objąć ubezpieczeniem utracone zyski, ale tylko w takim zakresie, w jakim zyski te objęte są przedmiotem ubezpieczenia oraz jego wartością.

Dodatkowo załącznik do ustawy o działalności ubezpieczeniowej i reasekuracyjnej wymienia ubezpieczenie utraconego zysku w odrębnej grupie. Wśród ubezpieczeń majątkowych prawodawca wyróżnia:

- różnego rodzaju ubezpieczenia casco, 
- ubezpieczenia przedmiotów w transporcie,

- ubezpieczenia innych szkód rzeczowych, w tym szkód spowodowanych żywiołami,

- różnego rodzaju ubezpieczenia OC,

- ubezpieczenia kredytu,

- ubezpieczenia różnych ryzyk finansowych, w tym ubezpieczenia utraty zysku,

- ubezpieczenia ochrony prawnej,

- ubezpieczenia pomocy względem osób, które popadły w trudności w czasie podróży lub poza miejscem zamieszkania ${ }^{68}$.

Wydaje się, że nie byłoby potrzeby odrębnego wskazywania ubezpieczeń innych ryzyk finansowych, w tym utraconego zysku, gdyby utracony zysk oraz pozostałe wskazane tam przedmioty ubezpieczenia objęte były innymi rodzajami ubezpieczeń, w szczególności ubezpieczeniami casco oraz rzeczowymi.

Podsumowując, w moim przekonaniu teoria lokalizacji szkody w istocie prowadzi do stwierdzenia, że w braku szczególnych postanowień umownych utracony zysk nie jest objęty ubezpieczeniem. To samo dotyczy wydatków i nakładów pośrednio związanych z zajściem wypadku ubezpieczeniowego, które w świetle reguł ogólnych mogłyby być objęte szkodą rzeczywistą (damnum emergerns), a które W. Warkałło traktuje jako odrębny składnik szkody. W świetle teorii lokalizacji szkody trudno zatem zgodzić się ze stwierdzeniem M. Kalińskiego, że objęcie odszkodowaniem ubezpieczeniowym utraconych korzyści i nakładów dokonywanych przez ubezpieczającego powinno mieć miejsce w przypadku ubezpieczeń mienia jako zasada, a nie wyjątek wprowadzony do treści umowy mocą OWU lub woli stron.

Odnosząc się jeszcze do wydatków i nakładów, należy wskazać, że ubezpieczeniem objęte są jedynie te, które zmierzają do przywrócenia przedmiotu ubezpieczenia do stanu, który istniałby, gdyby wypadek ubezpieczeniowy nie zaszedł. Wracając do przytaczanych wcześniej przykładów, jeżeli przedmiotem ubezpieczenia jest własność samo-

68 Por. dział II załącznika do ustawy, grupy od 3 do 18. 
chodu, ubezpieczeniem objęta jest także utrata wartości handlowej tego samochodu ${ }^{69}$, ale nie są objęte wydatki poniesione na holowanie uszkodzonego samochodu oraz nocleg poza miejscem zamieszkania. Jeżeli zaś przedmiotem ubezpieczenia jest brak spłaty pożyczki, nie są objęte ubezpieczeniem ewentualne wydatki poniesione przez pożyczkodawcę $\mathrm{w}$ celu pozyskania pieniędzy potrzebnych w terminie spłaty pożyczki z innego źródła niż od pożyczkobiorcy.

Oczywiście strony mogą ubezpieczyć się również od ryzyka dodatkowych wydatków związanych przykładowo z uszkodzeniem ubezpieczonego samochodu albo od ryzyka dodatkowych wydatków spowodowanych brakiem spłaty pożyczki w terminie. Do objęcia ubezpieczeniem takich wydatków potrzebne będzie jednak dodatkowe zastrzeżenie umowne, a zwykle zawarcie po prostu dodatkowej umowy ubezpieczenia. Właśnie przytoczone względy zdecydowały o wskazaniu jako odrębnych rodzajów ubezpieczeń w załączniku do ustawy o działalności ubezpieczeniowej i reasekuracyjnej ubezpieczenia świadczenia pomocy na korzyść osób, które popadły w trudności w czasie podróży lub podczas nieobecności w miejscu zamieszkania, a także ubezpieczenia ryzyka różnych ryzyk finansowych, w tym stałych wydatków ogólnych, nieprzewidzianych wydatków handlowych, utraty stałego źródła dochodu itp.

\subsubsection{Uszczerbki niepodlegające naprawieniu w prawie cywilnym}

W związku z ujęciem szkody jako każdego uszczerbku majątkowego $\mathrm{w}$ dobrach prawnie chronionych oraz przedmiotu ubezpieczenia jako każdego interesu majątkowego, który nie jest sprzeczny z prawem, nasuwają się dodatkowe kwestie. Dotyczą one po pierwsze, objęcia pojęciem szkody ubezpieczeniowej efektywnie poniesionych uszczerbków w zakresie interesu niepodlegającego ochronie na gruncie prawa cywilnego (damnum illicitum), po drugie, utraty tzw. korzyści niezgodnych $\mathrm{z}$ prawem lub niegodziwych (lucrum inhonestum vel illicitum) oraz po

${ }^{69}$ Uchwała SN z 12.10.2001 r., III CZP 57/01, OSNC 2002/5, poz. 57, wraz z aprobującą glosą A. Szpunara, OSP 2002/5, poz. 61. 
trzecie, tzw. czystej szkody ekonomicznej (pure economic loss). Dwie pierwsze kwestie oraz trzecią można rozdzielić, wskazując z jednej strony na warunek zgodności interesu ubezpieczeniowego z prawem oraz $\mathrm{z}$ drugiej strony na oderwanie interesu ubezpieczeniowego od prawa podmiotowego przy jednoczesnym wprowadzeniu wymagania możności wyceny interesu $\mathrm{w}$ pieniądzu ${ }^{70}$.

Odnośnie do pierwszego zagadnienia już prima facie wydaje się, że nie powinno być większej różnicy między szkodą w prawie cywilnym i szkodą w prawie ubezpieczeniowym. Warunek zgodności interesu ubezpieczeniowego z prawem jest obecny w zasadzie we wszystkich systemach prawnych. W prawie polskim nie poddawano go szerszej analizie. Należy zgodzić się z E. Kowalewskim, że zgodność interesu ubezpieczeniowego z prawem należy rozumieć szeroko, a więc nie tylko jako jego zgodność z prawem cywilnym, administracyjnym, karnym itp., ale także z obowiązującymi zasadami współżycia społecznego. Cytowany autor jako niepodlegające ochronie wymienia przykładowo interesy pasera, handlarza narkotyków oraz osoby odnoszącej korzyści z prania brudnych pieniędzy ${ }^{71}$.

Najwięcej kontrowersji rodził warunek legalności interesu w odniesieniu do utraty posiadania niezgodnego z prawem. W okresie obowiązywania tzw. teorii mienia, tj. przed zmianą art. 821 k.c., Sąd Najwyższy stwierdzał, że nabywca skradzionego samochodu, który przed nastąpieniem zdarzenia wywołującego szkodę, stał się jego posiadaczem w złej wierze i nie powiadomił o tym zakładu ubezpieczeń, nie ma uprawnienia do świadczenia z umowy ubezpieczenia autocasco ${ }^{72}$. De lege lata uzasadnienie tego stanowiska jest nawet prostsze niż kiedyś właśnie z uwagi na warunek zgodności interesu z prawem ${ }^{73}$. Nie ma w tym zakresie różnicy między prawem ubezpieczeniowym a prawem cywilnym, gdzie samą

70 Zagadnienie związków kategorii interesu ubezpieczeniowego i prawa podmiotowego jest dosyć skomplikowane. Co do tej kwestii, zob. przede wszystkim: S. Byczko, Interes..., s. 213-229, oraz B. Kucharski, Przeniesienie..., s. 105-112.

71 E. Kowalewski, Wprowadzenie do teorii interesu..., s. 82.

72 Zob. przykładowo uchwała SN z 30.04.1993 r., III CZP 41/93, OSNC 1993/10, poz. 179.

73 Zob. S. Byczko, Interes..., s. 254. 
utratę niezgodnego z prawem posiadania trudno uznać za uszczerbek w dobrach prawnie chronionych. Bez znaczenia pozostaje okoliczność, że ochronie posesoryjnej na gruncie prawa cywilnego podlega również posiadanie wadliwe i bezprawne $e^{74}$.

Nieco inaczej kwestia przedstawia się w odniesieniu do utraty niezgodnego z prawem posiadania nieruchomości. Można wskazać przykład osoby, która ubezpieczyła od ognia i innych zdarzeń losowych zajmowany (bezprawnie) bez tytułu prawnego budynek. Dla uniknięcia zarzutu naruszenia obowiązku deklaracji wypada założyć, że ubezpieczyciel o tę kwestię nie pytał lub uznał ją za nieistotną. Wydaje się, że rację ma S. Byczko przeciwstawiający tę sytuację poprzedniej, dotyczącej posiadania ruchomości. Stan niezgodnego z prawem posiadania nieruchomości jest sankcjonowany przez ustawodawcę w art. $172 \$ 2$ k.c. i może prowadzić do nabycia własności w przeciwieństwie do sytuacji prawnej posiadacza ruchomości, która ogranicza się do obowiązku zwrotu rzeczy właścicielowi. Wadliwy posiadacz nieruchomości w złej wierze nie tylko traci możliwość korzystania ze spalonych budynków, ale również, w razie upływu terminu zasiedzenia, nabywa własność rzeczy o mniejszej wartości ${ }^{75}$. W tym zakresie jawi się już różnica w odniesieniu do prawa cywilnego, gdzie roszczenia odszkodowawcze posiadacza w złej wierze bywają kwestionowane, choćby do upływu terminu zasiedzenia pozostało niewiele czasu. Według M. Kalińskiego uszczerbek osoby wyzutej z posiadania nie może zostać objęty indemnizacją nawet w przypadkach, gdy osoba ta byłaby w stanie wykazać, że w braku zdarzenia szkodzącego $\mathrm{z}$ wysokim prawdopodobieństwem nabyłaby własność rzeczy ${ }^{76}$.

74 M. Kaliński, Szkoda..., s. 300 oraz powoływana tam literatura i orzecznictwo.

75 S. Byczko, Interes..., s. 255-256.

76 M. Kaliński, Szkoda..., s. 301. Podobnie T. Dybowski, Odszkodowanie za naruszenie posiadania, NP 1970/1, s. 10-11. Autor ten czyni wyjątek jedynie w odniesieniu do roszczeń posiadacza o zwrot dokonanych nakładów, na rzecz których mógłby dochodzić on względem właściciela i roszczeń posiadacza związanych z niemożnością uczynienia zadość roszczeniom właściciela o zwrot rzeczy. Szerszą możliwość indemnizacji naruszonego posiadania odnosi również do nieformalnego nabywcy nieruchomości, który ma jego zdaniem względem zbywcy prawo oczekiwać, że nikt nie będzie go niepokoił w niezakłóconym posiadaniu. Por. T. Dybowski, Odszkodowanie za naruszenie..., s. 15-19. 
Różnica jest jeszcze bardziej widoczna w stosunku do posiadacza w dobrej wierze. Na gruncie prawa ubezpieczeniowego po zmianie art. 821 k.c. nie ma przeszkód, by przyznać posiadaczowi ochronę. Jak wiadomo, Sąd Najwyższy przyznawał ją nabywcom skradzionych samochodów jeszcze przed zmianą przepisów, wywodząc, że ochronie podlega również posiadanie jako stan faktyczny. W doktrynie stanowisko to wzbudziło rozbieżne opinie. Niektórzy kwestionowali jego uzasadnienie, wskazując na możliwość ubezpieczenia ekspektatywy nabycia własności ${ }^{77}$, roszczeń z rękojmi lub z tytułu nienależytego wykonania umowy względem zbywcy ${ }^{78}$, inni zaś wskazywali, że stanowisko SN jest w ogóle nie do pogodzenia z art. 821 k.c., który przed zmianą pozwalał ubezpieczyć mienie, czyli własność lub inne prawa majątkowe, ale nie stany faktyczne ${ }^{79}$. Wydaje się, że argumenty sceptyków odpadają na skutek odejścia od tzw. teorii majątku na rzecz tzw. teorii interesu, chyba żeby warunek zgodności interesu z prawem charakteryzować jako możliwość ubezpieczenia wyłącznie interesu prawnego. Jednak przy takim ujęciu zmiana treści art. 821 k.c. jest pozbawiona jakiegokolwiek znaczenia ${ }^{80}$. Abstrahuję tu od kwestii związanych z obowiązkiem deklaracji oraz spotykanych w praktyce postanowień OWU, które zastrzegają, że przedmiotem ubezpieczenia jest interes właściciela. Nadmieniam przy tym, że posiadaczowi w dobrej wierze, który błędnie sądził, że jest właścicielem, nie można zarzucić zawinionego naruszenia obowiązku deklaracji (art. 815 k.c.).

Cytowany już M. Kaliński sprzeciwia się objęciu indemnizacją naruszenia substancji posiadanej rzeczy w przypadku zniszczenia, uszkodzenia lub zaboru także w sytuacji, gdy posiadanie jest zgodne z prawem i w dobrej wierze. Jego zdaniem ochrona posesoryjna ma charakter

77 J. Pazdan, Glosa do uchwały SN z 7.08.1992 r., III CZP 93/92, OSP 1993/9, poz. 180.

78 S. Byczko, Niektóre problemy prawne zwiąane z umowq ubezpieczenia auto-casco na tle orzecznictwa Sąu Najwyższego, Pal. 1995/9-10, s. 14.

79 Tak T. Komosa, J. Krauss, Glosa do uchwaty SN z 8.07.1992 r., III CZP 80/92, PPH 1992/2, s. 26 i W. Marek, Glosa do uchwaty SN z 31.03.1993 r., III CZP 1/93, PPH 1994/1, s. 23.

80 Tak jednak, nie przywiązując uwagi do dokonanej zmiany, M. Kaliński, Szkoda..., s. 302-303. Co do motywów zmiany, zob. M. Orlicki, J. Pokrzywniak, Umowa..., s. 94-95. Zob. też S. Byczko, Interes..., s. 67-75; B. Kucharski, Przeniesienie..., s. 97-112. 
tymczasowy, powództwo odszkodowawcze zmierza do gospodarczej restytucji w majątku poszkodowanego. $Z$ tego punktu widzenia wątpliwe staje się poszukiwanie elementu bezprawności wymaganej do powstania odpowiedzialności deliktowej na gruncie art. 415 k.c. w samym fakcie naruszenia posiadania. Według M. Kalińskiego nie ma znaczenia, czy zaboru lub uszkodzenia rzeczy stanowiącej przedmiot posiadania dokonał właściciel czy osoba trzecia. Rozróżnienie takie nie uwzględnia bowiem argumentu o konieczności dwukrotnej indemnizacji w sytuacji, gdyby z roszczeniem wystąpił najpierw posiadacz, a następnie właściciel ${ }^{81}$. Przytoczone poglądy uważam za wątpliwe przynajmniej w sytuacji, gdy nie wiadomo, gdzie jest właściciel, i nie istnieje ryzyko dwukrotnej indemnizacji. Słuszne wydają się poglądy, że sama utrata posiadania może być szkodą, przy czym naruszenie posiadania może uzasadniać roszczenia odszkodowawcze posiadacza przeciw każdemu z wyjątkiem uprawnionego (właściciela rzeczy) ${ }^{82}$. W sytuacji sporu między posiadaczem oraz właścicielem posiadacz zwykle nie będzie mógł również uzyskać odszkodowania ubezpieczeniowego wobec braku albo odpadnięcia interesu.

W odróżnieniu od kwestii utraty posiadania zagadnienie utraty nieuczciwych zysków nie budzi większych wątpliwości. Nie podlegają one ochronie zarówno na gruncie prawa cywilnego, jak i prawa ubezpieczeniowego. Dotyczyć to będzie przede wszystkim wynagrodzenia z pracy na czarno albo innych dochodów, które nie są przedstawione do opodatkowania. Zyski tego rodzaju nie są obejmowane odszkodowaniem cywilnym także w obcych porządkach prawnych ${ }^{83}$. Utracone dochody oczywiście mogą być objęte ubezpieczeniem. Nie wdając się na tym etapie w rozważania związane z teorią lokalizacji szkody, można wskazać, że załącznik do ustawy o działalności ubezpieczeniowej i reasekuracyjnej wyróżnia ubezpieczenia niewystarczającego dochodu, utraty

81 M. Kaliński, Szkoda..., s. 300-301.

82 Możliwość indemnizacji szkody poniesionej przez posiadacza dopuszczono zarówno w orzecznictwie, i to nie tylko w odniesieniu do samochodów dwukrotnie kradzionych (wyrok SN z 28.05.1975 r., III CRN 70/75, OSNC 1976/7-8, poz. 164), jak i w literaturze (J. Ignatowicz, Ochrona posiadania, Warszawa 1963, s. 163-165; A. Szpunar, Odszkodowanie..., s. 36-37; A. Sinkiewicz, Pojęcie..., s. 69).

83 Por. B. Lewaszkiewicz-Petrykowska, Zasada..., s. 1072-1073. 
zysków oraz utraty stałego źródła dochodu i odpowiednio zredagowana umowa może takie ryzyka uwzględniać. Nie dotyczy to jednak utraty zysków z działalności sprzecznej z prawem lub z zasadami współżycia społecznego. Do kwestii tej można odnieść ogólne rozważania czynione na gruncie prawa cywilnego ${ }^{84}, \mathrm{z}$ tym zastrzeżeniem, że w sytuacji, gdy ubezpieczyciel zgodził się objąć ubezpieczeniem zyski z określonej działalności, znając jej charakter, nie będzie mógł następnie powoływać się na sprzeczność z zasadami współżycia społecznego.

Trzecie postawione na wstępie zagadnienie wiąże się z możnością objęcia pojęciem szkody podlegającej naprawieniu tzw. szkody czysto majątkowej (pure economic loss). Jak wiadomo, pojęcie to pochodzi z prawa anglosaskiego i w ostatnim czasie stanowi jedno z ulubionych zagadnień komparatystów. W prawie anglosaskim szkodę czysto majątkową definiuje się zwykle jako szkodę niebędącą konsekwencją uszczerbku na osobie poszkodowanego ani zniszczenia lub uszkodzenia przedmiotu jego własności ${ }^{85}$. W innym ujęciu kładzie się nacisk na brak związku pure economic loss z naruszeniem praw absolutnych poszkodowanego, chronionych erga omnes lub z naruszeniem jakiegokolwiek służącego poszkodowanemu prawa podmiotowego ${ }^{86}$. Niektórzy wyraźnie rozróżniają te dwa ujęcia szkody czysto ekonomicznej, wskazując, że pierwsze nakierowane jest na samą szkodę (a ściślej na jej fizyczny aspekt), natomiast drugie na interes ${ }^{87}$. Na gruncie prawa anglosaskiego kwestia wiąże się bezpośrednio z tzw. regułą braku kompensaty (non recovery rule), mówiącą najogólniej, że szkoda czysto majątkowa nie podlega naprawieniu co do zasady, ale jedynie wyjątkowo ${ }^{88}$.

${ }_{84}$ B. Lewaszkiewicz-Petrykowska, Zasada..., s. 1072-1073; A. Szpunar, Odszkodowanie..., s. 73; M. Kaliński, Szkoda..., s. 281-284.

85 B. Lewaszkiewicz-Petrykowska, Zasada..., s. 1074; T. Pajor, Poland [w:] Pure Economic Loss: New Horizons in Comparative Law, red. V.V. Pamler, M. Bussani, New York 2008, s. 258.

${ }^{86}$ M. Kaliński, Szkoda..., s. 243-244; R. Strugała, Szkoda czysto majątkowa - analiza prawnoporównawcza i konceptualizacyjna w prawie polskim, KPP 2017/3, s. 586; M. Mikołajewicz, Problematyka pure economic loss ze szczególnym uwzględnieniem szkody wyrzadzonej przez adwokata, WU 2010/2, s. 88-89.

87 J. Szczerbowski, Szkoda czysto majątkowa w kontekście unifikacji prawa prywatnego w Europie, Olsztyn 2013, s. 20 i wskazana tam literatura.

88 M. Mikołajewicz, Problematyka..., s. 90-91; R. Strugała, Szkoda..., s. 591-592. 
Precedens w tym zakresie stanowi sprawa Spartan Steel \& Alloys Ltd v. Martin \& Co Ltd, w której na skutek niedbalstwa pracowników pozwanej spółki przy remoncie drogi doszło do przerwania kabla doprowadzającego do powodowej huty energię elektryczną. Spowodowało to przerwę w pracy maszyn oraz zniszczenie masy płynnego odlewu. Nadto powodowa huta nie mogła wykonać czterech dalszych odlewów. W związku z tym huta domagała się zwrotu wartości płynnego odlewu oraz zysków, jakie osiągnęłaby z jego sprzedaży, a nadto sumy zysku, jakiego została pozbawiona wskutek niemożności wykonania czterech dalszych odlewów. Sąd ostatecznie przyznał jedynie odszkodowanie za pierwszą część szkody. Co do utraty zysku wynikającego z niemożności wykonania dalszych czterech odlewów, Lord Denning stwierdził, że względy porządku publicznego oraz zdrowego rozsądku sprzeciwiają się naprawieniu tego typu szkód, które spotykać mogą wszystkich. Szkody takie z trudem poddają się weryfikacji, a dopuszczenie ich indemnizacji doprowadziłoby do zalewu roszczeń. Zamiast podnosić niepewne roszczenia, powód powinien więcej pracować w kolejnych dniach ${ }^{89}$.

Komparatyści dzielą europejskie systemy prawne na trzy grupy zależnie od skłonności do objęcia pure economic loss zakresem szkody podlegającej naprawieniu. Systemy germańskie (Niemcy, Austria, Szwajcaria) zaliczane są zwykle do systemów konserwatywnych - niechętnych naprawieniu szkody czysto majątkowej. W prawie niemieckim brak indemnizacji szkody czysto majątkowej wynika przede wszystkim z art. 823 $\$ 1$ BGB, według którego zobowiązanie do naprawienia szkody nie powstaje, jeżeli szkoda nie jest rezultatem bezprawnego naruszenia wartości wyższego rzędu lub praw. Wyjątki dopuszczające kompensatę dotyczą sytuacji, gdy działanie sprawcy było umyślne lub rażąco sprzeczne z zasadami współżycia społecznego, naprawienie szkody przewiduje przepis szczególny albo naprawienie szkody uzasadnia cel normy prawnej chroniącej osoby trzecie ${ }^{90}$. Na przeciwległym biegunie leżą systemy romańskie (przede wszystkim francuski i belgijski), gdzie poza regułą tzw. nieprzewidywalności brak jest przepisów ograniczających napra-

89 Za B. Lewaszkiewicz-Petrykowska, Zasada..., s. 1074-1075. Sprawę omawia również R. Strugała, Szkoda..., s. 598.

90 R. Strugała, Szkoda..., s. 592-593. 
wienie szkód czysto majątkowych, a decyzje o zakresie kompensacji stanowią tu rezultat bardzo elastycznych reguł kauzalnego wnioskowania. System anglosaski z kolei określa się mianem pragmatycznego, rozstrzygnięcia zależą przede wszystkim od oceny obowiązku staranności ze strony sprawcy (duty of care) w powiązaniu z jego obowiązkiem rozsądnego przewidywania (reasonable foreseeability) ${ }^{91}$.

Prawo polskie zaliczane jest do systemów konserwatywnych. Z jednej strony istnieje szeroka liberalna formuła odpowiedzialności deliktowej wzorowana na konstrukcji art. 1392 francuskiego kodeksu cywilnego (Kodeksu Napoleona). Z drugiej strony reguła ta jest ograniczona przez orzecznictwo oraz doktrynę przede wszystkim przez dwa elementy, a mianowicie wymaganie adekwatnego (normalnego) związku przyczynowego między zawinionym działaniem a szkodą, oraz uznanie, że poszkodowany pośrednio ma jedynie wyjątkowo prawo do kompensacji, co jest przede wszystkim wynikiem rozumowania a contrario z art. 446 k.c. przewidującego możliwość naprawienia szkód doznanych przez osoby pośrednio poszkodowane jedynie w ściśle określonych sytuacjach związanych ze szkodą na osobie. $Z$ tą ostatnią kwestią wiąże się tzw. reguła bezprawności względnej, zgodnie z którą odpowiedzialność odnosi się wyłącznie do osób, wartości oraz interesów, których ochrona stanowi cel naruszonej normy ${ }^{92}$.

Według J. Strugały obydwie reguły tradycyjnie powoływane jako ograniczenia naprawienia szkody czysto majątkowej w prawie polskim nie stanowią właściwych narzędzi w tym zakresie. Rozpoczynając od ostatniej kwestii, rozumowanie a contrario z art. 446 k.c. ma swoje oczywiste wady, reguła bezprawności względnej popierana była przede wszystkim w starszej doktrynie, natomiast obecnie jest coraz częściej negowana. Jej obowiązywanie de lege lata nie jest wcale pewne ${ }^{93}$. Z kolei powo-

91 I. Kwiecień, Czyste straty finansowe - ryzyko odpowiedzialności i zakres ochrony w ubezpieczeniach OC podmiotów gospodarczych. Zarys problematyki, WU 2009/4, s. 69-70.

92 T. Pajor, Poland, s. 262. Znaczenie prawne opisywanych regulacji i koncepcji jako ograniczeń odpowiedzialności za szkody pośrednie jest coraz częściej kwestionowane. Zob. przede wszystkim B. Lackoroński, Odpowiedzialność cywilnoprawna za pośrednie naruszenie dóbr, Warszawa 2013, s. 111 i n., 157-158, 186 i n.

93 Co do krytyki tej koncepcji, zob. B. Lackoroński, Odpowiedzialność..., s. 157-158. 
ływanie się na brak związku przyczynowego oraz ewentualnie brak dostatecznego dowodu szkody (co było wykorzystywane przede wszystkim w orzecznictwie) stanowią środki doraźne, wykorzystywane tam, gdzie względy funkcjonalne przemawiają przeciwko poszkodowanemu. Przyczyniają się one do niezwykle restryktywnego, nie zawsze odpowiadającego powszechnemu odczuciu wykładania reguły normalności związku przyczynowego i nie służą pewności prawa ${ }^{94}$.

Cytowany autor, powołując się na B. Lewaszkiewicz-Petrykowską, zwraca uwagę, że odróżnienie uszczerbków podlegających i niepodlegających naprawieniu jest możliwe zgodnie z rozumieniem terminu szkody definiowanej jako uszczerbek w prawnie chronionych dobrach oraz interesach poszkodowanego. Właśnie odwołanie się do prawnie chronionych dóbr oraz interesów różnić ma szkodę w znaczeniu prawnym od szkody w znaczeniu potocznym. Zgodnie z tym, co napisano powyżej odnośnie do szkody efektywnie poniesionej w sferze majątkowej niepodlegającej ochronie oraz utraty niezgodnych z prawem lub niegodziwych zysków, szkoda dotykająca dóbr oraz interesów niepodlegających ochronie pozbawiona jest elementu bezprawności. Bezprawność występuje jedynie w przypadku naruszenia dóbr takich jak życie lub zdrowie oraz własność i inne prawa podmiotowe. Możliwe wydaje się również uznanie za godny ochrony interesu wszystkich podmiotów prawa cywilnego w pomnażaniu majątku ${ }^{95}$.

Powyższe rozważania ukierunkowują argumentację na relację między interesem ubezpieczeniowym oraz prawem podmiotowym. Podtrzymuję pogląd, że zmiana art. 821 k.c. ma znaczenie mniejsze niż powszechnie jej przypisywane. Jak wyżej wskazano, nie jest prawdą, że na gruncie art. 821 k.c. przed zmianą, który lansował teorię majątku, stwierdzając, że przedmiotem ubezpieczenia jest mienie, możliwe było ubezpieczenie wyłącznie materialnie istniejących tworów przyrody. Jeżeli różnica istnieje, to polega na tym, że obecnie ubezpieczyć można nie tylko interes prawny, ale również interes czysto gospodarczy. Ubezpieczyć można zatem interes polegający na istnieniu ryzyka szkody przy jednoczesnym

94 R. Strugała, Szkoda..., s. 601-602.
95 R. Strugała, Szkoda..., s. 603-604. 
braku uchwytnego prawa podmiotowego po stronie zainteresowanego. W przeszłości próbowałem wykazać, że istnienie prawa podmiotowego do pomnażania majątku można wywieść z przepisów Konstytucji ${ }^{96}$. Maciej Kaliński twierdzenie, że interes wszystkich podmiotów prawa prywatnego w utrzymaniu integralności i pomnażaniu majątku jest godny ochrony, zdaje się wywodzić z samej teorii różnicy ${ }^{97}$. Obydwa przedstawione ujęcia jeszcze bardziej zacierają różnice między teorią majątku oraz teorią interesu.

Na obecnym etapie nie podejmuję kolejnych prób wykazania, że w przypadkach tradycyjnie podawanych dla uzasadnienia odejścia od teorii majątku na rzecz teorii interesu często da się wykreować prawo podmiotowe podlegające ochronie. Kwestie te wykraczają poza zakres pracy. Aktualne rozważania zmierzają do wykazania, że niezależnie od tego, czy da się powiązać interes ubezpieczeniowy z prawem podmiotowym, sytuacje, w których istnieją kłopoty z wyodrębnieniem przysługującego potencjalnie poszkodowanemu prawa podmiotowego, mogą być objęte ubezpieczeniem. Innymi słowy, na gruncie prawa ubezpieczeniowego, jeżeli tak postanowiono w umowie, naprawieniu podlegać mogą szkody, które trudno objąć indemnizacją na gruncie prawa powszechnego jako dotykające interesów niemających charakteru prawnego, a przez to niepodlegających ochronie.

Dodać należy, że wyodrębnienie szczególnego typu odpowiedzialności gwarancyjno-repartycyjnej, jaką jest odpowiedzialność ubezpieczeniowa, sprawia, że w sferze tej odpowiedzialności odpadają typowe dla prawa anglosaskiego argumenty ekonomicznie wspierające regułę non recovery. Wskazuje się, że zgoda na indemnizację szkód czysto ekonomicznych mogłaby skutkować zalewem roszczeń (floodgate argument) oraz nadmiernym obciążeniem potencjalnie odpowiedzialnych. $Z$ tych względów stratę finansową lepiej jest pozostawić w ciężar tego, kto jej

96 B. Kucharski, Przeniesienie..., s. 111; M. Kaliński, Szkoda..., s. 180 i n.; R. Strugała zdaje się dochodzić do przeciwnego wniosku, że konstytucja chroni mienie. R. Strugała, Szkoda..., s. 604.

97 M. Kaliński, Szkoda..., s. 235-240. 
doznał ${ }^{98}$. Według ekonomicznej analizy prawa efektywne są takie normy, które minimalizują sumę nakładów poniesionych w celu odwrócenia potencjalnej szkody i jej rozmiarów ${ }^{99}$. Jak już wskazywano, w przypadku przerzucenia szkody z poszkodowanego na sprawcę w ujęciu globalnym nic się nie zmienia, ponieważ wyrwa w majątku poszkodowanego zastąpiona zostaje wyrwą w majątku sprawcy. W odniesieniu do odpowiedzialności ubezpieczeniowej mającej charakter repartycyjny wyrwa zostaje w zasadzie zniwelowana, szkoda rozkłada się bowiem na członków wielotysięcznej wspólnoty ryzyka w taki sposób, że jest dla nich niemal nieodczuwalna ${ }^{100}$. Subrogacja ubezpieczyciela w prawa poszkodowanego tej zasady nie zmienia, regres nie powstaje bowiem w sytuacjach, gdy sprawca nie jest prawnie odpowiedzialny.

Argumenty płynące z ekonomicznej analiza prawa wskazują również, że odpowiedzialność $w$ sensie ekonomicznym powinien ponosić podmiot, który może szkody uniknąć najmniejszym kosztem. Odpowiedzialność nie powstaje zatem wtedy, gdy szkody najłatwiej może uniknąć sam poszkodowany ${ }^{101}$. Odpowiedzialność $\mathrm{w}$ sensie prawnym powinna być natomiast nakładana wtedy, gdy szkody najłatwiej jest uniknąć potencjalnie odpowiedzialnemu (cheapest cost avoider). Tak uzasadnia się obciążenie odpowiedzialnością za szkodę czysto majątkową profesjonalistów. Wykrycie przez nich błędu jest łatwiejsze i mniej kosztowne niż jego wykrycie przez osobę zamawiającą usługę. Łatwo zauważyć, że obciążenie odpowiedzialnością ubezpieczyciela wydaje się z ekonomicznego punktu widzenia jeszcze tańsze z uwagi na element dyfuzji uszczerbku w ramach wspólnoty ryzyka. Podobnie jak w poprzednim układzie, w którym analiza ekonomiczna sprzeciwiała się przypisaniu odpowiedzialności sprawcy, tam, gdzie odpowiedzialność powstaje, także w odniesieniu do odpowiedzialności profesjonalistów, sytuacji nie zmienia regres ubezpieczyciela w stosunku do odpowiedzialnego profesjonalisty. Tak zwany regres nietypowy powstaje bowiem de lege lata

98 B. Lewaszkiewicz-Petrykowska, Zasada..., s. 1074-1075; R. Strugała, Szkoda..., s. 595 .

99 J. Szczerbowski, Szkoda..., s. 33.

100 W. Warkałło, Odpowiedzialność..., s. 114.

101 R. Strugała, Szkoda..., s. 596. 
zupełnie wyjątkowo w przypadkach uregulowanych przepisami szczególnymi odnoszącymi się do niektórych ubezpieczeń obowiązkowych ${ }^{102}$.

Wcześniej przedstawione uwagi prawnoporównawcze nasuwają obserwację, że anglosaskie rozumienie szkody czysto majątkowej bliższe jest koncepcji przeciwstawiającej ją szkodzie fizycznej (tangible loss) niż koncepcji upatrującej istoty takiej szkody w braku naruszenia konkretnego interesu podlegającego ochronie lub ściślej - prawa podmiotowego. Ta druga koncepcja wyrosła zapewne z próby ujęcia pure economic loss w kategorie znane prawu kontynentalnemu, w szczególności w poszukiwaniu granic naprawienia takiej szkody w art. $823 \$ 1$ BGB. Kłopoty w ustaleniu wspólnego pojęcia pure economic loss, łączące się z zupełnie innym aparatem pojęciowym common law w stosunku do kontynentalnych systemów prawa cywilnego, prowadzą zwykle do rozważań na konkretnych przykładach. Obecnie należy zastanowić się, czy w sytuacjach podawanych zwykle jako przykłady szkód czysto majątkowych niepodlegających naprawieniu na gruncie prawa cywilnego możliwe byłoby objęcie powstałych uszczerbków ubezpieczeniem.

Klasyfikacja szkód mających charakter czysto majątkowy jest przedmiotem sporów, podobnie jak samo pojęcie szkody czysto majątkowej ${ }^{103}$. Nie wdając się w te dyskusje, można wskazać następujące przypadki szkód czysto ekonomicznych:

1) szkody na liniach przesyłowych (tzw. cable cases). Na skutek uszkodzenia kabla należącego do elektrowni, np. przez pracującą koparkę, dochodzi do przerw w działalności korzystających $z$ energii przedsiębiorstw i utraty zysków;

2) zanieczyszczenie zasobów naturalnych. Na skutek wycieku ropy ze statku dochodzi do zanieczyszczenia wód i plaż, wobec czego nadbrzeżne hotele tracą klientelę, a rybacy zyski z połowów;

102 Przy okazji nowelizacji przepisów Kodeksu cywilnego o umowie ubezpieczenia nie zdecydowano się na wprowadzenie ogólnej regulacji przewidującej taki regres na gruncie ubezpieczenia OC. Zob. M. Serwach, Ubezpieczenia odpowiedzialności cywilnej $w$ świetle proponowanych zmian przepisów kodeksu cywilnego o umowie ubezpieczenia, PA 2006/2, s. 10-13; M. Krajewski, Ubezpieczenie..., s. 179-180.

103 Por. J. Szczerbowski, Szkoda..., s. 52-63. 
3) utrata dostępu do infrastruktury publicznej. Kierowca powoduje wypadek i uszkadza most, w związku z czym położona za mostem restauracja traci klientelę, ponieważ kierowcy, wybierając inną drogę, zmieniają miejsce posiłków;

4) utrata zatrudnienia. W sytuacjach 1-3 zwalniani są pracownicy przedsiębiorstw, które przestały funkcjonować lub utraciły klientelę. Szkoda jest zatem jeszcze bardziej oddalona od zdarzenia będącego jej pierwotnym źródłem;

5) kontuzja kluczowego zawodnika. Piłkarz będący zdobywcą większości bramek strzelanych przez swój zespół skręca kostkę na skutek poślizgnięcia się na oblodzonym chodniku. Drużyna przegrywa walkę o mistrzostwo, traci zyski związane z udziałem $\mathrm{w}$ rozgrywkach międzynarodowych itd.

Pomijam sytuacje związane $\mathrm{z}$ tzw. szkodą przeniesioną (np. autobus będący przedmiotem umowy dzierżawy ulega uszkodzeniu na skutek wypadku, wobec czego wydzierżawiający musi odwołać dwie wycieczki zagraniczne i traci związane z tym zyski) oraz szkodą indukowaną niewłaściwymi usługami (np. audytor przeszacowuje wartość spółki, wobec czego osoba zlecająca audyt płaci za akcje tej spółki dwukrotnie więcej, niż są one warte) ${ }^{104}$. W sytuacjach tego rodzaju zwykle nie kwestionuje się odpowiedzialności sprawcy na gruncie prawa polskiego ${ }^{105}$. Dodaję natomiast jeszcze przypadek 6) spadek wartości akcji. Na skutek pożaru w przedsiębiorstwie spółki kapitałowej oraz szkód w mieniu samej spółki wspólnicy lub akcjonariusze tej spółki ponoszą szkodę związaną ze spadkiem ich wartości ${ }^{106}$.

Odnośnie do sytuacji z punktów 1-5 w pewnym uproszczeniu można powiedzieć, że szkody nie podlegają indemnizacji na gruncie prawa pol-

104 Co do odpowiedzialności profesjonalistów, zob. również: E. Bagińska, Odpowiedzialność deliktowa w razie niepewności związku przyczynowego. Studium prawnoporównawcze, Toruń 2013, s. 267 i n.

105 Co do tych oraz podobnych przykładów, zob. przede wszystkim T. Pajor, Poland, s. 263-277; J. Szczerbowski, Szkoda czysto majątkowa..., s. 54, 71; I. Kwiecień, Czyste..., s. 64-66.

106 Przykład ten podają również I. Kwiecień, Czyste..., s. 65, oraz M. Kaliński, Szkoda..., s. 268 . 
skiego z uwagi na warunek adekwatności związku przyczynowego oraz zasadę, że osoby poszkodowane pośrednio mają prawo do kompensacji jedynie wyjątkowo, gdy tak stanowi przepis (art. 446 k.c. a contrario) w powiązaniu z kwestionowaną regułą bezprawności względnej ${ }^{107}$. Inna możliwa droga argumentacji polega na wykazywaniu, że w opisanych wyżej sytuacjach trudno skonstruować prawo podmiotowe podlegające ochronie ${ }^{108}$. Odnośnie do sytuacji 6) Sąd Najwyższy w znanym wyroku z 22.06.2012 r., V CSK 338/11 ${ }^{109}$, dopuścił naprawienie szkody poniesionej przez akcjonariusza spółki na skutek wydania wadliwych decyzji administracyjnych prowadzących ostatecznie do upadłości spółki. W doktrynie toczy się dyskusja dotycząca możności objęcia takiego interesu indemnizacją ${ }^{110}$. Oponenci stanowiska SN, poza argumentami przemawiającymi przeciwko naprawieniu szkody w pierwszych pięciu przypadkach, mają tu dodatkowe racje w postaci odrębności podmiotowej spółki oraz wspólników, a także istnienia roszczeń samej spółki o naprawienie poniesionej szkody, które to roszczenia w pewnych okolicznościach mogą w imieniu spółki podnosić jej wspólnicy (art. 486 k.s.h.).

Przenosząc powyższe przypadki na grunt prawa ubezpieczeń, w pierwszych trzech przykładach potencjalnie poszkodowanym trudno odmówić posiadania interesu ubezpieczeniowego w znaczeniu czysto gospodarczym. Interes ten nie jest sprzeczny z prawem, pomimo że trudno

107 Tak. T. Pajor, Poland, s. 264, 266, 267-268; M. Kaliński, Szkoda..., s. 245-246.

108 Tak, jak się zdaje, R. Strugała, Szkoda..., s. 605-606.

109 LEX nr 1228613, z glosami M. Kalińskiego, PiP 2013/2, s. 129, PiP 2015/11, s. 124, oraz B. Lackorońskiego, „Glosa” 2014/1, s. 48.

110 Por. M. Chłopecki, Szkoda poniesiona przez spółkę akcyjnq a szkoda poniesiona przez akcjonariusza w świetle przepisów kodeksu spólek handlowych i kodeksu cywilnego, PPH 2007/5. Autor, podobnie jak B. Lackoroński (vide glosa powołana w poprzednim przypisie), wypowiada się za dopuszczeniem indemnizacji podobnych uszczerbków. Podobnie B. Skorek, Odpowiedzialność za szkodę pośrednia wyrządzona wspólnikowi (akcjonariuszowi), PPH 2017/5, s. 40; A. Kappes, Czy ujmowanie szkody jako bezpośredniej uniemożliwia dochodzenie roszczeń odszkodowawczych przez wspólników spółek kapitałowych? [w:] Czynić postęp w prawie. Księga jubileuszowa dedykowana Profesor Birucie Lewaszkiewicz-Petrykowskiej, red. W. Robaczyński, Łódź 2017, s. 275-276. Przeciwne stanowisko zajmuje przykładowo M. Kaliński (vide glosa powołana w poprzednim przypisie). Zob. też M. Olechowski, O relacji między szkodą poniesiona przez spółkę akcyjna i szkoda poniesiona przez akcjonariusza - polemika, PPH 2007/9, s. 57. 
skonstruować konkretne prawo podmiotowe podlegające ochronie. Interes taki da się również wycenić, jeżeli zna się przeciętne dochody osiągane przez przedsiębiorców w określonych okresach i można stworzyć rozsądną prognozę na przyszłość. Wszystkie trzy sytuacje mogą być objęte ubezpieczeniem od utraty zysków. Oczywiście udowodnienie wysokości szkody w toku ewentualnego postępowania sądowego przeciw ubezpieczycielowi wymagać będzie zwykle dowodu z opinii biegłego.

Problem polega na tym, że proponowane przez polskich ubezpieczycieli warunki ubezpieczenia od utraty zysków stanowią zwykle rozszerzoną wersję ubezpieczenia mienia. Spodziewany zysk może być co do zasady objęty ubezpieczeniem, jeżeli zawarta była umowa ubezpieczenia mienia, co więcej, ubezpieczenie utraty zysku obejmuje szkody polegające na utracie przez ubezpieczającego zysku w okresie ubezpieczenia na skutek szkody w mieniu. Innymi słowy, wypadkiem ubezpieczeniowym w ubezpieczeniu utraty zysku jest szkoda w mieniu ubezpieczającego ${ }^{111}$. Szkoda ta przy tym zwykle rozumiana jest jako szkoda w konkretnych rzeczach (budynkach, maszynach, urządzeniach, innych środkach produkcji). Niezależnie od tego, że mienie obejmuje nie tylko własność, ale również inne prawa majątkowe i prawa składające się na mienie nie muszą mieć substratu w konkretnych rzeczach, w przypadkach opisanych wyżej w punktach 1-3 trudno twierdzić, że ubezpieczający doznał szkody w mieniu. Zastrzeżenie dotyczy pierwszego przypadku, gdzie przerwa w dostawie prądu mogła, ale nie musiała doprowadzić do szkody w mieniu, której konsekwencją była dopiero przerwa w produkcji skutkująca następnie utratą zysków.

Podkreślić jednak należy, że ograniczenia w zakresie pokrycia szkód doznanych w pierwszych trzech przypadkach wynikają jedynie z praktyki ubezpieczeniowej, nie zaś z obowiązującego prawa. Załącznik do ustawy ubezpieczeniowej przewiduje bowiem $\mathrm{w}$ dziale 2, w grupie 16 zatytułowanej: „Ubezpieczenia ryzyk finansowych" następujące rodzaje ubezpieczeń:

- ryzyka utraty zatrudnienia;

111 Vide OWU utraty zysku dostępne na stronach internetowych polskich ubezpieczycieli. 
- niewystarczającego dochodu;

- złych warunków atmosferycznych;

- utraty zysków;

- stałych wydatków ogólnych;

- nieprzewidzianych wydatków handlowych;

- utraty wartości rynkowej;

- utraty stałego źródła dochodu;

- pośrednich strat handlowych, poza wyżej wymienionymi;

- innych strat finansowych.

Jak widać, ubezpieczenie utraty zysków jest jednym z wielu wariantów. W omawianych przypadkach wchodzi w grę jeszcze przede wszystkim ubezpieczenie pośrednich strat handlowych. Załącznik stwarza możliwości niezwykle szerokie, korespondując z bardzo szerokim ujęciem interesu ubezpieczeniowego w art. 821 k.c. Problemem może być co najwyżej dostępność określonego ubezpieczenia na rynku oraz pozycja negocjacyjna konkretnego ubezpieczającego.

Obserwacja powyższa pozwala łatwo przejść do przykładu czwartego dotyczącego zwalnianych pracowników. Chociaż na gruncie prawa cywilnego ich szkoda nie podlega kompensacie, mogą oni ubezpieczyć się od utraty ryzyka zatrudnienia lub niewystarczającego dochodu. Ewentualne ograniczenia znów wynikać mogą z praktyki ubezpieczeniowej i zdolności negocjacyjnych pracowników, nie zaś z regulacji prawnej. Dodać można, że załącznik stwarza przynajmniej teoretyczną możliwość ubezpieczenia czystych szkód ekonomicznych w sytuacjach jeszcze innych niż przewidziane powyżej. Przykładowo przedsiębiorca prowadzący wyciąg narciarski, obawiający się wyjątkowo łagodnej zimy, może zawrzeć ubezpieczenie w zakresie złych warunków atmosferycznych. Ubezpieczenie takie może być substytutem ubezpieczenia od utraty zysków.

Przykład piąty, znany w doktrynie anglosaskiej jako key player, jest nieco bardziej skomplikowany. Niezależnie od tego, jak wielki wpływ na wyniki zespołu ma gra konkretnego zawodnika, zwycięstwo w rozgrywkach i związane z tym dochody zależą również od całego szeregu czynników. W literaturze cywilistycznej utratę szansy uznaje się za 
szkodę jedynie wyjątkowo, jeżeli prawdopodobieństwo konkretnego rezultatu było niezwykle wysokie ${ }^{112}$ albo w ogóle neguje się możliwość jej objęcia pojęciem szkody ${ }^{113}$. Oczywiście powiedzieć można, że załącznik do ustawy o działalności ubezpieczeniowej i reasekuracyjnej oraz art. 821 k.c. stwarzają formułę tak szeroką, że ubezpieczyć da się niemal wszystko, tym niemniej w opisanej sytuacji dochodzi kwestia wyceny interesu w postaci zysków możliwych do osiągnięcia na skutek nieosiągnięcia mistrzostwa, a także związku przyczynowego między wypadkiem konkretnego zawodnika i nieosiągnięciem określonego rezultatu przez drużynę. Czysto teoretycznie wydaje się, że w razie dużego prawdopodobieństwa zwycięstwa w rozgrywkach przez konkretny zespół rozważać można objęcie rezultatu niepomyślnego ubezpieczeniem pośrednich strat handlowych lub innych strat finansowych. Jak wiadomo, prostszym i spotykanym w praktyce rozwiązaniem jest zawarcie przez klub ubezpieczenia na życie pracownika ze wskazaniem siebie jako uposażonego. Pomijając kontrowersyjne zagadnienie interesu ubezpieczeniowego w ubezpieczeniu na życie, według przeważającego stanowiska polskie przepisy o umowie ubezpieczenia na życie w obecnym kształcie stwarzają taką możliwość, pozwalając jednocześnie ustalić wysokość sumy ubezpieczania na dowolnym poziomie ${ }^{114}$.

Ostatnia sytuacja dotycząca szkody poniesionej przez akcjonariusza lub udziałowca na skutek szkody wyrządzonej spółce znana jest anglosaskim systemom prawnym. W znanej angielskiej sprawie Macaura v. Nothern Assurance Co Ltd jedynemu wspólnikowi spółki kapitałowej, który sprzedał spółce drewno na kredyt, odmówiono interesu pozwalającego na ubezpieczenie drewna, wskazując na konieczność posiadania interesu prawnego. Odmienne rozstrzygnięcia zapadały w podobnych stanach faktycznych w USA oraz Kanadzie ze wskazaniem, że wystarczy

112 Tak przykładowo A. Szpunar, Odszkodowanie..., s. 46; z nowszych wypowiedzi zob. przede wszystkim E. Bagińska, Odpowiedzialność..., s. 239 i n.

113 Tak przykładowo A. Kaliński, Szkoda..., s. 258-259.

114 Por. art. $829 \$ 2$ i art. $831 \$ 1^{1}$ k.c. Prezentowany przeze mnie pogląd o konieczności posiadania przez ubezpieczającego interesu ubezpieczeniowego w życiu ubezpieczonego jest odosobniony. Tak B. Kucharski, Przeniesienie..., s. 182 i n.; S. Byczko, Interes..., s. 285 i n. 
interes gospodarczy ${ }^{115}$. Australijska ustawa o umowie ubezpieczenia również, jak się zdaje, pozwalałaby na zawarcie takiego ubezpieczenia. W doktrynie polskiej przeciwko istnieniu interesu wspólnika do majątku spółki kapitałowej wypowiedział się S. Byczko, uzasadniając to przede wszystkim odrębnością majątku spółki i wspólnika oraz odrębnością interesu spółki i wspólnika. Autor ten nie wykluczył jednocześnie ważności umów ubezpieczenia zawartych przez wspólnika w odniesieniu do majątku spółki w szczególnych przypadkach zbliżonych do stanu faktycznego zaistniałego w sprawie Macaura, jeżeli zdarzenie szkodzące spółce spowodowało szkodę u wspólnika i zdarzenia te łączył normalny związek przyczynowy. Nieco ostrożnie wypowiedział się za ważnością umowy ubezpieczenia dotyczącą majątku spółki osobowej zawartą przez jej wspólnika ponoszącego subsydiarną odpowiedzialność za długi spółki ${ }^{116}$.

W kwestiach tych rzeczywiście wskazana jest ostrożność. Jak wskazuje S. Byczko, dosyć trudno wyobrazić sobie zawarcie przez ubezpieczyciela umowy ubezpieczenia dotyczącej spółki ze wspólnikiem zamiast ze spółką, a następnie kwestionowanie przez tego samego ubezpieczyciela interesu po stronie wspólnika. Do rozstrzygnięć amerykańskich i kanadyjskich, w których argumentacja opierała się w dużej mierze na doktrynie piercing the corporate veil, należy podchodzić z dużą ostrożnością. Inaczej niż S. Byczko sądzę, że subsydiarna odpowiedzialność wspólnika spółki osobowej nie jest wystarczającym argumentem, by przyznać mu interes do majątku spółki, wobec wyraźnie zaznaczanej przez Kodeks spółek handlowych odrębności sfer majątkowych wspólnika i spółki oraz regulacji dotyczącej rozliczeń ze wspólnikiem wypowiadającym udział ${ }^{117}$.

Nawet zgodziwszy się, że art. 821 k.c. wymaga interesu czysto gospodarczego, który nie musi mieć przełożenia na interes prawny, trudno zaakceptować zawarcie umowy ubezpieczenia majątku spółki przez

115 Co do tych kwestii, zob. S. Byczko, Interes..., s. 28-36 i 261-263 oraz przytaczane tam anglosaskie judykaty.

116 S. Byczko, Interes..., s. 262-263.

117 Por. przede wszystkim art. 28, 36, 54 oraz 65 k.s.h. 
wspólnika w sytuacji, gdy ubezpieczenia takie może i powinna zawrzeć sama spółka. Trudno też wyobrazić sobie, by w sytuacji zawarcia dwóch odrębnych umów ubezpieczenia przez samą spółkę i przez wspólnika szkoda miałaby być kompensowana dwukrotnie. Zastosowanie przepisów o podwójnym ubezpieczeniu byłoby co najmniej kłopotliwe właśnie ze względu na odrębność oraz różną wartość interesu spółki oraz wspólnika. Dodatkowo podkreślić należy, że załącznik do ustawy o działalności ubezpieczeniowej i reasekuracyjnej przewiduje ubezpieczenie utraty wartości rynkowej, które przynajmniej teoretycznie odnieść można do akcji lub udziałów w spółkach kapitałowych, a nawet do udziałów w spółce osobowej, które z ograniczeniami wynikającymi z art. 10 k.s.h. również mogą być przedmiotem obrotu. Nie można również wykluczyć dopuszczalności zawarcia ubezpieczenia odpowiedzialności cywilnej przez wspólnika spółki osobowej, który obawia się odpowiedzialności za długi ponoszone przez spółkę ${ }^{118}$. Ubezpieczenie takie nie będzie jednak ubezpieczeniem aktywów należących do spółki, tylko ubezpieczeniem pasywów samego wspólnika podobnym do tzw. ubezpieczenia $\mathrm{D} \& \mathrm{O}$ (directors and officers).

Wszystkie te argumenty raczej przeczą istnieniu interesu wspólnika w stosunku do majątku spółki, przede wszystkim zaś przemawiają przeciwko potrzebie gospodarczej kreowania takiego interesu, w sytuacji gdy interes bezsprzecznie służy samej spółce. Argumenty te nie zmieniają natomiast generalnej konkluzji płynącej z powyższych rozważań, że przepisy prawa ubezpieczeniowego w wielu wypadkach dają szersze możliwości kompensacji szkody czysto ekonomicznej (pure economic loss) niźli ogólne przepisy prawa cywilnego. Konkluzja ta jest warta podkreślenia, zważywszy, że w prawie ubezpieczeniowym zakres indemnizacji jest co do zasady węższy niż w ogólnym prawie cywilnym.

118 Por. B. Kucharski, Ubezpieczenie odpowiedzialności cywilnej członków władz spótki kapitałowej [w:] Rynek ubezpieczeniowy - nadregulacja czy niedoregulowanie, red. M. Serwach, Łódź 2014, s. 271-272, 289-290 oraz wskazana tam literatura; B. Kucharski, Głos w dyskusji o ochronie wierzycieli w spółkach kapitałowych, PРH 2017/12, s. 55-56. Co do stanowiska wykluczającego w podobnych sytuacjach zawarcie ubezpieczenia OC, zob. A. Cudna, Ubezpieczenie odpowiedzialności cywilnej członków organów spółek kapitałowych, PUSiG 2001/8, s. 21; M. Krajewski, Ubezpieczenie..., s. 70-71. 
Wskazana konkluzja ponadto rzuca cień na stwierdzenie, że nie ma żadnej różnicy między pojęciem szkody w prawie cywilnym i w prawie ubezpieczeniowym, a w każdym razie zamazuje kontury pojęcia szkody. Można powątpiewać w prawidłowość stwierdzenia, że szkody w sytuacjach wyżej opisanych są szkodami również w rozumieniu prawa cywilnego, tyle że tam nie podlegają naprawieniu, podczas gdy w pewnym zakresie mogą być naprawione na gruncie prawa ubezpieczeniowego. Jak już była mowa, inaczej rzecz przedstawia się ze szkodami powstałymi na skutek działania sił przyrody oraz szkodami $\mathrm{z}$ tytułu utraconych zysków. Te pierwsze są bowiem bezspornie szkodami również na gruncie prawa cywilnego, tyle że tam nie podlegają naprawieniu. Te drugie odwrotnie, są szkodami również na gruncie prawa ubezpieczeniowego, ale naprawieniu podlegać mogą jedynie wyjątkowo, jeżeli uwzględnia je ubezpieczony interes.

\subsection{Związek przyczynowy między wypadkiem a szkodą}

Jak wcześniej wykazano, prezentowany niekiedy w literaturze pogląd, że związek przyczynowy nie jest przesłanką odpowiedzialności ubezpieczeniowej w razie określenia wypadku ubezpieczeniowego w postaci niekauzalnej, wydaje się błędny, przynajmniej w odniesieniu do ubezpieczeń majątkowych. Dla powstania odpowiedzialności ubezpieczyciela musi zatem istnieć związek przyczynowy między wypadkiem ubezpieczeniowym i szkodą. Kwestia związku przyczynowego w ubezpieczeniach jest kontrowersyjna. Pominąwszy omówiony problem, czy związek przyczynowy stanowi w ogóle przesłankę odpowiedzialności ubezpieczeniowej, spór dotyczy przede wszystkim zastosowania w odniesieniu do odpowiedzialności ubezpieczeniowej ogólnej reguły z art. $361 \$ 1$ k.c. mówiącej, że zobowiązany do odszkodowania ponosi odpowiedzialność jedynie za normalne następstwa działania lub zaniechania, z którego szkoda wynikła.

Wypowiedzi doktryny dotyczące wskazanego zagadnienia są nie tylko rozbieżne, ale często niejasne. Nierzadko trudno rozstrzygnąć, na jakim stanowisku stoi konkretny autor. Wydaje się, że można wyróżnić 
trzy grupy poglądów: po pierwsze, negujące zastosowanie kryterium adekwatnego związku przyczynowego $\mathrm{w}$ ubezpieczeniach, po drugie, aprobujące zastosowanie reguł ogólnych oraz po trzecie, poglądy kompromisowe, wedle których reguła ogólna ma w ubezpieczeniach zastosowanie w zakresie ograniczonym treścią konkretnych warunków ubezpieczenia. W obrębie poszczególnych grup występują stanowiska bardziej oraz mniej stanowcze.

Rozpoczynając od pierwszej grupy poglądów, sceptyczny wobec zastosowania art. $361 \$ 1$ k.c. na gruncie ubezpieczeń majątkowych był W. Warkałło. Według tego autora związek między działaniem lub zaniechaniem sprawcy a szkodą jest konieczną przesłanką odpowiedzialności sprawczej, tj. odpowiedzialności za własne lub cudze czyny. Związek ten zazębia się o zachowanie sprawcy lub osoby, za którą sprawca ponosi odpowiedzialność. Istnienie bezpośredniego lub - w przypadku odpowiedzialności za cudze czyny - choćby pośredniego związku tego rodzaju jest konieczną, naturalną przesłanką sprawstwa jako niezbędnego warunku powstania odpowiedzialności tego typu.

Przy odpowiedzialności ubezpieczeniowej, która ma na celu zabezpieczenie pokrycia szkód wyrządzonych przez inne osoby lub wynikłych ze zdarzeń w ogóle niebędących działaniem ludzkim, np. szkód żywiołowych przez ubezpieczyciela, któremu sprawstwa tych szkód przypisać nie można, sprawa przedstawia się zgoła inaczej. Zdarzeniem prawnym rodzącym stosunek odszkodowawczy jest tu bowiem raczej powstanie szkody u określonej osoby niż wyrządzenie szkody tej osobie. Związek przyczynowy w sensie sprawstwa zostaje w związku $\mathrm{z}$ tym zastąpiony związkiem normatywnym - w przypadku ubezpieczeń postanowieniem umowy wiążącym obowiązek naprawienia szkody wprost z określonymi okolicznościami jej powstania.

Samo założenie, że do powstania odpowiedzialności odszkodowawczej niezbędne jest wykazanie istnienia związku przyczynowego między szkodą a zdarzeniem, z którym ustawa wiąże obowiązek jej naprawienia, można uznać za prawidłowe również w zakresie odpowiedzialności ubezpieczeniowej. Nie chodzi jednak o nexus causalis między faktami, wskazujący na osobę sprawcy, ale o związek typu normatywnego usta- 
nowiony z woli stron między szkodą będącą następstwem określonego zdarzenia a osobą zobowiązaną do naprawienia tej szkody, choć osoba ta w najmniejszym stopniu nie przyczyniła się do powstania szkody ${ }^{119}$.

Witold Warkałło nie przesądzał, czy kryterium związku przyczynowego normalnego (adekwatnego) obowiązuje w ubezpieczeniach, ale jego poglądy zdają się ciążyć w kierunku negatywnym. Według wskazanego autora zasada adekwatnego związku przyczynowego z pewnością nie obowiązuje w ubezpieczeniach morskich, gdzie wyraźnie przyjęto kryterium bezpośredniości następstw (obecnie regułę te wyraża art. 320 k.m.). Ponadto z samego sformułowania art. 361 k.c.: „Zobowiązany do odszkodowania ponosi odpowiedzialność tylko za normalne następstwa działania lub zaniechania, z którego szkoda wynikła”, należy wnosić, że chodzi o odpowiedzialność sprawczą za czyny człowieka, wobec czego do odpowiedzialności ubezpieczeniowej przepis ten może znaleźć zastosowanie co najwyżej w drodze analogia legis ${ }^{120}$.

Bardziej stanowczo stanowisko negatywne wypowiada E. Kowalewski. Jego zdaniem związek przyczynowy w prawie ubezpieczeniowym w ogóle nie pełni roli przesłanki odpowiedzialności, odgrywając jedynie rolę kryterium określającego przedmiotowe granice szkody podlegającej kompensacji. Eugeniusz Kowalewski twierdzi, że chociaż reguła prawa morskiego obejmująca odpowiedzialnością ubezpieczyciela jedynie bezpośrednie następstwa wypadku ubezpieczeniowego nie ma odpowiednika w przepisach dotyczących ubezpieczeń lądowych, to jednak $\mathrm{w}$ praktyce jest powszechnie stosowana również w tych ubezpieczeniach. Autor konkluduje, że w prawie ubezpieczeniowym zamiast teorii adekwatnego związku przyczynowego stosuje się teorię causa proxima non remota spectatur ${ }^{121}$.

Potwierdzenie takiej konkluzji stanowić ma art. $826 \$ 3$ k.c. (obecnie art. $826 \$ 4$ ), który nakłada na ubezpieczyciela w ubezpieczeniu majątko-

119 W. Warkałło, Odpowiedzialnośćc..., s. 109-112; W. Warkałło [w:] W. Warkałło, W. Marek, W. Mogilski, Prawo..., s. 95-96.

120 W. Warkałło, Ubezpieczenie utraconych korzyści, s. 56.

121 E. Kowalewski, Odszkodowanie ubezpieczeniowe za utracone korzyści, s. 47. 
wym obowiązek pokrycia w granicach sumy ubezpieczenia poniesionych przez ubezpieczającego kosztów ratowania przedmiotu ubezpieczenia oraz zapobieżenia szkodzie i zmniejszenia jej rozmiarów i zastrzega przy tym, że chodzi wyłącznie o koszty celowe. Według E. Kowalewskiego zastrzeżenie dotyczące celowości kosztów podlegających kompensacie byłoby zbędne, gdyby w ubezpieczeniach znajdowała zastosowanie reguła ogólna $\mathrm{z}$ art. $361 \$ 1$ k.c., ponieważ koszty ratowania stanowią normalne następstwo wystąpienia wypadku. Dodatkowo autor wskazuje, że sformułowanie art. $361 \$ 1$ k.c. „,następstwa działania lub zaniechania, z którego szkoda wynikła" ogranicza zakres zastosowania tego przepisu do odpowiedzialności sprawczej ${ }^{122}$.

Zastosowanie kryterium normalności, gdy chodzi o odpowiedzialność odszkodowawczą ubezpieczyciela, kwestionuje również A. Cudna-Wagner. Autorka najpierw wywodzi, że art. $361 \$ 1$ k.c. nie ma charakteru bezwzględnie obowiązującego, następnie wskazuje, że zakres odpowiedzialności ubezpieczyciela zależy od określenia w OWU kształtu wypadku ubezpieczeniowego oraz innych jej przesłanek, wobec czego nie ma potrzeba odwoływania się do kryterium adekwatności. Nawet w sytuacji, gdy strony w umowie ubezpieczenia nie określą następstw, za które odpowiada ubezpieczyciel, kryterium normalności następstw nie obowiązuje z uwagi na szczególne cechy odpowiedzialności ubezpieczeniowej, w szczególności zaś teorię lokalizacji szkody. Zdaniem A. Cudnej-Wagner, gdyby kryterium normalności następstw obowiązywało, zbędny byłby przepis art. $826 \$ 3$ k.c. pozwalający na objęcie odszkodowaniem ubezpieczeniowym kosztów ratowania, które przecież pozostają w normalnym związku przyczynowym z wypadkiem ${ }^{123}$.

Przedstawicielami stanowiska kompromisowego zdają się być A. Koch, M. Kaliński oraz M. Krajewski. Według A. Kocha w ubezpieczeniach majątkowych istnieją podstawy do posłużenia się konstrukcją związku przyczynowego w zakresie określonym $\mathrm{w}$ art. $361 \$ 1$ k.c., czyli jako przesłanką i granicą odpowiedzialności. Z art. $805 \$ 2$ pkt 1 k.c. wynika bowiem, że świadczenie ubezpieczeniowe jest odszkodowaniem za szko-

122 E. Kowalewski, Odszkodowanie ubezpieczeniowe za utracone korzyści, s. 48.

123 A. Cudna-Wagner, Odpowiedzialność..., s. 79-86. 
dę powstałą wskutek przewidzianego w umowie wypadku. Ubezpieczyciel w świetle tego przepisu jest zatem zobowiązany do odszkodowania w rozumieniu art. $361 \$ 1$ k.c. Obserwacja ta nie oznacza jednak, że konstrukcja przyczynowości z art. $361 \$ 1$ k.c. znajdzie zastosowanie w pełnym zakresie w każdym rodzaju ubezpieczenia. Ustawa posługuje się bowiem sformułowaniem "przewidziany w umowie wypadek”, odsyłając do postanowień konkretnej umowy (warunków) ubezpieczenia. O potrzebie zastosowania kryterium normalności następstw decydować będzie zatem treść konkretnego stosunku ubezpieczenia, a ściślej - określonej w nim konstrukcji wypadku ubezpieczeniowego ${ }^{124}$.

$\mathrm{W}$ ubezpieczeniach mienia pole analiz kauzalnych jest zdaniem A. Kocha zwykle zawężone, ponieważ ryzyka ubezpieczeniowe są precyzyjnie określone w samych warunkach ubezpieczenia zarówno poprzez wskazanie przyczyn, jak i skutków. Przy takiej technice wskazania wypadku ubezpieczeniowego nie ma praktycznie miejsca na badanie normalności skutków, a ustalenie, czy skutek szkodowy był obiektywnie spowodowany przez zdarzenie opisane $w$ warunkach ubezpieczenia jako wypadek ubezpieczeniowy, sprowadza się do zastosowanie testu conditio sine qua non ${ }^{125}$.

Podsumowując, zdaniem A. Kocha dla ustalenia przesłanki związku przyczynowego w ubezpieczeniach zwykle wystarczające jest przeprowadzenie testu conditio sine qua non, który pozwala stwierdzić, czy wskazane w umowie następstwo szkodowe zostało spowodowane przyczyną (zdarzeniem) opisanym w umowie (warunkach ubezpieczenia). W niektórych przypadkach, np. w ubezpieczeniach od kradzieży, nie ma nawet potrzeby przeprowadzenia tej podstawowej czynności. Kryterium normalności następstw może znaleźć zastosowanie wyjątkowo, ponieważ krąg skutków danego zdarzenia wyznaczony jest apriorycznie i nie ma potrzeby ich wartościowania z punktu widzenia normalności. Potrzeba taka może pojawiać się jedynie, gdy szkoda jest skutkiem koincydencji kauzalnej wypadku ubezpieczeniowego oraz innych czynników ${ }^{126}$.

\footnotetext{
124 A. Koch, Związek przyczynowy w ubezpieczeniach, s. 7.

125 A. Koch, Związek przyczynowy w ubezpieczeniach, s. 12.

126 A. Koch, Związek przyczynowy w ubezpieczeniach, s. 13.
} 
W nieco szerszym zakresie dopuszcza stosowanie reguly adekwatnego związku przyczynowego M. Kaliński. Według tego autora w ubezpieczeniach chodzi o związek przyczynowy o charakterze częściowo normatywnym, łączący ogniwa większego łańcucha zdarzeń o niejednorodnym charakterze. Związek przyczynowy normalny musi zachodzić między wypadkiem a szkodą, związek normatywny polega zaś na tym, że do aktualizacji odpowiedzialności ubezpieczyciela poza samą szkodą wymagane jest istnienie umowy ubezpieczenia, obejmującej ochroną określone ryzyko (określającej wypadek) oraz nastąpienie samego wypadku $^{127}$.

Sformułowanie art. $805 \$ 2$ pkt 1 k.c., według którego świadczenie ubezpieczyciela w ubezpieczeniach majątkowych polega na zapłacie odszkodowania za szkodę powstałą wskutek przewidzianego w umowie wypadku, nie modyfikuje reguł ogólnych wskazanych w art. 361 $\$ 1$ k.c. co do kryterium „normalności”. Jedynie przedmiotowy zakres ubezpieczenia wynikający z przyjętych przez ubezpieczyciela ryzyk jest ograniczony. Jeżeli ubezpieczeniem objęty jest pożar, to ubezpieczyciel nie odpowiada za szkody powstałe wskutek gradobicia. Odpowiedzialność ubezpieczyciela w braku odmiennych uregulowań umowy lub OWU ogranicza się do normalnych następstw wypadku, przy czym nie bada się ogniw łańcucha przyczynowego, które łącznie spowodowały zajście wypadku ${ }^{128}$.

W odniesieniu do następstw szkodowych, które nie zostały wywołane działaniem człowieka, lecz zdarzeniami sensu stricto (np.: uderzenie pioruna), zastosowanie art. $361 \$ 1$ k.c. musi ulec pewnej modyfikacji. Kryterium normalności wydaje się uzasadnione nie tyle w odniesieniu do następstw „działania lub zaniechania”, o którym mowa w tym przepisie, ale szerzej w odniesieniu do zdarzeń stanowiących wypadek ubezpieczeniowy. Jeżeli w tym zakresie mieścić się będzie utrata korzyści, również ona powinna być objęta odszkodowaniem ubezpieczeniowym ${ }^{129}$.

\footnotetext{
127 M. Kaliński, Zasada..., cz. 1, s. 54.

128 M. Kaliński, Zasada..., cz. 1, s. 54.

129 M. Kaliński, Zasada..., cz. 1, s. 56.
} 
W monografii Szkoda na mieniu i jej naprawienie M. Kaliński stwierdza, że stosowanie reguły z art. $361 \$ 1$ k.c. zależy od tego, czy wypadek ubezpieczeniowy został określony w sposób kauzalny, czy niekauzalny, oraz czy ogólne warunki ubezpieczenia określają precyzyjnie przyczyny oraz skutki uszczerbku. Reguła ogólna wchodzi w grę, jeżeli wypadek ujęto kauzalnie i ogólne warunki nie określają precyzyjnie przyczyn i skutków uszczerbku. Jest tak, ponieważ w art. $361 \$ 1$ k.c. nie ma mowy wyłącznie o własnym albo swoim działaniu lub zaniechaniu, ale o następstwach zdarzenia, za które dłużnik ponosi odpowiedzialność. Pogląd, że w ubezpieczeniach związek przyczynowy adekwatny zastąpiono związkiem normatywnym, jest zatem prawidłowy jedynie przy niekauzalnym określeniu wypadku ubezpieczeniowego ${ }^{130}$.

Dosyć stanowczo za stosowaniem reguły adekwatności wypowiada się również M. Krajewski. Autor ten zwraca uwagę, że kryterium bezpośredniości następstw stosowane jest wyłącznie w prawie morskim. Nawet wskazanie w ogólnych warunkach ubezpieczenia lądowego, że ubezpieczyciel odpowiada jedynie za bezpośrednie następstwa wypadku, nie wyklucza stosowania kryterium adekwatności, przyjęcie bowiem odpowiedzialności za nadzwyczajne, choćby bezpośrednie skutki wypadku wydaje się mało racjonalne. Innymi słowy, dodanie kryterium bezpośredniości oznacza jedynie, że ubezpieczyciel odpowiada za skutki, które są jednocześnie skutkami bezpośrednimi i normalnymi.

Według M. Krajewskiego przeciwko stosowaniu kryterium adekwatności w ubezpieczeniach nie przemawia argument E. Kowalewskiego, dotyczący treści art. $826 \$ 3$ k.c. (obecnie art. $826 \$ 4$ k.c.). Koszty ratowania przedmiotu ubezpieczenia i ograniczenia szkody rzeczywiście pozostają w normalnym związku przyczynowym z wypadkiem. Kry-

130 M. Kaliński, Szkoda..., s. 362-363. W kontekście całej wypowiedzi autora niezupełnie zrozumiałe jest zastrzeżenie, że kryteria kauzalne stosowane do sprawstwa nie dotyczą odpowiedzialności gwarancyjnej ubezpieczyciela, ale jedynie odpowiedzialności za niewykonanie zobowiązania. Stosowanie reguł ogólnych do odpowiedzialności gwarancyjnej jest wątpliwe właśnie dlatego, że nie jest ona oparta na sprawstwie. Odpowiedzialność z tytułu niewykonania lub nienależytego wykonania zobowiązania jest natomiast odpowiedzialnością sprawczą, więc stosowanie reguł ogólnych wcale nie powinno być sporne. 
terium celowości nie ma znaczenia ograniczającego, ale rozszerzające odpowiedzialność, jeżeli umowa lub OWU stanowią, że ubezpieczyciel odpowiada jedynie za skutki bezpośrednie. Przepis nakazuje bowiem ubezpieczycielowi zwrot wszelkich kosztów, które były poniesione celowo, również w razie umownego zastrzeżenia, że odpowiedzialność ograniczona jest do skutków bezpośrednich.

Marcin Krajewski wywodzi, że możliwość precyzyjnego określenia w OWU przyczyn i następstw, za które ubezpieczyciel odpowiada, również nie wyłącza reguły adekwatności. Konsekwencje rezygnacji z kryterium normalności skutków byłyby trudne do zaakceptowania nawet przy dokładnym określeniu wypadku ubezpieczeniowego, co łatwo wykazać na przykładzie ubezpieczenia budynku od ognia. W takim ubezpieczeniu wypadkiem jest pożar, a szkodą, za którą odpowiada ubezpieczyciel, jest zniszczenie lub uszkodzenie budynku. Gdyby zrezygnować $\mathrm{z}$ kryterium adekwatności, ubezpieczyciel odpowiadałby również za szkodę powstałą wskutek wjechania w budynek przez wóz straży pożarnej zmierzający do odległego o wiele kilometrów pożaru ${ }^{131}$.

Będąc zwolennikiem stosowania w umowie ubezpieczenia kryterium adekwatnego związku przyczynowego, M. Krajewski przywołuje na uzasadnienie swego stanowiska również orzecznictwo Sądu Najwyższego. Przykładowo w wyroku z 27.07.1999 r., I CKN 496/99, Sąd Najwyższy stwierdził, że zalanie rzeczy wodą użytą do gaszenia pożaru objęte jest ryzykiem ubezpieczenia budynku, budowli i mieszkania od ognia i innych żywiołów ${ }^{132}$. W uzasadnieniu stwierdzono, że ubezpieczeniem tym objęte są wszelkie szkody pozostające w adekwatnym związku przyczynowym ze zdarzeniem w postaci pożaru.

Na stanowisku kompromisowym zdają się stać również S. Reps i J. Reps, według których ustalenie związku przyczynowego między szkodą a wypadkiem ubezpieczeniowym dokonuje się przy zastosowaniu testu conditio sine qua non. W odróżnieniu od ogólnych zasad odpowiedzialności, w ubezpieczeniach przyjmuje się, że związek przyczynowy nie musi być

131 M. Krajewski, Umowa ubezpieczenia. Art. 805-834 KC..., 2016, s. 225-227.
132 OSNC 2000/2, poz. 39. 
adekwatny, tzn. szkoda nie musi być normalnym następstwem wypadku ubezpieczeniowego. Odrębne reguły obowiązują w ubezpieczeniu OC, w którym ubezpieczyciel odpowiada za szkody doznane przez osoby niebędące stronami stosunku ubezpieczenia $\mathrm{w}$ granicach odpowiedzialności cywilnej ubezpieczonego, odpowiedzialność ta obejmuje wyłącznie normalne skutki działania lub zaniechania ubezpieczonego.

Według S. Repsa i J. Repsa w ubezpieczeniach, pomijając ubezpieczenia odpowiedzialności cywilnej, przyjmuje się powszechnie, że zakład ubezpieczeń odpowiada tylko za szkodę powstałą bezpośrednio wskutek wypadku, aczkolwiek dopuszcza się możliwość objęcia ubezpieczeniem także następstw pośrednich wypadku ubezpieczeniowego. Jednak wtedy, gdy z umowy lub OWU nie da się wywieść kryterium bezpośredniości następstw, w rachubę może wchodzić także odpowiedzialność zakładu ubezpieczeń za pośrednie następstwa wypadków ubezpieczeniowych, o ile między szkodą a wypadkiem zachodzi normalny związek przyczynowy. W takiej sytuacji odpowiedzialność zakładu ubezpieczeń może być oceniana w świetle art. $361 \$ 1$ k.c. ${ }^{133}$

Zwolennikiem ostatniego poglądu mówiącego o nieograniczonej stosowalności reguł ogólnych do odpowiedzialności ubezpieczeniowej przy jednoczesnej niemożności zmiany tej reguły wydaje się być Z. Brodecki. Zdaniem tego autora kryterium adekwatności nie dotyczy jedynie ubezpieczeń morskich, w przypadku których z ustawy wynika zastosowanie kryterium bezpośredniości następstw (obecnie art. 320 k.m.) ${ }^{134}$. Wywodzi on, że zakres stosowania kryterium normalności następstw w prawie odszkodowawczym jest precyzyjnie określony w art. $361 \$ 1$ k.c. Zasada przyjęta w tym przepisie określa związek przyczynowy jako przesłankę odpowiedzialności cywilnej za każdą szkodę, bez względu na źródło i granice obowiązku jej naprawienia. Z uwagi na to postanowienia ogólnych warunków ubezpieczenia zalecające stosowanie dodatkowej selekcji przyczyn i skutków w postaci bezpośredniości następstw uważa za sprzeczne $\mathrm{z}$ art. $361 \$ 1$ k.c., a zatem nieważne w związku z treścią art. 807 k.c. W dalszej części wywodu powoływany autor zdaje się jed-

\footnotetext{
133 S. Reps, J. Reps, Ubezpieczenia majątkowe przedsiębiorców, s. 160-161.

134 Z. Brodecki, Kilka..., s. 4.
} 
nak popadać w sprzeczność ze swoją podstawową tezą, wskazując, że powiązanie między wypadkiem ubezpieczeniowym a szkodą należy badać jedynie przy użyciu testu conditio sine qua non ${ }^{135}$.

Przedstawienie poglądów występujących w doktrynie pozwala przejść do zaprezentowania własnego stanowiska. Zagadnienie jest skomplikowane, należy zatem poruszać się krok po kroku, starannie rozważając wszystkie argumenty. Rozumowanie W. Warkałły mówiące, że art. 361 $\$ 1$ k.c. dotyczy jedynie odpowiedzialności sprawczej, koncentruje się na językowej wykładni przepisu, który wspomina o „działaniu lub zaniechaniu”. Przejęcia przez ubezpieczyciela na mocy umowy ryzyka zajścia określonych zdarzeń nie można oczywiście uznać za działanie lub zaniechanie, z którego szkoda wynikła ${ }^{136}$.

Inni autorzy zauważają jednak trafnie, że ustawodawca nie odwołuje się do działania lub zaniechania osoby zobowiązanej do naprawienia szkody. Co więcej, obecnie w cywilistyce powszechnie przyjmowany jest pogląd, że zastosowanie art. $361 \$ 1$ k.c. nie jest ograniczone do działania lub zaniechania, ale ma również zastosowanie w odniesieniu do innych zdarzeń prawnych, z którymi ustawa łączy obowiązek naprawienia szkody (np. w odniesieniu do ruchu przedsiębiorstwa lub pojazdu - art. 435 i 436 k.c. $)^{137}$.

Można oczywiście argumentować, że wprowadzenie pojazdu lub przedsiębiorstwa w ruch jest działaniem w większym stopniu niż uderzenie pioruna lub powódź. Z drugiej strony jednak przynajmniej potocznie mówi się o działaniu sił przyrody, zaś konwencja językowa odnosząca termin „działanie” jedynie do osób nie ma oparcia w ogólnych przepisach Kodeksu cywilnego. W świetle powyższych uwag słuszna wydaje się

135 Z. Brodecki, Kilka..., s. 5.

136 Zauważa to również M. Krajewski. Zob. M. Krajewski, Umowa ubezpieczenia. Art. 805-834 KC..., 2016, s. 226-227.

137 Tak stanowczo, zaznaczając, że sprawa nigdy nie była przedmiotem kontrowersji w literaturze i orzecznictwie, A. Koch, Związek przyczynowy jako podstawa odpowiedzialności odszkodowawczej w prawie cywilnym, Warszawa 1975, s. 168. Por. przykładowo T. Wiśniewski [w:] Kodeks cywilny. Komentarz. Księga trzecia. Zobowiązania, tytuł I, komentarz do art. 361, Lex Polonica. 
konstatacja, według której art. 361 k.c. odnosi się w istocie do następstw wszelkich zdarzeń, z którymi ustawa wiąże obowiązek naprawienia szkody. Wykładnia językowa nie przemawia zatem wyraźnie przeciwko uznaniu ubezpieczyciela w ubezpieczeniu majątkowym za osobę zobowiązaną do naprawienia szkody w rozumieniu art. $361 \S 1$ k.c.

Drugi argument przeciwników teorii adekwatnego związku przyczynowego w ubezpieczeniach polega na zastąpieniu tego związku związkiem bezpośrednim przy odwołaniu się do uregulowań prawa morskiego oraz brzmienia art. $826 \$ 4$ k.c. Tak rozumuje m.in. E. Kowalewski. Wbrew stwierdzeniom tego autora nie wydaje się jednak, by istniały podstawy normatywne do ekstrapolowania rozwiązań Kodeksu morskiego na grunt powszechnego prawa cywilnego. O ile bowiem Kodeks morski w zakresie nieuregulowanym odsyła do Kodeksu cywilnego, o tyle nie istnieje odesłanie w odwrotnym kierunku. Odwołanie się do art. 826 $\$ 4$ k.c. również wydaje się argumentem słabym. Przepis ten wskazuje jedynie, w jakim zakresie ubezpieczyciel zobowiązany jest do zwrotu tzw. kosztów ratowania mienia przed szkodą. Regulacja z art. $826 \$ 4$ k.c. jest potrzebna przede wszystkim ze względu na obowiązującą w ubezpieczeniach zasadę lokalizacji szkody. Sformułowanie „koszty celowe” wydaje się nadto treściowo węższe niż koszty pozostające w adekwatnym związku przyczynowym. Celowość odnosi się bowiem raczej do ekonomicznej opłacalności poniesienia określonych kosztów.

Trzeba zgodzić się z M. Krajewskim, że jest przynajmniej wątpliwe, czy ustawowe lub umowne ograniczenie skutków, za które odpowiada osoba zobowiązana do odszkodowania do skutków bezpośrednich, wyklucza regułę adekwatnego, czyli normalnego związku przyczynowego. Relacja między kryterium bezpośredniości a normalności następstw nie jest bowiem relacją wzajemnie wykluczającą się, ale krzyżującą. Nie wszystkie skutki bezpośrednie są normalne i na odwrót, nie wszystkie skutki normalne są bezpośrednie. Można chyba powiedzieć, że kryterium adekwatności lub też normalności następstw jest kryterium jakościowym, podczas gdy kryterium bezpośredniości - ilościowym, mającym na celu ograniczenie długości łańcucha przyczyn i skutków. 
Zwykle przyjmuje się, że związek przyczynowy adekwatny w rozumieniu art. $361 \$ 1$ k.c. może być związkiem wieloczłonowym, pod warunkiem że wszystkie ogniwa powiązane są ze sobą z uwzględnieniem kryterium normalności ${ }^{138}$. Bezpośredniość ogranicza odpowiedzialność zobowiązanego do ostatniego członu w łańcuchu przyczynowo-skutkowym. Nie każde jednak następstwo bezpośrednie jest następstwem normalnym. Dotyczy to w szczególności sytuacji, gdy szkoda stanowi następstwo więcej niż jednej przyczyny. $Z$ tego punktu widzenia rację zdaje się mieć A. Koch, że kryterium normalności może znaleźć zastosowanie w ubezpieczeniach przede wszystkim właśnie w przypadkach współprzyczynowości.

Dodać należy, że przeciwstawianie kryterium bezpośredniości oraz normalności następstw, widoczne przede wszystkim w rozważaniach E. Kowalewskiego i Z. Brodeckiego, jest wynikiem obserwacji, że przepisy ubezpieczeń morskich próbują ograniczyć odpowiedzialność zobowiązanego do skutków bezpośrednich, podczas gdy ogólne przepisy prawa odszkodowawczego do skutków normalnych. Kryterium bezpośredniości w ubezpieczeniach morskich wywodzi się z prawa anglosaskiego, gdzie miało służyć selekcji skutków, za które odpowiada sprawca, podobnie jak kryterium normalności w polskim porządku prawnym.

Kryterium bezpośredniości w prawie anglosaskim rozumiane jest zresztą niejednolicie, często odmiennie, niż wskazywałoby na to znaczenie słowa: „bezpośredni” (ang. proximate). Niezdecydowanie sądów angielskich zdaje się zaś wynikać poniekąd właśnie z braku kryterium normalności. Pod pojęciem przyczyny bezpośredniej nie zawsze kryje się przyczyna ostatnia. Bezpośredniość jest w większym stopniu od następstwa czasowego kwestią efektywności działania jednej z współprzyczyn, jednak również to drugie kryterium nie daje zadowalających rezultatów ${ }^{139}$. Badanie przyczynowości przebiega przy tym przez kilka

138 Zob. szerzej A. Koch, Związek przyczynowy jako podstawa..., s. 267-270. Tak również T. Wiśniewski [w:] Kodeks cywilny..., komentarz do art. 361, teza 5.

139 M. Song, Causation in Insurance Contract Law. Informa Law from Routledge, Oxon, New York 2014, s. 27. Podobnie J. Birds, Birds'..., s. 264. Zob. również A. Koch, Zwiazek przyczynowy jako podstawa..., s. 92-93 oraz wskazana tam starsza literatura angielska. 
etapów. Podstawowym testem jest test but for, w prawie polskim nazywany testem conditio sine qua non. Innymi słowy, wypadek jest przyczyną szkody, jeżeli bez niego szkoda by nie wystąpiła. Test ten jednak nie odpowiada na pytanie, czy szkoda była bezpośrednią konsekwencją wypadku. Dodatkowe kryterium stanowi zatem test, wedle którego szkoda ma być konsekwencją nieuniknioną ${ }^{140}$. John Birds specjalnie podkreśla, że causa proxima wcale nie oznacza przyczyny ostatniej, ale przyczynę najistotniejszą, dominującą, prawdziwą ${ }^{141}$, oraz że odnajdowanie takiej przyczyny jest w zasadzie sprawą zdrowego rozsądku sędziego ${ }^{142}$.

Kwestię dobrze ilustruje sprawa Leyland Shipping Co v. Norwich Union Fire Insurance Society $\operatorname{Ltd}^{143}$. Dotyczyła ona statku ubezpieczonego od szkód będących następstwem niebezpieczeństw morskich z wyłączeniem szkód wynikających z działań wojennych. Statek ten został storpedowany podczas I wojny światowej. Odholowano go do portu w Hawrze i tam przycumowano. Następnie na polecenie władz portu statek został odholowany tuż przed port, gdzie zatonął wskutek niespokojnego morza. Sąd rozstrzygnął sprawę na korzyść ubezpieczyciela, uznając, że właściwą przyczyną zatonięcia było storpedowanie, nie zaś niebezpieczeństwa morskie, pomimo że statek z pewnością by ocalał, gdyby nie usunięto go z portu albo gdyby morze było spokojne. Argumentacja polegała na wskazaniu, że pierwsza przyczyna przeważa i uważana jest za właściwą (bezpośrednią), o ile jedynie nie ułatwia zajścia przyczyny ostatecznej, która całkowicie zmienia stan rzeczy.

Kryterium bezpośredniości znalazło również normatywny wyraz w treści art. 1151 francuskiego Code civil. Przepis ten stanowi, że w przypadku niewykonania zobowiązania dłużnik odpowiada tylko za „bezpośrednie i proste" skutki niewykonania swojego obowiązku. Niektórzy autorzy, opierając się na tym sformułowaniu, wyprowadzali wniosek

140 M. Song, Causation..., s. 27.

141 „The proximate cause does not mean the last cause, but the effective, dominant or real cause" - J. Birds, Birds'..., s. 264. Zob. również M. Song, Causation..., s. 27; MacGillivray..., s. 20-101, 587.

142 J. Birds, Birds'..., s. 249. Zob. również A. Koch, Związek przyczynowy jako podstawa..., s. 92-93 oraz wskazana tam literatura angielska.

143 [1918] AC 350. 
o obowiązywaniu w prawie francuskim kryterium bezpośredniości. Nowsza literatura odrzuca jednak taką koncepcję, wskazując, że sformułowania ustawy nie można interpretować dosłownie. Celem przepisu jest jedynie podkreślenie, że powiązanie przyczynowe między faktem niewykonania zobowiązania a powstaniem szkody stanowi niezbędną przesłankę odpowiedzialności. Nie wskazuje on natomiast szczegółowych kryteriów selekcji kauzalnej ${ }^{144}$.

Powyższe rozważania pozwalają, jak się zdaje, na konstatację, że twierdzenie o obowiązywaniu w ubezpieczeniach lądowych teorii bezpośredniego związku przyczynowego nie ma wystarczającego uzasadnienia. Nie wyklucza to oczywiście wprowadzenia takiego kryterium na mocy umowy lub ogólnych warunków ubezpieczenia. Drugie skrajne stanowisko, a mianowicie stanowisko Z. Brodeckiego, który za nieważne uznaje postanowienia umowy lub OWU zawężające zakres odpowiedzialności ubezpieczyciela w porównaniu z regułą adekwatnego związku przyczynowego, również jednak wydaje się nie do zaakceptowania.

Trudno negować, że niedopuszczalne są ograniczenia odpowiedzialności z tytułu czynów niedozwolonych. Odpowiedzialność za niewykonanie istniejącego zobowiązania może jednak zostać umownie ograniczona. Przepis art. 473 k.c. pozwala na to wyraźnie, wskazując jako jedyną granicę szkody wyrządzone umyślnie. Poza tym ograniczenia są akceptowalne i, jak się zdaje, nic nie stoi na przeszkodzie, by zakres odpowiedzialności zawężono przez odwołanie się do przesłanki związku przyczynowego zamiast do przesłanki winy. Skoro możliwe jest ograniczenie odpowiedzialności za szkodę będącą następstwem niewykonania zobowiązania, tym bardziej możliwe wydaje się ograniczenie odpowiedzialności odszkodowawczej wynikającej z zawarcia umowy, na mocy której ubezpieczyciel zobowiązuje się wynagrodzić szkodę wynikającą z działania lub zaniechania określonych osób trzecich lub z zajścia określonych zdarzeń.

144 A. Koch, Związek przyczynowy jako podstawa..., s. 91-92 i wskazana tam literatura francuska. 
Prima facie zatem stanowiska skrajne należy odrzucić. Słuszny wydaje się zatem pogląd reprezentowany przez A. Kocha i M. Kalińskiego, że ubezpieczyciel w ubezpieczeniu majątkowym może być uznany za osobę zobowiązaną do naprawienia szkody w rozumieniu art. $361 \$ 1$ k.c., a zatem istnieją podstawy normatywne do stwierdzenia, że adekwatny związek przyczynowy między wypadkiem ubezpieczeniowym a szkodą stanowi podstawę odpowiedzialności ubezpieczyciela w ubezpieczeniu mienia. Sprawy nie można jednak przesądzić na podstawie stwierdzenia, że językowa wykładnia art. $361 \$ 1$ k.c. w zasadzie pozwala na objęcie ubezpieczyciela zakresem zawartej w nim normy oraz że nie ma podstaw do powszechnego stosowania w ubezpieczeniach kryterium bezpośredniości. Ostatecznie trudno przyjąć, że sformułowanie art. $361 \$ 1$ k.c.: „Zobowiązany do odszkodowania ponosi odpowiedzialność tylko za normalne następstwa działania lub zaniechania, z którego szkoda wynikła”, prowadzi do absolutnie jednoznacznych rezultatów w odniesieniu do odpowiedzialności ubezpieczyciela.

Wykładnia celowościowa prowadzi jednak do niejednoznacznych rezultatów, gdy chodzi o kryterium adekwatności. Jak wiadomo, na zasadach ogólnych ustalanie istnienia związku przyczynowego przebiega w dwóch etapach. Pierwszym jest test conditio sine qua non, drugim selekcja następstw za pomocą określonego kryterium, w prawie polskim - adekwatnego związku przyczynowego. Konieczność ograniczenia następstw zdarzenia początkowego uzasadnia się, wskazując, że poprzestanie na pozytywnym wyniku testu conditio sine qua non stwarzałoby ryzyko rozszerzenia granic odpowiedzialności ad infinitum. W literaturze podaje się przykład krawca, który nie zdążył na czas uszyć garnituru, w związku z czym jego klient spóźnił się na pociąg i zginął w katastrofie kolejowej ${ }^{145}$. Obciążenie krawca odpowiedzialnością za śmierć klienta jest nie do pomyślenia.

Obciążenie jednego tylko podmiotu odpowiedzialnością za następstwa, często bardzo odległe, kłóciłoby się z elementarnym poczuciem sprawiedliwości. Konieczność ograniczenia następstw poprzez odpowied-

145 A. Koch za A. Ohanowiczem [w:] A. Koch, Związek przyczynowy jako podstawa.., s. 81 . 
nio ukształtowaną przesłankę związku przyczynowego wynika stąd, że niewystarczającym instrumentem służącym temu celowi w dziedzinie odpowiedzialności odszkodowawczej okazuje się wina. Odpowiedzialność bowiem powstaje często niezależnie od winy - zgodnie z zasadą ryzyka lub zasadą słuszności ${ }^{146}$.

Jak łatwo zauważyć, argumenty za koniecznością ograniczenia selekcji następstw, za które odpowiada sprawca, dotyczą odpowiedzialności sprawczej kreowanej przez przepisy ustawowe. Dotyczyć one będą również odpowiedzialności ubezpieczyciela z obowiązkowego ubezpieczenia OC w zakresie, w jakim odpowiedzialność ta jest akcesoryjna w stosunku do odpowiedzialności sprawcy. Trafne są zatem przywoływane przez M. Krajewskiego orzeczenia Sądu Najwyższego, w których stwierdzono, że nie wykracza poza granice normalnego związku przyczynowego szkoda polegająca na utracie zarobku przez poszkodowanego w wypadku komunikacyjnym taksówkarza, będąca następstwem przedłużającej się naprawy taksówki ${ }^{147}$, albo szkoda poniesiona przez poszkodowanego w wypadku komunikacyjnym właściciela gospodarstwa rolnego równa cenie pracy w gospodarstwie, której nie mógł on po wypadku wykonywać osobiście ${ }^{148}$.

W odniesieniu do odpowiedzialności gwarancyjnej wynikającej z przyjęcia na siebie w drodze umowy obowiązku zapłaty odszkodowania za szkody wywołane przez osoby trzecie lub przez określone zdarzenia niezależne od zobowiązanego przedstawione argumenty tracą na sile. Dotyczy to szczególnie odpowiedzialności ubezpieczeniowej, gdy odpowiedzialność przyjmuje na siebie profesjonalna instytucja finansowa działająca dla zysku według reguł statystyki i posługująca się przygotowanymi zawczasu wzorcami umownymi. Jeżeli taki profesjonalista gwarantuje udzielenie ochrony na wypadek zajścia określonych przez siebie zdarzeń, wyłączając jednocześnie swoją odpowiedzialność za inne zdarzenia oraz w zamian za udzielaną gwarancję pobiera wynagrodze-

146 A. Koch, Zwiazek przyczynowy jako podstawa..., s. 82, oraz A. Koch, Metodologiczne zagadnienia związku przyczynowego w prawie cywilnym, Poznań 1975, s. 114.

147 Wyrok SN z 4.11.1977 r., II CR 355/77, OSNC 1978/11, poz. 205.

148 Uchwała SN z 6.04.1978 r., III CZP 19/78, OSNC 1978/12, poz. 219. 
nie, to można chyba od niego oczekiwać precyzyjnego ustalenia zakresu udzielanej ochrony ubezpieczeniowej. Nie istnieje potrzeba otaczania go dodatkową ochroną w postaci wprowadzania pozaumownych kryteriów ograniczających następstwa objęte odpowiedzialnością.

Warto powrócić w tym miejscu do często powtarzanego w doktrynie sformułowania, że reguła $\mathrm{z}$ art. $361 \$ 1$ k.c. znajduje zastosowanie nie tylko do działań lub zaniechań, ale również do wszystkich innych zdarzeń, z którymi ustawa wiąże obowiązek naprawienia szkody. Kluczowe wydaje się w tym sformułowaniu użyte in fine zastrzeżenie dotyczące ustawy. Daleko idąca selekcja następstw, za które odpowiada zobowiązany, jest uzasadniona wtedy, gdy obowiązek wynagrodzenia szkody zostaje mu niejako narzucony przez ustawę. Można powątpiewać, czy ma ona uzasadnienie wtedy, gdy ktoś z własnej nieprzymuszonej woli w zamian za określone wynagrodzenie gwarantuje wynagrodzenie szkód powstałych niezależnie od niego.

Dodać można, że zastosowanie kryterium adekwatnego związku przyczynowego w odniesieniu do następstw, za które ubezpieczyciel odpowiada, rodzi pytanie o racjonalność wprowadzenia podobnego pozaumownego kryterium selekcji następstw w odniesieniu do wyłączeń odpowiedzialności ubezpieczyciela. Pogląd o istnieniu kryterium normalności następstw zdaje się panować w odniesieniu do ustawowego wyłączenia za szkodę wyrządzoną umyślnie przez ubezpieczającego albo powstałą na skutek rażącego niedbalstwa ${ }^{149}$. Pogląd ten uzasadnia M. Krajewski, którego zdaniem odrzucenie opisanego kryterium mogłoby prowadzić do zaskakujących i krzywdzących dla ubezpieczającego rezultatów. Autor ten nie podaje jednak konkretnych przykładów. Dodać należy, że sformułowanie ustawodawcy „wyrządzenie szkody umyślnie” sugeruje w sposób wyraźny, że działanie ubezpieczającego nakierowa-

149 A. Wąsiewicz, Przyczynienie się ubezpieczającego do powstania szkody [w:] Ubezpieczenia w gospodarce rynkowej, t. 2, red. A. Wąsiewicz, Bydgoszcz 1994, s. 80; A. Cudna-Wagner, Odpowiedzialność..., s. 93. Autorka wydaje się przy tym mało konsekwentna, ponieważ wcześniej (s. 79-85) dość stanowczo wyklucza obowiązywanie kryterium normalności, gdy chodzi o związek przyczynowy między wypadkiem a szkodą. Zob. M. Krajewski, Umowa ubezpieczenia. Art. 805-834 KC..., 2016, s. 607. 
nie jest na wyrządzenie samemu sobie szkody, wobec czego kryterium normalności następstw wydaje się zbędne.

W odniesieniu do rażącego niedbalstwa oraz wyłączeń umownych sprawa wydaje się być nawet bardziej skomplikowana. Zagadnieniem, czy szkoda jest normalnym następstwem zdarzenia, co do którego ubezpieczyciel wyłączył swoją odpowiedzialność, w zasadzie nikt bliżej się nie zajmował, jednak można odnieść wrażenie, że spór toczy się między zwolennikami stanowiska, wedle którego potrzebny jest związek przyczynowy ustalany przy użyciu testu conditio sine qua non, oraz zwolennikami stanowiska, że wyłączenie odpowiedzialności jest skuteczne bez względu na istnienie jakiegokolwiek związku przyczynowego między zdarzeniem objętym wyłączeniem a szkodą ${ }^{150}$. Wydaje się jednak, że w tych sytuacjach szkoda rzadko jest normalnym następstwem działania lub zaniechania ze strony ubezpieczającego. Takie działanie lub zaniechanie ułatwia jedynie powstanie szkody na skutek określonego zdarzenia lub wyrządzenie jej przez osobę trzecią (np. pozostawienie niezamkniętego domu lub samochodu ułatwia złodziejowi dokonanie kradzieży, która nie jest normalnym następstwem zaniechania ubezpieczającego).

Wątpliwości co do zastosowania w ubezpieczeniach kryterium adekwatnego związku przyczynowego ujawniają się również przy odwołaniu do powołanego wyżej angielskiego leading case Leyland Shipping. Sprawę tę równie trudno byłoby rozstrzygnąć, stosując kryterium adekwatnego związku przyczynowego, jak na podstawie kryterium bezpośredniości następstw. Można bowiem powątpiewać, czy istniał adekwatny związek przyczynowy między storpedowaniem a zatonięciem statku oraz między naturalnymi niebezpieczeństwami morskimi a zatonięciem w sytuacji, gdyby okazało się, że żadna $\mathrm{z}$ wymienionych przyczyn samoistnie nie doprowadziłaby do zatonięcia ${ }^{151}$.

W nauce niemieckiej, a także polskiej wskazuje się, że konkluzja o występowaniu adekwatnego związku przyczynowego jest uzasadniona wtedy,

150 M. Krajewski, Umowa ubezpieczenia. Art. 805-834 KC..., 2016, s. 624-628.

151 Taka konstatacja oczywiście wymagałaby wiadomości specjalnych. 
gdy prawdopodobieństwo określonego skutku zwiększa się każdorazowo przez wystąpienie badanej przyczyny zgodnie z zasadami nauki oraz doświadczenia życiowego ${ }^{152}$. W rozpatrywanej sprawie Leyland Shipping zarówno storpedowanie statku, jak i sztorm zwiększały prawdopodobieństwo zatonięcia. W sprawie tej zachodzi jednak sytuacja obrazowo określana jako przecięcie dwóch niezależnych od siebie linii kauzalnych. Każde ze zdarzeń badanych, to jest storpedowanie statku oraz sztorm na morzu, może być dla drugiego rozpatrywane jako causa interveniens przerywająca łańcuch adekwatnego związku przyczynowego ${ }^{153}$.

Nasuwa się zatem wniosek, że sprawę najprościej byłoby rozstrzygnąć, stosując wyłącznie test conditio sine qua non. Przy rezygnacji z dodatkowych kryteriów selekcji kauzalnej werdykt byłby taki sam jak faktycznie powzięty. Zatonięcie statku było wynikiem konkurencyjnych przyczyn w postaci działań wojennych i niebezpieczeństw morskich. Skoro ubezpieczyciel wyłączył swoją odpowiedzialność za jedną z nich, to odszkodowanie nie należało się. Wprowadzanie jakichkolwiek dodatkowych kryteriów wartościujących zdaje się jedynie rozstrzygnięcie komplikować. Jeżeli umowa nie zawierałaby stosownego wyłączenia odpowiedzialności, ubezpieczony powinien otrzymać odszkodowanie.

Nie wydaje się przy tym, by przedstawiona interpretacja nadmiernie rozszerzała odpowiedzialność ubezpieczyciela. Przede wszystkim ubezpieczyciel ma prawo precyzyjnie oznaczyć zakres swojej odpowiedzialności. Jeżeli tego nie uczyni, zwykle działać będzie reguła in dubio contra proferentem. Reguła ta nakazuje tłumaczyć niejednoznaczne postanowienia ogólnych warunków umów na niekorzyść ubezpieczyciela, nie pozwala jednak rozszerzać jego odpowiedzialności w sposób nieograniczony, sprzeczny $\mathrm{z}$ intencją stron. $\mathrm{W}$ przykładzie podawanym przez M. Krajewskiego ubezpieczyciel, który zawarł umowę ubezpieczenia budynku od ognia, nie będzie odpowiadał za szkodę wywołaną przez wóz strażacki zmierzający do innego pożaru, ponieważ ubezpieczenie obejmowało pożar konkretnego budynku. Reguła adekwatnego związku

\footnotetext{
${ }^{152}$ A. Koch, Zwiazek przyczynowy jako podstawa..., s. 146-147.

153 A. Koch, Związek przyczynowy jako podstawa..., s. 272.
} 
przyczynowego nie jest zatem potrzebna, by ograniczyć zakres odpowiedzialności ubezpieczyciela.

Podobnego przykładu, który należy jednak rozstrzygnąć na korzyść ubezpieczonego, dostarcza orzecznictwo angielskie. W sprawie Marsden v. City and County Insurance ${ }^{154}$ właściciel sklepu ubezpieczył szkło okienne od wszelkich ryzyk z wyjątkiem ryzyka pożaru. Pożar, wybuchły na sąsiedniej posesji, spowodował zgromadzenie się tłumu ludzi, którzy następnie wpadli w panikę, doprowadzając do stłuczenia szyb w oknach. Ubezpieczyciel próbował odmówić wypłaty odszkodowania, twierdząc, że przyczyną stłuczenia okien był pożar, za który zgodnie z umową nie odpowiadał. Sąd stwierdził jednak, że bezpośrednią przyczyną były rozruchy stanowiące ryzyko objęte ubezpieczeniem. Sprawę tę znów można rozstrzygnąć bez potrzeby odwoływania się do kryterium bezpośredniości lub adekwatności. Jak się bowiem zdaje, istota rzeczy sprowadza się do wykładni wyłączenia odpowiedzialności, które dotyczyło pożaru na terenie ubezpieczonego sklepu, nie zaś wszelkich pożarów.

Argumentów na rzecz stosowania w ubezpieczeniach kryterium adekwatnego związku przyczynowego nie dostarczają również orzeczenia Sądu Najwyższego, w których sąd ten do takiego kryterium się odwoływał. Do konkluzji, że ubezpieczeniem od ognia objęte są szkody wywołane przez zalanie ubezpieczonych rzeczy wodą użytą do gaszenia pożaru, prowadzi również test conditio sine qua non ${ }^{155}$. Akcja ratownicza została podjęta tylko dlatego, że wybuchł pożar, szkoda pozostaje zatem w związku przyczynowym z wypadkiem. Można zresztą twierdzić, że wynikający z art. 826 k.c. nakaz zwrotu przez ubezpieczyciela kosztów akcji ratowniczej, choćby nieudanej, o ile tylko była celowa, obejmuje również nakaz zwrotu szkód wywołanych akcją ratowniczą, jeżeli dla ratowania dobra o większej wartości celowe było poświęcenie innego.

Należy jednak zwrócić uwagę, że doktryna niemiecka nie wyklucza selekcji następstw przy zastosowaniu kryterium adekwatności w sytuacjach, gdy umowa ubezpieczenia nie zawiera precyzyjnych sformułowań.

154 (1865) LR 1 CP 232. Sprawę omawia J. Birds, Birds'..., s. 249.

155 Wyrok SN z 27.07.1999 r., I CKN 496/99. 
Manfred Wandt wskazuje, że najważniejsze jest ustalenie celu umowy ubezpieczenia, tzn. zakresu ryzyka przejętego przez ubezpieczyciela. Innymi słowy, chodzi o ustalenie zakresu konkretnego, szczegółowo określonego w umowie ubezpieczenia wypadku. Kwestia ujawnia się z całą mocą przy specyficznych rodzajach ryzyka. Według tradycyjnej formuły należy pytać, czy ryzyko mogło zajść tylko w bardzo szczególnych okolicznościach, które miały nietypowy przebieg, i to właśnie one doprowadziły do zajścia szkody. Jeżeli jednak umowa ubezpieczenia nie ma specjalnej regulacji, odpowiedź na pytanie, czy zaistniałe okoliczności są prawnie relewantne, rozstrzyga się za pomocą znanej prawu obligacyjnemu teorii adekwatności. Teoria adekwatności w przypadku umów ubezpieczenia najczęściej prowadzi do odpowiednich wyników, bo zawierając umowę, strony mają na myśli zdarzenie zachodzące zazwyczaj przy normalnym przebiegu wypadków. Przy wyłączeniach i wyłączeniach odpowiedzialności należy zbadać ich sens, który zależy od wielu czynników ${ }^{156}$.

Podsumowując, raz jeszcze wydaje się, że należy odrzucić stanowiska skrajne. Argumentacja zwolenników pierwszego stanowiska, według którego kryterium adekwatnego związku przyczynowego w ubezpieczeniach w ogóle nie znajduje zastosowania, nasuwa daleko idące zastrzeżenia, podobnie jak pogląd o niedopuszczalności wprowadzenia do umowy ubezpieczenia kryteriów dalej idących albo po prostu odmiennych od kryterium adekwatności. Przeciwko zastosowaniu kryterium normalności następstw nie przemawia ani wykładnia językowa art. 361 k.c., ani natura prawna umowy ubezpieczenia. Wykładnia celowościowa prowadzi do rezultatów niejednoznacznych. Z jednej strony można twierdzić, jak autorzy niemieccy, że strony, wyznaczając zakres ochrony ubezpieczeniowej, mają na myśli zwykły przebieg wydarzeń, $\mathrm{z}$ drugiej strony, że nie zasługuje na dodatkową ochronę ubezpieczyciel, który nieprecyzyjnie ukształtował zakres przejmowanego ryzyka.

Trafne jest spostrzeżenie A. Kocha, że zwykle sformułowania ogólnych warunków umów ubezpieczenia precyzyjnie zakreślające zakres przejmowanego ryzyka ograniczają pola analiz kauzalnych. Dla udzielenia

156 M. Wandt, Versicherungsrecht, s. 356. 
odpowiedzi na pytanie, czy szkoda jest następstwem wypadku, przeważnie wystarcza przeprowadzeniu prostego testu conditio sine qua non. Dodać należy, że problem zakresu odpowiedzialności ubezpieczyciela zwykle będzie można rozstrzygnąć przy odwołaniu do ogólnych kryteriów wykładni oświadczeń woli oraz reguły in dubio contra proferentem. W sytuacjach wyjątkowych, budzących wątpliwości nie można jednak ostatecznie wykluczyć zastosowania kryterium normalności następstw, ponieważ żaden przepis nie wyklucza jego zastosowania. 
Rozdział 4

\section{OGRANICZENIA ODSZKODOWANIA UBEZPIECZENIOWEGO}

\subsection{Wartość ubezpieczenia}

Wartość ubezpieczenia stanowi kategorię techniczno-ubezpieczeniową i występuje jedynie w ubezpieczeniach mienia, albo używając terminologii proponowanej przez S. Byczko, w ubezpieczeniach aktywów, tj. w ubezpieczeniach majątkowych $\mathrm{z}$ wyłączeniem ubezpieczeń od odpowiedzialności cywilnej ${ }^{1}$. W ubezpieczeniu odpowiedzialności cywilnej pojęcie wartości ubezpieczenia nie znajduje zastosowania. Ubezpieczenie takie zawierane jest bowiem na wypadek konieczności zapłaty przez ubezpieczonego odszkodowania na rzecz osoby trzeciej, wartość takiego odszkodowania jest zaś nieznana w chwili zawarcia umowy ubezpieczenia. Ubezpieczenia osobowe z kolei dotyczą życia lub zdrowia ludzkiego, to jest dóbr osobistych niepodlegających wycenie w pieniądzu. Kodeks cywilny nie określa wartości ubezpieczenia. Czyni to Kodeks morski. Zgodnie z art. 300 k.m. wartością ubezpieczenia jest zwykła wartość przedmiotu ubezpieczenia.

W doktrynie E. Kowalewski definiuje wartość ubezpieczeniową jako wyrażoną w jednostkach pieniężnych rzeczywistą (rynkową) wartość przedmiotu ubezpieczenia ${ }^{2}$. Przytoczone określenie, nie przesądzając

\footnotetext{
${ }^{1}$ W. Warkałło, Ubezpieczenie utraconych korzyści..., s. 72.

2 Prawo ubezpieczeń gospodarczych, red. E. Kowalewski, s. 206.
} 
jeszcze jego trafności, może stanowić punkt odniesienia dla dalszej analizy pojęcia wartości ubezpieczeniowej, ponieważ trafnie zwraca uwagę na trzy kwestie. Dotyczą one po pierwsze, przedmiotu wartościowania, po drugie, wyrażenia wartości ubezpieczenia w jednostkach pieniężnych oraz po trzecie, określenia wartości ubezpieczenia jako wartości rzeczywistej.

Zaczynając od pierwszej kwestii, tj. przedmiotu wartościowania, można wskazać, że przed nowelizacją przepisów Kodeksu cywilnego o umowie ubezpieczenia z 2007 r. wartość ubezpieczenia definiowana była jako wartość ubezpieczonego mienia ${ }^{3}$. Po nowelizacji przepisów Kodeksu cywilnego z 2007 r., polegającej m.in. na zastąpieniu tzw. teorii majątku teorią interesu ubezpieczeniowego, takie określenie jest niezupełnie nieaktualne. Niektórzy przedstawiciele doktryny odwoływali się zresztą do teorii interesu jeszcze przed zmianą przepisów. Eugeniusz Kowalewski wiązał wartość ubezpieczenia $\mathrm{z}$ interesem ubezpieczeniowym już w 1997 r. ${ }^{4}$ Jego śladem M. Orlicki określał wartość ubezpieczenia jako wartość interesu stanowiącego przedmiot ochrony ubezpieczeniowej ${ }^{5}$.

W świetle obecnego brzmienia art. 821 k.c. związek wartości ubezpieczeniowej z interesem ubezpieczeniowym nie może budzić wątpliwości ${ }^{6}$. W tym kontekście zdziwienie budzi regulacja art. $824 \$ 2$ k.c., który pozwala ubezpieczającemu domagać się zmniejszenia sumy ubezpieczenia w razie zmniejszenia wartości ubezpieczonego mienia. Mając na uwadze ograniczenie zakresu stosowania pojęcia wartości ubezpieczeniowej do ubezpieczenia aktywów oraz określenie przedmiotu ubezpieczenia jako interesu majątkowego, można skonkludować, że wartość ubezpieczeniowa jest wartością interesu ubezpieczeniowego w ubezpieczeniu aktywów. Takie określenie wartości ubezpieczenia jest bardziej precyzyjne niż określenie odwołujące się do ogólnej kategorii

3 A. Wąsiewicz, Z.K. Nowakowski, Prawo...

4 E. Kowalewski, Wprowadzenie do teorii interesu..., s. 70.

5 M. Orlicki, Umowa ubezpieczenia, 2002, s. 157. Co do próby uzasadniania teorii interesu na gruncie przepisów przez przed zmianą przepisów, zob. B. Kucharski, Przeniesienie..., s. 106-107; na gruncie przepisów obecnych najszerzej S. Byczko, Interes..., passim.

${ }^{6}$ Co do tej kwestii, w szczególności S. Byczko, Interes..., s. 156. 
przedmiotu ubezpieczenia. Niemiecka ustawa o umowie ubezpieczenia również utożsamia wartość ubezpieczenia z wartością interesu ubezpieczeniowego (art. $74 \mathrm{VVG}$ ).

Drugie postawione zagadnienie dotyczyło konieczności wyrażenia wartości ubezpieczenia w pieniądzach. Zgodnie z art. 821 k.c. interes majątkowy stanowiący przedmiot ubezpieczenia ma być zgodny z prawem i dać się wycenić w pieniądzu. W myśl art. $824^{1} \$ 1$ k.c., który wyraża zasadę odszkodowania, suma pieniężna wypłacona przez ubezpieczyciela $\mathrm{z}$ tytułu ubezpieczenia nie może być wyższa od poniesionej szkody. Niezależnie od słuszności tradycyjnego poglądu, wedle którego świadczenie odszkodowawcze ubezpieczyciela musi przybierać postać świadczenia pieniężnego ${ }^{7}$, trudno nie dostrzec, że z art. 821 k.c. bezpośrednio, natomiast z $824^{1} \$$ k.c. pośrednio, wynika odniesienie do pieniądza jako miernika wartości odszkodowania. Taka korelacja stanowi zresztą ogólną zasadę prawa cywilnego wynikającą z obowiązywania systemu pieniężnego.

Wyprzedzając nieco tok dalszych rozważań, dodać można, że wartość ubezpieczenia pozostaje w relacji do sumy ubezpieczenia, która z kolei decyduje o wysokości składki, składka zaś, co nie budzi żadnych wątpliwości, jest świadczeniem pieniężnym. Nie przedłużając wywodu, należy zatem zgodzić się z poglądem, że wartość ubezpieczenia musi być wyrażona w pieniądzach. Wobec zniesienia w 2009 r. zasady walutowości nie powinna być również kwestionowana możliwość wyrażenia wartości ubezpieczenia w walucie obcej. Taką ewentualność można było zresztą rozważać już wcześniej, skoro wartość ubezpieczeniowa jest jedynie pośrednio powiązana ze świadczeniami stron.

Kolejna kwestia dotyczy określenia wartości ubezpieczenia jako wartości rzeczywistej (rynkowej). Takie ujęcie może wydawać się nieprecyzyjne. Przede wszystkim niektórzy autorzy odróżniają wartość rzeczywistą od rynkowej, definiując tę pierwszą jako wartość rynkową przedmiotu ubezpieczenia w stanie nowym z potrąceniem zużycia (amortyzacji)

\footnotetext{
7 Kwestia ta poruszana jest w odrębnym rozdziale pracy.
} 
określonego w OWU ${ }^{8}$. Tak rozumieć wartość rzeczywistą zdaje się również E. Kowalewski. Ponadto określenie wartości ubezpieczenia jako rzeczywistej pomija możliwość zawarcia ubezpieczenia w wartości nowej albo otaksowanej. Warto przypomnieć, że według art. 825 k.c. ${ }^{9}$, który został uchylony w 1984 r., sposób ustalenia wartości ubezpieczonego mienia, jak również sposób ustalenia szkody oraz wartości odszkodowania określały ogólne warunki ubezpieczenia. Właśnie w nawiązaniu do art. 825 k.c. odwołującego się do ogólnych warunków ubezpieczenia określali wartość ubezpieczenia W. Warkałło ${ }^{10}$ i A. Wąsiewicz ${ }^{11}$.

Wartość ubezpieczenia nie musi wynikać z treści umowy ubezpieczenia. Co więcej, wskazanie takiej wartości w umowie wydaje się stanowić odstępstwo od reguły. W myśl art. 301 k.m. wartość ubezpieczenia wymieniona w umowie oznacza wartość otaksowaną i jest miarodajna dla określenia odszkodowania ubezpieczeniowego. O wartości ubezpieczenia nie wspominają ani art. $295 \mathrm{k} . \mathrm{m}$. (wyznaczający minimalną treść polisy ubezpieczeniowej w ubezpieczeniu morskim), ani art. 16 u.d.u.r. (określający minimalną treść ogólnych warunków ubezpieczenia). Kodeks cywilny odnosi się do tej kwestii jedynie we wspomnianym art. 824 $\$ 2$ k.c., pozwalającym żądać zmniejszenia sumy ubezpieczenia w razie zmniejszenia wartości ubezpieczonego mienia. Z powyższego wynika, że wartość ubezpieczenia musi być wskazana w umowie ubezpieczenia jedynie wtedy, gdy ustalona zostaje na poziomie odbiegającym od wartości zwykłej (rzeczywistej) interesu ubezpieczeniowego. Podsumowując, ujęcie wartości ubezpieczeniowej jako wartości rzeczywistej, zwykłej albo rynkowej nie jest błędne, choć może wydawać się nieprecyzyjne. Celem uściślenia należy zatem powiedzieć, że wartość ubezpieczeniowa jest wartością zwykłą (rynkową) albo inną wartością wskazaną w umowie lub ogólnych warunkach ubezpieczenia.

8 B. Kęszycka, Prawo ubezpieczeń gospodarczych, Poznań 1999, s. 109.

9 Przepis uchylono ustawą z 20.09.1984 r. o ubezpieczeniach majątkowych i osobowych (Dz.U. poz. 242 ze zm.).

10 W. Warkałło, Ubezpieczenie utraconych korzyści..., s. 72.

11 A. Wąsiewicz, Z.K. Nowakowski, Prawo..., s. 49. 
Ostatni wątek pozwala płynnie przejść do istotnej kwestii określenia wartości ubezpieczenia na poziomie odbiegającym od wartości rynkowej interesu ubezpieczenia. Mozaikę możliwych rozwiązań w tej mierze przedstawia na diagramach E. Kowalewski. Poza wartością rzeczywistą autor ten wyróżnia wartość szacunkową, otaksowaną, inwentarzową (księgową), odtworzeniową oraz wartość nową ${ }^{12}$. Wartość rzeczywista to wartość zwykła, czyli rynkowa przedmiotu ubezpieczenia z potrąceniem tzw. amortyzacji. Innymi słowy, chodzi o aktualną wartość rynkową. Wydaje się, że postanowienie umowy lub OWU pozwalające ubezpieczycielowi na ustalanie współczynników amortyzacji na poziomie zupełnie dowolnym w taki sposób, że wartość rzeczywista odbiegałaby w sposób istotny od aktualnej wartości przedmiotu ubezpieczenia, może być uznane za sprzeczne z właściwością (naturą) stosunku prawnego ubezpieczenia. Wartość szacunkowa jest wartością jednostronnie ustalaną przez ubezpieczyciela na podstawie stosowanych przez niego cenników. Wartość księgowa to z kolei wartość wynikająca z prowadzonej przez ubezpieczającego dokumentacji księgowo-rachunkowej (ewidencji środków trwałych i obrotowych). Wartość odtworzeniowa jest stosowana przy szkodach częściowych określonych przedmiotów ubezpieczenia. Polega na tym, że pod uwagę bierze się koszt użytych do naprawy uszkodzonej maszyny lub urządzenia nowych części, choćby maszyna lub urządzenie nie była nowa. Wartość nowa stosowana jest często w odniesieniu do ubezpieczenia budynków i odpowiada wartości nowego obiektu, którym ubezpieczony zastępuje obiekt zniszczony w razie szkody całkowitej. Wartość otaksowana jest z kolei ustaloną umownie, przybliżoną wartością umowy ubezpieczenia, miarodajną dla określenia odszkodowania ${ }^{13}$.

Biorąc pod uwagę obowiązującą w ubezpieczeniach zasadę odszkodowania, zasadnicze znaczenie mają ubezpieczenia w wartości rzeczywistej, odtworzeniowej lub nowej oraz otaksowanej, uważane niekiedy za odstępstwa od tej zasady, przy czym wartość odtworzeniowa i wartość nowa stanowią postać tej samej wartości, określanej różnie w zależności od tego, czy wypadek ubezpieczeniowy powoduje szkodę częściową, czy

12 Prawo ubezpieczeń gospodarczych, red. E. Kowalewski, s. 208.

13 Prawo ubezpieczeń gospodarczych, red. E. Kowalewski, s. 208. 
całkowitą. Można się zastanawiać, czy wartość szacunkowa, inwentarzowa i księgowa powinny być wymieniane obok wartości rzeczywistej, odtworzeniowej lub nowej oraz otaksowanej. Kryterium ich wyróżnienia wydaje się stanowić bowiem konkretny sposób szacowania wartości rzeczywistej, odtworzeniowej lub nowej albo otaksowanej. Dalsze wywody koncentrować się będą na wartości rzeczywistej rozumianej jako aktualna wartość rynkowa, wartości nowej, przez którą należy rozumieć również odtworzeniową przy szkodach częściowych, oraz na wartości otaksowanej.

Sformułowanie art. $824^{1}$ k.c. wyrażającego zasadę odszkodowania wskazuje, że norma w nim zawarta nie ma charakteru bezwzględnie obowiązującego. Przepis zawiera zastrzeżenie, że suma pieniężna wypłacana przez ubezpieczyciela z tytułu umowy ubezpieczenia nie może być wyższa od poniesionej szkody, jeżeli nie umówiono się inaczej. Wypada odnotować, że podobnego zastrzeżenia nie zawierał przywoływany wcześniej art. 825 k.c., czyniąc w ten sposób z zasady odszkodowania, zdaniem niektórych, regułę bezwzględną, nieznajdującą odstępstw ${ }^{14}$. Autorzy wypowiadający się w omawianej kwestii są zgodni co do tego, że wynikający z art. $824^{1}$ k.c. względny charakter zasady odszkodowania nie upoważnia do przyjęcia całkowitej dowolności w kwestii wysokości świadczenia pieniężnego ubezpieczyciela, a co za tym idzie, w kwestii określenia wartości ubezpieczenia. Umowa całkowicie oderwana od wartości interesu ubezpieczeniowego byłaby umową hazardową zbliżoną do gry i zakładu oraz pozostającą w sprzeczności z naturą stosunku prawnego ubezpieczenia ${ }^{15}$. Dopuszczalne jest tylko takie ustalenie kryteriów wysokości świadczenia zakładu ubezpieczeń, które ma na celu zaspokojenie interesu ubezpieczeniowego naruszonego w wyniku wypadku ${ }^{16}$. Spór w doktrynie zdaje się dotyczyć tego, czy w przypadkach ubezpieczenia w wartości nowej i otaksowanej dochodzi do przełamania zasady odszkodowania.

14 Tak. M. Kaliński, Zasada..., cz. 1, s. 46.

15 M. Krajewski, Umowa ubezpieczenia. Art. 805-834 KC. Komentarz, Warszawa 2004, s. 218.

16 M. Krajewski, Umowa ubezpieczenia. Art. 805-834 KC..., 2004, s. 219 z powołaniem się na M. Orlickiego. 
W tym drugim kierunku wypowiada się M. Krajewski, według którego w omawianych przypadkach kryteria ustalenia wysokości świadczenia ubezpieczyciela ustalane są w sposób odbiegający od przyjętych w ogólnym prawie odszkodowawczym. Ze stanowiskiem dotyczącym przełamania zasady odszkodowania w odniesieniu do ubezpieczenia w wartości nowej nie zgadza się natomiast S. Byczko. Według tego autora odpowiedzialność ubezpieczeniowa dotyczy odszkodowania ustalonego w sposób określony w umowie oraz ogólnych warunkach ubezpieczenia i w tym sensie nie zachodzi sprzeczność między właściwymi dla prawa ubezpieczeniowego sposobami ustalania wysokości odszkodowania oraz samą zasadą odszkodowania ${ }^{17}$. Jak się zdaje, S. Byczko rozumie zasadę odszkodowania w prawie ubezpieczeniowym inaczej niż zakaz wzbogacenia poszkodowanego, mający zastosowanie w ogólnym prawie odszkodowawczym ${ }^{18}$. Autor ten twierdzi również, że o ile ubezpieczenie w wartości nowej jest zgodne zarówno z konstrukcją interesu ubezpieczeniowego, jak i z zasadą odszkodowania, o tyle ubezpieczenie w wartości otaksowanej trzyma się konstrukcji interesu, odchodzi jednak od zasady odszkodowania. Szymon Byczko tłumaczy swoje stanowisko odrębnością zasady odszkodowania od wymagania interesu ubezpieczeniowego ${ }^{19}$.

Zagadnienie ubezpieczenia w wartości nowej i otaksowanej zostało dokładnie omówione już w latach 70. XX w. przez W. Warkałłę. Nestor polskiej nauki prawa ubezpieczeniowego zwracał uwagę, że istnieje możliwość pogodzenia ubezpieczenia w wartości nowej z zasadą odszkodowania. Skoro pojęcie szkody obejmuje nie tylko szkodę efektywnie poniesioną, ale również wydatki i nakłady, nic nie stoi na przeszkodzie, by również różnica między wartością nowego i starego obiektu była objęta odszkodowaniem ubezpieczeniowym. Jeżeli zobowiązanie

17 S. Byczko, Interes..., s. 165-171.

18 Na kwestię, że zasada odszkodowania nie jest jakąś szczególną instytucją ubezpieczeniową, zwraca uwagę W. Warkałło, Ubezpieczenie utraconych korzyści... Samo sformułowanie odszkodowanie wskazuje przecież, że celem prawa odszkodowawczego jest kompensacja szkody, nie zaś wzbogacenie poszkodowanego. M. Kaliński negatywny aspekt zasady odszkodowania określa mianem zasady restytucji. Zob. M. Kaliński, Zasada..., cz. 1, s. 44-46.

19 S. Byczko, Interes..., s. 169. 
odszkodowawcze jest zobowiązaniem przemiennym i stosownie do art. 363 k.c. poszkodowany ma prawo wyboru między restytucją naturalną i rekompensatą pieniężną, to nie stanowi naruszenia zasady odszkodowania sytuacja, w której poszkodowany otrzymuje obiekt nowy zamiast starego, w sytuacji gdy obiekt o określonym stopniu zużycia jest na rynku nieosiągalny. Od strony funkcjonalnej nic się nie zmienia, jeżeli nowy obiekt pełni dokładnie takie same zadania co stary ${ }^{20}$.

Witold Warkałło wskazywał, że ubezpieczenie w wartości nowej próbowano pogodzić z zasadą odszkodowania dzięki twórczej koncepcji upatrującej w tym ubezpieczeniu ubezpieczenia rzeczy oraz wydatków dotyczących tej rzeczy. Zdaniem tego autora trafniejsza była inna próba zachowująca materialną jedność ubezpieczenia w wartości nowej, według której wydatek dokonany w celu nabycia nowej rzeczy w miejsce zniszczonej rzeczy starej jest koniecznym następstwem wypadku ubezpieczeniowego i dlatego może być ujmowany jako część składowa szkody wynagradzanej odszkodowaniem ubezpieczeniowym. Podstawę prób pogodzenia zasady odszkodowania z ubezpieczeniem wartości nowej W. Warkałło widział w przeformułowaniu zasady odszkodowania poprzez uznanie, że odszkodowanie ubezpieczeniowe przeobraziło się z kategorii wartości w kategorię kosztów, w której mieszczą się również wydatki konieczne, obciążające ubezpieczającego wskutek nastąpienia wypadku'21.

Ubezpieczenie w wartości otaksowanej autor ten również starał się pogodzić z zasadą odszkodowania. Powoływał rozwiązania zachodnioeuropejskie, które pod różnymi warunkami pozwalają ubezpieczycielowi kwestionować wartość otaksowaną, jeżeli przekracza ona rzeczywistą wartość ubezpieczenia. Następnie wskazywał, że według polskiego Kodeksu morskiego umowa nie ma skutku prawnego co do nadwyżki sumy ponad wartość ubezpieczenia, jeżeli określona w umowie suma ubezpieczenia jest wyższa od wartości ubezpieczenia ${ }^{22}$. Zdaniem W. Warkałły polski ustawodawca dopuszczał możliwość udowodnienia przez ubez-

\footnotetext{
20 W. Warkałło, Ubezpieczenie utraconych korzyści..., s. 74.

${ }^{21}$ W. Warkałło, Ubezpieczenie utraconych korzyści..., s. 78-79.

22 Obecnie reguła ta wynika $\mathrm{z}$ art. $302 \mathrm{k} . \mathrm{m}$.
} 
pieczyciela okoliczności, że wartość faktyczna ubezpieczonego przedmiotu w chwili wypadku ubezpieczeniowego (tzw. wartość końcowa) była inna niż wartość otaksowana przewidziana w umowie. Opisane zabezpieczenie zasady odszkodowania uważał jednak za nieskuteczne wobec postawy ubezpieczycieli niechętnie biorących na siebie ciężar trudnego w praktyce dowodu i niechcących wikłać się w procesy o niepewnym wyniku ${ }^{23}$.

Wbrew twierdzeniom W. Warkałły z regulacji Kodeksu morskiego, niezmienionej w omawianych kwestiach, trudno wywieść, że ubezpieczyciel może dowodzić zawyżenia wartości otaksowanej w stosunku do rzeczywistej wartości przedmiotu ubezpieczenia w chwili wypadku (wartości końcowej). Kodeks morski czyni bezskuteczną umowę ubezpieczenia w zakresie, w jakim ustalona suma ubezpieczenia przewyższa wartość ubezpieczenia. Jak wskazywano, brzmienie tego kodeksu sugeruje, że wartość ubezpieczenia może być wartością zwykłą albo wartością wskazaną w umowie. Wartość wskazana w umowie, zwana wartością otaksowaną, jest miarodajna do określenia wysokości odszkodowania, choćby nie była tożsama $\mathrm{z}$ wartością rzeczywistą. Nawet gdyby regułę pozwalającą na taki przeciwdowód można było wywieść $\mathrm{z}$ Kodeksu morskiego, nie można by jej odnieść wprost do ubezpieczeń lądowych, pomijając przypadki transportu multimodalnego ${ }^{24}$.

Podsumowując powyższe wywody, wydaje się, że ubezpieczenie w wartości nowej łatwiej pogodzić z zasadą odszkodowania niż ubezpieczenie w wartości otaksowanej. Można bowiem twierdzić, że w przypadku zniszczenia używanej rzeczy przywrócenie stanu poprzedniego w sensie ekonomicznym bardzo często wymaga jej zastąpienia rzeczą nową, trudno natomiast twierdzić, że wypłata odszkodowania w umówionej wartości przekraczającej wysokość poniesionej przez ubezpieczającego szkody nie prowadzi do wzbogacenia. $\mathrm{W}$ odniesieniu do tego drugiego

23 W. Warkałło, Ubezpieczenie utraconych korzyści..., s. 74 i 78.

24 Zgodnie z obecnym art. $292 \mathrm{k} . \mathrm{m}$. umową ubezpieczenia morskiego można objąć nie tylko niebezpieczeństwa związane z żeglugą morską, ale również niebezpieczeństwa, na które w związku z przewozem morskim przedmiot ubezpieczenia jest narażony w przewozie lotniczym, na wodach śródlądowych lub na lądzie. 
przypadku prawo polskie nie wskazuje szczegółowych rozwiązań stojących na straży zasady odszkodowania podobnych do przewidywanych przez niektóre obce porządki prawne.

Odnosząc się do prawa obcego, można wskazać, że zgodnie z art. 76 VVG wartość ubezpieczeniowa może być ustalona w drodze uzgodnienia sumy otaksowanej. Domniemywa się, że wartość otaksowana odpowiada wartości interesu ubezpieczeniowego $\mathrm{w}$ chwili zajścia wypadku, chyba że wartość otaksowana istotnie przewyższa rzeczywistą wartość ubezpieczenia w chwili zajścia wypadku. W prawie angielskim również możliwe jest porozumienie się co do ubezpieczenia w wartości otaksowanej, co skutkuje wypłatą uzgodnionej sumy w chwili zajścia wypadku. Taka umowa nie jest jednak skuteczna, jeżeli uzgodniona wartość jest rażąco zawyżona ${ }^{25}$.

Specjalnych regulacji dotyczących ubezpieczenia w wartości otaksowanej brakuje natomiast we francuskim kodeksie ubezpieczeń. Artykuł L 121-1 tego kodeksu, otwierający rozdział o ubezpieczeniach szkodowych, podkreśla, że ubezpieczenie jest umową o odszkodowanie. Wartość odszkodowania, które ubezpieczyciel zobowiązany jest wypłacić ubezpieczającemu, nie może przekraczać wartości ubezpieczonego majątku w chwili szkody. Dopuszcza się ograniczenia wysokości odszkodowania w postaci udziału własnego lub franszyzy. Zgodnie z art. L121-3, jeżeli ubezpieczenie zawarto na sumę przewyższającą wartość ubezpieczenia na skutek oszustwa jednej ze stron, druga strona może żądać unieważnienia umowy oraz domagać się naprawienia szkody. W braku oszustwa umowa jest ważna jedynie w zakresie aktualnej rzeczywistej wartości ubezpieczenia i ubezpieczyciel pozbawiony jest prawa żądania składki od nadwyżki.

Pytanie o zgodność ubezpieczenia w wartości otaksowanej z zasadą odszkodowania pozostaje zatem otwarte. Rację ma przy tym S. Byczko, że

25 J. Birds, Birds' Modern Insurance Law, London 2007, s. 292. Wyraźne przeszacowanie wartości przez ubezpieczającego może być traktowane jako złamanie obowiązku deklaracji, w innych przypadkach umowa może okazać się nieważna jako zakład (gaming policy). 
podobnie jak w odniesieniu do ubezpieczenia w wartości nowej, spory o ubezpieczenie $\mathrm{w}$ wartości otaksowanej oraz jego zgodność $\mathrm{z}$ zasadą odszkodowania pozostają dość jałowe i dotyczą niuansów. W zasadzie wszyscy pozostają zgodni co do tego, że względny charakter zasady odszkodowania nie oznacza dowolności, także przy ustalaniu wartości ubezpieczenia jako wartości otaksowanej. Istota rzeczy sprowadza się do tego, że ubezpieczenie ma stać na straży interesu majątkowego będącego jego przedmiotem. Jeżeli całkowicie odrywa się od wartości tego interesu, przestaje być ubezpieczeniem, przekształcając się $\mathrm{w}$ istocie w umowę hazardową.

Ze stanowiskiem, według którego możliwość zawierania ubezpieczeń w wartości nowej i otaksowanej wynika z okoliczności, że odszkodowanie ubezpieczeniowe jest odszkodowaniem umownym, można zgodzić się jedynie częściowo. Umowny charakter odszkodowania ubezpieczeniowego pozwala jedynie na wprowadzenie ograniczeń o charakterze techniczno-ubezpieczeniowym, nie pozwala natomiast ustalać odszkodowania na poziomie przekraczającym wysokość poniesionej szkody. Dopuszczenie takiej możliwości oznaczałoby w istocie, że świadczenie pieniężne ubezpieczyciela w ubezpieczeniu majątkowym może przybierać postać uzgodnionej sumy pieniężnej zamiast odszkodowania ${ }^{26}$. Zastrzeżenie $z$ art. $824^{1} \$ 1$ k.c., według którego suma pieniężna wypłacana przez ubezpieczyciela nie może być wyższa od poniesionej szkody, o ile nie umówiono się inaczej, nie przekreśla normy z art. 805 $\$ 2$ k.c., określającej świadczenie pieniężne ubezpieczyciela w ubezpieczeniu majątkowym mianem odszkodowania i przeciwstawiającej je świadczeniom o charakterze nieodszkodowawczym wypłacanym w ubezpieczeniach osobowych.

Zastrzeżenie $\mathrm{z}$ art. $824^{1} \$ 1$ k.c. stanowi jedynie regułę interpretacyjną pozwalającą uniknąć sporów o samą dopuszczalność zawierania ubez-

26 Jednakże w doktrynie niemieckiej, pomimo istnienia przytoczonej reguły umożliwiającej kwestionowanie wartości otaksowanej odbiegającej istotnie od wartości rynkowej, wyrażany jest pogląd, że w ubezpieczeniach nie obowiązuje ogólny zakaz wzbogacenia, a wartość ustalona przez strony ma decydujące znaczenie. M. Wandt, Versicherungsrecht, s. 299. 
pieczeń w wartości nowej oraz w wartości otaksowanej. Nie oznacza jednak dopuszczalności umawiania się w ubezpieczeniach majątkowych o wypłatę świadczeń o charakterze nieodszkodowawczym. Szymon Byczko ma rację, że interes ubezpieczeniowy i zasada odszkodowania stanowią konstrukcje odrębne w tym sensie, że wymaganie interesu ma znaczenie także w chwili zawarcia umowy ubezpieczenia, natomiast zasada odszkodowania ujawnia się dopiero z chwilą wypadku. Wskazany czasowy rozstęp nie zmienia jednak faktu, że obydwie konstrukcje pozostają ze sobą w bardzo ścisłym związku. Można powiedzieć, że zasada odszkodowania oraz konstrukcja interesu stanowią dwie strony tego samego zagadnienia.

Ubezpieczenie w wartości otaksowanej daje się pogodzić z zasadą odszkodowania w tym sensie, że jego dopuszczalność ograniczona jest odszkodowawczym charakterem świadczenia pieniężnego w ubezpieczeniu majątkowym. Dokładnie ilustrują to podawane przykłady takiego ubezpieczenia. W ubezpieczeniu transportowym może chodzić o ochronę właściciela towaru przed zmianami cen giełdowych w trakcie jego transportu. Zmiany cen giełdowych na niekorzyść prowadzą jednak do szkody w szerokim rozumieniu. W ubezpieczeniu autocasco umowa o wypłatę odszkodowania równego cenie nowego samochodu w pewnym okresie od daty zawarcia umowy ubezpieczenia dotyczącej nowego samochodu będzie ważna tak długo, jak długo ubezpieczającemu nie będzie opłacało się spowodować wypadku. Trzeba bowiem pamiętać, że zakup nowego samochodu zamiast samochodu uszkodzonego wiąże się z określonymi niedogodnościami, z ryzykiem, że nowy samochód nie będzie identyczny z uszkodzonym, oraz z dodatkowymi wydatkami polegającymi choćby na pokryciu kosztów związanych z zawarciem samej transakcji kupna, kosztów rejestracji nowego pojazdu oraz jego ubezpieczenia.

W tym kontekście zastrzeżenia budzi znana z praktyki dopuszczalność zawierania ubezpieczeń na warunkach, wedle których po 3 latach od daty zakupu luksusowego auta ubezpieczyciel zapłaci wartość z faktury. Ubezpieczenia tego rodzaju zbliżają się do umów hazardowych, sprawiając, że ubezpieczony, jak również oferujący takie ubezpieczenia sprzedawca auta stają się zainteresowani zajściem wypadku ubezpie- 
czeniowego. Licząc na sprzedaż kolejnego nowego samochodu i dalszą owocną współpracę, sprzedawcy samochodów oferujący takie ubezpieczenia swoim klientom mogą proponować, że tuż przed upływem 3 lat stary samochód „zginie”. Oczywiście działania tego rodzaju, niezależnie od prawnokarnych aspektów związanych z ich oceną, naruszają również umowę agencyjną łączącą sprzedawcę samochodów z ubezpieczycielem, w imieniu którego zawiera umowy.

W razie ustalenia, że strony umówiły się przy ubezpieczeniu majątkowym o wypłatę świadczenia niemającego charakteru odszkodowania tak, że perspektywa zajścia wypadku ubezpieczeniowego nie stwarza dla ubezpieczającego istotnego ryzyka, zamiast tego pozwalając mu wskutek wypadku zarobić, umowa przestaje mieć charakter ubezpieczenia. Umowa taka jest nieważna w zakresie, w jakim prowadzi do wzbogacenia ubezpieczającego, jako sprzeczna z właściwością (naturą) stosunku prawnego ubezpieczenia majątkowego i przez to wykracza poza granicę swobody umów określoną w art. $353^{1}$ k.c. Podsumowując ten wątek, można zaryzykować stwierdzenie, że ubezpieczenia w wartości nowej i otaksowanej stanowią nie tyle wyjątek od zasady odszkodowania charakterystycznej dla całego prawa cywilnego, ile pewnego rodzaju wyjątek od zasady lokalizacji szkody. Mogą bowiem niekiedy pozwalać na kompensację wydatków poniesionych na nabycie rzeczy nowej lub wydatków bezpośrednio związanych z utratą rzeczy starej, nie powinny natomiast prowadzić do oczywistego wzbogacenia. Wydaje się nadto, że brak wyraźnych reguł pozwalających uznać za bezskuteczne ustalenie wartości oszacowania na poziomie rażąco odbiegającym od wartości rzeczywistej stanowi mankament polskiej regulacji umowy ubezpieczenia.

Omówienie ubezpieczenia w wartości odbiegającej od wartości rzeczywistej pozwala przejść do kolejnego zagadnienia. Nie zostało jeszcze wyjaśnione, kiedy oraz przez kogo ustalana jest wartość ubezpieczenia. Pierwsza kwestia wydaje się prosta tylko pozornie. Prima facie wydaje się, że wartość ubezpieczenia ustalana jest w chwili zawarcia umowy 
ubezpieczenia ${ }^{27}$. Za takim stanowiskiem przemawia okoliczność, że w chwili zawarcia umowy ustalane są suma ubezpieczenia oraz na jej podstawie wysokość składki, suma ubezpieczenia powinna zaś odzwierciedlać wartość ubezpieczenia.

Kodeks morski każe co do zasady brać pod uwagę wartość ubezpieczenia z chwili zawarcia umowy. Zgodnie z art. $300 \$ 2$ k.m. „Wartość ubezpieczenia ustala się według następujących zasad:

1) wartością ubezpieczenia statku jest wartość statku w chwili rozpoczęcia ubezpieczenia (...);

2) wartością ubezpieczenia ładunku jest wartość ładunku w miejscu i czasie załadowania łącznie z kosztami ubezpieczenia i dostarczenia ładunku do miejsca przeznaczenia;

3) wartością ubezpieczenia frachtu jest suma frachtu brutto łącznie z kosztami ubezpieczenia;

4) wartością ubezpieczenia innych przedmiotów ubezpieczenia, z wyjątkiem zobowiązania z tytułu odpowiedzialności cywilnej, jest kwota, na której utratę jest narażony ubezpieczający w chwili rozpoczęcia ubezpieczenia (...)”.

Jak widać, w punktach 1 i 4 ustawodawca wprost odwołuje się do rozpoczęcia ubezpieczenia. W punkcie 2 mowa jest o wartości ładunku w miejscu i czasie załadowania, ponieważ od chwili załadowania powstaje dotyczące ładunku niebezpieczeństwo związane z żeglugą morską, które może być objęte umową ubezpieczenia morskiego zgodnie $\mathrm{z}$ art. $292 \mathrm{k} . \mathrm{m}$. W punkcie 3 mowa jest o wartości frachtu bez odwołania się do konkretnego momentu w czasie, ponieważ raz ustalona wartość frachtu pozostaje co do zasady niezmieniona przez cały czas trwania przewozu.

Warto zwrócić uwagę, że sformułowanie "rozpoczęcie ubezpieczenia” może rodzić wątpliwość co do tego, czy chodzi o formalny, czy materialny początek ubezpieczenia. Wątpliwość ta jest oczywiście czysto

27 W ten sposób wypowiada się co do zasady doktryna. Por. B. Kęszycka, Prawo..., s. 109, 190; Prawo ubezpieczeń gospodarczych, red. E. Kowalewski, s. 206; M. Krajewski, Umowa ubezpieczenia. Art. 805-834 KC..., 2016, s. 205. 
teoretyczna, ponieważ rzadko wartość ubezpieczenia ulegnie zmianie w okresie tzw. karencji między zawarciem ubezpieczenia a początkiem odpowiedzialności ubezpieczyciela. Poza tym, jak już wskazywano, art. 301 k.m. określa wartość otaksowaną jako wartość wymienioną w umowie, miarodajną dla ustalenia odszkodowania ubezpieczeniowego. Dodatkowo art. 302 k.m. reguluje konsekwencje ustalenia sumy ubezpieczenia na poziomie mniejszym lub większym od wartości ubezpieczenia, wskazując, że jeśli suma ubezpieczenia jest wyższa, ubezpieczenie jest bezskuteczne w zakresie nadwyżki, natomiast jeżeli suma ubezpieczenia jest niższa, ubezpieczyciel odpowiada za szkody w stosunku, w jakim suma ubezpieczenia pozostaje do wartości ubezpieczenia.

Jak już wskazywano, znajdująca zastosowanie w ubezpieczeniach lądowych regulacja Kodeksu cywilnego nie określa wprost pojęcia wartości ubezpieczenia. W art. $824 \$ 2$ k.c. ustawodawca odwołuje się do wartości ubezpieczonego mienia oraz przyznaje stronom umowy ubezpieczenia uprawnienia w zakresie zmniejszenia sumy ubezpieczenia w sytuacji, gdy wartość ubezpieczonego mienia uległa zmniejszeniu po zawarciu ubezpieczenia. Odwołując się expressis verbis do chwili zawarcia ubezpieczenia, ustawodawca zdaje się zakładać, że wartość ubezpieczenia ustalana jest $\mathrm{w}$ chwili zawarcia umowy. Warto przy tym raz jeszcze odnotować, że reforma polegająca na zastąpieniu teorii majątku teorią interesu nie została przeprowadzona konsekwentnie. Zmieniając art. 824 k.c., zapewne zapomniano bowiem zastąpić sformułowanie „Wartość ubezpieczonego mienia” sformułowaniem „wartość ubezpieczonego interesu”.

Mając na uwadze powyższe, należy jednak pamiętać, że dla określenia wysokości odszkodowania miarodajna jest wartość przedmiotu ubezpieczenia z chwili wypadku, tzn. wartość końcowa. W prawie angielskim uważa się nawet, że interes ubezpieczeniowy w ubezpieczeniach majątkowych musi istnieć właśnie w chwili wypadku, nie ma natomiast konieczności, by występował on w chwili zawarcia umowy ubezpieczenia $^{28}$. Dodatkowo wartość otaksowana ustalana jest niejako na stałe właśnie po to, by uniknąć szacowania jej ponownie w razie zmiany

28 J. Birds, Birds'..., s. 284. 
wartości interesu w trakcie trwania umowy. Zmiany takie są czymś oczywistym. Zdarza się zresztą, że ogólne warunki niektórych rodzajów ubezpieczenia wyróżniają wartość początkową, aktualną i końcową. Według Z. Szymańskiego wartość ubezpieczenia to wartość przedmiotu ubezpieczenia z chwili zawarcia umowy. Na określenie wartości z chwili zajścia wypadku autor ten używa terminu „wartość odszkodowawcza”29.

Przytoczona regulacja Kodeksu morskiego wskazuje, że dla potrzeb ustalenia relacji między wartością ubezpieczenia a sumą ubezpieczenia oraz określenia systemu odpowiedzialności ubezpieczyciela istotna jest przede wszystkim wartość początkowa. Zasada Kodeksu morskiego nie może być jednak przenoszona wprost na grunt Kodeksu cywilnego, niezawierającego wyraźnej regulacji. Warto przy tym odnotować, że ustawodawstwa francuskie i niemieckie przyjmują regułę przeciwną, odnosząc kwestie niedoubezpieczenia do wartości ubezpieczenia z chwili wypadku. Wskazują na to normy art. 75 VVG oraz art. L121-5 Code des assurances.

Wziąwszy pod uwagę, że odszkodowanie ustala się według wartości ubezpieczenia $z$ daty szkody, nic nie stoi na przeszkodzie, aby również w prawie polskim umowa lub ogólne warunki ubezpieczenia wprowadzały zasadę, że o istnieniu niedoubezpieczenia decyduje wartość ubezpieczenia $\mathrm{z}$ chwili wypadku. W praktyce zresztą tak zwykle się zdarza. Można co najwyżej stwierdzić, że zasada Kodeksu morskiego powinna mieć zastosowanie w ubezpieczeniach lądowych, jeżeli co innego nie wynika z ogólnych warunków ubezpieczenia. Marcin Orlicki pisze, że chwilę miarodajną dla ustalania wartości ubezpieczenia powinny wskazywać ogólne warunki ubezpieczenia ${ }^{30}$. Jeżeli ani umowa, ani ogólne warunki nie precyzują tej kwestii, zwykle z kontekstu winno wynikać, czy chodzi o wartość początkową, aktualną czy końcową.

Podsumowując, utożsamianie wartości ubezpieczenia $\mathrm{z}$ wartością początkową interesu ubezpieczeniowego z chwili zawarcia umowy nie wydaje się właściwe. W chwili zawarcia ubezpieczenia wartość ubez-

29 Z. Szymański, Prawo..., s. 107.

30 M. Orlicki, Umowa ubezpieczenia, 2002, s. 158. 
pieczenia przeważnie w ogóle nie jest określana i nikt jej szczegółowo nie bada. Istotna jest przede wszystkim wartość końcowa, tj. wartość ubezpieczenia w chwili wypadku, i często to właśnie ona decyduje o tym, czy zachodzi przypadek nadubezpieczenia albo niedoubezpieczenia. Regulacja pozwalająca żądać zmiany wysokości składki wraz ze zmianą wartości ubezpieczenia pozwala wyróżnić wartość aktualną. Mianem wartości ubezpieczenia mogą być określane zależnie od kontekstu i uregulowania umownego zarówno wartość początkowa, aktualna, jak i końcowa przedmiotu ubezpieczenia.

Ostatnia kwestia dotyczy pytania o stronę umowy ustalającą wartość ubezpieczenia. Oczywiście ostatecznie wartość otaksowana określona $\mathrm{w}$ umowie ustalana jest w drodze porozumienia stron. Poza tym przyjmuje się, że wartość ubezpieczenia podaje ubezpieczający, ponosząc ryzyko związane z jej zawyżeniem lub zaniżeniem ${ }^{31}$. W pierwszym przypadku ubezpieczający zapłaci wyższą składkę, a odszkodowanie i tak nie będzie przekraczać rzeczywistej wartości końcowej interesu ubezpieczeniowego. W drugim przypadku dojdzie do tzw. niedoubezpieczenia, a konsekwencje zależeć będą od ustalonego w umowie lub ogólnych warunkach systemu odpowiedzialności ubezpieczyciela. To zagadnienie zostanie rozważone w dalszej części pracy.

Opisywany sposób postawienia sprawy stanowi jednak uproszczenie. W praktyce, szczególnie w odniesieniu do samochodów, wartość ubezpieczeniowa ustalana jest przez ubezpieczyciela w chwili zawarcia umowy jedynie szacunkowo na podstawie odpowiednich zestawień lub programów (EUROTAX, INFO-EXPERT). Często ubezpieczyciele dokonują również odpowiednich oględzin i sporządzają dokumentację fotograficzną. Następnie, gdy dochodzi do wypadku, także wtedy, gdy następuje on krótko po zawarciu umowy, ubezpieczyciel dla potrzeb ustalenia wysokości należnego odszkodowania wycenia wartość samochodu raz jeszcze, tym razem dokładnie i zwykle na znacznie niższą kwotę niż w chwili zawierania umowy. Prawo polskie nie zna angielskiej

31 A. Wąsiewicz, Z.K. Nowakowski, Prawo..., s. 49; S. Reps, J. Reps, Ubezpieczenia majątkowe przedsiębiorców, s. 91-92; M. Krajewski, Umowa ubezpieczenia. Art. 805-834 KC..., 2016, s. 205. 
instytucji estoppel niepozwalającej stronie, która utrzymuje drugą stronę w przekonaniu o istnieniu pewnych faktów, twierdzić, że prawdziwy stan rzeczy był inny ${ }^{32}$. W konsekwencji, obserwując polską praktykę ubezpieczeniową, można odnieść wrażenie, że istotna część pojazdów jest celowo nadubezpieczana.

Prima facie w opisywanej sytuacji można dopatrywać się szczególnego przypadku culpa in contrahendo. Ubezpieczyciel jako profesjonalista zobowiązany zachować określony poziom staranności powinien ponosić odpowiedzialność ex delicto ${ }^{33}$. Zakres odszkodowania, jakiego może domagać się ubezpieczający, wydaje się być ograniczony do nadpłaconych składek. Nie wydaje się natomiast możliwe, by w opisywanej sytuacji dochodziło do zawarcia umowy ubezpieczenia w wartości otaksowanej pomimo pokusy przyjęcia takiego rozwiązania ${ }^{34}$. Zawarcie ubezpieczenia w wartości otaksowanej musi wszak wynikać z warunków umowy. W szczególności konieczne jest wskazanie wartości otaksowanej w umowie. W przypadku ubezpieczenia autocasco samochodu w umowie wskazywana jest zwykle wyłącznie suma ubezpieczenia ustalana na poziomie tożsamym z zawyżoną wartością ubezpieczenia.

Konkludując, założenie, że wartość ubezpieczenia ustala w chwili zawarcia umowy ubezpieczający, który zna prawdziwy stan rzeczy, często nie odpowiada prawdzie. Wątpliwe staje się w związku z tym twierdzenie, że właśnie ubezpieczający powinien ponosić negatywne konsekwencje ustalenia tej wartości na poziomie zawyżonym albo zaniżonym. Sprawa ta zostanie jeszcze poruszona. Dodać można, że pomimo istnienia podstaw do domagania się od ubezpieczyciela zwrotu nadpłaconej składki, mankamentem wydaje się brak w polskiej ustawie rozwiązań podob-

32 Por. przykładowo E. McKendrick, Contract Law, MacMillan Press Ltd 1997, s. 100.

33 W doktrynie dominuje stanowisko, że odpowiedzialność z tytułu culpa in contrahendo jest odpowiedzialnością deliktową. Tak przykładowo: W. Czachórski, Odpowiedzialność odszkodowawcza w ramach tzw. ujemnego interesu umowy, RPEiS 1968/3, s. 119 i n.; Z. Radwański, Zawarcie umowy [w:] System Prawa Prywatnego, red. Z. Radwański, t. 2, Część ogólna. red. Z. Radwański, Warszawa 2002, s. 351-352; P Machnikowski, Treść umowy [w:] System Prawa Prywatnego, red. Z. Radwański, t. 5, Prawo zobowiązań - część szczegółowa, red. E. Łętowska, Warszawa 2012, s. 568.

34 Por. B. Kęszycka, Prawo..., s. 109, przypis 21. 
nych do zawartych w cytowanym art. L121-3 francuskiego kodeksu ubezpieczeń, który wyraźnie pozbawia ubezpieczyciela prawa do żądania składki w sytuacji zawarcia ubezpieczenia na sumę przekraczającą wartość ubezpieczenia.

\subsection{Suma ubezpieczenia}

Sumę ubezpieczenia definiuje się zwykle jako określoną w umowie kwotę pieniężną stanowiącą górną granicę odpowiedzialności ubezpieczyciela $^{35}$. Niektórzy piszą po prostu, że suma ubezpieczenia to kwota, na którą ubezpieczono dany przedmiot ubezpieczenia ${ }^{36}$, albo kwota, na którą zawarto umowę ubezpieczenia ${ }^{37}$. E. Kowalewski oraz M. Krajewski wskazują na dodatkową funkcję sumy ubezpieczenia jako podstawy naliczenia składki ${ }^{38}$. Zestawiając ze sobą powyższe określenia, można bez ryzyka większej pomyłki zdefiniować sumę ubezpieczenia jako określoną w umowie ubezpieczenia kwotę pieniężną, na którą ubezpieczono dany przedmiot ubezpieczenia, wyznaczającą górną granicę odpowiedzialności ubezpieczyciela oraz stanowiącą podstawę obliczenia składki.

W odróżnieniu od wartości ubezpieczenia suma ubezpieczenia znajduje zastosowanie we wszystkich rodzajach ubezpieczeń. W ubezpieczeniu odpowiedzialności cywilnej, gdzie przedmiotem ubezpieczenia jest interes ubezpieczającego polegający na ryzyku uszczuplenia majątku w razie konieczności zapłaty odszkodowania na rzecz osób trzecich, suma ubezpieczenia przybiera postać sumy gwarancyjnej. Jest tak, ponieważ nie można określić wysokości przyszłych roszczeń odszkodowawczych osób trzecich względem ubezpieczającego, w związku z czym nie występuje pojęcie wartości ubezpieczenia. W ubezpieczeniu OC szkoda nie może być odniesiona do konkretnej rzeczy lub prawa służącego ubezpieczającemu, suma gwarancyjna stanowi zatem jedynie

35 M. Orlicki, Umowa ubezpieczenia, 2002, s. 160; M. Krajewski, Umowa ubezpieczenia. Art. 805-834 KC..., 2016, s. 206.

36 Prawo ubezpieczeń gospodarczych, red. E. Kowalewski, s. 206.

37 A. Wąsiewicz, Z.K. Nowakowski, Prawo..., s. 52.

38 Prawo ubezpieczeń gospodarczych, red. E. Kowalewski, s. 206; M. Krajewski, Umowa ubezpieczenia. Art. 805-834 KC..., 2016, s. 206. 
górny limit odpowiedzialności gwarancyjnej ubezpieczyciela za szkody wyrządzone osobom trzecim. Często suma gwarancyjna odnoszona jest do jednego roszczenia. Spotykane jest również rozwiązanie ustalające odrębnie sumę ubezpieczenia w odniesieniu do jednego zdarzenia objętego ubezpieczeniem oraz wszystkich zdarzeń ${ }^{39}$.

Przepisy ogólne Kodeksu cywilnego o umowie ubezpieczenia nie posługują się pojęciem sumy ubezpieczenia. Odwołują się jednak do niego zarówno przepisy o ubezpieczeniach majątkowych (art. 824 i $824^{1}$ k.c.), jak i przepisy o ubezpieczeniach osobowych (art. 831 i 832 k.c.). Na konieczność sprecyzowania sumy ubezpieczenia w umowie ubezpieczenia wskazują expressis verbis zarówno art. $824 \$ 1$ k.c., jak i art. $302 \$ 1$ k.m. Odniesienie sumy ubezpieczenia do wartości ubezpieczenia wynika $\mathrm{z}$ art. $824 \$ 2 \mathrm{i} 3 \mathrm{k}$.c. oraz art. $302 \$ 1$ k.m. Suma ubezpieczenia powinna być określona w pieniądzu. W tym zakresie można odwołać się do wcześniejszych wywodów dotyczących określenia wartości ubezpieczenia.

Jeżeli chodzi o rolę sumy ubezpieczenia jako limitu odpowiedzialności, wskazać należy, że w ubezpieczeniach osobowych suma ubezpieczenia stanowi jedyną granicę. W ubezpieczeniach majątkowych, jak już była mowa, wysokość świadczenia pieniężnego ubezpieczyciela limitowana jest również przez wartość ubezpieczenia oraz wysokość poniesionej przez ubezpieczającego szkody. Niezależnie jednak od tego, jak wysoka jest wartość ubezpieczania oraz szkoda, świadczenie odszkodowawcze ubezpieczyciela nie może przekraczać sumy ubezpieczenia, zaś w ubezpieczeniu odpowiedzialności cywilnej - sumy gwarancyjnej. Zapewne $\mathrm{z}$ tego powodu E. Kowalewski określa sumę ubezpieczenia jako bezwzględną górną granicę świadczenia ubezpieczeniowego ${ }^{40}$. Jeżeli wartość ubezpieczenia jest mniejsza niż suma ubezpieczenia, świadczenie ubezpieczyciela nie może być wyższe od wartości ubezpieczenia. W żadnym

39 Tak często jest na przykład przy obowiązkowych ubezpieczeniach profesjonalistów. Pytanie, czy suma gwarancyjna jest szczególną postacią sumy ubezpieczenia, czy pojęciem zupełnie odrębnym, stawia przykładowo M. Krajewski, wskazując, że spór może mieć znaczenie wyłącznie teoretyczne, art. 824 k.c. nie może bowiem odnosić się do sumy gwarancyjnej. To samo dotyczy art. $824^{1} \$ 2$ i 3 k.c.

40 Prawo ubezpieczeń gospodarczych, red. E. Kowalewski, s. 206. 
razie odszkodowanie ubezpieczeniowe nie może przekraczać wysokości poniesionej przez ubezpieczającego szkody.

Na relacje między sumą ubezpieczenia, wartością ubezpieczenia i szkodą oraz ich wpływ na wysokość należnego odszkodowania zwrócono uwagę w orzecznictwie. Warte przytoczenia są: wyrok SA w Poznaniu z 17.11.1994 r. ${ }^{41}$ oraz wyrok SN z 19.07.2000 r. ${ }^{42}$ Wyrok SA w Poznaniu dotyczył spalenia drewnianego kiosku spożywczego, który ubezpieczony był na $250 \mathrm{mln}$ starych złotych. Ubezpieczyciel wypłacił dobrowolnie 99343000 zł. Powódka domagała się zasądzenia dalszej kwoty $150656600 \mathrm{zł} \mathrm{z} \mathrm{odsetkami} \mathrm{i} \mathrm{kosztami} \mathrm{postępowania} \mathrm{stanowiącej} \mathrm{dopłatę}$ odszkodowania do kwoty równej sumie ubezpieczenia.

Sąd Wojewódzki w Poznaniu uwzględnił w całości powództwo, stwierdzając, że w ubezpieczeniach majątkowych suma ubezpieczenia powinna być równa rzeczywistej wartości przedmiotu ubezpieczenia, gdyż wówczas odszkodowanie odpowiada wartości szkody. Skoro więc powódka zadeklarowała w ofercie (wniosku) sumę ubezpieczenia kiosku na $250 \mathrm{mln}$ zł, a pozwany, przyjmując tę ofertę, nie zgłosił sprzeciwu i od tej kwoty wyliczył składkę ubezpieczeniową, należy przyjąć, że uznał ją za rzeczywistą wartość obiektu. Zgodnie z $\$ 15$ ust. 7 OWU ubezpieczyciel miał obowiązek zawiadamiać na piśmie, że jego zdaniem podana we wniosku suma ubezpieczenia jest niewłaściwa. Pozwany nie kwestionował sumy, a zatem brak jest podstaw do uwzględnienia jego zarzutu, że suma ubezpieczenia przekracza rzeczywistą wartość obiektu. Sąd ten dodatkowo powołał się na opinię biegłego z dziedziny budownictwa, który wyliczył koszt odbudowy spalonego kiosku na kwotę 100397190 zł przy przyjęciu cen obowiązujących w III kwartale 1992 r. i na kwotę 136153000 zł przy przyjęciu cen obowiązujących w IV kwartale 1993 r. oraz na przedstawiony przez powódkę kosztorys wybudowania kiosku według cen z I kwartału 1994 r. wskazujący na kwotę 248551576 zł, przyjmując, iż wyceny potwierdzają, że rzeczywista wartość szkody w dacie ustalenia odszkodowania przekracza nawet sumę ubezpieczenia. Rewizję od tego wyroku złożył pozwany ubezpieczyciel.

${ }^{41}$ Wyrok SA w Poznaniu z 17.11.1994 r., I ACr 377/94, „Wokanda” 1995/8, s. 48.

42 Wyrok SN z 19.07.2000 r., II CKN 1068/98, LEX nr 50887. 
Sąd Apelacyjny w Poznaniu nie podzielił argumentacji przedstawionej w wyroku sądu pierwszej instancji i uchylił wyrok do ponownego rozpoznania, wskazując, że „Suma ubezpieczenia nie jest identyczna z wartością ubezpieczenia. Suma ubezpieczenia jest to kwota pieniężna, na którą zawarto ubezpieczenie. Stanowi ona górną granicę odpowiedzialności ubezpieczyciela (...) i jest podstawą do obliczenia składki ubezpieczeniowej. Suma ta nie musi być więc równa wartości ubezpieczeniowej, może być od niej niższa, ale nie powinna jej przewyższać. W razie nastąpienia wypadku ubezpieczeniowego zakład ubezpieczeń jest obowiązany wypłacić odszkodowanie, a nie sumę ubezpieczenia. Odszkodowanie z tytułu ubezpieczenia majątkowego nie może być wyższe od poniesionej szkody". Dodatkowo w $\$ 5$ ust. 4 pkt 1 OWU określono, że rzeczywistą wartość budynków i budowli - której powinna odpowiadać suma ubezpieczenia - stanowi wartość w stanie nowym, po potrąceniu zużycia, i ten sposób obliczania wartości kiosku należy mieć na uwadze przy ustalaniu odszkodowania ubezpieczeniowego.

Zdaniem Sądu Apelacyjnego w Poznaniu nie można się również zgodzić ze stanowiskiem sądu pierwszej instancji, który podzielił pogląd powódki, że wysokość odszkodowania winna być ustalona według ceny $\mathrm{z}$ daty orzekania w procesie (art. $363 \$ 2$ k.c.). Ustalenie odszkodowania ubezpieczeniowego następuje $\mathrm{w}$ toku postępowania likwidacyjnego, które kończy się wydaniem przez zakład ubezpieczeń decyzji o wypłacie świadczenia i jego wysokości lub o odmowie wypłaty. Wykorzystanie przez powódkę drogi sądowej i wytoczenie powództwa odszkodowawczego nie usprawiedliwia ustalenia odszkodowania według cen $\mathrm{z}$ daty orzekania, ponieważ i w takiej sytuacji sąd nie może zasądzić więcej, niż zakład ubezpieczeń zobowiązany był wypłacić ubezpieczonemu.

Przytoczony wyrok Sądu Apelacyjnego w Poznaniu należy zaaprobować z pewnymi uwagami. Ubezpieczenie nie było zgodnie z umową omawianym wcześniej ubezpieczeniem w wartości nowej. Niezakwestionowanie przez ubezpieczyciela zadeklarowanej przez ubezpieczającą wartości kiosku nie mogło prowadzić do obowiązku wypłaty świadczenia pieniężnego przekraczającego wysokość poniesionej przez ubezpieczającą szkody, ale ewentualnie jedynie do zwrotu części nadpłaconej składki. Takie żądanie nie było zaś zgłaszane. Nadto, gdyby okazało się, że wypła- 
cone odszkodowanie było zaniżone, różnica powinna zostać wypłacona według cen $\mathrm{z}$ daty ustalania odszkodowania w procesie. Ani specyfika odszkodowania ubezpieczeniowego, ani okoliczność, że zakład ubezpieczeń ustala wysokość odszkodowania w postępowaniu likwidacyjnym, nie prowadzą do zmiany reguły z art. 363 k.c. co do kwot, które nie zostały wypłacone w terminie.

Stan faktyczny sprawy zakończonej wyrokiem SN z 19.07.2000 r. był podobny, przy czym chodziło o odszkodowanie za skradziony samochód Toyota Supra ubezpieczony na 120000 zł. Powód domagał się w procesie kwoty tożsamej z sumą ubezpieczenia. Pozwany uznał powództwo do kwoty 79000 zł, w pozostałym zakresie wnosząc o jego oddalenie. Sąd wojewódzki, poza kwotą uznaną, dodatkowo zasądził 26000 zł, w pozostałym zakresie oddalając powództwo. Apelacja powoda została oddalona.

Rozpatrując kasację, Sąd Najwyższy zwrócił uwagę, że stanowisko powoda konsekwentnie domagającego się zasądzenia kwoty 120000 zł, a więc ustalonej przez strony w umowie ubezpieczenia, wynika z przekonania, że skoro obie strony oszacowały wartość samochód w chwili zawarcia umowy ubezpieczenia na tę kwotę, nie ma żadnego uzasadnienia, aby odszkodowanie za kradzież, która nastąpiła w dwa miesiące po zawarciu umowy, było mniejsze. Dalej zauważył, że podstawowy problem w sprawie polegał na tym, że dopiero w postępowaniu sądowym wyszło na jaw, że ubezpieczony pojazd był wyprodukowany w 1994 r., a nie - jak przyjmowały strony w umowie ubezpieczeniowej - w 1995 r. To była zasadnicza przyczyna, dla której sądy ustaliły, że rzeczywista wartość pojazdu była o 15000 zł niższa od sumy jego ubezpieczenia. W konsekwencji Sąd Najwyższy oddalił kasację, zaznaczając, że w każdym przypadku odpowiedzialności ubezpieczyciela z autocasco należy ustalać rzeczywistą wartość ubezpieczonego samochodu i ta wartość wyznaczać powinna kwotę przysługującego ubezpieczonemu odszkodowania, nie mogąc jednak przekroczyć pułapu ustalonej w umowie sumy ubezpieczenia. W okolicznościach sprawy nie mógł mieć zatem zasadniczego znaczenia fakt, że powód poniósł szkodę niedługo po umownym ustaleniu sumy ubezpieczenia na kwotę wyższą. Decyduje bowiem wysokość szkody rzeczywistej, a nie zadeklarowanej w umowie. 
Stanowisko Sądu Najwyższego należy podzielić. Zgodnie z wcześniejszymi uwagami, w omawianej sprawie nawet brak okoliczności w postaci przyjęcia przez strony, że samochód był rok młodszy niż w rzeczywistości, nie powinien zdecydować o przyznaniu odszkodowania tożsamego z ustaloną przez strony sumą ubezpieczenia. Przeszacowanie wartości pojazdu na skutek winy ubezpieczyciela mogło jedynie ewentualnie skutkować powstaniem po stronie ubezpieczającego roszczenia o zwrot nadpłaconej składki ubezpieczeniowej.

Sposób myślenia ubezpieczającego można jednak zrozumieć, wziąwszy pod uwagę opisywaną wcześniej praktykę ubezpieczycieli wyliczania wartości ubezpieczenia w różny sposób, zależnie od tego, czy czyni się to na potrzeby zawarcia umowy ubezpieczenia i wyliczenia składki ubezpieczeniowej od sumy ubezpieczenia tożsamej z tak ustaloną wartością ubezpieczenia, czy też na potrzeby wyliczenia odszkodowania należnego w razie zajścia wypadku. Zwykle ubezpieczyciele skrupulatnie podchodzą do ustalenia wartości ubezpieczenia tylko w tej drugiej sytuacji. W pierwszej przyjmują natomiast wartość wynikającą z przyjętego systemu odniesienia (EUROTAX, INFO-EXPERT), nie dbając o to, czy za ubezpieczony pojazd można na rynku uzyskać tak ustaloną kwotę. Wbrew obiegowemu sposobowi myślenia praktyka ta, niewątpliwie naganna, nie uzasadnia roszczeń o wypłatę odszkodowania tożsamego z sumą ubezpieczenia, pominąwszy rzadkie sytuacje, gdy z warunków umowy wynikać będzie zawarcie ubezpieczenia w wartości oszacowanej lub ubezpieczenia w wartości nowej.

Rozważając rolę sumy ubezpieczenia jako górnego limitu odpowiedzialności ubezpieczyciela, należy zastanowić się nad jeszcze jedną kwestią, a mianowicie, czy limit ten dotyczy każdej szkody z osobna, czy wszystkich szkód łącznie. Czy w sytuacji, gdy w okresie ubezpieczenia zachodzi kilka wypadków ubezpieczeniowych, ubezpieczyciel może być zobowiązany do wypłaty odszkodowań przekraczających łącznie uzgodnioną sumę ubezpieczenia? Kwestia określana jest w nauce jako wyczerpywanie się sumy ubezpieczania. Znaczenie praktyczne tego problemu nie wydaje się duże. Przede wszystkim szkoda całkowita prowadzi do unicestwienia przedmiotu ubezpieczenia. Jeżeli ubezpieczony zastępuje utraconą rzecz nową rzeczą, musi zawrzeć kolejną 
umowę. Ponadto trudno sobie wyobrazić, by omawiana kwestia nie została uregulowana w umowie lub ogólnych warunkach ubezpieczenia. Kontrowersje dotyczą więc rzadkiej w praktyce sytuacji, gdy wysokość kilku szkód częściowych przekracza sumę ubezpieczenia i umowa oraz OWU nie zawierają żadnej regulacji dotyczącej wyczerpania się sumy ubezpieczenia.

W doktrynie prawa ubezpieczeniowego przeważa stanowisko, wedle którego w braku odmiennych uzgodnień ubezpieczyciel odpowiada do wysokości sumy ubezpieczenia za każdą szkodę. Zajmują je przykładowo W. Warkałło ${ }^{43}$, A. Wąsiewicz ${ }^{44}$, M. Orlickii ${ }^{45}$, M. Krajewski, B. Kęszycka i M. Kaliński. W ten sposób omawiane zagadnienie unormowane jest również przez Kodeks morski. Artykuł $325 \$ 1$ k.m. stanowi, że ubezpieczyciel odpowiada za szkody z każdego wypadku objętego ubezpieczeniem do wysokości sumy ubezpieczenia. Zgodnie z art. $325 \$ 2$ k.m. za szkody wynikłe z kilku następujących po sobie wypadków objętych ubezpieczeniem ubezpieczyciel odpowiada stosownie do $₫ 1$, nawet jeżeli łączna suma szkód przekracza sumę ubezpieczenia. Stanowisko przeciwne, zgodnie z którym suma ubezpieczenia stanowi górną granicę odpowiedzialności, choćby łączna suma szkód była wyższa, prezentują m.in. J. Łopuski, L. Ogiegło oraz W. Dubis ${ }^{46}$. Ten drugi pogląd został też zaaprobowany przez Sąd Najwyższy w wyroku z 20.07.1990 r. ${ }^{47}$ Uczestnicy dyskusji dotyczącej wyczerpania sumy ubezpieczenia niestety nie uzasadniają swoich stanowisk.

W sprawie zakończonej wyrokiem Sądu Najwyższego z 20.07.1990 r. powódka wnosiła o odszkodowanie w wysokości 9341000 zł za mienie

43 W. Warkałło, Prawo..., s. 52.

44 A. Wąsiewicz, Ubezpieczenia..., s. 137.

45 M. Orlicki, Umowa ubezpieczenia, 2002, s. 161; M. Krajewski, Umowa ubezpieczenia. Art. 805-834 KC..., 2016, s. 208-209; B. Kęszycka, Prawo..., s. 111-112; M. Kaliński, Zasada..., cz. 2, s. 2.

46 J. Łopuski, Kodeks cywilny [w:] Kodeks cywilny z komentarzem, t. 2, red. J. Winiarz, Warszawa 1989, s. 738; L. Ogiegło [w:] Kodeks cywilny, t. 2, Komentarz. Art. 450-1088. Przepisy wprowadzajace, red. K. Pietrzykowski, Warszawa 2013, s. 1384; W. Dubis [w:] Kodeks cywilny. Komentarz, red. E. Gniewek, P. Machnikowski, Warszawa 2011, s. 729.

47 Wyrok SN z 20.07.1990 r., I CR 451/90, LEX nr 9034. 
ukradzione z jej mieszkania podczas dwóch włamań. Suma ubezpieczenia ustalona była na 5000000 zł. Pozwany wnosił o oddalenie powództwa, twierdząc, że włamań nie było, a nadto powódka udostępniła klucz do mieszkania osobie nieuprawnionej. Sąd wojewódzki ustalił, że do mieszkania powódki włamano się dwukrotnie. W wyniku pierwszego włamania skradziono powódce mienie o wartości przekraczającej sumę ubezpieczenia, a sprawcy zostali skazani wyrokiem sądu karnego. Odszkodowanie należne powódce wynosi zatem $5000000 \mathrm{zł}$. W wyniku drugiego włamania powódka poniosła szkodę, której wartość ustalono na kwotę 3424000 zł. Sprawców kradzieży nie ustalono. Sąd wojewódzki zasądził zatem łącznie 8424000 zł odszkodowania, oddalając powództwo w pozostałym zakresie.

W rewizji pozwany zarzucił naruszenie przez sąd szeregu postanowień ogólnych warunków ubezpieczenia mieszkań oraz nieuprawnione w świetle zgromadzonych dowodów ustalenie, że włamania miały miejsce i powódka poniosła szkodę. Sąd Najwyższy, rozpoznając wówczas sprawę jako sąd drugiej instancji, wziął pod uwagę z urzędu, że sąd wojewódzki, uwzględniając powództwo ponad sumę ubezpieczenia, naruszył art. 824 k.c., zgodnie z którym, jeżeli strony nie umówiły się inaczej, ustalona w umowie suma ubezpieczenia stanowi górną granicę odpowiedzialności ubezpieczyciela. Ani z umowy, ani z OWU nie wynikało, by strony umówiły się inaczej, a zatem pozwany odpowiadać może maksymalnie do sumy ubezpieczenia niezależnie od liczby włamań do mieszkania powódki oraz wysokości poniesionych przez nią szkód. Sąd Najwyższy uwzględnił również inne zarzuty podnoszone przez pozwanego w rewizji i uchylił wyrok, przekazując sprawę do ponownego rozpoznania.

Jak z powyższego wynika, argumentacja Sądu Najwyższego zdaje się opierać na wykładni językowej art. 824 k.c. Komentatorzy prezentujący pogląd zbieżny z wyrażonym przez SN zwykle cytują na jego poparcie po prostu omówiony wyrok. Wbrew przytoczonemu stanowisku wykładnia językowa art. 824 k.c. nie prowadzi jednak do jednoznacznych rezultatów. Kodeks cywilny nie precyzuje, czy suma ubezpieczenia stanowi górną granicę odpowiedzialności ubezpieczyciela za jeden wypadek, czy też za wszystkie wypadki łącznie. W odróżnieniu od Kodeksu mor- 
skiego brak jest w prawie cywilnym szczególnych przepisów dotyczących odpowiedzialności ubezpieczyciela. Nie wydaje się też, by z braku uregulowania podobnego do zawartego w Kodeksie morskim można wywodzić a contrario, że ustawodawca chciał uregulować sprawę inaczej.

Wykładnia celowościowa przemawia przeciw podglądowi Sądu Najwyższego. Po pierwsze, umowa ubezpieczenia jest umową losową. Wprawdzie pogląd ten bywa kontestowany, jednak argumenty odwołujące się do tego, że ubezpieczyciel działa zgodnie z regułami statystycznego prawdopodobieństwa, nie odnoszą się do konkretnej umowy ubezpieczenia, a właśnie tę należy badać, odpowiadając na pytanie o losowość. Zawierając umowę ubezpieczenia majątkowego, strony nie wiedzą, czy w okresie ubezpieczenia wypadek ubezpieczeniowy zajdzie, ile razy zajdzie ani jaki będzie jego zakres. Skoro możliwość wystąpienia wielu wypadków ubezpieczeniowych rodzących szkody o różnym zakresie wynika $\mathrm{z}$ istoty umowy ubezpieczenia, nie ma podstaw, by ograniczać odpowiedzialność ubezpieczyciela w sposób niewynikający wprost z umowy albo ogólnych warunków ubezpieczenia.

Powyższy wniosek pozwala sformułować drugi argument. Przepisy Kodeksu cywilnego o umowie ubezpieczenia są bezwzględnie obowiązujące. Odstępstwa od reguł wyrażonych w kodeksie dopuszczalne są w zasadzie wyłącznie na korzyść ubezpieczającego uważanego za słabszą stronę stosunku ubezpieczenia. Rozważa się nadanie charakteru semiimperatywnego na korzyść ubezpieczającego regulacji o umowie ubezpieczenia co do zasady ${ }^{48}$. Ubezpieczyciel jako profesjonalista prowadzący działalność ubezpieczeniową zajmuje z natury rzeczy uprzywilejowaną pozycję. Ustawa o działalności ubezpieczeniowej i reasekuracyjnej nakazuje interpretować wszystkie niejasno sformułowane postanowienia OWU na korzyść ubezpieczającego. Tendencja ochrony konsumenta we współczesnym prawie umów jest wyraźna do tego stopnia, że niektórzy będącą fundamentem prawa umów zasadę wolności umów proponują

48 Zob. przede wszystkim M. Orlicki, Regulacja umowy ubezpieczenia..., s. 47 i n. oraz wskazana tam literatura. Poza tym zob. również M. Więcko-Tułowiecka, Ochrona konsumentów w umowach ubezpieczenia, Warszawa 2014, passim. 
zastąpić zasadą sprawiedliwości umów ${ }^{49}$. W tych okolicznościach wydaje się, że brak w OWU postanowienia o wyczerpaniu sumy ubezpieczenia należy interpretować na korzyść ubezpieczającego. Wobec powyższego trafny jest pogląd większości doktryny odnoszący w braku wyraźnych uzgodnień sumę ubezpieczenia do każdego zdarzenia. Innymi słowy, wyczerpanie sumy ubezpieczenia musi wyraźnie wynikać z umowy albo OWU.

Kolejne zagadnienie dotyczy związku sumy ubezpieczenia ze składką ubezpieczeniową oraz narzędzi prawnych przyznanych stronom na wypadek zmiany wartości interesu ubezpieczeniowego po zawarciu umowy ubezpieczenia. Wskazane iunctim jawi się wyraźnie w świetle przywoływanego już art. $824 \$ 2$ k.c., który w razie zmniejszenia wartości ubezpieczonego mienia pozwala ubezpieczającemu wystąpić z żądaniem obniżenia składki, natomiast ubezpieczycielowi jednostronnie zmniejszyć składkę. Zmniejszenie sumy ubezpieczenia leży w interesie ubezpieczającego, nie budzi bowiem wątpliwości, że powinno łączyć się ze zmniejszeniem składki ubezpieczeniowej w takiej proporcji do składki pierwotnej, w jakiej zmniejszona suma ubezpieczenia pozostaje do sumy ustalonej przy zawarciu umowy ${ }^{50}$.

W wyroku z 19.07.2000 r. Sąd Najwyższy zajął stanowisko, że uprawnienie do odpowiedniego zmniejszenia sumy ubezpieczenia nie może być rozpatrywane w kategorii obowiązku ubezpieczyciela. Stanowisko to powtarzane jest bez zastrzeżeń przez niektórych komentatorów ${ }^{51}$. Podkreślić trzeba jednak, że Sąd Najwyższy rozważał sytuację, gdy ubezpieczający, który sam nie wystąpił z żądaniem zmniejszenia składki, twierdził, że należy mu się odszkodowanie odpowiadające początkowej wartości przedmiotu ubezpieczenia, skoro ubezpieczyciel wiedząc o zmniejszeniu tej wartości, nie obniżył składki. Pogląd Sądu Najwyższego dotyczy zatem jedynie nieistnienia obowiązku ubezpie-

49 K. Zweigert, H. Kötz, An Introduction to Comparative Law, Oxford 1998.

50 M. Krajewski, Umowa ubezpieczenia. Art. 805-834 KC..., 2016, s. 210.

51 Wyrok SN z 19.07.2000 r., II CKN 1068/98; H. Ciepła [w:] Kodeks cywilny. Komentarz. Księga trzecia..., komentarz do art. 824 k.c., teza 6. A. Chróścicki, Umowa ubezpieczenia po nowelizacji kodeksu cywilnego. Komentarz, Warszawa 2008, s. 131. 
czyciela zmniejszenia składki we własnym zakresie przy braku wniosku ubezpieczającego.

Marcin Krajewski trafnie wskazuje, że na żądanie ubezpieczającego ubezpieczyciel ma obowiązek zmniejszyć składkę, tzn. ubezpieczającemu przysługuje odpowiednie roszczenie. Jeżeli ubezpieczyciel nie dokona zmniejszenia sumy ubezpieczenia dobrowolnie, ubezpieczający może wystąpić na drogę sądową o wydanie orzeczenia stwierdzającego obowiązek złożenia oświadczenia woli. Prawomocne orzeczenie sądu uwzględniające powództwo zastępuje oświadczenie ubezpieczyciela ${ }^{52}$. Inny pogląd byłby nie do utrzymania. Ubezpieczyciele nie indagowani przez ubezpieczających nie korzystają z prawa do zmniejszenia składki, nie leży to bowiem $w$ ich interesie.

Uprawnienie ubezpieczyciela do zmniejszenia sumy ubezpieczenia ma charakter uprawnienia kształtującego. Współdziałanie ubezpieczającego nie jest konieczne ${ }^{53}$. Skuteczność skorzystania z uprawnienia uzależniona jest jedynie od zawiadomienia ubezpieczającego. Zgodnie z art. 824 $\$ 3$ k.c. zmniejszenie sumy ubezpieczenia pociąga za sobą odpowiednie zmniejszenie składki, począwszy od dnia pierwszego tego miesiąca, w którym ubezpieczający zażądał zmniejszenia sumy ubezpieczenia lub w którym ubezpieczyciel zawiadomił ubezpieczającego o jednostronnym zmniejszeniu tej sumy.

Regulacja ustawowa ogranicza się do sytuacji, gdy po zawarciu umowy wartość ubezpieczonego mienia uległa zmniejszeniu. Kodeks cywilny nie reguluje natomiast sytuacji odwrotnej, tj. zwiększania wartości ubezpieczonego mienia po zawarciu umowy. Przeważa stanowisko, że w takim przypadku ubezpieczający może żądać podwyższenia sumy ubezpieczenia, a ubezpieczyciel powinien takiego podwyższenia dokonać, pobierając różnicę składki. Gdyby ubezpieczyciel odmówił podwyższenia składki, ubezpieczający miałby prawo wytoczyć powództwo

52 M. Krajewski, Umowa ubezpieczenia. Art. 805-834 KC..., 2016, s. 209.

53 M. Krajewski, Umowa ubezpieczenia. Art. 805-834 KC..., 2016, s. 209. 
o zobowiązanie do złożenia oświadczenia woli54 ${ }^{54}$ Zdaniem M. Krajewskiego słuszność tego poglądu ograniczona jest do sytuacji, gdy ogólne warunki ubezpieczenia wyraźnie przyznają ubezpieczającemu uprawnienia inicjujące $w$ razie podwyższenia wartości ubezpieczonego mienia. W braku stosownych postanowień umownych żądanie ubezpieczającego nie miałoby podstawy prawnej.

Podgląd M. Krajewskiego wydaje się słuszny. Trzeba mieć na względzie, że zmiana umowy wymaga co do zasady konsensu stron. Teoretycznie można wyobrazić sobie sytuację, w której podwyższenie sumy ubezpieczenia nawet przy proporcjonalnym zwiększeniu składki narazi ubezpieczyciela na ryzyko, którego ten nie jest w stanie ponieść samodzielnie, i zmusi do poszukiwania reasekuracji. Ubezpieczający nie jest pozbawiony ochrony, może przecież w razie odmowy podniesienia sumy ubezpieczenia zawrzeć dodatkową umowę ubezpieczenia. Oczywiście znaczenie praktyczne omawianego problemu jest znikome. Trudno sobie wyobrazić, by ubezpieczyciel przy oczywistej zmianie wartości przedmiotu ubezpieczenia, mając odpowiednie możliwości finansowe, nie wyraził zgody na podniesienie sumy ubezpieczenia w zamian za pobranie dodatkowej składki.

Ostatni istotny problem do rozważenia w niniejszym podrozdziale dotyczy możliwości wystąpienia z żądaniem podwyższenia sumy ubezpieczenia $\mathrm{w}$ ubezpieczeniu mienia $\mathrm{z}$ powołaniem się na waloryzacje sądową (art. $358^{1} \$ 3$ k.c.), ewentualnie na klauzulę rebus sic stantibus (art. $357^{1}$ k.c.). Kwestia wywołana została uchwałą SN z 25.11 .1991 r. $^{55}$ W sprawie chodziło o ubezpieczenie krów od padnięcia oraz uboju z konieczności. Umowa została zawarta w listopadzie 1989 r. Miesiąc później jedna z krów została dobita. Powstał spór dotyczący tego, czy chodziło o przypadek uboju z konieczności. Ostatecznie sąd pierwszej instancji przyznał rację powodowi, dodatkowo zasądzając na jego rzecz odszkodowanie według cen $\mathrm{z}$ daty orzekania, w kwocie znacznie prze-

54 H. Ciepła [w:] Kodeks cywilny. Komentarz. Ksiega trzecia..., komentarz do art. 824 k.c., teza 6, S. Reps, J. Reps, Ubezpieczenia majątkowe przedsiębiorców, s. 102-103; L. Ogiegło [w:] Kodeks..., s. 730.

${ }_{55}$ Uchwała SN z 26.11.1991 r., III CZP 122/91, OSP 1992/7-8, poz. 170. 
kraczającej wysokość sumy ubezpieczenia. Powód nadal niezadowolony zaskarżył wyrok. Sąd apelacyjny powziął wątpliwości, które można streścić w pytaniu, czy art. $358^{1} \$ 3$ pozwala na zasądzenie odszkodowania w kwocie przekraczającej wysokość sumy ubezpieczenia.

Sąd Najwyższy odpowiedział na pytanie negatywnie, jednocześnie jednak uznał, że zastosowanie może znaleźć art. $357^{1}$ k.c. W uzasadnieniu podniósł, że w chwili zawarcia umowy nie jest znana wysokość odszkodowania, ale jedynie jego limit w postaci sumy ubezpieczenia. Zasada nominalizmu nie ma zastosowania do świadczeń, których wysokość nie została jeszcze ustalona. Ponadto, skoro odszkodowanie zasądza się według cen $\mathrm{z}$ daty orzekania, nie powstaje kwestia zasady nominalizmu, wobec czego nie ma potrzeby stosowania art. $358^{1}$ k.c. przewidującego wyjątki od tej zasady. Sąd nie wykluczył jednak podwyższenia odszkodowania ubezpieczeniowego ponad wartość sumy ubezpieczenia w razie nadzwyczajnej zmiany stosunków z powołaniem się na art. $357^{1}$ k.c. po rozważeniu okoliczności sprawy w świetle wskazanych w tym przepisie przesłanek.

Orzeczenie skrytykowali A. Szpunar, A. Brzozowski oraz M. Nesterowicz. Glosatorzy zgodzili się z Sądem Najwyższym co do niedopuszczalności stosowania waloryzacji sądowej, wskazując, że świadczenie $\mathrm{z}$ umowy ubezpieczenia majątkowego ma charakter odszkodowawczy, wobec czego nie jest zobowiązaniem pieniężnym sensu stricto. Krytyka dotyczyła dopuszczenia przez SN stosowania klauzuli rebus sic stantibus. Wszyscy glosatorzy wskazywali przede wszystkim, że w sprawie nie zachodziły okoliczności, które można było uznać za nadzwyczajną zmianę stosunków. Adam Szpunar twierdził, że sąd pierwszej instancji przyznał powodowi odszkodowanie przewyższające sumę ubezpieczenia, a Sąd Najwyższy jeszcze dodatkowo otworzył furtkę do podwyższenia tej sumy. Cytowany autor wskazał, że podwyższenie świadczenia jednej ze stron $\mathrm{w}$ rozumieniu art. $357^{1}$ k.c. nie jest $\mathrm{w}$ żadnym razie równoznaczne z możliwością podwyższenia sumy ubezpieczenia. Jego zdaniem w sprawie zachodził przypadek niedoubezpieczenia, wobec czego powód winien ponieść część straty. Nadto, skoro w doktrynie panuje zgoda, że ubezpieczającemu zawsze przysługuje prawo żądania podwyższenia 
sumy ubezpieczenia, powód mógł skorzystać z tej możliwości, ale tego nie uczynił.

Według A. Brzozowskiego 300-procentowy poziom inflacji w okresie między datą zawarcia ubezpieczenia a datą orzekania mieścił się w granicach normalnego ryzyka, według zasad rozkładu ryzyka przyjętego przez strony w umowie ubezpieczenia. Główny zarzut A. Brzozowskiego dotyczył burzenia przez Sąd Najwyższy koncepcji umowy ubezpieczenia oraz sumy ubezpieczenia. Według tego glosatora zmiany będące następstwem inflacji polegać mogą jedynie na nominalnym wzroście wartości ubezpieczeniowej względem sumy ubezpieczenia, nie wywołując jednak zmiany sumy ubezpieczenia. Jeżeli wartość ubezpieczenia przekracza sumę ubezpieczenia, występuje tzw. podubezpieczenie i suma stanowi bezwzględną granicę odpowiedzialności ubezpieczyciela. Podobne argumenty podnosił M. Nesterowicz. Autor ten dodatkowo wskazał, że nie można dublować elementu nadzwyczajności tkwiącego immanentnie w umowie ubezpieczenia przez stosowanie klauzuli rebus sic stantibus.

Pomimo krytyki w doktrynie, Sąd Najwyższy podtrzymał swoje wcześniejsze stanowisko w uchwale z 31.05.1994 $\mathrm{r}^{56}$ Linia orzecznictwa została utrwalona uchwałą 7 sędziów z 29.12.1994 r. ${ }^{57}$, zgodnie z tezą której „W sprawach o świadczenia z obowiązkowego ubezpieczenia rolników od odpowiedzialności cywilnej, w których określono wysokość sumy gwarancyjnej, przepis art. $358^{1} \$ 3$ k.c. nie ma zastosowania; w wyjątkowych wypadkach możliwe jest jednak zastosowanie w tych sprawach art. $357^{1} \$ 1$ k.c." W uzasadnieniu SN podtrzymał argumentację dotyczącą pierwszego zagadnienia, rozróżniając przy tym wyraźnie świadczenia z umów ubezpieczenia osobowego, które mogą być waloryzowane jako niemające charakteru odszkodowawczego, od świadczeń odszkodowawczych z ubezpieczeń majątkowych, w tym ubezpieczenia OC, które nie poddają się waloryzacji. Nad krytyką dotyczącą dopuszczalności stosowania w odniesieniu do umów ubezpieczenia klauzuli rebus sic stantibus SN przeszedł do porządku dziennego, stwierdzając, że w dok-

56 Uchwała SN z 31.05.1994 r., III CZP 74/94, OSNCP 1994/12, poz. 237.

57 Uchwała SN (7) z 29.12.1994 r., III CZP 120/94, OSNC 1995/4, poz. 55, z częściowo krytyczną glosą A. Szpunara, PiP 1995/7, s. 95. 
trynie zwykle nie kwestionuje się stosowania przedmiotowej klauzuli do umów ubezpieczenia w całkowicie wyjątkowych wypadkach. Sąd Najwyższy zwrócił przy tym uwagę, że musi mieć miejsce nadzwyczajna zmiana stosunków nieobjęta ryzykiem ubezpieczeniowym.

Przytoczona uchwała 7 sędziów SN również napotkała krytykę A. Szpunara. Według glosatora każdy wiedział o spadku wartości pieniądza w latach 1985-1990. Rolnik, zawierając umowę obowiązkowego ubezpieczenia OC, płacił składkę w symbolicznej wysokości. Transformacja gospodarki następowała stopniowo. Nie można zatem uznać, że miała miejsce nadzwyczajna zmiana stosunków. Następnie A. Szpunar skrytykował głosy domagające się ograniczenia ubezpieczeń obowiązkowych, zauważając proroczo, że świadomość prawna rolnika jest tylko rzekomo wystarczająco duża, żeby liczyć, że zawrze on właściwe ubezpieczenie. Autor argumentował również, że nieporozumieniem są próby korektury istniejącej sytuacji społeczno-gospodarczej za pomocą prawa cywilnego, natomiast klauzula rebus sic stantibus, będąc odstępstwem od zasady pacta sunt servanda, ma charakter wyjątkowy i powinna być odnoszona zawsze do indywidualnego przypadku.

Przed przejściem do zaprezentowania własnego stanowiska należy wskazać, że Sąd Najwyższy podtrzymał swoje stanowisko jeszcze kilkakrotnie. W orzecznictwie przyjęło się w szczególności, że art. $357^{1}$ k.c. może uzasadniać zapłatę na rzecz poszkodowanego w wypadkach komunikacyjnych kwot przekraczających sumę gwarancyjną w obowiązkowym ubezpieczeniu $\mathrm{OC}^{58}$. Biorąc pod uwage przedmiot niniejszej pracy, warty przytoczenia jest przede wszystkim wyrok z 21.09.2011 r. ${ }^{59}$, w którym stwierdzono, że przyczyną oznaczenia wysokości świadczenia przewidzianego umową ubezpieczenia budynków od ognia i zdarzeń losowych w rozmiarze przewyższającym sumę ubezpieczenia może być, przy spełnieniu przesłanek $\mathrm{z}$ art. $357^{1}$ k.c., nadzwyczajna zmiana stosunków dotycząca ustawowo wprowadzonego podwyższenia stawek

58 Wyrok SN z 13.01.2000 r., II CKN 644/98, LEX nr 51053; postanowienie SN z 30.01.2008 r., III CZP 140/07, LEX nr 359439; ostanio wyrok SN z 24.11.2017 r., I CSK 77/17, LEX nr 2473797. Wyrok SN z 17.10.2012 r., II CSK 646/11, LEX nr 1243010.

59 Wyrok SN z 21.09.2011 r., I CSK 727/10, LEX nr 1043967. 
podatku VAT. Co ciekawe, powodem w tej ostatniej sprawie znów był rolnik, tym razem domagający się odszkodowania ponad sumę ubezpieczenia z obowiązkowego ubezpieczenia budynków wchodzących w skład gospodarstwa rolnego.

Dodać należy, że pogląd o niemożności waloryzacji sumy ubezpieczenia i sumy gwarancyjnej na podstawie art. $358^{1} \$ 3$ k.c. z uwagi na odszkodowawczy charakter świadczenia ubezpieczyciela jest wyrażany w doktrynie powszechnie. Prezentują go w szczególności M. Orlicki ${ }^{60}$, E. Kowalewski i M. Serwach ${ }^{61}$ oraz K. Niezgoda ${ }^{62}$. W ostatnim czasie pojawiły się jednak głosy kontestujące takie stanowisko. Pochodzą one od Ł. Węgrzynowskiego ${ }^{63}$ oraz M. Krajewskiego. Zdaniem tego ostatniego autora w sytuacji, gdy szkoda przekroczy ustaloną sumę ubezpieczenia albo sumę gwarancyjną, ubezpieczyciel zwalnia się ze zobowiązania przez zapłatę kwoty, która nie jest już surogatem dobra utraconego wskutek zdarzenia wywołującego szkodę, lecz stanowi z góry określoną abstrakcyjną wartość pieniężną. Wtedy przestaje działać mechanizm waloryzacyjny związany z naturą świadczenia odszkodowawczego polegający na odwołaniu się do cen z daty orzekania. Zobowiązanie ubezpieczyciela staje się wówczas zobowiązaniem pieniężnym sensu stricto i uzasadnione staje się sięganie do art. $358^{1}$ k.c.

Odmiennie niż M. Serwach i E. Kowalewski ${ }^{64}$, M. Krajewski dopuszcza również waloryzację sumy ubezpieczenia i sumy gwarancyjnej na postawie art. $357^{1}$ k.c. Jego zdaniem żadne szczególne reguły prawa ubezpieczeniowego nie stanowią wystarczającej podstawy do wykluczenia stosowania tego przepisu. Nie może być mowy o dublowaniu występującego w umowie ubezpieczenia elementu nadzwyczajności, bo umowa ta ma zabezpieczać przed innego rodzaju ryzykiem niż nadzwyczajna zmiana

60 M. Orlicki, Umowa ubezpieczenia, 2002, s. 195-196.

${ }_{61}$ M. Serwach, E. Kowalewski, Klauzula rebus sic stantibus a podwyższenie sumy gwarancyjnej w ubezpieczeniach odpowiedzialności cywilnej, RU 2006/1, s. 7-8.

62 K. Niezgoda [w:] J. Miaskowski, K. Niezgoda, P. Skawiński, Ustawa o ubezpieczeniach obowiązkowych, Ubezpieczeniowym Funduszu Komunikacyjnym i Polskim Biurze Ubezpieczycieli Komunikacyjnych. Komentarz, Warszawa 2012, s. 66.

63 Ł. Węgrzynowski, Dopuszczalność..., s. 73 i n.

${ }_{64}$ M. Serwach, E. Kowalewski, Klauzula..., s. 8 i n. 
stosunków w rozumieniu tego przepisu. Nie przekonuje też argument, że ubezpieczającemu za zapłatą dodatkowej składki zawsze przysługuje żądanie podwyższenia sumy ubezpieczenia. Takie prawo przysługuje bowiem ubezpieczającemu tylko, gdy przyznaje mu je umowa. Nadto zaś skorzystanie z niego przed wyczerpaniem sumy ubezpieczenia albo sumy gwarancyjnej wymagałoby przewidzenia przez ubezpieczającego nadzwyczajnej zmiany stosunków ${ }^{65}$.

Jak pisał A. Szpunar, szczegóły nie powinny przesłaniać pola widzenia. Szczegółem wydaje się okoliczność, że w sprawach rozpatrywanych przez Sąd Najwyższy nadzwyczajnym zdarzeniem miała być inflacja szalejąca na przełomie lat 80. i 90. XX w., natomiast powodami byli rolnicy, którzy zamiast próbować się doubezpieczać, domagali się świadczeń ponad wartość sumy ubezpieczenia. Trudno nie przyznać racji S. Szpunarowi co do tego, że inflacja, szczególnie zaś inflacja trwająca już przed zawarciem umowy, nie powinna być traktowana jako nadzwyczajna zmiana stosunków, której strony nie przewidywały, jak również co do tego, że prawotwórcza działalność sądów polegająca na podejmowaniu nieopartych na zasadach prawnych decyzji ad hoc dla korekty istniejących stosunków gospodarczych jest niedopuszczalna. Wziąwszy pod uwagę konkretne stany faktyczne, przedstawione rozstrzygnięcia SN wydają się wątpliwe. Istota rzeczy sprowadza się jednak do odpowiedzi na pytanie, czy szczególne cechy umowy ubezpieczenia uniemożliwiają niezależnie od okoliczności podwyższenie przez sąd sumy ubezpieczenia z powołaniem się na małą lub dużą klauzulę rebus sic stantibus. Tak twierdzili glosatorzy, Sąd Najwyższy wykluczył waloryzację sądową, dopuścił zaś klauzulę rebus sic stantibus.

Rozpoczynając od kwestii zmiany sumy ubezpieczenia w drodze waloryzacji sądowej, wypada zgłosić wątpliwość co do powszechnie wyrażanego poglądu, jakoby świadczenie ubezpieczyciela w ubezpieczeniu mienia nie miało charakteru zobowiązania pieniężnego sensu stricto. Oczywiście, zobowiązania odszkodowawcze co do zasady nie mają charakteru zobowiązań pieniężnych sensu stricto. Wynika to z kilku

65 M. Krajewski, Ubezpieczenie..., s. 324-325. Podobnie Ł. Węgrzynowski, Dopuszczalność..., s. 79-84. 
przyczyn. Po pierwsze, odszkodowanie jest co do zasady świadczeniem zastępczym, wchodzącym w grę jedynie, gdy istniejące zobowiązanie nie zostanie wykonane. Po drugie, na zasadach ogólnych szkoda może być naprawiona według wyboru poszkodowanego albo przez przywrócenie do stanu poprzedniego, albo przez zapłatę odpowiedniej sumy pieniężnej. Po trzecie, zakres szkody podlegającej naprawieniu jest często trudny do przewidzenia. Może ona bowiem obejmować nie tylko szkodę rzeczywiście poniesioną $\mathrm{w}$ wąskim rozumieniu, ale również wydatki poniesione $\mathrm{z}$ woli podmiotu poszkodowanego pozostające $\mathrm{w}$ bezpośrednim związku z poniesioną rzeczywistą szkodą, a nadto dodatkowo utracone zyski.

W odniesieniu do odszkodowania ubezpieczeniowego wszystkie wymienione argumenty odpadają. Po pierwsze, świadczenie odszkodowawcze jest świadczeniem głównym, strony po prostu umawiają się, że wykonanie umowy nastąpi w drodze naprawienia przez ubezpieczyciela szkody, której on sam nie wyrządził. Po drugie, niezależnie od zagadnienia dopuszczalności spełnienia przez ubezpieczyciela świadczenia odszkodowawczego w drodze restitutio in integrum, które będzie przedmiotem dalszych rozważań, z umowy wynika zwykle, że ubezpieczający może liczyć wyłącznie na odszkodowanie pieniężne. Po trzecie, omawiana wcześniej teoria lokalizacji szkody prowadzi do wniosku, że zakres odszkodowania jest stosunkowo łatwy do przewidzenia i także w razie szkody całkowitej nie może przekraczać wartości ubezpieczonego interesu. Do tego należy dodać argument M. Krajewskiego, że w sytuacji, gdy szkoda przekracza sumę ubezpieczenia, a ubezpieczyciel wypłaca tę sumę, to właśnie ona, nie zaś wysokość szkody wskazuje na wysokość zobowiązania pieniężnego ubezpieczyciela. Suma nie stanowi więc surogatu utraconego dobra, a mechanizm waloryzacyjny związany z naturą świadczenia odszkodowawczego przestaje działać6 ${ }^{6}$.

Powyższe uwagi prowadzą do wniosku, że w warunkach hiperinflacji zasadniczym sposobem dostosowania stosunku ubezpieczeniowego do zmienionych okoliczności powinna być właśnie waloryzacja sądowa, nie

${ }_{66}$ M. Krajewski, Ubezpieczenie..., s. 315, 318, oraz M. Krajewski, Umowa ubezpieczenia. Art. 805-834 KC..., 2016, s. 543. 
zaś klauzula rebus sic stantibus. Kwestia ta została przesądzona w orzecznictwie i doktrynie, co do niemających charakteru odszkodowawczego świadczeń z ubezpieczeń osobowych, znane jest w szczególności bogate orzecznictwo i praktyka w zakresie waloryzacji świadczeń z polis zaopatrzenia dzieci. Waloryzacja jest oczywiście co do zasady wyłączona, gdy chodzi o ubezpieczających przedsiębiorców niebędących osobami fizycznymi (art. $358^{1} \$ 4$ k.c.). Waloryzacja powinna być również wyłączona wtedy, gdy umowa zawierana już była w warunkach inflacji i albo przewidywała mechanizmy waloryzacyjne, albo przyznawała ubezpieczającemu prawo wystąpienia z żądaniem podwyższenia sumy ubezpieczenia. Co do zasady nie należy jednak wykluczać możliwości waloryzacji sądowej sumy ubezpieczenia w warunkach hiperinflacji. Istnieją również zasadnicze wątpliwości co do traktowania hiperinflacji, która zawsze ma swoje gospodarcze przyczyny i nigdy nie pojawia się z dnia na dzień, jako nadzwyczajnej zmiany stosunków uzasadniającej zastosowanie klauzuli rebus sic stantibus ${ }^{67}$.

Odnośnie do argumentów, które mają wykluczać stosowanie klauzuli rebus sic stantibus w ubezpieczeniach majątkowych, w doktrynie podniesiono, że zmiana wysokości świadczeń, o której mowa w art. $357^{1}$ oraz $358^{1} \$ 3$ k.c., nie jest równoznaczna $z$ dopuszczalnością zmiany sumy ubezpieczenia. Argument ten również nie przekonuje. Artykuł $358^{1}$ $\$ 3$ k.c. wspomina o zmianie wysokości albo sposobu spełnienia świadczenia pieniężnego zobowiązania, natomiast art. $357^{1} \mathrm{k}$.c. o oznaczeniu sposobu wykonania zobowiązania, oznaczeniu wysokości świadczenia, a nawet o rozwiązaniu stosunku prawnego. Wydaje się, że sformułowania te należy rozumieć szeroko, aby sąd próbujący dostosować stosunek prawny do zmienionych okoliczności mógł w razie wystąpienia wskazanych w przepisie przesłanek znaleźć sprawiedliwe wyjście z sytuacji.

67 Przeważa jednak pogląd, że hiperinflacja może w określonych okolicznościach zostać uznana za nadzwyczajną zmianę stosunków. Zob. przykładowo W. Robaczyński, Kilka uwag na temat relacji art. $357^{1}$ k.c. a art. $358^{1}$ \$3, „Rejent” 1996/11, s. 75. Podobnie M. Krajewski, którego zdaniem hiperinflacja z przełomu lat 80. i 90. ubiegłego wieku mogła być uznana za nadzwyczajną zmianę stosunków, s. 544-545. Tak jak się zdaje, również A. Brzozowski, Wpływ zmiany okoliczności na zobowiązania [w:] System Prawa Prywatnego, red. Z. Radwański, t. 6, Prawo zobowiązań - część ogólna, red. A. Olejniczak, Warszawa 2014, s. 1293. 
Wbrew sugestiom glosatorów nie jest oczywiste, że zmiana sposobu spełnienia świadczenia pieniężnego oraz oznaczenie sposobu wykonania zobowiązania albo wysokości świadczenia nie mogą oznaczać zmiany sumy ubezpieczenia w umowie ubezpieczenia. Suma ubezpieczenia występuje również w ubezpieczeniach osobowych, co do których dopuszczalność waloryzacji świadczeń ubezpieczeniowych jest przesądzona ${ }^{68}$. Nadto przepis pozwala sądowi nawet na rozwiązanie stosunku prawnego, co jest ingerencją dalej idącą niż zmiana jego treści. Trudno chyba kwestionować, że przynajmniej systematyka kodeksu wskazuje na odniesienie klauzuli rebus sic stantibus do wszystkich umów, w tym umowy ubezpieczenia.

Wątpliwy jest także argument M. Nesterowicza, że umowa ubezpieczenia zawiera w sobie element nadzwyczajności, który byłby zdublowany, gdyby dopuścić stosowanie klauzuli rebus sic stantibus. Sąd Najwyższy ma rację, że umowa ubezpieczenia ma chronić przed określonym w niej wyraźnie oznaczonym ryzykiem, nie można zatem in abstracto twierdzić, że wszystkie nadzwyczajne okoliczności mieszczące się w rodzaju tych, o których mowa w art. $357^{1}$ k.c., objęte były ryzykiem, które strony brały albo choćby powinny były wziąć pod uwagę, zawierając umowę ubezpieczenia. Należy zgodzić się z Ł. Węgrzynowskim ${ }^{69}$ i M. Krajewskim, że umowa ubezpieczenia ma co do zasady chronić przed innym ryzykiem niż stanowiące przesłankę zastosowania klauzuli rebus sic stantibus.

Zjawisko niedoubezpieczenia należy łączyć przede wszystkim z umyślnym zaniżeniem wartości ubezpieczenia, ewentualnie z objęciem umową ubezpieczenia ryzyka związanego ze zmianą cen. Proponowane przez glosatorów rozwiązanie, wedle którego zawsze wtedy, gdy wartość końcowa ubezpieczenia jest większa od sumy ubezpieczenia, zachodzi niedoubezpieczenie, wobec czego istota ubezpieczenia sprawia, że ubezpieczający musi ponieść część szkody niepokrytą przez sumę ubezpieczenia, niezależnie od okoliczności prowadzących do dysproporcji między sumą i wartością ubezpieczenia, wydaje się zbyt kostyczne. Dodać można, że nawet A. Szpu-

68 Szerzej zob. przede wszystkim A. Szpunar, Waloryzacja świadczeń ubezpieczeniowych [w:] Ubezpieczenia w gospodarce rynkowej, t. 3, red. A. Wąsiewicz, Bydgoszcz 1997, s. 137 i n.

69 Ł. Węgrzynowski, Dopuszczalność..., s. 76-77. 
nar, początkowo całkowicie odrzucający stosowanie art. $357^{1}$ k.c. do umów ubezpieczenia, ostatecznie złagodził stanowisko, przyznając, że w zupełnie wyjątkowych wypadkach takiej możliwości wykluczyć nie można ${ }^{70}$.

Podsumowując, nie odnosząc się do trafności rozstrzygnięć Sądu Najwyższego w konkretnych sprawach, należy skonkludować, po pierwsze, że wbrew powszechniej opinii nie jest całkowicie wyłączone stosowanie w odniesieniu do umów ubezpieczenia majątkowego waloryzacji świadczeń z art. $358^{1} \$ 3$ k.c. Poza tym, wbrew niektórym twierdzeniom, Sąd Najwyższy ma rację, że nie można co do zasady wykluczyć stosowania $\mathrm{w}$ odniesieniu do umów ubezpieczenia klauzuli rebus sic stantibus z art. $357^{1}$ k.c. Oczywiście każda z obu instytucji może wejść w grę wyłącznie wtedy, gdy w okolicznościach konkretnej sprawy spełnione są wszystkie przesłanki jej zastosowania. Mała i duża klauzula rebus sic stantibus powinny być stosowane bardzo ostrożnie, dotyczy to w szczególności kwalifikowania określonych zdarzeń lub zjawisk jako okoliczności nadzwyczajnych, których strony nie mogły przewidzieć w rozumieniu art. $357^{1}$ k.c. Tym niemniej, stosowania obu omawianych instytucji w odniesieniu do umowy ubezpieczenia majątkowego nie należy a limine odrzucać. Oczywiście aktualne znaczenie powyższych wniosków dla umów ubezpieczeń mienia zawieranych na roczne okresy w sytuacji, gdy od dłuższego czasu nie występują zjawiska społeczne, polityczne albo gospodarcze mogące stanowić przesłanki zastosowania art. $358^{1} \S 3$ albo art. $357^{1}$ k.c., jest raczej teoretyczne.

\subsection{Systemy odpowiedzialności ubezpieczycieli71}

Jak wcześniej wskazywano, suma ubezpieczenia może zostać ustalona na poziomie równym, większym albo mniejszym od wartości ubezpieczeniowej. Pierwsza sytuacja jest optymalna. Druga, zwana nadubez-

70 A. Szpunar, Waloryzacja..., s. 135-136.

71 Zob. B. Kucharski, Between the principle of average and the principle of first risk [w:] Insurance Challenges of Anno Domini 2018, red. K. Malinowska, A. Tarasiuk, Warszawa 2018, s. 231 i n. 
pieczeniem ma niekorzystne skutki dla ubezpieczającego, który płaci składki ustalane na podstawie sumy ubezpieczenia, natomiast nie ma szansy otrzymać odszkodowania przekraczającego wartość ubezpieczenia. Trzecia sytuacja, określana mianem niedoubezpieczenia, rodzi najwięcej problemów. Odpowiedzialność ubezpieczyciela kształtuje się zależnie od przyjęcia jednego z dwóch systemów odpowiedzialności: systemu odpowiedzialności na pierwsze ryzyko albo systemu odpowiedzialności proporcjonalnej.

W systemie odpowiedzialności na pierwsze ryzyko ubezpieczyciel odpowiada za każdą szkodę do wysokości sumy ubezpieczenia. W zakresie przekraczającym wysokość sumy ubezpieczenia szkoda pozostaje natomiast niepokryta. Stosunek sumy ubezpieczenia do początkowej wartości ubezpieczenia nie jest w zasadzie istotny. Znaczenie ma jedynie stosunek między sumą ubezpieczenia a wartością końcową, czyli, jak chcą niektórzy, wartością odszkodowawczą. Szkoda całkowita nigdy nie będzie skompensowana w całości. Szkoda częściowa może być skompensowana, jeżeli jej wartość nie przekracza sumy ubezpieczenia. System odpowiedzialności na pierwsze ryzyko jest zatem korzystny dla ubezpieczającego, szczególnie w sytuacjach, w których prawdopodobieństwo zajścia szkody całkowitej jest niewielkie w porównaniu do prawdopodobieństwa zajścia szkody częściowej. Ubezpieczający może zapłacić składkę od niższej sumy ubezpieczenia i mieć nadzieję, że ponoszone przez niego szkody będą w całości pokrywane przez odszkodowanie ubezpieczeniowe ${ }^{72}$.

W systemie odpowiedzialności proporcjonalnej ubezpieczyciel odpowiada za szkody w takim stosunku, w jakim suma ubezpieczenia pozostaje do wartości ubezpieczenia. W przypadku szkody całkowitej nie powinno być zatem różnic w porównaniu do odpowiedzialności na pierwsze ryzyko. W przypadku szkody częściowej różnice są natomiast zasadnicze, odszkodowanie bowiem, niezależnie od innych ograniczeń odpowiedzialności ubezpieczeniowej, z istoty rzeczy nie może być odszkodowaniem pełnym, choćby wysokość poniesionej szkody była znacznie niższa niż wysokość sumy ubezpieczenia. Przykładowo,

72 Zob. A. Wąsiewicz, Z.K. Nowakowski, Prawo..., s. 60. 
jeżeli interes ubezpieczeniowy wart $10 \mathrm{mln}$ zł ubezpieczony został na 4 mln zł, szkody częściowe będą kompensowane co najwyżej w 40\%. Odszkodowanie ubezpieczeniowe za szkodę opiewającą na $300000 \mathrm{zł}$ wyniesie zatem nie więcej niż $120000 \mathrm{zł}$.

Przyjęty system odpowiedzialności zależy co do zasady od treści umowy oraz ogólnych warunków ubezpieczenia. Kodeks cywilny nie zawiera wyraźnej regulacji co do preferowanej zasady odpowiedzialności ubezpieczyciela. Powstaje zatem pytanie, jaka reguła winna być stosowana w sytuacji, gdy strony tej kwestii wyraźnie nie uregulowały. Dla porównania wypada wskazać, że Kodeks morski jako zasadę przyjmuje system odpowiedzialności proporcjonalnej. Zgodnie z art. $302 \$ 4$ k.m., jeżeli określona w umowie suma ubezpieczenia jest niższa od wartości ubezpieczenia, ubezpieczyciel odpowiada za szkody w stosunku, w jakim pozostaje suma do wartości ubezpieczenia. Przypomnieć należy, że wartością ubezpieczenia według Kodeku morskiego jest wartość z chwili rozpoczęcia ubezpieczania (art. $300 \$ 2$ k.m.).

Na podobnym stanowisku co Kodeks morski stoją zachodnioeuropejskie ustawodawstwa kontynentalne, przydając jednak znaczenia wartości ubezpieczenia $\mathrm{z}$ chwili wypadku ubezpieczeniowego. Według art. 75 niemieckiej VVG, w sytuacji gdy suma ubezpieczenia jest istotnie niższa od wartości ubezpieczenia w chwili zajścia wypadku, ubezpieczyciel odpowiada za szkodę w takim stosunku, w jakim suma ubezpieczenia pozostaje do wartości ubezpieczenia. Także francuski Code des assurances stanowi w art. L121-5, że jeżeli wartość ubezpieczonego majątku przekracza w chwili szkody sumę ubezpieczenia, ubezpieczający pozostaje swoim ubezpieczycielem co do nadwyżki i w konsekwencji ponosi ryzyko w odpowiedniej części szkody, chyba że strony umówiły się inaczej.

Interesujące jest, że pomimo wyraźnej preponderancji klauzuli proporcji we francuskim kodeksie ubezpieczeń, klauzula ta uważana jest za niesprawiedliwą w sytuacji, gdy niedoubezpieczenie nie jest wynikiem świadomego działania ubezpieczającego. Dotyczy to przede wszystkim stosunków konsumenckich. Z tego powodu rekomendacja francuskiej Komisji ds. Klauzul Niedozwolonych z 1985 r. wskazuje, 
że w ubezpieczeniach konsumenckich, w szczególności w ubezpieczeniach ruchomości wykorzystywanych przez rodzinę ubezpieczającego, preferowanym rozwiązaniem powinien być system odpowiedzialności na pierwsze ryzyko ${ }^{73}$.

Prawo angielskie obecnie nie opowiada się wyraźnie za żadnym z systemów odpowiedzialności, przyjmując stanowisko pośrednie. Ubezpieczenia podlegające reżimowi Marine Insurance Act 1906 zawierane są zgodnie z art. 67 ust. 2 w systemie odpowiedzialności proporcjonalnej. System ten stosuje się również $\mathrm{w}$ innych ubezpieczeniach przedsiębiorców. Według J. Birdsa w stosunkach handlowych, gdy polisa ani ogólne warunki ubezpieczenia nie zawierają wyraźnych postanowień $\mathrm{w}$ tej mierze, regułę proporcji należy uważać za dorozumianą. Poza tym jednak, w szczególności gdy chodzi o ubezpieczenie ruchomości domowych, klauzule proporcji są niepopularne z wyjątkiem ubezpieczeń zawieranych przez agentów Lloyd's. W ubezpieczeniach konsumenckich w braku wyraźnych zastrzeżeń reguła proporcjonalności nie jest dorozumiana, a zatem ubezpieczający ma prawo do odszkodowania w granicach szkody częściowej, jeżeli tylko nie przekracza ona sumy ubezpieczenia ${ }^{74}$. Precedens $w$ tej mierze stanowi sprawa Sillem v. Thornton z 1852 r. dotycząca ubezpieczenia ogniowego domu ${ }^{75}$.

Principles of European Insurance Contract Law przygotowane przez grupę Restatement of European Contract Law dają natomiast pierwszeństwo regule odpowiedzialności na pierwsze ryzyko. Zgodnie z art. 8:102 PEICL ubezpieczyciel odpowiada za każdą szkodę do wysokości sumy ubezpieczenia, nawet jeśli suma ubezpieczenia jest niższa niż wartość ubezpieczonego mienia w chwili zajścia wypadku ubezpieczeniowego. Ubezpieczyciel alternatywnie jest uprawniony do zaproponowania ochrony według systemu odpowiedzialności proporcjonalnej i wtedy wypłacane odszkodowanie pozostawać będzie $\mathrm{w}$ takim stosunku do wartości szkody, w jakim pozostaje suma ubezpieczenia do rzeczywistej

73 Y. Lambert-Faivre, L. Leveneur, Droit..., s. 424. Nieco łagodniej odnośnie do tej kwestii M. Chagny, L. Perdrix, Droit des assurances, Paris 2009, s. 301.

74 J. Birds, Birds'..., s. 294.

75 Sillem v. Thornton (1954) 3 E \& B 868. 
wartości ubezpieczonego mienia z chwili wystąpienia szkody. Koszty ratowania mienia przed szkodą powinny być zwrócone w tych samych proporcjach.

Zaletą proponowanego rozwiązania według autorów PEICL jest łatwiejsze zarządzanie ubezpieczeniem, ponieważ ubezpieczony (w szczególności konsument) nie musi ciągle dbać, by suma ubezpieczenia odpowiadała zmieniającej się wartości ubezpieczonego mienia, w szczególności zaś nie musi się obawiać, że w razie jakiejkolwiek szkody nie uzyska jej pełnego naprawienia ${ }^{76}$. Autorzy odnotowują przy tym, że większość krajów europejskich dopuszcza regułę proporcji albo wprost daje jej pierwszeństwo, wymieniając przy tym poza krajami, których regulacje omówiono wyżej: Belgię, Grecję, Włochy, Luksemburg, Holandię, Danię, Austrię, Portugalię, Szwajcarię, Hiszpanię i Szwecję. W Finlandii, Luksemburgu i Belgii powołanie się przez ubezpieczyciela na regułę redukcji proporcjonalnej jest niedopuszczalne w sytuacji, gdy kalkulacji sumy ubezpieczenia dokonywał sam ubezpieczyciel lub jego agent.

W literaturze polskiej większość autorów poprzestaje na stwierdzeniu, że o tym, który system odpowiedzialności ubezpieczyciela znajduje zastosowanie w konkretnej sprawie, decyduje treść umowy ubezpieczenia lub ogólnych warunków. Na pytanie, jaki system stosować w braku odpowiednich postanowień umownych, odpowiadają m.in. S. Reps i J. Reps oraz M. Orlicki. Ci pierwsi w publikacji dotyczącej ubezpieczeń majątkowych przedsiębiorców wyrażają pogląd, według którego w opisywanej sytuacji zakład ubezpieczeń odpowiada na pierwsze ryzyko, to znaczy zobowiązuje się do pełnego pokrycia szkody w granicach sumy ubezpieczenia. Stanowiska tego jednak nie uzasadniają ${ }^{77}$. Pełniejsza jest wypowiedź M. Orlickiego, który preferencję zasady odpowiedzialności na pierwsze ryzyko wywodzi z reguł zawartych w art. 805 i 824 k.c. ${ }^{78}$

76 Principles..., s. 237.

77 S. Reps, J. Reps, Ubezpieczenia majątkowe przedsiębiorców, s. 101.

78 M. Orlicki, O możliwości stosowania reguły proporcji przy niedoubezpieczeniu, PA 2011/2, s. 66. M. Krajewski ocenia kwestię jako niebudzącą wątpliwości na gruncie Kodeksu cywilnego, powołując się na S. Repsa i J. Repsa oraz M. Orlickiego. Zob. M. Krajewski, Umowa ubezpieczenia. Art. 805-834 KC..., 2016, s. 536. 
Próbując przedstawić własne stanowisko, należy stwierdzić, że regulacja Kodeksu cywilnego o umowie ubezpieczenia nie dostarcza argumentów pozwalających na przyjęcie poglądu odmiennego niż wyżej przedstawiony. Kwestia wysokości odszkodowania w ubezpieczeniu aktywów uregulowana jest przede wszystkim w przytaczanych wcześniej art. 824 oraz $824^{1}$ k.c. Pierwszy z nich dotyczy pojęcia sumy ubezpieczenia oraz przewiduje mechanizm dostosowania tej sumy do zmieniającej się wartości ubezpieczenia. Drugi wyraża zasadę odszkodowania, a następnie normuje ubezpieczenie podwójne. We wskazanych przepisach nie ma wzmianek pozwalających na obniżenie odszkodowania za szkodę częściową proporcjonalnie do relacji między sumą ubezpieczenia a wartością ubezpieczenia. Artykuł 824 k.c., wskazując, że suma ubezpieczenia stanowi górną granicę odpowiedzialności ubezpieczyciela, o ile strony nie umówiły się inaczej, wyraźnie sugeruje pierwszeństwo reguły odpowiedzialności na pierwsze ryzyko.

Poglądu dotyczącego obowiązywania - w braku wyraźnych zastrzeżeń reguły redukcji proporcjonalnej można próbować bronić, wskazując, że w niektórych rodzajach ubezpieczeń, w szczególności w ubezpieczeniu budynków od ognia oraz innych zdarzeń losowych, znajduje ona zastosowanie zwyczajowo. Jak wiadomo, art. 56 k.c. wyznaczający zakres skutków wywoływanych przez czynność prawną, art. 65 k.c. dotyczący reguł wykładni oświadczeń woli oraz art. 354 k.c., wskazujący na kryteria wykonania zobowiązania przez dłużnika, odwołują się do ustalonych w danych stosunkach zwyczajów.

Próby powoływania się przez ubezpieczyciela na zwyczaj wydają się jednak skazane na niepowodzenie, mając na uwadze, że umowa ubezpieczenia jest umową adhezyjną, ogólne warunki umów narzucane są przez ubezpieczyciela ubezpieczającemu, natomiast przyjęcie zasady odpowiedzialności proporcjonalnej co od zasady nie będzie dla tego ostatniego korzystne. Jest wątpliwe, by uregulowania umowne, narzucane przez przedsiębiorcę konsumentom, mogły być traktowane jako obowiązujący w danych stosunkach zwyczaj, choćby uregulowania takie były narzucane powszechnie. 
Podobne wątpliwości znalazły wyraz w wyroku Sądu Najwyższego z 11.10.2005 r. ${ }^{79}$ dotyczącym wynagrodzenia za badania medyczne i pobranie szpiku, w którym stwierdzono, że jednostronnie ustalone przez powódkę cenniki nie mogą być uznane za obowiązującą taryfę, o jakiej mowa w art. $735 \$ 2$ k.c. W przepisie tym nie chodzi bowiem o taryfę jednostronnie ustaloną przez podmiot świadczący usługi, nawet jeśli jest ona powszechnie przez ten podmiot stosowana i znana szerszemu kręgowi odbiorców. Taka taryfa może wiązać drugą stronę tylko wtedy, jeśli stanowi integralną część umowy. Wyrok nie dotyczył wprawdzie obowiązywania zwyczaju, ale obowiązywania taryfy powódki w danych stosunkach, jednak argumentacja w nim zawarta może być również odniesiona do zwyczaju. Podsumowując, wypada przyjąć, że w braku wyraźnych postanowień sąd powinien zinterpretować ogólne warunki umów na niekorzyść ubezpieczającego zgodnie z regułą in dubio contra proferentem. Argumentacja dotycząca obowiązywanie reguły odpowiedzialności na pierwsze ryzyko jest zatem podobna jak w odniesieniu do omawianej wcześniej reguły braku wyczerpania sumy ubezpieczenia.

Dodać należy, że w praktyce można spotkać się z poglądem znacznie bardziej radykalnym, według którego reguła redukcji proporcjonalnej jest sprzeczna $\mathrm{z}$ istotą umowy ubezpieczenia i nie może być uznana za obowiązującą nawet, gdy została wyraźnie przewidziana przez ogólne warunki umów. Najbardziej stanowczo pogląd ten wyraził C. Orłowski z Biura dawnego Rzecznika Ubezpieczonych. Według tego autora polskiemu prawu ubezpieczeniowemu zasada odpowiedzialności proporcjonalnej jest nieznana. Zgodnie z cytowanym stanowiskiem brak stosownego postanowienia w kodeksie oznacza, że klauzule umowy lub OWU przewidujące redukcję proporcjonalną powinny być na podstawie art. 807 k.c. uznane za nieważne jako sprzeczne z prawem. Cezary Orłowski, powołując się na niepublikowany wyrok Sądu Apelacyjnego w Warszawie z 2.10.2008 r., VI ACa 140/08, wskazuje ponadto, że skoro składkę ubezpieczeniową wylicza się na podstawie ustalonej sumy ubezpieczenia, umniejszanie świadczenia pieniężnego ubezpieczyciela przez zastosowanie zasady proporcji oraz uzależnienie stosowania tej zasady od prawidłowości deklarowanej przez ubezpieczającego wartości

79 Wyrok SN z 11.10.2005 r., V CK 244/05, LEX nr 398447. 
ubezpieczonego mienia narusza zasadę ekwiwalentności świadczeń wyrażoną w art. 805 k.c. ${ }^{80}$

Klauzulę odpowiedzialności proporcjonalnej za nieważną uznał również Sąd Apelacyjny w Gdańsku w wyroku z 6.08.2014 r., V ACa 936/14 ${ }^{81}$. Sprawa dotyczyła umowy ubezpieczenia budynków od ognia i innych żywiołów zawartej przez spółkę jawną prowadzącą piekarnię. W uzasadnieniu również powołano się na wzajemność ubezpieczenia oraz zasadę ekwiwalentności świadczeń. Według sądu w rozpatrywanej umowie klauzulę odpowiedzialności ukształtowano w sposób sprzeczny z zasadami współżycia społecznego, a więc dobrymi obyczajami, w tym z zasadą uczciwości i lojalności, albowiem w praktyce wyłączała ona całkowicie regułę, wedle której ubezpieczyciel powinien ponosić odpowiedzialność będącą równowartością świadczenia (składki) ubezpieczającego. Dalej sąd stwierdził, że wartość sumy ubezpieczenia wskazywał ubezpieczający i nie była ona w żaden sposób weryfikowana przez ubezpieczyciela. Jednocześnie wskazanie tej sumy w sposób odpowiadający wartości odtworzeniowej ubezpieczonego mienia przez ubezpieczającego, tak by nie wystąpił przypadek niedoubezpieczenia, było w praktyce prawie niemożliwe, co potwierdzać miała rozbieżność między wydaną $\mathrm{w}$ sprawie opinią biegłego oraz opiniami prywatnymi sporządzonymi na zlecenie ubezpieczającego.

Stanowisko przeciwne do prezentowanego przez C. Orłowskiego oraz Sąd Apelacyjny w Gdańsku zajął M. Orlicki, którego wypowiedź dotycząca dopuszczalności klauzuli redukcji proporcjonalnej długo była najpełniejszą w polskiej literaturze. Zdaniem tego autora, choć z przepisów wynika pierwszeństwo systemu odpowiedzialności na pierwsze ryzyko, stosowanie systemu odpowiedzialności proporcjonalnej jest w pełni dopuszczalne, a co więcej, reguła proporcji nie może być traktowana jako niedozwolona klauzula umowna w umowie konsumenckiej. Autor uzasadnił swoje stanowisko: po pierwsze, uświęconym tradycją stosowaniem klauzuli proporcji, po drugie, troską o utrzymanie ekwi-

80 C. Orłowski, Dopuszczalność stosowania zasady proporcji w sytuacji niedoubezpieczenia, MU 2012/50, s. 22 i n.

81 LEX nr 1842253. 
walentności świadczeń stron, czemu, jego zdaniem, opisywana klauzula ma służyć, oraz po trzecie, przynależnością reguły proporcji do postanowień określających główne świadczenia stron, które nie mogą być traktowane jako klauzule niedozwolone, o ile zostały sformułowane w sposób jednoznaczny ${ }^{82}$.

Podobny pogląd bezwzględnej ważności klauzuli redukcji proporcjonalnej zdaje się wynikać również z wyroku Sądu Najwyższego z 7.10.2010 r., IV CSK 149/10 $0^{83}$. W sprawie chodziło o ubezpieczenie śmigłowca „Sokół” na sumę 1500000 zł. Zarówno ubezpieczyciel, jak i ubezpieczający, zawierając umowę, zdawali sobie sprawę, że wartość śmigłowca jest większa. Śmigłowiec uległ zniszczeniu podczas akcji gaśniczej w Hiszpanii. Pomimo wystąpienia szkody całkowitej ubezpieczyciel stwierdził, że niedoubezpieczenie sięgało 34\%, i pomniejszył odszkodowanie, powołując się na $\$ 28$ ust. 3 OWU, zgodnie z którym w razie ustalenia sumy ubezpieczenia na kwotę niższą o ponad 15\% od wartości rzeczywistej ubezpieczonego statku powietrznego wyliczone odszkodowanie pomniejsza się w takim stopniu, w jakim suma ubezpieczenia pozostaje do wartości rzeczywistej statku. Ubezpieczający nie zgodził się z takim stanowiskiem i pozwał ubezpieczyciela o brakującą kwotę odszkodowania, wskazując, że wskaźnik, o jakim mowa w OWU, powinien być odniesiony do wartości szkody, nie zaś do ustalonego odszkodowania.

Sąd pierwszej instancji uwzględnił powództwo, jednak Sąd Apelacyjny w L. zmienił wyrok i obniżył odszkodowanie, przyjmując, że podstawą obliczenia należnego powodowi świadczenia winna być zgodnie z $\$ 28$ ust. 3 OWU suma ubezpieczenia, nie zaś wartość śmigłowca w chwili szkody. Sąd Najwyższy oddalił skargę kasacyjną powoda, uznając, że następstwa ustalenia sumy ubezpieczenia na poziomie znacznie niższym od wartości rzeczywistej ubezpieczonego składnika majątkowego zostały jednoznacznie określone i bezpośrednio wskazywały na zakres

${ }^{82}$ M. Orlicki, O możliwości..., s. 67-69. Zob. również powoływaną przez cytowanego autora literaturę o charakterze przede wszystkim publicystycznym, będącą odzwierciedleniem toczącej się na łamach prasy ubezpieczeniowej dyskusji dotyczącej dopuszczalności stosowania reguły proporcji.

83 LEX nr 677774, z glosą Ł. Żarnowca, WU 2012/4. 
ochrony interesu ubezpieczonego. Odniesienie wskaźnika obliczonego według przewidzianej reguły do odszkodowania określonego stosownie do OWU stanowiło w tej sytuacji wiążące ukształtowanie uprawnień stron umowy.

W nowszej literaturze zwrócono uwagę, że spotykane w praktyce ogólne warunki ubezpieczenia kształtują zasadę proporcji na dwa sposoby. Pierwszy przewiduje proporcjonalne zmniejszenie w proporcji do sumy ubezpieczenia wartości szkody, za którą odpowiada ubezpieczyciel, drugi zaś proporcjonalne zmniejszenie kwoty wypłaconego odszkodowania. Różnice między obydwoma sposobami ujawniają się w sytuacji, gdy poniesiona szkoda przekracza sumę ubezpieczenia. Dla zobrazowania zagadnienia można powrócić do przykładu, gdy interes ubezpieczeniowy mający wartość $10 \mathrm{mln}$ zł ubezpieczono na $4 \mathrm{mln}$ zł. Zakładając, że zaistniała szkoda o wartości $6 \mathrm{mln}$ zł, przy zastosowaniu pierwszego sposobu wysokość przyznanego odszkodowania ubezpieczeniowego odpowiadać będzie wartości sumy ubezpieczenia, czyli $4 \mathrm{mln}$ zł, natomiast przy przyjęciu drugiego sposobu przyznane odszkodowanie wyniesie tylko $40 \%$ całkowitej sumy ubezpieczenia, czyli 1,6 mln zł. Właśnie drugi sposób znalazł zastosowanie w cytowanym wyżej wyroku SN dotyczącym śmigłowca.

Autorzy opisujący wskazane wyżej różnice, w szczególności Ł. Żarnowiec, J. Nawracała i M. Krajewski, zakwestionowali dopuszczalność drugiego sposobu zastosowania zasady proporcji, wskazując, że sposób ten $\mathrm{w}$ istocie odnosi proporcję do wysokości sumy ubezpieczenia, co w rezultacie powoduje, że ubezpieczony nie może otrzymać odszkodowania w wysokości jej odpowiadającej ${ }^{84}$. Do tego sposobu wydaje się w istocie odnosić wypowiedź C. Orłowskiego, że ubezpieczyciel nie bierze pod uwagę wypłaty całej sumy ubezpieczenia i takie ryzyko nie jest przez niego skalkulowane, jednak autor ten nie uczynił stosow-

${ }_{84}$ Ł. Żarnowiec w glosie do wyroku SN z 7.10.2010 r., IV CSK 149/10 cytowanej wyżej. J. Nawracała, Odpowiedzialność..., s. 43; M. Krajewski, Umowa ubezpieczenia. Art. 805-834 KC..., 2016, s. 538. 
nego zastrzeżenia ${ }^{85}$. Dodatkowo przy tej metodzie w grę mogą wejść, poza samą zasadą proporcji, jeszcze inne czynniki powodujące redukcję odszkodowania. Umowa ubezpieczenia może bowiem przewidywać udział własny w szkodzie lub franszyzę redukcyjną. W tych przypadkach ubezpieczony nie ma szansy otrzymać odszkodowania wyższego niż różnica między sumą ubezpieczenia pomniejszoną o udział własny bądź franszyzę, następnie zaś pomniejszoną raz jeszcze przez zastosowanie zasady proporcji ${ }^{86}$.

Stanowisko zbliżone do powyższego zajął Sąd Najwyższy w wyroku z 15.05.2015 r., V CSK 470/14. W sprawie tej sąd apelacyjny, uwzględniając apelację ubezpieczyciela, przyjął, że budynek zniszczony na skutek pożaru był niedoubezpieczony w 43\%, i obniżył odszkodowanie o kwotę 387 138,62 zł odpowiadającą poziomowi niedoubezpieczenia. Sąd Najwyższy uwzględnił z kolei skargę kasacyjną powodów, wskazując, że zastosowanie przez ubezpieczyciela zasady proporcji, ograniczającej wysokość odszkodowania w razie tzw. niedoubezpieczenia, nie może oznaczać, że pomimo określenia w umowie sumy ubezpieczenia w wysokości powodującej niedoubezpieczenie mienia w dacie zawarcia umowy, odszkodowanie ubezpieczeniowe nigdy nie mogłoby osiągnąć poziomu sumy ubezpieczenia, będącej przecież elementem wyznaczającym kalkulację wysokości składki ubezpieczeniowej. Ostatecznie jednak Sąd Najwyższy w sposób nieco zaskakujący nie uznał postanowienia $\$ 30$ OWU, przewidującego zmniejszenie należnego odszkodowania zgodnie z zasadą proporcji, za nieważne, jako wykraczające poza zakres dopuszczalnej swobody umów. Zamiast tego uznał je za sformułowane w sposób niejednoznaczny oraz interpretując na korzyść ubezpieczonego, przyjął, że przewidywało ono proporcjonalne zmniejszenie szkody. Wniosek ten można tłumaczyć okolicznością, że Sąd Najwyższy orzekał w składzie odmawiającym wzajemności umowy ubezpieczenia oraz względami słusznościowymi - uznanie klauzuli proporcji za nieważną prowadziłoby do przyjęcia, że umowa była zawarta w systemie na pierwsze ryzyko.

85 J. Nawracała, Odpowiedzialność..., s. 37-38; C. Orłowski, Dopuszczalność stosowania zasady proporcji..., s. 25.

${ }^{86}$ J. Nawracała, Odpowiedzialność..., s. 38. 
Jeszcze inny wariant poglądu kompromisowego w przedmiocie dopuszczalności klauzuli proporcji stanowi, że jest ona co do zasady dopuszczalna, przynajmniej w pierwszej postaci, przewidującej proporcjonalne zmniejszenie zakresu szkody podlegającej naprawieniu, jednak $\mathrm{w}$ umowach $\mathrm{z}$ konsumentami może być uznana za klauzulę niedozwoloną. Takie stanowisko zajął w szczególności Sąd Najwyższy w często cytowanym w późniejszych orzeczeniach wyroku z 16.10.2014 r., III CSK $302 / 13$. W sprawie tej nie rozważano samego odniesienia reguły redukcji proporcjonalnej do szkody podlegającej naprawieniu albo do należnego odszkodowania. Sąd Najwyższy uznał klauzulę proporcji przewidzianą w ogólnych warunkach ubezpieczenia budynku od ognia $\mathrm{i}$ innych zdarzeń losowych za sprzeczną z dobrymi obyczajami oraz rażąco naruszającą interesy ubezpieczających. W stanie faktycznym sprawy spłonął budynek ubezpieczony na sumę 1600000 zł. Wartość odtworzeniowa na dzień szkody została ustalona przez sąd pierwszej instancji na kwotę przekraczającą 2700000 zł. Sąd pierwszej instancji uwzględnił niedoubezpieczenie powodów sprawiające, że mogli się domagać jedynie 58,11\% rzeczywistej wysokości szkody, i zasądził na ich rzecz 163 919,20 zł. Sąd apelacyjny zmienił ustalenia faktyczne, przyjmując, że budynek był niedoubezpieczony w $35 \%$, i zasądził na rzecz powodów odpowiednio więcej.

Sąd Najwyższy w składzie rozpoznającym sprawę przyjął, że umowa ubezpieczenia jest umową wzajemną, i powziął wątpliwość co do tego, jak ma się reguła redukcji proporcjonalnej do zasady ekwiwalentności świadczeń. Według SN świadczenie pieniężne ubezpieczyciela spełniane w razie zajścia wypadku powinno odpowiadać przejmowanemu ryzyku ubezpieczeniowemu rekompensowanemu wartością zapłaconej składki. Składka została obliczona przy uwzględnieniu sumy ubezpieczenia, ubezpieczyciel powinien zatem ponosić odpowiedzialność będącą równowartością otrzymanej od ubezpieczającego składki. Dalej SN stwierdził, że ocena prawidłowości określenia sumy ubezpieczenia zależy od staranności zawodowej ubezpieczyciela będącego profesjonalistą, nie zaś od staranności ubezpieczającego.

Następnie SN przyjął, że zakres ubezpieczenia został określony w sposób niejednoznaczny, ponieważ klauzula proporcjonalności, sama przez 
się niewystarczająco zrozumiała dla przeciętnego konsumenta, została „ukryta” w $\$ 80$ ogólnych warunków ubezpieczenia. Uzupełniająco SN wskazał na nielojalność ubezpieczyciela, który zaakceptował bez żadnej próby weryfikacji proponowaną przez ubezpieczającego wartość ubezpieczonej rzeczy, ustalając odpowiednio sumę ubezpieczenia oraz wysokość składki, następnie zaś dopiero po zajściu szkody zweryfikował wartość sumy ubezpieczenia, porównując ją z wartością odtworzeniową budynku, naruszając tym samym zasadę równości prawnej stron.

Podobny pogląd wyrażono w wyroku SN z 9.08.2016 r., II CSK 743/15: ubezpieczający według polisy wykupili standard ubezpieczenia maksimum, następnie zaś, kiedy ubezpieczony budynek spłonął, szkodę podlegającą naprawieniu pomniejszono w proporcji do procenta niedoubezpieczenia o 62000 zł. Sąd Najwyższy zgodził się z poglądem sądu pierwszej instancji i uznał za niesłuszne stanowisko sądu apelacyjnego, który stwierdził, że klauzuli proporcji nie można uznać za niedozwoloną, skoro powódka podpisała się pod wnioskiem ubezpieczeniowym, potwierdzając jednocześnie, że otrzymała ogólne warunki umów i zapoznała się z nimi. Zdaniem SN powodowie, którzy wykupili najbogatszą wersję ubezpieczenia „maximum” (optimum), mogli liczyć na to, że szkoda poniżej sumy ubezpieczenia będzie pokryta w całości. Zasada ograniczenia odszkodowania według klauzuli proporcjonalności powinna być przez pozwaną negocjowana $\mathrm{z}$ nimi indywidualnie, do czego nie doszło. Postanowienie dotyczące wariantu maximum uznano za niejednoznaczne, gdyż nie było w nim odniesienia liczonego na jego podstawie odszkodowania do sumy ubezpieczenia. Samą klauzulę proporcjonalności uznano natomiast za niedozwoloną w sytuacji, gdy ubezpieczyciel, pomimo przedłużania polisy, nigdy nie zwrócił uwagi powodom na problem niedoubezpieczenia.

W opisane wyżej stanowisko kompromisowe, dopuszczające potraktowanie klauzuli proporcji za klauzulę niedozwoloną, wpisuje się również wyrok Sądu Najwyższego z 10.06.2016 r., IV CSK 624/15. W wyroku tym Sąd Najwyższy uznał za nieskuteczną klauzulę proporcji w umowie zawartej z przedsiębiorcą będącym osobą fizyczną. Sąd okręgowy podzielił co do zasady stanowisko pozwanego ubezpieczyciela, który obniżył odszkodowanie za spalony zakład stolarski proporcjonalnie 
do współczynnika niedoubezpieczenia. Podobnie uczynił sąd apelacyjny, przyjmując jeszcze wyższy współczynnik niedoubezpieczenia wynoszący aż 0,69 , oraz konsekwentnie zmniejszył zasądzone przez sąd okręgowy odszkodowanie. Sąd apelacyjny wyraził przy tym pogląd, że klauzula proporcjonalności jest zrozumiała dla przeciętnie rozsądnego przedsiębiorcy.

Sąd Najwyższy uwzględnił skargę kasacyjną powoda, cytując wcześniej omówiony wyrok w sprawie III CSK 302/13 oraz zwracając dodatkowo uwagę na okoliczność, że umowa ubezpieczenia jest umową najwyższego zaufania. Zgodnie z uzasadnieniem ubezpieczający ma prawo wiedzieć, co jest objęte ubezpieczeniem, a co nie, natomiast ogólne warunki ubezpieczenia powinny być dla niego zrozumiałe. Ubezpieczający, zawierając umowę ubezpieczenia, oznaczył wartość odtworzeniową, załączając dokładny opis budynków i budowli wchodzących w skład zakładu stolarskiego. Dane te zostały zaakceptowane bez zastrzeżeń przez agenta pozwanego ubezpieczyciela. Pozwany nie podawał w wątpliwość wartości odtworzeniowej budynków w chwili zawierania umowy i nie kwestionował przyjętej przez powoda metody wyceny. Pozwany mógł się zorientować z OWU, że odszkodowanie odpowiadające sumie ubezpieczenia otrzyma jedynie w razie zajścia szkody całkowitej, natomiast $\mathrm{w}$ razie zakwalifikowania szkody jako częściowej poniesie ryzyko niedoubezpieczenia. Argumentem przesądzającym o uznaniu racji ubezpieczającego było stwierdzenie, że OWU nie pozwalały na określenie granic między szkodą całkowitą a częściową. Szkoda została zakwalifikowana jako częściowa, mimo że spalony zakład stolarski był niezdatny do prowadzenia działalności. Zawierając umowę, pozwany nie mógł przewidzieć wysokości odszkodowania, jakie może uzyskać. Odszkodowanie zostało w istocie ustalone nie według reguł zawartej umowy, ale według nieuzgodnionych zasad wynikających z praktyki pozwanego, poznanej przez powoda dopiero na etapie wykonania umowy.

Przechodząc do własnych konkluzji, wypada zauważyć, że nie jest zupełnie jasne, czy skrajne poglądy kwestionujące oraz dopuszczające zasadę proporcji bez zastrzeżeń odnoszą się do zasady proporcji w obydwu jej postaciach, tj. w postaci odnoszącej proporcję do wysokości szkody podlegającej naprawieniu, czy też do należnego odszkodowania. Przy 
takim założeniu obydwa skrajne poglądy należy uznać za niesłuszne. Ze stanowiskiem, że reguła redukcji proporcjonalnej jest niedopuszczalna co do zasady, trudno się zgodzić. Pamiętać trzeba, że opisana reguła ma za sobą wieloletnią tradycję, a Kodeks morski oraz obce systemy prawne uznają ją za rozwiązanie modelowe. Milczenie Kodeksu cywilnego co do tego, jaką regułę stosować w razie niedoubezpieczenia, nie powinno być interpretowane jako zakaz wprowadzenia reguły redukcji proporcjonalnej w ogólnych warunkach ubezpieczenia. Zakazu stosowania reguły redukcji proporcjonalnej nie da się wywieść z art. 824 k.c. Przepis ten mówi jedynie, że o ile nie umówiono się inaczej, suma ubezpieczenia stanowi górną granicę odpowiedzialności ubezpieczyciela i nie wyklucza wprowadzania innych ograniczeń odpowiedzialności. Początkowe zastrzeżenie sprawia, że próby wyprowadzania zakazu proporcji z art. 824 k.c. nie mogą się powieść, niezależnie od znanych mankamentów wnioskowania a contrario.

Teza o wzajemności ubezpieczenia, która jak wiadomo, jest kwestionowana w doktrynie i orzecznictwie, również nie pozwala a limine wykluczyć dopuszczalności redukcji proporcjonalnej. Składkę ubezpieczeniową wylicza się wprawdzie zgodnie z określoną sumą ubezpieczenia, jednak wysokość tej sumy nie jest jedynym kryterium mającym znaczenie dla ustalenia składki. Nieuprawnione jest założenie, że składka winna być szacowana na jednakowym poziomie niezależnie od tego, według jakiego systemu odpowiedzialności odpowiada ubezpieczyciel. Ryzyko przejmowane w ubezpieczeniu na pierwsze ryzyko jest daleko większe niż ryzyko przejmowane w ubezpieczeniu w systemie odpowiedzialności proporcjonalnej. W ubezpieczeniach mienia ryzyko wystąpienia szkody jakiejkolwiek jest bowiem znacznie większe niż ryzyko wystąpienia szkody całkowitej. Jeżeli suma ubezpieczenia ma odpowiadać wartości ubezpieczonego mienia, ryzyko wystąpienia szkody wyczerpującej szkodę ubezpieczenia jest daleko mniejsze niż ryzyko wystąpienia jakiejkolwiek szkody.

W przypadku ubezpieczenia na pierwsze ryzyko, w którym suma ubezpieczenia może być niższa od wartości ubezpieczenia, udział kolejnych szkód w wyczerpaniu sumy ubezpieczenia będzie znacznie większy, tym większy, im wyższa jest dysproporcja między sumą ubezpieczenia 
a wartością ubezpieczenia. W porównaniu do ubezpieczenia w systemie odpowiedzialności na pierwsze ryzyko nie zmienia się wprawdzie częstotliwość szkód, zwiększa się jednak wysokość wypłacanych odszkodowań w relacji do sumy ubezpieczenia. W ubezpieczeniu na pierwsze ryzyko ubezpieczyciel wypłaci generalnie większe odszkodowanie w proporcji do sumy ubezpieczenia niż w ubezpieczeniu w systemie proporcjonalnym. W ubezpieczeniu mienia właśnie suma ubezpieczenia stanowi podstawę obliczenia składki. Z tego względu, jeżeli OWU dopuszczają w ogóle wybór między jednym z dwóch systemów, składka w systemie odpowiedzialności na pierwsze ryzyko zawsze będzie wyższa ${ }^{87}$.

W literaturze podkreśla się również, że dopuszczalność klauzuli proporcjonalności nie powinna budzić wątpliwości z aksjologicznego i czysto utylitarnego punktu widzenia. Pozwala ona bowiem na stosowanie przez ubezpieczycieli niższych stawek taryfowych w ubezpieczeniu w systemie odpowiedzialności proporcjonalnej niż w przypadku ubezpieczenia na pierwsze ryzyko. W tym kontekście słuszne jest stwierdzenie zwolenników systemu odpowiedzialności proporcjonalnej, którzy wskazują, że system ten w istocie pozwala na zachowanie ekwiwalentności świadczeń ubezpieczającego i ubezpieczyciela, zamiast być z tą zasadą sprzecz$n y^{88}$. Podnosi się również, że kwestionowanie zasady proporcji grozi nieusprawiedliwionym zawężeniem oferowanych na polskim na rynku wariantów ubezpieczenia w porównaniu do rynków innych krajów ${ }^{89}$.

Dodać należy, że stanowisko, w myśl którego stosowanie zasady proporcji powinno być wykluczone co do zasady, jako wykraczające poza granice swobody umów z art. $353^{1}$ k.c., jest bardzo rzadko spotykane w orzecznictwie. Niepublikowany wyrok Sądu Apelacyjnego w Warszawie z 2.10.2008 r., VI ACa 140/08, na który powoływał się C. Orłowski, dotyczył, jak się zdaje, klauzuli proporcji w wariancie powodującym $\mathrm{w}$ istocie pomniejszenie sumy ubezpieczenia, natomiast niepublikowany wyrok Sądu Okręgowego w Katowicach z 2.12.2011 r., IV Ca 552/11,

87 Tak J. Nawracała, Odpowiedzialność..., s. 36-37.

88 J. Nawracała, Odpowiedzialność..., s. 37 oraz M. Orlicki, O możliwości..., s. 64.

89 M. Orlicki, O możliwości..., s. 67-68; M. Krajewski, Umowa ubezpieczenia. Art. 805-834 KC..., 2016, s. 537. 
uznawał klauzulę proporcji za niedozwoloną klauzulę umowną w umowie zawieranej z konsumentem.

Rację mają natomiast autorzy zwracający uwagę na niedopuszczalność zastrzeżenia klauzuli proporcji w sposób odnoszący ją do sumy wypłaconego odszkodowania zamiast do wysokości szkody, za którą odpowiada ubezpieczyciel, w konsekwencji czego nawet w przypadku zaistnienia szkody całkowitej ubezpieczający nie otrzymuje całej sumy ubezpieczenia. Właśnie w tym przypadku zachodzi sprzeczność między regułą proporcji a zasadą ekwiwalentności świadczeń. Ubezpieczyciel, który powinien szacować wysokość składki w proporcji do sumy ubezpieczenia, w ogóle nie bierze pod uwagę wypłaty świadczenia w wysokości tożsamej z tą sumą i takie ryzyko nie jest przez niego skalkulowane.

Ponadto regulacja Kodeksu morskiego, przytoczone wyżej regulacje francuska i niemiecka, które przyjmują system odpowiedzialności proporcjonalnej jako zasadę, jak również stanowisko Marine Insurance Act 1906 oraz sądownictwa angielskiego, uznającego prymat tego systemu w ubezpieczeniach z przedsiębiorstwami, dotyczą jedynie reguły proporcji odnoszonej do wielkości szkody podlegającej naprawieniu, nie zaś do wysokości należnego ostatecznie ubezpieczonemu odszkodowania. W tym kontekście zastrzeżenia może budzić mało precyzyjne sformułowanie art. 8:102 ust. 1 PEICL pozwalającego ubezpieczycielowi oferować alternatywnie do ubezpieczenia na pierwsze ryzyko ubezpieczenie w systemie, wedle którego odszkodowanie zostanie zmniejszone proporcjonalnie (tekst angielski: „indemnity to be paid shall be limited to the proportion (...)”). Zapewne autorzy traktowali niemożność ograniczenia przez ubezpieczyciela swej odpowiedzialności za szkodę całkowitą poniżej sumy ubezpieczenia jako pewną oczywistość.

Odwołując się zatem do historii ubezpieczeń oraz rozwiązań obcych, można wskazać, że jedynym uświęconym systemem odpowiedzialności proporcjonalnej jest system, według którego odszkodowanie ubezpieczeniowe wyliczane jest zgodnie z wzorem: wysokość szkody razy suma 
ubezpieczenia podzielić przez wartość ubezpieczenia ${ }^{90}$. System odpowiedzialności proporcjonalnej odnoszący regułę proporcji w istocie do sumy ubezpieczenia stanowi natomiast przykład twórczości polskich ubezpieczycieli, która pozostaje w jaskrawej sprzeczności z uświęconą tradycją oraz z zasadą ekwiwalentności świadczeń w umowie wzajemnej. Wydaje się, że opisywany system narusza przynajmniej dwa z trzech kryteriów ograniczających zasadę wolności umów wskazanych $\mathrm{w}$ art. $353^{1}$ k.c., a mianowicie właściwość (naturę) stosunku prawnego ubezpieczenia oraz zasady współżycia społecznego.

Najtrudniejsza jest ocena stanowiska wynikającego z orzeczeń Sądu Najwyższego, w których przyjęto, że zasada odpowiedzialności proporcjonalnej jest co do zasady dopuszczalna, może jednak stanowić klauzulę niedozwoloną $\mathrm{w}$ umowach $\mathrm{z}$ konsumentami, ewentualnie może być uznana za klauzulę nieprecyzyjną, interpretowaną na korzyść ubezpieczonego nawet $w$ umowach niekonsumenckich. Niejednoznacznie wypada już ocena pierwszego orzeczenia Sądu Najwyższego, które nadało kierunek całej linii, to jest wyroku z 16.10.2014 r., III CSK 302/13. Zgodnie z tym wyrokiem reguła redukcji proporcjonalnej może być uznana za nieobowiązującą w umowach $\mathrm{z}$ konsumentami, jeżeli nie wynika wprost z umowy, ale z ogólnych warunków umów, natomiast ubezpieczający będący konsumentem nie zdawał sobie sprawy z niedoubezpieczenia ani $\mathrm{z}$ jego konsekwencji. Rezultat taki wydaje się rozsądny i sprawiedliwy, problematyczne jest natomiast przedstawione uzasadnienie.

Sąd Najwyższy słusznie zwraca uwagę, że w okolicznościach sprawy ubezpieczający działał w dobrej wierze, nie zdając sobie sprawy z niedoubezpieczenia. Zupełnie inaczej powinna wypaść ocena sytuacji, gdyby ubezpieczający, mając świadomość niedoubezpieczenia oraz jego konsekwencji, zdecydował się na nie, uznając, że niedoubezpieczenie zwyczajnie mu się opłaca, albo sytuacji, gdy ubezpieczający celowo zaniżył deklarowaną wartość ubezpieczenia, żeby zaoszczędzić na składce, nie zastanawiając się przy tym nad konsekwencjami swej decyzji. Warto przypomnieć, że francuska Komisja ds. Klauzul Niedozwolonych już

90 Taki wzór podaje przykładowo Prawo ubezpieczeń gospodarczych, red. J. Kowalewski, s. 216. 
w 1985 r. odradzała stosowanie reguły proporcjonalności, gdyby miała ona prowadzić do pokrzywdzenia ubezpieczającego, który nie miał świadomości niedoubezpieczenia.

Kontrowersyjny pogląd o wzajemności umowy ubezpieczenia jest, jak starano się wcześniej wykazać, trafny, jednak sam argument, jakoby wzajemność sprzeciwiała się regule redukcji proporcjonalnej w wersji odnoszącej ją do wysokości szkody, wydaje się mało przekonujący ze względów wcześniej przytoczonych. Nieuprawnione jest założenie, że przyjęty system odpowiedzialności pozostaje bez wpływu na wysokość składki. Podobnie wątpliwe wydaje się uznanie przez Sąd Najwyższy klauzuli proporcjonalności za niejednoznaczną tylko dlatego, że znalazła się w $\$ 80$ ogólnych warunków umów. Uzasadnienie nie wskazuje, że sam sposób sformułowania klauzuli był niejednoznaczny, sugerując raczej, że reguła redukcji proporcjonalnej jest dla przeciętnego konsumenta niezrozumiała ze swej istoty.

Obowiązek szkolny obejmuje w Polsce przymus uczęszczania do szkoły podstawowej i gimnazjum a następnie kontynuowania nauki aż do ukończenia 18 roku życia. Reguły czytania, pisania i rozumienia, jak również podstawowe reguły matematyki objęte są programem szkoły podstawowej. W tych okolicznościach trudno obronić tezę, że reguła redukcji proporcjonalnej powinna być uznana za klauzulę niedozwoloną niezależnie od sposobu jej sformułowania jako niezrozumiała dla przeciętnego konsumenta. Odnośnie do ukrycia klauzuli w $\$ 80$ OWU rodzi się pytanie, czy wnioski powinny się różnić, gdyby regułę redukcji proporcjonalnej zawarto przykładowo w $\$ 15$ albo $\$ 10$ OWU? Rozumowanie takie zdaje się prowadzić do tezy, że klauzule dotyczące głównych świadczeń stron mogą być uznane za niejednoznaczne, ilekroć nie znajdą się w samej umowie, ale w warunkach umów, i nie zostaną wyróżnione w szczególny sposób. Teza taka jest kusząca ze względów słusznościowych, wydaje się jednak sprzeczna z przepisem definiującym klauzulę niedozwoloną, który przez "postanowienia umowy” rozumie przede wszystkim postanowienia ogólnych warunkach umów i regulaminów ${ }^{91}$.

91 Wyrok SA w Łodzi z 30.04.2014 r., I ACa 1209/13, LEX nr 1496006. 
Dodać należy, że zgodnie z art. 17 ust. 1 u.d.u.r. zakład ubezpieczeń ma obowiązek zawrzeć w stosowanych przez siebie ogólnych warunkach ubezpieczenia informacje, które postanowienia OWU określają:

1) przesłanki wypłaty odszkodowania i innych świadczeń lub wartości wykupu ubezpieczenia;

2) ograniczenia oraz wyłączenia odpowiedzialności zakładu ubezpieczeń uprawniające do odmowy wypłaty odszkodowania i innych świadczeń lub ich obniżenia;

3) koszty oraz wszelkie inne obciążenia potrącane ze składek ubezpieczeniowych, z aktywów ubezpieczeniowych funduszy kapitałowych lub poprzez umorzenie jednostek uczestnictwa ubezpieczeniowych funduszy kapitałowych;

4) wartość wykupu ubezpieczenia w poszczególnych okresach trwania ochrony ubezpieczeniowej oraz okres, w którym roszczenie o wypłatę wartości wykupu nie przysługuje.

Wydaje się, że wywiązanie się przez ubezpieczyciela z obowiązku, o którym mowa w punkcie 2, obecnie uniemożliwia twierdzenie, że klauzula proporcji była niejednoznaczna jako ukryta w treści OWU.

Propozycja, by reguła redukcji proporcjonalnej dla swej skuteczności była ujmowana w samej umowie lub dokumencie ubezpieczenia, nie zaś w OWU, może zatem stanowić postulat de lege ferenda, jednak twierdzenie jej odpowiadające wydaje się trudne do obrony również de lege lata. Uzasadnienie rozstrzygnięcia Sądu Najwyższego może więc budzić ostrożny sprzeciw. Wydaje się, że rozumowanie powinno raczej zmierzać do wykazania, że reguła redukcji proporcjonalnej nie należy do głównych świadczeń stron i dlatego w konkretnych okolicznościach może być uznana za klauzulę niedozwoloną zupełnie niezależnie od tego, czy została wyrażona w sposób jednoznaczny. Można twierdzić, że reguła, o którą chodzi, nie określa głównych świadczeń stron, ale jedynie pośrednio oddziałuje na wysokość świadczenia pieniężnego ubezpieczyciela w konkretnej sytuacji, gdy szkoda okazuje się być szkodą częściową, a suma ubezpieczenia okazuje się niższa niż wartość ubezpieczenia.

W orzecznictwie dosyć powszechnie wyrażany jest pogląd, że ratio legis art. $385^{1} \$ 1$ k.c., jakim jest interes konsumenta, przemawia za wąską 
wykładnią sformułowania „postanowienia dotyczące głównych świadczeń stron”. Takie stanowisko wyrażono przykładowo w wyroku Sądu Apelacyjnego w Warszawie z 18.09.2013 r., VI ACa 201/13², zgodnie z którym nie zalicza się do głównych świadczeń stron postanowień, których zastosowanie wywiera jedynie wpływ na wysokość świadczenia, w tym świadczeń głównych, chodzi bowiem o postanowienia bezpośrednio „określające” główne świadczenia, nie zaś takie, które tylko pośrednio łączą się z nimi. W innych wyrokach do „postanowień określających główne świadczenia stron” zaliczano tylko takie elementy konstrukcyjne umowy, bez uzgodnienia których nie doszłoby w ogóle do jej zawarcia (essentialia negotii) ${ }^{93}$. Klauzula proporcjonalności do takich elementów nie należy, ponieważ jej nieuzgodnienie powoduje, zgodnie z tym, co napisano powyżej, że umowa jest zawarta w systemie na pierwsze ryzyko.

Omawiane wąskie ujęcie postanowień dotyczących głównych świadczeń stron jest szczególnie aktualne w odniesieniu do umowy ubezpieczenia. Gdyby termin „postanowienia określające główne świadczenia stron” wykładany był na gruncie tej umowy szeroko, gwarantowana przez art. $385^{1} \$ 1$ k.c. ochrona konsumentów byłaby iluzoryczna. Wynika to przede wszystkim $\mathrm{z}$ wątpliwości dotyczących samego charakteru świadczenia ubezpieczyciela, powszechnego stosowania wyłączeń oraz ograniczeń odpowiedzialności, jak również ograniczeń wysokości samego świadczenia pieniężnego ubezpieczyciela. Wątpliwy wydaje się w szczególności prezentowany niekiedy w doktrynie pogląd, że główne świadczenie ubezpieczyciela w rozumieniu art. $385^{1} \$ 1$ k.c. polega na różnie rozumianym ponoszeniu ryzyka zapłaty określonej sumy pieniężnej ${ }^{94}$.

Pogląd taki prowadzi do niemożności poddania kontroli - przez pryzmat kryteriów klauzuli niedozwolonej - jakichkolwiek postanowień ogól-

92 LEX nr 1392122.

93 Wyrok SA w Warszawie z 6.03.2013 r., VI ACa 1241/12, LEX nr 1322083.

94 Pogląd ten prezentuje w szczególności J. Pokrzywniak. Zob. J. Pokrzywniak, Regulacja prawna umowy ubezpieczenia a orzecznictwo w sprawach klauzul abuzywnych [w:] Rynek ubezpieczeniowy - nadregulacja czy niedoregulowanie, red. M. Serwach, Łódź 2014, s. 171 oraz wskazana w tym opracowaniu literatura i orzecznictwo. 
nych warunków ubezpieczenia, które ograniczają zakres gwarantowanej przez ubezpieczyciela ochrony ubezpieczeniowej, jeżeli tylko zostaną sformułowane w sposób jednoznaczny. Gdyby taki pogląd przyjąć, gros postanowień umieszczonych w rejestrze prowadzonym przez Prezesa Urzędu Ochrony Konkurencji i Konsumentów nigdy nie powinno się tam znaleźćc ${ }^{5}$. Trudno przykładowo zaakceptować wykluczenie stosowania przepisów o klauzulach niedozwolonych do postanowień wprowadzających franszyzę redukcyjną albo udział własny na wyjątkowo wysokim poziomie albo wyłączającym odpowiedzialność ubezpieczyciela w sytuacjach, które z uwagi na istotę danego ubezpieczenia powinny być objęte odpowiedzialnością.

Jak wynika z wcześniejszych rozważań, możliwe do obrony jest stanowisko, że świadczenie ubezpieczyciela polega nie tylko na zapłacie oznaczonej w umowie sumy pieniężnej, ale również na zespole czynności składających się na tzw. ponoszenie ryzyka ${ }^{96}$, jednakże ponoszenie ryzyka nie ma charakteru świadczenia głównego w rozumieniu art. $385^{1}$ $\$ 1$ k.c. W świetle znanych kontrowersji dotyczących wyodrębnienia w strukturze stosunku zobowiązaniowego świadczeń głównych i ubocznych użycie przez ustawodawcę w omawianym przepisie sformułowania „świadczenia główne” zamiast po prostu „świadczenia” wskazuje na chęć zawężenia zastrzeżenia zawartego w ostatnim fragmencie przepisu jedynie do konkretnych i najistotniejszych obowiązków składających się na świadczenie w szerokim znaczeniu. Świadczeniem głównym ubezpieczyciela w umowie ubezpieczenia na gruncie art. $385^{1} \$ 1$ k.c. byłaby w takim ujęciu jedynie zapłata określonego w umowie odszkodowania oraz zapłata umówionej sumy pieniężnej, wymienione w art. $805 \$ 2$ k.c. po słowach „W szczególności”.

Podsumowując powyższy wywód, pogląd Sądu Najwyższego o dopuszczalności reguły redukcji proporcjonalnej w umowy ubezpieczenia nale-

95 Zob. Klauzule abuzywne w działalności ubezpieczeniowej. Raport Rzecznika Ubezpieczonych, Warszawa, luty 2012, por. http://www.rzu.gov.pl/files/20655_5243_Raport_ Rzecznika_Ubezpieczonych_poswiecony_klauzulom_abuzywnym_w_dzialalnosci_ ubezpieczeniowej.pdf (dostęp: 3.11.2018 r.).

96 Szerzej zob. B. Kucharski, Przeniesienie..., s. 50 i n. 
ży zaaprobować. Jeżeli jednak reguła, o której mowa, wynika z ogólnych warunków umów, które nie były przedmiotem negocjacji, ubezpieczający będący konsumentem lub osobą fizyczną prowadzącą działalność gospodarczą nie miał świadomości niedoubezpieczenia ani mechanizmu działania klauzuli proporcjonalności, klauzula może być uznana za niewiążącą ubezpieczającego jako kształtująca jego prawa i obowiązki w sposób sprzeczny z dobrymi obyczajami i rażąco naruszająca jego interesy. Rodzi się przy tym refleksja, że przejęte z dyrektywy europejskiej przepisy o klauzulach niedozwolonych zawierają mankament polegający na nieodróżnianiu sytuacji, w której kwestionowana klauzula została wyrażona w samej umowie i objęta konsensem, oraz w sytuacji, gdy klauzula była jedynie zawarta w ogólnych warunkach umów, które obowiązują niezależnie od objęcia ich konsensem ${ }^{97}$. Sąd Najwyższy próbował wybrnąć z tej sytuacji, wyrażając pogląd, że klauzula może być uznana za niejednoznaczną tylko z uwagi na jej „ukrycie” w jednym z dalszych postanowień ogólnych warunków umów. Wydaje się, że należało raczej dokonać zawężającej wykładni pojęcia „świadczenie główne” objętego zastrzeżeniem zawartym w drugim zdaniu art. $385^{1} \$ 1$ k.c.

Na koniec należy również odnieść się do orzeczeń, w których Sąd Najwyższy uznawał klauzulę proporcji za niejednoznaczną i odwołując się do reguły in dubio contra proferentem, wyłączał jej stosowanie. Stosunkowo najprościej wypada ocena wyroku z 9.08.2016 r., II CSK 743/15, w którym SN stwierdził, że powodowie, którzy wykupili najbogatszą wersję ubezpieczenia „maximum” (optimum), mogli liczyć na to, że szkoda poniżej sumy ubezpieczenia będzie pokryta w całości. Wydaje się, że w sprawie tej w istocie zachodziła sprzeczność między zawartą umową ubezpieczenia a ogólnymi warunkami. W takiej sytuacji, jak wiadomo, pierwszeństwo ma treść umowy. Podobne rozstrzygnięcia Sąd Najwyższy formułował już wcześniej. Przykładowo w wyroku z 12.01.2007 r., IV CSK 307/06 ${ }^{98}$, uznał za nieskuteczne zawarte w OWU ubezpieczenia samochodu wyłączenie odpowiedzialności za kradzież rozbójniczą

97 Pogląd wyrażający tzw. teorię zewnętrzną, zgodnie z którą ogólne warunki ubezpieczenia obowiązują niezależnie od objęcia ich konsensem, Sąd Najwyższy wyraził w wyroku z 30.11.2000 r., I CKN 970/98, OSNC 2001/6, poz. 93.

98 LEX nr 238967. 
określoną inaczej niż w Kodeksie karnym i obejmującą również kradzież przez zaskoczenie w sytuacji, gdy według polisy ubezpieczający wykupili tzw. ubezpieczenie pełne.

Zaaprobować można również wyrok SN z 10.06.2016 r., IV CSK 624/15, w którym uznano, że klauzula proporcji w połączeniu z niejasnymi postanowieniami dotyczącymi kwalifikacji szkody jako częściowej lub całkowitej oraz ustalania wysokości szkody jest niejasna i nie może być zastosowana w umowie z przedsiębiorcą. Jeżeli OWU rzeczywiście nie określały precyzyjnie szkody całkowitej oraz częściowej i warunków ustalania wysokości szkody, uznać je należało za sprzeczne z art. 12a pkt 5 ustawy z 22.05.2003 r. o działalności ubezpieczeniowej ${ }^{99}$, który nakazywał ubezpieczycielowi określić w OWU ubezpieczenia majątkowego sposób ustalania wysokości szkody. Ustawa o działalności ubezpieczeniowej i reasekuracyjnej zawiera podobną regulację w art. 16 pkt 5. Dodać należy, że sytuacja, gdy ani umowa, ani OWU nie określają opisanych kwestii, może być uznana za sprzeczną z podstawową zasadą prawa zobowiązań, jaką jest zasada oznaczoności świadczenia ${ }^{100}$. Powoływanie się przez ubezpieczyciela, który nie określił precyzyjnie wysokości swojego świadczenia, na nieważność umowy byłoby z całą pewnością sprzeczne z art. 5 k.c. Ostateczny wniosek SN o związaniu stron umową ubezpieczenia w wersji na pierwsze ryzyko wydaje się zatem słuszny, choć jest sprzeczny z intencjami ubezpieczyciela. Przypomnieć należy, że w omawianej sprawie ubezpieczający był osobą fizyczną zawierającą umowę w związku z prowadzeniem przedsiębiorstwa w postaci zakładu stolarskiego, a zgodnie $\mathrm{z}$ art. $805 \$ 4$ k.c. do osób fizycznych będących przedsiębiorcami znajdują zastosowanie przepisy o niedozwolonych klauzulach umownych. Wydaje się zatem, że w okolicznościach sprawy Sąd Najwyższy mógł nawet uznać klauzulę za niedozwoloną.

Ostatni powołany wyrok jest istotny również ze względu na odniesienie się do zasady najwyższego zaufania, która chronić ma nie tylko ubezpieczyciela w razie podawania przez ubezpieczającego nieprawdziwych okoliczności, ale również ubezpieczającego czy ubezpieczonego

99 Dz.U. z 2015 r. poz. 1206 ze zm.

100 Por. Z. Radwański, Teoria umów, Warszawa 1977, s. 72. 
przed sprzecznym z dobrymi obyczajami działaniem ubezpieczyciela jako profesjonalisty oraz silniejszej strony stosunku ubezpieczenia. W orzecznictwie Sądu Najwyższego dotyczącym klauzuli proporcji często powtarza się motyw nieuczciwości ubezpieczyciela, który zawierając umowę, polega na sumie ubezpieczeniowej określanej przez ubezpieczającego, w żaden sposób nie weryfikując, czy odpowiada ona wartości ubezpieczeniowej, przede wszystkim zaś nie zwracając uwagi kontrahenta na konsekwencje niedoubezpieczenia. Następnie dopiero w razie zajścia wypadku, ubezpieczyciel dokonuje precyzyjnej wyceny ubezpieczonego interesu, zwykle przy udziale biegłych, co ostatecznie prowadzi do wniosku o niedoubezpieczeniu oraz do zastosowania reguły redukcji proporcjonalnej.

W literaturze argumentacja tego rodzaju bywa kwestionowana. Zwraca się uwagę, że pomijając niektóre ubezpieczenia, w szczególności ubezpieczenia autocasco, w przypadku których ubezpieczyciel dysponuje bazami danych w rodzaju Info-Ekspert oraz Eurotax, na etapie zawarcia umowy w większości przypadków niemożliwa jest weryfikacja przez ubezpieczyciela poprawności zadeklarowanej przez ubezpieczającego sumy ubezpieczenia. Powodowałoby to wydłużenie procesu zawierania umowy ubezpieczenia oraz znaczny wzrost kosztów związanych z jej zawarciem. Powyższa obserwacja dotyczy w szczególności ubezpieczeń ogniowych budynków, przy których powszechnie stosowany jest system odpowiedzialności proporcjonalnej. Upatrywanie rażącego naruszenia interesów ubezpieczonego oraz sprzeczności z dobrymi obyczajami w samym fakcie, że weryfikacja sumy ubezpieczenia w kontekście wartości ubezpieczenia następuje dopiero na etapie likwidacji szkody, ma być w związku z powyższym niesłuszne i świadczyć o oderwaniu orzecznictwa Sądu Najwyższego od realiów rynkowych ${ }^{101}$.

Wydaje się, że słuszność, jak często bywa, leży pośrodku. Autorzy powołujący się na niemożność precyzyjnej weryfikacji wartości wyjątkowo cennych, w szczególności zaś oznaczonych co do tożsamości składników mienia, mają dużo racji. Problem sprowadza się jednak do tego, że ubezpieczyciele proponujący ochronę w systemie odpowiedzialności

101 Tak przykładowo J. Nawracała, Odpowiedzialność..., s. 47. 
proporcjonalnej nie zwracają na to uwagi ubezpieczających i nie dokonują jakichkolwiek prób weryfikacji podawanych przez ubezpieczających wartości interesu stanowiącego przedmiot ubezpieczenia. Jest zastanawiające, że przy zawieraniu umowy ubezpieczenia autocasco samochodu wartego od kilku do kilkudziesięciu tysięcy złotych ubezpieczyciel zwykle dokonuje się jego oględzin i wykonuje zdjęcia, natomiast przy ubezpieczeniu domu wartego zwykle od kilkuset tysięcy do kilku milionów przeważnie w ogóle nie interesuje się jego wyglądem. Można więc odnieść wrażenie, że w praktyce klauzula proporcji traktowana jest przez ubezpieczycieli jako wybieg mający pozwolić przynajmniej na zaniżenie wartości odszkodowania w sytuacjach, gdy nie będzie można całkowicie uniknąć odpowiedzialności.

Rozważania dotyczące reguł odpowiedzialności ubezpieczyciela w razie niedoubezpieczenia na gruncie prawa polskiego wypada podsumować, formułując następujące wnioski. Po pierwsze, w braku odmiennych zastrzeżeń regułą jest odpowiedzialność na pierwsze ryzyko. Rozwiązanie to jest prawidłowe ze względów przytoczonych w uzasadnieniu regulacji PEICL. Polski art. 824 k.c. wydaje się jednak mało precyzyjny. Zapewne byłoby lepiej, gdyby stanowił, że jeżeli nie umówiono się inaczej, suma ubezpieczenia stanowi górną granicę odpowiedzialności ubezpieczyciela, choćby wartość ubezpieczonego interesu była od niej wyższa. Zmiana przepisu przez dodanie końcowego zastrzeżenia nie jest jednak nieodzowna, skoro jego interpretacja nie budzi w doktrynie ani orzecznictwie istotnych wątpliwości.

Po drugie, ubezpieczyciel może zastrzec w umowie lub ogólnych warunkach ubezpieczenia, że odpowiada za szkodę w proporcji, w jakiej suma ubezpieczenia pozostaje do wartości ubezpieczeniowej z chwili zawarcia umowy lub z chwili szkody. Niedopuszczalne jest natomiast, jako sprzeczne $z$ istotą umowy ubezpieczenia oraz zasadami współżycia społecznego, zastrzeżenie, według którego proporcjonalnemu obniżeniu ulega odszkodowanie ubezpieczeniowe. Zastrzeżenie takie powoduje bowiem $\mathrm{w}$ istocie odniesienie zasady proporcji do sumy ubezpieczenia. Gdyby było ono skuteczne, ubezpieczyciel nie wypłacałby sumy ubezpieczenia nawet w razie zajścia szkody całkowitej. W konsekwencji ubezpieczyciel, kalkulując składkę w odniesieniu do sumy ubezpiecze- 
nia, w ogóle nie ponosiłby ryzyka wypłaty takiej sumy, co jest sprzeczne z zasadą ekwiwalentności świadczeń.

Zastrzeżenie klauzuli proporcji powodującej proporcjonalne zmniejszenie odszkodowania ubezpieczeniowego zamiast wielkości szkody, za którą odpowiada ubezpieczyciel, stanowi w związku z powyższym postanowienie nieważne. Teoretycznie zatem, pomimo zastrzeżenia klauzuli proporcji, umowa ubezpieczenia powinna być uważana za zawartą w systemie odpowiedzialności na pierwsze ryzyko. Trudno bowiem, nawet przy życzliwości dla ubezpieczającego, interpretować klauzulę nakazującą proporcjonalne zmniejszenie wypłacanego odszkodowania jako klauzulę nakazują proporcjonalne zmniejszenie szkody, za którą odpowiada ubezpieczyciel.

Wydaje się jednak, że skutek, do którego dochodził Sąd Najwyższy, stosując regułę in dubio contra proferentem, można wywieść $\mathrm{z}$ art. 58 $\$ 3$ k.c., ewentualnie $\mathrm{z}$ art. $385^{1} \$ 2$ k.c. w umowach $\mathrm{z}$ konsumentami. Klauzula nakazująca proporcjonalne zmniejszenie odszkodowania byłaby nieważna jedynie w części dopuszczającej jego zmniejszenie poniżej sumy ubezpieczenia w razie zajścia szkody całkowitej, w pozostałym zakresie pozostawałaby w mocy. Rozwiązanie prowadzące $\mathrm{w}$ istocie do przekształcenia klauzuli proporcji w wersji niedozwolonej w klauzulę w wersji dozwolonej jest bardziej elastyczne i lepiej odpowiada intencjom stron niż przekształcenie zawartej umowy ubezpieczenia proporcjonalnego w ubezpieczenie na pierwsze ryzyko.

Po trzecie, w umowach z konsumentami klauzula proporcji może być w pewnych okolicznościach uważana za niedozwoloną, także gdy przewiduje proporcjonalne zmniejszenie zakresu szkody objętej odpowiedzialnością ubezpieczyciela. Klauzula proporcjonalności wbrew prezentowanym $\mathrm{w}$ doktrynie i orzecznictwie poglądom nie należy do klauzul określających zakres głównych świadczeń stron. Jedynie pośrednio wpływa ona na wartość wypłacanego odszkodowania, gdy szkoda okazuje się być całkowita, a wartość ubezpieczenia okazuje się przekraczać sumę ubezpieczenia. Klauzula taka może zatem okazać się niedopuszczalna w szczególności, gdy ubezpieczyciel lub agent nie próbował weryfikować podanej przez ubezpieczającego w dobrej wierze wartości 
ubezpieczenia, nie zwrócił ubezpieczającemu wyraźnie uwagi na konsekwencje istotnego jej zaniżenia oraz traktował system odpowiedzialności proporcjonalnej jako wybieg mający na celu ograniczenie wysokości odszkodowania ubezpieczeniowego poniżej wartości poniesionej przez ubezpieczającego szkody. Możliwość uznania klauzuli redukcji proporcjonalnej za niedozwoloną nie dotyczy raczej sytuacji, gdy wynikała ona $\mathrm{z}$ treści samej polisy ubezpieczeniowej.

Po czwarte, klauzula proporcji zastrzeżona w umowie z przedsiębiorcą niebędącym osobą fizyczną może okazać się nieskuteczna zupełnie wyjątkowo, gdy do takiego wniosku doprowadzą pośrednie środki kontroli wzorca umownego polegające na interpretowaniu postanowień niejednoznacznych na korzyść ubezpieczającego, ubezpieczonego lub uprawnionego z umowy ubezpieczenia (art. 15 ust. 5 u.d.u.r.). Dotyczyć to może w szczególności sytuacji, gdy w umowie i OWU brak będzie reguł dotyczących odróżnienia szkody całkowitej od szkody częściowej oraz ustalania wysokości odszkodowania, ewentualnie reguły takie okażą się niejednoznaczne. Pamiętać trzeba, że prawidłowo zastrzeżona klauzula proporcji prowadzi do rezultatów mniej korzystnych dla ubezpieczającego niż system odpowiedzialności na pierwsze ryzyko tylko przy szkodzie częściowej. Jeżeli zatem ubezpieczający nie jest w stanie przewidzieć, kiedy szkoda zostanie uznana za częściową ani według jakich reguł ubezpieczyciel będzie szacował jej wysokość, należy, interpretując postanowienia OWU na korzyść osoby uprawnionej do świadczenia ubezpieczeniowego, przyjąć, że ubezpieczenie zawarto w systemie odpowiedzialności na pierwsze ryzyko.

Po piąte, jeżeli ubezpieczenie zawierane jest w systemie odpowiedzialności proporcjonalnej, należy postulować, aby wynikało to z treści polisy ubezpieczeniowej, podobnie jak coraz częściej dzieje się w odniesieniu do udziału własnego. Postępowanie ubezpieczycieli polegające na umieszczeniu takiego zastrzeżenia na polisie zamiast w OWU, wbrew pozorom w dłuższej perspektywie czasowej może działać na ich korzyść, w ten sposób bowiem klauzula proporcji przestanie być postrzegana przez społeczeństwo i sądy jako nieuczciwy „kruczek prawny” pozwalający ubezpieczycielowi ograniczyć odpowiedzialność. Klauzula proporcji nie jest oczywiście zła sama w sobie. Jak wskazywano, ubezpieczenie 
w systemie odpowiedzialności proporcjonalnej może być tańsze i bardziej opłacalne dla ubezpieczającego, kiedy ryzyko szkody całkowitej jest niewielkie. Chodzi jedynie o to, by ubezpieczający wybierał takie ubezpieczenie świadomie. Eugeniusz Kowalewski przed ćwierćwieczem postulował określenie minimalnej treści polisy w przepisach Kodeksu cywilnego o umowie ubezpieczenia ${ }^{102}$. Gdyby ustawodawca zdecydował się na taką zmianę, powinien nakazać, by zawarcie ubezpieczenia w systemie odpowiedzialności proporcjonalnej wynikało z treści polisy.

\subsection{Techniczne ograniczenia odpowiedzialności ubezpieczyciela}

Poza kwestiami związanymi z relacją wartości i sumy ubezpieczenia, zakres odszkodowania ubezpieczeniowego zależy również od wprowadzenia tzw. technicznych ograniczeń odpowiedzialności ubezpieczyciela. Mianem tym obejmuje się zwykle pojęcia franszyzy integralnej, redukcyjnej oraz udziału własnego w szkodzie. Sformułowanie „ograniczenia techniczne” można rozumieć w ten sposób, że ograniczenia, o których mowa, odnoszą się do szeroko rozumianej techniki ubezpieczeń, są powszechnie stosowane w praktyce i uświęcone długą tradycją ubezpieczeń, jednak przynajmniej w polskim prawie nie mają regulacji.

Franszyza integralna (lub warunkowa) zwalnia ubezpieczyciela z odpowiedzialności, jeżeli szkoda nie przekracza określonej kwoty, jeżeli zaś szkoda określoną kwotę przekracza, ubezpieczyciel odpowiada bez żadnych potrąceń, tak jakby franszyzy nie było. Kwota może być określona wprost lub jako ułamek bądź procent określonej podstawy - zwykle wartości lub sumy ubezpieczenia. Franszyzę integralną wprowadza się, by uniknąć formalności związanych z likwidacją szkód bagatelnych. Znaczna liczba drobnych postępowań likwidacyjnych, których koszty przekraczałyby wysokość wypłacanych odszkodowań albo byłyby w sto-

102 E. Kowalewski postulował taką zmianę, jak dotąd bezskutecznie, już w $1992 \mathrm{r}$. Por. E. Kowalewski, Prawo ubezpieczeń gospodarczych. Ewolucja..., s. 150-151. Regulacja Kodeksu morskiego nie zawiera takiego zastrzeżenia z tej prostej przyczyny, że w ubezpieczeniach morskich pierwszeństwo reguły proporcji wynika z ustawy. 
sunku do nich nieproporcjonalnie wysokie, odbijałaby się oczywiście na zyskowności zakładu ubezpieczeń ${ }^{103}$.

Franszyza redukcyjna (bezwarunkowa) powoduje z kolei obniżenie każdego odszkodowania ubezpieczeniowego o z góry określoną kwotę lub ułamek bądź procent określonej podstawy. Wysokość szkody nie ma przy tym znaczenia, każde odszkodowanie obniżane jest bowiem w ten sam sposób. W przypadku poniesienia szkody o wartości niższej lub równej wartości franszyzy odszkodowanie oczywiście w ogóle nie jest wypłacane. W literaturze wskazuje się zwykle, że franszyza redukcyjna jest często zastrzegana w przypadku ubezpieczenia przedmiotów podlegających ubytkom naturalnym lub różnicom wagowym w transporcie lub przechowaniu, co pozwala ubezpieczycielowi uniknąć odpowiedzialności za te ubytki lub różnice ${ }^{104}$.

W istocie problem sprowadza się raczej do uniknięcia wątpliwości związanych z kwalifikacją określonego zdarzenia jako ubytku naturalnego lub naturalnej różnicy wagowej. Jak bowiem wskazywano, ubytki naturalne w ogóle nie mogą generować szkód podlegających naprawieniu na ogólnych zasadach. Dodać można, że nawet w braku specjalnych wyłączeń i ograniczeń ubezpieczyciel nie powinien odpowiadać za ubytki naturalne, ponieważ w sytuacji, gdy ubytki są rzeczywiście naturalne, tzn. wynikają immanentnie z istoty konkretnej rzeczy albo substancji, ich poniesienie jest pozbawione cechy niepewności, a zatem nie może stanowić wypadku ubezpieczeniowego ${ }^{105}$. Niezależnie od powyższego, ogólne warunki ubezpieczenia przeważnie przewidują wyraźne wyłączenia dotyczące ubytków naturalnych.

103 W. Warkałło, W. Marek, W. Mogilski, Prawo..., s. 127; A. Wąsiewicz, Z.K. Nowakowski, Prawo..., s. 61; Prawo ubezpieczeń gospodarczych, red. E. Kowalewski, s. 220; B. Kęszycka, Prawo..., s. 115; M. Orlicki, Umowa ubezpieczenia, 2002, s. 167; M. Orlicki, Umowa ubezpieczenia [w:] System..., t. 8, s. 846-847; M. Krajewski, Umowa ubezpieczenia. Art. 805-834 KC..., 2016, s. 549.

104 M. Krajewski, Umowa ubezpieczenia. Art. 805-834 KC..., 2016, s. 550.

105 Podobnie A. Wąsiewicz, Z.K. Nowakowski, Prawo..., s. 61; B. Kęszycka, Prawo..., s. 115-116. 
Udział własny z kolei polega na przejęciu przez ubezpieczyciela ryzyka każdej szkody jedynie w procentowo lub ułamkowo określonej części. Część szkody niepokrywana przez ubezpieczyciela objęta jest ryzykiem samego ubezpieczającego czy też udziałem własnym ubezpieczającego. Udział własny różni się od franszyzy redukcyjnej tym, że jego wysokość odnoszona jest do wysokości szkody, a zatem przed jej zajściem nie jest znana kwotowa wysokość udziału własnego. Wskazuje się, że udział własny stanowi w istocie ustalone między stronami niedoubezpieczenie, ograniczając w praktyce sumę ubezpieczenia w relacji do wartości ubezpieczeniowej. W związku z powyższym w przeciwieństwie do franszyzy redukcyjnej od wielkości udziału własnego nie nalicza się składki ubezpieczeniowej ${ }^{106}$. Zastrzeżenie udziału własnego ma znaczenie przede wszystkim prewencyjne. Stosuje się je w tych ubezpieczeniach, w których wystąpienie szkody uzależnione jest w dużej mierze od zachowania przez ubezpieczającego należytej staranności i dbałości o stan ubezpieczonego interesu. Udział własny wprowadzany jest przykładowo powszechnie $\mathrm{w}$ ubezpieczeniach autocasco ${ }^{107}$.

Wspomniana wyżej okoliczność, że pojęcia franszyzy integralnej, franszyzy redukcyjnej oraz udziału własnego nie są regulowane ustawowo, oznacza, że w praktyce ich znaczenie wynika z ogólnych warunków ubezpieczenia. Zaproponowane znaczenia omawianych terminów odpowiadają określeniom używanym zwykle w literaturze prawniczej oraz najczęściej występującym w obrocie ubezpieczeniowym. Może się jednak zdarzyć, że konkretna regulacja umowna lub uczestnik rynku definiować będzie wspomniane określenia inaczej. Ostatnio w praktyce zaciera się w szczególności granica między franszyzą redukcyjną i udziałem własnym. Spotyka się również określenia mieszane, według których np. udział w szkodzie wynosi odpowiednio 5, 10 lub 15\% sumy ubezpieczenia, jednak nie mniej niż określona kwota, np. 500 zł lub $1000 \mathrm{zt}^{108}$. Zamęt potęguje również okoliczność, że w ubezpieczeniach

\footnotetext{
106 Prawo ubezpieczeń gospodarczych, red. E. Kowalewski, s. 220.

107 B. Kęszycka, Prawo..., s. 116; M. Orlicki, Umowa ubezpieczenia [w:] System..., t. 8, s. 717; M. Krajewski, Umowa ubezpieczenia. Art. 805-834 KC..., 2016, s. 550.

108 Zob. wyjaśnienie C. Orłowskiego na stronie internetowej Rzecznika Finansowego: https://rf.gov.pl/pytania-i-odpowiedzi/ubezpieczenia-malych-i-srednich-przedsiebiorstw/ Co_to_jest_franszyza_co_to_znaczy_udzial_wlasny__20332 (dostęp: 3.11 .2018 r.).
} 
business interruption występują także franszyzy czasowe, tj. określone czasowo limity przerw w produkcji, do przekroczenia których zakład ubezpieczeń nie odpowiada za wywołane nimi szkody. Czymś jeszcze innym jest tzw. karencja, tj. opóźnienie rozpoczęcia lub zakończenia materialnego okresu ubezpieczenia w stosunku do początku formalnego okresu ubezpieczenia. Kwestie początku ubezpieczenia były omawiane wcześniej w rozdziale dotyczącym przesłanek odpowiedzialności odszkodowawczej ubezpieczyciela.

Zacieranie się różnicy między franszyzą integralną i udziałem własnym jest do pewnego stopnia uzasadnione aktualnym brzmieniem przepisów o umowie ubezpieczenia, które składkę jako świadczenie ubezpieczającego wiążą nie tylko z zakresem czasowym, ale również kwotowym ochrony udzielanej przez ubezpieczyciela. Zgodnie z art. $824 \$ 3$ k.c. „Zmniejszenie sumy ubezpieczenia pociąga za sobą odpowiednie zmniejszenie składki (...)". Wydaje się przynajmniej dyskusyjne, czy dopuszczalne jest zastrzeżenie franszyzy redukcyjnej (bezwarunkowej) przy jednoczesnym pobieraniu składki od całej sumy ubezpieczenia, skoro wprowadzenie franszyzy prowadzi w praktyce do wniosku, że zakład ubezpieczeń nie bierze pod uwagę ryzyka wypłaty całej sumy ubezpieczenia, zawsze pomniejszając swoje świadczenie odpowiednio o wysokość franszyzy. W tym zakresie można odwołać się do wcześniejszych uwag dotyczących niedopuszczalności klauzuli proporcji odnoszonej do wysokości wypłacanego odszkodowania, a przez to do sumy ubezpieczenia zamiast do wielkości szkody, za którą odpowiada zakład ubezpieczeń.

Wydaje się, że opisywana praktyka w istocie może być uznana za sprzeczną z właściwością stosunku prawnego ubezpieczenia jako umowy wzajemnej. Przyjąwszy, że ubezpieczający nie może płacić składki od sumy objętej franszyzą redukcyjną, rozróżnienie między nią a udziałem własnym opierałoby się wyłącznie na tym, że franszyza wyrażona jest kwotowo, wobec czego jej wysokość znana jest z góry, podczas gdy udział własny wyraża się w procentach w stosunku do konkretnej szkody, a zatem jego dokładna wysokość znana jest dopiero, gdy dojdzie do szkody. W tym zakresie jednak w praktyce używane są właśnie bardzo różne rozwiązania i żeby wiedzieć, czym jest udział własny lub 
franszyza, trzeba ustalić rozumienie tych pojęć przez uczestnika rynku ubezpieczeniowego, który powołuje się na nie.

Opisywany zamęt terminologiczny widoczny jest również w obcych regulacjach oraz praktyce ubezpieczeniowej. Najmniej wątpliwości kwestia ta budzi we Francji. Powoływany już wcześniej art. L121-1 Code des assurances stanowi, że ubezpieczenie jest umową o odszkodowanie. Odszkodowanie, które ubezpieczyciel winien jest ubezpieczającemu, nie może przekraczać wartości ubezpieczonego mienia w chwili szkody. Można jednak przewidzieć, że ubezpieczający będzie swym własnym ubezpieczycielem do określonej sumy lub kwoty albo że należne mu odszkodowanie będzie zmniejszone z góry o określoną wartość.

Yvonne Lambert-Faivre i Laurent Leveneur odróżniają obowiązkowy udział własny ubezpieczonego w szkodzie oraz franszyzę awaryjną. Ten pierwszy polega na tym, że ubezpieczający w celach prewencyjnych pozostaje w części niedoubezpieczony, ponosząc ryzyko szkody $\mathrm{w}$ ustalonym zakresie. W zakresie niedoubezpieczenia nie nalicza się składki ubezpieczeniowej. Rozwiązanie takie spotykane jest w celach prewencyjnych między innymi w obowiązkowych ubezpieczeniach odpowiedzialności cywilnej profesjonalistów. Przykładowo w ubezpieczeniu notariuszy obowiązkowy udział własny wynosi 10\% szkody, nie więcej niż 7500 euro.

Franszyza z kolei może mieć charakter prosty (franchise simple) albo absolutny (franchise absolute). Ta pierwsza tożsama jest $\mathrm{z}$ franszyzą integralną, znaną z polskiej praktyki ubezpieczeniowej, i zastrzegana bywa $\mathrm{z}$ tych samych powodów. Chodzi zatem o szkody bagatelne, dla których koszty likwidacji byłyby nieproporcjonalnie wysokie w stosunku do wypłacanych odszkodowań. Jeżeli szkoda przekracza wysokość franszyzy, uprawniony otrzymuje pełne odszkodowanie bez potraceń. Franszyza absolutna skutkuje natomiast zawsze obniżeniem odszkodowania o określoną wartość. Jedyna różnica między franszyzą absolutną a obligatoryjnym udziałem własnym sprowadza się do tego, że franszyza jest w pełni dobrowolna, ubezpieczający może zawrzeć ubezpieczenie 
bez franszyzy, jeżeli tylko chce, tyle że ubezpieczenie takie będzie droższe od ubezpieczenia uwzględniającego franszyzę ${ }^{109}$.

W prawie niemieckim rozróżnienie między udziałem własnym a franszyzą integralną również jest trudno uchwytne. Na zamęt terminologiczny zwraca uwagę $\mathrm{M}$. Wandt. Autor ten wskazuje, że udział własny w wysokości 5\% szkody stosuje się przykładowo ze względów prewencyjnych w ubezpieczeniu autocasco. Udział ten jest według M. Wandta tożsamy z franszyzą redukcyjną, ponieważ skutkuje zawsze obniżeniem odszkodowania o ustaloną wartość. Inaczej sytuacja przedstawia się w przypadku franszyzy integralnej - do pewnej wartości szkody odszkodowania w ogóle nie są wypłacane, zaś po jej przekroczeniu wypłacane są w całości, bez potrąceń. Rozwiązanie takie oszczędza kosztów administracyjnych przy drobnych szkodach. Można również ustalić, że ubezpieczający ponosi koszty nie do konkretnej sumy albo do wysokości pewnego udziału w szkodzie. Najbardziej znany przykład dotyczy ubezpieczenia kosztów chorobowych, w przypadku którego ustala się, że ubezpieczyciel ponosi koszty leczenia $\mathrm{w}$ określonym procencie. Tak ubezpieczają się przede wszystkim osoby mające prawo do państwowej opieki medycznej w zakresie pewnej części kosztów leczenia ${ }^{110}$.

W doktrynie brytyjskiej wyróżnia się klauzule nadwyżki, zwane inaczej klauzulami potrącenia (excess or deductible clauses), skutkujące tym, że ubezpieczający ponosi pewien udział w każdej szkodzie wyrażony w pieniądzu lub w procentach szkody. Ubezpieczający jest zatem $\mathrm{w}$ tym zakresie własnym ubezpieczycielem. Franszyza jest natomiast tożsama z polską franszyzą integralną, innymi słowy, do pewnej wartości szkody ubezpieczyciel w ogóle nie wypłaca odszkodowania, zaś powyżej tej wartości wypłaca je w całości. Okoliczność, czy szkoda przekracza franszyzę, zależy m.in. od tego, czy franszyza odnoszona będzie do szkody pojedynczej, czy również do serii indywidualnych szkód. Podobne klauzule, będąc zastrzegane $\mathrm{w}$ interesie ubezpieczyciela, będą zawsze interpretowane ściśle przeciwko niemu.

\footnotetext{
109 Y. Lambert-Faivre, L. Leveneur, Droit..., s. 429-430.

110 M. Wandt, Versicherungsrecht, s. 307-308.
} 
Podstawowym celem obydwu wskazanych typów klauzul jest chęć uniknięcia relatywnie wysokich kosztów likwidacji szkód bagatelnych. Mogą one być również skuteczne w zakresie unikania ryzyka przez ubezpieczającego. Ten drugi cel jest charakterystyczny dla klauzul trzeciego typu określanych mianem gwarantowanego niedoubezpieczenia (warranteed part uninsured), które spotykane są zarówno w ubezpieczeniach, jak i w reasekuracji, i które interpretuje się jako zapewnienie (warranty) ubezpieczającego, że pozostanie niedoubezpieczony w pewnym zakresie. Złamanie tego zapewnienia przerywa stosunek ubezpieczenia. Zgodnie $z$ orzecznictwem zawarcie drugiego ubezpieczenia obejmującego gwarantowane niedoubezpieczenie w pierwszym nie jest złamaniem zapewnienia $^{111}$.

Powyższe uwagi prawnoporównawcze nie prowadzą, jak się zdaje, do jednoznacznych wniosków w zakresie odróżnienia franszyzy redukcyjnej i udziału własnego. Principles of European Contract Law milczą w zakresie opisywanych ograniczeń odpowiedzialności. Dodać można, że już J. Łazowski, powołując się na niemiecki przedwojenny leksykon ubezpieczeniowy, wskazywał, że udział własny może być wyrażony jako pewna z góry określona suma lub jako ułamek świadczenia, względnie sumy ubezpieczenia. Według tego autora w praktyce mianem franszyzy określano jedynie franszyzę integralną, natomiast franszyzie redukcyjnej nadano miano ryzyka własnego ubezpieczonego ${ }^{112}$.

Rozważania można zamknąć, wskazując, że ewentualnego odróżnienia udziału własnego oraz franszyzy redukcyjnej upatrywać wypada przede wszystkim w postulatach polskiej powojennej klasycznej literatury ubezpieczeniowej (W. Warkałło, A. Wąsiewicz, E. Kowalewski), gdzie przyjęło się używanie określenia udziału własnego w odniesieniu do postanowień o funkcji przede wszystkim prewencyjnej, wyrażanych procentowo lub ułamkowo w stosunku do wysokości szkody, stano-

111 M. Clarke, The Law..., s. 937-938. Udziały kwotowe od procentowych odróżnia wyraźnie B.R. Hardy-Ivamy. Zob. E.R. Hardy-Ivamy, General Principles of Insurance Law, London-Dublin-Edinburgh 1993, s. 462. Co do podobnych klauzul w prawie angielskim, zob. również J. Lowry, P. Rawlings, R. Merkin, Insurance Law..., s. 329; Colinvaux's..., s. 352; J. Birds, Birds'..., s. 317.

112 J. Łazowski, Wstęp..., s. 95. 
wiących niedoubezpieczenie, w zakresie których nie nalicza się składki. Natomiast określenie „franszyza redukcyjna” rezerwowano do postanowień zmierzających przede wszystkim do wyznaczenia granic ubytków uznawanych za naturalne, wyrażanych kwotowo, niestanowiących niedoubezpieczenia, gdzie składkę nalicza się od całej sumy ubezpieczenia, pomimo możności obniżenia odszkodowania o wysokość franszyzy. Sformułowane powyżej wątpliwości odnośnie do możności stosowania de lege lata ostatniego z kryteriów, które w istocie było jedynym kryterium ścisłym i operatywnym, sprawiają, że obecnie rozróżnienie uzasadniać można przede wszystkim tradycją oraz ostrożnym odnoszeniem się do pozostałych kryteriów.

\subsection{Ubezpieczenie podwójne ${ }^{113}$}

\subsubsection{Pojęcie ubezpieczenia podwójnego (wielokrotnego)}

Sytuacja, w której ten sam interes ubezpieczony jest od tego samego ryzyka u dwóch lub więcej ubezpieczycieli na sumy, które łącznie przewyższają wartość ubezpieczeniową, określana jest zwykle mianem ubezpieczenia podwójnego ${ }^{114}$. Określenie to może być mylące wtedy, gdy ubezpieczycieli jest więcej niż dwóch. Określenie „ubezpieczenie wielokrotne" rezerwowane było w starszej literaturze dla ubezpieczenia tego samego ryzyka u dwóch lub więcej ubezpieczycieli na sumy, które łącznie nie przekraczają wartości ubezpieczeniowej, zwanego też niekiedy ubezpieczeniem pro rata ${ }^{115}$. Z tradycyjną terminologią zrywa nowa regulacja Kodeksu morskiego, który w art. 303 sytuację określaną

113 Zob. B. Kucharski, Odpowiedzialność ubezpieczycieli w ubezpieczeniu podwójnym [w:] Czynić postęp w prawie. Księga jubileuszowa dedykowana Profesor Birucie Lewaszkiewicz-Petrykowskiej, red. W. Robaczyński, Łódź 2017.

114 Ubezpieczenie podwójne najdokładniej opisał w literaturze polskiej J. Łopuski. Zob. J. Łopuski, Podwójne ubezpieczenie [w:] Ubezpieczenia w gospodarce rynkowej, t. 3, red. A. Wąsiewicz, Bydgoszcz 1997, s. 118 i n. Samo określenie wywodzi się z literatury niemieckiej i było używane już w okresie międzywojennym. Zob. J. Łazowski, Wstęp..., s. 91-92.

115 J. Łazowski, Wstęp..., s. 94. 
wcześniej mianem ubezpieczenia podwójnego nazywa ubezpieczeniem wielokrotnym ${ }^{116}$. Kodeks cywilny używa obydwu określeń w odniesieniu do sytuacji, gdy ten sam interes ubezpieczono od tego samego ryzyka. Należy zatem przyjąć, że ubezpieczenie wielokrotne zachodzi, gdy ubezpieczycieli jest więcej niż dwóch. W dalszym toku rozważań wskazane określenia będą używane zamiennie.

Kwestii, które wywołuje ubezpieczenie podwójne, jest kilka. Wiążą się one przede wszystkim z zasadą odszkodowania, która nie pozwala ubezpieczającemu domagać się świadczeń pieniężnych przekraczających wysokość poniesionej szkody, choćby ten sam przedmiot został ubezpieczony u kilku ubezpieczycieli i każde z ubezpieczeń zawarto na sumę przekraczającą wartość ubezpieczeniową. Wśród tych problemów najważniejsze zdają się dotyczyć zakresu roszczeń ubezpieczającego względem każdego z ubezpieczycieli, wzajemnych zależności między tymi roszczeniami oraz rozliczeń regresowych między ubezpieczycielami.

Ubezpieczenie podwójne może wystąpić wyłącznie w ubezpieczeniach majątkowych, włączając w to ubezpieczenie odpowiedzialności cywilnej. W ubezpieczeniach osobowych, gdzie nie mają zastosowania ani wartość ubezpieczeniowa, ani zasada odszkodowania, istnieje możliwość ubezpieczenia zdrowia lub życia tej samej osoby od tych samych ryzyk u wielu ubezpieczycieli na dowolne sumy. Każdy z ubezpieczycieli będzie zobowiązany do wypłaty świadczenia w granicach swojej sumy ubezpieczenia. Nie wystąpią charakterystyczne dla podwójnego ubezpieczenia problemy wymagające szczególnego uregulowania ustawowego ${ }^{117}$.

W ubezpieczeniu odpowiedzialności cywilnej wprawdzie nie występuje pojęcie wartości ubezpieczenia, natomiast suma ubezpieczenia zastąpiona zostaje sumą gwarancyjną, ubezpieczenie podwójne może jednak mieć miejsce. W sytuacji gdy wysokość szkody wyrządzonej przez ubezpieczonego osobie trzeciej jest niższa niż sumy gwarancyjne kilku

116 E. Kowalewski posługuje się aktualną nomenklaturą Kodeksu morskiego. Autor ten mówi o ubezpieczeniu wielokrotnym w nawiasie (podwójnym) - Por. E. Kowalewski [w:] Prawo ubezpieczeń gospodarczych, red. E. Kowalewski, s. 218.

117 J. Łopuski, Podwójne ubezpieczenie, s. 119. 
zawartych przez niego ubezpieczeń, odszkodowanie ubezpieczeniowe nie może przekraczać wysokości szkody i pojawiają się problemy zakresu roszczeń względem każdego z ubezpieczycieli oraz zależności między tymi roszczeniami, przy czym roszczenia będą mogły być realizowane bezpośrednio przez poszkodowanego. Pojawia się również problem rozliczeń regresowych między ubezpieczycielami.

W nauce francuskiej Y. Lambert-Faivre formułuje szereg przesłanek występowania ubezpieczenia podwójnego: po pierwsze, ubezpieczony musi być ten sam obiekt, po drugie, występować musi identyczność ryzyka objętego ochroną ubezpieczeniową, po trzecie, przedmiotem ubezpieczenia musi być ten sam interes, po czwarte, umowy mają być zawarte z kilkoma różnymi ubezpieczycielami, po piąte, umowy mają być zawarte na pokrywające się okresy ubezpieczenia, po szóste, sumy ubezpieczeniowe we wszystkich ubezpieczeniach łącznie muszą przekraczać wartość ubezpieczeniową, po siódme, ubezpieczający powinien być tą samą osobą ${ }^{118}$.

Pierwsza przesłanka wydaje się być przynajmniej wątpliwa jako zawierająca się w przesłance trzeciej. Istotne wydaje się nie to, by ubezpieczony był ten sam obiekt, ale to, by przedmiotem ubezpieczenia był ten sam interes majątkowy. Można sobie wyobrazić, że przedmiotem ubezpieczenia jest ten sam interes, gdy obiekty ubezpieczenia pokrywają się jedynie częściowo, i w takiej sytuacji podwójnego ubezpieczenia nie można wykluczyć. Przykładowo podwójne ubezpieczenie wystąpi, gdy zegarek ubezpieczony w ramach ubezpieczenia ruchomości domowych zostanie na czas naprawy powierzony zegarmistrzowi, który zadbał o polisę obrotową zawartą na rachunek osób powierzających mu zegarki, a następnie przed zwrotem właścicielowi zegarek zostanie zniszczony wskutek przyczyn zupełnie niezależnych od zegarmistrza.

Z drugiej strony w niektórych sytuacjach problematyczne może być stwierdzenie tożsamości interesu przy ubezpieczeniu tego samego obiektu. W razie ustalenia, że przedmiotem ubezpieczeń, pomimo pozornego podobieństwa, są w istocie różne interesy, podwójne ubezpieczenie nie

118 Y. Lambert-Faivre, L. Leveneur, Droit..., s. 415-417. 
wystąpi. Wracając do przykładu zegarka, można je przykładowo wykluczyć, gdy zegarek ubezpieczony w ramach ubezpieczenia ruchomości domowych zostaje zniszczony w trakcie naprawy z przyczyn obciążających zegarmistrza, który miał ubezpieczenie od odpowiedzialności cywilnej ${ }^{119}$. W angielskim orzecznictwie przyjęto, że nie było ubezpieczenia podwójnego w sytuacji, gdy ziarno zostało ubezpieczone jednocześnie przez przechowawcę i składającego na przechowanie, a do szkody doszło w okolicznościach obciążających odpowiedzialnością przechowawcę ${ }^{120}$. Nie ma tożsamości interesów w sytuacji, gdy zgodnie z prawem szkoda winna być w całości poniesiona przez jednego z ubezpieczycieli.

Omawiana kwestia sprawiała problemy również polskim sądom. W uchwale z 30.11.2005 r. Sąd Najwyższy stwierdził wyraźnie, że „Zakaz wypłaty podwójnej sumy ubezpieczenia (...) nie dotyczy sytuacji, w której interesy majątkowe ubezpieczonych, będące przedmiotem ubezpieczenia, są różne, nawet jeżeli odnoszą się do tego samego dobra majątkowego"121. W omawianej sprawie sąd pierwszej instancji oddalił powództwo o odszkodowanie za spalony lokal stanowiący współwłasność powodów i przez nich ubezpieczony z uwagi na to, że najemczyni lokalu uzyskała odszkodowanie z tytułu innego ubezpieczenia zawartego przez siebie. Rozpoznając zagadnienie prawne przedstawione przez sąd apelacyjny, Sąd Najwyższy uznał, że do podwójnego ubezpieczenia nie doszło, występowały bowiem dwa różne interesy ubezpieczeniowe, których zakres wyznaczony był przez dwa podmioty uprawnione z tytułu dwóch umów ubezpieczenia (powodowie oraz najemczyni lokalu). Sąd Najwyższy stwierdził dalej, że jeśli dwa podmioty zawarły dwie różne umowy ubezpieczenia, ich interesy będące przedmiotem ubezpieczenia zawsze są różne, nawet jeśli dotyczą tego samego dobra majątkowego.

Jak wynika z drugiej przesłanki, dla istnienia podwójnego ubezpieczenia konieczne jest, by ten sam interes ubezpieczony był od tego samego ryzyka. Od tej zasady nie ma wyjątków. Jeżeli dom objęty jest

119 J. Birds, Birds'..., s. 339.

120 Mercantile Insurance Co. v. London, Liverpool \& Globe Insurance Co. [1875] Ch D 569.

121 Uchwała SN z 30.11.2005 r., III CZP 96/05. 
dwoma ubezpieczeniami, jednym od ognia, a drugim od kradzieży, podwójne ubezpieczenie nie występuje. Podobnie nie ma podwójnego ubezpieczenia, jeżeli jedno z ubezpieczeń AC dotyczących tego samego samochodu nie obejmuje na przykład kradzieży szczególnie zuchwałej zdefiniowanej w określony sposób i ubezpieczający, chcąc uniknąć także tego ryzyka, zawrze drugie ubezpieczenie AC o ograniczonym do tego ryzyka zakresie.

Co do przesłanki piątej, dotyczącej pokrywania się czasowych zakresów ubezpieczenia, konieczne jest, by przynajmniej częściowo pokrywały się materialne okresy ubezpieczenia, to jest okresy, w których ubezpieczyciele ponoszą odpowiedzialność. Przykładowo podwójne ubezpieczenie nie wystąpi zatem, gdy ktoś zamiast przedłużyć ubezpieczenie domu wygasające z końcem kwietnia, w połowie kwietnia ubezpieczy dom na kolejny rok u innego ubezpieczyciela, ale składkę opłaci dopiero z początkiem maja i polisa nie będzie zawierała zastrzeżenia, że drugi ubezpieczyciel odpowiada przed zapłaceniem składki. Podobnie nie będzie podwójnego ubezpieczenia, jeżeli zawarte zostaną dwa ubezpieczenia na dokładnie ten sam okres, ale ubezpieczający w ogóle nie zapłaci składki warunkującej początek materialnego okresu ubezpieczenia jednego $\mathrm{z}$ nich ${ }^{122}$.

Odnośnie do przesłanki szóstej, wedle której sumy ubezpieczenia mają łącznie przekraczać wartość ubezpieczenia, można wskazać, że podwójne ubezpieczenie nie wystąpi w szczególności wtedy, gdy ubezpieczający zawiera z jednym z ubezpieczycieli ubezpieczenie na sumę ubezpieczenia niższą od wartości interesu ubezpieczeniowego, a następnie u innego ubezpieczyciela ubezpiecza się w zakresie, w jakim jest niedoubezpieczony u pierwszego, ewentualnie wtedy, gdy ubezpieczenie z drugim ubezpieczycielem pokryć ma udział własny lub franszyzę zastrzeżone $\mathrm{w}$ umowie ubezpieczenia zawartej z pierwszym ubezpieczycielem.

W ostatnio opisanych sytuacjach nie zachodzi ubezpieczenie podwójne, ale tzw. ubezpieczenie uzupełniające. Niektórzy obrazowo, ale mało precyzyjnie wskazują, że ubezpieczenie uzupełniające dotyczy wszystkich

122 Por. sprawę Equitable Fire \& Accident Office Ltd v. Ching Wo Hong [1907] AC 96. 
przypadków, gdy ochrona ubezpieczeniowa nie pokrywa się, ale uzupełnia $^{123}$. Ujmując rzecz dokładniej, można stwierdzić, że ubezpieczenie uzupełniające występuje, gdy ten sam interes ubezpieczeniowy ubezpieczony jest od tego samego ryzyka w taki sposób, że odszkodowanie ubezpieczeniowe uzyskane od każdego $\mathrm{z}$ ubezpieczycieli z osobna nie skompensowałoby w całości poniesionej szkody całkowitej. Ograniczenia odpowiedzialności skutkujące celowością zawarcia ubezpieczenia uzupełniającego mogą wystąpić również w ubezpieczeniu OC, przy czym, zamiast zaniżonej sumy ubezpieczenia, pojawia się suma gwarancyjna na poziomie niższym niż potencjalny zakres szkód objętych odpowiedzialnością ubezpieczonego.

Zawarcie ubezpieczeń uzupełniających może być uzasadnione względami ekonomicznymi dotyczącymi składki ubezpieczeniowej, gdy ubezpieczenia uzupełniające będą łącznie tańsze niż jedno ubezpieczenie zawarte w pełnym zakresie. Łatwo również wyobrazić sobie sytuację, gdy wartość ubezpieczonego interesu z czasem zwyżkuje, np. na skutek dokonanych inwestycji i ubezpieczający, zamiast doubezpieczać się, postanawia zawrzeć nowe ubezpieczenie w zakresie pojawiającego się niedoubezpieczenia. Niezależnie od przyczyny zawarcia więcej niż jednego ubezpieczenia istotne jest odpowiednie sformułowanie zawieranych umów co do kwotowego zakresu ryzyka obejmowanego następnym ubezpieczeniem. Zakres ten powinien ograniczać się do nadwyżki potencjalnej szkody ponad przyjętą sumę ubezpieczenia lub sumę gwarancyjną w ubezpieczeniu OC, ewentualnie do udziału własnego lub franszyzy wynikającej z pierwszego ubezpieczenia. Jeżeli zakresy następnych ubezpieczeń nie zostaną sformułowane precyzyjnie, ubezpieczenia mogą okazać się częściowo ubezpieczeniami uzupełniającymi, a częściowo podwójnymi.

Widoczne są podobieństwa między ubezpieczeniami uzupełniającymi a koasekuracją. Zarówno ubezpieczenia uzupełniające, jak również umowa koasekuracji leżą u źródła wielości stosunków prawnych występujących między ubezpieczającym a poszczególnymi ubezpieczycielami.

${ }^{123}$ J. Łopuski, Podwójne ubezpieczenie, s. 119-121. Por. również M. Krajewski, Umowa ubezpieczenia. Art. 805-834 KC..., 2016, s. 222. 
Ponadto w obu przypadkach nie występuje zbieg świadczeń wymagający rozwiązania przy ubezpieczeniu podwójnym. Różnica polega na tym, że w przypadku koasekuracji źródłem wszystkich stosunków prawnych jest jedna umowa ubezpieczenia, na mocy której kilku ubezpieczycieli dzieli między siebie ciężar zapłaty ewentualnego odszkodowania, a intencja przyjęcia takiego rozwiązania wychodzi zwykle od jednego z nich, podczas gdy w przypadku ubezpieczeń uzupełniających się, zawieranych jest kilka umów ubezpieczenia, co podyktowane jest zwykle względami dotyczącymi ubezpieczającego. Kwestię obrazują przytaczane wyżej przykłady z zegarkiem.

Co do przesłanki siódmej, wydaje się, że na gruncie prawa polskiego ubezpieczenie podwójne może wystąpić, choćby ubezpieczający nie był tą samą osobą we wszystkich ubezpieczeniach. Wystarczy, że osoba będąca ubezpieczającym w jednym ubezpieczeniu będzie jednocześnie ubezpieczonym w innym ubezpieczeniu zawartym na jej rachunek, oczywiście o ile spełnione są pozostałe warunki. Podobnie zagadnienie ujmowane jest w prawie angielskim ${ }^{124}$. Warunek dotyczący tożsamości ubezpieczającego wynika $\mathrm{z}$ prawie francuskim z brzmienia art. L121-4 Code des assurances, który rozpoczyna się od słów: „Kto jest ubezpieczającym w kilku polisach wystawionych przez różnych ubezpieczycieli (...)”. Sformułowanie przepisu przemawia za tożsamością ubezpieczającego w ubezpieczeniu podwójnym również w prawie niemieckim (art. 77 VVG rozpoczyna się od sformułowania: „Kto ubezpiecza ten sam interes od tego samego ryzyka u kilku ubezpieczycielami (...)”).

\subsubsection{Ewolucja polskiej regulacji}

Polska regulacja ubezpieczenia podwójnego podlegała ewolucji. Początkowo odpowiednie unormowanie zawierał jedynie Kodeks morski z 1961 r. Według art. 273 dawnego k.m. przy ubezpieczeniu podwójnym wszystkie zakłady ubezpieczeń odpowiadały tylko do wysokości wartości ubezpieczenia, a w granicach tej wartości każdy z nich odpowiadał w stosunku do przyjętej przez niego sumy ubezpieczenia. Występująca

124 J. Birds, Birds'..., s. 340. 
w ubezpieczeniach lądowych monopolizacja ubezpieczeń ustawowo podzielonych między PZU oraz WARTĘ czyniła kwestię w znacznym stopniu bezprzedmiotową, sytuacje rodzące problem ubezpieczenia podwójnego mogły występować wyłącznie w obrocie międzynarodowym $^{125}$.

Ustawa o działalności ubezpieczeniowej z 1990 r. w zasadzie ograniczała regulację dotyczącą podwójnego ubezpieczenia do powtórzenia zasady odszkodowania, stanowiąc, że w razie zbiegu świadczeń z tytułu dwóch lub więcej ubezpieczeń z tego samego zdarzenia, odszkodowanie wypłaca się do wysokości szkody w granicach sum ubezpieczenia w ramach każdego ze stosunków ubezpieczenia, z uwzględnieniem odszkodowań już wypłaconych z innego stosunku ubezpieczenia (art. 8 ust. 2). Nie unormowano zatem kwestii o podstawowym znaczeniu dla podwójnego ubezpieczenia, a mianowicie zakresu roszczeń ubezpieczającego względem poszczególnych ubezpieczycieli oraz wzajemnych rozliczeń między ubezpieczycielami.

W doktrynie przyjmowano, że ubezpieczający mógł wystąpić do dowolnie wybranego ubezpieczyciela o zapłatę całości odszkodowania i jednocześnie brak było podstaw do roszczeń regresowych między ubezpieczycielami ${ }^{126}$. Ubezpieczyciel, który spełnił świadczenie, był zatem w gorszej sytuacji od pozostałych ${ }^{127}$. Regulację krytykowano również za zamęt terminologiczny ${ }^{128}$. Artykuł 8 ust. 1 u.d.u. z 1990 r. odnosił się wyraźnie do ubezpieczeń majątkowych. Artykuł 8 ust. 2 u.d.u. z 1990 r. mówił o świadczeniu odszkodowawczym ubezpieczyciela, które może wystąpić tylko w takich ubezpieczeniach, zaś kolejny ustęp zawierał zbędne zastrzeżenie, że ust. 2 nie odnosi się do ubezpieczeń na życie i od następstw nieszczęśliwych wypadków.

\footnotetext{
125 J. Łopuski, Podwójne ubezpieczenie, s. 123.

126 S. Reps, J. Reps, Ubezpieczenia majątkowe i osobowe, Warszawa 1997, s. 79; M. Orlicki, Umowa ubezpieczenia, 2002, s. 166; B. Kęszycka, Prawo..., s. 114. Odmiennie Prawo ubezpieczeń gospodarczych, red. E. Kowalewski, s. 218. Autor ten przyjmował, że ubezpieczyciele w stosunkach wewnętrznych ponoszą ciężar odszkodowania według proporcji wynikającej z Kodeksu morskiego.

127 M. Krajewski, Umowa ubezpieczenia. Art. 805-834 KC..., 2016, s. 220.

128 J. Łopuski, Podwójne ubezpieczenie, s. 123.
} 
Zmiany dokonano ustawą o działalności ubezpieczeniowej z $2003 \mathrm{r}$. Dodany do Kodeksu cywilnego art. $824^{1} \$ 2$ k.c. nie pozwalał ubezpieczającemu domagać się wypłaty całego odszkodowania od każdego z ubezpieczycieli. Zamiast tego każdy z ubezpieczycieli odpowiadał $\mathrm{w}$ takim stosunku, $\mathrm{w}$ jakim przyjęta przez niego suma ubezpieczenia pozostawała do łącznych sum ubezpieczenia wynikających $\mathrm{z}$ ubezpieczenia podwójnego. Kwestia rozliczeń regresowych pozostawała zatem bezprzedmiotowa. Zagadnienie uregulowano zatem w sposób podobny jak w dawnym Kodeksie morskim. Pozycja ubezpieczającego uległa w ten sposób pogorszeniu w stosunku do regulacji ustawy o działalności ubezpieczeniowej z 1990 r., a odpowiedzialność ubezpieczycieli istotnie ograniczono w stosunku do tego, co przyjęli na siebie w zawartych umowach. Dodatkowo w razie upadłości jednego z ubezpieczycieli przyjęte rozwiązanie pozbawiało ubezpieczającego należnej od tego ubezpieczyciela części odszkodowania ${ }^{129}$.

Wyżej wskazane argumenty krytyczne zgłoszone przez M. Krajewskiego doprowadziły do kolejnej zmiany regulacji, której dokonano na mocy nowelizacji przepisów kodeksu o umowie ubezpieczenia z 2007 r. ${ }^{130}$ Ubezpieczający zyskał prawo domagania się od każdego z ubezpieczycieli pełnego odszkodowania. Ubezpieczyciele między sobą odpowiadają proporcjonalnie do przyjętych przez każdego z nich sum ubezpieczenia. Jednocześnie dodano art. $824^{1} \S 3$ k.c. odnoszący się do sytuacji, gdy choć jedna z zawartych umów ubezpieczenia jest ubezpieczeniem w wartości nowej lub otaksowanej. Wcześniejsza regulacja nie pozwalała ubezpieczającemu żądać odszkodowania przenoszącego wysokość poniesionej szkody również w takich przypadkach. Gdyby zaś takie prawo uznać i zastosować proporcjonalny system rozliczeń między ubezpieczycielami, kosztami świadczenia przenoszącego wysokość szkody byliby obciążeni również ubezpieczyciele, którzy nie zawierali ubezpieczenia w wartości nowej lub otaksowanej. Wobec powyższego w art. $824^{1} \S 3$ k.c. przewidziano rozwiązanie, wedle którego roszczenie o wypłatę świadczenia przenoszącego wysokość szkody przysługuje jedynie wobec ubezpieczyciela, który zobowiązał się do takiego świadczenia. Co do wewnętrz-

129 M. Krajewski, Umowa ubezpieczenia. Art. 805-834 KC..., 2016, s. 221.

130 Nowelizacja z 2007 r. 
nych rozliczeń między ubezpieczycielami, należy przyjąć, że w umowie ubezpieczenia przewidującej wypłatę odszkodowania przenoszącego wysokość szkody suma ubezpieczenia odpowiada wartości ubezpieczeniowej ${ }^{131}$. Opisane rozwiązanie obowiązuje do dzisiaj.

Zgodzić się należy z poglądem, że sytuacja ubezpieczycieli w ubezpieczeniu podwójnym zbliża się do odpowiedzialności solidarnej, choć w braku wyraźnej podstawy solidarności należy przyjąć odpowiedzialność in solidum ${ }^{132}$. Stwierdzenie to nie wyjaśnia, które przepisy o solidarności należy stosować ${ }^{133}$. Prima facie ubezpieczenie podwójne, bardziej niż sytuacje typowej solidarności, ciąży w kierunku wielości zobowiązań ${ }^{134}$. Ubezpieczyciele odpowiadają wszak na podstawie różnych umów i ogólnych warunków ubezpieczenia. Umowy mogą odmiennie kształtować zarówno zakres odszkodowania ubezpieczyciela, jak i przesłanki zwalniające ubezpieczyciela $z$ odpowiedzialności. To nie wyklucza jednak solidarności, skoro w myśl art. 368 k.c. zobowiązanie może być solidarne, chociażby każdy z dłużników był zobowiązany w sposób odmienny.

Analiza przepisów o solidarności dłużników zdaje się wskazywać, że nie ma przeszkód dla ich stosowania do ubezpieczenia podwójnego, z wyjątkiem reguły dotyczącej wzajemnej reprezentacji dłużników so-

131 M. Orlicki, J. Pokrzywniak, Umowa..., s. 110-113. Podobnie M. Krajewski, Umowa ubezpieczenia. Art. 805-834 KC..., 2016, s. 576 oraz inni powoływani przez niego komentatorzy. Trudny do utrzymania pogląd o stosowaniu art. $824^{1}$ k.c. wprost do ubezpieczenia OC prezentują: S. Reps, Zastosowanie przepisów kodeksu cywilnego w ubezpieczeniach obowiazkowych, PA 2005/4, s. 18; M. Bucoń, Odpowiedzialność cywilna uczestników wypadku komunikacyjnego, Warszawa 2008, s. 139; oraz M. Wałachowska, W sprawie stosowania przepisów kodeksu cywilnego do ubezpieczenia obowiązkowego [w:] System prawny ubezpieczeń obowiązkowych. Przesłanki i kierunki reform, red. E. Kowalewski, W.W. Mogilski, Toruń 2014, s. 249-250.

132 M. Krajewski, Umowa ubezpieczenia. Art. 805-834 KC..., 2016, s. 574; D. Fuchs, Podwójne (wielokrotne) ubezpieczenie de lege lata oraz de lege ferenda, PPH 2006/6, s. 29.

133 A. Szpunar, O solidarności niewłaściwej, RPEiS 1980/4, s. 28. Co do pojęcia odpowiedzialności in solidum, zob. przede wszystkim M. Pyziak-Szafnicka, Wielość dłużników i wierzycieli [w:] System Prawa Prywatnego, red. Z. Radwański, t. 5, Prawo zobowiąań -+ część ogólna, red. E. Łętowska, Warszawa 2006, s. 394 i n. oraz podana tam literatura; B. Lewaszkiewicz-Petrykowska, Zobowiązanie „in solidum”, SPE 1976/17, s. 13.

134 Zob. B. Lewaszkiewicz-Petrykowska, Konstrukcja solidarności biernej w kodeksie cywilnym, SPE 1974/12, s. 18-21. 
lidarnych przy odnowieniu (art. 374 k.c.). Zastrzec przy tym wypada, że przy rozliczeniach między ubezpieczycielem i ubezpieczającym kwestia odnowienia będzie mieć znaczenie marginalne. Nie ma raczej przeszkód dla zastosowania pomiędzy ubezpieczycielami w ubezpieczeniu podwójnym art. $375 \$ 2$ k.c. dotyczącego rozszerzonej skuteczności wyroku oddalającego powództwo z powołaniem się na zarzuty wspólne dla wszystkich. Regulacja art. $824^{1} \$ 2$ i 3 in fine k.c., wyjaśniająca, w jaki sposób ubezpieczyciele odpowiadają w stosunkach między sobą, nie przekreśla zasady z art. 375 k.c., wedle której zakres regresu między dłużnikami solidarnymi zależy od istniejącego między nimi stosunku prawnego, ale jedynie ją doprecyzowuje. Podsumowując ten wątek, można zastanowić się, czy odstępując od wykreowania w art. $824^{1}$ k.c. odrębnej podstawy solidarności, ustawodawca nie był nadmiernie ostrożny.

Zdaniem M. Orlickiego art. $824^{1}$ k.c. nie znajduje zastosowania do ubezpieczenia OC, gdzie nie występuje kategoria wartości ubezpieczeniowej i nie można ustalić, czy łączna suma odszkodowań przekracza taką wartość ${ }^{135}$. Oczywiście jednak również w ubezpieczeniu OC łączna suma wypłaconych świadczeń z ubezpieczeń OC obejmujących ten sam okres i to samo ryzyko nie może przekraczać wysokości szkody. Dlatego w tym przypadku należy stosować reguły zbieżne do zawartych w art. $824^{1} \$ 2$ k.c. Ubezpieczający może zatem dochodzić od jednego lub wszystkich ubezpieczycieli całości odszkodowania w dowolnych proporcjach, przy czym odszkodowanie wypłacone przez każdego z nich nie może przekraczać ustalonej z nim sumy gwarancyjnej. W stosunkach między sobą ubezpieczyciele rozliczają się w proporcji do przyjętych przez siebie sum gwarancyjnych ${ }^{136}$. Zaproponowane stanowisko zostało zaakceptowane przez Sąd Najwyższy w uchwale z 13.05.2016 r., III CZP 16/16 $6^{137}$. Nieco inny pogląd prezentuje M. Krajewski, zdaniem którego stosowanie art. $824^{1}$ k.c. do ubezpieczenia OC per analogiam powinno polegać na rozliczaniu się ubezpieczycieli nie w proporcji do

135 M. Orlicki, J. Pokrzywniak, Umowa..., s. 110-113, oraz J. Pokrzywniak, Regres między ubezpieczycielami w przypadku podwójnego ubezpieczenia OC [w:] Księga pamiątkowa dedykowana Profesorowi Andrzejowi Kochowi, red. A. Olejniczak, M. Orlicki, J. Pokrzywniak, Poznań 2017.

136 J. Pokrzywniak, Regres...

137 OSNC 2017/3, poz. 32. 
odszkodowania, które powinien zapłacić każdy z nich, gdyby nie wystąpiło ubezpieczenie podwójne ${ }^{138}$. Różnica między obydwoma systemami rozliczeń zostanie wyjaśniona dalej.

Stosownie do wcześniejszych uwag, wedle których pojęcie ubezpieczenia podwójnego lub wielokrotnego znajduje również zastosowanie w ubezpieczeniu OC, propozycja M. Orlickiego jest słuszna. Zauważyć jednak należy, że regulacja Kodeksu cywilnego pozostaje niepełna. W odniesieniu do ubezpieczenia podwójnego w ubezpieczeniu OC istnieje luka w prawie, którą należy próbować wypełnić, stosując przepisy o ubezpieczeniu podwójnym w innych ubezpieczeniach majątkowym per analogiam. Nie jest to poważny mankament, tym niemniej trudno zrozumieć, dlaczego nowelizując przepisy Kodeksu cywilnego o umowie ubezpieczenie, ustawodawca nie dodał do art. $824^{1}$ kolejnego paragrafu, nakazującego odpowiednio stosować do ubezpieczenia OC reguły zawarte $\mathrm{w} \$ 2$ i 3 .

Kończąc uwagi dotyczące aktualnego stanu prawnego, należy dodać, że Kodeks morski z 2001 r. również zerwał z zasadą pozwalającą ubezpieczającemu domagać się od konkretnego ubezpieczyciela jedynie odszkodowania proporcjonalnego do przyjętej przez tego ubezpieczyciela sumy ubezpieczenia. Uniknięto jednocześnie mankamentów, które zawierał art. $824^{1} \$ 2$ k.c. w brzmieniu sprzed zmiany z 2007 r. Zgodnie $\mathrm{z}$ art. $303 \mathrm{k} . \mathrm{m}$. przy ubezpieczeniu wielokrotnym ubezpieczający może żądać od każdego z ubezpieczycieli odszkodowania zgodnego z zawartą z nim umową, przy czym odszkodowania łącznie nie mogą przekraczać wysokości szkody. W stosunkach wzajemnych między ubezpieczycielami udział każdego z nich określa się w proporcji między odszkodowaniem, które musiałby zapłacić, a sumą wszystkich odszkodowań. Dodatkowo w razie świadomego zawarcia ubezpieczenia wielokrotnego ubezpieczający powinien niezwłocznie zawiadomić o tym zainteresowanych ubezpieczycieli, informując ich o treści zawartych umów ubezpieczenia.

138 M. Krajewski, Umowa ubezpieczenia. Art. 805-834 KC..., 2016, s. 577-578. Według M. Orlickiego ten drugi system jest zasadny jedynie, gdy sposoby ustalania sum gwarancyjnych w poszczególnych umowach ubezpieczenia OC istotnie różnią się od siebie. Por. M. Orlicki, Regres..., s. 322-323. 
Umyślne naruszenie tego obowiązku pozbawia ubezpieczającego prawa do odszkodowania.

\subsubsection{Systemy rozliczeń między ubezpieczycielami}

Jak łatwo zauważyć, rozwiązanie przyjęte w Kodeksie cywilnym odbiega od regulacji Kodeksu morskiego przede wszystkim co do przyjętego sytemu rozliczeń między ubezpieczycielami uczestniczącymi w ubezpieczeniu podwójnym. Na gruncie Kodeksu cywilnego rozliczają się oni, biorąc pod uwagę stosunek sumy ubezpieczenia przyjętej przez każdego $\mathrm{z}$ nich do łącznych sum ubezpieczenia wynikających $\mathrm{z}$ ubezpieczenia wielokrotnego, podczas gdy według Kodeksu morskiego decyduje proporcja między odszkodowaniem, które każdy z ubezpieczycieli musiałby zapłacić, gdyby był jedyny, a sumą wszystkich odszkodowań. Wypada przyjrzeć się, jak kwestia uregulowana jest w obcych systemach prawnych.

Francuski Code des assurances zawiera unormowanie podobne do polskiego Kodeksu morskiego. Zgodnie z art. L121-4 Code des assurances kto ubezpieczył ten sam interes od tego samego ryzyka u wielu ubezpieczycieli, powinien niezwłocznie powiadomić każdego ubezpieczyciela o innych ubezpieczycielach, z którymi zawarł umowy, wskazując sumy ubezpieczenia. Jeżeli ubezpieczenia wielokrotne zostały zawarte w złej wierze, ubezpieczyciele mają prawo żądać unieważnienia umów oraz domagać się odszkodowań. W razie zawarcia ubezpieczeń wielokrotnych w dobrej wierze każde $\mathrm{z}$ nich jest ważne w granicach przyjętej sumy ubezpieczenia, niezależnie od daty zawarcia, przy czym ubezpieczający nie może domagać się odszkodowania przenoszącego wysokość szkody. W tych granicach ubezpieczający może domagać się odszkodowania od każdego z ubezpieczycieli. W stosunkach między ubezpieczycielami udział każdego z nich określa się w proporcji, w jakiej odszkodowanie, jakie miałby zapłacić, gdyby był jedynym ubezpieczycielem, pozostaje do ogólnej sumy odszkodowań, które obciążałyby ubezpieczycieli, gdyby każdy z nich był jedyny. 
Niemiecka VVG odnosi się do ubezpieczenia podwójnego w art. 77 i 78. Nakazują one ubezpieczającemu powiadomić ubezpieczycieli o zawarciu wielu ubezpieczeń dotyczących tego samego interesu i tego samego ryzyka. Ubezpieczyciele w ubezpieczeniu podwójnym odpowiadają solidarnie, przy czym każdy z nich odpowiada zgodnie z zawartą przez siebie umową, a ubezpieczający nie może domagać się odszkodowania przenoszącego wysokość poniesionej szkody. Między sobą ubezpieczyciele odpowiadają proporcjonalnie do kwot, do których odpowiadają indywidualnie, każdy zgodnie z zawartą przez siebie umową. Ubezpieczenie wielokrotnie zawarte $\mathrm{z}$ intencją uzyskania nielegalnej korzyści jest nieważne, ubezpieczycielowi należy się składka za okres do chwili, w której dowiedział się o podstawie nieważności umowy.

W prawie angielskim zagadnienie jest bardziej skomplikowane z uwagi na brak regulacji ustawowej ubezpieczenia podwójnego. W praktyce OWU ubezpieczyciele zwykle zawierają klauzulę proporcji pozwalającą ubezpieczającemu w razie zawarcia wielu ubezpieczeń żądać od ubezpieczyciela jedynie części przypadającej od niego odszkodowania. Pytanie dotyczące rozliczeń między ubezpieczycielami pojawia się, gdy jeden z ubezpieczycieli, nieświadomy istnienia innych ubezpieczeń, płaci całość odszkodowania, a następnie uzyskawszy stosowną wiedzę, występuje z roszczeniem regresowym do innych. Rozstrzygnięcia co do zasadności regresu w opisanej sytuacji są rozbieżne, podnoszą się również głosy, że klauzula odpowiedzialności proporcjonalnej w razie zawarcia podwójnego ubezpieczenia powinna być co do zasady niedopuszczalna $^{139}$.

Co do zakresu roszczeń regresowych między ubezpieczycielami w braku klauzuli proporcjonalności, w prawie angielskim wskazuje się dwa możliwe podejścia, odpowiadające rozwiązaniom przyjętym w polskim Kodeksie cywilnym oraz w Kodeksie morskim. Według jednego podejścia, zwanego koncepcją odpowiedzialności maksymalnej, każdy z ubezpieczycieli odpowiada za szkodę w takiej proporcji, w jakiej suma, na którą opiewa wystawiona przezeń polisa, pozostaje do sum wszystkich ubezpieczeń. Z kolei według drugiej koncepcji każdy z ubezpieczycieli

139 J. Birds, Birds'..., s. 315-318. 
odpowiada w proporcji, w jakiej suma odszkodowania, którą winien zapłacić, gdyby był jedyny, pozostaje do sum wszystkich odszkodowań. To drugie podejście określane jest mianem odpowiedzialności niezależnej.

Różnice między systemem odpowiedzialności maksymalnej a systemem odpowiedzialności niezależnej mogą być wbrew pozorom istotne i uwidaczniają się przy szkodzie częściowej. Przykładowo, przy założeniu, że zawarto dwa ubezpieczenia: jedno na sumę 30000 zł oraz jedno na sumę 10000 zł, natomiast szkoda opiewa na kwotę 4000 zł, przy rozliczeniu według teorii odpowiedzialności maksymalnej udziały ubezpieczycieli w szkodzie wynoszą $2 / 3$ do $1 / 3$, natomiast przy rozliczeniu według teorii odpowiedzialności niezależnej udziały te są równe ${ }^{140}$.

Orzecznictwo dotyczące tych kwestii jest skromne. Brak precedensów przesądzających na rzecz generalnej słuszności jednej z powyższych koncepcji w ubezpieczeniu aktywów. Co do ubezpieczenia OC w sprawie Commercial Union Assurance Co vs. Hayden, stwierdzono, że należy stosować koncepcję odpowiedzialności niezależnej. Sędzia Cairns w uzasadnieniu wskazał na kilka argumentów przemawiających za takim rozwiązaniem: po pierwsze, składka ubezpieczeniowa w ubezpieczeniu OC nie jest ustalana w proporcji do sumy gwarancyjnej, po drugie, zwykle szkoda jest na poziomie wielokrotnie niższym niż suma gwarancyjna, po trzecie, istnieją ubezpieczenia OC bez sumy gwarancyjnej, a do nich pierwszej koncepcji w ogóle nie dałoby się zastosować ${ }^{141}$.

Zdaniem redaktorów MacGillivray oraz J. Birdsa koncepcja odpowiedzialności niezależnej sprawdza się lepiej ${ }^{142}$, co widać w szczególności w odniesieniu do ubezpieczeń o różnym zakresie. Ten ostatni autor podaje przykład zegarka wartego 20 funtów oddanego do naprawy i skradzionego zegarmistrzowi, objętego z jednej strony zawartym przez właściciela ubezpieczeniem ruchomości domowych na ogólną sumę 10000 funtów oraz z drugiej strony zawartym przez zegarmistrza na

\footnotetext{
140 J. Birds, Birds'..., s. 341-342.

141 [1977] QB 804.

142 MacGillivray..., paragrafy 23-32 oraz 32-53.
} 
rachunek osób powierzających mu swoje zegarki ubezpieczeniem obrotowym na ogólną sumę 3000 funtów. Trudno zgodzić się na rozwiązanie, jakie daje w tej sytuacji koncepcja odpowiedzialności maksymalnej: ubezpieczyciel właściciela zapłaciłby 10/13 odszkodowania, natomiast ubezpieczyciel zegarmistrza 3/13. Wynik taki ignorowałoby fakt, że oba ubezpieczenia obejmują cały szereg innych przedmiotów i mają różny charakter. Trafnie zatem odpowiedzialność niezależną zastosowano w sprawie American Surety Co of New York v. Wrightson ${ }^{143}$.

Przenosząc terminologię angielską na polski grunt, łatwo zauważyć, że Kodeks cywilny hołduje koncepcji odpowiedzialności maksymalnej, podczas gdy Kodeks morski koncepcji odpowiedzialności niezależnej. Warto przy tym podkreślić, że uchwalając nowy Kodeks morski, ustawodawca odszedł od regulacji zawartej w art. 273 dawnego k.m., nie tylko pozwalając na domaganie się od każdego z ubezpieczycieli odszkodowania przenoszącego przypadający nań udział. Dawne unormowanie ograniczało odpowiedzialność każdego z ubezpieczycieli jedynie do przypadającej nań kwoty, przy czym udziały określano w odniesieniu do konstrukcji odpowiedzialności maksymalnej. Należy się domyślać, że zmiany były skutkiem poglądów J. Łopuskiego, który dostrzegał różnice między obydwoma systemami rozliczeń ${ }^{144}$. Uwagi prawnoporównawcze wskazują, że koncepcja odpowiedzialności niezależnej przyjmowana jest w art. L121-4 francuskiej Code des assurances oraz art. 78 niemieckiej VVG, a także w doktrynie brytyjskiej. Mylne jest zatem twierdzenie, że aktualne unormowanie zawarte w Kodeksie cywilnym jest zbieżne $z$ rozwiązaniem przyjmowanym przez obce systemy prawne, w szczególności z rozwiązaniem niemieckim oraz francuskim ${ }^{145}$.

Argumentem przemawiającym za koncepcją odpowiedzialności maksymalnej jest sposób wyliczenia składki w tych ubezpieczeniach, pozostający często w proporcji do przyjętej sumy ubezpieczenia. Można jednak zapytać, skoro przy szkodzie częściowej każdy z ubezpieczycieli

143 (1910) 103 L.T. 663.

144 J. Łopuski, Podwójne ubezpieczenie, s. 126-127.

145 Tak M. Orlicki, J. Pokrzywniak, Umowa..., s. 112. M. Orlicki dostrzegł jednak różnicę w późniejszej publikacji: M. Orlicki, Regres..., s. 322-323. 
w ramach zawartej przez siebie umowy musiałby zapłacić pełne odszkodowanie, gdyby był ubezpieczycielem jedynym, dlaczego w razie wystąpienia ubezpieczenia podwójnego ubezpieczyciel, który zawarł ubezpieczenie na niższą sumę ubezpieczenia, miałby odnieść korzyść podwójną, wynikającą nie tylko z obecności innego ubezpieczyciela, ale również z niższej sumy ubezpieczenia? Przytoczone wyżej rozważania autorów brytyjskich zdają się wskazywać, że argumentów na rzecz koncepcji odpowiedzialności niezależnej jest znacznie więcej.

Dodatkowo należy zauważyć, że druga koncepcja daje lepsze rezultaty nie tylko przy ubezpieczeniach o różnym zakresie, ale także w sytuacji, gdy niektóre $\mathrm{z}$ ubezpieczeń zawarte są $\mathrm{w}$ systemie odpowiedzialności proporcjonalnej, inne zaś w systemie odpowiedzialności na pierwsze ryzyko. Koncepcja odpowiedzialności maksymalnej sugerująca, by ustalać odszkodowanie w proporcji do sumy ubezpieczenia, de facto pozbawiłaby klauzulę proporcjonalności, zastrzeżoną przez jednego z ubezpieczycieli, jakiegokolwiek znaczenia przy rozliczeniach regresowych między nimi, podczas gdy na wysokość składki wpływa nie tylko suma ubezpieczenia, ale również cały szereg okoliczności, w szczególności właśnie przyjęty system odpowiedzialności.

Wydaje się zatem, że koncepcja odpowiedzialności niezależnej pozwala respektować postanowienia każdej z zawartych umów ubezpieczenia, czego nie można powiedzieć o koncepcji odpowiedzialności maksymalnej. Podsumowując, zmiany uchwalone w drodze nowelizacji przepisów Kodeksu cywilnego o umowie ubezpieczenia, choć co do zasady słuszne, zawierają bardzo istotny mankament w postaci przyjęcia koncepcji odpowiedzialności maksymalnej zamiast odpowiedzialności niezależnej, aprobowanej w reprezentatywnych obcych systemach prawnych i prowadzącej do rezultatów bardziej sprawiedliwych. Mankament ten należałoby usunąć przy okazji ewentualnej kolejnej nowelizacji. 


\subsubsection{Zawarcie ubezpieczenia podwójnego w złej wierze}

Kolejną kwestią wymagającą rozważenia jest zawarcie podwójnego ubezpieczenia w złej wierze $\mathrm{z}$ intencją uzyskania odszkodowania przekraczającego wysokość szkody. Przytoczone wyżej regulacje francuska i niemiecka zawierają w tej mierze podobne rozwiązania, wymagając w pierwszym rzędzie od ubezpieczającego powiadomienia wszystkich ubezpieczycieli, z którymi zawarł umowy, o istnieniu innych ubezpieczeń dotyczących tego samego interesu i tego samego ryzyka ze wskazaniem sum ubezpieczenia. Według prawa francuskiego w razie zawarcia ubezpieczenia podwójnego w złej wierze ubezpieczyciel, który dowiedział się o istnieniu innego ubezpieczenia, ma roszczenie o unieważnione umowy oraz o odszkodowanie. Według prawa niemieckiego każde ubezpieczenie zawarte z intencją uzyskania nielegalnej korzyści jest nieważne z mocy prawa, ubezpieczycielowi należy się składka za okres do chwili, w której dowiedział się o podstawie nieważności umowy.

W prawie angielskim podwójne ubezpieczenie nie jest uregulowane ustawowo. Obowiązek powiadomienia ubezpieczyciela o innym ubezpieczeniu o tożsamym zakresie może wynikać z ogólnych warunków umów. Przed wejściem w życie ustawy o ubezpieczeniach konsumenckich z 2012 r. ${ }^{146}$ oraz ustawy ubezpieczeniowej z 2015 r. ${ }^{147}$ złamanie powinności nakazującej poinformowanie ubezpieczyciela o drugim ubezpieczeniu upoważniało ubezpieczyciela do wypowiedzenia umowy albo odmowy wypłaty odszkodowania. W skrajnych przypadkach, gdy stosowne postanowienia zawierały wszystkie zawarte umowy, ubezpieczony mógł w ogóle nie uzyskać odszkodowania.

Nowe ustawy w sposób zasadniczy zmieniają angielskie prawo ubezpieczeniowe dotyczące doktryny dobrej wiary, w szczególności w zakresie obowiązków deklaracji oraz notyfikacji. Najogólniej rzecz ujmując, po zmianach ubezpieczający narażony jest na konsekwencje niedochowania obowiązku deklaracji bądź notyfikacji jedynie wtedy, gdy niedo-

\footnotetext{
146 Consumer Insurance (Disclosure and Representation) Act 2012.

147 Insurance Act 2015.
} 
chowanie obowiązku było skutkiem winy umyślnej lub niedbalstwa oraz gdy ubezpieczyciel, wiedząc o nieujawnionej okoliczności, nie zawarłby umowy albo zawarł ją na innych warunkach ${ }^{148}$. Dodatkowo Insurance Act z 2015 r. stwierdza, że wcześniejsze reguły prawa angielskiego pozwalające jednej ze stron umowy ubezpieczenia uchylić się od swych obowiązków umownych z uwagi na naruszanie przez drugą stronę obowiązków dobrej wiary zostają uchylone. Ustawa zawiera jednak również generalną regulację pozwalającą ubezpieczycielowi na odmowę zaspokojenia roszczenia nieuczciwego, a takim roszczeniem będzie roszczenie o wypłatę odszkodowania z kolejnej polisy, jeżeli roszczenie zostało wcześniej zgłoszone innemu ubezpieczycielowi. Wydaje się, że właśnie to unormowanie służyć będzie aktualnie jako narzędzie ochrony ubezpieczyciela w razie zawarcia podwójnego ubezpieczenia w złej wierze.

W prawie polskim kwestię zawarcia ubezpieczenia podwójnego z intencją uzyskania nienależnego odszkodowania reguluje jedynie Kodeks morski, pozbawiając ubezpieczającego odszkodowania w razie niedochowania obowiązku powiadomienia ubezpieczyciela o świadomym zawarciu ubezpieczenia wielokrotnego. Kodeks cywilny milczy co do samego obowiązku notyfikacji, jak i konsekwencji jego niedochowania. Według J. Łopuskiego w razie umyślnego zawarcia ubezpieczenia podwójnego z zamiarem uzyskania odszkodowania przenoszącego wysokość szkody należałoby przyjąć nieważność umowy. Cytowany autor powołuje się jednak na regulacje niemiecką i francuską, nie podając uzasadnienia swego poglądu na gruncie prawa polskiego ${ }^{149}$.

Stanowisko J. Łopuskiego można oczywiście wesprzeć, powołując się na art. 58 k.c., zgodnie z którym czynność prawna sprzeczna z ustawą lub mająca na celu jej obejście jest nieważna. $W$ takim ujęciu ubezpieczenie podwójne, zawarte z intencją uzyskania odszkodowania przekraczającego wysokość szkody, jest nieważne jako mające na celu obejście zasady odszkodowania. Zgodnie z art. $824^{1} \$ 2$ k.c. w razie zawarcia ubezpieczenia podwójnego ubezpieczający nie może żądać odszko-

148 Zob. artykuł 2, część 1, załącznik nr 1 do ustawy o ubezpieczeniach konsumenckich z 2012 r. oraz art. 8 ustawy o ubezpieczeniach z 2015 r.

149 J. Łopuski, Podwójne ubezpieczenie, s. 124. 
dowania przenoszącego wysokość szkody. Przepis ten stanowi istotną wskazówkę interpretacyjną przy wykładni art. $824^{1} \$ 1$ k.c., zgodnie z którym świadczenie z ubezpieczenia majątkowego nie może przekraczać wysokości szkody, o ile nie umówiono się inaczej. Uprawniony jest zatem wniosek, że wynikająca z $\$ 1$ możliwość uzyskania świadczenia ubezpieczeniowego przenoszącego wysokość szkody odnosi się jedynie do ubezpieczenia w wartości nowej oraz otaksowanej, nie zaś do ubezpieczenia podwójnego.

Wykładnia art. $824^{1}$ k.c. nie budzi wobec powyższego wątpliwości co do tego, że świadczenie z ubezpieczenia majątkowego nie może przekraczać wysokości szkody także w razie zawarcia ubezpieczenia podwójnego i prowadzi do wniosku, że podwójne ubezpieczenia zawarte $\mathrm{z}$ intencją uzyskania takiego świadczenia jest nieważne. Kwestia nie dotyczy zatem teoretycznej możliwości powołania się przez ubezpieczyciela na nieważność ubezpieczenia zawartego w złej wierze, ale raczej praktycznego znaczenia takiego zarzutu. Problem polega na tym, że opisany zarzut będzie skuteczny jedynie w razie udowodnienia ubezpieczającemu, że zawierał podwójne ubezpieczenia w celu obejścia prawa, konkretnie zaś art. $824^{1} \$ 2$ k.c.

Zgodnie z terminologią prawa karnego działanie celowe to działanie podjęte w zamiarze bezpośrednim, czyli skierowane wprost na uzyskanie określonego celu. Udowodnienie działania w złej wierze nakierowanego na obejście prawa wymaga wniknięcia w sferę mentalną ubezpieczającego i poznania jego motywów w chwili zawierania kolejnych ubezpieczeń. Dowód taki wydaje się wyjątkowo kłopotliwy, zważywszy, że motywy zawarcia podwójnego ubezpieczenia mogą być różne, a świadomość ubezpieczeniowa polskiego społeczeństwa jest nikła. Ubezpieczający często w ogóle nie będzie zdawał sobie sprawy z samego zawarcia ubezpieczenia podwójnego albo $\mathrm{z}$ tego, że prawo nie pozwala na uzyskanie świadczenia ubezpieczeniowego przenoszącego wysokość szkody także w sytuacji, gdy uiszczając relatywnie wysokie składki, zapłacono za ochronę ze strony dwóch lub więcej ubezpieczycieli. Zasada ignorantia iuris nocet nie upoważnia do przypisywania zamiaru obejścia prawa osobie nieświadomej treści norm prawnych. 
Ciężar dowodu spoczywający na ubezpieczycielu, który pragnąłby udowodnić, że ubezpieczający, zawierając więcej niż jedno ubezpieczenie, działał w celu obejścia zasady odszkodowania, można porównać do ciężaru udowodnienia tzw. subiektywnych przesłanek skargi pauliańskiej, szczególnie zaś do działania w celu pokrzywdzenia przyszłych wierzycieli (art. $527 \$ 1$ i art. 530 k.c.). Dodatkowo, inaczej niż na gruncie przepisów o skardze pauliańskiej, w odniesieniu do dowodu zawarcia ubezpieczenia w zamiarze obejścia zasady odszkodowania ustawodawca nie przewiduje żadnych domniemań ani tym bardziej wyjątków. Tymczasem właśnie ułatwienia dowodowe, o których mowa w art. $527 \$ 2$ i 3, art. 528 oraz 530 zdanie drugie k.c., nadają skardze pauliańskiej wymierne znaczenie praktyczne.

Podsumowując, pogląd o nieważności podwójnego ubezpieczenia zawartego zintencją uzyskania odszkodowania przekraczającego wysokość szkody jest trafny, jednak przeprowadzenie przez ubezpieczyciela dowodu umożliwiającego podniesienie zarzutu nieważności w rzeczywistości często będzie graniczyć z niemożliwością. Brak precyzyjnej regulacji umożliwiającej przeprowadzenie takiego dowodu jest zatem kolejnym mankamentem obecnej regulacji. Regulacja Kodeksu morskiego nakładająca na ubezpieczającego obowiązek powiadomienia ubezpieczycieli o podwójnym ubezpieczeniu i pozbawiająca go prawa do odszkodowania w razie umyślnego naruszenia tego obowiązku również nie jest pozbawiona mankamentów. Udowodnienie umyślnego naruszenia obowiązku zawiadomienia wydaje się łatwiejsze niż udowodnienie zawarcia ubezpieczenia w celu uzyskania świadczenia przenoszącego wysokość szkody, jednak ze względów praktycznych wydaje się, że również w tym zakresie należałoby zrezygnować z umyślności.

Podobne mankamenty zawierają zresztą regulacje niemiecka i francuska, które również wydają się zbyt łagodne dla ubezpieczającego. Samo wprowadzenie obowiązku notyfikacji zawarcia podwójnego ubezpieczenia oraz sankcji w postaci możności unieważnienia umowy w razie zawarcia takiego ubezpieczenia w złej wierze problemu nie rozwiązuje. $\mathrm{W}$ moim przekonaniu postulowana regulacja powinna wprowadzać w braku zawiadomienia domniemanie złej wiary ubezpieczającego. 
Z przytoczonych przepisów polskiego Kodeksu morskiego, Code des assurances oraz VVG domniemanie takie nie wynika ${ }^{150}$.

\subsubsection{Postanowienia umowne dotyczące ubezpieczenia podwójnego}

Można postawić pytanie, czy przedstawiony problem dostępności praktycznej zarzutu nieważności ubezpieczenia zawartego w złej wierze daje się rozwiązać przez wprowadzenie obowiązku powiadomienia o podwójnym ubezpieczeniu na mocy ogólnych warunków ubezpieczenia oraz wyłączenie odpowiedzialności w razie niedochowania tego obowiązku. Artykuł $815 \$ 3$ k.c. wprowadzający sankcje w razie obowiązku deklaracji oraz notyfikacji wskazuje, że ubezpieczyciel nie odpowiada, jeżeli wypadek ubezpieczeniowy jest skutkiem nieujawnionej okoliczności. Co do zasady nie ma powiązania przyczynowo-skutkowego pomiędzy zajściem wypadku ubezpieczeniowego a zawarciem podwójnego ubezpieczenia. Wydaje się zatem, że problemu nie daje się rozwiązać poprzez wprowadzenie odpowiedniego obowiązku deklaracji oraz notyfikacji zmian ryzyka.

Orzecznictwo Sądu Najwyższego dopuszcza nałożenie na ubezpieczającego dodatkowych obowiązków prewencyjnych, wywodząc je $\mathrm{z}$ art. 827 k.c. ${ }^{151}$, milczy natomiast, gdy chodzi o inne dodatkowe obowiązki nieprzewidziane przez kodeks. W doktrynie możliwość nakładania na ubezpieczającego powinności nieprzewidzianych przez kodeks również jest ograniczana do obowiązków prewencyjnych ${ }^{152}$.

150 Niejednoznacznie co do interpretacji francuskiej regulacji wypowiada się Y. Lambert-Faivre, wskazując, że powiadomienie stwarza domniemanie dobrej wiary. Tego rodzaju domniemanie nie oznacza jednak, że brak powiadomienia jest równoznaczny ze złą wiarą. Dopóki ciężar udowodnienia ubezpieczającemu złej wiary spoczywa na ubezpieczycielu, jego sytuacja jest nie do pozazdroszczenia. Wydaje się, że zamiast tego, to ubezpieczający winien udowodnić, że działał w dobrej wierze.

151 Zob. przykładowo wyroki SN: z 17.06.1983 r., I CR 189/83, OSNC 1984/4, poz. 54; z 18.12.2003 r., I CK 365/02, LEX nr 599511; z 8.10.2004 r., V CK 70/04, LEX nr 146334.

152 Stanowczo wyklucza możliwość nakładania na ubezpieczającego innych powinności przykładowo S. Byczko, Prawo..., s. 147. 
Argumentu przeciwko możliwości ich nakładania można upatrywać choćby w art. 818 k.c., w którym wyjątkowo ustawodawca pozwala wprowadzić do OWU obowiązek zawiadomienia o wypadku w określonym terminie. Nadto w orzecznictwie i doktrynie nie ma zgodności co do tego, czy naruszenie nieprzewidzianych w ustawie obowiązków prewencyjnych może być sankcjonowane, gdy jest wynikiem jakiejkolwiek winy ubezpieczającego, czy też konieczna jest wina umyślna lub rażące niedbalstwo ${ }^{153}$. Podsumowując, możliwość wprowadzenia na mocy OWU dodatkowego obowiązku zawiadomienia ubezpieczyciela o zawarciu podwójnego ubezpieczenia oraz wyłączenia prawa do odszkodowania w razie zawinionego naruszenia tego obowiązku jest przynajmniej wątpliwa. Brak obowiązku notyfikacji zawarcia podwójnego ubezpieczenia stanowi zatem kolejny istotny mankament obecnej regulacji.

Ostatnia kwestia wiąże się ściśle z jeszcze jednym problemem nasuwającym się w związku $\mathrm{z}$ ubezpieczeniem podwójnym, a mianowicie dopuszczalnością modyfikowania reguł wynikających $\mathrm{z}$ art. $824^{1}$ k.c. na mocy ogólnych warunków ubezpieczenia. Na wstępie należy przypomnieć, że przepisy Kodeksu cywilnego o umowie ubezpieczenia są co do zasady bezwzględnie obowiązujące, a ich umowne modyfikacje są dopuszczalne wyjątkowo, i to zwykle jedynie na korzyść ubezpieczającego ${ }^{154}$. Zgodnie z art. 807 k.c. postanowienia ogólnych warunków ubezpieczenia lub postanowienia umowy ubezpieczenia sprzeczne z przepisami tytułu XXVII o umowie ubezpieczenia są nieważne, chyba że dalsze przepisy przewidują wyjątki. Jak była mowa, art. $824^{1} \$ 1$ k.c. pozwala na pozorne odstępstwa od zasady odszkodowania w postaci ubezpieczenia w wartości nowej oraz otaksowanej. Kolejne paragrafy, dotyczące podwójnego ubezpieczenia, nie zawierają zastrzeżeń sugerujących możliwość odejścia od wskazanych w nich reguł.

153 Co do tej kwestii, zob. m.in. M. Krajewski, Umowa ubezpieczenia. Art. 805-834 KC..., 2016, s. 252-258; M. Orlicki, Umowa ubezpieczenia, 2002, s. 243-245; B. Kucharski, Powinność zabezpieczenia kluczyków i dokumentów samochodowych w ubezpieczeniu AC, PA 2010/1, s. 56 i n. oraz podana tam literatura i orzecznictwo.

154 Co do tej kwestii, zob. przede wszystkim M. Orlicki, Regulacja..., s. 47 i n. 
Obecna regulacja dotycząca podwójnego ubezpieczenia z pewnością sprzeciwia się wprowadzeniu do ogólnych warunków ubezpieczenia postanowień, które statuowałyby inne reguły odpowiedzialności ubezpieczycieli w razie podwójnego ubezpieczenia niż przewidziane $\mathrm{w}$ art. $824^{1}$ $\$ 1$ i 2 k.c. Niemożliwy będzie zatem w szczególności powrót na mocy regulacji umownej do stanu prawnego sprzed zmiany przepisów poprzez wprowadzenie w razie podwójnego ubezpieczenia klauzuli proporcjonalności, według której ubezpieczający miałby prawo żądać od każdego z ubezpieczycieli jedynie części odszkodowania, jaka przypadałaby nań, biorąc pod uwagę stosunek przyjętej przezeń sumy ubezpieczenia do łącznych sum ubezpieczenia przewidzianych przez wszystkich ubezpieczycieli ${ }^{155}$, albo biorąc pod uwagę stosunek odszkodowania, które ubezpieczyciel musiałby zapłacić, gdyby był ubezpieczycielem jedynym, do ogólnych sum odszkodowania wynikających z wielokrotnego ubezpieczenia. Jak wyżej wskazano, w związku z brzmieniem art. $824^{1}$ $\$ 1$ i 2 k.c., który nie nakłada na ubezpieczającego żadnego obowiązku notyfikacji, wątpliwości budzić może również spotykane w praktyce angielskiej zastrzeżenie OWU uzależniające prawo do odszkodowania od powiadomienia ubezpieczyciela o zawarciu podwójnego ubezpieczenia.

Można postawić również pytanie o dopuszczalność wyłączenia odpowiedzialności ubezpieczyciela na wypadek zawarcia przez ubezpieczającego innego ubezpieczenia, dotyczącego tego samego ryzyka i tego samego interesu. Co do tej kwestii, przykładów znów dostarcza praktyka common law. Angielscy ubezpieczyciele, formułując polisy i ogólne warunki umów, nie tylko uzależniają prawo do odszkodowania od zawiadomienia o podwójnym ubezpieczeniu, ale często idą jeszcze dalej, wyłączając swą odpowiedzialność w razie istnienia innego ubezpieczenia obejmującego to samo ryzyko i ten sam interes ${ }^{156}$.

155 Vide art. $824^{1} \$ 2$ przed zmianą dokonaną na mocy nowelizacji z $2007 \mathrm{r}$. oraz omawiane wcześniej angielskie orzecznictwo dotyczące klauzuli proporcjonalności w razie podwójnego ubezpieczenia.

156 Takie wyłączenie bywa również kumulowane z klauzulą proporcji, co wywołuje rozbieżne reakcje orzecznictwa. Por. J. Birds, Birds'..., s. 344-345. 
Jeżeli tylko jedna z dwóch konkurujących polis zawiera takie zastrzeżenie, odszkodowanie w całości wypłaca ubezpieczyciel, który podobnych klauzul w OWU nie zawarł. Problem pojawia się wtedy, gdy obydwie polisy (lub w przypadku ubezpieczenia wielokrotnego wszystkie) zawierają podobne zastrzeżenia. Orzecznictwo zdaje się sugerować, że w opisanych wypadkach klauzule wyłączające odpowiedzialność wzajemnie się znoszą i ubezpieczyciele odpowiadają na normalnych zasadach. W sprawie National Employers Mutual v. Hayden sędzia Stevenson stwierdził, że sąd powinien w takich sytuacjach obarczyć każdego z ubezpieczycieli słusznym udziałem w szkodzie. Pozwoli to uniknąć absurdu i niesprawiedliwości, jakie byłyby rezultatem przyjęcia, że osoba, która zapłaciła składkę za ochronę udzielaną przez dwóch ubezpieczycieli, pozostaje bez ochrony, jeżeli tylko każdy z nich wyłączył swoją odpowiedzialność $\mathrm{w}$ razie ubezpieczenia tego samego ryzyka gdzie indziej ${ }^{157}$.

W prawie polskim podobne klauzule wykluczające odpowiedzialność ubezpieczyciela w razie stwierdzenia podwójnego ubezpieczenia wydają się niedopuszczalne jako pozostające w sprzeczności z art. $824^{1}$ k.c. Skoro niedopuszczalne jest zastrzeżenie przez ubezpieczycieli klauzuli proporcjonalności w stosunkach zewnętrznych, tym bardziej niedopuszczalne są klauzule wyłączające odpowiedzialność. Podobny pogląd znalazł zresztą wyraz w orzecznictwie SOKiK. Klauzula przewidująca nieodpowiedzialność ubezpieczyciela w razie wystąpienia ubezpieczenia podwójnego znajduje się w rejestrze klauzul niedozwolonych ${ }^{158}$. Dodać należy, że sformułowanie art. $824^{1}$ k.c. wyłącza także inne niż przewidziane w art. $824^{1}$ k.c. uregulowanie rozliczeń między ubezpieczycielami również w stosunkach wewnętrznych. Niedopuszczalne wydaje się zatem uregulowanie na mocy porozumień między ubezpieczycielami, że rozliczać będą się oni nie według reguły odpowiedzialności maksymalnej, ale według klauzuli odpowiedzialności niezależnej, przyjmowanej przez Kodeks morski i odrębne systemy prawne, które, jak wykazano powyżej, znacznie lepiej sprawdzałoby się w praktyce.

157 National Employers Mutual General Insurance Association Ltd v. Hayden [1979] 2 Lloyd Rep. 235, s. 152.

158 Klauzula nr 3461, wyrok SOKiK z 19.09.2011 r., XVII AmC 145/10, MSiG 2012/167, poz. 11544 . 


\section{Rozdział 5 \\ USTALANIE ODSZKODOWANIA UBEZPIECZENIOWEGO}

\subsection{Wprowadzenie}

Konkluzja pierwszego rozdziału pracy, że ubezpieczyciel ponosi odpowiedzialność cywilną o charakterze odszkodowawczym, nie wyklucza odrębności co do zakresu odszkodowania ubezpieczeniowego w porównaniu z odszkodowaniem na ogólnych zasadach prawa cywilnego. Odrębności dotyczące ustalania odszkodowania w ubezpieczeniu mienia związane są przede wszystkim z kwalifikacją reżimu odpowiedzialności odszkodowawczej ubezpieczyciela jako odpowiedzialności gwarancyjnej, mającej ściśle określone przesłanki, oraz typu tej odpowiedzialności jako odpowiedzialności gwarancyjno-repartycyjnej oraz ograniczonej (niepełnej).

Ograniczony charakter odpowiedzialności ubezpieczeniowej wyznaczają przede wszystkim omówione wcześniej zasady dotyczące: lokalizacji szkody, wartości i sumy ubezpieczenia oraz wzajemnych relacji tych pojęć, systemów odpowiedzialności ubezpieczyciela w razie niedoubezpieczenia, ubezpieczenia wielokrotnego oraz techniczno-ubezpieczeniowych ograniczeń odpowiedzialności ubezpieczyciela. Kwalifikacja prawna odpowiedzialności ubezpieczeniowej, przesłanki tej odpowiedzialności oraz omówione zasady prawa ubezpieczeniowego dotyczące ustalania zakresu odszkodowania wyznaczają w zasadzie odpowiedzi na wszystkie mogące pojawić się pytania. Dla usunięcia wątpliwości 
wypada jednak odnieść się do kilku szczegółowych kwestii tradycyjnie rozważanych przede wszystkim w odniesieniu do odszkodowania z ubezpieczenia odpowiedzialności cywilnej. Dotyczą one:

- kosztów przywrócenia rzeczy do stanu poprzedniego i tzw. kosztorysowej metody ustalania odszkodowania,

- kwalifikacji szkody jako całkowitej oraz zwrotu kosztów różnicy między wartością mienia sprzed wypadu a pozostałościami,

- możności objęcia odszkodowaniem ubezpieczeniowym podatku VAT, ubytku wartości handlowej pojazdu oraz wynagrodzenia pełnomocnika prawnego,

- stosowania w ubezpieczeniach zasady wyrównania korzyści z uszczerbkiem,

- możności miarkowania odszkodowania ubezpieczeniowego przez sąd.

Wskazane zagadnienia zostaną omówione po kolei. Z góry można zaznaczyć, że odpowiedzi udzielane w odniesieniu do obowiązkowego ubezpieczenia OC posiadaczy pojazdów mechanicznych nie mogą być wprost przenoszone na grunt ubezpieczeń mienia. Wynika to, ogólnie rzecz ujmując, z obowiązywania w obowiązkowym ubezpieczeniu OC posiadaczy pojazdów mechanicznych zasady pełnego odszkodowania oraz nieobowiązywaniem tej zasady w ubezpieczeniu mienia. Bardziej szczegółowo można zaś wskazać: po pierwsze, na zasadę akcesoryjności odpowiedzialności ubezpieczyciela wobec odpowiedzialności sprawcy szkody w zakresie ubezpieczenia OC, która w ubezpieczeniu mienia nie ma zastosowania, oraz po drugie, na szczególne regulacje dotyczące zakresu odszkodowania z ubezpieczeń obowiązkowych ${ }^{1}$.

1 Por. art. 9, 13 ust. 2 i 3, art. 34 ust. 1 oraz art. 36 u.u.o. 


\subsection{Elementy odszkodowania z ubezpieczenia mienia}

\subsubsection{Koszty przywrócenia do stanu poprzedniego i kosztorysowa metoda wyliczania odszkodowania}

Kosztorysowa metoda szacowania polega na jego wyliczeniu na podstawie kosztu części zamiennych oraz robocizny potrzebnej do naprawy uszkodzonej rzeczy w oderwaniu od rzeczywiście poniesionych kosztów. Ogólne warunki ubezpieczeń AC przewidują zwykle tę metodę jako alternatywę dla metody serwisowej (fakturowej) polegającej na pokryciu przez ubezpieczyciela rachunków wystawionych przez serwis naprawczy, z którego skorzystał ubezpieczony. Sąd Najwyższy od wielu lat konsekwentnie prezentuje pogląd, że odszkodowania wyliczonego w ten sposób ubezpieczający może domagać się niezależnie od tego, czy naprawa pojazdu rzeczywiście miała miejsce ${ }^{2}$. Pogląd wiązany jest zwykle ze stanowiskiem, pojawiającym się zarówno w orzecznictwie, jak i w literaturze, wedle którego pokrycie przez ubezpieczyciela kosztów naprawy pojazdu odpowiada naprawieniu szkody w drodze restytucji naturalnej ${ }^{3}$. Samo zagadnienie dopuszczalności naprawienia przez ubezpieczyciela szkody w drodze restytucji naturalnej będzie szerzej omówione w ostatnim rozdziale pracy.

2 Wyrok z 27.06.1988 r., I CR 151/88, LEX nr 8894; wyrok z 11.06.2001 r., V CKN 266/00, OSP 2002/3, poz. 40; uchwała z 15.11.2001 r., III CZP 68/01, OSNC 2002/6, poz. 74; wyrok z 16.01.2002 r., IV CKN 635/00, LEX nr 78370; wyrok z 29.01.2002 r., V CKN 682/00, LEX nr 54343; wyrok z 20.02.2002 r., V CKN 903/00, OSNC 2003/1, poz. 15; wyrok z 20.02.2002 r., V CKN 908/00, LEX nr 54365; wyrok z 16.05.2002 r., V CKN 1273/00, LEX nr 55515; wyrok z 11.06.2003 r., V CKN 308/01, LEX nr 157324; uchwała z 13.06.2003 r., III CZP 32/03, OSNC 2004/4, poz. 51; wyrok z 7.08.2003 r., IV CKN 387/01, LEX nr 141410; wyrok z 12.02.2004 r., V CK 187/03, „Wokanda” 2004/7-8, s. 15, postanowienie SN z 12.01.2006 r., III CZP 76/05, LEX nr 175463; uchwała (7) z 17.05.2007 r., III CZP 150/06, OSNC 2007/10, poz. 144; wyrok z 6.11.2015 r., II CSK 58/15, LEX nr 1929079.

3 Tak przykładowo: B. Balas-Noszczyk, K. Malinowska, W sprawie..., s. 23; A. Szpunar, Ustalenie odszkodowania z tytułu obowiązkowego ubezpieczenia komunikacyjnego, KPP 1993/1, s. 31 i n.; A. Wąsiewicz, Ustalenie.., s. 42; E. Kowalewski, Odszkodowanie za ubytek wartości handlowej pojazdu poddanego naprawie, WU 2011/3, s. 31-32. 
Pogląd Sądu Najwyższego dotyczący przyznania odszkodowania na podstawie kosztorysu naprawy w sytuacji, gdy ta nie została dokonana, zakwestionował M. Kaliński. Zdaniem tego autora w omawianym przypadku nie występuje żadna $\mathrm{z}$ dwóch ekskluzywnych form naprawienia szkody przewidzianych w art. 363 k.c. ${ }^{4}$ Nie sposób mówić o przywróceniu do stanu poprzedniego, ponieważ świadczenie spełniane jest w formie pieniężnej. Roszczenia poszkodowanego w ubezpieczeniu odpowiedzialności cywilnej ograniczone są zresztą do domagania się świadczenia w takiej formie, co wynika przede wszystkim z użycia w art. 822 k.c. sformułowania ,ubezpieczyciel zobowiązuje się do zapłacenia określonego w umowie odszkodowania".

Trudno również twierdzić, że przy tzw. metodzie kosztorysowej wyliczenia odszkodowania dochodzi do zapłaty odpowiedniej sumy pieniężnej. Zgodnie z teorią różnicy suma odpowiednia winna być obliczana jako różnica między wartością pojazdu sprzed szkody a wartością pozostałości (wraku), nie zaś jako koszt przywrócenia do stanu poprzedniego. Skoro poszkodowany nie poniósł jeszcze kosztów restytucji, to uszczerbek w tym rozmiarze jeszcze go nie dotknął, jego szkoda jest zatem szkodą przyszłą, niepewną i abstrakcyjną. Nie ma instrumentów pozwalających na kontrolę wykorzystania przez poszkodowanego otrzymanej sumy. Według M. Kalińskiego stanowisko Sądu Najwyższego prowadzi do wzbogacenia poszkodowanego w przypadkach, gdy zaniecha on naprawy.

Maciej Kaliński uważa, że Sąd Najwyższy, aprobując tzw. kosztorysową metodę likwidacji szkody, aprobuje de facto istnienie trzeciej, nieznanej Kodeksowi cywilnemu postaci naprawienia szkody, polegającej na zapłacenie sumy pieniężnej potrzebnej do naprawienia rzeczy. Cytowany autor zwraca uwagę, że taki sposób naprawienia szkody przewidziany jest w prawie niemieckim. Artykuł 249 ust. 2 zdanie pierwsze BGB stanowi bowiem, że w sytuacji, gdy odszkodowanie jest należne w związku z wyrządzeniem krzywdy określonej osobie lub uszkodzeniem okre-

4 M. Kaliński, O wadliwej obiektywizacji szkody, SI 2007, t. 47, s. 108-110; M. Kaliński, Glosa do wyroku SN z 12.01.2006 r., II CK 327/05, PA 2009/7, s. 67 i n.; M. Kaliński, Szkoda..., s. 496-497. 
ślonej rzeczy, uprawniony może domagać się zamiast przywrócenia do stanu poprzedniego sumy pieniężnej potrzebnej do przywrócenia do tego stanu ${ }^{5}$. Artykuł 363 k.c. nie zawiera jednak podobnej regulacji.

Problem kosztorysowej metody szacowania odszkodowania analizowała szerzej również B. Janiszewska. Według tej autorki na gruncie ubezpieczenia OC do przyjęcia są trzy stanowiska. Pierwsze zakłada wykluczenie reguły z art. 363 k.c. przez przepisy szczególne wskazujące, że świadczenie ubezpieczyciela polega na zapłacie. Według drugiego stanowiska zapłata sumy pieniężnej potrzebnej do naprawy pojazdu jest specyficzną formą przywrócenia do stanu poprzedniego. Trzeci pogląd charakteryzuje żądanie zapłaty kwoty odpowiadającej kosztom restytucji jako zapłatę odpowiedniej sumy pieniężnej. Ostatecznie autorka przyjmuje ostatnie stanowisko, wskazując, że pierwsze trudno pogodzić z ochronną funkcją obowiązkowego ubezpieczenia OC pojazdów mechanicznych jako wybitnie niekorzystne dla poszkodowanego, drugie zaś zbyt szeroko interpretuje przywrócenie stanu poprzedniego oraz jest niespójne systemowo. Zdaniem cytowanej autorki, chociaż kwalifikowanie zwrotu kosztów naprawy zleconej przez poszkodowanego jako restytucji naturalnej budzi zastrzeżenia, ukształtowana linia orzecznictwa Sądu Najwyższego okazuje się zatem słuszna ${ }^{6}$.

Marcin Krajewski twierdzi z kolei, że prawidłowa interpretacja art. 822 k.c. dotyczącego zobowiązania ubezpieczyciela w umowie ubezpieczenia odpowiedzialności cywilnej nie polega na prostym wyeliminowaniu jednej z opcji służących poszkodowanemu na gruncie art. 363 k.c., ale raczej na jej modyfikacji poprzez przekształcenie roszczenia o przywrócenie do stanu poprzedniego w roszczenie o zapłatę kosztów restytucji. Roszczenie takie nie jest roszczeniem o przywrócenie do stanu poprzedniego w znaczeniu ścisłym. Nie przysługuje poszkodowanemu na zasadach ogólnych, ale jest specyficzną instytucją prawa

\footnotetext{
${ }^{5}$ Nie wydaje się jednak, by ustawodawca niemiecki traktował to jako trzeci sposób naprawienia szkody poza restytucją i zapłatą odpowiedniej sumy, ale raczej jako szczególną postać restytucji. Co do tej kwestii, zob. M. Piwowar, O sposobach naprawienia szkody, PiP 2013/4, s. 91.

${ }^{6}$ Zob. B. Janiszewska, Nadmierne koszty restytucji a odpowiedzialność ubezpieczyciela za tzw. szkody komunikacyjne, SI 2007, t. 47, s. 43 i n.
} 
ubezpieczeniowego wynikającą $\mathrm{z}$ nałożenia na siebie norm $\mathrm{z}$ art. 363 $\$ 1$ oraz art. $822 \$ 1$ k.c. Oznacza to, że do odszkodowania w wysokości kosztów restytucji należy stosować pozostałe zasady z art. $363 \$ 1$, pominąwszy sam sposób jego spełniania, w szczególności zaś zasadę, że odszkodowanie w takiej wysokości nie służy, jeżeli przywrócenie do stanu poprzedniego jest niemożliwe albo pociąga za sobą nadmierne trudności lub koszty ${ }^{7}$. Ostatecznie jednak autor ten postuluje korektę art. 363 k.c. w sposób zbliżony do treści art. 249 BGB przez wyraźne wskazanie, że w sytuacji, gdy przywrócenie do stanu poprzedniego jest możliwe, poszkodowany może domagać się takiego przywrócenia lub zapłaty sumy koniecznej do jego dokonania ${ }^{8}$.

Jawi się pytanie, czy argumentacja podobna do przedstawionej przez M. Krajewskiego na gruncie art. 822 k.c. jest możliwa do obrony w odniesieniu do ubezpieczenia AC. Ewentualna odpowiedź negatywna stawiałaby pod znakiem zapytania powszechną praktykę polegającą na stosowaniu również w tym ubezpieczeniu tzw. kosztorysowej metody likwidacji szkód’. Wydaje się, że rozważając opisaną kwestię, należy odnieść się do wcześniejszych uwag o ubezpieczeniu w wartości nowej oraz ubezpieczeniu w wartości otaksowanej. Umowa ubezpieczenia majątkowego polega na zobowiązaniu się przez ubezpieczyciela w zamian za zapłatę składki do spełniania w razie zajścia wypadku przewidzianego w umowie świadczenia polegającego zwykle na zapłacie określonego w umowie odszkodowania (art. 805 k.c.). Przedmiotem ubezpieczenia może być każdy niesprzeczny z prawem i dający się wycenić w pieniądzu interes majątkowy (art. 821 k.c.). Jeżeli nie umówiono się inaczej, suma pieniężna wypłacana tytułem odszkodowania nie może być wyższa od poniesionej szkody (art. $824^{1} \$ 1$ k.c.).

Z powyższego wynika, że odszkodowanie z tytułu ubezpieczenia mienia jest odszkodowaniem umownym. Jeżeli tak się umówiono, może

7 M. Krajewski, Ubezpieczenie..., s. 293-294. Pogląd ten został, jak się zdaje, zaaprobowany przez SN w wyroku z 6.11.2015 r., II CSK 58/15.

8 M. Krajewski, Szkoda na mieniu wynikająca z wypadków komunikacyjnych, raport Ministerstwa Sprawiedliwości, Warszawa 2017, s. 91.

9 Wyrok z 12.01.2006 r., II CK 327/05, LEX nr 164791, z glosą M. Kalińskiego, PA 2009/7, s. 70. 
ono przybierać postać odszkodowania wyliczonego przy użyciu teorii różnicy, jak również odszkodowania mającego na celu pokrycie kosztów przywrócenia do stanu poprzedniego, i to niezależnie od tego, czy ubezpieczający zamierza przywracać samochód do stanu poprzedniego $^{10}$. Warunkiem skuteczności takiego ustalenia jest, by ubezpieczenie chroniło ubezpieczony, niesprzeczny z prawem interes majątkowy i nie przeradzało się w umowę hazardową prowadzącą do wzbogacenia ubezpieczonego. Tak zarysowany cel ubezpieczenia nie stoi w sprzeczności z ustalaniem odszkodowania na podstawie kosztorysu uwzględniającego koszty celowej naprawy, choćby ubezpieczony nie zamierzał takiej naprawy dokonywać.

Funkcjonalnie rzecz ujmując, stan, w którym ubezpieczony pozostawiony jest $z$ wrakiem oraz pieniędzmi pozwalającymi na naprawę auta, bliższy jest zapewne stanowi sprzed wypadku od stanu, w którym ubezpieczony pozostawiony jest $\mathrm{z}$ odszkodowaniem uwzględniającym jedynie różnicę między wartością auta sprzed wypadku oraz wartością wraku. Odszkodowanie wyliczone w ten drugi sposób nie skompensuje ubezpieczonemu kłopotów i kosztów związanych z kupnem kolejnego nowego samochodu. Nawet przyjąwszy, że M. Kaliński ma rację, kwestionując tzw. kosztorysową metodę ustalania odszkodowania jako wykraczającą poza formułę art. $363 \$ 1$ k.c. (co w świetle powyższej argumentacji może być dyskusyjne), strony umowy ubezpieczenia mienia z pewnością mogą ustalić, że odszkodowanie zostanie ustalone na podstawie kosztorysu części oraz robocizny potrzebnych do przywrócenia uszkodzonego samochodu do stanu sprzed wypadku. Na marginesie można dodać, że pomysły wykluczenia możliwości ustalania odszkodowania metodą kosztorysową, z którymi w przeszłości występowali parlamentarzyści, spotkały się z ostrym sprzeciwem samych ubezpieczycieli.

Nie wydaje się przy tym, by tzw. kosztorysowa metoda wyliczenia odszkodowania w ubezpieczeniu mienia była specyficzną ubezpieczeniową formą przywrócenia do stanu poprzedniego. Ubezpieczyciel zobowiązuje się wszak w tym przypadku do zapłaty odszkodowania

10 Możliwość modyfikacji reguł wynikających z art. 363 w OWU dostrzega również M. Kaliński, Glosa do wyroku SN z 12.01.2006 r., II CK 327/05, s. 70. 
pieniężnego mogącego pokryć koszty naprawy, nie zaś do wykonania naprawy. Ubezpieczyciel nie ma ponadto możliwości kontrolowania sposobu spożytkowania odszkodowania przez ubezpieczonego. Ubezpieczyciel po prostu ustala w umowie, że w sytuacji, gdy samochód jest technicznie i gospodarczo zdatny do naprawy, odszkodowanie zostanie wypłacone albo na podstawie przedstawionych przez ubezpieczonego rachunków, albo na podstawie dokonanej przez ubezpieczyciela symulacji kosztów naprawy. W obu przypadkach chodzi o wypłatę odszkodowania pieniężnego. Odwołując się do sformułowań art. $805 \$ 2$ pkt 1 oraz art. $824^{1} \$ 1$ w zw. z art. $363 \$ 1$ k.c., można wskazać, że strony umowy ubezpieczenia w granicach przyznanej im swobody kształtowania sposobu określenia odszkodowania ubezpieczeniowego ustalają, jaką sumę pieniężną uznają za odpowiednią ${ }^{11}$.

Ustalenie takie pozostaje zwykle w związku z ustaleniem, że w sytuacji, gdy przewidywany koszt naprawy przekroczy określony w umowie procent wartości rzeczy sprzed wypadku, kształtujący się zwykle na poziomie 70\% wartości, suma odpowiednia w rozumieniu art. $363 \$ 1$ k.c. odpowiadać będzie różnicy między wartością rzeczy sprzed wypadku a wartością pozostałości (wraku). Kwestia ta wiąże się z umowną regulacją poziomu tzw. szkody całkowitej i będzie przedmiotem rozważań w kolejnym podrozdziale. Jeszcze innym zagadnieniem jest dopuszczalność ustalenia w umowie ubezpieczenia mienia, że szkoda zostanie przez ubezpieczyciela naprawiona w drodze przywrócenia do stanu poprzedniego. Jak wskazano, to ostatnie zagadnienie będzie przedmiotem analizy w ostatnim rozdziale pracy. Wyprzedzając tok dalszych rozważań, należy jednak wskazać, że inaczej niż w odniesieniu do ubezpieczenia OC, w odniesieniu do którego art. 822 k.c. stanowi, że ubezpieczyciel zobowiązuje się do zapłacenia określonego w umowie odszkodowania, na gruncie ubezpieczeń mienia nie ma norm, które wyraźnie ograniczałyby świadczenie ubezpieczyciela do odszkodowania w formie pieniężnej. W ubezpieczeniu mienia rozumowanie nie opiera się zatem na przekształceniu restytucji na ogólnych zasadach w zapłatę odszkodowania odpowiadającego kosztom restytucji (tak w odniesieniu do ubezpieczenia odpowiedzialności cywilnej M. Krajewski), ale na ustaleniu, jaką sumę pieniężną strony uznają na mocy zawartej umowy za odpowiednią (tak w od-

11 W odniesieniu do umowy ubezpieczenia OC por. B. Janiszewska, Nadmierne..., s. 62. 
niesieniu do ubezpieczenia odpowiedzialności cywilnej B. Janiszewska). Niezależnie od powyższego postulat odpowiedniej korekty art. $363 \$ 1$ k.c. jest niepozbawiony racji jako ostatecznie usuwający rozbieżności między teorią dwóch ekskluzywnych form naprawienia szkody oraz praktyką aprobującą trzecią, nieprzewidzianą wyraźnie w przepisie formę pośrednią.

\subsubsection{Kwalifikacja szkody jako całkowitej i zwrot różnicy między wartością mienia sprzed szkody a pozostałościami}

Drugi ze wskazanych problemów dotyczy rozróżnienia szkody całkowitej i częściowej. Rozróżnienie to rodzi problemy, gdy rzecz ucieleśniająca przedmiot ubezpieczenia nie zostanie całkowicie utracona przez ubezpieczającego, ale jedynie uszkodzona w stopniu umożliwiającym przywrócenie jej do stanu poprzedniego. Konsekwencje potraktowania przez ubezpieczyciela szkody jako całkowitej znów najlepiej są widoczne w ubezpieczeniach komunikacyjnych. Ubezpieczyciel wypłaca w takiej sytuacji odszkodowanie wyliczone poprzez odjęcie od wartości pojazdu przed szkodą wartości wraku pojazdu. Praktyka tego rodzaju może być dotkliwa dla ubezpieczających, wziąwszy pod uwagę omówiony wyżej pogląd, że poszkodowany ma prawo domagać się odszkodowania odpowiadającego przybliżonym kosztom naprawy niezależnie od tego, czy naprawa rzeczywiście miała miejsce. Dlatego bardzo często ubezpieczający dąży do zmiany decyzji ubezpieczyciela ${ }^{12}$.

Na gruncie ubezpieczenia OC posiadaczy pojazdów mechanicznych w orzecznictwie Sądu Najwyższego ukształtował się pogląd negujący możliwość potraktowania przez ubezpieczyciela szkody jako całkowitej w sytuacji, gdy koszt naprawy pojazdu nie przekracza wartości pojazdu z chwili szkody ${ }^{13}$. Spośród nowszych orzeczeń na uwagę zasługuje wyrok z 6.11.2015 r., II CSK 58/15, w którym Sąd Najwyższy przyjął, że w przy-

12 M. Krajewski, Ubezpieczenie..., s. 301-302.

13 Wyrok z 20.02.1981 r., I CR 17/81, OSNC 1981/10, poz. 199; wyrok z 13.12.1988 r., I CR 280/88, LEX nr 78219; wyrok z 20.02.2002 r., V CKN 903/00; wyrok z 11.06.2003 r., V CKN 308/01; postanowienie SN z 12.01.2006 r., III CZP 76/05. 
padku budynku wpisanego do rejestru zabytków żądanie restytucji może być zasadne także wtedy, gdy jej koszty znacząco przewyższają wartość samego budynku przed szkodą, co można by zapewne odnieść również do samochodów zabytkowych ${ }^{14}$.

Stanowisko ubezpieczycieli dążących do zakwalifikowania szkody jako całkowitej oraz jej naprawienia przez wypłatę odszkodowania odpowiadającego różnicy między wartością rzeczy nieuszkodzonej a pozostałościami zwalczano, twierdząc, że niedopuszczalne jest narzucanie przez ubezpieczyciela poszkodowanemu naprawienia szkody w drodze zapłaty odpowiedniej sumy pieniężnej w sytuacji, gdy na zasadach ogólnych poszkodowany mógłby wybierać między przywróceniem do stanu poprzedniego a zapłatą odpowiedniej sumy pieniężnej. Nadto odmowa pokrycia kosztów naprawy równałaby się odebraniu prawa do wyboru przywrócenia do stanu poprzedniego w sytuacji, gdy restytucja jest możliwa i nie pociąga za sobą nadmiernych trudności i kosztów ${ }^{15}$.

Pytanie brzmi zatem, czy w OWU AC ubezpieczyciel może zastrzec, że potraktuje jako całkowitą szkodę generującą koszty naprawy niższe od wartości pojazdu przed wypadkiem. Wydaje się, że o ile na gruncie ubezpieczenia OC należy bronić linii orzecznictwa wykluczającej taką możliwość, powołując się przy tym na zasady pełności odszkodowania, akcesoryjności ubezpieczenia oraz argumentację dotyczącą wykładni art. 363 w zw. z art. 822 k.c., o tyle w odniesieniu do ubezpieczenia AC wskazane argumenty są wątpliwe. Klauzule OWU, w których ubezpieczyciele definiują jako szkodę całkowitą uszkodzenie pojazdu w takim zakresie, że koszty jego naprawy ustalane metodą kosztorysową

14 Kwestie te omawia M. Krajewski w cytowanym wyżej raporcie Ministerstwa Sprawiedliwości. Zob. M. Krajewski, Szkoda..., s. 20.

15 Zob. w szczególności B. Janiszewska, Uwagi o ustaleniu „szkody całkowitej” w obowiązkowych ubezpieczeniach komunikacyjnych, SI 2007, t. 47, s. 65 i n.; B. Chmielowiec, Praktyczne problemy związane z kwalifikacja szkody jako całkowitej i podejmowane w tym zakresie działania Rzecznika Ubezpieczonych, MU 2010/41; B. Chmielowiec, Kilka uwag o pojęciu i praktyce tzw. szkody całkowitej w ubezpieczeniach komunikacyjnych, PUSiG 10/01. 
przekraczają 70\% jego wartości sprzed szkody, wydają się trudne do podważenia ${ }^{16}$.

Moim zdaniem zakres swobody ubezpieczyciela w zakresie kształtowania OWU wyznaczony przepisami art. 807 k.c. oraz art. 16 u.d.u.r. pozwala ubezpieczycielowi stwierdzić, że jeżeli koszty naprawy przekraczają ustalony procent wartości pojazdu sprzed szkody, szkoda będzie kwalifikowana jako całkowita. Wątpliwe wydaje się jednak stanowisko SOKiK, że postanowienia tego rodzaju w ogóle nie poddają się kontroli przez pryzmat przepisów o klauzulach niedozwolonych (art. $385^{1}-385^{3}$ k.c.), o ile są sformułowane jednoznacznie jako określające główne świadczenia stron ${ }^{17}$. Zupełnie inną rzeczą jest kwestia, czy ubezpieczyciel ma całkowitą swobodę w zakresie określania wysokości stopnia wartości pojazdu sprzed szkody decydującego o nieopłacalności naprawy i kwalifikacji szkody jako całkowitej, a także ocena praktyk polegających na zaniżaniu wartości pojazdu przed szkodą oraz zawyżaniu wartości wraku.

Ostatnie zagadnienie podlega oczywiście ocenie ad casum i wykracza poza zakres pracy. Odpowiedź na pytanie co do swobody w zakresie określenia procenta wartości, powyżej której szkoda będzie kwalifikowana jako całkowita, zależy natomiast od punktu widzenia. Prima facie nic nie stoi na przeszkodzie, by ubezpieczyciel w ogóle wykluczył tzw. kalkulację kosztorysową i w każdym przypadku przewidywał jedynie wypłatę odszkodowania liczonego jako różnica między wartością pojazdu przed szkodą a wartością pojazdu uszkodzonego. Można argumentować, że ubezpieczyciel decyduje o zakresie udzielanej ochrony oraz wysokości pobieranej za to składki. Na rynku oferowane są ubezpieczenia lepsze

16 Por. $\$ 4$ pkt 15 OWU AC PZU SA, $\$ 2$ pkt 18 OWU AC STU ERGO Hestia SA, $\$ 3$ ust. 8 OWU AC TUiR Allianz Polska SA, \$2 pkt 11 OWU AC TUiR Warta SA.

17 Por. uzasadnienie wyroku SA w Warszawie z 27.05.2009 r., VI ACa 1473/08, LEX nr 785833, Klauzule..., 2012, s. 108. SOKiK nie ma przy tym żadnych wątpliwości, że przedmiotem takiej kontroli może być klauzula kształtująca wysokość odszkodowania na poziomie cen netto, jeżeli nie przedstawiono rachunków za naprawę. Co do wykładni pojęcia „główne świadczenia stron”, odesłać należy do rozważań dotyczących postanowień wprowadzających klauzulę proporcji albo wyłączających odpowiedzialność ubezpieczyciela. 
i gorsze, a rzeczą ubezpieczającego jest wybór warunków oraz kosztów ubezpieczenia, które mu odpowiadają.

Takie postawienie sprawy wydaje się jednak nadmiernym uproszczeniem. Ubezpieczenie ma pełnić funkcję ochronną. Ochrona przy wykluczeniu prawa ubezpieczającego do naprawy uszkodzonego pojazdu często byłaby iluzoryczna. W innych państwach europejskich za niedozwolone w rozumieniu dyrektywy Rady 93/13/EWG z 5.04.1993 r. w sprawie nieuczciwych warunków w umowach konsumenckich ${ }^{18}$ uważa się przede wszystkim klauzule umowne, które są dla konsumenta niekorzystne i których przeciętny konsument nie mógł się spodziewać, wziąwszy pod uwagę cel oraz okoliczności umowy ${ }^{19}$. Nie budzi wątpliwości, że przy ocenie zgodności klauzuli z dobrymi obyczajami należy mieć na względzie zwyczaje ukształtowane i stosowane w obrocie ubezpieczeniowym. Skoro zwykle margines, od którego szkoda uważana jest za całkowitą, kształtuje się na poziomie $60-80 \%{ }^{20}$, moim zdaniem przyjąć należy, że niedozwolone są postanowienia kwalifikujące szkodę jako całkowitą, pomimo że koszty naprawy nie przekraczają $60 \%$ wartości pojazdu sprzed szkody. Oczywiście, to nie warunki stosowane powszechnie przez ubezpieczycieli wyznaczają dobre obyczaje, ale na odwrót - dobre obyczaje powinny wyznaczać te warunki. Trzeba jednak wyważyć zakres swobody ubezpieczyciela w zakresie kształtowania OWU AC oraz interes osób poszukujących ochrony ubezpieczeniowej. Wszystkie te uwagi prowadzą do wniosku, że o uznaniu określonej klauzuli za nieważną w świetle art. $353^{1}$ k.c. albo art. $385^{1}$ k.c. będą decydować okoliczności konkretnego przypadku, natomiast określony wyżej pułap 60-70\% traktować należy bardzo orientacyjnie, wystrzegając się automatyzmu.

18 Dz.Urz. UE L 95, s. 29, ze zm.

19 Szczegółowo zob. M. Ziemiak, Postanowienia niedozwolone na tle umów ubezpieczenia. Studium cywilnoprawne, Toruń 2017, s. 79 i n.

20 Por. warunki OWU AC dostępne na stronach internetowych polskich ubezpieczycieli. 


\subsubsection{Podatek VAT}

Kolejna kwestia dotyczy objęcia bądź nieobjęcia odszkodowaniem ubezpieczeniowym podatku VAT. Na gruncie ubezpieczenia OC ukształtował się pogląd, że odszkodowanie ustalone metodą kosztorysową winno uwzględniać ten podatek w zakresie, w jakim poszkodowany nie może obniżyć podatku od niego należnego o kwotę podatku naliczonego ${ }^{21}$. Dla praktyki kwestię tę rozstrzyga uchwała SN z 17.05.2007 r., III CZP 150/06, w której Sąd Najwyższy podsumował swoje dotychczasowe orzecznictwo, stwierdzając, że odszkodowanie przysługujące na podstawie umowy ubezpieczenia odpowiedzialności cywilnej posiadacza pojazdu mechanicznego za szkodę powstałą w związku z ruchem tego pojazdu, ustalone według cen części zamiennych i usług, obejmuje kwotę podatku od towarów i usług (VAT) w zakresie, w jakim poszkodowany nie może obniżyć podatku od niego należnego o kwotę podatku naliczonego. Pogląd SN znalazł również odzwierciedlenie w punkcie 15.2 Wytycznych KNF dotyczących likwidacji szkód komunikacyjnych z 16.12.2014 r. ${ }^{22}$ Sąd Najwyższy nie uzależnia uwzględniania VAT w kwocie odszkodowania od tego, czy VAT został faktycznie zapłacony ${ }^{23}$. Dla porównania przytaczany już wcześniej art. 249 ust. 2 niemieckiego BGB stanowi w zdaniu drugim, że odszkodowanie w kwocie odpowiadającej kosztom przywrócenia do stanu poprzedniego winno uwzględniać VAT, tylko jeżeli został on naliczony.

21 Zob. w szczególności M. Krajewski, Szkoda..., s. 53 i n.

22 Załącznik do uchwały nr 414/2014 Komisji Nadzoru Finansowego z 16.12.2014 r. w sprawie wydania Wytycznych dotyczących likwidacji szkód z ubezpieczeń komunikacyjnych (Dz.Urz. KNF z 2015 r. poz. 11).

23 Wcześniej stanowisko SN bywało rozbieżne, choć przeważał pogląd wyrażony w cytowanej wyżej uchwale z 17.05.2007 r. Pogląd, według którego odszkodowanie winno obejmować VAT jedynie, gdy poszkodowany nie ma prawa do obniżenia należnego od niego VAT o kwotę podatku należnego. Zob. wyrok z 12.01.2006 r., II CK 327/05; wyrok z 7.08.2003 r., IV CKN 387/01; wyrok z 20.02.2002 r., V CKN 908/00, uchwała z 15.11.2001 r., III CZP 68/01; wyrok z 22.08.2001 r., V CKN 415/00, LEX nr 602738; wyrok z 18.01.2001 r., V CKN 193/00, LEX nr 53113; uchwała z 16.10.1998 r., III CZP 42/98, OSNC 1999/4, poz. 69, uchwała z 22.04.1997 r., III CZP 14/97, OSNC 1997/8, poz. 103. Co do późniejszych orzeczeń, zob. wyrok z 19.11.2015 r., IV CSK 764/14, LEX nr 1962543. 
W ustawie o działalności ubezpieczeniowej i reasekuracyjnej zrezygnowano z odpowiednika art. 17a ustawy o działalności ubezpieczeniowej z 2003 r. Przepis ten, dotyczący zarówno ubezpieczeń OC, jak i ubezpieczeń mienia, stanowił, że w przypadku okazania zakładowi ubezpieczeń przez podmiot, któremu przysługuje odszkodowanie, niebędący płatnikiem podatku od towarów i usług, faktury (faktur) za naprawę szkody komunikacyjnej zakład ubezpieczeń jest zobowiązany uwzględnić w odszkodowaniu podatek od towarów i usług. Przepis wykładany a contrario mógł prowadzić do wniosku, że w przypadku nieokazania rachunków odszkodowanie nie musiało uwzględniać VAT ${ }^{24}$. Według uzasadnienia nowej ustawy przepis był zbędny z uwagi na ukształtowaną linię orzecznictwa, a nadto odczytywany dosłownie wskazywał wręcz na mniejszy niż przyznawany przez judykaturę zakres uprawnień poszkodowanych, uzależniając zwrot podatku od przedstawienia faktur.

Na gruncie ubezpieczeń mienia w odniesieniu do tej kwestii ścierają się dwa zasadnicze stanowiska. Według pierwszego z nich, dominującego w literaturze, ubezpieczyciel, mając swobodę w zakresie kształtowania ograniczeń odpowiedzialności w OWU, ma również swobodę co do określenia, w jakiej mierze zwraca podatek VAT. W szczególności może uzależnić jego zwrot od przedstawienia faktur za naprawę, natomiast zasady dotyczące ubezpieczenia OC nie mogą być w tym zakresie stosowane $^{25}$. Drugie stanowisko prezentuje SOKiK, którego zdaniem postanowienie umów OWU AC odbiegające od praktyki ukształtowanej na gruncie ubezpieczenia OC stanowią klauzule niedozwolone. Sąd ten powołuje się przy tym na zasadę, że uszczerbek w majątku poszkodowanego powstaje z chwilą wypadku, a jego wysokość nie jest uzależniona od tego, czy naprawa zostaje dokonana, oraz na cytowaną wyżej uchwałę 7 sędziów SN. Zdaniem SOKiK okoliczność, że powołana wyżej uchwała SN dotyczy ubezpieczenia OC, pozostaje bez znaczenia ${ }^{26}$.

24 Zob. w szczególności M. Krajewski, Ubezpieczenie..., s. 295-297, oraz wskazana tam literatura. Zdaniem cytowanego autora wykładnia a contrario była nieuprawniona.

25 Zob. przede wszystkim M. Wałachowska, M. Ziemiak, Odszkodowanie z ubezpieczenia autocasco a VAT, WU 2012/1, s. 31 i n.

26 Klauzule przewidujące wypłatę odszkodowania z ubezpieczenia autocasco bez podatku VAT albo uzależniające zwrot tego podatku od przedstawienia faktur za naprawę pojazdu wpisano do rejestru klauzul niedozwolonych prowadzonego przez 
Omawiany problem dosyć dokładnie analizuje B. Chmielowiec z Biura dawnego Rzecznika Ubezpieczonych ${ }^{27}$. Cytowany autor wskazuje z jednej strony, że powoływanie się przez SOKiK na zasady rządzące ustalaniem odszkodowania w zakresie obowiązkowego ubezpieczenia OC posiadaczy pojazdów komunikacyjnych jest nietrafne, z drugiej jednak strony swobodę zakładu ubezpieczeń w zakresie kształtowania treści OWU ograniczają zasady wynikające z art. $353^{1}$ k.c. oraz $385^{1}$ k.c. (w zakresie obrotu konsumenckiego), przy uwzględnieniu szczególnego charakteru umowy ubezpieczenia jako umowy najwyższego zaufania.

Ostatecznie B. Chmielowiec aprobuje rozstrzygnięcia SOKiK, w konkretnych przypadkach dochodząc jednocześnie do wniosku, że konstrukcja OWU AC przewidująca wypłatę odszkodowania dla ubezpieczonego konsumenta w kwocie netto bez podatku VAT w przypadku rozliczeń metodą kosztorysową jest dopuszczalna po spełnieniu trzech warunków, które niwelują ryzyko niedozwolonego charakteru tych postanowień. Po pierwsze, konsument powinien mieć zapewnioną możliwość wyboru sumy ubezpieczenia (w wartościach netto lub brutto) na etapie zawierania umowy ubezpieczenia. Po drugie, konsument powinien zostać przed zawarciem umowy jednoznacznie poinformowany, że konsekwencją wyboru sumy ubezpieczenia w wartościach netto, bez podatku VAT, będzie wypłata kwoty odszkodowania również w wartościach netto i postanowienie umowne powinno zostać wyeksponowane we wzorcu umownym. Po trzecie w końcu, powinna zostać odpowiednio zróżnicowana składka w przypadku zawarcia ubezpieczenia na sumę ubezpieczenia netto (składka odpowiednio mniejsza) oraz na sumę ubezpieczenia brutto (składka odpowiednio wyższa) ${ }^{28}$.

UOKiK pod numerami 1265 (wyrok SA w Warszawie z 23.05.2007 r., VI ACa 110/07, LEX nr 1643035), 2001 (wyrok SA w Warszawie z 27.05.2009 r., VI ACa 1473/08, LEX nr 785833, Klauzule..., 2012, s. 105) oraz 2012 (wyrok SA w Warszawie z 9.02.2010 r., VI ACa 782/09, LEX nr 844686, Klauzule..., 2012, s. 117).

27 B. Chmielowiec, Podatek od towarów i ustug (VAT) przy wypłacie odszkodowań z umów ubezpieczenia w zakresie ubezpieczeń gospodarczych, RU 2014/2, oraz B. Chmielowiec, Podatek VAT $w$ rozliczeniu kosztorysowym $w$ ramach ubezpieczenia autocasco, MU 2011/45.

28 B. Chmielowiec, Podatek od towarów..., s. 28. 
Nawiązując do wcześniejszych uwag dotyczących rozróżniania udziału własnego oraz franszyzy integralnej, zgodzić się należy z trzecim ze wskazanych warunków. W moim przekonaniu niedopuszczalne jest ustalenie składki od wartości brutto przedmiotu ubezpieczenia przy jednoczesnym postanowieniu, że odszkodowanie będzie zawsze wypłacane w kwotach netto. Omawianą sytuację można by porównać w istocie do franszyzy integralnej na poziomie $23 \%$ wartości. Jest ona w moim przekonaniu nie do pogodzenia $\mathrm{z}$ zasadą wzajemności umowy ubezpieczenia. Nie oznacza to jednak, że niedopuszczalne jest zastrzeżenie w OWU, uzależniające zwrot VAT-u od jego faktycznego zapłacenia.

Wątpliwe wydają się natomiast dwa pierwsze warunki. Co do pierwszego, a mianowicie obowiązku zapewnienia potencjalnemu ubezpieczającemu przed zawarciem umowy wyboru ubezpieczenia w wartości netto i brutto, nie bardzo wiadomo, skąd ma wynikać taki obowiązek. Co do drugiego, postulat, by ważniejsze wyłączenia i ograniczenia odpowiedzialności były wyeksponowane w treści wzorca, jest z pewnością słuszny. De lege lata trudno jednak uznać, że postanowienia, które nie zostały wyeksponowane we wzorcu, można uznać za niejednoznaczne bądź nieważne tylko z tej przyczyny. Kwestia była już wyjaśniana przy okazji omawiania wyroku SN z 16.10.2014 r., III CSK 302/13, w którym Sąd Najwyższy uznał za niejednoznaczną klauzulę proporcji „ukrytą” $\mathrm{w} \$ 80$ OWU.

Cytowany już art. 17 u.d.u.r. nakazujący poinformowanie ubezpieczającego, które postanowienia określają ograniczenia odpowiedzialności umożliwiające obniżenie odszkodowania, rozwiązuje problem jedynie do pewnego stopnia. Brak realizacji przez ubezpieczyciela obowiązku $\mathrm{z}$ art. 17 u.d.u.r. może wprawdzie w pewnych okolicznościach sprawić, że klauzula zostanie uznana za niejednoznaczną. Z drugiej strony jednak trudno przyjąć, że zawarcie określonego postanowienia na pierwszej stronie OWU w jednej z rubryk umieszczanej tam tabelki powoduje jej „wyeksponowanie”29. Jak wskazywano, ustawodawca nie rozwiązał

29 Por. M. Krajewski [w:] Ustawa o działalności ubezpieczeniowej i reasekuracyjnej. Komentarz, red. M. Szczepańska, P. Wajda, Warszawa 2017, komentarz do art. 17, teza 9 i 11. 
problemu również w art. 8 ust. 4 u.d.u..$^{30}$, ponieważ przewidziany tam dokument informujący o produkcie ubezpieczeniowym zawierać ma główne wyłączenia odpowiedzialności zakładu ubezpieczeń, uprawniające do odmowy wypłaty odszkodowania i innych świadczeń, nie ma jednak mowy o ograniczeniach odpowiedzialności. Niezależnie od tego nawet realizacja obowiązku wskazania "głównych wyłączeń odpowiedzialności” w dokumencie, który ma być krótki, będzie trudna.

Dodatkowo - w moim przekonaniu - trudne do obrony jest stanowisko, wedle którego klauzula przewidująca wypłatę odszkodowania w kwocie odpowiadającej kosztom części i robocizny potrzebnej do przywrócenia do stanu poprzedniego w wartości netto nie dotyczy głównych świadczeń stron w sytuacji, gdy na podstawie wartości netto wyliczona została składka. Tego rodzaju klauzula określa wszak w sposób bezpośredni wysokość świadczenia pieniężnego ubezpieczyciela wypłacanego w razie zajścia wypadku. Opisywane klauzule w określonych przypadkach mogą być uznane za niejednoznaczne. Wątpliwe jest jednak, czy sama rozbieżność pomiędzy sposobem ustalania odszkodowania w razie wyboru przez ubezpieczającego tzw. wariantu serwisowego a sposobem ustalania odszkodowania w razie wyboru wariantu kosztorysowego jest wystarczająca. Istotne mogą być przede wszystkim sprzeczności pomiędzy treścią polisy a treścią OWU albo sprzeczności pomiędzy poszczególnymi postanowieniami OWU. Sprzeczności takie polegać mogą szczególnie na stworzeniu z jednej strony wrażenia, że ubezpieczenie zapewnia pełną ochroną, $\mathrm{z}$ drugiej strony zaś na ustalaniu odszkodowania na podstawie cen części i robocizny w wartościach netto.

Podsumowując rozważania, wydaje się, że ubezpieczyciel co do zasady ma prawo wskazać, że odszkodowanie ustalane będzie na podstawie cen netto, a tym bardziej zastrzec, że w razie wyboru wariantu kosztorysowego odszkodowanie będzie obejmować podatek VAT tylko w sytuacji, gdy ubezpieczający jest w stanie udowodnić, że koszt tego podatku został rzeczywiście poniesiony. Jeżeli klauzule tego rodzaju są jednoznaczne i ani polisa, ani ogólne warunki umów nie starają się stworzyć błędnego wrażenia, że ubezpieczenie zapewnia pełną ochronę, wtedy trudno je

30 Por. art. 8 ust. 6 u.d.u. 
zakwestionować. Jak już wskazywano, są ubezpieczenia lepsze i gorsze, przy czym te drugie zwykle kosztują mniej ${ }^{31}$. W określonych sytuacjach jednak klauzule tego rodzaju będzie można uznać za klauzule niedozwolone w umowach z konsumentami albo nawet wykraczające poza zakres swobody umów wyznaczony art. $353^{1}$ k.c. Ta ostatnia sytuacja będzie zachodzić, gdy ubezpieczyciel, ustalając składkę na podstawie sumy ubezpieczenia uwzględniającej wartość brutto, w istocie nie będzie brał pod uwagę wypłaty odszkodowania odpowiadającego cenom brutto.

\subsubsection{Ubytek wartości handlowej i wynagrodzenie pełnomocnika}

Innym budzącym wątpliwości na gruncie ubezpieczenia OC składnikiem odszkodowania jest tzw. ubytek wartości handlowej pojazdu poddanego naprawie. Problem streszcza się w pytaniu, czy w sytuacji, gdy naprawiony pojazd, pomimo profesjonalnie przeprowadzonej reperacji jest wart mniej niż przed wypadkiem, odszkodowanie może objąć również ubytek jego wartości. Sąd Najwyższy zastanawiał się nad tą kwestią wielokrotnie. Najistotniejsze znaczenie dla praktyki w tej mierze ma uchwała Sądu Najwyższego z 12.10.2001 r., III CZP 57/01, zgodnie z którą odszkodowanie za uszkodzenie samochodu może obejmować oprócz kosztów jego naprawy także zapłatę sumy pieniężnej, odpowiadającej różnicy między wartością tego samochodu przed uszkodzeniem i po naprawie ${ }^{32}$.

31 Por. wypowiedź M. Orlickiego przytoczona przez A. Popiołek, Odszkodowanie z VAT czy bez? Ubezpieczyciel kontra UOKiK, „Gazeta Wyborcza” z 3.02.2012 r., http:// next.gazeta.pl/Gospodarka/1,122003,11080550,Odszkodowanie_z_VAT_czy_bez_ Ubezpieczyciel_kontra.html (dostęp: 5.11.2018 r.).

32 Uchwała SN z 12.10.2001 r., III CZP 57/01, OSNC 2002/5, poz. 57, z glosą aprobującą A. Szpunara, OSP 2002/5, poz. 61, oraz krytyczną E. Kowalewskiego i M. Nestorowicza, PA 2003/3, s. 70. Stanowisko SN w tej mierze ewoluowało - por. wyrok SN z 3.02.1997 r., III CRN 450/70, OSNC 1971/11, poz. 205, oraz uchwała SN z 19.03.1998 r., III CZP 72/97, OSNC 1998/9, poz. 133. Również te kwestie w odniesieniu do ubezpieczenia OC analizuje M. Krajewski w cytowanym wyżej Raporcie. Zob. M. Krajewski, Szkoda..., s. 60 i n. 
W doktrynie obecnie nikt nie wyklucza możliwość objęcia odszkodowaniem ubytku wartości handlowej pojazdu. Część autorów, w szczególności E. Kowalewski, broni jednak poglądu, że poszkodowany nie może domagać się zasądzenia dodatkowo sumy obejmującej utratę wartości handlowej w sytuacji, gdy wybrał naprawienie szkody w drodze restytucji naturalnej poprzez pokrycie kosztów naprawy, ponieważ z chwilą dokonania wyboru jednej z alternatywnych form naprawienia szkody druga staje się niedostępna. Ostatecznie jednak również E. Kowalewski dopuszcza objęcie odszkodowaniem ubytku wartości handlowej w określonym przypadkach, przede wszystkim gdy uszkodzeniu uległ pojazd nowy, luksusowy i wcześniej nienaprawiany ${ }^{33}$.

Inni autorzy zdają się skłaniać do poglądu, że objęcie ubytku wartości handlowej pojazdu odszkodowaniem staje się standardem rynkowym, choć może być wykluczone w określonych sytuacjach, przede wszystkim gdy uszkodzeniu uległ pojazd już wcześniej naprawiany albo gdy reperacja polega na wymianie uszkodzonych części na nowe ${ }^{34}$. Podobny pogląd prezentują przedstawiciele Rzecznika Finansowego ${ }^{35}$. Uzasadnieniem teoretycznym tego drugiego stanowiska jest stwierdzenie, że zastosowanie każdego ze sposobów naprawienia szkody jest wprawdzie ekskluzywne,

33 E. Kowalewski, M. Nesterowicz, Glosa..., s. 73-74; E. Kowalewski, Odszkodowanie za ubytek wartości..., s. 31-32; E. Kowalewski, Deminuacja wartości handlowej pojazdu poddanego naprawie jako przedmiot odszkodowania - koincydencja czy alternatywność roszczeń poszkodowanego [w:] Odszkodowanie za ubytek wartości handlowej pojazdu poddanego naprawie, red. E. Kowalewski, Toruń 2012, s. 64-65.

34 Tak M. Kaliński, Tak zwany ubytek wartości handlowej jako składnik odszkodowania ubezpieczeniowego, PS 2012/10; M. Kaliński, Odpowiedzialność odszkodowawcza [w:] System Prawa Prywatnego, t. 6, Prawo zobowiąań - część ogólna, red. A. Olejniczak, Warszawa 2014, s. 178; K. Ludwichowska-Redo, Odszkodowanie za ubytek wartości handlowej pojazdu po wypadku komunikacyjnym (na tle prawnoporównawczym), PiP 2012/11, s. 107. Zob. również M. Piwowar, O sposobach..., s. 87 i wskazana tam literatura.

35 Zob. Stanowisko Rzecznika Ubezpieczonych w sprawie tzw. potrąceń amortyzacyjnych dokonywanych przez zakłady ubezpieczeń w przypadku likwidacji szkody w ramach ubezpieczenia OC posiadaczy pojazdów mechanicznych dostępne na stronie internetowej Rzecznika Finansowego oraz wytyczną nr 10 Wytycznych KNF dotyczące likwidacji szkód z ubezpieczeń komunikacyjnych. Zob. również A. Olędzka, Obniżenie wartości handlowej pojazdu po naprawie a odszkodowanie z tytułu ubezpieczenia komunikacyjnego OC, WU 2012/1, oraz A. Łazarska, Szacowanie szkody za utratę możliwości korzystania $z$ utraconego pojazdu, PS 2015/5. 
jednak w sytuacji, gdy reperacja, przywracając rzeczy funkcjonalność, nie przywraca jej pełnej wartości, naprawienie w ramach jednej szkody polegać może zarówno na restytucji, jak też, uzupełniająco, na zapłacie sumy pieniędzy ${ }^{36}$.

Pierwsza koncepcja, pozornie czystsza konstrukcyjnie, w istocie jest trudna do pogodzenia z teorią różnicy. Nie wydaje się, by ustawodawca, nadając formom naprawienia szkody charakter upoważnienia przemiennego, zakładał, że rozłączny charakter każdej z możliwości jest istotniejszy od zasady pełnego odszkodowania. Ubytek wartości handlowej, jeżeli rzeczywiście występuje, stanowi immanentną część szkody. Szkoda, o której mowa, ma postać damnum emergens, jest szkodą aktualną, nie zaś przyszłą. Nie można jej również kwalifikować jako szkody czysto handlowej (pure economic loss), ponieważ stanowi ona konsekwencję fizycznego uszkodzenia samochodu, w stosunku do którego poszkodowanemu służy określone prawo podmiotowe ${ }^{37}$. Pośredni charakter uszczerbku polegającego na utracie wartości handlowej pojazdu nie przeszkadza objęciu go odszkodowaniem. Nie budzi bowiem większych wątpliwości, że szkody pośrednie podlegają w prawie polskim naprawieniu, jeżeli tylko wszystkie ogniwa związku przyczynowego dają się zamknąć formułą przyczynowości adekwatnej ${ }^{38}$.

Powyższe uwagi prowadzą prima facie do wniosku, że ubytek wartości handlowej pojazdu powinien podlegać naprawieniu nie tylko w ubezpieczeniu odpowiedzialności cywilnej, ale również w ubezpieczeniu autocasco. Skonkretyzowany charakter szkody ubezpieczeniowej ucieleśnionej w interesie stanowiącym przedmiot ubezpieczenia nie przeszkadza wszak stosowaniu do tej szkody teorii różnicy, która znajduje

${ }^{36}$ Por. w szczególności przytaczane wyżej opracowania M. Kalińskiego i K. Ludwichowskiej-Redo.

37 Kwestia pure economic loss została poruszona w rozdziale 3 przy omawianiu szkody jako przesłanki odpowiedzialności ubezpieczeniowej.

${ }_{38}$ Podobnie K. Krupa-Lipińska, Ubytek wartości handlowej w kontekście rodzajów szkód oraz problematyki związku przyczynowego [w:] Odszkodowanie za ubytek wartości handlowej pojazdu poddanego naprawie, red. E. Kowalewski, Toruń 2012, s. 80-95. Co do szkód pośrednich, zob. przede wszystkim B. Lackoroński, Odpowiedzialność... 
zastosowanie do ustalania odszkodowania ubezpieczeniowego, tyle że w granicach ograniczonych teorią lokalizacji szkody.

W dawnym wyroku z 3.02.1971 r., III CRN 450/70, Sąd Najwyższy odmówił objęcia ubytku wartości handlowej pojazdu odszkodowaniem z ubezpieczenia autocasco. Według tezy tego wyroku, jeżeli w wyniku naprawy przywrócono uszkodzony samochód do stanu poprzedniego (art. $363 \$ 1$ k.c.), właściciel samochodu nie może żądać zasądzenia ponadto sumy pieniężnej odpowiadającej obniżeniu „wartości handlowej" samochodu. Niezależnie od kwestii, czy przywrócenie do stanu poprzedniego w ogóle dokonuje się w sytuacji, gdy pojazd poddany naprawie wart jest mniej niż pojazd bezwypadkowy, trafność cytowanego wyroku została zanegowana w przytoczonej wyżej uchwale z 12.10.2001 r. W uzasadnieniu uchwały Sąd Najwyższy stwierdził, że rozstrzygnięcie z 1970 r. ma obecnie wartość tylko historyczną, gdyż zapadło w warunkach gospodarki centralnie kierowanej i ułomnego, szczątkowego rynku. Sąd Najwyższy wydaje się zatem obecnie przyjmować, że utrata wartości handlowej winna być rekompensowana także w ramach odszkodowania $\mathrm{z}$ ubezpieczenia AC.

Przypadki powiększania odszkodowania z ubezpieczenia AC o ubytek wartości handlowej nie występują jednak we współczesnej praktyce ubezpieczeniowej. Stosowane przez ubezpieczycieli OWU AC zwykle bardzo precyzyjnie wskazują metody wyliczania odszkodowania za szkodę częściową, rozróżniając metodę fakturową (serwisową) oraz kosztorysową często $\mathrm{w}$ różnych wariantach, $\mathrm{z}$ zasady jednak nie przewidują poza zwrotem udokumentowanych albo nieudokumentowanych kosztów naprawy odszkodowania za ubytek wartości handlowej poddanego naprawie pojazdu. W literaturze podkreśla się, że funkcję podobną do klauzuli w AC, pozwalającej na kompensację ubytku wartości handlowej poddanego naprawie pojazdu, pełni w pewnym stopniu dobrowolne ubezpieczenie straty finansowej GAP (Guaranteed Asset Protection), które w zależności od oferty pozwolić może na uzyskanie 
w przypadku szkody całkowitej w pojeździe dodatkowego odszkodowania w wysokości $20 \%$ wartości rynkowej samochodu ${ }^{39}$.

W odniesieniu do opisanej praktyki można postawić kilka pytań. Czy określenie w OWU sposobu obliczania wysokości odszkodowania za szkodę częściową przy jednoczesnym braku wyraźnego ograniczenia odpowiedzialności za ubytek wartości handlowej pozwala ubezpieczycielowi twierdzić, że za taki ubytek nie odpowiada, niezależnie od okoliczności konkretnego stanu faktycznego? Czy w sytuacji, gdy składka została ustalona w proporcji do sumy ubezpieczenia odpowiadającej wartości ubezpieczenia, uprawnione jest twierdzenie, że odszkodowanie w ramach autocasco z zasady nie obejmuje ubytku wartości handlowej pojazdu poddanego naprawie, który w przypadku pojazdów względnie nowych jest rynkowym standardem? Ewentualnie, niezależnie od zwykłych celów i zakresu tzw. ubezpieczenia GAP, czy właściwa jest praktyka polegająca na pobieraniu przez ubezpieczyciela dodatkowych składek za ochronę w zakresie, który przynajmniej prima facie mieści się w zakresie ubezpieczenia autocasco? Jak należy wykładać termin „postanowienia określające główne świadczenia stron” na gruncie art. $385^{1}$ k.c.?

Odpowiedź na tak postawione pytania zależy w dużej mierze od stanowiska w podstawowej kwestii charakteru prawnego odpowiedzialności ubezpieczeniowej, która została rozstrzygnięta w pierwszym rozdziale pracy. Odpowiedzialność ubezpieczyciela jest odpowiedzialnością w sensie prawnym, a odszkodowanie ubezpieczeniowe, będąc odszkodowaniem umownym, nie przestaje być odszkodowaniem. Umowa ubezpieczenia może oczywiście wyznaczać jego granice, jeżeli jednak wyraźnie tego nie czyni i z przepisów szczególnych o umowie ubezpieczenia nie wynika nic innego, zastosowanie znajdują reguły ogólne. Jeżeli zakład ubezpieczeń pobiera składkę od określonej sumy ubezpieczenia, nie może nie brać pod uwagę ryzyka wypłaty odszkodowania odpowia-

39 B. Chmielowiec, Utrata wartości handlowej pojazdu, MU 2012/49, przypis 1. Angielska nazwa tego ubezpieczenia oraz analiza OWU dostępnych na stronach internetowych polskich ubezpieczycieli wskazuje jednak, że ubezpieczenie to nakierowane jest przede wszystkim na ochronę przed utratą wartości pojazdu w miarę upływu czasu jego użytkowania. 
dającego tej sumie. Zasady współżycia społecznego i dobre obyczaje powinny determinować treść OWU, a nie na odwrót. Termin „główne świadczenia stron" należy odnosić jedynie do granic odszkodowania ubezpieczeniowego bezpośrednio powiązanych z wysokością składki ${ }^{40}$.

Wszystkie powyższe uwagi prowadzą do tezy, że postanowienia OWU nieprzewidujące wypłaty odszkodowania odpowiadającego ubytkowi wartości handlowej pojazdu mogą być w określonych sytuacjach uznane za klauzule niedozwolone, a nawet za wykraczające poza dopuszczalny zakres granic swobody umów. Dotyczyć to będzie przede wszystkim ubezpieczenia nowych luksusowych pojazdów, gdy ubytek wartości handlowej będzie stanowić istotną część szkody. Sformułowana teza może wydać się kontrowersyjna, stanowi jednak konsekwencję wcześniej uzasadnionych założeń ogólnych.

Znacznie mniej kontrowersyjna i prostsza jest odpowiedź na pytanie, czy odszkodowaniem w ramach ubezpieczenia mienia może zostać objęty koszt usług pełnomocnika w postępowaniu przedsądowym ${ }^{41}$, czy też koszt opinii rzeczoznawcy. W rozdziale o przesłankach odpowiedzialności odszkodowawczej ubezpieczyciela opowiedziano się za stanowiskiem, że zasada lokalizacji szkody wyklucza objęcie ubezpieczeniem mienia utraconych korzyści, chyba że właśnie one stanowiły przedmiot ubezpieczenia ${ }^{42}$. To samo dotyczy wydatków pośrednio związanych ze szkodą ucieleśnioną w przedmiocie ubezpieczenia. Konkluzja ta wyznacza odpowiedź na pytanie o możliwość objęcia odszkodowaniem w ubezpieczeniu mienia kosztów wynagrodzenia pełnomocnika i innych wydatków pośrednio związanych z poniesioną szkodą.

40 Co do tej kwestii, zob. przede wszystkim M. Ziemiak, Postanowienia..., s. 352-364. Cytowany autor szeroko omawia problem, nie zajmuje jednak wyraźnego stanowiska.

41 Problem ten i podobny, dotyczący zwrotu kosztów rzeczoznawcy, który wyda opinię prywatną na zlecenie poszkodowanego, są przedmiotem zainteresowania doktryny i orzecznictwa w odniesieniu do ubezpieczenia OC. Zob. M. Krajewski, Szkoda..., s. 80 i n. oraz wskazana tam literatura i orzecznictwo.

42 Pogląd przeciwny prezentują M. Kaliński, Zasada..., cz. 2, s. 29-30, 43; M. Krajewski, Umowa ubezpieczenia. Art. 805-834 KC..., 2016, s. 565. Szerzej zob. uwagi zawarte $\mathrm{w}$ rozdziale trzecim. 
Koszty wynagrodzenia pełnomocnika mogą być objęte szczególnym rodzajem ubezpieczenia. Mowa oczywiście o ubezpieczeniu ochrony prawnej, które często poza zwrotem kosztów pełnomocnika prawnego przewiduje również możliwość domagania się od ubezpieczyciela porad prawnych na etapie przedsądowym. Ubezpieczenie to stanowi szczególny rodzaj ubezpieczenia wydatków, wyraźnie przewidziany w załączniku do ustawy o działalności ubezpieczeniowej i reasekuracyjnej, podobnie jak wyraźnie przewidziane jest tam ubezpieczenie utraty zysków ${ }^{43}$. Nie oznacza to jednak, że koszty pełnomocnika objęte są ubezpieczeniem casco albo ubezpieczeniem szkód rzeczowych. W ubezpieczeniach tych wartość i suma ubezpieczenia obejmują właściwy przedmiot ubezpieczenia zwykle ucieleśniony w konkretnej rzeczy. Wartość ani suma ubezpieczenia nie obejmują natomiast kosztów wynagrodzenia pełnomocnika, które nie podlega zwrotowi, chyba że strony coś odmiennego przewidziały w warunkach ubezpieczenia. W praktyce tego typu postanowienia w ogólnych warunkach ubezpieczeń casco oraz ubezpieczeń szkód rzeczowych wyobrazić sobie dosyć trudno. Rozważania dotyczące objęcia kosztów wynagrodzenia pełnomocnika odszkodowaniem w ubezpieczeniu odpowiedzialności cywilnej nie mają zastosowania do ubezpieczenia mienia ${ }^{44}$.

43 Szerzej co do ubezpieczenia ochrony prawnej zob. uwagi zawarte w ostatnim rozdziale pracy dotyczącym możności naprawienia przez ubezpieczyciela szkody w formie niepieniężnej.

44 Zagadnienie ma bogate orzecznictwo i literaturę, które nie będą szerzej przytaczane. Aktualne stanowisko SN zawiera uchwała SN (7) z 13.03.2012 r., III CZP 75/11, OSNC 2012/7-8, poz. 81. Co do literatury, zob. przykładowo: E. Kowalewski, M. Nesterowicz, E. Bagińska, M. Wałachowska, M.P. Ziemiak, W.W. Mogilski, M. Serwach, W sprawie refundacji kosztów wynagrodzenia pełnomocnika w ubezpieczeniowym postępowaniu likwidacyjnym, WU 2011/4; T. Młynarski, Zwrot kosztów ustanowienia pełnomocnika na etapie postępowania przedsądowego - stan sprzed uchwały i po uchwale Sądu Najwyższego $z$ dnia 13 marca 2012 r., RU 2012/2; A. Daszewski, Zwrot kosztów ustanowienia pełnomocnika na etapie postępowania przedsądowego w świetle uchwały Sądu Najwyższego z dnia 13 marca 2012 r., RU 2012/2; M. Wałachowska, M. Ziemiak, Kompensacja kosztów pomocy prawnej w postępowaniu likwidacyjnym, PiP 2014/1. Zob. również cytowany wyżej raport autorstwa M. Krajewskiego, Szkoda..., s. 80 i n. oraz wskazana tam literatura i orzecznictwo. 


\subsection{Wyrównanie korzyści z uszczerbkiem i miarkowanie odszkodowania ubezpieczeniowego}

\subsubsection{Wyrównanie korzyści z uszczerbkiem}

Kolejna istotna kwestia dotyczy stosowania na gruncie ubezpieczeń majątkowych zasady wyrównania korzyści z uszczerbkiem (compensatio lucri cum damno) oraz łączenia odszkodowania ubezpieczeniowego $\mathrm{z}$ innymi świadczeniami. Jak wiadomo, mianem wyrównania korzyści z uszczerbkiem określa się sytuację, gdy to samo zdarzenie jest dla poszkodowanego źródłem strat i korzyści. Adam Szpunar trafnie zauważył, że compensatio lucri cum damno obejmuje bardzo różne stany faktyczne, zaś przeprowadzenie ścisłej cezury między zastosowaniem omawianej konstrukcji a ustaleniem rozmiarów szkody jest niemożliwe ${ }^{45}$. Maciej Kaliński wskazuje, że w omawianych przypadkach w istocie nie dochodzi do redukcji, względnie miarkowania ustalonego odszkodowania. Chodzi raczej o element ustalenia rozmiaru prawnie relewantnego uszczerbku oraz konsekwencję teorii różnicy, sąd nie ma zatem w tym zakresie swobody ${ }^{46}$.

Trudności w rozgraniczeniu między ustaleniem odszkodowania a compensatio lucri cum damno świetnie ilustruje sfera ubezpieczeń gospodarczych, podawana zwykle jako klasyczny przykład zastosowania tej drugiej instytucji ${ }^{47}$. Wskazywane w doktrynie i orzecznictwie przesłanki zastosowania zasady compensatio lucri cum damno wymagają zwykle tożsamości zdarzenia będącego źródłem korzyści i uszczerbku albo adekwatnego związku przyczynowego między zdarzeniem szkodzącym i korzyścią, ewentualnie zaś obydwu wskazanych przesłanek ${ }^{48}$. Jak łatwo zauważyć, w zakresie ubezpieczeń paradoksalnie brakuje ich obydwu.

45 M. Kaliński, Szkoda..., s. 459; M. Śmigiel, Zasada compensatio lucri cum damno a świadczenia z ubezpieczeń gospodarczych, PUG 2001/4, s. 14; A. Szpunar, Ustalenie odszkodowania w prawie..., s. 95-96; A. Szpunar, Odszkodowanie..., s. 78.

46 M. Kaliński, Szkoda..., s. 460.

47 Tak przykładowo A. Szpunar, Ustalenie odszkodowania w prawie..., s. 104.

48 M. Kaliński, Szkoda..., s. 460-461 i wskazana tam literatura. 
W sytuacji gdy poszkodowany przez osobę trzecią ma również roszczenie do ubezpieczyciela, roszczenie to wynika z zawarcia umowy ubezpieczenia, które jest zdarzeniem odrębnym od zdarzenia szkodzącego i równocześnie stanowi causa interveniens w łańcuchu związku przyczynowego między zdarzeniem szkodzącym a uzyskaniem korzyści ${ }^{49}$.

Być może problem sprowadza się do tego, że samo wyrównanie korzyści z uszczerbkiem nie jest skodyfikowaną instytucją prawną. Jak wiadomo, Kodeks cywilny, w odróżnieniu od Kodeksu zobowiązań, nie zawiera w tej mierze żadnych regul. $\mathrm{W}$ istocie compensatio lucri cum damno jest swego rodzaju zdroworozsądkową operacją stanowiącą prostą konsekwencję założenia, że szkoda stanowi różnicę między dwoma stanami majątkowymi: obecnym, istniejącym na skutek zdarzenia szkodzącego, i hipotetycznym, który istniałby, gdyby zdarzenie szkodzące nie miało miejsca ${ }^{50}$. W istocie więc o tym, czy w określonych przypadkach możliwa jest kumulacja świadczenia ubezpieczeniowego z innymi świadczeniami, decyduje charakter świadczenia ubezpieczeniowego. Jeżeli ma ono charakter odszkodowawczy, a tak jest w ubezpieczeniu mienia, to nie może być kumulowane z odszkodowaniem z innych źróde ${ }^{51}$.

Powyższe uwagi można zilustrować dość banalnym przykładem pochodzącym z praktyki. Podczas podróży lotniczej do Ameryki zostaje zagubiony bagaż ubezpieczającego stanowiący przedmiot ubezpieczenia. Szkoda zostaje zgłoszona ubezpieczycielowi, który kwestionuje wartość znajdujących się w bagażu garniturów, koszul i galanterii, domagając się rachunków za ich zakup. Nie wdając się w rozważania dotyczące zasad i granic odpowiedzialności przewoźnika lotniczego, powiedzieć można, że odpowiada on za poniesioną przez ubezpieczającego szkodę. Ubezpieczający nie może zatem domagać się odszkodowania ubezpieczeniowego, jeżeli przewoźnik zapłacił odszkodowanie lub deklaruje jego dobrowolną zapłatę. W opisanej sytuacji dalsza korespondencja $\mathrm{z}$ ubezpieczycielem mająca na celu udowodnienie wartości utraconych rzeczy traci sens. Ubezpieczyciel, płacąc ewentualnie przed przewoź-

\footnotetext{
49 Podobnie, jak się zdaje, M. Śmigiel, Zasada..., s. 14-15.

50 Por. A. Szpunar, Ustalenie odszkodowania w prawie..., s. 106.

${ }^{51}$ Podobnie, jak się zdaje, M. Śmigiel, Zasada..., s. 16.
} 
nikiem, wstąpiłby w prawa ubezpieczającego do wysokości zwróconej kwoty na mocy art. $828 \$ 1$ k.c. Wnioski te wydają się oczywiste dla prawnika. Laik może jednak myśleć, że skoro „wykupił ubezpieczenie” (zapłacił składkę ubezpieczeniową), to przysługują mu świadczenia $\mathrm{z}$ dwóch źródeł.

Obawy odnośnie do stanu wiedzy przeciętnego obywatela potwierdza sytuacja z 2010 r., kiedy rząd zdecydował przyznać osobom poszkodowanym na skutek powodzi zasiłki z pomocy społecznej, wskazując jednocześnie, że osoby ubezpieczone mogą poza zasiłkiem domagać się odszkodowania. Premier Donald Tusk stwierdził wtedy, że „Nie może być kary dla tego, kto się ubezpieczył, ale nie może zostać bez pomocy ten, kto nie był ubezpieczony. Pomoc jest niezbędna dla tych, którzy np.: stracili dom, ale ten kto był ubezpieczony ma ten bonus, że ma te swoje dodatkowe pieniądze"52.

Marcin Orlicki, komentując decyzję rządu D. Tuska, wskazuje, że w sytuacji, gdy poszkodowany na podstawie rachunków i faktur dokumentujących restytucje zniszczonego mienia najpierw dostaje zasiłek, następnie zaś przedkłada te rachunki ubezpieczycielowi, by uzyskać odszkodowanie, w istocie dochodzi do wzbogacenia poszkodowanego, to zaś jest sprzeczne z zasadą wyrażoną w art. $824^{1} \$ 1$ k.c. Bonus, o którym mówił premier, to nic innego jak zakazane wzbogacenie. Konkludując, M. Orlicki stwierdza, że dopóki poszkodowani będą mogli liczyć na świadczenia restytucyjne ze strony państwa, system ubezpieczeniowy nie zadziała ${ }^{53}$.

52 Por. M. Orlicki, O zaliczaniu świadczeń ze środków publicznych na rzecz ofiar powodzi na poczet odszkodowań z ubezpieczeń majątkowych [w:] Ubezpieczenia gospodarcze. Wybrane zagadnienia prawne, red. B. Gnela, Warszawa 2011, s. 165-171. Stanowisko premiera łatwo zrozumieć, wziąwszy pod uwagę, że jeden z jego poprzedników musiał się podać do dymisji po tym, jak powódź skomentował jako prawnik słowami: „To jest kolejny przypadek, kiedy potwierdza się, że trzeba być przezornym i trzeba się ubezpieczać, a ta prawda ciągle jest mało powszechna”.

53 M. Orlicki, O zaliczaniu..., s. 170-171. 
Sytuacje, w których dochodzi do zbiegu odszkodowania służącego od sprawcy szkody oraz świadczenia ubezpieczeniowego, szczegółowo opracował W. Warkałło, wskazując na następujące cztery możliwości:

- świadczenie ubezpieczeniowe jest świadczeniem jedynym,

- świadczenie ubezpieczeniowe jest świadczeniem zastępczym,

- świadczenie ubezpieczeniowe jest świadczeniem dodatkowym,

- świadczenie ubezpieczeniowe jest świadczeniem zaliczalnym (tj. ulega zarachowaniu na poczet odszkodowania).

Pierwsza możliwość dotyczy sytuacji, gdy szkoda jest wynikiem działania sił przyrody, wojny, rozruchów, aktów władzy, ewentualnie działania samego ubezpieczonego lub nieustalonego sprawcy. Druga obejmuje ubezpieczenia OC, w których poszkodowany, mogąc pozwać sprawcę lub ubezpieczyciela, wybiera tego drugiego, a w konsekwencji odszkodowanie z ubezpieczenia OC zastępuje mu odszkodowanie od sprawcy. Sytuacja trzecia i czwarta wywołują natomiast kontrowersje. W uproszczeniu można powiedzieć, że świadczenie ubezpieczeniowe może być dodatkiem do świadczenia $\mathrm{z}$ innych źródeł $\mathrm{w}$ ubezpieczeniach osobowych. Typowym przykładem jest zbieg świadczeń z ubezpieczenia wypadkowego ze świadczeniem od sprawcy. Z kolei w ubezpieczeniach mienia zasadą jest, że świadczenie ubezpieczeniowe zaliczane jest na poczet świadczenia od sprawcy, a zatem ubezpieczony może uzyskać odszkodowanie od sprawcy tylko w takim zakresie, w jakim odszkodowanie ubezpieczeniowe nie pokryło poniesionej przezeń szkody ${ }^{54}$.

Na tle przedstawionych możliwości wypada zwrócić uwagę na dwie kwestie. Po pierwsze, przeciwstawienie ubezpieczenia OC innym ubezpieczeniom majątkowym nie zawsze jest słuszne. W ubezpieczeniach tych bowiem, podobnie jak w innych ubezpieczeniach majątkowych, obowiązuje zasada odszkodowania. Ponadto sumę ubezpieczenia zastępuje tam suma gwarancyjna. W konsekwencji, pomimo że odpowiedzialność ubezpieczyciela jest akcesoryjna w stosunku do odpowiedzialności sprawcy i mówić można o obowiązywaniu zasady odszkodo-

54 Zob. W. Warkałło, Zbieg uprawnień do świadczenia z ubezpieczenia i $z$ tytułu odpowiedzialności za wyrządzenie szkody, RPEiS 1968/3, s. 289-307, oraz W. Warkałło, Ubezpieczenie a odpowiedzialność..., s. 113-123. 
wania, to jedynie w granicach sumy gwarancyjnej. W tych wszystkich sytuacjach, gdy suma gwarancyjna jest niższa niż wysokość poniesionej szkody, powiedzieć można, że odszkodowanie ubezpieczeniowe będzie odszkodowaniem zaliczalnym, odszkodowanie uzyskane od sprawcy obejmuje bowiem jedynie szkodę niepokrytą odszkodowaniem ubezpieczeniowym.

Po drugie, wątpliwości dotyczące rozróżnienia między sytuacją, gdy świadczenie $\mathrm{z}$ ubezpieczenia jest świadczeniem dodatkowym, oraz sytuacją, gdy świadczenie jest świadczeniem zaliczanym, dotyczą ubezpieczeń uważanych tradycyjnie za osobowe, w szczególności ubezpieczenia NNW, w którym niektóre świadczenia ubezpieczeniowe zdają się mieć charakter świadczeń stricte odszkodowawczych (zwrot kosztów leczenia, protez, przeszkolenia zawodowego itp.). Odnośnie do ubezpieczeń mienia, stanowiących przedmiot niniejszej pracy, zakaz łączenia świadczeń ubezpieczyciela $\mathrm{z}$ istoty rzeczy mającego charakter odszkodowawczy z innymi odszkodowaniami wynika stąd, że odszkodowanie kompensujące szkodę już skompensowaną pozwala powiększyć stan majątku o wartość szkody i przestaje być odszkodowaniem.

Dodać można, że uchylony art. 825 k.c., w odróżnieniu od aktualnego art. $824^{1} \$ 1$ k.c., stanowił, że odszkodowanie nie może przewyższać wysokości poniesionej szkody, bez początkowego zastrzeżenia ,jeżeli strony nie umówiły się inaczej”. Nadto nie budzi wątpliwości, że wyrównanie korzyści z uszczerbkiem wchodzi w grę w szczególności tam, gdzie ustawodawca wprowadza roszczenie regresowe ${ }^{55}$. Przykładem roszczenia regresowego w szerokim rozumieniu jest art. 828 k.c., zgodnie z którym, jeżeli nie umówiono się inaczej, z dniem zapłaty odszkodowania przez ubezpieczyciela roszczenie ubezpieczającego przeciwko osobie odpowiedzialnej za szkodę przechodzi z mocy prawa na ubezpieczyciela do wysokości zapłaconego odszkodowania.

Problem ubezpieczeń osobowych ze świadczeniem odszkodowawczym można rozstrzygnąć, przyjmując, że ubezpieczenie NNW łączy

${ }_{55}$ M. Kaliński, Szkoda..., s. 463; A. Szpunar, Ustalenie odszkodowania w prawie..., s. 98. 
ze sobą elementy ubezpieczenia osobowego i ubezpieczenia mienia ${ }^{56}$. $\mathrm{W}$ zakresie, w jakim świadczenia $\mathrm{z}$ niego wynikające mają charakter odszkodowawczy, ubezpieczenie to chroni w istocie interes majątkowy ubezpieczającego polegający na konieczności uszczuplenia jego majątku w razie zajścia wypadku na skutek wydatkowania kwot potrzebnych do pokrycia kosztów leczenia, protez, przeszkolenia zawodowego itp. ${ }^{57}$ Ubezpieczenie to jest w istocie ubezpieczeniem koniecznych wydatków i trudno odgraniczyć je od tzw. ubezpieczenia medical assistance, które przy takim ujęciu również byłoby ubezpieczeniem mienia, tj. ubezpieczeniem majątkowym niebędącym ubezpieczeniem odpowiedzialności cywilnej ${ }^{58}$. Świadczenia $\mathrm{z}$ tego rodzaju ubezpieczeń nie mogą być kumulowane ze świadczeniami z innych źródeł. Konkluzja ta nie dotyczy natomiast kwestii łączenia z odszkodowaniami z innych źródeł świadczeń z ubezpieczenia osobowego, mających na celu wynagrodzenie szkód niemajątkowych. W tym zakresie nie ma przeszkód do kumulacji. Krzywda ma, jak wiadomo, charakter niewymierny. Zapobiegliwość osób, które dodatkowo ubezpieczyły się, powinna być w miarę możliwości promowana ${ }^{59}$. Zagadnienie kumulacji świadczeń mających na celu wynagrodzenie krzywdy nie będzie rozważane jako wykraczające poza zakres pracy ${ }^{60}$. Niezależnie od kwalifikacji prawnej świadczeń

56 Zdecydowanie przeciwko kumulowaniu świadczeń odszkodowawczych z ubezpieczeń wypadkowych ze świadczeniami z innych źródeł wypowiadał się W. Warkałło. Por. W. Warkałło, W. Marek, W. Mogilski, Prawo..., s. 133-138. Zważyć jednak trzeba, że autor ten był zwolennikiem wąskiego ujęcia szkody nieobejmującego krzywdy. Co do tej ostatniej kwestii, zob. W. Warkałło, Odpowiedzialność..., s. 125-129.

57 Tak M. Orlicki, Umowa ubezpieczenia, 2002, s. 173; M. Śmigiel, Zasada..., s. 22; M. Krajewski, Umowa ubezpieczenia. Art. 805-834 KC..., 2016, s. 66-67. Zob. również A. Szpunar, Ustalenie odszkodowania w prawie..., s. 87. Autor nie ma wątpliwości, że wszelkie koszty wynikłe z uszkodzenia ciała lub rozstroju zdrowia stanowią szkodę majątkową. Pogląd ten kwestionuje natomiast M. Kaliński, Zasada..., cz. 1, s. 51-53. Według tego autora świadczenia z ubezpieczeń osobowych mogą być łączone z odszkodowaniami z innych źródeł niezależnie od swego charakteru.

58 Co do ubezpieczeń assistance, zob. rozważania zawarte w ostatnim rozdziale pracy dotyczącym możliwości naprawienia przez ubezpieczyciela szkody w formie niepieniężnej.

59 Zob. M. Kaliński, Zasada..., cz. 1, s. 51 oraz wskazana tam literatura. Autor ten jednak moim zdaniem nietrafnie odnosi te uwagi również do szkody majątkowej na osobie.

60 Zob. przykładowo W. Warkałło, Ubezpieczenie a odpowiedzialność..., s. 119-123; A. Szpunar, Odszkodowanie.., s. 85-87; M. Kaliński, Zasada..., cz. 1, s. 48 i n. 
odszkodowawczych z ubezpieczenia wypadkowego pozostają one na marginesie niniejszych rozważań.

Odnośnie do świadczeń z ubezpieczeń mających typowo majątkowy charakter na przeszkodzie kumulowaniu ich $\mathrm{z}$ odszkodowaniami $\mathrm{z}$ innych źródeł stoją: zasada interesu ubezpieczeniowego, będąca jej odbiciem zasada odszkodowania, a także przytaczane powyżej uregulowanie przewidujące subrogację ubezpieczyciela w prawa ubezpieczającego względem osoby odpowiedzialnej za szkodę, określane często mianem cessio legis. Jeżeli odszkodowanie zapłacone przez sprawcę i odszkodowanie ubezpieczeniowe służą zaspokojeniu tego samego interesu, nie mogą być kumulowane ${ }^{61}$. W sytuacji, gdy osoba odpowiedzialna za szkodę zapłaci odszkodowanie, roszczenia względem ubezpieczyciela wygasają, natomiast w sytuacji, gdy odszkodowanie zapłaci ubezpieczyciel, to do wysokości dokonanej zapłaty przejmuje roszczenia ubezpieczającego względem sprawcy.

Wydaje się, że nawet uregulowanie umowne wykluczające cessio legis, dopuszczalne zgodnie $\mathrm{z}$ art. $828 \$ 1$ k.c., ale w praktyce trudne do wyobrażenia, nie pozwoli ubezpieczającemu domagać się od sprawcy naprawienia szkody w granicach otrzymanego wcześniej odszkodowania ubezpieczeniowego. Ubezpieczający nie będzie mógł bowiem udowodnić w tym zakresie szkody. Dodać przy tym należy, że uregulowania dotyczące interesu ubezpieczeniowego (art. 821 k.c.) i zasady odszkodowania w ubezpieczeniach (art. $824^{1} \$ 1$ k.c.) stanowią konsekwencję zasady odszkodowania będącej fundamentem ogólnego prawa odszkodowawczego. Interes ubezpieczeniowy służy bowiem temu, komu zagraża szkoda, a zapłacenie pełnego odszkodowania niweluje szkodę, zaspokajając interes. Regulacja dotycząca regresu ubezpieczeniowego (art. 828 k.c.) stanowi konsekwencję dwóch wcześniejszych zasad i nie powinna stanowić punktu wyjścia dla rozumowania wykluczającego podwójną kompensację.

${ }^{61}$ Por. M. Kaliński, Szkoda..., s. 462, z powołaniem się na T. Dybowskiego i K. Zagrobelnego. 
W kontekście powyższych rozważań dziwić może teza wyroku SN z 13.10.2005 r., I CK 185/0562, zgodnie z którą dobrowolne naprawienie przez osobę trzecią na własny koszt uszkodzonego w wypadku samochodu w zasadzie nie podlega zaliczeniu na poczet odszkodowania należnego w związku z wypadkiem. W uzasadnieniu tego wyroku Sąd Najwyższy wywodzi, że przesłanką zastosowania zasady compensatio lucri cum damno jest tożsamość źródła uszczerbku oraz korzyści. W sytuacji zachodzącej w sprawie takiej tożsamości natomiast brakowało, ponieważ podstawę dla odszkodowania zapłaconego przez ubezpieczyciela stanowiła, poza samym wyrządzeniem szkody, umowa ubezpieczenia.

Ponadto Sąd Najwyższy stwierdza, że do kategorii korzyści niepodlegających uwzględnieniu przy ustalaniu odszkodowania zalicza się powszechnie dobrowolne świadczenia osób trzecich na rzecz poszkodowanego. Celem takich świadczeń nie jest $\mathrm{z}$ reguły zwolnienie osoby odpowiedzialnej od obowiązku naprawienia szkody, lecz nieodpłatne przysporzenie korzyści poszkodowanemu; przy tym bez nabycia roszczenia regresowego wobec osoby odpowiedzialnej. Uzyskana przez poszkodowanego w przypadku takiego świadczenia korzyść nie jest normalnym następstwem zdarzenia, które spowodowało uszczerbek, a zatem nie można przyjąć tożsamości źródła uszczerbku i korzyści.

Dalej SN powołuje się na zasadę prawną wynikającą z uchwały składu 7 sędziów z 27.03.1961 r. ${ }^{63}$, według której w wypadku, gdy zakład pracy ubezpieczył pracownika od następstw nieszczęśliwego wypadku w PZU i płacił składki ubezpieczeniowe, odszkodowanie za skutki nieszczęśliwego wypadku należne pracownikowi od zakładu pracy nie ulega zmniejszeniu o kwotę wypłaconą pracownikowi przez PZU na podstawie umowy ubezpieczeniowej. Jednakże fakt otrzymania przez pracownika z PZU pewnej sumy na podstawie umowy ubezpieczeniowej może być uwzględniony przy ustalaniu wysokości odszkodowania na podstawie art. $158 \S 1$ k.z.

${ }^{62}$ OSNC 2006/7-8, poz. 133. Na temat wyroku krytycznie wypowiada się również M. Krajewski. Zob. M. Krajewski, Umowa ubezpieczenia. Art. 805-834 KC..., 2016, s. 580.

63 Uchwała SN (7) - zasada prawna z 27.03.1961 r., I CO 27/60, OSNC 1962/2, poz. 40 . 
Stanowisko wyrażone $\mathrm{w}$ wyroku z 13.10.2005 r. wydaje się nietrafne. Jak już wskazano, kryterium tożsamości zdarzenia będącego źródłem szkody oraz korzyści zawodzi w ubezpieczeniach, a w każdym razie musi być rozumiane odmiennie niż w ogólnym prawie odszkodowawczym. Jeżeli czyn będący źródłem szkody jest tożsamy z wypadkiem ubezpieczeniowym, nie można wywodzić, jak Sąd Najwyższy, że uszczerbek poszkodowanego i odniesiona przez niego korzyść są następstwem różnych zdarzeń. W istocie, skoro odpowiedzialność sprawcy oraz ubezpieczyciela służyły zabezpieczeniu tego samego interesu ubezpieczającego, bronić można stanowiska, że zachodziła tożsamość zdarzenia. Nawet zaś, gdyby się z takim wnioskiem nie zgodzić, przeciwko stanowisku SN przemawia teoria różnicy. Nie budzi przecież wątpliwości, że poszkodowany, którego uszkodzony samochód został najpierw naprawiony na koszt sprawcy, otrzymawszy od ubezpieczyciela odszkodowanie odpowiadające kosztom naprawy, zostałby wzbogacony ${ }^{64}$.

Nie przekonuje również drugi z przytoczonych przez Sąd Najwyższy argumentów. Trudno bronić stanowiska, że sprawca świadom swej odpowiedzialności, który naprawia wyrządzoną szkodę, nie czekając na powództwo i ewentualnie egzekucję komorniczą, czyni to $\mathrm{w}$ istocie dobrowolnie. Świadczenie polegające na pokryciu kosztów przywrócenia samochodu do stanu sprzed wypadku nie jest spełniane w celu nieodpłatnego przysporzenia korzyści poszkodowanemu (causa donandi), ale w celu wykonania zobowiązania powstałego na skutek wyrządzenia czynu niedozwolonego (causa solvendi). Uzyskana przez poszkodowanego w przypadku takiego świadczenia korzyść jest oczywiście normalnym następstwem zdarzenia, które spowodowało uszczerbek.

Powołując się na zasadę prawną wynikającą z uchwały z 27.03.1961 r., dotyczącą możności zaliczenia odszkodowania wypłaconego poszkodowanemu przez PZU na podstawie zawartej umowy ubezpieczenia NNW na poczet odszkodowania za skutki nieszczęśliwego wypadku należnego od zakładu pracy, Sąd Najwyższy zupełnie pomija nieodszkodowawczy charakter świadczeń z ubezpieczenia osobowego w zakresie, w jakim

${ }^{64}$ Na kwestie te zwraca w szczególności uwagę A. Szpunar. Zob. A. Szpunar, Ustalenie odszkodowania w prawie..., s. 120-124, 126 i 130. 
mają one na celu wynagrodzenie krzywdy. W uzasadnieniu powoływanej zasady prawnej SN wyjaśnił, że omawiana korzyść, choć zwana odszkodowaniem, $w$ istocie nie miała charakteru odszkodowania, nie zależała bowiem od wysokości szkody. Suma ubezpieczenia w ubezpieczeniu osobowym jest świadczeniem wzajemnym z umowy ubezpieczeniowej, określonym przez strony przy zawieraniu umowy, a jej wysokość jest niezależna od rozmiaru następstw wypadku.

W krytykowanym wyroku z 13.10.2005 r. Sąd Najwyższy pomija nie tylko uzasadnienie, ale również drugie zdanie tezy powołanej uchwały 7 sędziów z 1961 r., według którego fakt otrzymania przez pracownika z PZU pewnej sumy na podstawie umowy ubezpieczeniowej może być uwzględniony przy ustalaniu wysokości odszkodowania na podstawie art. $158 \$ 1$ k.z. Jak już wskazywano, według niekwestionowanego w doktrynie i orzecznictwie stanowiska brak w Kodeksie cywilnym odpowiednika art. $158 \$ 1$ k.z. nie stanowi przeszkody dla stosowania zasady compensatio lucri cum damno, która jest immanentną implikacją teorii różnicy.

Typowym przykładem wyrównania korzyści z uszczerbkiem w ubezpieczeniach majątkowych jest omawiany wcześniej sposób likwidacji szkody całkowitej sprowadzający się do zarachowania na poczet odszkodowania wartości wraku. Innym charakterystycznym przykładem, wymagającym omówienia na obecnym etapie, jest praktyka zakładów ubezpieczeń polegająca na potrącaniu zużycia części, które po uszkodzeniu zostały wymienione na nowe. Stanowisko wskazujące na konieczność potrącenia dotychczasowego zużycia rzeczy jest aprobowane także w ogólnym prawie cywilnym i panuje również w obcych porządkach prawnych ${ }^{65}$.

Na gruncie ubezpieczeń opisana praktyka budziła wątpliwości przede wszystkim w odniesieniu do ubezpieczenia $\mathrm{OC}^{66}$. Wskazywano, że pro-

65 A. Szpunar, Ustalenie odszkodowania w prawie..., s. 131.

66 Zob. A. Wąsiewicz, Ubezpieczenia komunikacyjne, Bydgoszcz 1996, s. 87-89; A. Wąsiewicz, Ubezpieczenia..., 1996, s. 81-83; G. Bieniek, Odpowiedzialność cywilna za wypadki drogowe, Warszawa 2006, s. 151-152; A. Szpunar, Odszkodowanie..., s. 61; E. Kowalewski, M. Wałachowska, M. Ziemiak, Merkantylny ubytek wartości części zamiennych [w:] Kolokwium naukowe, dnia 5 kwietnia 2012 roku zorganizowane przez 
wadzi ona do zaakceptowania sytuacji, w której ubezpieczający, chcąc naprawić uszkodzony samochód, ma obowiązek wyszukiwania części używanych, których stopień zużycia odpowiada zużyciu samochodu przed szkodą ${ }^{67}$. Sąd Najwyższy na ogół przyjmował, że uwzględnienie amortyzacji części jest możliwe w sytuacjach wyjątkowych, gdy naprawa doprowadziła do istotnego wzrostu wartości pojazdu sprzed wypad$\mathrm{ku}^{68}$. Finałem dyskusji stała się podjęta na skutek wniosku Rzecznika Ubezpieczonych uchwała Sądu Najwyższego z 12.04.2012 r., III CZP $80 / 11^{69}$. Sąd Najwyższy uznał, że zakład ubezpieczeń zobowiązany jest na żądanie poszkodowanego do wypłaty, w ramach odpowiedzialności z tytułu ubezpieczenia odpowiedzialności cywilnej posiadacza pojazdu mechanicznego, odszkodowania obejmującego celowe i ekonomicznie uzasadnione koszty nowych części i materiałów służących do naprawy uszkodzonego pojazdu. Jeżeli ubezpieczyciel wykaże, że prowadzi to do wzrostu wartości pojazdu, odszkodowanie może ulec obniżeniu o kwotę odpowiadającą temu wzrostowi.

W ubezpieczeniu AC powszechną praktyką ubezpieczycieli jest wskazywanie procentowych współczynników amortyzacji zależnie do wieku pojazdu w tabeli stanowiącej część ogólnych warunków ubezpieczenia. Stosowane współczynniki różnią się zależnie od zakładu ubezpieczeń.

Polską Izbę Ubezpieczeń we współpracy z Uniwersytetem Mikołaja Kopernika w Toruniu oraz Uniwersytetem Kardynała Stefana Wyszyńskiego w Warszawie, Warszawa 2012, s. 12-13; D. Fuchs, Odszkodowanie z tytułu ubezpieczenia OC posiadacza pojazdu a kwestia amortyzacji części zamiennych użytych do naprawy uszkodzonego pojazdu, WU 2012/1; B. Chmielowiec, Amortyzacja wartości części koniecznych do naprawy pojazdu w świetle uchwały Sądu Najwyższego z dnia 12 kwietnia 2012 r., RU 2013/1.

67 Zob. przykładowo Stanowisko Rzecznika Ubezpieczonych w sprawie tzw. potrąceń amortyzacyjnych dokonywanych przez zakłady ubezpieczeń w przypadku likwidacji szkody w ramach ubezpieczenia OC posiadaczy pojazdów mechanicznych dostępne na stronie internetowej Rzecznika Finansowego: (https://rf.gov.pl/files/20599_5219_ Stanowisko_Rzecznika_Ubezpieczonych_w_sprawie_tzw_potracen_amortyzacyjnych_ dokonywanych_przez_zaklady_ubezpieczen_w_prz.pdf, dostęp: 5.11.2018 r.) oraz wskazana tam literatura i orzecznictwo.

68 Wyroki SN: z 20.10.1972 r., II CR 425/72, OSNCP 1973/6, poz. 111; z 20.02.1981 r., I CR 17/81; z 13.12.1988 r., I CR 280/88; z 5.11.1980 r., III CRN 223/80, OSNC 1981/10, poz. 186; z 11.06.2003 r., V CKN 308/01. Zob. również M. Krajewski, Szkoda..., s. 31 i 56.

69 OSNC 2012/10, poz. 112, z glosą T. Szanciło, M. Prawn. 2013/7, s. 385-389. Co do jej omówienia, zob. również B. Chmielowiec, Amortyzacja... 
Powiedzieć można, że przy samochodach 5-7-letnich oscylują na poziomie $50 \%$, natomiast powyżej 10-letnich często przekraczają $60 \%$. Zwykle również ubezpieczyciele wskazują, że w przypadku możliwości wyboru między częścią oryginalną a zamiennikiem odszkodowanie wyliczane jest na podstawie cen zamienników. Wielu ubezpieczycieli umożliwia przy tym wybór wariantu ubezpieczenia, w którym amortyzacja jest zniesiona, a odszkodowanie wyliczane jest na podstawie cen części oryginalnych. Ubezpieczenie ze zniesioną amortyzacją, w którym odszkodowanie wyliczane jest według oryginalnych części, jest droższe, podobnie jak ubezpieczenie ze zniesionym udziałem własnym ${ }^{70}$.

Rodzi się pytanie, czy postanowienia OWU ustalające współczynniki amortyzacji w sposób istotnie odbiegający od rzeczywistej wartości części używanych mogą być traktowane jako wykraczające poza zakres dozwolonej swobody umów albo jako klauzule niedozwolone w umowach $\mathrm{z}$ konsumentami. Odpowiedź na tak postawione pytanie powinna być pozytywna. Klauzule ustalające współczynniki na poziomie rażąco odbiegającym od faktycznej wartości uszkodzonych części, jak również umożliwiające amortyzację bez odwołania się do jakichkolwiek kryteriów mogą być uznane za wykraczające poza dopuszczalny zakres swobody umów. Powoływać można sprzeczność z właściwością i naturą stosunku ubezpieczenia (zniweczenie ochronnego celu umowy), z ustawą (reguły nakazujące zakładom ubezpieczeń formułowanie postanowień umowy i wzorców umownych w sposób jednoznaczny i zrozumiały oraz wskazywanie w OWU zakresu odpowiedzialności, rozmiaru szkody i sposobu określania odszkodowania - art. 15 i 16 u.d.u.r.), a także z zasadami współżycia społecznego (naruszenie dobrych obyczajów określonych w zasadach dobrych praktyk PIU oraz wytycznych KNF dotyczących likwidacji szkód z ubezpieczeń komunikacyjnych).

70 Autonomię ubezpieczycieli w tym zakresie potwierdza m.in. wyrok SN z 25.04.2002 r., I CKN 1466/99, OSNC 2003/5, poz. 64, który dotyczy jednak nieco innego problemu. W sprawie chodziło bowiem o to, czy ubezpieczyciel ma obowiązek zwrócić wartość części nabytych przez ubezpieczającego w sytuacji, gdy istnieje możliwość nabycia ich taniej. Sąd Najwyższy stwierdził, że ubezpieczony, który nabywa autoryzowane części samochodowe potrzebne do naprawy uszkodzonego w wypadku pojazdu, nie ma obowiązku poszukiwania sprzedawcy oferującego je najtaniej, jeżeli $\mathrm{z}$ treści umowy ubezpieczenia autocasco nie wynika nic innego. 
Jeszcze dalej powinna iść możliwość uznania postanowień OWU wyznaczających współczynniki amortyzacji na rażąco wysokim poziomie albo odwołujących się do amortyzacji bez wskazania jej kryteriów za postanowienia niedozwolone. Przede wszystkim zgodnie z przyjętym wąskim rozumieniem pojęcia postanowienia, określające główne świadczenia stron klauzule wskazujące szczegółowe sposoby wyliczania odszkodowania rzadko będą mogły być uznane za objęte tym terminem, jeszcze rzadziej będą zaś jednoznaczne w rozumieniu art. $385^{1} \$ 1$ k.c. Odnośnie do pierwszej kwestii jest w moim przekonaniu wysoce wątpliwe, czy postanowienia przewidujące szczegółowe sposoby wyliczenia odszkodowania zależnie od tego, czy szkoda jest całkowita, czy częściowa, czy wybrano serwisowy, czy kosztorysowy sposób likwidacji szkody, czy naprawa dokonana ma być w ASO, czy w warsztacie objętym siecią ubezpieczyciela, czy w jeszcze innym warsztacie, jakiego rodzaju części użyto itd., zajmujące kilka stron w OWU, co jest przecież normą, w ogóle mogą być uznane za postanowienia określające główne świadczenia stron $^{71}$. Inaczej będzie przede wszystkim wtedy, gdy z treści samej polisy będzie wynikać, że odszkodowanie ustalane jest przy uwzględnieniu amortyzacji części, w związku z czym składka jest relatywnie niska.

Odnośnie do kwestii drugiej, to jest jednoznaczności wzorca, brak określenia kryteriów amortyzacji wydaje się niejednoznaczny sam w sobie. Można wskazać, że w Rejestrze Klauzul Niedozwolonych prowadzonym przez Prezesa UOKiK wpisane jest m.in. postanowienie, według którego koszt części zamiennych miał być określany „z uwzględnieniem procentowego ustalonego rynkowego ubytku wartości części - nieprzekraczającego procentowo ustalonego poziomu ubytku wartości rynkowej pojazdu ustalanego przez ubezpieczyciela i wskazanego w kalkulacji naprawy"72. Natomiast wskazanie wysokości współczynników będzie mogło być uznane za jednoznaczne jedynie wtedy, gdy z treści OWU w sposób oczywisty dla przeciętnego konsumenta będzie wynikać, w jakiej dokładnie sytuacji ubezpieczyciel będzie uprawniony do ich zastosowania.

71 Inaczej, jak się zdaje, M. Krajewski, Umowa ubezpieczenia. Art. 805-834 KC..., 2016, s. 76; J. Pokrzywniak, Regulacja..., s. 171.

${ }^{72}$ Klauzula nr 1652. Wyrok SOKiK z 4.05.2009 r., XVII AmC 48/08, LEX nr 519311. 
Dodać należy, że w praktyce ubezpieczyciele bardzo często proponują zarówno ubezpieczenia uwzględniające, jak i nieuwzględniające amortyzacji. Te drugie ubezpieczenia są droższe. Można oczywiście twierdzić, że naprawienie używanego pojazdu częściami oryginalnymi prowadzi w określonych sytuacjach do wzbogacenia poszkodowanego i jest sprzeczne z zasadą odszkodowania. Wydaje się jednak, że praktykę proponowania ubezpieczenia w wariancie nieuwzględniającym amortyzacji należy zaaprobować. Istota rzeczy sprowadza się bowiem do tego, by poszkodowany funkcjonalnie znalazł się w stanie możliwie najbliższym do stanu sprzed szkody. Nawet jeżeli wymiana uszkodzonej części na nową doprowadzi do realnego wzrostu wartości rzeczy, zakres swobody stron w zakresie sposobu ustalania odszkodowania ubezpieczeniowego pozwala na takie uzgodnienie. W tym zakresie należy odwołać się do wcześniejszych wywodów dotyczących możności stosowania kosztorysowej metody wyliczania odszkodowania.

Zagadnieniem bardzo zbliżonym do kwestii amortyzacji czasowej części jest ich amortyzacja jakościowa oraz ustalanie kosztów robocizny. Pytania dotyczą swobody stron w zakresie ustalenia, że koszt przywrócenia rzeczy do stanu poprzedniego będzie wyliczany na podstawie części oryginalnych albo dostępnych na rynku zamienników oraz w zakresie ustalenia, że koszty robocizny ustalane będą na podstawie stawek w autoryzowanej stacji obsługi (ASO) albo stawek stosowanych poza taką stacją ${ }^{73}$ Zagadnienie amortyzacji jakościowej również było przedmiotem kontrowersji na gruncie ubezpieczenia OC. Rzecznik Ubezpieczonych zwrócił się do Sądu Najwyższego ze stosownym pytaniem prawnym. Postanowieniem 7 sędziów z 20.06.2012 r., III CZP $85 / 11^{74}$, Sąd Najwyższy odmówił podjęcia uchwały, wskazując, że istniejące $\mathrm{w}$ orzecznictwie wątpliwości zostały dostatecznie wyjaśnione

73 Co do tej kwestii, zob. P. Wawszczak, Części zamienne - nowe, ale jakie? - wnioski i uwagi z lektury wystapienia Rzecznika Ubezpieczonych z dnia 8 listopada 2011 r. i postanowienia Sądu Najwyższego z dnia 20 czerwca 2012 r., RU 2013/1; J. Orlicka, Klauzula napraw a zakres obowiązu odszkodowawczego w ubezpieczeniach komunikacyjnych, RU 2007/2, s. 98-99; J. Nawracała, Szkody częściowe w pojazdach, „Miesięcznik Ubezpieczeniowy" 2010/12, s. 17 i n.; M. Krajewski, Umowa ubezpieczenia. Art. 805-834 KC..., 2016, s. 470 i n.; M. Krajewski, Szkoda..., s. 34 i 58.

74 OSNC 2013/3, poz. 37. 
powoływaną wcześniej uchwałą z 12.04.2012 r. dotyczącą możliwości uwzględniania przez ubezpieczyciela czasowej amortyzacji części. Według SN przedstawione mu w pytaniu zagadnienie nie odnosiło się do wykładni prawa, ale do jego stosowania.

Pomimo że uchwała nie została podjęta, uzasadnienie postanowienia SN zawiera w zasadzie odpowiedź na pytanie Rzecznika. Sąd Najwyższy wskazał, że „Unormowania rozporządzenia Komisji Europejskiej nr 451/2010 z dnia 27 maja 2010 r. w sprawie stosowania art. 101 ust. 3 Traktatu o funkcjonowaniu Unii Europejskiej do kategorii porozumień wertykalnych i praktyk uzgodnionych w sektorze pojazdów silnikowych (Dz.U. L 129/52 z dnia 28 maja 2010 r.) oraz rozporządzenia Rady Ministrów z dnia 8 października 2010 r. w sprawie wyłączeń określonych porozumień wertykalnych w sektorze pojazdów samochodowych spod zakazu porozumień ograniczających konkurencję (Dz.U. Nr 198, poz. 1315) dotyczą jedynie wymienionych w nich porozumień i nie ograniczają praw poszkodowanego do żądania ustalenia odszkodowania z uwzględnieniem cen części oryginalnych”. Powołane akty prawne regulowały problematykę porozumień grupowych w sektorze motoryzacyjnym, dopuszczając do napraw serwisowych przy wykorzystaniu nieoryginalnych części zamiennych. Zakłady ubezpieczeń wykorzystywały je jako podstawę legalności praktyki wyliczania odszkodowania w ubezpieczeniu OC na podstawie dostępnych na rynku zamienników części oryginalnych.

Sąd Najwyższy w omawianym postanowieniu wyjaśnił, że „oryginalność części wykorzystywanych do naprawy pojazdu stanowi istotny czynnik decydujący o tym, czy naprawa jest wystarczająca do przywrócenia jego do stanu poprzedniego. Jest oczywiste, że ich dobór może prowadzić do pogorszenia położenia poszkodowanego. Pogorszenie takie miałoby miejsce zarówno wtedy, gdyby użyta część była pod istotnymi względami częścią gorszą od tej, która uległa uszkodzeniu, jak i wtedy, gdyby równowartość «restytucyjna» części zastępczej była niepewna. Nie oznacza to jednak, że w razie uszkodzenia części pochodzącej bezpośrednio od producenta pojazdu, do naprawy albo obliczania kosztów naprawy mogą być wykorzystane tylko ceny takich «części oryginalnych bezpośrednio pochodzących od producenta pojazdu». W ten sam sposób 
należy co do zasady ocenić wykorzystanie przy ustalaniu odszkodowania także innych części nowych, które są tej samej jakości co części pochodzące bezpośrednio od producenta pojazdu, oznaczone jego znakiem towarowym albo logo rozprowadzone w opakowaniach w ten sposób oznaczonych i dystrybuowane w ramach jego sieci dystrybucji.

Takimi częściami są występujące w obrocie części wyprodukowane przez tego samego producenta, który dostarcza producentowi pojazdu do montażu pojazdów lub części zamienne. Są to części produkowane zgodnie ze specyfikacjami i standardami produkcyjnymi, ustalonymi przez producenta pojazdu, a więc części dokładnie tej samej jakości co części pochodzące bezpośrednio od producenta pojazdu, a różniące się tylko oznakowaniem. Z tego względu ich użycie należy co do zasady uznać za równoważne użyciu części oryginalnych. Do wykazania przez ubezpieczyciela, że podstawą kalkulacji odszkodowania były ceny takich właśnie części wystarczające byłoby wskazanie, iż części pochodzą od producenta części dostarczającego te części producentowi pojazdu, i że producent tych części zaświadczył, iż zostały wyprodukowane zgodnie ze specyfikacjami i standardami produkcyjnymi ustalonymi przez producenta pojazdów. Oczywiście, okoliczności te powinny być uprzednio przez ubezpieczyciela ustalone".

Dopuszczone przez Sąd Najwyższy części różniące się od części oznakowanych przez producenta określa się w praktyce mianem części Q. Zdaniem SN użycie części oryginalnych oznakowanych przez producenta i pochodzących bezpośrednio od niego może być jednak uzasadnione w niektórych przypadkach. „Oczywiste jest, że reguła dotycząca zasadności wykorzystania przy ustalaniu wysokości odszkodowania cen części równoważnych oryginalnym nie jest miarodajna w każdym przypadku. W niektórych przypadkach istotną cechą decydującą o zupełności restytucji jest - obok jakości części - samo pochodzenie części od producenta pojazdu, a więc w praktyce opatrzenie go znakiem towarowym lub logo producenta pojazdu. Odnosi się to w szczególności do wspomnianych pojazdów będących jeszcze na gwarancji producenta, który wymaga od autoryzowanych warsztatów, by w ramach napraw gwarancyjnych korzystały wyłącznie z części zamiennych dostarczanych przez producenta pojazdów na potrzeby tych napraw". 
Należy wyjaśnić, że w praktyce rynkowej stosowana jest przez zakłady ubezpieczeń i dystrybutorów części zamiennych klasyfikacja części zamiennych, która rozróżnia aż sześć kategorii części zamiennych o następujących symbolach:

- „O” - oryginalna część zamienna pochodząca bezpośrednio od producenta pojazdów i oznakowana jego logo;

- „Q” - oryginalna część zamienna oznakowana logo producenta części dostarczającego dany element na pierwszy montaż;

- „PC/PT” - nieoryginalna część zamienna o porównywalnej jakości posiadająca dodatkowo certyfikat jakości;

- „PJ” - nieoryginalna część zamienna o porównywanej jakości, szczególnie polecana przez dostawcę (dystrybutora) tej części (ale nie przez producenta pojazdów);

- „P” - nieoryginalna część o porównywalnej jakości;

- „ZJ” - zwykły nieoryginalny zamiennik o podwyższonej jakości, polecany przez dostawcę (dystrybutora) tej części, niespełniający kryteriów części grupy P (części nieoryginalnych o porównywalnej jakości);

- „Z”- pozostałe nieoryginalne zamienniki ${ }^{75}$.

Ubezpieczyciele proponują zwykle zarówno ubezpieczenia uwzględniające amortyzację jakościową, jak i ubezpieczenia nieuwzględniające takiej amortyzacji, tzn. przewidujące naprawę samochodu częściami oryginalnymi. To samo dotyczy kosztów robocizny, które stosownie do postanowień umowy mogą być ustalane według stawek ASO albo w inny sposób. Oczywiście składka w ubezpieczeniu przewidującym wyliczanie odszkodowania przy wykorzystaniu części nieoryginalnych oraz stawek stosowanych przez nieautoryzowane warsztaty naprawcze jest niższa. Praktykę stosowania wskazanych rodzajów ubezpieczeń należy co do zasady zaaprobować. Istotne jest, by z ogólnych warunków ubezpieczenia w sposób jednoznaczny wynikało, ceny jakich dokładnie części będą brane pod uwagę oraz według jakich dokładnie stawek ustalane będą koszty robocizny.

75 P. Wawszczak, Części zamienne..., s. 170-171; M. Krajewski, Szkoda..., s. 34-35. 
Ostatecznie możliwość uznania za sprzeczne z właściwością i naturą stosunku prawnego ubezpieczenia jest wyjątkowa i dotyczy jedynie klauzul przewidujących, że koszt części zamiennych ustalany będzie na podstawie kosztu zamienników rażąco odbiegających jakością od części zastosowanych w ubezpieczonym pojeździe albo kosztu jakichkolwiek zamienników bez wskazania precyzyjnych kryteriów pozwalających ustalić, o którą kategorię chodzi. Kwestia obejmuje przede wszystkim pojazdy nowe oraz luksusowych marek. W nieco szerszym zakresie podobne postanowienia mogłyby być uznane za klauzule niedozwolone w umowach z konsumentami. Odnieść to należy przede wszystkim do sytuacji, gdy kontrahent ubezpieczyciela nie był poinformowany o możliwości wyboru między ubezpieczeniem droższym oraz tańszym albo został pozbawiony takiego wyboru i jednocześnie nie zdawał sobie sprawy, że koszty części zamiennych będą wyliczane w szczególny sposób. Według podobnych reguł powinna przebiegać ocena klauzul przewidujących wyliczanie kosztów naprawy według stawek stosowanych przez nieautoryzowane warsztaty naprawcze, co zwykle idzie w parze z określaniem kosztów na podstawie cen zamienników części. Do kwestii tych znajdują odpowiednie zastosowanie wcześniejsze uwagi o redukcji odszkodowania ze względu na amortyzację czasową części.

\subsubsection{Miarkowanie odszkodowania z ubezpieczenia mienia - wzmianka}

Ostatnie z postawionych na wstępnie pytań dotyczy stosowania do odszkodowania z ubezpieczenia mienia art. 440 k.c. przewidującego prawo miarkowania odszkodowania przez sąd stosownie do stanu majątkowego stron oraz zasad współżycia społecznego. Przepis ten znajduje zastosowanie wyłącznie między osobami fizycznymi oraz umiejscowiony jest wśród norm dotyczących odpowiedzialności deliktowej. Przytoczone dwie zasady, a mianowicie możliwość stosowania prawa do sądowego miarkowania odszkodowania między osobami fizycznymi w zakresie odpowiedzialności deliktowej, nie są co do zasady kwestionowane w dok- 
trynie $^{76}$. W orzecznictwie ukształtował się również pogląd wykluczający stosowanie zasady miarkowania $\mathrm{w}$ ubezpieczeniu odpowiedzialności cywilnej, w przypadku której odpowiedzialność ubezpieczyciela ma charakter akcesoryjny w stosunku do odpowiedzialności sprawcy szko$\mathrm{dy}^{77}$. W doktrynie pogląd Sądu Najwyższego jest zwykle aprobowany ${ }^{78}$. Argumenty krytyczne wobec tego zapatrywania nie były odnoszone do ubezpieczeń majątkowych innych niż ubezpieczenie odpowiedzialności cywilnej ${ }^{79}$. Polemika z poglądami dopuszczającymi miarkowanie w odniesieniu do świadczeń z odpowiedzialności cywilnej wykracza poza ramy opracowania.

Ubezpieczyciel oczywiście nie jest osobą fizyczną, a jego odpowiedzialność nie ma charakteru odpowiedzialności deliktowej. Nawet przyjmując, że w sytuacji, gdy ubezpieczyciel na mocy umowy ubezpieczenia zobowiązuje się pokryć szkodę wyrządzoną przez inną osobę, przez co jego odpowiedzialność w bardzo ograniczonym zakresie wyznaczonym przez przepisy szczególne o ubezpieczeniach oraz regulacje umowne ma charakter akcesoryjny w stosunku do odpowiedzialności sprawcy, nie sposób uzasadnić twierdzeń przeciwnych. Wyróżnienie trzeciego reżimu odpowiedzialności, odrębnego od odpowiedzialności ex contractu oraz ex delicto, również nie pozwala twierdzić, że do tego reżimu powinna znaleźć zastosowanie zasada miarkowania odszkodowania.

Niezależnie od powyższego przesłanki miarkowania odszkodowania dotyczą stanu majątkowego stron i zasad współżycia społecznego. Trudno

76 Por. przykładowo: A. Szpunar, Odszkodowanie..., s. 103, 104; M. Kaliński, Szkoda..., s. 593-594; A. Sinkiewicz, Miarkowanie wysokości odszkodowania w prawie cywilnym [w:] Rozprawy cywilistyczne. Ksiegga pamiątkowa dedykowana Profesorowi Edwardowi Drozdowi, red. M. Pecyna, J. Pisuliński, M. Podrecka, Warszawa 2013, s. 347-348; M. Warciński, Miarkowanie odszkodowania (art. 440 k.c.) [w:] Prawo prywatne wobec wyzwań współczesności. Księga pamiątkowa dedykowana Profesorowi Leszkowi Ogiegle, red. M. Fras, P. Ślęzak, Warszawa 2017, s. 504 i 509.

77 Wyroki SN: z 18.12.1968 r., II CR 409/68, OSNC 1969/11, poz. 207; z 21.08.1970 r., II CR 355/70, LEX 6788; z 10.02.1972 r., II CR 668/71, OSP 1972/10, poz. 182; z 19.12.1977 r., II CR 469/77, OSNC 1978/10, poz. 183; z 17.10.1985 r., I CR 271/85, OSNC 1986/10, poz. 156; z 27.11.1997 r., III CKN 239/97, OSNC 1998/5, poz. 98.

78 Zob. M. Krajewski, Ubezpieczenie..., s. 438 oraz wskazana tam literatura.

79 W. Warkałło, Odpowiedzialność..., s. 1960. 
przyjąć, że w sytuacji, gdy przeciwko sobie stają zakład ubezpieczyciel - tj. spółka akcyjna, ewentualnie towarzystwo ubezpieczeń wzajemnych albo oddział zagranicznego oddziału ubezpieczeń, którego działalność nakierowana jest na wypłacanie odszkodowań ubezpieczeniowych, oraz osoba fizyczna lub nawet przedsiębiorca poszukujący ochrony, przesłanki wskazane w art. 440 k.c. mogłyby uzasadniać zmniejszenie odszkodowania należnego od ubezpieczyciela. Nadto, jak wielokrotnie podnoszono, odszkodowanie ubezpieczeniowe w ubezpieczeniu mienia niemal nigdy nie jest odszkodowaniem pełnym i podlega całemu szeregowi ograniczeń szczególnych. Trudno przyznawać sądowi dodatkową możliwość zmiarkowania odszkodowania w zakresie, w jakim ubezpieczyciel o to nie zadbał, redagując warunki ubezpieczenia. Jeszcze innym argumentem może być powszechnie akceptowany wyjątkowy charakter prawa miarkowania, przemawiający za restryktywną wykładnią przepisu, który stanowi jego podstawę.

Podsumowując powyższe wywody, pogląd o stosowaniu do odszkodowania ubezpieczeniowego w ubezpieczeniu mienia prawa miarkowania odszkodowania uważam za niemożliwy do udowodnienia. Szczegółowe uzasadnienie poglądu przeciwnego, wykluczającego miarkowanie odszkodowania ubezpieczeniowego, przypominałoby natomiast przysłowiowe wyważanie otwartych drzwi. Dodać można, że już W. Warkałło stwierdzał stanowczo, że ograniczenie odszkodowania ubezpieczeniowego poprzez zastosowanie sędziowskiego prawa ius moderandi w ogóle nie wchodzi w rachubę $e^{80}$.

\subsection{Koszty ratowania jako składnik odszkodowania ubezpieczeniowego}

\subsubsection{Zagadnienia wstępne}

Zgodnie $\mathrm{z}$ art. $826 \$ 4$ k.c. ubezpieczyciel obowiązany jest, w granicach sumy ubezpieczenia, zwrócić koszty wynikłe z zastosowania środków mających na celu ratowanie przedmiotu ubezpieczenia oraz zapobie-

80 W. Warkałło, Ubezpieczenie utraconych korzyści..., s. 59. 
żenie szkodzie lub zmniejszenie jej rozmiarów, jeżeli środki te były celowe, chociażby okazały się bezskuteczne. Umowa lub ogólne warunki ubezpieczenia mogą zawierać postanowienia korzystniejsze dla ubezpieczającego. Obowiązek zastosowania środków mających na celu ratowanie przedmiotu ubezpieczenia oraz zapobieżenie szkodzie lub zmniejszenie jej rozmiarów określany jest zwykle skrótowo mianem obowiązku ratowania. Stanowi on powinność ubezpieczeniową aktualną w chwili zajścia wypadku ubezpieczeniowego. Analiza prawna powinności ubezpieczeniowych wykracza poza ramy pracy. Rozważania dotyczyć będą jedynie kwestii związanych z zakresem kosztów ratowania objętych odszkodowaniem ubezpieczeniowym. Obydwie kwestie trudno rozdzielić, zakres obowiązku prewencji wyznacza bowiem zakres roszczenia ubezpieczającego związanego z jego wykonaniem.

W związku z powyższym należy zwrócić uwagę na kilka kwestii. Po pierwsze, ustawa o działalności ubezpieczeniowej i reasekuracyjnej, podobnie jak jej poprzedniczki, zalicza zapobieganie powstawaniu albo zmniejszenie skutków zdarzeń losowych oraz finansowanie tych działań z funduszu prewencyjnego, jeżeli jest wykonywane przez zakład ubezpieczeń, do czynności ubezpieczeniowych (art. 4 ust. 9 pkt 4). Wynika stąd, że przeceniana w minionej epoce społeczno-gospodarczej funkcja prewencyjna ubezpieczeń wciąż ma istotne znaczenie ${ }^{81}$.

Po drugie, w literaturze i orzecznictwie zdaje się przeważać pogląd, że powinność ratowania stanowi konkretyzację wynikającego z art. 354 k.c. obowiązku współdziałania wierzyciela z dłużnikiem w wykonaniu zobowiązania i jako taka kwalifikowana może być jako obowiązek wierzyciela $^{82}$. Stanowisko to kontestuje M. Krajewski, wskazując, że wykonanie

${ }^{81}$ Co do tej kwestii, zob. szerzej D. Fuchs, Zakres obowiązu prewencji w prawie ubezpieczeń gospodarczych. Uwagi na tle art. 826 k.c., PA 2004/2, s. 38-44, oraz J. Woronkiewicz, Granice swobody kształtowania obowiązków prewencyjnych $w$ umowie ubezpieczania w świetle art. 826 i 827 k.c., PA 2016/1, s. 24-25.

82 Tak SN w uzasadnieniu uchwały z 16.10.1998 r., III CZP 42/98. H. Ciepła [w:] Kodeks cywilny. Komentarz, t. 5, Zobowiązania. Część szczegółowa, red. J. Gudowski Warszawa 2017, komentarz do art. 826 k.c., teza 1; J. Kondek [w:] Kodeks cywilny. Komentarz, t. 3B, Zobowiązania. Część szczegółowa. Ustawa o terminach zapłaty, red. K. Osajda, Warszawa 2017, s. 1686; B. Kucharski, Przeniesienie..., s. 66-68. 
obowiązku ratowania nie ma na celu umożliwienia spełniania świadczenia przez ubezpieczyciela, ale zmniejszenie jego rozmiarów. Wydaje się jednak, że obowiązki mające na celu utrzymanie świadczenia drugiej strony w rozsądnych oraz wynikających z umowy granicach mogą być kwalifikowane jako obowiązki wierzyciela, ponieważ utrzymując obowiązek świadczenia dłużnika w rozsądnych granicach, wierzyciel współdziała w jego wykonaniu (art. 354 \$ 2 k.c.).

Po trzecie, naruszenie obowiązku ratowania mienia jest sankcjonowane odmową pokrycia szkód wynikających z tego tytułu tylko w sytuacji, gdy jest skutkiem winy umyślnej lub rażącego niedbalstwa, co jak się zdaje, powinno być ogólną regułą w zakresie obowiązków prewencyjnych ${ }^{83}$. Nie budzi wątpliwości, że przepis art. $826 \$ 3$ k.c. ma charakter bezwzględnie obowiązujący. Ubezpieczyciel nie ma zatem prawa kształtować w umowie lub OWU sankcji za naruszenie obowiązku ratowania niezależnie od stopnia winy ubezpieczającego oraz związku przyczynowego między zaniechaniem ubezpieczającego a wystąpieniem szkody bądź jej rozmiarami.

Po czwarte, pewne wątpliwości budzi przedmiotowy zakres obowiązku ratowania. Artykuł $826 \$ 1$ k.c. zobowiązuje ubezpieczającego do użycia środków dostępnych. Komentatorzy podkreślają, że słowo „dostępne” odnoszące się do środków, które powinien zastosować ubezpieczający, oznacza nietrudne do zdobycia, osiągalne w danej sytuacji bądź w danych okolicznościach. Ubezpieczający z pewnością nie ma obowiązku sięgać po środki nadzwyczajne, wymagające od niego niezwyczajnego trudu i starań, czasem wręcz niebezpieczne ${ }^{84}$. Sformułowanie „środki dostępne” powinno być oczywiście interpretowane odpowiednio do rodzaju ubezpieczenia, wypadku ubezpieczeniowego oraz okoliczności jego zajścia ${ }^{85}$.

83 B. Kucharski, Uwagi o nowej regulacji umowy ubezpieczenia, Pal. 2008/1-2, s. 51.

${ }^{84}$ H. Ciepła [w:] Kodeks..., t. 5, red. J. Gudowski, komentarz do art. 826 k.c., teza 2; Z. Gawlik [w:] Kodeks cywilny. Komentarz, t. 3, Zobowiązania - część szczególna, red. A. Kidyba, Warszawa 2014, komentarz do art. 826 k.c., teza 4 z powołaniem się na L. Ogiegłę. Zob. również J. Woronkiewicz, Granice..., s. 30.

${ }_{55}$ M. Glicz [w:] Komentarz do niektórych przepisów ustawy - Kodeks cywilny, red. M. Serwach [w:] Prawo ubezpieczeń gospodarczych, t. 2, LEX/el 2010, komentarz do art. 826, teza 2 . 
Artykuł 826 k.c. otrzymał nowe brzmienie w wyniku nowelizacji z 2007 r. W zakresie objętym przedmiotem rozważań zmiany w porównaniu do dawnego stanu prawnego dotyczyły trzech kwestii. Przede wszystkim zawężono spoczywający na ubezpieczającym obowiązek prewencji poprzez rezygnację ze sformułowania nakazującego mu użyć „Wszelkich dostępnych środków” na rzecz sformułowania „dostępnych środków”" Nadto przed zmianą przepis przewidywał wyraźnie wyłączenie odpowiedzialności ubezpieczyciela za szkody będące skutkiem rażąco niedbałego naruszenia obowiązku ratowania, milczał natomiast w odniesieniu do kwestii winy umyślnej. Wyłączenie odpowiedzialności w tym ostatnim przypadku uzasadniano rozumowaniem a minori ad maius $^{87}$. Trzecia zmiana polegała na odniesieniu kwestii związanych z obowiązkiem ratowania do ubezpieczonego w ubezpieczeniu na cudzy rachunek (art. $826 \$ 5$ k.c.).

W toku prac nad nowelizacją zrezygnowano natomiast z pomysłu, by środki, których użyć ma ubezpieczający, precyzowała umowa lub ogólne warunki ubezpieczenia. Wydaje się, że trafne były argumenty krytyków tego pomysłu zwracających uwagę, że ograniczenie obowiązku ratowania do czynności wynikających z OWU skutkowałoby ograniczeniem funkcji prewencyjnej i niepotrzebnym zawężeniem środków, jakie powinien podejmować ubezpieczający ${ }^{88}$. Skonkludować można, że rezygnacja ze sformułowania „wszelkie środki” przy jednoczesnym porzuceniu pomysłu ograniczenia środków, których należy użyć do tych, które zostały enumeratywnie wymienione w umowie lub OWU, stanowiła „złoty środek” pozwalający utrzymać obowiązek prewencji w optymalnych granicach.

${ }^{86}$ Zob. E. Kowalewski, A. Wąsiewicz, Postulowany kształt umowy ubezpieczenia w kodeksie cywilnym, PiP 1993/11-12, s. 3; M. Orlicki, J. Pokrzywniak, Umowa..., s. 115.

87 Co do tej kwestii, zob. M. Krajewski, Umowa ubezpieczenia. Art. 805-834 KC..., 2016, s. 591; A. Cudna-Wagner, Odpowiedzialność..., s. 90.

88 P. Sukiennik, Projekt ustawy $z$ dnia... o zmianie ustawy - Kodeks cywilny oraz ustawy o ubezpieczeniach obowiązkowych, Ubezpieczeniowym Funduszu Gwarancyjnym i Polskim Biurze Ubezpieczycieli Komunikacyjnych $z$ komentarzem odzwierciedlajacym dorobek prac Sejmowej Podkomisji Nadzwyczajnej do nowelizacji Kodeksu cywilnego [w:] Umowa ubezpieczenia. Dyskusja nad forma prawna i treścia unormowań, red. A. Nowak, D. Fuchs, S. Nowak, Warszawa 2007, s. 10-11. 
W doktrynie wyrażany jest pogląd, wedle którego pomimo rezygnacji z tego ostatniego pomysłu nie ma przeszkód, by w umowie lub OWU oznaczono środki, których użyć powinien ubezpieczający ${ }^{89}$. Rację należy przyznać M. Krajewskiemu, którego zdaniem odpowiednie postanowienia wzorca mogłyby mieć walor jedynie informacyjny, art. $826 \$ 1$ k.c. ma bowiem charakter bezwzględnie obowiązujący, wobec czego OWU nie mogą ograniczać zakresu obowiązków ubezpieczającego w porównaniu z nim ani tym bardziej nakładać nań obowiązków dalej idących ${ }^{90}$.

\subsubsection{Uwagi prawnoporównawcze}

Dla pełnego obrazu zwrócić należy uwagę, że obowiązek prewencji oraz zwrot kosztów ratowania często przewidują również obce porządki prawne. Artykuł 82 niemieckiej VVG z 2008 r. zobowiązuje ubezpieczającego do przedsięwzięcia środków mających na celu, w razie zajścia wypadku ubezpieczeniowego, zależnie od okoliczności, uniknięcie szkody lub zmniejszenie jej rozmiarów. W zakresie rozsądku ubezpieczający powinien przy tym stosować się do wskazówek ubezpieczyciela. Jeżeli obowiązek ratowania naruszono umyślnie, ubezpieczyciel nie odpowiada za szkody stąd wynikające. W razie rażącego niedbalstwa ubezpieczyciel ma prawo zmniejszyć odszkodowanie stosownie do stopnia winy. Jeżeli naruszenie obowiązku było podstępne, ubezpieczyciel nie odpowiada za szkodę także w razie braku związku przyczynowego.

Kolejny przepis nakazuje ubezpieczycielowi zwrócić koszty przedsięwziętych przez ubezpieczającego w opisanych celach środków, a nawet na żądanie ubezpieczającego wypłacić zaliczkę, choćby środki te okazały się bezskuteczne, jeżeli tylko w okolicznościach sprawy mogły wydawać się ubezpieczającemu konieczne. Jeżeli ubezpieczyciel ma prawo zmniejszyć odszkodowanie ubezpieczeniowe, może również zmniejszyć świadczenie $\mathrm{z}$ tytułu kosztów ratowania. Koszty poniesione zgodnie z instrukcjami ubezpieczyciela winny być zwrócone także ponad sumę ubezpieczania.

89 Tak m.in.: M. Orlicki, J. Pokrzywniak, Umowa..., s. 115; Z. Gawlik [w:] Kodeks..., t. 3, red. A. Kidyba, komentarz do art. 826, teza 3; J. Woronkiewicz, Granice..., s. 33.

90 M. Krajewski, Umowa ubezpieczenia. Art. 805-834 KC..., 2016, s. 586. 
W odniesieniu do ubezpieczenia zwierząt koszty żywienia, hodowli oraz badań weterynaryjnych nie są uważane za koszty ratowania.

Podobnych reguł nie zawiera prawo francuskie. Regulacja art. L122-3 Code des assurances, dotycząca ubezpieczenia ogniowego, przewiduje wprawdzie, że za prawnie relewantną szkodę objętą ubezpieczeniem uważa się wyłącznie szkodę bezpośrednią wywołaną przez wypadek ubezpieczeniowy lub środki mające na celu ratowanie mienia, jednak regułą tą objęta jest wyłącznie szkoda efektywnie poniesiona w celu ratowania mienia, nie zaś wydatki poniesione przez ubezpieczającego. W pewnych sytuacjach wydatki obejmujące koszty ratowania mogą być zwrócone zgodnie z regułami dotyczącymi prowadzenia spraw bez zlecenia, ewentualnie regułami bezpodstawnego wzbogacenia, jeżeli ubezpieczyciel na skutek wysiłków ubezpieczającego zmierzających do ratowania mienia rzeczywiście skorzystał ${ }^{91}$.

W prawie angielskim również brak reguł nakładających na ubezpieczającego obowiązek ratowania mienia przed szkodą, a w konsekwencji zwykle przyjmuje się, że wydatki z tym związane mogą być objęte odszkodowaniem, jeżeli wyraźnie wynika to z warunków konkretnego ubezpieczenia ${ }^{92}$. Rozróżnia się w tym zakresie dwie sytuacje. W pierwszej ratowanie mienia zagrożonego ryzykiem prowadzi do jego zniszczenia lub utraty. Klasycznym przykładem jest sprawa Symington \& CO v. Union Insurance Society of Canton ${ }^{93}$, w której palące się drewno korkowe zostało wyrzucone za burtę statku. W tym przypadku odszkodowanie przyznano, uznając, że właściwą przyczyną był pożar, a wyrzucenie drewna w okolicznościach sprawy było nieuniknione (imminent peril).

Inaczej jest, jeżeli środki przedsięwzięte w celu odwrócenia grożącego niebezpieczeństwa rzeczywiście uratowały mienie przed szkodą. Wydaje się, że koszty poniesione dla zastosowania tych środków mogą być zwrócone tylko, jeżeli wyraźnie wynika to z treści polisy. Sąd nie zinterpretuje raczej brzmienia umowy ubezpieczenia w sposób pozwalający

\footnotetext{
91 Principles..., s. 253-254.

92 M. Clarke, The Law..., s. 920-921.

93 [1928] 1 Lloyds Rep 287.
} 
na uznanie zwrotu poniesionych kosztów ratowania za postanowienie dorozumiane (implied term) ${ }^{94}$. Z tego względu w sprawie Yorkshire Water Services Ltd v. Sun Alliance \& London Ins plc ${ }^{95}$ uznano, że koszt usypania wałów, które przeszkodziły przedostaniu się zanieczyszczonego mułu do sąsiedniej rzeki, nie podlegał zwrotowi. Odmienne rozstrzygnięcie zapadło w nowozelandzkiej sprawie Bridgeman v. Alien Mutual, gdzie przyjęto, że skoro szkoda zdarzyłaby się, gdyby nic nie uczyniono, to koszty ratowania były nieuniknione, a zatem doktryna imminent peril uzasadnia objęcie ich odszkodowaniem. Koszty ratowania podlegają co do zasady zwrotowi niezależnie od warunków umowy również w USA i Australii ${ }^{96}$.

Redaktorzy Principles of European Insurance Contract Law zwracają uwagę, że prawodawstwa państw europejskich, w których zwrot kosztów ratowania jest zwykle regułą, różnią się co do dwóch kwestii. Po pierwsze, w zakresie przyjęcia obiektywnego lub subiektywnego kryterium kosztów, które mogą zostać uznane za celowe, oraz po drugie, co do tego, czy obowiązek zwrotu kosztów ratowania ograniczony jest sumą ubezpieczenia. Obiektywne kryterium celowości przyjmowane jest, poza Polską, w Holandii, Finlandii, Grecji, Portugalii, Hiszpanii i Szwajcarii. Subiektywne przekonanie ubezpieczającego brane jest natomiast pod uwagę, poza Niemcami, w Austrii, Belgii, Luksemburgu oraz we Włoszech. Co do drugiego zagadnienia, koszty ratowania zwracane są w granicach sumy ubezpieczenia z wyjątkiem kosztów wynikających z instrukcji ubezpieczyciela w Niemczech, Austrii, Portugalii, Polsce, natomiast powyżej sumy ubezpieczenia w Belgii, Finlandii, Grecji, Włoszech, Luksemburgu oraz Szwecji i Szwajcarii ${ }^{97}$. W Grecji, Holandii i Szwajcarii ta ostatnia reguła nie ma charakteru bezwzględnie obowiązującego.

Rozwiązanie proponowane w art. 9:102 PEICL przyjmuje ostatecznie subiektywny test celowości oraz zwrot kosztów ratowania ponad

\footnotetext{
94 J. Birds, Birds'..., s. 262-263.

95 [1997] 2 Lloyds Rep 21.

96 M. Clarke, The Law..., s. 960-946.

97 Principles..., s. 254.
} 
sumę ubezpieczenia. Przepis mówi, że ubezpieczyciel powinien zwrócić koszty poniesione oraz równowartość szkody poniesionej przez ubezpieczającego lub ubezpieczonego wobec zastosowania środków w celu zmniejszenia rozmiarów szkody w zakresie, w jakim ubezpieczający lub ubezpieczony miał podstawy w okolicznościach sprawy uważać zastosowanie tych środków za uzasadnione, chociażby okazało się bezskuteczne. W razie zastosowania środków, o których mowa, ubezpieczyciel powinien spełnić świadczenie ubezpieczającemu lub odpowiednio ubezpieczonemu, nawet jeśli razem z odszkodowaniem suma ta przekroczy sumę ubezpieczenia.

\subsubsection{Czasowy zakres kosztów podlegających zwrotowi}

Wracając na grunt prawa polskiego, łatwo zauważyć, że art. $826 \$ 4$ k.c. wprowadza kilka warunków objęcia kosztów ratowania odszkodowaniem ubezpieczeniowym. Przede wszystkim koszty te podlegają zwrotowi jedynie w granicach sumy ubezpieczenia oraz pod warunkiem, że były celowe. Dodatkowo istotny jest przedmiotowy zakres omawianych kosztów, wyznaczony treścią art. $826 \$ 4$ k.c., a dotyczący kosztów ratowania przedmiotu ubezpieczenia oraz zapobieżenia szkodzie lub zmniejszenia jej rozmiarów. Do rozważenia pozostaje również sprawa temporalnego zakresu obowiązku ratowania, a ściślej momentu, w którym aktualizuje się ten obowiązek.

Odnośnie do ostatniej kwestii w literaturze wyrażono pogląd, że obowiązek ratowania mienia powstaje nie z chwilą zaistnienia wypadku ubezpieczeniowego, ale dopiero z chwilą wystąpienia szkody. Dla M. Krajewskiego pogląd ten jest konsekwencją stanowiska, że wypadkiem ubezpieczeniowym jest zdarzenie wywołujące obowiązek świadczenia po stronie ubezpieczyciela, innymi słowy, jest nim dopiero szkoda, nie zaś jej przyczyna. Dodatkowo według M. Krajewskiego stanowisko mówiące, że obowiązek przeciwdziałania szkodzie powstaje już z zajściem wypadku rozumianego jako przyczyna szkody, byłby niekorzystny dla ubezpieczającego, szkoda może mieć bowiem bardzo wiele przyczyn, w związku z czym obowiązek prewencji miałby zbyt szeroki zakres. 
Stanowisko takie byłoby również niekorzystne dla ubezpieczyciela, który musiałby liczyć się z bardzo dużą liczbą roszczeń o zwrot kosztów podjętych działań zapobiegawczych, potencjalnie przewyższających wartościowo roszczenia $\mathrm{z}$ tytułu rzeczywiście doznanych szkód ${ }^{98}$.

Podobny pogląd prezentuje J. Woronkiewicz, który również utożsamia wypadek ze szkodą. Autor ten przyznaje, że określenie wypadku w niektórych ubezpieczeniach mienia może dawać podstawy do wprowadzenia obowiązku prewencji, zanim powstanie szkoda. Ostatecznie jednak, powołując się przede wszystkim na regułę obowiązującą w ubezpieczeniu OC, wedle której ubezpieczyciel zobowiązuje się do zapłacenia odszkodowania za szkody wyrządzone osobom trzecim, za które odpowiedzialność ponosi ubezpieczający lub ubezpieczony, przyjmuje, że obowiązki prewencyjne przed wystąpieniem szkody podlegają regulacji art. 827 k.c. ${ }^{99}$

Niekonsekwentny w omawianej kwestii wydaje się być D. Fuchs. W jednej publikacji mającej charakter ogólny prezentuje on pogląd podobny do stanowiska M. Krajewskiego, składając jednak postulat de lege ferenda objęcia obowiązkiem odszkodowawczym kosztów przeciwdziałania szkodzie, utożsamianej $\mathrm{z}$ wypadkiem ubezpieczeniowym ${ }^{100}$. W innej publikacji dotyczącej obowiązków prewencyjnych wspólnoty mieszkaniowej, która zawarła umowę ubezpieczenia nieruchomości wspólnej, D. Fuchs broni poglądu, że koszty przeciwdziałania szkodzie objęte są odszkodowaniem ubezpieczeniowym de lege lata, $i$ powołuje się przy tym na definicję zdarzenia losowego z ustawy o działalności ubezpieczeniowej z 2003 r. W tej drugiej publikacji D. Fuchs wyraża pogląd, że jeżeli wspólnota mieszkaniowa w razie wystąpienia wypadku ubezpieczeniowego, ale jeszcze przed wystąpieniem szkody podejmie działania naprawcze, np. zawierając odpowiednie umowy określające zakres robót budowlanych, to $\mathrm{w}$ razie rzeczywistego wykonania tych prac będzie

\footnotetext{
98 M. Krajewski, Umowa ubezpieczenia. Art. 805-834 KC..., 2016, s. 584.

99 J. Woronkiewicz, Granice..., s. 28-29.

100 Podobnie D. Fuchs, Zakres..., s. 45.
} 
mogła zwrócić się do ubezpieczyciela o zwrot kosztów poniesionych $\mathrm{z}$ tego tytułu do wysokości sumy ubezpieczonej nieruchomości ${ }^{101}$.

We wcześniejszej części niniejszej pracy zaprezentowano pogląd podający w wątpliwość łączenie wypadku ubezpieczeniowego w ubezpieczeniu mienia z zajściem szkody. Innymi słowy, na pytanie M. Krajewskiego: „wypadek ubezpieczeniowy: przyczyna czy skutek??, udzielono tej pierwszej odpowiedzi. Pogląd oparty na językowej wykładni art. $805 \$ 2$ pkt 1 k.c., zgodnie z którym świadczenie ubezpieczyciela w ubezpieczeniu mienia polega na zapłacie określonego odszkodowania za szkodę powstałą wskutek przewidzianego w umowie wypadku, został szerzej uzasadniony w rozdziale dotyczącym przesłanek odpowiedzialności odszkodowawczej ubezpieczyciela. W moim przekonaniu nie ma podstaw, by rozciągać skutkowe ujęcie wypadku w ubezpieczeniu na życie (śmierć ubezpieczonego) oraz w ubezpieczeniu odpowiedzialności cywilnej (szkoda wyrządzona osobie trzeciej ${ }^{102}$ ) na ubezpieczenia mienia.

Za prezentowanym stanowiskiem dodatkowo przemawia językowa wykładnia art. $826 \$ 1$ k.c., gdzie mowa o podjęciu środków zmierzających w razie zajścia wypadku do zapobieżenia szkodzie lub zwiększenia jej rozmiarów. Podstawowy argument stanowią jednak względy celowościowe. Nawet M. Krajewski przyznaje, że najszersze możliwości zapobieżenia szkodzie istnieją przed zajściem jakiejkolwiek szkody. Dodać można, że pogląd, wedle którego ubezpieczający chcąc domagać się zwrotu kosztów akcji ratowniczej, musi czekać na pierwsze symptomy szkody, przykładowo nie powinien gasić pożaru, dopóki jakieś składniki jego majątku nie zostały strawione w pożarze, wydaje się sprzeczny ze zdrowym rozsądkiem oraz godzi w prewencyjną funkcję ubezpieczeń.

101 D. Fuchs, Obowiązki prewencyjno-ratownicze wspólnoty mieszkaniowej jako specyficznego podmiotu stosunku majątkowego w ubezpieczeniach majątkowych - uwagi na tle art. 826 k.c., RU 2010/1.

$102 \mathrm{~W}$ tych rodzajach tzw. skutkowe ujęcie wypadku również może być kontestowane. W ubezpieczeniu na życie zwykle nie każda śmierć jest bowiem wypadkiem, ale wynika z określonych zdarzeń, natomiast w ubezpieczeniu OC roszczenie ubezpieczającego uzależnione jest od ustalenia, że odpowiedzialność za szkodę wyrządzoną osobie trzeciej ponosi ubezpieczający lub ubezpieczony. 
Pogląd ten jest również nie do pogodzenia z rozumieniem obowiązku prewencji w obcych systemach prawnych. Przypomnieć wypada, że art. 82 niemieckiej VVG, podobnie jak jego polski odpowiednik, mówi o środkach mających na celu stosownie do okoliczności uniknięcie szkody lub zmniejszenie jej rozmiarów. W prawie anglosaskim rozważania dotyczące obowiązku przeciwdziałania szkodzie oraz objęcia odszkodowaniem związanych z tym kosztów odnoszone są przede wszystkim do obowiązku zapobieżenia szkodzie, zagadnienie zmniejszenia szkody traktowane jest jako mniej istotne. Artykuł 9:102 PEICL expressis verbis odnosi się wprawdzie do wydatków i szkód poniesionych w wyniku działań mających na celu jedynie zmniejszenie szkody już zaistniałej (measures to mitigate the loss), jednak rozważania autorów dotyczące tej regulacji wydają się być odnoszone również do zapobieżenia szkodzie (avert the loss).

Trudno podzielić argumenty M. Krajewskiego, który twierdzi, że obowiązek zapobieżenia szkodzie jest za szeroki, ponieważ bardzo wiele przyczyn może prowadzić do zaistnienia szkody. Przepis wprowadza w tym zakresie szereg ograniczeń. Przede wszystkim, co nie budzi wątpliwości, odnosi się on wyłącznie do sytuacji, gdy zaszedł już wypadek ubezpieczeniowy. Sama ta okoliczność stanowi bardzo istotne ograniczenie. Dodatkowo naruszenie obowiązku ratowania jest sankcjonowane, jeżeli rzeczywiście pozostaje w związku przyczynowym z naruszeniem obowiązku ratowania oraz gdy jest skutkiem winy umyślnej lub rażącego niedbalstwa. Ponadto M. Krajewski stanowczo broni teorii adekwatnego związku przyczynowego na gruncie ubezpieczeń, co prowadzi do wniosku, że utrata prawa do świadczenia dotyczy jedynie szkód pozostających w adekwatnym (normalnym) związku przyczynowym z zaniechaniem ubezpieczającego. Niezależnie od powyższego należy pamiętać, że przepis mówi o środkach dostępnych dla konkretnego ubezpieczającego w okolicznościach spraw, nie wymagając środków nadzwyczajnych, a co za tym idzie, nie przewidując obowiązku ich zwrotu.

Trudno również podzielić obawy, że ubezpieczyciel odpowiadałby za ekscentryczne zachowania ubezpieczających przeczulonych na punkcie dbałości o swoje mienie, generujących koszty przekraczające kwoty 
potencjalnych szkód ${ }^{103}$. Najistotniejsze ograniczenie wskazane przez przepis dotyczy celowości podjętych środków. Jest wątpliwe, czy koszt środka zapobiegawczego przekraczający wysokość potencjalnej szkody mógłby zostać uznany za obiektywnie celowy, a w każdym razie dotyczyć to może okoliczności zupełnie wyjątkowych. Dodatkowo w prawie polskim odpowiedzialność ubezpieczyciela za koszty ratowania ograniczona jest sumą ubezpieczenia. Podsumowując ten wątek, można stwierdzić, że przypisywana Hipokratesowi prawda „lepiej zapobiegać niż leczyć" winna mieć swoje odpowiednie zastosowanie również na gruncie art. 826 k.c., szczególnie że za takim ujęciem przemawia również jego treść.

Wyraźne brzmienie przepisu, jak również względy celowości przeczą stanowisku, że tzw. obowiązek ratowania staje się aktualny dopiero z chwilą zajścia szkody. Pogląd M. Krajewskiego prowadził do wniosku, że obowiązek ratowania obejmuje jedynie zmniejszenie już zaistniałej szkody, co z kolei implikuje, że sformułowanie „zapobieżenie szkodzie” jest całkowicie zbędne i pozbawione treści. Ponadto wskazać można, że większość komentatorów prezentuje pogląd zbieżny z zaprezentowanym powyżej, wyraźnie rozróżniając zapobieżenia szkodzie oraz zmniejszenia jej rozmiarów, a nawet niekiedy, podkreślając objęcie obowiązkiem $\mathrm{z}$ art. $826 \$ 1$ k.c., także przeciwdziałania szkodzie jeszcze niezaistnia$\nmid j^{104}$. Kwestia ta ma oczywiście bezpośrednie przełożenie na zakres kosztów ratowania podlegających zwrotowi w ramach odszkodowania ubezpieczeniowego.

Przyznać trzeba, że w konkretnych sytuacjach rozstrzygnięcie, czy wypadek ubezpieczeniowy zaszedł, może być problematyczne. Dobrą ilustracją opisywanych kwestii jest wyrok Sądu Apelacyjnego w Krakowie z 13.05.2014 r., I ACa 319/14 ${ }^{105}$. W stanie faktycznym ostrzeżenie przed powodzią spowodowało, że powódka w celu uniknięcia strat zdecydowa-

103 Por. Principles..., s. 252; M. Clarke, The Law..., s. 945.

104 Zob. przykładowo H. Ciepła [w:] Kodeks...., t. 5, red. J. Gudowski, komentarz do art. 826 k.c., teza 2; Z. Gawlik [w:] Kodeks..., t. 3, red. A. Kidyba, komentarz do art. 826 , teza 1 .

105 LEX nr 1602917. 
ła się na przewiezienie mebli z magazynu w jednej miejscowości do magazynu w innej miejscowości. Decyzję tę podjęła ze względu na mniejsze ryzyko nadejścia fali powodziowej do drugiego miejsca. Przedsięwzięte środki i tak nie uratowały mienia przed powodzią. Zakład ubezpieczeń w apelacji od niekorzystnego wyroku sądu okręgowego argumentował, że mienie przechowywane w tej drugiej miejscowości nie było objęte ubezpieczeniem, natomiast art. $826 \$ 4$ k.c. nie ma zastosowania do roszczenia powódki, gdyż wywiozła ona meble przed powodzią, co nie mieści się w pojęciu „w razie zajścia zdarzenia”. Sąd apelacyjny oddalił apelację, wskazując, że powódź jest zjawiskiem przyrodniczym o rozmiarach i skutkach niedających się dokładnie przewidzieć i rozciągniętym w czasie. Nie można wymagać od ubezpieczonego, aby w obliczu grożącej szkody zwlekał z czynnościami ratującymi mienie do momentu zalewania go wodą.

Trafność wskazanego rozstrzygnięcia zależy od sposobu określenia w umowie wypadku ubezpieczeniowego, co nie wynika z uzasadnienia. Jeżeli wypadek określono jako powódź, sąd apelacyjny zdaje się mieć rację, jeżeli natomiast powódź odniesiono wyraźnie do pierwszego magazynu albo wspomniano o zalaniu, trafność rozstrzygnięcia wydaje się wątpliwa. W omawianej sprawie kwestia dotyczyła, ściśle rzecz biorąc, efektywnie poniesionej szkody w wąskim rozumieniu, nie zaś kosztów przewiezienia rzeczy, wydaje się jednak, że szkody pozostające w normalnym związku przyczynowym ze zdarzeniem objętym ubezpieczeniem mieszczą się w szeroko rozumianych kosztach wynikających z zastosowania środków zmierzających do ratowania mienia. Zagadnienie to dostrzegli redaktorzy PEICL, odrębnie wymieniając efektywne szkody związane $\mathrm{z}$ ratowaniem mienia oraz poniesione $\mathrm{w}$ wykonaniu obowiązku ratowania wydatki. Odnosząc podobne stany faktyczne do wydatków zmierzających do ratowania mienia, można wyobrazić sobie pożar w sąsiednim budynku oraz koszty poniesione przez ubezpieczającego w celu zapobieżenia rozprzestrzenienia się pożaru. Rozstrzygnięcie znów będzie zależało od określenia w polisie wypadku ubezpieczeniowego. Co do zasady jednak ubezpieczający będzie miał prawo do zwrotu kosztów akcji ratowniczej niezależnie od tego, czy pożar wyrządził jakiekolwiek szkody. 


\subsubsection{Przedmiotowy i kwotowy zakres kosztów podlegających zwrotowi}

Jak wskazano, ustawa wymienia „środki podjęte w celu ratowania przedmiotu ubezpieczenia oraz zapobieżenia szkodzie lub zmniejszenia jej rozmiarów". W porównaniu do art. 826 k.c. sprzed zmiany dodano zapis, że środki mają być podjęte „w celu ratowania przedmiotu ubezpieczenia”, zapewne chcąc rozbudować cele, którym służyć mają przewidywane środki ${ }^{106}$. Relacja między środkami mającymi na celu ratowanie przedmiotu ubezpieczenia oraz środkami mającymi na celu zapobieżenie szkodzie oraz zmniejszenie jej rozmiarów nie jest jednak jasna, a komentatorzy jej nie tłumaczą. Dosyć trudno wyobrazić sobie środki mające na celu ratowanie przedmiotu ubezpieczenia niemające na celu zapobieżenia szkodzie lub zmniejszenia jej rozmiarów, a nadto jest wątpliwe, czy koszt tego rodzaju środków mógłby podlegać zwrotowi. W sytuacji, gdy art. $826 \$ 1$ k.c. rozpoczyna się od słów „W razie zajścia wypadku ubezpieczający”, nie można również objąć sformułowaniem „ratowanie przedmiotu ubezpieczenia" środków mających na celu przeciwdziałanie zajściu samego wypadku ubezpieczeniowego. Podsumowując, dodatek w postaci „kosztów ratowania przedmiotu ubezpieczenia” wydaje się nieszkodliwy, ale jednocześnie zbędny.

Następne zagadnienie dotyczy ograniczenia zwrotu kosztów ratowania do kosztów „celowych, choćby okazały się bezskuteczne”. W pewnym stopniu koresponduje to z zakresem obowiązku z art. $826 \$ 1$ k.c., którym objęte są jedynie koszty dostępne dla ubezpieczającego. Znaczenie sformułowania „środki dostępne” zostało wyżej omówione. Kryteria „dostępności” z art. $826 \$ 1$ k.c. oraz „celowości” z art. $826 \$ 4$ k.c. są oczywiście niezależne, tym niemniej pozostają ze sobą w pewnym związku. Użycie środków, których obiektywnie nie można było wymagać od ubezpieczającego w określonej sytuacji z uwagi na pierwsze kryterium, często może być uznane za „niecelowe”.

106 D. Mróz, Kodeks cywilny. Komentarz do zmian wprowadzonych ustawa $z$ dnia 13 kwietnia 2007 r. o zmianie ustawy - Kodeks cywilny oraz o zmianie niektórych innych ustaw, LEX/el 2008. 
Jak wyżej wskazano, polski Kodeks cywilny, odmiennie od regulacji niemieckiej oraz PEICL, przyjmuje obiektywne kryterium celowości środków. Celowość nie jest wszakże oceniana przez pryzmat skutku. Przepis wyraźnie bowiem upoważnia ubezpieczającego do domagania się zwrotu kosztów środków, które okazały się bezskuteczne, jeżeli tylko były celowe. Użycia kryterium obiektywnego bez odniesienia się do sytuacji konkretnego ubezpieczającego nie należy uważać za błąd. Wydaje się zresztą, że sformułowanie przepisu nie wyklucza zupełnie uwzględnienia elementów subiektywnych. Jak wskazuje M. Krajewski, oceny celowości poniesionych kosztów nie należy dokonywać ex post, kiedy znany jest rzeczywisty rozwój wypadków, ale biorąc pod uwage informację znane ubezpieczającemu w chwili ich ponoszenia.

Użycie lakonicznego sformułowania „koszty celowe” nie wyklucza odniesienia do bardzo popularnej w prawie anglosaskim kategorii rozsądku. Należy przyznać rację J. Woronkiewiczowi, że granica wypełniania obowiązku prewencji oraz domagania się związanych z tym kosztów winna być wypełniona trzema kryteriami, a mianowicie: rozsądkiem, proporcją ekonomicznego rozeznania co do wartości potencjalnej szkody oraz kosztów związanych $\mathrm{z}$ ratowaniem mienia, i wreszcie aksjologicznym zestawieniem wartości dobra ratowanego $\mathrm{z}$ dobrem narażonym przy zastosowaniu środków zapobieżenia szkodzie w razie zajścia wypadku ${ }^{107}$. Domaganie się zwrotu kosztów związanych z narażeniem życia, zdrowia lub mienia o istotnej wartości dla ratowania obiektywnie trywialnych i błahych składników mienia raczej nie będzie zasadne. Wątpliwości dotyczyć mogą rzeczy, których dotyczy premium affectionis. Wydaje się, że brak odniesienia się w przepisie do subiektywnej sytuacji ubezpieczonego jest zamierzony i zwykle wykluczać będzie zwrot istotnych wydatków oraz szkód poniesionych w związku z ich ratowaniem, jeżeli obiektywnie przedstawiały nikłą wartość.

Ostatnia kwestia dotyczy kwotowych ograniczeń zwrotu poniesionych kosztów ratowania w granicach sumy ubezpieczenia, co jest niezgodne z propozycją PEICL, choć bywa spotykane w systemach prawnych niektórych państw europejskich. Sprawa ma przynajmniej dwa aspekty.

107 J. Woronkiewicz, Granice..., s. 31. 
Pierwszy dotyczy spotykanych w praktyce postanowień OWU, ograniczających zwrot kosztów ratowania w ramach sumy ubezpieczenia proporcją lub określoną kwotą. Przykładowo ubezpieczyciel przewiduje, że zwrot kosztów ratowania następuje w granicach sumy ubezpieczenia, przy czym nie może przekroczyć 10\% jej wartości lub też kwoty 10000 zł. Praktyka ta budzi zasadnicze wątpliwości w doktrynie. Wskazuje się, że semiimperatywny charakter art. $826 \$ 4$ k.c. pozwala na rozszerzenie odpowiedzialności ubezpieczyciela na koszty ratowania ponad sumę ubezpieczenia, sprzeciwia się natomiast postanowieniom przewidującym, że koszt ten nie może przekroczyć jej odpowiedniej części ${ }^{108}$. $\mathrm{Z}$ poglądem tym trudno się nie zgodzić.

Drugi aspekt jest ważniejszy i dotyczy samej zasadności rozwiązania polegającego na limitowaniu kosztów ratowania sumą ubezpieczenia. Zagadnienie to wiąże się z charakterem wydatków poniesionych w celu ratowania mienia. W literaturze wskazano, że wydatki te stanowią $\mathrm{w}$ istocie zwiększenie szkody wywołanej wypadkiem ubezpieczeniowym - powiązane z nim normalnym związkiem przyczynowym ${ }^{109}$. Eugeniusz Kowalewski zaznacza natomiast, że ograniczenie roszczenia o zwrot kosztów do kosztów „celowych” stanowi odstępstwo od reguł adekwatnego związku przyczynowego ${ }^{110}$. Abstrahując od kwestii związku przyczynowego między kosztami ratowania a wypadkiem, podkreślić należy, że w braku wyraźnej regulacji ustawowej zwrot kosztów ratowania nie przysługiwałby ubezpieczającemu z uwagi na zasadę lokalizacji szkody ${ }^{111}$, i to niezależnie od wyraźnych ograniczeń w ogólnych warunkach ubezpieczenia ${ }^{112}$.

108 Tak przykładowo M. Krajewski, Umowa ubezpieczenia. Art. 805-834 KC..., 2016, s. 594; M. Kościelniak, Zakres obowiązku refundacji kosztów przewidzianych w art. 826 $\$ 1$ k.c. na przykładzie wybranych zapisów ogólnych warunków ubezpieczenia autocasco, MU 2012/51; s. 29, G. Woronkiewicz, Granice..., s. 33.

109 M. Krajewski, Umowa ubezpieczenia. Art. 805-834 KC..., 2016, s. 593 z powołaniem się na J. Kondka.

110 E. Kowalewski, Odszkodowanie ubezpieczeniowe za utracone korzyści, s. 47.

111 Zob. uwagi z rozdziału 4 dotyczącego ograniczeń odpowiedzialności ubezpieczeniowej.

112 Inaczej M. Krajewski, Umowa ubezpieczenia. Art. 805-834 KC..., 2016, s. 593, według którego zasada lokalizacji szkody jest wynikiem odpowiedniej regulacji OWU. 
Na zewnętrzny charakter kosztów ratowania w stosunku do szkody ubezpieczeniowej zwraca się uwagę w literaturze angielskiej. Malcolm Clarke wskazuje przykładowo, że szkoda wywołana przez wodę użytą do gaszenia pożaru w ubezpieczeniu mienia będzie objęta odszkodowaniem, natomiast koszty ratowania już nie, ponieważ ubezpieczenie ogniowe obejmuje szkody w mieniu stanowiącym przedmiot ubezpieczenia, nie zaś szkody dla jego kieszeni ${ }^{113}$. Angielskie prawo czynów niedozwolonych wyraźnie oddziela szkodę fizyczną od szkody polegającej na wydatkach poniesionych $\mathrm{w}$ celu stworzenia barier dla rozprzestrzeniania się szkody. Te drugie uważane są za szkodę czysto ekonomiczną, niepodlegającą naprawieniu. Wprawdzie reguły prawa czynów niedozwolonych nie mają większego znaczenia dla prawa umów ubezpieczenia, jednak w obu przypadkach istnienie odpowiedzialności zależy od jej przyjęcia (a ściślej od możliwości przewidywania). Sąd angielski raczej nie przyjmie, że ubezpieczyciel w ramach ubezpieczenia mienia zamierzał przejąć ryzyko wydatków, których wysokości nie sposób przewidzieć i które mogą zależeć od subiektywnej sytuacji konkretnego ubezpieczającego ${ }^{114}$.

Jak się zdaje, z podobnych względów w prawie francuskim przyjmuje się, że bezpośrednia materialna szkoda wynikająca z wypadku i podjęcia środków zmierzających do zapobieżenia szkodzie, o której mowa w art. L122-3 Code des assurances, obejmuje efektywną szkodę w mieniu będącym przedmiotem ubezpieczenia, nie obejmuje zaś wydatków poniesionych na sfinansowanie akcji ratowniczej. Ryzyko wydatków odnoszące się w rzeczywistości do sfery pasywów obejmowane być może niektórymi rodzajami ubezpieczeń, w szczególności ubezpieczeniem ochrony prawnej oraz ubezpieczeniem assistance, nie należy natomiast do ubezpieczenia mienia. Stanowi ono w istocie szkodę pośrednią, niepodlegającą co do zasady naprawieniu w ubezpieczeniu mienia oraz nieobjętą wartością ubezpieczenia ${ }^{115}$.

\footnotetext{
113 M. Clarke, The Law..., s. 945.

114 M. Clarke, The Law..., s. 945.

115 S. Beaugendre, Contrat..., s. 31.
} 
W prawie polskim sprawa przenikania się wydatków związanych z ratowaniem mienia oraz wydatków związanych $\mathrm{z}$ udzieleniem ubezpieczającemu pomocy jest dobrze widoczna na styku ubezpieczenia autocasco oraz samochodowego assistance. Wydatki związane $\mathrm{z}$ koniecznością holowania uszkodzonego pojazdu mechanicznego, przetransportowaniem, umieszczeniem pojazdu na parkingu powinny być przez zakład ubezpieczeń zrefundowane ubezpieczającemu na zasadach przewidzianych w treści art. 826 k.c. Mieszczą się one w ramach świadczenia wynikającego z umowy ubezpieczenia autocasco, jeżeli są celowe dla ratowania samego samochodu oraz zapobieżenia szkodzie w nim zlokalizowanej lub zmniejszenia jej rozmiarów. Ewentualnie poniesione przez ubezpieczającego koszty noclegu lub transportu zastępczego, związane $\mathrm{z}$ uczestnictwem w wypadku lub awarią z dala od miejsca zamieszkania, są już objęte sferą ubezpieczenia assistance, które chroni majątek ubezpieczającego jako całość przed nadzwyczajnymi wydatkami związanymi $\mathrm{z}$ wypadkiem lub awarią.

W doktrynie na okoliczność, że koszt prewencji stanowi odrębną część świadczenia ubezpieczeniowego, zwracają uwagę D. Fuchs i M. Woronkiewicz ${ }^{116}$. Ten ostatni wskazuje, że zwrot kosztów ratowania mienia przed szkodą w ramach sumy ubezpieczenia niejednokrotnie będzie prowadził do znacznego wyczerpania sumy ubezpieczenia i paradoksu polegającego na braku wypłaty odszkodowania za szkody w mieniu stanowiącym przedmiot ubezpieczenia. Cytowany autor postuluje nawet umowne ustalanie „niejako podwójnej sumy ubezpieczenia przeznaczonej na odszkodowanie w razie wypadku ubezpieczeniowego oraz na koszy zapobiegania szkodzie i zmniejszenia jej rozmiarów"117.

Opisane względy, w szczególności okoliczność, że koszty ratowania nie mieszczą się nawet w wartości ubezpieczenia, wydają się wskazywać na wadliwość rozwiązania przyjętego przez polskiego ustawodawcę, które ogranicza zwrot kosztów ratowania do sumy ubezpieczenia. Można jednak zapytać, z jakiej racji ubezpieczyciel miałby ponosić ryzyko wydatków niemieszczących się w sumie ubezpieczenia, skoro na podstawie

116 D. Fuchs, Zakres..., s. 47; J. Woronkiewicz, Granice..., s. 33.

117 J. Woronkiewicz, Granice..., s. 34. 
tej sumy ustalał składkę ubezpieczeniową. Z całą pewnością istnieje konflikt interesów, który prawo powinno rozstrzygnąć. Redaktorzy PEICL tłumaczą przyjęte rozwiązanie właśnie potrzebą wyważenia interesów stron.

Z jednej strony ubezpieczyciel nie powinien ponosić ryzyka ekstrawagancji zrozpaczonego ubezpieczającego. Przy kalkulacji składki ubezpieczeniowej ubezpieczyciel zwykle nie bierze pod uwagę ryzyka kosztów ratowania i jest wątpliwe, czy takie ryzyko w ogóle daje się skalkulować. $\mathrm{Z}$ drugiej strony ubezpieczający nie powinien być powstrzymywany w akcji ratowniczej przez myśl, że odszkodowanie w żadnym razie nie może przekroczyć sumy ubezpieczenia. Nawet ubezpieczający zachowujący w obliczu wypadku przysłowiową zimną krew rzadko będzie w stanie dokładnie oszacować koszty akcji ratowniczej, tak by nie przekroczyły z góry ustalonego limitu. Akcja podejmowana ze świadomością ograniczenia całego świadczenia ubezpieczyciela wysokością sumy ubezpieczenia z dużym prawdopodobieństwem okaże się nieskuteczna. Ostatecznie zdaniem redaktorów PEICL względy słuszności przemawiają za obciążeniem ryzykiem raczej ubezpieczyciela niż ubezpieczającego oraz za objęciem kosztów ratowania odszkodowaniem bez względu na wysokość sumy ubezpieczenia ${ }^{118}$.

Powyższa argumentacja wydaje się przekonująca. Poza zewnętrznym ze swej istoty charakterem wydatków poniesionych $\mathrm{w}$ celu ratowania mienia w stosunku do szkody ubezpieczeniowej oraz względami mającymi na celu zapewnienie skuteczności akcji ratowniczej dodać można dwa mniej istotne argumenty. Ubezpieczający niemal zawsze jest gospodarczo słabszą stroną umowy ubezpieczenia. Ubezpieczyciel ma większy potencjał, a jego działalność $\mathrm{z}$ istoty rzeczy nastawiona jest na wypłacanie odszkodowań. Dodatkowo, nawet przy braku ograniczenia w postaci sumy ubezpieczenia, test celowości wydatków wydaje się dostatecznym zabezpieczeniem interesów wierzyciela, a przy tym znacznie bardziej elastycznym niż suma ubezpieczenia. W odniesieniu do porządków prawnych, gdzie suma ubezpieczenia nie wyznacza limitu zwrotu kosztów ratowania, zwraca się uwagę, że testy celowości, rozsądku lub

118 Principles..., s. 252. 
konieczności ponoszonych wydatków pełnią podobną funkcję. Była już mowa o tym, że koszty ratowania przekraczające wysokość potencjalnego odszkodowania rzadko kiedy będą mogły być uznane za koszty celowe $^{119}$. Spotykane $w$ niektórych państwach zastrzeżenie, że zwrot kosztów ratowania należy się ponad sumę ubezpieczenia tylko w razie przestrzegania wskazówek ubezpieczyciela, wydaje się zbyt daleko idące, ponieważ zwykle skuteczność akcji ratowniczej zależy od jej szybkości, ta zaś wyklucza kontaktowanie się z ubezpieczycielem i oczekiwanie na jego wskazówki.

Oczywiście norma $\mathrm{z}$ art. $826 \$ 4$ k.c. jest semiimperatywna ${ }^{120}$. Z drugiego zdania tego przepisu wynika, że umowa lub ogólne warunki ubezpieczenia mogą zawierać postanowienia korzystniejsze dla ubezpieczającego. Jako najczęstszy przykład postanowienia odbiegającego od reguł kodeksowych wskazuje się właśnie postanowienie, według którego ubezpieczyciel jest zobowiązany do zwrotu kosztów ratowania mienia niezależnie od zastrzeżonej sumy ubezpieczenia ${ }^{121}$. W praktyce tego rodzaju szczodrobliwość ze strony ubezpieczycieli wydaje się mało prawdopodobna. Powyższe uwagi pozwalają sformułować ostrożny postulat de lege ferenda, aby przy okazji kolejnej reformy przepisów Kodeksu cywilnego o umowie ubezpieczenia dokonać korekty reguły dotyczącej zwrotu kosztów ratowania poprzez wskazanie, że ubezpieczyciel zobowiązany jest do pokrycia w ramach odszkodowania kosztów celowych niezależnie od wysokości sumy ubezpieczenia. Można rozważyć zastrzeżenie, że rezygnacja $\mathrm{z}$ ograniczenia w postaci sumy ubezpieczenia dotyczy wydatków konsultowanych z ubezpieczycielem, jeżeli okoliczności sprawy na taką konsultację pozwalały.

119 Tak Principles..., s. 254.

120 Co do implikacji takiego ukształtowania przepisu, zob. M. Kościelniak, Zakres..., s. 29 i n.

121 M. Krajewski, Umowa ubezpieczenia. Art. 805-834 KC..., 2016, s. 594. 


\subsection{Termin spełnienia świadczenia pieniężnego ubezpieczyciela}

\subsubsection{Wprowadzenie}

Realność ochrony ubezpieczeniowej w dużej mierze zależy od pewności oraz szybkości wypłaty odszkodowania ubezpieczeniowego. W doktrynie podkreślano, że pewien automatyzm w uzyskaniu odszkodowania ubezpieczeniowego stanowi o przewadze kompensacji ubezpieczeniowej nad innymi formami kompensacji ${ }^{122}$. Współczesny sens zasady najwyższego zaufania w umowie ubezpieczenia polega w równej mierze na zaufaniu ubezpieczyciela do informacji uzyskiwanych od ubezpieczającego i jego ostrożnej postawy, co na wierze ubezpieczającego w profesjonalizm i rzetelność ubezpieczyciela ${ }^{123}$. Odszkodowanie ubezpieczeniowe może być ubezpieczającemu potrzebne natychmiast, żeby odbudować zniszczony budynek, naprawić uszkodzoną maszynę lub zastąpić skradziony samochód innym. Pewność i terminowość uzyskania odszkodowania ma szczególne znaczenie dla przedsiębiorców chcących zapobiec przerwom w działalności gospodarczej.

Kłopoty związane z ustaleniem terminu płatności świadczenia ubezpieczyciela ilustruje prawo angielskie, gdzie w orzecznictwie ścierały się dwie koncepcje. Według pierwszej z nich, będącej naturalną konsekwencją tradycyjnej angielskiej koncepcji utożsamiającej odszkodowanie ubezpieczeniowe $\mathrm{z}$ odszkodowaniem $\mathrm{z}$ tytułu niewykonania umowy, ubezpieczyciel znajdował się w zwłoce od chwili zajścia szkody i od tej chwili rozpoczynał bieg termin przedawnienia. Drugi pogląd odwoływał się do czasu rozsądnego przy uwzględnieniu wszystkich okoliczności sprawy, konieczności wyjaśnienia przez ubezpieczyciela zasady odpowiedzialności i wielkości należnego odszkodowania, a także współdziałania ze strony ubezpieczającego ${ }^{124}$. Znalazł on podsumowanie

122 W. Warkałło, Ubezpieczenie a odpowiedzialność..., s. 140 i n.

123 B. Kucharski, Przeniesienie..., s. 59-60; K. Malinowska, Umowa ubezpieczenia w Europie bez granic, Bydgoszcz 2008, s. 180, 190, 194; J. Birds, Birds'..., s. 159 i n.

124 Zob. przykładowo M. Clarke, The Law..., s. 964-969. 
w regulacji art. 13a dodanego w maju 2017 r. do ustawy ubezpieczeniowej z 2015 r. ${ }^{125}$

Zgodnie z tym przepisem w każdej umowie ubezpieczenia domniemywa się istnienie postanowienia, według którego ubezpieczyciel winien zapłacić w rozsądnym czasie. Czas rozsądny ustala się, biorąc pod uwagę konieczność wyjaśnienia i oszacowania szkody przez ubezpieczyciela oraz okoliczności konkretnego przypadku. W szczególności brać należy pod uwagę rodzaj ubezpieczenia, rozmiar i stopień skomplikowania roszczenia, przestrzeganie reguł ustawowych oraz branżowych i etycznych, a także czynniki poza kontrolą ubezpieczyciela. Jeżeli ubezpieczyciel wykaże, że były rozsądne podstawy, by kwestionować roszczenie co do wysokości lub zasady, nie uchybia terminowi płatności, wstrzymując się z wypłatą przez czas trwania sporu. Sposób likwidacji szkody przez ubezpieczyciela jest istotny dla rozstrzygnięcia, czy ubezpieczyciel naruszył termin płatności oraz ewentualnie kiedy.

Jak widać, przepis jest kazuistycznie sformułowany, co jest charakterystyczne dla prawa anglosaskiego, gdzie regulacje ustawowe często podsumowują dorobek orzecznictwa. Dodatkowo jest mało precyzyjny, a w dwóch miejscach odwołuje się do rozsądku jako klauzuli generalnej. Można zaryzykować stwierdzenie, że kwestia terminu spełnienia świadczenia przez ubezpieczyciela w dalszym ciągu będzie rodzić spory. Wydaje się, że najbardziej istotną zdobyczą regulacji jest rezygnacja z koncepcji, według której ubezpieczyciel popadał w zwłokę z chwilą zajścia wypadku, oraz wprowadzenie w ostatnim ustępie, poza odsetkami za opóźnienie, odszkodowania za niespełnienie świadczenia w terminie, które wcześniej nie było dostępne.

Prawodawstwa Europy kontynentalnej rozstrzygają kwestię różnie. Coraz rzadziej termin spełnienia świadczenia $\mathrm{z}$ umowy ubezpieczenia podlega ogólnym regułom prawa cywilnego. Takie rozwiązanie obowiązuje przykładowo w prawie holenderskim, belgijskim oraz włoskim z pominięciem ubezpieczeń samochodowych. Drugi model, zbliżo-

125 The Insurance Act z 12.02.2015 r. obowiązujący od 12.08.2016 r. Art. 13a dodano 4.05.2017 r. 
ny do pierwszego, polega na ogólnym wskazaniu, że wypłata odszkodowania ubezpieczeniowego powinna nastąpić natychmiast lub bez zbędnej zwłoki (tak np. art. 7 ust. 7 greckiej ustawy o umowie ubezpieczenia). Trzecia możliwość sprowadza się do pozostawienia kwestii do uregulowania w warunkach ubezpieczenia. Przykładowo zgodnie Z art. L113-5 francuskiego Code des assurances ubezpieczyciel winien wykonać świadczenie wskazane w umowie w uzgodnionym terminie i nie wolno mu tego terminu przekroczyć.

Coraz powszechniej przyjmowane jest rozwiązanie czwarte, polegające na wskazaniu konkretnego terminu oscylującego najczęściej między czternastoma a trzydziestoma dniami od daty otrzymania przez ubezpieczyciela zawiadomienia o szkodzie albo od daty uzyskania informacji potrzebnych do ustalenia zasady i zakresu odpowiedzialności. Zwykle dodatkowo wskazuje się termin, w którym ubezpieczyciel winien wypłacić bezsporną część świadczenia. Dosyć typowa w tej grupie jest regulacja niemieckiej VVG, zgodnie z którą ubezpieczyciel winien wypłacić świadczenie, kiedy uzyskał informacje pozwalające na ustalenie swej odpowiedzialności oraz wysokości należnego świadczenia. Jeżeli ubezpieczyciel nie zdołał wyjaśnić tych kwestii w ciągu miesiąca od daty otrzymania zawiadomienia o wypadku, ubezpieczający może domagać się przynajmniej części świadczenia, którą ubezpieczyciel będzie musiał zapłacić zgodnie z przewidywaniami. Bieg terminu wstrzymuje brak niezbędnego współdziałania ze strony ubezpieczającego (art. 14 VVG).

Rozwiązanie przyjęte w Principles of European Insurance Contract Law również nawiązuje do europejskich trendów, by termin określić precyzyjnie. Artykuł 6:104 PEICL wskazuje, że ubezpieczyciel, który przyjął zgłoszenie szkody, winien płacić lub wykonać usługę, do której się zobowiązał, bez zbędnej zwłoki. Jeżeli nawet nie można oszacować całkowitej wartości szkody, ubezpieczający jest uprawniony przynajmniej do części odszkodowania, która winna być zapłacona bez zbędnej zwłoki. Wypłata świadczenia powinna mieć przy tym miejsce w ciągu tygodnia od przyjęcia i oszacowania przez ubezpieczyciela szkody lub jej części. Warto jednak zastrzec, że w odróżnieniu od ustawodawstwa niemieckiego nie wprowadza się żadnego terminu gilotynującego, liczonego od zawiadomienia ubezpieczyciela o wypadku. Różnice dotyczące tej 
kwestii są z punktu widzenia stron umowy niezmiernie istotne. Wprowadzenie terminu liczonego od ustalenia zasady i wysokości należnego świadczenia przez ubezpieczyciela umożliwia mu powoływanie się na niemożność powzięcia niezbędnych ustaleń i z punktu widzenia ubezpieczającego jest wysoce niekorzystne.

W nurt preferujący zastrzeżenie wyraźnie oznaczonego terminu liczonego od daty zawiadomienia wpisuje się także regulacja $z$ art. 817 polskiego k.c., zgodnie z którą ubezpieczyciel winien spełnić świadczenie w ciągu 30 dni od otrzymania zawiadomienia o wypadku. Gdyby w powyższym terminie wyjaśnienie okoliczności koniecznych do ustalenia odpowiedzialności ubezpieczyciela albo wysokości świadczenia okazało się niemożliwe, świadczenie powinno być spełnione w ciągu $14 \mathrm{dni}$ od dnia, w którym przy zachowaniu należytej staranności wyjaśnienie tych okoliczności było możliwe. Jednakże bezsporną część świadczenia ubezpieczyciel powinien spełnić w terminie wcześniej przewidzianym. Cała norma jest semiimperatywna - istnieje możliwość uzgodnienia warunków korzystniejszych dla uprawnionego do świadczenia, co oczywiście w praktyce zdarza się rzadko ${ }^{126}$.

Możliwości manipulowania terminem płatności przez ubezpieczyciela na niekorzyść ubezpieczającego są ograniczone. Wydaje się, że ubezpieczyciel może wpływać na termin przede wszystkim przez odpowiednie określenie zakresu przejmowanego ryzyka. Przykładowo w wyroku z 5.12.2000 r., IV CKN 185/00 127 , stwierdzono, że pokrycie przez ubezpieczyciela kosztów leczenia i nieszczęśliwych wypadków za granicą nie jest uzależnione od ich udokumentowania przez ubezpieczającego. Uzasadnienie wskazuje jednak, że SN skłonny byłby zgodzić się z ubezpieczycielem, który powoływał się na przedwczesność powództwa z uwagi na nieprzedstawienie przez powódkę dowodów poniesienia kosztów leczenia, gdyby OWU wskazywały wyraźnie, że przedmiotem ubezpieczenia są jedynie koszty poniesione.

126 Kwestię omawiałem wcześniej w opracowaniu: Termin..., s. 158 i n., które wykorzystuję w niniejszej pracy.

127 LEX nr 162229. 
Do kwestii tej można się odnieść, zwracając uwagę na niekonsekwentne zdaniem niektórych orzecznictwo SN na gruncie ubezpieczenia OC posiadaczy pojazdów mechanicznych z jednej strony dopuszczające zwrot kosztów naprawy pojazdu niezależnie od tego, czy naprawa została wykonana ${ }^{128}$, oraz z drugiej strony wykluczające zwrot kosztów wynajmu pojazdu zastępczego, jeżeli koszty takie nie zostały poniesione ${ }^{129}$. W dobrowolnych ubezpieczeniach mienia ubezpieczyciel może swobodnie kształtować zakres swojej odpowiedzialności, nie będąc skrępowany normami prawa powszechnego kształtującymi warunki ubezpieczeń obowiązkowych ani zasadami akcesoryjności odpowiedzialności ubezpieczyciela wobec odpowiedzialności sprawcy i pełności odszkodowania. Dopuszczalne wydaje się zatem zastrzeżenie, że ubezpieczyciel wypłaca odszkodowanie odpowiadające wydatkowanym kosztom przywrócenia stanu poprzedniego tylko w takim zakresie, $\mathrm{w}$ jakim ubezpieczający jest w stanie udokumentować ich poniesienie. Rozwiązanie takie byłoby oczywiście niewygodne z punktu widzenia ubezpieczających, niezgodne z kierunkiem, w jakim zmierza prawo ubezpieczeniowe. Ubezpieczenie ukształtowane $\mathrm{w}$ ten sposób winno być znacznie tańsze od ubezpieczenia, którego warunki nie uzależniają pokrycia przez ubezpieczyciela kosztów przywrócenia do stanu poprzedniego od uprzedniego poniesienia tych kosztów przez ubezpieczającego.

\subsubsection{Charakter prawny terminu i konsekwencje jego niedochowania}

Nie budzi wątpliwości, że termin z art. 817 k.c. jest zarówno terminem płatności świadczenia ubezpieczeniowego (terminem wymagalności), jak również terminem rozpoczynającym bieg przedawnienia roszczeń wobec ubezpieczyciela ${ }^{130}$. Uchylony nowelą z 2007 r. art. 819 \$ 2 k.c.

128 Wyrok SN z 27.06.1988 r., I CR 151/88; wyrok SN z 7.08.2003 r., IV CKN 387/01; wyrok SN z 12.02.2004 r., V CK 187/03.

129 Uchwała SN (7) z 17.11.2011 r., III CZP 5/11, OSNC 2012/3, poz. 28, z glosami T. Szanciło, OSP 2013/1, poz. 2, E. Wiewiórowskiej-Domagalskiej, EPS 2013/3, s. 47 i n., B. Panfila, „Glosa” 2014/2, s. 58 i n., T. Kotuka, LEX/el. 2012.

130 Por. A. Chróścicki, Umowa..., s. 93. Autor nietrafnie przyjmuje, że wcześniej termin $\mathrm{z}$ art. 817 był terminem płatności, nie był zaś terminem wymagalności. Przed 
nakazywał liczyć bieg terminu przedawnienia od dnia zdarzenia objętego ubezpieczeniem. Termin przedawnienia rozpoczynał zatem bieg przed terminem wymagalności, co było sprzeczne z podstawowymi regułami prawa cywilnego. Regulacja niekiedy prowadziła do sytuacji, w których ubezpieczający, nie wiedząc o zajściu wypadku, nie zgłaszał szkody, a mimo to rozpoczynał się bieg terminu przedawnienia ${ }^{131}$. Niezależnie od powyższego zgłaszano wątpliwości odnośnie do użycia w art. 819 $\$ 2$ k.c. terminu „zdarzenie objęte ubezpieczeniem” zamiast „wypadek ubezpieczeniowy" ${ }^{132}$. Zmianę należy zatem ocenić pozytywnie.

Skoro termin wskazany w art. 817 jest terminem wymagalności, to z jego upływem ubezpieczyciel popada w opóźnienie, a jeżeli uchybienie terminowi jest zawinione, to w zwłokę. Istnieje pogląd, że zasada ustalenia odszkodowania według cen $z$ daty wyrokowania obowiązująca także w ubezpieczeniach uzasadnia przyznanie odsetek dopiero od tej daty ${ }^{133}$. Pogląd ten aprobowany m.in. przez A. Szpunara wydawał się jednak w znacznej mierze podyktowany istotnymi zmianami cen w dobie szalejącej inflacji ${ }^{134}$. Omawiana kwestia straciła na znaczeniu w związku z ustabilizowaniem się sytuacji cenowej i Sąd Najwyższy od wskazanego poglądu odstąpił, wskazując, że odsetki należą się od daty zgłoszenia szkody ${ }^{135}$. Niezależnie od tego trafne wydaje się stanowisko,

uchyleniem art. $819 \$ 2$ k.c. mógł po prostu prowadzić do sytuacji, gdy bieg terminu przedawnienia rozpoczynał się przed terminem wymagalności.

131 Zastrzeżenia zgłaszali przedstawiciele doktryny. Zob. A. Szpunar, Przedawnienie..., s. 44; E. Kowalewski, J. Łopuski, Przedawnienie roszczeń z ubezpieczenia gospodarczego, SU 1989, t. X, s. 93-94; M. Orlicki, Umowa ubezpieczenia, 2002, s. 202-203; M. Krajewski, Umowa ubezpieczenia. Art. 805-834 KC..., 2016, s. 153-154. Motywy zmiany tłumaczy J. Pokrzywniak [w:] M. Orlicki, J. Pokrzywniak, Umowa..., s. 92.

132 A. Cudna-Wagner, Odpowiedzialność..., s. 135; M. Krajewski, Umowa ubezpieczenia. Art. 805-834 KC..., 2004, s. 154.

133 Tak w szczególności M. Kaliński, Szkoda..., s. 518-522 oraz powołane tam orzecznictwo i literatura.

134 Zob. przykładowo uchwała SN z 8.07.1993 r., III CZP 80/93, z glosą krytyczną A. Szpunara, OSP 1994/3, poz. 50; uchwała SN z 6.09.1994 r., III CZP 105/94, OSNC 1995/2, poz. 26 z glosą aprobującą A. Szpunara, PPH 1995/6, s. 37.

135 Orzecznictwo SN jest rozbieżne i bardzo bogate. Jego dorobek podsumowuje wyrok z 18.02.2010 r., II CSK 434/09, LEX nr 602683, dotyczący terminu płatności odszkodowania z obowiązkowego ubezpieczenia OC posiadaczy pojazdów mechanicznych, w którym SN zajmuje stanowisko, według którego zarówno odszkodowanie, 
według którego w sytuacji, gdy ceny z daty upływu terminu wskazanego w art. 817 k.c. były istotnie niższe od cen z daty wyrokowania, odsetki można naliczać od tej pierwszej daty, ale jedynie od odszkodowania wyliczonego przy przyjęciu cen aktualnych w tej dacie ${ }^{136}$. Przyjęcie biegu odsetek dopiero od daty wyrokowania uzasadnione jest natomiast w przypadku zmiany wysokości świadczenia z powołaniem się na waloryzację sądową (art. $358^{1} \$ 3$ k.c.) albo klauzulę rebus sic stantibus (art. $357^{1}$ k.c.), w tych przypadkach bowiem wyrok ma charakter konstytutywny ${ }^{137}$.

Niedawno dokonane radykalne zmiany przepisów Kodeksu cywilnego o odsetkach każą wypowiedzieć się również co do wysokości odsetek należnych od ubezpieczyciela. W grę wchodzą oczywiście odsetki ustawowe za opóźnienie z art. $481 \$ 2$ k.c., odpowiadające sumie stopy referencyjnej Narodowego Banku Polskiego i 5,5 punktów procentowych. Oczywiście można sobie wyobrazić zastrzeżenie odsetek wyższych, ograniczonych wysokością maksymalnych odsetek za opóźnienie odpowiadających dwukrotności wysokości odsetek ustawowych za opóźnienie. Wziąwszy jednak pod uwagę, że ogólne warunki ubezpieczenia przygotowywane są przez ubezpieczycieli i z reguły nie podlegają negocjacji, jest to możliwość czysto teoretyczna. Nie sposób nie zgodzić się z wypowiedziami, że odsetki za opóźnienie na poziomie $7 \%$ w stosunku rocznym (stopa referencyjna NBP na grudzień 2018 r. wynosi 1,5\%) są generalnie za niskie i jedynie w niewielkim stopniu mogą motywować dłużnika, niezależnie od jego statusu, do terminowego spełniania świadczenia ${ }^{138}$.

W toku prac parlamentarnych nad nowelizacją przepisów Kodeksu cywilnego rozważano, by termin odsetek za opóźnienie należnych od ubezpieczyciela odpowiadał wysokości odsetek maksymalnych, a nawet

jak i zadośćuczynienie stają się wymagalne po wezwaniu ubezpieczyciela do zapłaty odszkodowania i od tej chwili zaczynają biec odsetki.

136 M. Krajewski, Umowa ubezpieczenia. Art. 805-834 KC..., 2016, s. 351 z powołaniem się na M. Lemkowskiego, Odsetki cywilnoprawne, Warszawa 2007, s. 276 i n.

137 Por. przykładowo wyrok SA w Gdańsku z 27.07.1993 r., I ACr 487/93, „Wokanda” 1994/8 oraz wyrok SN z 21.09.2011 r., I CSK 727/10.

138 Tak choćby M. Wojewoda, W. Robaczyński, O odsetkach po roku obowiązywania nowych rozwiązań, M. Prawn. 2017/1, s. 20. 
stanowił 10-krotność odsetek za opóźnienie, jednak ostatecznie pomysły te zarzucono. Wynik prac aprobuje M. Krajewski, wskazując, że obciążanie ubezpieczyciela odsetkami wyższymi niż wymagane od innych podmiotów byłoby sprzeczne z zasadą równości wobec prawa ${ }^{139}$. Warto jednak zauważyć, że już obecnie wysokość odsetek za opóźnienie nie jest równa dla wszystkich podmiotów. Wyższe od kodeksowych odsetek za opóźnienie są w szczególności odsetki za opóźnienie w transakcjach handlowych odpowiadające stopie referencyjnej powiększonej o 8\%, co w sumie daje odsetki za opóźnienie w wysokości 9,5\% ${ }^{140}$. Dosyć trudno znaleźć argumenty, dla których odsetki za opóźnienie w płatności ze strony profesjonalnej instytucji finansowej, jaką jest zakład ubezpieczeń, były niższe niż odsetki za opóźnienie w transakcjach handlowych. Takiego rozwiązania nie uzasadnia w moim przekonaniu szczególny cel ustawy o terminach zapłaty, jakim jest ochrona dostawców dużych sieci handlowych. Argumenty wysuwane przeciwko kredytowaniu sieci handlowych przez dostawców są w dużej mierze aktualne, gdy odnieść je do kredytowania instytucji finansowych przez ich klientów. Dodać można, że art. 6:105 ust. 1 PEICL przewiduje w razie opóźnienia ubezpieczyciela odsetki w tej samej wysokości co odsetki w transakcjach handlowych ${ }^{141}$.

Konsekwencją zawinionego opóźnienia, czyli zwłoki, jest, poza zapłatą odsetek, odpowiedzialność ubezpieczyciela za szkodę spowodowaną niewykonaniem zobowiązania w terminie. Odszkodowanie może być w tej sytuacji wyższe niż podstawowe odszkodowanie ubezpieczeniowe i obejmować w szczególności zyski utracone przez uprawnionego w związku z niezapłaceniem w terminie świadczenia podstawowego. W tych okolicznościach w grę wchodzi odpowiedzialność ex contractu na

139 M. Krajewski, Umowa ubezpieczenia. Art. 805-834 KC..., 2016, s. 351.

140 Art. 4 pkt 3 ustawy z 8.03.2013 r. o terminach zapłaty w transakcjach handlowych (Dz.U. z 2016 r. poz. 684 ze zm.).

141 Zob. Principles..., s. 219. Niektóre ustawodawstwa obce przyjmują dla ubezpieczyciela specjalną podwyższoną stopę odsetek za opóźnienie. Por. przykładowo art. 211-13 i 242-1 Code des assurances przewidujące odpowiednio w obowiązkowym ubezpieczeniu pojazdów mechanicznych oraz obowiązkowym ubezpieczeniu budynków stopę odpowiadającą dwukrotnej wysokości odsetek ustawowych, oraz art. 20 ust. 3 hiszpańskiej ustawy o umowie ubezpieczenia, który dotyczy nie tylko ubezpieczeń obowiązkowych i przewiduje stopę podwyższoną o połowę w porównaniu do stopy ustawowych odsetek za opóźnienie. 
zasadach ogólnych ${ }^{142}$. Odszkodowanie nie jest już limitowane zasadami prawa ubezpieczeniowego, choć w granicach ustawowych dopuszczalne będą umowne modyfikacje odpowiedzialności za niewykonanie zobowiązania. Istniejące w orzecznictwie rozbieżności co do obciążenia ubezpieczyciela odpowiedzialnością z tytułu niewykonania lub nienależytego wykonania zobowiązania wydają się należeć do przeszłości. Sąd Najwyższy odróżnia obecnie odpowiedzialność gwarancyjno-repartycyjną z umowy ubezpieczenia od odpowiedzialności za niewykonanie lub nienależyte wykonanie tej umowy na zasadach ogólnych. Po ostatnich zmianach w prawie angielskim można powiedzieć, że zasada ta przyjmowana jest również $w$ reprezentatywnych obcych systemach prawnych, przy czym zwykle nie jest wyrażana wprost w ustawie, ale traktowana jako pewna oczywistość.

Zgodnie z art. 6:105 ust. 2 PEICL w razie nieterminowej płatności ubezpieczyciel obowiązany jest nie tylko do zapłaty odsetek za opóźnienie, ale również odszkodowania za wszelkie dodatkowe szkody wywołane przez zwłokę ze strony ubezpieczyciela. Redaktorzy PEICL podkreślają, że nie jest to szczególna zasada prawa ubezpieczeń, ale jedynie odzwierciedlenie ogólnej reguły Europejskiego Prawa Umów (art. 9:508 PEICL), która w przypadku niewykonania umowy przyjmuje odszkodowanie odpowiadające sumie pozwalającej postawić wierzyciela w takiej sytuacji, w jakiej byłby, gdyby umowa została wykonana. Pomimo niedoprecyzowania tej kwestii w PEICL, ubezpieczyciel zgodnie $\mathrm{z}$ art. 9:508 PEICL odpowiada w granicach szkody, jaką przewidywał lub mógł rozsądnie przewidzieć w chwili zawarcia umowy jako prawdopodobne następstwo niewykonania umowy ${ }^{143}$.

142 Zob. szerzej B. Kucharski, Odpowiedzialność ubezpieczyciela za niewykonanie umowy ubezpieczenia [w:] Ubezpieczenia gospodarcze. Wybrane zagadnienia prawne, red. B. Gnela, Warszawa 2011, s. 47 i n. oraz wskazana tam literatura i orzecznictwo. Podobnie M. Krajewski, Umowa ubezpieczenia. Art. 805-834 KC..., 2016, s. 350.

143 Principles..., s. 220. 


\subsubsection{Pojęcie zawiadomienia o wypadku}

Odrębna grupa zagadnień wyłaniających się w związku z interpretacją art. 817 k.c. wiąże się z pojęciem zawiadomienia o wypadku. Wątpliwości dotyczyć mogą tego, od kogo pochodzić ma zawiadomienie, charakteru prawnego zawiadomienia, konieczności sprecyzowania roszczenia co do wysokości, formy zawiadomienia oraz interpretacji sformułowania ustawowego, które nakazuje liczyć trzydziestodniowy termin od daty otrzymania przez ubezpieczyciela zawiadomienia o wypadku. Większość z tych kwestii omawiałem w innym opracowaniu, na którym w dużej mierze opieram poniższe rozważania ${ }^{144}$.

W literaturze dominuje pogląd, że zawiadomienie nie musi pochodzić od ubezpieczającego ani od innej osoby uprawnionej do świadczenia ubezpieczeniowego $^{145}$. Do wniosku, że zawiadomienie może pochodzić od kogokolwiek, prowadzić ma wykładnia art. 817 k.c. oraz art. 29 u.d.u.r., nakazującego ubezpieczycielowi informować ubezpieczającego oraz ubezpieczonego o wpływie zgłoszenia, jeżeli nie są oni osobami występującymi z tym zawiadomieniem. Ponadto $\mathrm{z}$ art. $818 \$ 4$ k.c. ma wynikać, że ustawodawca zrównuje zgłoszenie szkody przewidziane w OWU z każdym przypadkiem uzyskania przez ubezpieczyciela informacji o wypadku ${ }^{146}$.

Pogląd ten wydaje się niewłaściwy z kilku powodów. Przede wszystkim powinna istnieć korelacja między art. 817 i 818 k.c. Ten drugi przepis pozwala ubezpieczycielowi nałożyć obowiązek powiadomienia ubezpieczyciela o wypadku w określonym terminie na ubezpieczającego lub ubezpieczonego, z czego ubezpieczyciele skwapliwie korzystają. Innymi słowy, realizacja obowiązku powiadomienia o wypadku winna pozostawać w związku i być uzgodniona z początkiem biegu terminu spełnienia świadczenia przez ubezpieczyciela.

\footnotetext{
144 B. Kucharski, Termin..., s. 161 i n.

145 Tak W. Dubis [w:] Kodeks..., red. E. Gniewek, P. Machnikowski, s. 1339; W. Chróścicki, Umowa..., s. 93.

146 S. Byczko, Proces..., s. 173.
} 
Ponadto z art. 29 ust. 2 u.d.u.r. wynika, że w ubezpieczeniu grupowym osobami uprawnionymi występującymi z roszczeniem mogą być również spadkobiercy. Z kolei art. 29 ust. 4 i 5 u.d.u.r. nakładają na zakład ubezpieczeń obowiązek zawiadomienia ubezpieczonego oraz osoby występującej z roszczeniem o przyczynach niemożności zaspokojenia ich roszczeń oraz o tym, że świadczenie przysługuje w innej wysokości niż w zgłoszonym roszczeniu. Przepisy te sugerują, że zawiadomienie pochodzi od osoby, której służy roszczenie. Wprawdzie kolejny ustęp art. 29 u.d.u.r. wśród osób uprawnionych do żądania od ubezpieczyciela informacji i dokumentów wymienia, poza ubezpieczającym, ubezpieczonym, uprawnionym $\mathrm{z}$ umowy, również inną osobę występującą z roszczeniem, jednak można domniemywać, że chodzi o osoby działające w imieniu ubezpieczającego, ubezpieczonego albo uprawnionego z umowy.

Dodać należy, że zawiadomienie powinno pochodzić od osoby, która może je skonkretyzować. Skoro przepisy mówią o zawiadomieniu, nie wystarcza jakakolwiek informacja. Konieczne jest podanie podstawowych danych, w szczególności tożsamości ubezpieczającego, ubezpieczonego, uprawnionego, numeru polisy oraz choćby podstawowego zakresu doznanych szkód. Przede wszystkim jednak z zawiadomienia powinna wynikać intencja skorzystania przez uprawnionego z ochrony ubezpieczeniowej. Przykładowo trudno wyobrazić sobie, by zgłoszenie przez poszkodowanego szkody z OC sprawcy albo pochodząca od policji informacja o wypadku komunikacyjnym mogły być traktowane jako zawiadomienie o wypadku w ubezpieczeniu AC sprawcy. Sprawca może mieć przecież życzenie usunięcia uszkodzeń powstałych w jego samochodzie na własny koszt, żeby nie tracić zniżek za bezszkodową jazdę w ubezpieczeniu AC. To samo dotyczy innych ubezpieczeń majątkowych ${ }^{147}$.

Podsumowując, wbrew brzmieniu art. 817 k.c. oraz niektórym wypowiedziom należy przyjąć, że termin spełnienia świadczenia przez ubezpieczyciela rozpoczyna bieg dopiero po otrzymaniu przez ubezpieczy-

147 B. Kucharski, Termin..., s. 162-163. W przytoczonym opracowaniu powołano argumenty wynikające z uchylonej ustawy o działalności ubezpieczeniowej z 2003 r. 
ciela zawiadomienia osoby, której służyć mogą jakiekolwiek roszczenia $\mathrm{z}$ umowy ubezpieczenia. Poza ubezpieczającym i ubezpieczonym w grę mogą wchodzić uposażony w ubezpieczeniu na życie (art. 831 k.c.), poszkodowany w ubezpieczeniu OC (art. $822 \$ 4$ k.c.), wierzyciel hipoteczny w ubezpieczeniu nieruchomości (art. 89 u.k.w.h.), nabywca przedmiotu ubezpieczenia, na którego przeszły prawa $\mathrm{z}$ umowy ubezpieczenia (art. $823 \$ 1$ k.c.), ewentualnie inna osoba, na którą uprawniony przelał wierzytelność powstałą lub mogącą powstać wskutek zajścia wypadku ubezpieczeniowego (art. $823 \$ 4$ k.c.), a także następcy prawni wymienionych osób ${ }^{148}$.

Argument, wedle którego z zawiadomienia o wypadku wynikać ma intencja skorzystania z ochrony ubezpieczeniowej, prowadzi do wniosków odnośnie do charakteru takiego zawiadomienia. W tym zakresie istotne są również wcześniejsze uwagi o rozpoczęciu biegu terminu spełnienia świadczenia przez ubezpieczyciela. Dodać można, że przy omawianiu charakteru prawnego zawiadomienia ubezpieczyciela nasuwa się analogia do wezwania z art. 455 k.c., którego natura prawna jest sporna wobec spostrzeżenia, że bieg terminu rozpoczyna się niezależnie od intencji wzywającego. Ostatnio dominuje jednak pogląd, według którego wezwanie jest jednostronnym oświadczeniem woli o charakterze prawnokształtującym $^{149}$.

Jak wskazuje M. Krajewski, skutek w postaci nadejścia terminu spełnienia świadczenia nie wystąpi, jeżeli zawiadamiający o wypadku ubezpieczeniowym wyraźnie go wyłączy. Wszczynanie w tej sytuacji postępowania likwidacyjnego nie miałoby sensu. Poglądy upatrujące w zawiadomieniu oświadczenia wiedzy, ewentualnie przejawu woli niemającego charakteru oświadczenia woli należy z powyższych względów odrzucić. Stanowisko wyróżniające przejawy woli niemające charakteru

148 Por. B. Kucharski, Termin..., s. 162-163. Argumentacja ta została zaaprobowana przez M. Krajewskiego, Umowa ubezpieczenia. Art. 805-834 KC..., 2016, s. 330-331.

149 T. Wiśniewski [w:] Kodeks cywilny. Komentarz. Zobowiązania. Część ogólna, t. 3, red. J. Gudowski, Warszawa 2018, komentarz do art. 455, teza 3; Z. Gawlik [w:] Kodeks..., t. 3, red. A. Kidyba, komentarz do art. 455, teza 9; A. Zoll [w:] System..., t. 6, red. A. Olejniczak, s. 1081-1082. 
oświadczeń woli wydaje się zresztą trudne do utrzymania w świetle ogólnych zasad prawa cywilnego ${ }^{150}$.

Kolejne kwestie wiążą się z treścią zawiadomienia o wypadku, w szczególności pojawia się pytanie, czy konieczne jest sprecyzowanie roszczenia co do wysokości. Sąd Najwyższy odpowiedział na to pytanie pozytywnie w wyroku z 6.07.1999 r., III CKN 315/98 ${ }^{151}$, stwierdzając, że ubezpieczyciel nie pozostaje w opóźnieniu co do kwot nieobjętych jego „decyzją”, jeżeli poszkodowany po jej otrzymaniu lub wcześniej nie określi kwotowo swego roszczenia ${ }^{152}$. Argumentacja oparta była w pewnej mierze na $\$ 32$ nieobowiązującego obecnie rozporządzenia Ministra Finansów z 9.12.1992 r. w sprawie ogólnych warunków obowiązkowego ubezpieczenia odpowiedzialności cywilnej posiadaczy pojazdów mechanicznych za szkody powstałe w związku z ruchem tych pojazdów ${ }^{153}$, któremu obecnie odpowiada art. 14 u.u.o. Przepisy rozporządzenia z 1992 r. zamiennie posługiwały się terminami „zawiadomienie” i „roszczenie”, a także nawiązywały w swej treści do „wysokości roszczeń”, podobnie jak obecnie czyni to powoływany wcześniej art. 29 u.d.u.r.

Przytoczone stanowisko Sądu Najwyższego formułowane w odniesieniu do roszczeń poszkodowanych z obowiązkowego ubezpieczenia OC posiadaczy pojazdów komunikacyjnych, ze szczególnym uwzględnie-

150 Por. przykładowo M. Pyziak-Szafnicka, Glosa do uchwały SN z 26.04.1995 r., III CZP 29/95, OSP 1996/7-8, s. 355.

151 OSNC 2000/2, poz. 31.

152 Podobne stanowisko SN zajął w uzasadnieniu wyroku z 4.07.2002 r., I CKN 837/00, LEX nr 56891. Nieco łagodniejsze natomiast w wyroku z 13.08.2008 r., I CSK 114/07, LEX nr 487518, w którym stwierdzono, że „oprócz zawiadomienia o wypadku poszkodowany powinien określić roszczenia. Jeśli tego nie uczyni zakład ubezpieczeń powinien wystąpić z propozycją ugody. Równoznaczne z taką propozycją jest oświadczenie zakładu o wysokości odszkodowania. Jeśli poszkodowany nie określił wysokości roszczenia, a zakład ubezpieczeń mając dane do jego ustalenia, nie oświadczy jaką kwotę uważa za właściwe odszkodowanie, powstaje w zasadzie stan opóźnienia. Natomiast z chwilą wypłacenia kwoty ustalonej przez ubezpieczyciela obowiązek wypowiedzenia się odnośnie do tego, czy jest ona odpowiednia, powraca do wierzyciela (poszkodowanego). Od chwili zgłoszenia przez niego żądania dalszych roszczeń, zakład pozostaje w opóźnieniu, o ile oczywiście roszczenia te będą uzasadnione”. Zob. również wyrok SN z 18.02.2010 r., II CSK 434/09.

153 Dz.U. Nr 96, poz. 475 ze zm. Rozporządzenie utraciło moc obowiązującą z dniem wejścia w życie ustawy z 22.05.2003 r. o działalności ubezpieczeniowej. 
niem roszczenia o zadośćuczynienie, nie koresponduje z orzecznictwem dotyczącym odpowiedzialności ubezpieczycieli za szkody majątkowe. Sąd Najwyższy wielokrotnie podkreślał, że ustalenie wysokości szkody, podobnie jak przesądzenie samej zasady odpowiedzialności, powinno nastąpić w postępowaniu likwidacyjnym. Takie stanowisko wyrażono zwłaszcza w wyroku z 4.01.2007 r., V CSK 400/06 ${ }^{154}$, w którego uzasadnieniu stwierdzono, że zawiadamiając zakład ubezpieczeń o wypadku, powódka doprowadziła do rozpoczęcia biegu 30-dniowego terminu, w którym zakład ubezpieczeń obowiązany był spełnić świadczenie. W tym czasie zakład ubezpieczeń powinien wykonać wszystkie czynności zmierzające do ustalenia, jakie skutki wywołała powódź, o którą chodziło w sprawie, jaki jest zakres prac pozwalających usunąć konsekwencje tej powodzi i jaka jest równowartość kosztów tych prac. Zawiadomienie o szkodzie spowodowało, że ubezpieczyciel był obowiązany wypłacić odszkodowanie mające na celu naprawienie wszystkich szkód w mieniu objętym ubezpieczeniem.

Regulacje z art. 817 k.c., art. 29 u.d.u.r., a także art. 14 u.u.o. nie pozostawiają złudzeń co do istnienia obowiązku ubezpieczyciela ustalenia wysokości szkody w postępowaniu likwidacyjnym. Nadto przepisy dotyczące terminu spełnienia świadczenia przez ubezpieczyciela stanową legis specialis względem ogólnych przepisów Kodeksu cywilnego, dotyczących wymagalności roszczenia, w szczególności art. 455 k.c. ${ }^{155}$ Pomimo szczególnego charakteru zadośćuczynienia i roszczeń dotyczących szkody na osobie w ogóle, moim zdaniem pożądane i możliwe jest wypracowanie jednolitego stanowiska dotyczącego ubezpieczeń OC oraz ubezpieczeń mienia.

154 LEX nr 277309.

155 Tak wyrok SN z 18.02.2010 r., II CSK 434/09. Inaczej wyrok SA w Łodzi z 11.02.1993 r., I ACr 41/93, M. Prawn. 2001/14, s. 752. Według tezy tego wyroku określone w art. 817 k.c. terminy spełnienia świadczeń przez zakład ubezpieczeń, wiążące wymagalność świadczenia $\mathrm{z}$ datą otrzymania przez zakład ubezpieczeń zawiadomienia o wypadku, mają zastosowanie w postępowaniu szkodowym toczącym się w zakładzie ubezpieczeń w wyniku złożenia takiego zawiadomienia przez poszkodowanego. Jeśli natomiast zakład ubezpieczeń w postępowaniu szkodowym nie spełnił należnych świadczeń, do roszczeń dochodzonych w postępowaniu sądowym mają zastosowanie przepisy ogólne o wymagalności świadczeń pieniężnych. Oznacza to, że określone kwotowo świadczenie jest wymagalne niezwłocznie po wezwaniu dłużnika do jego spełnienia. 
Z powyższych względów osoba uprawniona do świadczenia w zawiadomieniu nie musi wskazywać jego wysokości. Oczywiście ciążący na ubezpieczycielu obowiązek terminowego świadczenia zależy od spełnienia dodatkowych przesłanek dotyczących współdziałania poszkodowanego oraz obiektywnych możliwości ustalenia okoliczności koniecznych do określenia odszkodowania ${ }^{156}$. Ubezpieczyciel nie może jednak twierdzić, że bieg terminu spełnienia świadczenia nie rozpoczął się w ogóle tylko dlatego, że uprawniony nie wezwał do wypłaty świadczenia w określonej wysokości.

Jeszcze inną kwestią jest, czy w zawiadomieniu należy określić rodzaj dochodzonych roszczeń, co ma szczególne znaczenie w umowie ubezpieczenia OC. Z moim wcześniejszym poglądem, aprobującym taką potrzebę, polemizuje M. Krajewski. Jego zdaniem opisane wymaganie jest równie bezzasadne co wymaganie sprecyzowania roszczeń co do wysokości i w praktyce oznaczałoby konieczność skorzystania przez poszkodowanego $\mathrm{z}$ fachowej pomocy prawnej, przeciętny poszkodowany nie zdaje sobie bowiem sprawy z przyjętej w prawie cywilnym klasyfikacji roszczeń. Ostatecznie autor ten przyjmuje, że zawiadomienie w ogóle nie musi odnosić się do roszczeń przysługujących uprawnionemu, byleby wynikało z nich, choćby w sposób dorozumiany, że zgłaszający zamierza dochodzić takich roszczen ${ }^{157}$.

Nie negując trafności przedstawionej argumentacji, należy wskazać, że określenie rodzaju roszczeń nie musi nawiązywać do ich cywilistycznej klasyfikacji ani specjalistycznej terminologii. Do rozpoczęcia terminu do spełnienia świadczenia przez ubezpieczyciela niezbędne jest jednak określenie roszczeń w sposób wystarczający dla wyznaczenia kierunków postępowania likwidacyjnego. Odnośnie do ubezpieczeń mienia, których dotyczy niniejsza praca, kwestia może być istotna w szczególności wtedy, gdy warunki ubezpieczenia umożliwiają uprawnionemu wybór między domaganiem się przywrócenia do stanu poprzedniego oraz

156 Tak SN w wyrokach: z 6.07.1999 r. III CKN 315/98, oraz z 4.01.2007 r., V CSK 400/06.

157 M. Krajewski, Umowa ubezpieczenia. Art. 805-834 KC..., 2016, s. 332. 
dochodzeniem zapłaty odszkodowania w pieniądzu ${ }^{158}$ albo gdy polisa ubezpieczeniowa łączy w sobie w istocie kilka różnych rodzajów ubezpieczenia. Przykładowo w sytuacji, gdy ubezpieczający, który posiada powszechną w praktyce polisę pakietową w ubezpieczeniu komunikacyjnym obejmującą OC, zieloną kartę, AC, assistance, NW itd., zgłasza szkodę samochodową z tej polisy, ograniczając się do wskazania, że ma uszkodzony samochód, trudno przyjąć, by ubezpieczyciel po upływie 30 dni od zgłoszenia był w zwłoce co do pokrycia kosztów wynajmu samochodu zastępczego, kosztów noclegu, pobytu w szpitalu itp. Dodać można, że nawet M. Krajewski kwestionujący potrzebę określenia w zawiadomieniu rodzaju roszczenia przyznaje, że niesprecyzowanie roszczenia może doprowadzić do niemożliwości ustalenia odpowiedzialności ubezpieczyciela lub wysokości szkody w terminie 30 dni (art. 817 $\S 2$ k.c.), wobec czego ubezpieczyciel i tak nie popadnie w opóźnienie ${ }^{159}$.

Kwestia formy zawiadomienia w istocie przedstawia się dość podobnie. Można powiedzieć, że co do zasady forma jest dowolna. Skoro art. 817 i 818 k.c. milczą na temat formy, to ubezpieczyciel, mając na uwadze ich semiimperatywny charakter, nie ma prawa wprowadzać w umowach lub OWU warunku zachowania formy szczególnej pod rygorem braku skutków z art. 817 k.c. oraz wystąpienia skutków z art. $818 \$ 3$ k.c. ${ }^{160}$ $\mathrm{Z}$ drugiej jednak strony w praktyce ubezpieczyciele często wymagają wypełnienia specjalnego formularza. Nieuzasadniona odmowa jego wypełnienia może być poczytana za brak współdziałania ubezpieczającego z ubezpieczycielem w likwidacji szkody. Jeżeli nawet termin zapłaty rozpocznie bieg z chwilą zawiadomienia złożonego w inny sposób, to nie skończy się w terminie 30-dniowym, ilekroć zawiadomienie nie będzie zawierało wszystkich informacji niezbędnych dla ustalenia zasady i zakresu odpowiedzialności ubezpieczyciela.

Zawiadomienie może również przybrać postać doręczenia pozwu ubezpieczycielowi. Sąd Najwyższy kilkakrotnie wypowiadał się twierdząco

\footnotetext{
158 Co do takiej możliwości, zobacz ostatni rozdział pracy.

159 M. Krajewski, Umowa ubezpieczenia. Art. 805-834 KC..., 2016, s. 332.

160 M. Krajewski, Umowa ubezpieczenia. Art. 805-834 KC..., 2016, s. 333.
} 
co do tej ostatniej kwestii ${ }^{161}$. Oczywiście w takiej sytuacji odsetki zaczną swój bieg również dopiero z tą chwilą. Kierowanie sprawy na drogę sądową bez uprzedniego zawiadomienia ubezpieczyciela może nadto sprawić, że ubezpieczyciel będzie miał prawo domagać się zwrotu kosztów procesu nawet w wypadku uwzględnienia powództwa, jeżeli tylko wykaże, że nie dał powodu do wytoczenia powództwa i uznał je przy pierwszej czynności ${ }^{162}$.

Odnośnie do czwartej kwestii, a mianowicie interpretacji sformułowania „otrzymanie przez ubezpieczyciela zawiadomienia o wypadku”, należy podkreślić, że nie jest istotne, czy ubezpieczyciel faktycznie zapoznał się z zawiadomieniem. Pomimo pewnych różnic co do treści art. 817 oraz $61 \$ 1$ zdanie pierwsze k.c. przyjąć należy, że wystarczy, by zawiadomienie doszło do ubezpieczyciela w taki sposób, że mógł zapoznać się $\mathrm{z}$ jego treścią. Nie jest zatem konieczne, aby ubezpieczyciel faktycznie zapoznał się z treścią zawiadomienia. Wystarczy, że mógł to uczynić $\mathrm{z}$ uwagi na to, że zawiadomienie zostało mu doręczone.

Istotne znaczenie w tej mierze może mieć art. 30 u.d.u.r., zgodnie z którym zawiadomienia i oświadczenia składane w związku z zawartą umową ubezpieczenia agentowi ubezpieczeniowemu uznaje się za złożone zakładowi ubezpieczeń, w imieniu lub na rzecz którego agent ubezpieczeniowy działa, o ile zostały złożone na piśmie lub na innym trwałym nośniku. Przepis ten jest bezwzględnie obowiązujący; zakład ubezpieczeń nie może wyłączyć ani ograniczyć upoważnienia agenta ubezpieczeniowego do odbierania oświadczeń ${ }^{163}$. Zwrócić należy uwagę, że obecna regulacja za skuteczne uznaje jedynie zawiadomienia składane agentowi na piśmie lub na innym trwałym nośniku. Przykładowo zatem skuteczne będzie co do zasady zawiadomienie złożone agentowi w formie wiadomości e-mail, nieskuteczne zaś zawiadomienie złożone

161 Ostatnio w wyroku z 2.03.2006 r., I CSK 7/2005, LEX nr 179967. Wcześniej takie samo rozstrzygnięcie zapadło w uchwale z 28.10.1976 r., III CZP 46/76, LEX nr 7865, oraz w wyroku z 18.08.1986 r., II CR 187/86, OSNCP 1987/11, poz. 180.

162 J. Pokrzywniak [w:] M. Orlicki, J. Pokrzywniak, Umowa..., s. 87.

163 Szerzej co do tej kwestii, zob. B. Kucharski, O zawiadomieniach i oświadczeniach składanych agentowi ubezpieczeniowemu [w:] Informacja w prawie ubezpieczeń gospodarczych, red. B. Gnela, M. Szaraniec, Warszawa 2015, s. 344 i n. 
ustnie bezpośrednio lub w nienagranej przez agenta rozmowie telefonicznej (art. 3 ust. 1 pkt 49 u.d.u.r. w zw. $z$ art. 2 pkt 4 ustawy o prawach konsumenta) $)^{164}$.

Nawet jeżeli ubezpieczyciel przewidział jakiś szczególny sposób zawiadomienia o wypadku lub powołał specjalną komórkę organizacyjną, do której takie zawiadomienia mają być kierowane, nie oznacza to możliwości ustanowienia wyłącznie skutecznego sposobu zawiadomienia o wypadku ${ }^{165}$. Znów jednak można wyobrazić sobie sytuacje, w których określone działanie lub zaniechanie ze strony ubezpieczającego może być poczytane za brak współdziałania w likwidacji szkody, uprawniający ubezpieczyciela do twierdzenia, że nie zdołał wyjaśnić sytuacji w terminie 30 dni. Niekiedy kwestia będzie problematyczna. Można sobie przykładowo wyobrazić, że w rozmowie telefonicznej z ubezpieczycielem ubezpieczający proszony jest o dokonanie zgłoszenia pod inny podany numer albo o wysłanie wiadomości e-mail pod określony adres. Jeżeli ubezpieczający obieca to uczynić, a następnie prośbę zignoruje, ubezpieczyciel będzie mógł twierdzić, że zgłoszenie do niego nie dotarło, a w każdym razie, że nie dotarło w sposób umożliwiający mu wyjaśnienie w terminie okoliczności koniecznych do ustalenia jego odpowiedzialności albo wysokości należnego świadczenia. We wszystkich podobnych sytuacjach decydować będą konkretne realia, przy czym należy mieć na względzie, że ustawa mówi o „okolicznościach koniecznych", nie zaś o wszystkich okolicznościach, które mogą być istotne, a sposób zachowania stron należy oceniać zgodnie z kryteriami wskazanymi w art. 353 i 354 k.c.

164 Ustawa z 30.05.2014 r. o prawach konsumenta (Dz.U. z 2017 r. poz. 683 ze zm.). Szerzej zob. D. Lubasz [w:] Ustawa o prawach konsumenta. Komentarz, red. D. Lubasz, M. Namysłowska, Warszawa 2015, komentarz do art. 2, teza 44.

165 J. Krajewski, Umowa ubezpieczenia. Art. 805-834 KC..., 2016, s. 333. 


\subsubsection{Okoliczności uzasadniające przekroczenie terminu podstawowego}

W doktrynie podkreśla się, że ubezpieczyciel powinien co do zasady spełnić świadczenie w terminie trzydziestodniowym. Czternastodniowy termin $\mathrm{z}$ art. $817 \$ 2$ k.c. ma charakter wyjątkowy i wchodzi w grę jedynie wtedy, gdy ubezpieczyciel zdoła udowodnić, że pomimo zachowania należytej staranności nie był w stanie wyjaśnić okoliczności koniecznych dla ustalenia jego odpowiedzialności lub wysokości należnego świadczenia. W orzecznictwie ukształtował się pogląd oceniający staranność wymaganą od ubezpieczyciela w postępowaniu likwidacyjnym na stosunkowo wysokim poziomie. Szczególnie w przeszłości bardzo częste było wstrzymywanie się przez ubezpieczycieli z wypłatą odszkodowania do zakończenia postępowania karnego w sytuacji, gdy szkoda była wynikiem popełnienia przestępstwa, lub do zakończenia postępowania cywilnego, gdy ubezpieczający skierował sprawę na drogę sądową.

Praktyki tego rodzaju były co do zasady oceniane przez Sąd Najwyższy krytycznie. Zwracano uwagę, że żaden przepis prawa z zakresu ubezpieczeń nie daje podstaw, by ustalenie przesłanek odpowiedzialności ubezpieczyciela lub też ustalenie wysokości odszkodowania albo zadośćuczynienia łączyć z jakimkolwiek toczącym się innym postępowaniem. Przepisy Kodeksu cywilnego oraz ustawy o działalności ubezpieczeniowej i reasekuracyjnej nakładają na ubezpieczyciela obowiązek aktywnego, samodzielnego wyjaśnienia okoliczności wypadku i wysokości szkody. Ubezpieczyciel co do zasady nie ma prawa wstrzymywać się z wypłatą świadczenia ubezpieczeniowego do czasu zakończenia innego postępowania $^{166}$.

Niejednokrotnie jednak tłumaczenie ubezpieczyciela, że ustalenie okoliczności wypadku nie było możliwe przed zakończeniem postępowania

166 Zob. przykładowo wyrok SN z 10.01.2000 r., III CKN 1105/98, OSNC 2000/7-8, poz. 134; wyrok SN z 15.07.2004 r., V CK 640/03, LEX nr 194105; wyrok SA w Gdańsku z 20.07.1993 r., I ACr 443/93, „Wokanda” 1994/3, s. 42; wyrok SA w Poznaniu z 6.07.2005 r., I ACa 18/05, LEX nr 175174; wyrok SA w Poznaniu z 21.04.1993 r., I ACr 93/93, LEX $\mathrm{nr}$ 9160. Zob. również wyroki przytaczane przez M. Krajewskiego, Umowa ubezpieczenia. Art. 805-834 KC..., 2016, s. 343-344. 
karnego, okazywało się skuteczne. Sądy przyznawały rację ubezpieczycielowi czekającemu na wynik postępowania karnego przede wszystkim w sytuacjach, gdy zachodziły wątpliwości co do samego zajścia wypadku ubezpieczeniowego. Przykładowo w sprawie II CKN 284/00 ${ }^{167}$ istniało uzasadnione podejrzenie, że samochód, którego kradzież zgłosił powód, $\mathrm{w}$ istocie został przez niego zbyty, a następnie wywieziony z Polski ${ }^{168}$, natomiast w sprawie II CK 369/02 ${ }^{169}$ podejrzenie, że pożar ubezpieczonej hurtowni został umyślnie wywołany przez samego powoda.

Analiza orzecznictwa pozwala sformułować wniosek, że ubezpieczyciel ma prawo powstrzymać się z wypłatą odszkodowania ubezpieczeniowego do czasu zakończenia postępowania karnego, jeżeli istnieją uzasadnione okolicznościami wątpliwości, czy wypadek ubezpieczeniowy rzeczywiście miał miejsce, czy też został sfingowany przez uprawnionego lub w porozumieniu z nim. Istotne jest również, by ubezpieczyciel nie był w stanie poczynić odpowiednich ustaleń samodzielnie, co może mieć miejsce, gdy określeni świadkowie nie chcą złożyć zeznań wobec ubezpieczyciela, a w postępowaniu karnym obciąża ich taki obowiązek. Jednak nawet w tych sytuacjach ubezpieczyciel powinien w miarę możliwości brać udział w toczącym się postępowaniu karnym, a przynajmniej śledzić jego przebieg i wykorzystywać na bieżąco uzyskane informacje w postępowaniu likwidacyjnym ${ }^{170}$.

Jeszcze więcej problemów rodzą sytuacje, gdy sporna jest nie zasada odpowiedzialności, ale jej zakres i ubezpieczający, nie mogąc się doczekać zakończenia postępowania likwidacyjnego przez ubezpieczyciela, kieruje sprawę na drogę sądową. Przykładowo w sprawie V CSK 400/06 ${ }^{171}$

167 Wyrok SN z 15.06.2000 r., II CKN 284/00, LEX nr 52568.

168 Podobna sytuacja miała miejsce w sprawie III CKN 17/01, gdzie w postępowaniu karnym nie udało się ustalić, czy zgłoszona kradzież miała miejsce, a ubezpieczyciel zapłacił odszkodowanie dopiero po uwolnieniu pozwanego od zarzutu składania fałszywych zeznań. Zob. wyrok SN z 17.07.2003 r., III CKN 17/01, LEX nr 1130166. Zob. również wyroki przytaczane przez M. Krajewskiego, Umowa ubezpieczenia. Art. 805-834 KC..., 2016, s. 334-336.

169 Wyrok SN z 20.01.2004 r., II CK 369/02, LEX nr 1129088.

170 Tak M. Krajewski, Umowa ubezpieczenia. Art. 805-834 KC..., 2016, s. 346 z powołaniem się na wyrok SN z 17.07.2003 r., III CKN 17/01.

171 Wyrok SN z 4.01.2007 r., V CSK 400/06. 
chodziło o usunięcie skutków powodzi w ubezpieczonym budynku. Powódka początkowo dochodziła $10000 \mathrm{zł}$. W sprawie dopuszczano kilka opinii biegłych, a powództwo było modyfikowane stosownie do ich wniosków. Ostatecznie powódka żądała 207000 zł, uzyskując niewiele mniej. Sąd Najwyższy stwierdził, że w sytuacji, gdy ustalenie wysokości szkody jest sporne między stronami i wymaga zasięgnięcia przez sąd wiadomości specjalnych (art. $278 \$ 1$ k.p.c.), termin wymagalności świadczenia może być określony dopiero po zweryfikowaniu wysokości szkody przez biegłych.

Z kolei w stanie faktycznym sprawy III CK $327 / 02^{172}$ doszło do pożaru magazynu, w którym znajdowały się zioła, skupowane przez powoda w celu dalszej odsprzedaży. Powód nie ewidencjonował transakcji, wobec czego ilość oraz wartość spalonych ziół dowodzona była w procesie przede wszystkim przy pomocy świadków pracujących w gospodarstwie powoda oraz opinii biegłej. Powód szacował wartość ziół na 625000 zł. Ubezpieczyciel dobrowolnie wypłacił $318000 \mathrm{zł}$. W wyniku procesu dopłacić musiał jeszcze 156000 zł. Sąd Najwyższy uchylił wyrok sądu apelacyjnego do ponownego rozpoznania w zakresie odsetek, które zostały zasądzone od daty wystąpienia przez powoda z żądaniem zapłaty 625000 zł, stwierdzając, że „określenie ubezpieczonego w umowie jako przedsiębiorcy usprawiedliwiało przekonanie ubezpieczyciela, że będzie mógł przy pomocy dokumentów weryfikować stan mienia w chwili pożaru wskazywany przez ubezpieczonego. Dokumenty takie niewątpliwie ułatwiłyby obiektywne określenie wysokości szkody, a ponieważ powód, wbrew obowiązkowi publicznemu nie wystawiał ich odnośnie do przychodu, zachodziła konieczność ustalania stanu rzeczywistego innymi środkami".

Wątpliwości w podobnych sprawach dotyczą zakresu aktywności wymaganej od ubezpieczyciela w toku postępowania likwidacyjnego. W szczególności rodzi się pytanie, czy ubezpieczyciel powinien z własnej inicjatywy powoływać biegłych różnych specjalności oraz ustalać wysokość szkody wszelkimi środkami dowodowymi. Odpowiedź powinna być twierdząca $\mathrm{z}$ tym zastrzeżeniem, że w ubezpieczeniach dobrowolnych

172 Wyrok SN z 7.05.2004 r., III CK 327/02, LEX nr 1125277. 
sposób ustalania wysokość szkody może być wskazany w ogólnych warunkach ubezpieczenia, ubezpieczający ma zaś obowiązek współdziałać z ubezpieczycielem w likwidacji szkody. Ubezpieczyciel nie może zatem bezczynnie czekać na wszczęcie postępowania sądowego. Jeżeli jednak mimo działań podejmowanych z należytą starannością nie zdoła wyjaśnić okoliczności koniecznych do ustalenia odpowiedzialności albo wysokości świadczenia przed skierowaniem sprawy przez ubezpieczającego na drogę sądową, to nie ma już potrzeby dublowania dowodów przeprowadzonych w postępowaniu sądowym na drodze postępowania likwidacyjnego. Stan opóźnienia co do konkretnych roszczeń powstawać będzie dopiero w miarę postępów postępowania sądowego, którego wyniki winny mieć odzwierciedlenie w działaniach ubezpieczyciela.

Powyższe wywody można zakończyć uwagami dotyczącymi postępowania likwidacyjnego, które nie zostało dotąd omówione. Pogląd, według którego świadczenie ubezpieczyciela ma charakter całego szeregu czynności znajdujących ewentualnie finał w wypłacie odszkodowania ubezpieczeniowego i jest rozciągnięte w czasie, pozwala objąć zakresem tego świadczenia również postępowanie likwidacyjne. W świetle konkurencyjnego poglądu, prezentowanego obecnie w literaturze przez nielicznych i ograniczającego świadczenie ubezpieczyciela do świadczenia pieniężnego spełnianego w razie zajścia wypadku, postępowanie likwidacyjne wydaje się być jedynie konglomeratem czynności przygotowawczych mających na celu spełnienie świadczenia w przyszłości ${ }^{173}$.

Jedynie pierwsze stanowisko pozwala wypracować spójną koncepcję umowy ubezpieczenia $\mathrm{z}$ istotnymi konsekwencjami w sferze terminu spełnienia świadczenia pieniężnego ubezpieczyciela. Składka będąca świadczeniem ubezpieczającego ma odpowiednik w świadczeniu ubezpieczyciela obejmującym także obowiązek aktywnego prowadzenia postępowania likwidacyjnego. Innymi słowy, składka poza tzw. składką na ryzyko albo inaczej składką netto, obejmuje również inne koszty działal-

173 Zob. jednak S. Byczko, który aprobując koncepcję złożonego charakteru świadczenia ubezpieczyciela, zdaje się jednocześnie kwalifikować czynności składające się na postępowanie likwidacyjne jako czynności przygotowawcze, konieczne do prawidłowego wykonania zobowiązania. S. Byczko, Proces..., s. 173. 
ności zakładu ubezpieczeń, w tym koszty postępowania likwidacyjnego. Skoro ubezpieczający zapłacił także za prowadzenie przez ubezpieczyciela postępowania likwidacyjnego, ma prawo oczekiwać, że ubezpieczyciel będzie traktował ten obowiązek na równi z innymi obowiązkami składającymi się na treść jego świadczenia, nie zaś jako obowiązek dodatkowy niemający związku ze świadczeniem albo tym bardziej jako swego rodzaju bonus dla ubezpieczającego uzyskiwany przez tego ostatniego niejako przy okazji. Prezentowana koncepcja w sposób dodatkowy uzasadnia stanowisko w kwestii obowiązku ubezpieczyciela zakończenia postępowania likwidacyjnego $\mathrm{w}$ terminie 30 dniowym oraz poziomu staranności przy tym wymaganej.

Dodać należy, że ustawa o działalności ubezpieczeniowej i reasekuracyjnej normuje postępowanie likwidacyjne w sposób szczątkowy, daje jednak ubezpieczycielowi narzędzia do realizacji jego zobowiązania w zakresie przeprowadzenia postępowania likwidacyjnego. W zakresie ubezpieczenia mienia istotny jest w szczególności art. 42 u.d.u.r. pozwalający ubezpieczycielowi żądać od sądu, prokuratury, policji oraz innych organów i instytucji informacji o stanie sprawy oraz udostępnienia zebranych materiałów, jeżeli są one niezbędne do ustalenia okoliczności wypadków i zdarzeń losowych będących podstawą odpowiedzialności oraz wysokości odszkodowania lub świadczenia ${ }^{174}$.

Z ogólnych przepisów prawa cywilnego oraz ze szczególnego charakteru umowy ubezpieczenia jako umowy najwyższego zaufania można natomiast wyprowadzić obowiązek ubezpieczającego współdziałania z ubezpieczycielem w zakresie likwidacji szkody. Należy przy tym zauważyć, że o ile w literaturze występują wątpliwości co do kwalifikacji prawnej konkretnych powinności ubezpieczającego, o tyle obowiązek współdziałania w likwidacji szkody powszechnie kwalifikowany jest jako obowiązek wierzyciela ${ }^{175}$. Upoważnia to do ostrożnego traktowania

174 Co do ubezpieczeń osobowych, zob. również art. 37 i 38.

175 Zob. M. Krajewski, Umowa ubezpieczenia. Art. 805-834 KC..., 2016, s. 141, 335-336, 20; S. Byczko, Proces..., s. 175-176. Szczególnie ten drugi autor wydaje się być jednak mało konsekwentny, w innych publikacjach sprzeciwia się bowiem traktowaniu obowiązków ubezpieczającego jako obowiązków wierzyciela. Por. S. Byczko, Powinności ubezpieczającego a inne obowiązki w umowie ubezpieczenia mienia [w:] Odpowiedzialność 
powinności ubezpieczającego w procesie likwidacji szkody, obciążania go obowiązkami tylko wtedy, gdy wynika to z ustawy, albo w szczególnie uzasadnionych sytuacjach faktycznych, gdy powinność współdziałania wynika z natury zobowiązania, a także do twierdzenia, że ubezpieczyciel może wskazać na brak współdziałania ubezpieczającego jako przyczynę niespełnienia świadczenia pieniężnego w terminie jedynie wyjątkowo, gdy bez tego współdziałania ustalenie okoliczności zdarzenia rzeczywiście jest niemożliwe ${ }^{176}$.

cywilna. Ksiega pamiątkowa ku czci Profesora Adama Szpunara, red. M. Pyziak-Szafnicka, Kraków 2004, s. 331-332.

176 S. Byczko, Proces..., s. 176 i 177. 



\section{Rozdział 6 \\ WYŁĄCZENIA ODPOWIEDZIALNOŚCI UBEZPIECZYCIELA}

\subsection{Wprowadzenie}

Zgodnie z art. 827 k.c. ubezpieczyciel jest wolny od odpowiedzialności, jeżeli ubezpieczający wyrządził szkodę umyślnie; w razie rażącego niedbalstwa odszkodowanie nie należy się, chyba że umowa lub ogólne warunki ubezpieczenia stanowią inaczej lub zapłata odszkodowania odpowiada w danych okolicznościach względom słuszności. Nadto, jeżeli nie umówiono się inaczej, ubezpieczyciel nie ponosi odpowiedzialności za szkodę wyrządzoną umyślnie przez osobę, z którą ubezpieczający pozostaje we wspólnym gospodarstwie domowym. W razie zawarcia umowy ubezpieczenia na cudzy rachunek powyższe stosuje się odpowiednio do ubezpieczonego. Przytoczone regulacje pozwalają sformułować trzy ustawowe wyłączenia odpowiedzialności: 1) wyrządzenie szkody umyślnie przez ubezpieczającego lub ubezpieczonego, 2) wyrządzenie szkody na skutek rażącego niedbalstwa ubezpieczającego lub ubezpieczonego z zastrzeżeniem sytuacji, gdy umowa lub OWU stanowią inaczej lub wypłata odszkodowania odpowiada w danych okolicznościach względom słuszności, 3) wyrządzenie szkody umyślnie przez osobę, z którą ubezpieczający lub ubezpieczony pozostaje we wspólnym gospodarstwie domowym z zastrzeżeniem odmiennych uregulowań umownych.

Powyższe wyłączenia zostaną omówione w toku dalszych rozważań. Wcześniej jednak należy zwrócić uwagę na dwie kwestie: pierwsza 
dotyczy ubezpieczalności innych stopni winy ubezpieczającego niż umyślność i rażące niedbalstwo, druga powinności ubezpieczeniowych jako negatywnych przesłanek odpowiedzialności ubezpieczyciela. Rozpoczynając od pierwszego zagadnienia, podkreślenia wymaga, że art. 827 k.c. wyłącza odpowiedzialność ubezpieczyciela za szkody wyrządzone umyślnie i wskutek rażącego niedbalstwa. Lżejsze niż umyślność stopnie winy ubezpieczającego objęte są ryzykiem przejmowanym przez ubezpieczyciela. Do istoty ubezpieczenia należy, że chroni ono nie tylko przed niekorzystnymi skutkami zdarzeń niezależnych od człowieka, w szczególności zjawisk przyrodniczych, czy też przed szkodami wyrządzonymi ubezpieczającemu przez osoby trzecie, ale również przed jego własnym roztargnieniem i niedbalstwem ${ }^{1}$.

W wielu rodzajach ubezpieczeń właśnie działanie lub zaniechanie ubezpieczającego jest przyczyną zdarzenia szkodzącego. Przykładowo do zalania dochodzi bardzo często na skutek niedokręcenia kranu, natomiast do uszkodzenia samochodu na skutek braku właściwej reakcji ubezpieczającego na sytuację drogową. Gdyby w opisanych wypadkach ograniczać odszkodowanie, funkcja ochronna ubezpieczenia zostałaby wydatnie ograniczona lub przekreślona. Bardzo często motywem zawarcia ubezpieczenia jest chęć zapewnienia sobie ochrony w razie tego rodzaju uchybień po stronie ubezpieczającego. $Z$ opisanych względów należy przyjąć, że art. 827 k.c. reguluje kwestię winy ubezpieczającego w sposób kompleksowy, a co za tym idzie, w ubezpieczeniach majątkowych, pominąwszy ubezpieczenia OC, gdzie odpowiedzialność ubezpieczyciela ma charakter akcesoryjny w stosunku do odpowiedzialności sprawcy, nie stosuje się przepisu art. 362 k.c. o przyczynieniu się poszkodowanego do powstania szkody. Sprawa ta nie budzi obecnie żadnych wątpliwości w doktrynie².

${ }^{1}$ W prawie angielskim tak M. Clarke, Policies and Perceptions of Insurance Law..., s. 166.

2 W. Warkałło, Ubezpieczenie [w:] System prawa cywilnego, t. 3, cz. 2, Prawo zobowiązań - część szczegółowa, red. S. Grzybowski, Ossolineum 1976, s. 932. A. Wąsiewicz, Przyczynienie..., s. 87-88, A. Szpunar, Glosa do uchwały SN z 26.09.1996 r., III CZP 108/96, OSP 1997/7-8, poz. 141; M. Krajewski, Umowa ubezpieczenia. Art. 805-834 KC..., 2016, s. 609. 
Orzecznictwo Sądu Najwyższego dotyczące omawianej kwestii również wydaje się ukształtowane, pomimo początkowych wahań. W dwóch następujących po sobie wyrokach z początku lat 80. ubiegłego wieku ${ }^{3}$, dotyczących zaniedbań po stronie hodowców kurcząt, Sąd Najwyższy najpierw wykluczył stosowanie przepisu o przyczynieniu, a następnie dopuścił. Kolejno, w uchwale z 26.09.1996 r., III CZP 108/964, Sąd Najwyższy zajął się pożarem gospodarstwa rolnego wywołanym przez małoletniego syna powoda. Wprawdzie ubezpieczenie budynków rolniczych, podobnie jak ubezpieczenie zwierząt gospodarczych, uregulowane było przepisami szczególnymi, jednak Sąd Najwyższy powołał się na brzmienie art. 827 k.c., wskazując, że w świetle tego przepisu tylko wina kwalifikowana ubezpieczającego, osoby pozostającej z nim we wspólnym gospodarstwie lub za którą ponosi odpowiedzialność pozostawała poza ryzykiem objętym ubezpieczeniem.

Powyższy pogląd został potwierdzony w wyroku z 23.06.1999 r., I CKN 57/985. Sprawa dotyczyła skradzionej Toyoty, którą sprawca wyprowadził z parkingu, posługując się dowodem rejestracyjnym pozostawionym przez powoda w torbie ulokowanej w bagażniku. W uzasadnieniu Sąd Najwyższy stwierdził, że z umiejscowienia przepisu art. 362 k.c. w przepisach ogólnych Kodeksu cywilnego o zobowiązaniach wynika w sposób oczywisty, że ma on zastosowanie zarówno w reżimie odpowiedzialności ex contractu, jak i ex delicto i może być stosowany we wszystkich wypadkach odpowiedzialności z tytułu niewykonania lub nienależytego wykonania zobowiązań. Stwierdzenie to nie dotyczy jednak odpowiedzialności z tytułu umowy ubezpieczenia, gdyż przepisy normujące tę umowę zmodyfikowały ogólne zasady odpowiedzialności odszkodowawczej, w tym skutki prawne przyczynienia się poszkodowanego do szkody.

3 Wyrok SN z 8.10.1980 r., IV CR 382/80, OSNC 1981/5, poz. 83, oraz wyrok z 14.07.1981 r., IV CR 222/81, OSNC 1982/2-3, poz. 32, z glosą A. Szpunara, PiP 1983/1, s. 138.

$4 \mathrm{Z}$ aprobującą glosą A. Szpunara.

5 OSNC 2000/1, poz. 13. 
W ostatnim wyroku SN wskazał również, że unormowanie ujęte w art. 362 k.c. stoi w opozycji do istoty ubezpieczenia, które m.in. polega właśnie na zapewnieniu ubezpieczającemu ochrony w razie rozmaitych uchybień w jego postępowaniu wywołujących powstanie szkody albo też stanowiących przyczynienie się do jej powstania lub zwiększenia. W konsekwencji możliwość uwzględnienia przyczynienia prowadziłaby wprost do unicestwienia podstawowych celów ubezpieczenia, tj. osłabienia czy nawet wyłączenia jego funkcji ochronnej i kompensacyjnej. Słuszny pogląd o braku zastosowania art. 362 k.c. w ubezpieczeniu mienia SN powtórzył m.in. w uzasadnieniach wyroków z 20.05.2004 r. oraz z 7.05.2009 r. ${ }^{6}$

Druga z zasygnalizowanych kwestii wstępnych dotyczy niewykonania przez ubezpieczającego dodatkowych obowiązków (tzw. powinności), co zgodnie z ustawą stanowi w określonych sytuacjach negatywną przesłankę odpowiedzialności ubezpieczyciela. Jak wskazano w pierwszym rozdziale pracy, przy okazji rozważań dotyczących zasady odpowiedzialności absolutnej, niewykonanie przez ubezpieczającego lub ubezpieczonego powinności ustawowych skutkować może zwolnieniem ubezpieczyciela z odpowiedzialności, jeżeli było zawinione i szkoda pozostaje w związku przyczynowym z naruszeniem. Pominąwszy naruszenie powinności deklaracji oraz notyfikacji zmian ryzyka, potrzebna jest przy tym wina kwalifikowana ubezpieczającego w postaci umyślności lub rażącego niedbalstwa. Nie jest wyraźnie sankcjonowane naruszenie powinności zabezpieczenia roszczeń regresowych ubezpieczyciela, która aktualizuje się na tym samym etapie, jeżeli została wprowadzona w umowie lub w OWU. Brak jakiejkolwiek regulacji w tym przedmiocie wydaje się być lapsusem ustawodawcy. W doktrynie przyjmuje się zwykle, że naruszenie tej powinności przez ubezpieczającego może rodzić po stronie ubezpieczyciela roszczenia odszkodowawcze ${ }^{7}$.

${ }^{6}$ Wyrok z 20.05.2004 r., II CK 341/03, LEX nr 174171, oraz wyrok z 7.05.2009 r., IV CSK 16/09, LEX nr 515706. Uzasadnienia tych wyroków budzą jednak zastrzeżenia w zakresie, w jakim SN stwierdza, że naruszenie przez ubezpieczającego umownych obowiązków prewencyjnych nie podlega ocenie w świetle art. 827 k.c. Kwestia zostanie omówiona szerzej w dalszych wywodach.

7 Szerzej co do tej kwestii M. Krajewski, Umowa ubezpieczenia. Art. 805-834 KC..., 2016, s. 596. 
Ponadto do ograniczenia odpowiedzialności ubezpieczyciela może prowadzić naruszenie przez ubezpieczającego lub ubezpieczonego obowiązku zawiadomienia o szkodzie we właściwym czasie, jeżeli taki obowiązek przewidziano w umowie lub OWU. Skuteczne podniesienie przez ubezpieczyciela tego zarzutu warunkowane jest znów winą umyślną lub rażącym niedbalstwem ubezpieczającego, związkiem przyczynowym między zaniechaniem powiadomienia a zwiększeniem szkody lub niemożnością ustalenia przez ubezpieczyciela okoliczności i skutków wypadku oraz brakiem wiedzy ubezpieczyciela o wypadku pochodzącej z innych źródeł (art. 818 k.c.). Norma ustawowa zdaje się wykluczać całkowite zwolnienie ubezpieczyciela $\mathrm{z}$ odpowiedzialności, pozwalając mu jedynie, w razie spełnienia wskazanych wyżej warunków, na odpowiednie zmniejszenie świadczenia. Rozwiązanie to może rodzić wątpliwości dotyczące możności odmowy wypłaty odszkodowania, gdy brak zawiadomienia całkowicie uniemożliwił ustalenie okoliczności wypadku ubezpieczeniowego oraz kryteriów i dopuszczalnej wysokości pomniejszenia odszkodowania ${ }^{8}$.

Zagadnienia związane z naruszeniem ustawowych powinności ubezpieczeniowych nie będą szczegółowo omawiane, ponieważ wykraczają poza ramy pracy. Czym innym jest bowiem określenie granic wypadku ubezpieczeniowego i ograniczenie ryzyka przejmowanego przez ubezpieczyciela poprzez sformułowanie odpowiednich wyłączeń, czym innym zaś nałożenie na ubezpieczającego określonych powinności. Obydwie kwestie niewątpliwie pozostają ze sobą w bliskim związku, tym niemniej pierwsza dotyczy obowiązków ubezpieczyciela, druga zaś obowiązków ubezpieczającego ${ }^{9}$. Nawet jeżeli obowiązki dodatkowe ubezpieczającego ujmowane będą jako szczególne obowiązki w strukturze umowy ubezpieczenia, niemające odpowiedników w postaci roszczeń ubezpieczyciela, nie są one objęte zakresem świadczenia tego ostatniego ${ }^{10}$. Wyłączenie

8 M. Orlicki, J. Pokrzywniak, Umowa..., s. 92.

9 Por. rozważania dotyczące odróżnienia umownych powinności prewencyjnych od wyłączeń odpowiedzialności zawarte w kolejnym podrozdziale.

10 Spór toczy się na kilku płaszczyznach: po pierwsze, co do tego, czy powinności mogą być traktowane podobnie jak inne obowiązki obligacyjne (teoria zobowiązania), czy też stanowią szczególną kategorię prawa ubezpieczeniowego (teoria przesłanki); po drugie, w obrębie teorii przesłanki, czy stanowią obowiązki dłużnika, czy też obowiązki 
powinności ubezpieczeniowych poza zakres pracy wydaje się uprawione także w świetle prezentowanego przez autora poglądu, że stanowią one $\mathrm{w}$ istocie obowiązki ubezpieczającego jako wierzyciela w stosunku obligacyjnym ubezpieczenia ${ }^{11}$. Kwestia stopnia zawinienia wymaganego dla zwolnienia się przez ubezpieczyciela $\mathrm{z}$ odpowiedzialności w razie naruszenia przez ubezpieczającego lub ubezpieczonego powinności umownych zostanie wyjaśniona w dalszej części niniejszego rozdziału, przy okazji odróżnienia ich od wyłączeń odpowiedzialności.

\subsection{Umyślne wyrządzenie szkody przez ubezpieczającego}

Poruszona kwestia rozróżnienia wyłączeń odpowiedzialności od dodatkowych obowiązków ubezpieczającego pozwala przejść do pierwszego z ustawowych wyłączeń, a mianowicie wyłączenia odpowiedzialności ubezpieczyciela za szkody wywołane przez ubezpieczającego lub ubezpieczonego umyślnie. Wyłączenie to ujmowane jest przez część autorów właśnie w kategoriach powinności ubezpieczającego powstrzymania się od wywołania umyślnie szkody ${ }^{12}$. Inni autorzy wskazują, że w istocie chodzi nie o powinność ubezpieczającego niewyrządzania sobie umyślnie szkody, ale o takie jego zachowania, które nie mogą być objęte zakresem wypadku ubezpieczeniowego wobec niespełnienia jego podstawowej cechy polegającej na niezależności od woli ubezpieczającego lub ubezpieczonego ${ }^{13}$.

wierzyciela; po trzecie, co do tego, czy ich istnienie pozwala zakwalifikować umowę ubezpieczenia do odrębnej kategorii umów najwyższego zaufania. Co do tych kwestii, zob. S. Byczko, Powinności ubezpieczającego a inne obowiązki..., s. 321 i n.; B. Kucharski, Przeniesienie..., s. 55-72; M. Orlicki, Umowa ubezpieczenia, 2002, s. 229-233; M. Krajewski, Umowa ubezpieczenia. Art. 805-834 KC..., 2016, s. 284-285 oraz 620-621.

11 Por. B. Kucharski, Przeniesienie..., s. 65-72.

12 Tak przykładowo M. Orlicki, Umowa ubezpieczenia, 2002, s. 241. W literaturze przedwojennej B. Hełczyński, Ubezpieczenie na cudzy rachunek, Kraków 1927, s. 192.

13 Tak przykładowo Z. Szymański, Prawo..., s. 107; S. Byczko, Obowiązki dodatkowe ubezpieczajacego w umowie ubezpieczenia mienia, niepublikowana praca doktorska napisana pod kierunkiem W.J. Katnera i obroniona w 2003 r. na Uniwersytecie Łódzkim, s. 262-263. Por. również A. Wąsiewicz, Przyczynienie..., s. 80; E. Kowalewski, Prawo ubezpieczeń gospodarczych. Ewolucja..., s. 165. 
Druga grupa autorów ma dużo racji, jednakże wagi rozróżnienia nie należy przeceniać. Wobec sformułowania ustawy, która kategorycznie wyłącza odpowiedzialność ubezpieczyciela za szkody wyrządzone umyślnie, powyższa różnica ujęcia wydaje się pozbawiona znaczenia. $\mathrm{W}$ istocie chodzi o spojrzenie na ten sam problem $\mathrm{z}$ różnych punktów widzenia. Witold Warkałło, którego niektórzy uważają za zwolennika istnienia obowiązku niewyrządzania samemu sobie szkody ${ }^{14}$, z jednej strony wyróżniał powinność prewencyjną niepowodowania wypadku działaniem własnym ubezpieczającego albo działaniem osób, za które ubezpieczający odpowiada ${ }^{15}$. Z drugiej strony wyraźnie przeciwstawiał normy z art. 826 i 827 k.c., wskazując, że o ile ta pierwsza ustanawia sankcję za niespełnienie dodatkowego obowiązku ustawowego ratowania mienia, o tyle art. 827 k.c. wyłącza odpowiedzialność ubezpieczyciela za wypadki niemające cech zdarzenia losowego, co byłoby sprzeczne z naturą oraz społeczno-gospodarczym celem ubezpieczenia ${ }^{16}$. Także A. Wąsiewicz podnosił, że zdarzenia mające postać wypadku ubezpieczeniowego w rozumieniu OWU, ale wywołane rozmyślnie, mogą być traktowane w dwojaki sposób: albo jako wypadki ubezpieczeniowe, które nie rodzą po stronie ubezpieczyciela obowiązku wypłaty świadczenia $\mathrm{z}$ uwagi na naganne postępowanie ubezpieczającego, albo jako zdarzenia nienoszące w ogóle cech wypadku z uwagi na wyłączenie ich z zakresu ryzyka ${ }^{17}$.

Samo sformułowanie art. 827 k.c. oraz natura umowy ubezpieczenia uniemożliwiająca objęcie odpowiedzialnością ubezpieczyciela zdarzeń niemających charakteru wypadków ubezpieczeniowych, z uwagi na brak cechy niezależności od woli ubezpieczającego, przemawiają za poglądem, że ustawodawca zmierzał do sformułowania ustawowego wyłączenia odpowiedzialności, nie zaś do nałożenia na ubezpieczającego powinności prewencyjnej niewyrządzenia samemu sobie umyślnie szkody. Ponadto trudno mówić o obowiązku właściciela niewyrządzania

14 Tak. S. Byczko, Obowiązki dodatkowe ubezpieczajacego..., s. 256-257.

15 W. Warkałło, Ubezpieczenie [w:] System..., t. 3, cz. 2.

16 W. Warkałło, Prawo..., s. 137, oraz W. Warkałło, Ubezpieczenie [w:] System..., t. 3, cz. 2, s. 938-939.

17 A. Wąsiewicz, Z.K. Nowakowski, Prawo..., s. 63-64. 
szkody samemu sobie umyślnie, skoro na prawo własności składa się również uprawnienie do zniszczenia swojej rzeczy.

Z drugiej strony jednak natura umowy ubezpieczenia oraz funkcja prewencyjna ubezpieczeń, której również obecnie nie można zupełnie marginalizować, przemawiają za możliwością nałożenia na mocy ustawy na ubezpieczającego właściciela powinności niewyrządzania szkody samemu sobie. Obowiązek przeciwdziałania szkodzie nie dotyczy oczywiście jedynie działań umyślnych i rażąco niedbałych, jednakże natura prawna ubezpieczenia, które ma chronić ubezpieczającego także przed skutkami własnych zaniedbań, przemawia za możliwością sankcjonowania wyłącznie takich działań.

Wbrew zastrzeżeniom niektórych autorów nie ma zatem nic dziwnego w powinności niewyrządzania szkody samemu sobie. Słuszny wniosek, że art. $827 \$ 1$ k.c. formułuje w istocie ustawowe wyłączenie odpowiedzialności, nie przekreśla zupełnie trafności obserwacji, że wyłączeniu temu odpowiada obowiązek ubezpieczającego niewywoływania szkody własnym działaniem. Podkreślenia wymaga, że art. 827 k.c. odnosi się nie do okoliczności obiektywnych niezależnych od człowieka, ale do działania bądź zaniechania ubezpieczającego. Pogląd o istnieniu powinności ubezpieczającego ułatwia pewne analizy teoretyczne, o czym w dalszym toku rozważań ${ }^{18}$. Obowiązek ten koreluje z ustawowym wyłączeniem odpowiedzialności za szkody wyrządzone sobie umyślnie.

W doktrynie wskazuje się, że objęcie odpowiedzialnością ubezpieczyciela szkód wyrządzonych przez ubezpieczającego lub ubezpieczonego umyślnie byłoby sprzeczne nie tylko z art. 827, ale również z istotą umowy ubezpieczenia. Takie ujęcie odpowiada naczelnej zasadzie prawa cywilnego, zgodnie z którą za winę umyślną zawsze się odpowiada (dolus semper praestatur) ${ }^{19}$. Jak wskazywał W. Warkałło, zasada bezwzględnej odpowiedzialności ma stronę pozytywną i negatywną. W zakresie odpowiedzialności sprawczej występuje ona w formie pozy-

18 Porównaj przykładowo M. Orlicki, M. Kępiński, O wykładni art. 827 kodeksu cywilnego, PS 2006/3.

19 M. Krajewski, Umowa ubezpieczenia. Art. 805-834 KC..., 2016, s. 601. 
tywnej jako bezwzględny obowiązek naprawienia szkody, zaś w zakresie odpowiedzialności gwarancyjnej w formie negatywnej jako wyłączenie tego obowiązku ${ }^{20}$. Omawiane kwestie nie budzą większych wątpliwości $\mathrm{w}$ doktrynie prawa ubezpieczeniowego ${ }^{21}$.

Ustalenie zakresu pojęcia działań własnych ubezpieczającego jest proste, gdy ubezpieczającym jest jedna osoba fizyczna. Zagadnienie komplikuje się, gdy ubezpieczającym jest osoba prawna lub ułomna osoba prawna, ewentualnie gdy jako ubezpieczający występują współwłaściciele rzeczy. Co do pierwszej kwestii, panuje zgoda, że do działań ubezpieczającego będącego osobą prawną lub ułomną osobą prawną nie znajduje zastosowania konstrukcja winy anonimowej. Wina oznaczać musi w tym przypadku winę organu, wspólnika lub innej osoby, która zgodnie z ustawą lub statutem miała prawo reprezentować ubezpieczającego ${ }^{22}$.

Sprawa jest najtrudniejsza, gdy chodzi o współwłasność. Marcin Krajewski jest zdania, że w zakresie współwłasności w częściach ułamkowych nie ma podstaw do przyjęcia, że umyślne wyrządzenie szkody przez jednego ze współwłaścicieli zwalnia ubezpieczyciela z odpowiedzialności wobec pozostałych. Umyślne działanie jednego ze współwłaścicieli ma charakter zdarzenia losowego w stosunku do pozostałych, w ustawie brak przesłanek, by uznać, że współwłaściciele odpowiadają za siebie nawzajem. Z ekonomicznego punktu widzenia przedmiotem ubezpieczenia jest nie tyle cała rzecz, ile udziały przysługujące poszczególnym współwłaścicielom. Współwłaściciele, którzy nie wyrządzili szkody, winni otrzymać odszkodowania odpowiadające ich udziałom, przy czym udział współwłaściciela, którego działanie umyślne lub rażące niedbalstwo było źródłem szkody, nie dzieli się między pozostałych. Działania poszczególnych współwłaścicieli mogą skutkować względem wszystkich w sytuacjach, gdy umowa lub ogólne warunki wyraźnie to

20 Szerzej: W. Warkałło, Odpowiedzialność..., s. 96 oraz 299-303.

21 Warto jednak zastrzec, że umyślnego wyrządzenia szkody nie można utożsamiać z winą umyślną ubezpieczającego. Osoba, która umyślnie niszczy swoją rzecz, korzysta ze swojego prawa własności, wobec czego brakuje obiektywnego elementu winy. Tak M. Krajewski, Umowa ubezpieczenia. Art. 805-834 KC..., 2016, s. 602.

22 Tak przykładowo E. Kowalewski, Glosa do wyroku SN z 22.04.2004 r., II CK 144/03, PA 2005/1. 
przewidują, gdy współwłaściciele byliby objęci klauzulą reprezentantów (kwestia zostanie omówiona dalej), a także gdy współwłasność ma charakter bezudziałowy (łączny) ${ }^{23}$.

Według M. Krajewskiego powyższe rozumowanie nie dotyczy współwłasności łącznej. Innego zdania jest J. Kondek, który rozciąga pogląd o odpowiedzialności ubezpieczyciela względem pozostałych współwłaścicieli przy rażącym niedbalstwie jednego z nich również na współwłasność w częściach ułamkowych. Autor ten twierdzi, że także w tym wypadku można wskazać odrębny interes każdego ze współwłaścicieli, ponieważ pojęcie interesu ubezpieczeniowego jest szersze niż przedmiotu prawa ${ }^{24}$. Pogląd ten wydaje się jednak wątpliwy. Okoliczność, że interes ubezpieczeniowy nie musi być utożsamiany z prawem, nie pozwala zwykle przyznać poszczególnym współwłaścicielom łącznym odrębnych interesów. Ujmowany czysto gospodarczo interes współwłaścicieli łącznych będzie zwykle tożsamy, a nadto wobec niepodzielności ich udziałów we współwłasności trudno będzie oszacować wartość interesów służących poszczególnym współwłaścicielom łącznym.

Uzupełniająco dodać można, że w obcych ustawodawstwach wyłączenie odpowiedzialności ubezpieczyciela za szkody wyrządzone umyślnie jest powszechne. Niemiecka ustawa o umowie ubezpieczenia (VVG) przewiduje takie wyłączenie w art. 81 ust. 1, holenderski kodeks cywilny w art. 7.953, francuski Code des assurances w art. L113-1, angielski Marine Insurance Act $1906 \mathrm{w}$ art. 55 s. 2a. W angielskich ubezpieczeniach lądowych nieubezpieczalność szkód spowodowanych przez ubezpieczającego umyślnie traktowana jest jako oczywistość. Przyjmuje się bowiem, że ubezpieczenie może chronić jedynie przed niekorzystnymi skutkami wypadków mających charakter losowy oraz zgodnych z prawem. Wypadek jest losowy, o ile jego zajście nie jest nieuniknione oraz o ile nie został umyślnie spowodowany przez ubezpieczającego. $Z$ tego względu nawet w braku wyraźnych zastrzeżeń przyjmuje się, że polisa zawiera dorozumiane wyłączenie odpowiedzialności za szkody

23 M. Krajewski, Umowa ubezpieczenia. Art. 805-834 KC..., 2016, s. 628.

24 Zob. J. Kondek [w:] Kodeks..., t. 3B, red. K. Osajda, s. 1009. 
wyrządzone umyślnie ${ }^{25}$. W prawie hiszpańskim nieubezpieczalność wypadków spowodowanych umyślnie, poza przepisami hiszpańskiej ustawy o umowie ubezpieczenia ${ }^{26}$, uzasadnia się brzmieniem art. 1275 Código civil, wedle którego nieważne są umowy, których przyczyna jest sprzeczna z prawem lub dobrymi obyczajami ${ }^{27}$.

Odpowiednią regulację zawierają także Zasady Europejskiego Prawa o Umowie Ubezpieczenia. Według art. 9:102 PEICL ani ubezpieczający, ani ubezpieczony nie mają prawa do odszkodowania w zakresie, w jakim szkoda została wyrządzona ich działaniem lub zaniechaniem umyślnym albo rażąco niedbałym przy świadomości, że szkoda prawdopodobnie wystąpi. Uzasadniając przywołaną regulację, autorzy projektu wskazują, że skłonność ubezpieczającego do działań nieuczciwych jest dla ubezpieczyciela trudna do oszacowania, wobec czego ubezpieczenie szkód wyrządzonych umyślnie, nawet gdyby uznać je za dopuszczalne, byłoby tak drogie, że nie znalazłoby nabywców.

\subsection{Wyrządzenie szkody przez ubezpieczającego wskutek rażącego niedbalstwa}

Drugie z ujętych w art. 827 k.c. wyłączeń odpowiedzialności dotyczy szkód powstałych na skutek rażącego niedbalstwa ubezpieczającego lub ubezpieczonego. Nowelizacja z 2007 r. wprowadziła niewielką zmianę $\mathrm{w}$ tej mierze. W przeszłości art. $827 \$ 1$ zdanie drugie stanowił, że w razie rażącego niedbalstwa odszkodowanie nie należy się, chyba że zapłata odszkodowania odpowiada w danych okolicznościach zasadom współżycia społecznego lub interesom gospodarki narodowej. Korekta polega zatem po pierwsze, na umożliwieniu objęcia ubezpieczeniem rażącego niedbalstwa, gdy strony tak zdecydują, po drugie, na zastąpieniu zasad

25 M. Clarke, The Law of Insurance Contract, London 2014, s. 493 oraz 497-498, powołując się przede wszystkim na sprawę British \& Foreign Marine Ins Co Ltd vs. Gaunt [1921] 2 AC, 41.

26 Ustawa 5/1980 z 8.10.1980 r. o umowie ubezpieczenia.

27 J.B. Grau, N.L. Chiner, J.O. Iglesia, Insurance Law in Spain, The Netherlands 2014, s. 71. 
współżycia społecznego względami słuszności, po trzecie, na odejściu od możliwości wypłaty odszkodowania, gdy odpowiada to interesom gospodarki narodowej. W zakresie dwóch ostatnich kwestii nowelizacja była wyrazem tendencji do odchodzenia od klauzul, których wprowadzenie wynikało z założeń ustroju socjalistycznego, i nie wywołała zmiany merytorycznejej.

W literaturze wskazuje się, że zrównanie rażącego niedbalstwa z winą umyślną odpowiada rzymskiej zasadzie culpa lata dolo aequiparatur i podyktowane zostało przede wszystkim względami praktycznymi. Wyłączenie odpowiedzialności za szkody będące następstwem rażącego niedbalstwa ma jednak zupełnie inny charakter niż wyłączenie za szkody wywołane umyślnie. Jedynie ta druga kategoria szkód nie mieści się w kategorii wypadku ubezpieczeniowego jako zdarzenia niezależnego od woli ubezpieczającego. Szkody będące wynikiem rażącego niedbalstwa ubezpieczonego są co do zasady ubezpieczalne, nieobjęcie ich zakresem ryzyka przejmowanego przez ubezpieczyciela wynika z art. 827 k.c. oraz może być zmienione wolą stron umowy ubezpieczenia ${ }^{29}$. Szczególnie w przeszłości wskazywano, że o wyłączeniu odpowiedzialności za rażące niedbalstwo decydują przede wszystkim względy prewencyjne ${ }^{30}$.

O ile wyłączenie odpowiedzialności za szkody wywołane umyślnie jest w prawodawstwach zagranicznych powszechne, o tyle szkody będące wynikiem rażącego niedbalstwa traktowane są niejednolicie. Francuski Code des assurances w art. L113-1 ogranicza wyłączenie odpowiedzialności do winy umyślnej, podkreślając przy tym, że ubezpieczyciel ponosi ryzyko szkód będących wynikiem nieprzewidzianych wypadków, do których doszło na skutek winy ubezpieczającego. Na podobnym stano-

28 M. Orlicki, J. Pokrzywniak, Umowa..., s. 120; M. Krajewski, Umowa ubezpieczenia. Art. 805-834 KC..., 2016, s. 603.

29 Por. M. Krajewski, Umowa ubezpieczenia. Art. 805-834 KC..., 2016, s. 603; K. Malinowska, S. Nowak, Wina ubezpieczającego (ubezpieczonego) a odpowiedzialność ubezpieczyciela w umowie ubezpieczenia [w:] Umowa ubezpieczenia. Dyskusja nad forma prawna i treścia unormowań, red. A. Nowak, D. Fuchs, S. Nowak, Warszawa 2007, s. 137 i 139,

30 Por. przykładowo W. Warkałło, Prawo..., s. 138-139; A. Wąsiewicz, Z.K. Nowakowski, Prawo..., s. 63. 
wisku stoją inne romańskie systemy prawne, w szczególności: belgijski, hiszpański i portugalski.

Ustawa niemiecka pozwala ubezpieczycielowi w razie rażącego niedbalstwa ze strony ubezpieczającego zmniejszyć odszkodowanie proporcjonalnie do stopnia winy (art. 81 ust. 2 VVG). Prawo zmniejszenia odszkodowania za szkody, do których doszło na skutek rażącego niedbalstwa, przewidują również systemy: szwajcarski, szwedzki oraz fiński. Z kolei rozwiązanie podobne do polskiego, pozwalające ubezpieczycielowi na odmowę spełniania świadczenia w całości, przyjmowane jest w Austrii, Grecji, Holandii oraz we Włoszech ${ }^{31}$.

W praktyce angielskiej przyjmuje się, że szkody, do których doszło na skutek rażącego niedbalstwa ubezpieczającego, objęte są ubezpieczeniem, chyba że polisa nakłada na ubezpieczającego obowiązek przedsiębrania rozsądnych środków w celu zabezpieczenia mienia przed szkodą. Postanowienia tego typu, wcześniej spotykane przede wszystkim w polisach ubezpieczenia odpowiedzialności cywilnej, stały się powszechne również w ubezpieczeniu mienia. Sądy przyjmują, że nawet jeżeli polisa zawiera podobne zastrzeżenie, zwykłe niedbalstwo nie uprawnia ubezpieczyciela do odmowy wypłaty odszkodowania. W stanie faktycznym sprawy Sofi v. Prudential Assurance Co Ltd ${ }^{32}$ ubezpieczający oraz jego rodzina mieli chwilę czasu przed odchodzącym promem do Francji i postanowili obejrzeć zamek w Dover. W tym celu zostawili samochód na niestrzeżonym przydrożnym parkingu. W skrytce na wycieraczki przewozili biżuterię, którą zabrali z domu, ponieważ wcześniej mieli włamanie i uznali, że w ten sposób będzie bezpieczniejsza. Podczas nieobecności rodziny biżuteria została skradziona, a ubezpieczyciel odmówił wypłaty odszkodowania, powołując się na klauzulę wymagającą od ubezpieczającego przedsięwzięcia rozsądnych środków prewencyjnych. Uzasadniając wyrok korzystny dla ubezpieczającego, sędzia Lloyd

31 Por. Principles..., s. 249.

32 [1993] 2 Lloyd's Rep 559. 
wskazał, że w okolicznościach sprawy nie można ubezpieczającemu zarzucić rażącego niedbalstwa w naruszeniu tego obowiązku³ ${ }^{33}$.

Mając na uwadze wszystkie powyższe rozbieżności, redaktorzy Principles of European Insurance Contract Law proponują w art. 9:101 rozwiązanie przewidujące nieodpowiedzialność ubezpieczyciela, jeżeli ubezpieczający wyrządził szkodę umyślnie lub wskutek rażącego niedbalstwa przy świadomości, że szkoda prawdopodobnie nastąpi. Jednocześnie wskazują, że z zastrzeżeniem wyraźnych postanowień umownych przewidujących możliwość zmniejszenia odszkodowania stosownie do stopnia winy ubezpieczający lub ubezpieczony mają prawo do odszkodowania za szkody będące następstwem ich niedbalstwa. Przyjęte rozwiązanie umożliwia zatem zastrzeżenie prawa zmniejszenia odszkodowania stosownego do stopnia winy nie tylko w razie niedbalstwa o stopniu rażącym. Rozwiązanie to może się wydawać dosyć liberalne w porównaniu do przewidywanej przez systemy germańskie możliwości zmniejszenia odszkodowania stosownie do stopnia rażącego niedbalstwa. Zważyć jednak należy, że samo rażące niedbalstwo wydaje się stopniem winy o stosunkowo wąskim zakresie i dosyć trudno wyobrazić sobie jego stopniowalność.

Ostatnia uwaga może stanowić wprowadzenie do analizy bogatego orzecznictwa polskiego Sądu Najwyższego, dotyczącego wykładni pojęcia rażącego niedbalstwa na gruncie ubezpieczeń. Odmowy wypłaty odszkodowań ubezpieczeniowych są niezwykle często uzasadniane rażącym niedbalstwem ze strony ubezpieczających, stąd wykładnia tego pojęcia stanowi problem o znaczeniu zasadniczym. Nowsze wypowiedzi Sądu Najwyższego dotyczące tej kwestii wydają się bardzo wyważone. Przykładowo zaaprobowano odmowę wypłaty odszkodowania przez ubezpieczyciela za szkody powstałe wskutek pożaru mieszkania wywołanego wrzuceniem niewygaszonego niedopałka papierosa do kosza na

33 Ściśle rzecz ujmując, prawnicy angielscy niekiedy rozróżniają między niedbalstwem zwykłym - negligence, niedbalstwem o stopniu podwyższonym - recklessness, oraz rażącym niedbalstwem - gross negligence. Dla uchylenia się przez ubezpieczyciela od odpowiedzialności wymaga się przynajmniej recklessness. 
śmieci ${ }^{34}$. Uzasadniając wyrok, SN wskazał, że „wrzucenie do zawierającego łatwopalne przedmioty kosza na śmieci niedopałka papierosa lub zapałki, bez uprzedniego upewnienia się o całkowitym jego zgaszeniu, stanowi przekroczenie podstawowych, elementarnych zasad staranności, a w konsekwencji ocena takiego zachowania jako rażąco niedbałego jest uprawniona. Te podstawowe, elementarne zasady wynikają z jednej strony ze szczególnej dolegliwości skutków mogących wystąpić w wypadku ich naruszenia, a z drugiej strony z powszechności wiedzy o możliwości spowodowania $w$ ten sposób pożaru, dostępnej nawet dla osób na bardzo niskim poziomie intelektualnym, jak też z okoliczności, że możliwość zapobieżenia takim zagrożeniom, chociażby przez używanie popielniczki, jest łatwo dostępna i powszechnie stosowana”.

Skuteczne okazało się również wyłączenie odpowiedzialności za szkodę powstałą wskutek wydania przesyłki oszustom, gdy ubezpieczający przewoźnik nie pouczył dalszego przewoźnika o wcześniejszych podobnych przypadkach utraty przesyłek oraz sposobie działania oszustów ${ }^{35}$. Powołanie się przez ubezpieczyciela na rażące niedbalstwo ubezpieczającego uznano natomiast za nieskuteczne, gdy przesyłka została wydana oszustom, ale nie było wcześniejszych przypadków utraty przesyłek ${ }^{36}$. $\mathrm{W}$ tej drugiej sprawie SN zwrócił uwagę na różnice między niedbalstwem zwykłym i rażącym, stwierdzając, że „rażące niedbalstwo jest kwalifikowaną postacią braku staranności w przewidywaniu skutków działania i jest to takie zachowanie, które wręcz graniczy z umyślnością i nie może być traktowane za równoznaczne z pojęciem «należytej staranności», o którym mowa w art. 355 k.c. Gdyby pojęcia te były znaczeniowo tożsame, $827 \$ 1$ k.c. wyłączałby odpowiedzialność ubezpieczyciela nie w przypadku rażącego niedbalstwa, ale w przypadku działania poszkodowanego bez zachowania należytej staranności”.

W zakresie ubezpieczeń samochodowych Sąd Najwyższy podzielił rację ubezpieczyciela, który uchylił się od odpowiedzialności za szkodę powstałą na skutek kradzieży pojazdu wraz z dowodem rejestracyjnym.

\footnotetext{
34 Wyrok SN z 11.05.2005 r., III CK 522/04, LEX nr 151664.

35 Wyrok SN z 7.03.2008 r., III CSK 270/07, LEX nr 487542.

36 Wyrok SN z 22.04.2004 r., II CK 142/03, LEX nr 484721.
} 
Ustalenia faktyczne stanowiące podstawę wyroku wskazywały, że pozostawianie dokumentów w pojazdach było stałą praktyką w przedsiębiorstwie ubezpieczającego ${ }^{37}$. Uchylenie się od odpowiedzialności za podobną szkodę okazało się dla odmiany nieskuteczne, gdy ojciec ubezpieczającego pozostawił w bagażniku pojazdu zaparkowanego przed sklepem neseser z zamkiem cyfrowym, zawierający m.in. dowód rejestracyjny pojazdu ${ }^{38}$, a także gdy ubezpieczający pozostawił w samochodzie jedynie kartę pojazdu, inne zaś dokumenty, w szczególności dowód rejestracyjny, zabrał ze sobą ${ }^{39}$. Nieskuteczna okazała się również odmowa wypłaty odszkodowania za uszkodzenia ciągnika siodłowego, który w dniu wypadku nie miał ważnych badań technicznych, a podróż przedłużyła się wobec zatrzymania kierowcy na granicy. Zachowania ubezpieczającej, która wysłała pojazd z ładunkiem na Ukrainę, nie uznano w tych okolicznościach za rażąco niedbałe ${ }^{40}$.

Sąd Najwyższy słusznie podkreśla różnicę między niedbalstwem rażącym, które może być zrównane z umyślnością, a niedbalstwem zwykłym, które polega na niedochowaniu należytej staranności, zastrzegając jednocześnie, że oceniając rażące niedbalstwo nieokreślone dokładnie przez kodeks, porównawczo można odnosić się do należytej staranności, której poziom określony jest w art. 355 k.c. Rażące niedbalstwo, o którym stanowi art. $827 \$ 1$ k.c., można przypisać w wypadku nieprzewidywania szkody jako skutku działania lub zaniechania ubezpieczającego, o ile doszło do przekroczenia podstawowych i elementarnych zasad staranności. Ocenę, czy miało miejsce rażące niedbalstwo, należy odnosić do okoliczności konkretnej sprawy, co wymaga pogłębionej oceny sądu ${ }^{41}$.

37 Wyrok SN z 30.01.2013 r., V CSK 75/12, LEX nr 1311857.

38 Wyrok SN z 26.01.2005 r., V CSK 90/05, LEX nr 195430.

39 Wyrok SN z 29.01.2009 r., V CSK 291/08, LEX nr 484739, z glosą P. Hyrlika, „Glosa” 2011/2.

40 Wyrok SN z 4.11.2010 r., IV CSK 153/10, LEX nr 1232801. W tej sprawie nie było również związku przyczynowego między zachowaniem ubezpieczającej a szkodą, która powstała na skutek zasłabnięcia kierowcy.

41 Tak przykładowo w cytowanym wyżej wyroku SN z 29.01.2009 r., V CSK 291/08, z glosą P. Hyrlika. 
Dobrym podsumowaniem uwag dotyczących rażącego niedbalstwa wydaje się cytowane przez W. Warkałłę stwierdzenie braci H. i L. Mazeaud, że sprawca szkody nigdy nie przyznaje się do winy umyślnej i stara się przesłonić swe złe zamiary pozorami braku znajomości rzeczy, „przywdziewając maskę imbecyla”. Dążąc do udaremnienia tej mistyfikacji, ustawodawca zrównuje skutki rażącego niedbalstwa - to jest postępowania, które wskazywałoby na to, że dana osoba nie wiedziała tego, co wszyscy wiedzą, i nie przewidywała tego, co wszyscy przewidywali - ze skutkami winy umyślnej ${ }^{42}$. Niekiedy można odnieść wrażenie, że ubezpieczyciele mają skłonność do kwalifikowania jakichkolwiek uchybień po stronie ubezpieczającego jako rażącego niedbalstwa. Praktyka te nie powinna być aprobowana przez sądy. Nie budzi wątpliwości, że to ubezpieczyciel musi udowodnić rażące niedbalstwo jako strona wywodząca zeń skutki prawne.

\subsection{Wyrządzenie szkody umyślnie przez osoby pozostające z ubezpieczającym we wspólnym gospodarstwie domowym}

Zagadnienie odpowiedzialności ubezpieczyciela za szkody wyrządzone umyślnie przez inne osoby niż ubezpieczający należy do skomplikowanych. Regulacja polska w tej mierze przeszła znamienną ewolucję. Artykuł 827 w brzmieniu przed zmianą z 2007 r. wyłączał odpowiedzialność ubezpieczyciela za szkody wyrządzone umyślnie przez osoby, z którymi ubezpieczający pozostawał we wspólnym gospodarstwie domowym, lub osoby, za które ubezpieczający ponosił odpowiedzialność. Po zmianie wyłączenie ograniczono do osób, z którymi ubezpieczający pozostaje we wspólnym gospodarstwie domowym, zastrzegając, że strony mogą umówić się inaczej.

W obcych systemach prawnych, pominąwszy powszechne wyłączenie odpowiedzialności za szkody wyrządzone umyślnie przez ubezpieczonego, obowiązują w omawianej kwestii bardzo różne rozwiązania. Francuski Code des assurances poza art. L113-1 zdanie drugie, który

${ }^{42}$ W. Warkałło, Odpowiedzialność..., s. 299. 
wyłącza odpowiedzialność za szkody będące wynikiem umyślnych i bezprawnych działań ubezpieczającego lub jego oszustwa, zawiera przepis statuujący normę niemal przeciwną do wynikającej z art. 827 k.c. przed zmianą. Artykuł L121-2 Code des assurances stanowi bowiem, że ubezpieczyciel powinien pokryć szkody wyrządzone przez osoby, za które ubezpieczający odpowiada zgodnie z art. 1384 Kodeksu Napoleona, niezależnie od charakteru i stopnia winy tychże osób. Podobną regulację zawiera art. $1900 \$ 2$ włoskiego kodeksu cywilnego.

Niemiecka VVG z 2008 r. ogranicza się do omówionego już wyłączenia za szkodę wyrządzoną umyślnie przez ubezpieczającego, nie rozszerzając wyłączenia na inne osoby trzecie. W doktrynie wskazuje się jednak, że ubezpieczyciel nie odpowiada również za szkody wyrządzone umyślnie przez osoby, które mogą być uznane za reprezentantów ubezpieczającego według doktryny Reprasentantenhaftung. Na podobnym stanowisku stoi prawo angielskie, gdzie panuje pogląd, że ubezpieczyciel nie odpowiada za szkody, które mogą być przypisane ubezpieczającemu na zasadach tamtejszej koncepcji agency. Uznaje się natomiast, że odpowiedzialności ubezpieczyciela nie wyłączają umyślne działania współmałżonka albo pracownika ubezpieczającego ${ }^{43}$.

Rozwiązanie podobne do polskiego obowiązuje w Finlandii, gdzie art. 33 ustawy o umowie ubezpieczenia wyłącza odpowiedzialność ubezpieczyciela za szkody wyrządzone umyślnie przez współwłaścicieli oraz domowników ubezpieczającego. W Grecji nieodpowiedzialność ubezpieczyciela odnosi się do szkód wyrządzonych umyślnie przez profesjonalistów, którym ubezpieczający powierzył ochronę nad ubezpieczonym mieniem (art. $7 \$ 5$ greckiej ustawy o umowie ubezpieczenia). Podobne rozwiązanie wprowadza również art. $14 \$ 3$ szwajcarskiej Federalnej Ustawy o Umowie Ubezpieczenia z $1908 \mathrm{r}^{44}$

W większości z wymienionych krajów reguły prawa dotyczące odpowiedzialności ubezpieczycieli za szkody wyrządzone przez osoby trzecie nie mają znaczenia bezwzględnie obowiązującego, dlatego w praktyce

\footnotetext{
43 J. Birds, Birds'..., s. 215.

44 Por. Principles..., s. 249-250.
} 
zasadnicze znaczenie mają postanowienia umowne zawarte w ogólnych warunkach ubezpieczenia. Zasady Europejskiego Prawa o Umowie Ubezpieczenia poprzestają na omówionych wyżej regułach dotyczących odpowiedzialności za szkody wyrządzone przez ubezpieczającego, nie wykluczając uregulowania odpowiedzialności ubezpieczyciela za działania osób trzecich w ogólnych warunkach ubezpieczenia, co wydaje się rozwiązaniem wątpliwym.

Jak wskazano, art. $827 \$ 3$ k.c. w obecnej wersji wyłącza odpowiedzialność ubezpieczyciela za szkody wyrządzone umyślnie przez osoby, z którymi ubezpieczający pozostaje we wspólnym gospodarstwie domowym, chyba że strony umówiły się inaczej. Przed zmianą z 2007 r. art. 827 $\$ 1$ k.c. wyłączał nie tylko odpowiedzialność za szkody wyrządzone umyślnie przez osoby, z którymi ubezpieczający pozostaje w gospodarstwie domowym, ale również przez osoby, za które ubezpieczający ponosił odpowiedzialność. Do wszystkich wyżej wymienionych osób odnosiło się drugie zdanie umożliwiające wypłatę odszkodowania w razie wyrządzenia szkody na skutek rażącego niedbalstwa, o ile odpowiadało to względom słuszności albo interesom gospodarki narodowej. Przedmiotem kontrowersji był zakres grupy osób, za które ubezpieczający ponosi odpowiedzialność.

W doktrynie najpowszechniej reprezentowany był pogląd, że przez osoby, za które ubezpieczający ponosi odpowiedzialność, należy rozumieć wszystkie osoby, za które ubezpieczający może odpowiadać na podstawie odpowiedzialności deliktowej, a więc małoletnich i inne osoby pozostające pod nadzorem ubezpieczającego (art. 427 k.c.), osoby, którym ubezpieczający powierzył wykonanie czynności (art. 428 k.c.), oraz podwładnych (art. 429 k.c.) ${ }^{45}$. Według M. Krajewskiego ujęcie to miało słabe uzasadnienie formalne, powołane przepisy o odpowiedzialności deliktowej wyjaśniają bowiem, za kogo osoba zobowiązana do naprawienia szkody odpowiada wobec poszkodowanych osób trzecich,

45 E. Montalbetti [w:] Kodeks cywilny. Komentarz, t. 2, Warszawa 1972, s. 1660; S. Reps, J. Reps, Ubezpieczenia majątkowe przedsiębiorców, s. 155; H. Ciepła [w:] Komentarz do kodeksu cywilnego. Księga trzecia. Zobowiązania, t. 2, red. G. Bieniek, Warszawa 2002, s. 557-558. 
natomiast art. $827 \$ 1$ k.c. dotyczy osób, za które ubezpieczający może odpowiadać w relacji do ubezpieczyciela. Dodatkowo konsekwencją opisanego poglądu była niemożność wyłączenia odpowiedzialności pracodawcy za pracownika, który wyrządził szkodę umyślnie lub wskutek rażącego niedbalstwa, co pozostawało w sprzeczności z potrzebami oraz praktyką obrotu.

Zgodnie $\mathrm{z}$ inną koncepcją reprezentowaną przede wszystkim przez W. Warkałłę krąg osób, za które ubezpieczający ponosi odpowiedzialność w rozumieniu art. 827 k.c., przedstawiał się odmiennie w ubezpieczeniu odpowiedzialności cywilnej oraz w ubezpieczeniu mienia. W ubezpieczeniu OC chodziło o osoby, za które można odpowiadać w rozumieniu przepisów Kodeksu cywilnego o odpowiedzialność deliktowej, natomiast w ubezpieczeniu mienia mogły być to tylko osoby, za które ubezpieczający odpowiada jak za własne działania i zaniechania na podstawie art. 474 k.c., lecz w granicach określonych w OWU. Wobec tego ubezpieczyciel wolny był od odpowiedzialności za szkodę wyrządzoną umyślnie przez pracownika ubezpieczającego w mieniu, nad którym pracownik ten stosownie do OWU miał sprawować pieczę. Ubezpieczyciel był natomiast zobowiązany pokryć szkodę wyrządzoną z winy umyślnej przez pracownika ubezpieczającego nieobciążonego takim obowiązkiem ${ }^{46}$.

Poglądowi W. Warkałły zarzucano sprzeczność z inną powszechnie akceptowaną tezą tego autora o tym, że odpowiedzialność ubezpieczeniowa nie mieści się w reżimie deliktowym ani kontraktowym, ale ma odrębny od niej charakter, nie będąc odpowiedzialnością sprawczą; był to więc zarzut w istocie podobny do adresowanego wobec pierwszego z poglądów. Dodatkowo wskazywano, że sięganie do art. 474 k.c. ma wątpliwe podstawy, ponieważ nawet gdyby przyjmować istnienie obowiązku ubezpieczającego niewyrządzania szkody w ubezpieczonym mieniu, obowiązek taki nie ma charakteru stosunku zobowiązaniowego mię-

46 W. Warkałło, Prawo..., s. 134; W. Warkałło, W. Marek, W. Mogilski, Prawo..., s. 123-124; W. Warkałło, Ubezpieczenie [w:] System..., t. 3, cz. 2, s. 936. 
dzy ubezpieczającym a ubezpieczycielem, wobec czego trudno mówić o osobach, którym ubezpieczający poleca wykonanie zobowiązania ${ }^{47}$.

Zastrzeżenia te stały się podstawą do sformułowania trzeciego poglądu, wedle którego w ubezpieczeniu mienia osoby do kręgu osób, za które ubezpieczający ponosi odpowiedzialność, należały osoby, którym ubezpieczający w ten sposób delegował swoje obowiązki z umowy ubezpieczenia, iż można przyjąć, że działały one za niego. Stanowisko to wyrażone zostało najpierw przez J. Łopuskiego, który jednak nie sprecyzował wyraźnie pojęcia delegowania obowiązków, formułując postulat de lege ferenda i kontestując brzmienie art. $827 \$ 1$ k.c. sprzed zmiany ${ }^{48}$.

Jeszcze inny pogląd prezentował M. Krajewski, którego zdaniem osobami, za które ubezpieczający ponosi odpowiedzialność, mogły być wyłącznie osoby wskazane przez strony w ogólnych warunkach ubezpieczenia, w razie zaś braku określenia tych osób kategoria ta miała być pusta ${ }^{49}$. Ten pogląd miał słabe oparcie $\mathrm{w}$ treści ustawy, przepis art. 827 k.c. był bowiem bezwzględnie obowiązujący i nie wskazywał na możliwość określenia zakresu kategorii osób, za które ubezpieczający ponosi odpowiedzialność przez strony umowy ubezpieczenia ${ }^{50}$. W żaden sposób nie wynikała zeń zaś intencja ustawodawcy pozostawienia kategorii osób, za które ubezpieczający ponosi odpowiedzialność jako pustej w razie braku sprecyzowania w OWU, jakie osoby do niej należą.

Sąd Najwyższy w wyroku z 22.04.2004 r., II CK 144/03 ${ }^{51}$, uznał postulat J. Łopuskiego za obowiązujący de lege lata kierunek wykładni. Sprawa dotyczyła tragicznej postaci pewnego szeregowego magazyniera, który, będąc na urlopie, ukrył się w sali magazynowej i gdy wszyscy opuścili budynek, ukradł pieniądze ze znajdującej się tam kasy pancernej,

47 M. Krajewski, Umowa ubezpieczenia. Art. 805-834 KC..., 2004, s. 248.

48 J. Łopuski, W sprawie wykładni art. $827 \$ 1$ k.c. i potrzeby nowego uregulowania umowy ubezpieczenia, PA 2002/2, s. 9.

49 M. Krajewski, Umowa ubezpieczenia. Art. 805-834 KC..., 2004, s. 248.

50 Tak przykładowo T. Kwieciński, J. Pokrzywniak, Glosa do wyroku SN z 22.04.2003 r., II CK 144/03, „Glosa” 2006/4.

51 LEX nr 103201, z glosami A. Szlęzaka, OSP 2004/12, poz. 159, E. Kowalewskiego, PA 2004/1, oraz T. Kwiecińskiego i J. Pokrzywniaka powołaną w poprzednim przypisie. 
a potem żeby zatrzeć ślady, podpalił magazyn. Po skazaniu wyrokiem karnym magazynier popełnił samobójstwo w więzieniu. W sprawie cywilnej przeciwko ubezpieczycielowi sądy dwóch instancji uznały, że zakład ubezpieczeń odpowiada za szkodę powstałą na skutek pożaru, ponieważ nie została ona wyrządzona przez magazyniera przy wykonywaniu powierzonych mu czynności. O ile samo rozstrzygnięcie wydawało się rozsądne, o tyle argumentacja odwołująca się do przesłanek $\mathrm{z}$ art. 430 k.c. była wątpliwa.

Sąd Najwyższy uchylił wyrok sądu apelacyjnego do ponownego rozpoznania. W uzasadnieniu SN, zapewne wbrew intencjom J. Łopuskiego, objął kategorią osób, za które ubezpieczający ponosi odpowiedzialność, osoby działające za ubezpieczającego, choćby w następstwie faktycznego delegowania na nie obowiązków wynikających z umowy ubezpieczenia. Pogląd ten został powtórzony w kolejnych orzeczeniach ${ }^{52}$ mimo krytycznego odzewu doktryny. Komentatorzy wskazywali, że stanowisko Sądu Najwyższego prowadzić może do poszerzenia kategorii osób, za które odpowiada ubezpieczający, nawet w porównaniu do poglądu tradycyjnego, omówionego wyżej jako pierwszy ${ }^{53}$.

Rozpoznając omawianą sprawę ponownie, Sąd Apelacyjny w Poznaniu stwierdził, że brak jest podstaw do ograniczania możliwości uznania czynności delegowania obowiązków z umowy ubezpieczenia tylko do takich pracowników, do których wyraźnych zadań, w myśl umowy o pracę, należy administrowanie majątkiem bądź ochrona mienia. Takie ograniczenie kręgu osób, których wina umyślna wywołuje skutek w postaci ustawowego wyłączenia odpowiedzialności zakładu ubezpieczeń, nie znajduje uzasadnienia w treści art. $827 \$ 1$ k.c. i ogólnych warunków ubezpieczenia mienia, będących integralną częścią umowy łączącej strony procesu. Zdaniem tego sądu również okoliczność, że pracownik nie działał zgodnie z umową o pracę i wszystkimi swoimi

${ }^{52}$ Wyrok SN z 13.10.2005 r., IV CK 181/05, LEX nr 186907, oraz wyrok SN z 16.01.2013 r., II CSK 202/12, LEX nr 1303227.

53 Poza wyżej powołanymi glosami zob. artykuł M. Orlickiego i M. Kępińskiego, O wykładni... 
obowiązkami, była niewystarczająca do zwolnienia się przez pracodawcę od odpowiedzialności za pracowników ${ }^{54}$.

Najwłaściwsze wydawało się stanowisko tych krytyków poglądu SN, którzy próbowali interpretować sformułowanie „osoby, za które ubezpieczający ponosi odpowiedzialność", zwracając uwagę na pojęcie wypadku ubezpieczeniowego jako zdarzenia przyszłego, niepewnego i niezależnego od woli ubezpieczającego, a także na faktyczną możliwość przeciwdziałania przez ubezpieczającego wyrządzeniu szkody przez określone osoby. W tym kontekście przytoczyć należy pogląd T. Kwiecińskiego i J. Pokrzywniaka, według których „za osoby, za które ubezpieczający ponosi odpowiedzialność należało uważać tylko takie osoby, których umyślne działanie lub zaniechanie wyrządzające szkodę nie ma z punktu widzenia ubezpieczającego cechy losowości” ${ }^{35}$.

$\mathrm{W}$ podobnym tonie wypowiedzieli się, przedstawiając nieco inną argumentację, M. Orlicki i M. Kępiński. Wskazywali oni, że przez osoby, za które ubezpieczający ponosi odpowiedzialność, rozumieć należało osoby, nad którymi ubezpieczający powinien sprawować swego rodzaju nadzór polegający na przeciwdziałaniu umyślnemu lub wynikającemu z rażącego niedbalstwa wyrządzeniu przez nie szkody. Zdaniem M. Orlickiego i M. Kępińskiego odpowiedzialność w rozumieniu art. 827 \$ 1 k.c. miała oznaczać powinność ubezpieczającego, polegającą na nadzorowaniu określonych osób. Ostatecznie jednak ostatni z powołanych autorów poparł pogląd, że w braku wyraźnych postanowień w OWU kategoria osób, za które ubezpieczający ponosi odpowiedzialność, była pusta ${ }^{56}$.

Przedstawiona dyskusja ma obecnie znaczenie historyczne, nie pozostaje jednak bez znaczenia dla interpretacji obowiązujących unormowań. W zasadzie wszyscy autorzy byli zgodni, że art. 827 k.c. wymaga korek-

54 Wyrok SA w Poznaniu z 28.06.2005 r., I ACa 1938/04, LEX nr 175162.

55 T. Kwieciński i J. Pokrzywniak w cytowanej wyżej glosie, s. 66. Zdaniem tych autorów, jeżeli do kategorii „osób, za które ubezpieczający ponosi odpowiedzialność” mają należeć osoby, których wina ma być traktowana jako własna wina samego ubezpieczającego, to krąg tych osób mogą tworzyć wyłącznie osoby z grona zarządzających przedsiębiorstwem osoby prawnej, nie zaś wszyscy podwładni i pracownicy.

56 M. Orlicki, M. Kępiński, O wykładni..., s. 7 i 10. 
ty, która została dokonana nowelizacją z 2007 r. Na gruncie obecnego brzmienia istotne są dwa pytania, po pierwsze, jakie osoby uznać należy za osoby, z którymi ubezpieczający pozostaje we wspólnym gospodarstwie domowym, oraz po drugie, na czym polegać mogą odmienne od regulacji ustawowej ustalenia stron. Pierwsza kwestia nigdy nie budziła wątpliwości. Komentatorzy byli i są zgodni, że więzy krwi nie mają znaczenia pierwszorzędnego, istotne jest natomiast faktyczne prowadzenie wspólnego gospodarstwa domowego. Nie wystarcza zatem wspólne zamieszkanie, niezbędne jest również istnienie więzi gospodarczej ${ }^{57}$.

Odnośnie do kwestii drugiej, postanowienia umowne ustalające, czyje działania należy uznać za równoważne w skutkach $\mathrm{z}$ winą ubezpieczającego, określa się mianem klauzuli reprezentantów. W literaturze nie ma precyzyjnych wypowiedzi dotyczących jej możliwego zakresu. Marcin Orlicki i Jakub Pokrzywniak wskazują, że na tle obecnej regulacji art. $827 \$ 3$ nie ma przeszkód, by umownie poszerzyć krąg osób, za których działania ubezpieczyciel nie odpowiada ${ }^{58}$. Pogląd ten aprobuje również M. Krajewski ${ }^{59}$.

Odmienne zdanie zdaje się prezentować M. Serwach, wskazując, że klauzula reprezentantów powinna obejmować wyłącznie osoby, których wina własna jest zrównana $z$ winą własną ubezpieczającego ${ }^{60}$. Powołana autorka wyraża obawę, że pogląd liberalny pozostawiający stronom zbyt dużą swobodę może doprowadzić do wypaczenia idei zmierzającej do zawężenia kręgu osób, za których działania ubezpieczyciel nie odpowiada, i stanowić będzie dużą pokusę dla ubezpieczycieli. Ogólne warunki mogą przecież precyzować, że ubezpieczyciel nie odpowiada przykładowo za szkody wyrządzone z winy umyślnej przez wszystkich pracowników ubezpieczającego. Przy takim ujęciu ubezpieczyciel nie odpowiadałby niezależnie od tego, czy mienie zostało powierzone pra-

57 M. Krajewski, Umowa ubezpieczenia. Art. 805-834 KC..., 2016, s. 614, H. Ciepła [w:] Kodeks..., t. 5, red. J. Gudowski, komentarz do art. 827, teza 6; Z. Gawlik [w:] Kodeks..., t. 3, red. A. Kidyba, komentarz do art. 827, teza 14, A. Chróścicki, Umowa..., s. 139.

58 M. Orlicki, J. Pokrzywniak, Umowa..., s. 121.

59 M. Krajewski, Umowa ubezpieczenia. Art. 805-834 KC..., 2016, s. 617.

60 M. Orlicki, J. Pokrzywniak, Umowa..., s. 121. 
cownikowi w ramach umowy o pracę oraz czy pracownik miał być za nie odpowiedzialny materialnie ${ }^{61}$.

W literaturze i orzecznictwie można spotkać jeszcze pogląd, który M. Serwach po rozważeniu zdaje się odrzucać. Autorka początkowo zastanawia się, czy wobec bezwzględnie obowiązującego charakteru art. $827 \$ 1$ k.c., który obecnie wyłącza jedynie odpowiedzialność ubezpieczyciela za szkody wywołane umyślnie przez ubezpieczającego, klauzule rozszerzające nieodpowiedzialność ubezpieczyciela na inne osoby mogą być w ogóle skuteczne. Opisany pogląd zdaje się podzielać J. Kondek. Podobne stanowisko pojawia się również w orzecznictwie, gdzie można odnaleźć judykaty wykluczające w zasadzie dopuszczalność klauzuli reprezentantów i ograniczające zastrzeżenie rozpoczynające art. $827 \$ 2$ k.c. do możliwości zmiany reguły wykluczającej odpowiedzialność ubezpieczyciela za szkody wyrządzone przez osoby pozostające $\mathrm{z}$ ubezpieczającym w gospodarstwie domowym wyłącznie na korzyść tego ostatniego ${ }^{62}$.

Sąd Najwyższy nie odniósł się wyraźnie do omawianej kwestii. Sąd Ochrony Konkurencji i Konsumentów w wyroku z 4.04.2017 r., XVII AmA 107/14 ${ }^{63}$, potwierdził niedozwolony charakter klauzuli zawartej w umowie generalnej ubezpieczenia zawieranego $\mathrm{z}$ organizatorami turystyki, która wyłączała odpowiedzialność ubezpieczyciela za szkody wyrządzone umyślnie lub powstałe wskutek niedbalstwa ubezpieczonego lub osób, za które ponosi on odpowiedzialność, lub członków jego rodziny. Zgodnie z uzasadnieniem wyroku modyfikacja ustawowego zakresu odpowiedzialności ubezpieczyciela możliwa jest jedynie na korzyść ubezpieczonego i może polegać tylko na objęciu odpowiedzialnością ubezpieczyciela działań ubezpieczonego i celowych działań osób przebywających z nim we wspólnym gospodarstwie domo-

${ }_{61}$ M. Serwach, Klauzula reprezentantów - blaski i cienie art. 827 k.c. sprzed i po nowelizacji, PA 2007/3, s. 37-38.

62 J. Kondek [w:] Kodeks..., t. 3B, red. K. Osajda, s. 1011. Przytaczany przez tego autora wyrok SN z 7.03.2008 r., III CSK 270/07, LEX nr 487542, nie może jednak stanowić przykładu, został bowiem wydany na gruncie stanu prawnego sprzed zmiany z 2007 r., a nadto Sąd Najwyższy skupił się na samej wykładni pojęcia rażącego niedbalstwa.

63 LEX nr 2282539. 
wym. Wyrok jest niewątpliwie słuszny, skoro kwestionowana klauzula wyłączała odpowiedzialność za jakiekolwiek niedbalstwo. Uzasadnienie zdaje się jednak wskazywać, że za niedozwolone uznano samo poszerzenie kręgu osób, za których działania nie odpowiada ubezpieczyciel, w porównaniu do zakresu wynikającego z art. $827 \S 3$ k.c.

Podobny wniosek płynie z uzasadnienia wyroku Sądu Apelacyjnego w Łodzi z 22.12.2013 r., I ACa 494/13 ${ }^{64}$, które jednak odnosiło się do ubezpieczenia odpowiedzialności cywilnej przewoźnika drogowego. Zgodnie z $\$ 5$ OWU pozwanego ubezpieczyciel był wolny od odpowiedzialności, jeżeli ubezpieczający lub osoba, za którą ubezpieczający ponosił odpowiedzialność, wyrządziła szkodę umyślnie. Za osoby, za które ubezpieczający ponosi odpowiedzialność, uważane były osoby, którym ubezpieczający powierza wykonanie przewozu lub za pomocą których przewóz wykonuje. Zdaniem SA wykreślenie z art. 827 k.c. wzmianki o osobach, za które ubezpieczający ponosi odpowiedzialność, świadczy o tym, że obecnie skutek w postaci wyłączenia odpowiedzialności ubezpieczyciela wywiera tylko własne umyślne działanie ubezpieczającego bądź ubezpieczonego. Działania zaś osób, za które ponosi on odpowiedzialność na mocy innych przepisów, są irrelewantne, chyba że zarazem są to osoby pozostające $z$ nim we wspólnym gospodarstwie domowym (z mocy art. $827 \$ 3$ k.c.).

W omawianym wyroku SA uznał za skuteczne uchylenie się ubezpieczyciela od odpowiedzialności za szkodę spowodowaną przez kierowcę, który przekroczył dopuszczalną prędkość o $10 \mathrm{~km}$ i zjechał z drogi. Sąd powołał się na rażąco niedbałe niedochowanie powinności z $\$ 17$ ust. 1 OWU, który zobowiązywał ubezpieczającego do przestrzegania przepisów mających na celu zapobieganie powstaniu szkody, w szczególności dotyczących bezpieczeństwa w ruchu drogowym. Wskazał również na art. $827 \$ 2$ k.c., który w ubezpieczeniu OC pozwala ustalić inne zasady odpowiedzialności ubezpieczyciela niż wynikające z $\$ 1$. Rozstrzygnięcie wydaje się wątpliwe, jednak jego ocena wykracza poza główny wątek rozważań.

64 LEX nr 1433807. 
Nieco bardziej instruktywny może być wyrok Sądu Okręgowego w Łodzi z 25.08.2016 r., X GC 571/1665. W sprawie chodziło o ubezpieczenie AC ciągnika siodłowego. Ogólne warunki zawierały wyłączenie odpowiedzialności ubezpieczyciela za szkody w odniesieniu do zdarzeń wywołanych rażącym niedbalstwem samego ubezpieczonego lub osoby uprawnionej do korzystania z pojazdu. Do szkody doszło na skutek zawadzenia podniesionej skrzyni rozładunkowej o belkę stropową. Sąd stwierdził, że kierowcy powoda nie można przypisać rażącego niedbalstwa, i powołał się na przytoczony wyżej wyrok Sądu Apelacyjnego w Łodzi. Jednocześnie wyraził pogląd, że powołana wyżej klauzula OWU pozwanego wyłączała jego odpowiedzialność w sposób dalej idący, niż wynika to z art. $827 \$ 1$ k.c. Stanowisko sądu w przedmiocie braku rażącego niedbalstwa po stronie kierowcy wydaje się trafne, jednakże pogląd co do nieważności powołanej klauzuli OWU AC jest wątpliwy. Zdumiewa w szczególności brak odniesienia się do treści art. 827 \$ 3 k.c., który zawiera regulację dotyczącą klauzuli reprezentantów.

Własne stanowisko w przedmiocie dopuszczalnego de lege lata zakresu klauzuli reprezentantów można sformułować w kilku punktach. Po pierwsze, nie powinno być wątpliwości co do tego, że rozpoczynające art. $827 \S 3$ k.c. zastrzeżenie „jeżeli nie umówiono się inaczej” umożliwia objęcie odpowiedzialnością ubezpieczyciela szkód wyrządzonym umyślnie przez wszystkie inne osoby niż ubezpieczający i ubezpieczony, włączając w to osoby, z którymi ubezpieczający i ubezpieczony pozostają we wspólnym gospodarstwie domowym. Wziąwszy pod uwagę, że OWU pisane są przez ubezpieczycieli w sposób dla nich maksymalnie korzystny oraz że w zakresie mienia prywatnego OWU rzadko mogą być negocjowane, możliwość taka, pomijając sytuacje wyjątkowe, nie będzie szeroko wykorzystywana w praktyce.

Po drugie, ustawowe wyłączenie dotyczące osób znajdujących się z ubezpieczającym lub z ubezpieczonym w gospodarstwie domowym odnosić się może przede wszystkim do ubezpieczeń dotyczących mienia prywatnego i jest pozbawione większego znaczenia, gdy chodzi o ubezpieczenia mienia przedsiębiorstw. Interpretacja przepisu łącząca go z art. 827 
$\$ 1$ k.c. i wychodząca od założenia, że ma on tzw. semiimperatywny charakter, wobec czego można go zmieniać jedynie na korzyść ubezpieczającego, uniemożliwia umowne wyłączenie odpowiedzialności za osoby inne niż pozostające z ubezpieczającym i ubezpieczonym we wspólnym gospodarstwie domowym, jako wyłączenie idące dalej niż ustawowe. Pamiętając o pierwszej uwadze, stwierdzić trzeba, że taka interpretacja pozbawiałaby zatem początkowe zastrzeżenie i klauzulę reprezentantów praktycznego znaczenia. Jeżeli zatem Sąd Ochrony Konkurencji i Konsumentów oraz cytowane wyżej sądy łódzkie miały na myśli taką interpretację, to ich stanowisko wydaje się błędne. Artykuł $827 \$ 3$ k.c. należy odczytywać jako odzwierciedlenie zgody ustawodawcy na dostosowanie przez strony brzmienia klauzuli reprezentantów do rodzaju konkretnego ubezpieczenia.

Po trzecie, $\mathrm{z}$ drugiej strony pogląd o zupełnie nieskrępowanej swobodzie ubezpieczyciela w kształtowaniu klauzuli reprezentantów rzeczywiście może prowadzić $\mathrm{w}$ praktyce do poszerzenia w porównaniu do stanu sprzed zmiany kręgu osób, za których działania ubezpieczyciel nie odpowiada, zamiast do zawężenia tego kręgu ${ }^{66}$. Na gruncie poprzedniego brzmienia przepisu niedopuszczalne wydawało się przynajmniej umowne wyłączenie odpowiedzialności za osoby, których nie dało się zakwalifikować do grupy osób, za które ubezpieczający ponosi odpowiedzialność. Obecnie nie sposób zakładać, że ubezpieczyciele powstrzymają się od korzystania z przyznanej im swobody w ukształtowaniu klauzuli reprezentantów, w szczególności poprzez wyłączenie odpowiedzialności za szkody wyrządzone umyślnie przez pracowników ubezpieczającego, niezależnie od przyjęcia przez tych pracowników odpowiedzialności za powierzone im mienie.

Marcin Orlicki i Jakub Pokrzywniak wyraźnie negują pogląd M. Serwach, że klauzula reprezentantów powinna obejmować wyłącznie osoby, których wina może być zrównana $\mathrm{z}$ winą ubezpieczającego. Swoje stanowisko uzasadniają rezygnacją przez ustawodawcę ze sformułowania „osoba, za którą ubezpieczający ponosi odpowiedzialność". W kontekście tego stanowiska jawi się pytanie, czy poza zwykłymi ograniczeniami,

${ }^{66}$ M. Serwach, Klauzula reprezentantów..., s. 36-37. 
którym podlegać muszą wyłączenia odpowiedzialności, by zachować moc, i które zostaną omówione dalej, cytowani autorzy widzą jakieś granice klauzuli reprezentantów. Wydaje się, że takie granice istnieć powinny. Obaw o możliwość rozszerzania zakresu klauzuli reprezentantów w sposób idący dalej, niż miało to miejsce przed zmianąa art. 827, i sprzeczny z intencjami ustawodawcy nie należy ignorować. Pojawia się jedynie pytanie, czy rzeczywiście wykaz osób, za które nie odpowiada ubezpieczyciel, może obejmować wyłącznie osoby, których wina może być zrównana $\mathrm{z}$ winą ubezpieczającego.

Przed zmianą przepisu uważano, że osoby, za które ubezpieczający ponosi odpowiedzialność, to właśnie osoby, których wina może być zrównana z winą ubezpieczającego. Poza powoływanymi już wypowiedziami J. Łopuskiego oraz M. Orlickiego i M. Kępińskiego warto przytoczyć pogląd E. Kowalewskiego, który powołując się na niemiecką doktrynę Reprasentantenhaftung, wskazywał, że osoba, za którą ubezpieczający ponosi odpowiedzialność, to osoba reprezentująca samego ubezpieczającego, a ściślej jego powinności w umowie ubezpieczenia w kontekście konkretnego umownego stosunku ubezpieczenia.

Podsumowując, wypada raz jeszcze wskazać, że wolą ustawodawcy, który w art. $827 \S 3$ wyłączył odpowiedzialność ubezpieczyciela za szkody spowodowane umyślnie przez osoby pozostające z ubezpieczającym we wspólnym gospodarstwie domowym, było umożliwienie stronom dostosowania brzmienia klauzuli reprezentantów do rodzaju i kształtu konkretnej umowy ubezpieczenia. Chodziło zatem nie o całkowitą swobodę, ale o możliwość zrównania skutków działań określonych osób ze skutkami działań osób pozostających we wspólnym gospodarstwie domowym, gdy wymaga tego konkretna umowa ubezpieczenia. Odwołując się do przypadków wynikających z wyżej przytoczonych wyroków, wątpliwa wydaje się zatem dopuszczalność wyłączenia odpowiedzialności w ubezpieczeniu ogniowym budynków przedsiębiorcy za działania wszystkich pracowników ubezpieczającego, niezależnie od ich rangi, zakresu obowiązków oraz okoliczności, czy powinni być akurat w pracy. Możliwe jest natomiast w ubezpieczeniu AC przewoźnika wyłączenie odpowiedzialności ubezpieczyciela za umyślne działania kierowców, którym powierzone zostają konkretne samochody, a także umyślne 
działania dalszych przewoźników, którym ubezpieczający w ramach prowadzonej przez siebie i przez nich działalności powierzył przewóz. Najogólniej powiedzieć można, że powinno chodzić o osoby, które ubezpieczający może oraz powinien kontrolować i których działania oraz zaniechania nie będą mieć z punktu ubezpieczającego cechy losowości.

Na koniec warto zwrócić uwagę na jeszcze jedną - czwartą kwestię. Doktryna i orzecznictwo nie zauważają, że obecne ukształtowanie art. 827 k.c. zdaje się wykluczać dopuszczalność wyłączenia odpowiedzialności ubezpieczającego za rażące niedbalstwo osób innych niż ubezpieczający i ubezpieczony. O rażącym niedbalstwie mowa jest bowiem wyłącznie w art. $827 \$ 1$ k.c., który odnosi się tylko do ubezpieczającego. Artykuł $827 \$ 3$ k.c. wyłącza natomiast odpowiedzialność ubezpieczyciela za szkody wyrządzone przez osoby pozostające z ubezpieczającym w gospodarstwie domowym umyślnie, ale nie wspomina o rażącym niedbalstwie. $Z$ kolei art. $827 \$ 4$ k.c. każe wszystkie powyższe reguły odnosić do ubezpieczonego w ubezpieczeniu na cudzy rachunek. Przedstawiona gramatyczna wykładnia przepisu zdaje się jednak uniemożliwiać sankcjonowanie na mocy ogólnych warunków umów naruszenia powinności prewencyjnych przez jakiekolwiek inne osoby niż ubezpieczający i ubezpieczony, wobec czego trudno ją pogodzić z potrzebami obrotu. Kwestia możliwości uchylenia się przez ubezpieczyciela od odpowiedzialności z uwagi na naruszenie umownych obowiązków prewencyjnych zostanie poruszona w toku dalszych wywodów. Na obecnym etapie wypada wskazać, że dopuszczalne musi być również uchylenie się od odpowiedzialności przez ubezpieczyciela za szkody wywołane rażąco niedbałym działaniem niektórych osób innych niż ubezpieczający czy ubezpieczony.

W kontekście powyższych uwag obecne brzmienie przepisu także pozostawia wiele do życzenia. Z jednej strony usunięto ustawową możliwość uchylenie się od odpowiedzialności przez ubezpieczyciela za umyślne wyrządzenie szkody przez osoby, za które ubezpieczający ponosi odpowiedzialność, wskazując na niepewność prawa oraz zbyt szeroki zakres wyłączenia. $Z$ drugiej strony nie wyjaśniono jednak, jaki obecnie zakres może mieć umowna modyfikacja klauzuli reprezentantów, co prowadzić może do zastrzegania przez ubezpieczycieli wyłączeń prowa- 
dzących do rozszerzenia kategorii osób, których działania nie stanowią wypadku ubezpieczeniowego w porównaniu ze stanem prawnym sprzed zmiany. Skutki takiej redakcji przepisu odzwierciedlają rozbieżne poglądy co do możliwego kształtu klauzuli reprezentantów. Ponadto przepis zdaje się wskazywać, że dopuszczalne jest wyłączenie odpowiedzialności wyłącznie za winę umyślną, nie zaś za rażące niedbalstwo osób innych niż ubezpieczający i ubezpieczony, podczas gdy wykładnia funkcjonalna i potrzeby praktyki wykluczają taką interpretację.

\subsection{Umowne wyłączenia odpowiedzialności ubezpieczyciela}

Jak wielokrotnie podkreślano, zasadniczym elementem stosunku prawnego ubezpieczenia jest ryzyko wystąpienia szkody na skutek określonego w umowie zdarzenia. Ryzyko to określono nieprecyzyjnie jako negatyw interesu ubezpieczeniowego, czyli przedmiotu ubezpieczenia. Brak precyzji wskazanego określenia wynika stąd, że interes ubezpieczeniowy może być zagrożony w związku z szeregiem różnych zdarzeń, spośród których nie wszystkie muszą być objęte ubezpieczeniem. Kwestia była w pewnym zakresie przedmiotem rozważań w podrozdziale dotyczącym wypadku ubezpieczeniowego jako przesłanki odpowiedzialności ubezpieczyciela. Sprowadzając rzecz do najprostszych przykładów, wypada wskazać, że dom może być objęty ubezpieczeniem od ognia oraz od trzęsienia ziemi, samochód zaś może być objęty ubezpieczeniem od kradzieży oraz od wypadków drogowych.

Omawiane zagadnienie ilustruje art. 295 k.m., zgodnie z którym polisa ubezpieczenia morskiego, poza interesem ubezpieczeniowym, winna określać m.in. oznaczenie niebezpieczeństw objętych umową, czyli objętych umową ryzyk albo wypadków ubezpieczeniowych. Oczywiście pojęcie ryzyka jest zdarzeniem wieloznacznym i nawet w żargonie ubezpieczeniowym ma różne konotacje ${ }^{67}$. Przepisy Kodeksu cywilnego o umowie ubezpieczenia w ogóle nie posługują się tym pojęciem. W każdym razie w nauce ubezpieczeń bardzo często używa się pojęcia „ryzyko”

67 Zob. E. Kowalewski, Wprowadzenie do teorii ryzyka..., s. 11 i n. 
w znaczeniu zbliżonym do wypadku objętego ubezpieczeniem, w tym znaczeniu można mówić o ryzyku ognia, kradzieży czy ryzyku kolizji drogowej. Równie często mówi się o ryzyku, czyli prawdopodobieństwie zajścia tych zdarzeń.

W umowach ubezpieczenia, poza ogólnym pozytywnym określeniem wypadku ubezpieczeniowego, bardzo często używa się szeregu zastrzeżeń albo wyłączeń wskazujących wprost, jakie konkretnie sytuacje nie są objęte odpowiedzialnością ubezpieczyciela. Kwestię tę dobrze widać w świetle regulacji ustawy o działalności ubezpieczeniowej i reasekuracyjnej. Według art. 16 u.d.u.r. ogólne warunki ubezpieczenia określać mają m.in. rodzaj ubezpieczenia i jego przedmiot oraz zakres odpowiedzialności zakładu ubezpieczeń. Artykuł 17 u.d.u.r. stanowi natomiast, że ogólne warunki ubezpieczenia mają zawierać informacje o postanowieniach zawierających ograniczenia oraz wyłączenia odpowiedzialności zakładu ubezpieczeń uprawniających do odmowy wypłaty odszkodowania i innych świadczeń lub ich obniżenia.

Formułując zastrzeżenia lub wyłączenia odpowiedzialności, ubezpieczyciel ogranicza przejmowane przez siebie ryzyko zajścia określonych zdarzeń, działając tym samym w swoim interesie. Z drugiej jednak strony działanie takie jest sprzeczne $\mathrm{z}$ interesem ubezpieczającego, wykluczając w określonych sytuacjach prawo do odszkodowania. Oczywiście ograniczenia i wyłączenia odpowiedzialności ubezpieczyciela powinny wpływać na koszt ochrony ubezpieczeniowej. W wielu sytuacjach ubezpieczającemu opłaca się zrezygnować z ochrony ubezpieczeniowej w konkretnych sytuacjach, jeżeli prawdopodobieństwo ich zajścia wydaje mu się stosunkowo niewielkie w porównaniu do kosztu objęcia ich ochroną ubezpieczeniową.

Tak rozumiane wyłączenia odpowiedzialności ubezpieczyciela należy odróżnić od ograniczeń wysokości odszkodowania ubezpieczeniowego, które w ubezpieczeniu mienia przybiera postać odszkodowania umownego, tzn. odszkodowania, którego zakres, poza samą zasadą odszkodowania, wyznacza treść konkretnej umowy ubezpieczenia. Ograniczenia odszkodowania ubezpieczeniowego zostały omówione w poprzednich rozdziałach. Jak wskazano, mają one związek przede wszystkim z teorią 
lokalizacji szkody oraz relacją między wartością ubezpieczenia i sumą ubezpieczenia. Innymi opisanymi uprzednio sposobami ograniczenia wysokości odszkodowania są tzw. techniczne ograniczenia odpowiedzialności ubezpieczyciela w postaci franszyzy integralnej lub redukcyjnej oraz udziału własnego.

W niniejszym rozdziale pracy przedmiotem zainteresowania są zatem takie postanowienia, które ograniczają zakres wypadku ubezpieczeniowego i tym samym zakres ryzyka przejmowanego przez ubezpieczyciela. Podstawowym zagadnieniem, poza odróżnieniem wyłączeń czy też ograniczeń odpowiedzialności ubezpieczyciela od ograniczeń odszkodowania ubezpieczeniowego, jest odróżnienie tych pierwszych od dodatkowych powinności prewencyjnych, które mogą być nakładane na ubezpieczającego lub ubezpieczonego na mocy ogólnych warunków ubezpieczenia. Inne kwestie dotyczą zakresu swobody ubezpieczyciela w formułowaniu wyłączeń odpowiedzialności, a także sposobu interpretacji postanowień OWU zmierzających do ograniczenia zakresu wypadku ubezpieczeniowego. Zagadnienia te będą przedmiotem dalszych rozważań w wyżej wskazanej kolejności.

\subsubsection{Umowne wyłączenia odpowiedzialności a powinności prewencyjne}

Pogląd o konieczności odróżnienia wyłączeń odpowiedzialności ubezpieczyciela od obowiązków prewencyjnych jako pierwszy wyraził A. Wąsiewicz, powołując się na dorobek doktryny niemieckiej. Autor ten stawiał pytanie, jaką rolę w kontekście odpowiedzialności gwarancyjnej ubezpieczyciela mogą odgrywać zawarte w OWU postanowienia zobowiązujące ubezpieczającego (ubezpieczonego) do przestrzegania określonych obowiązków o charakterze ogólnym wynikających np. z przepisów o ochronie przeciwpożarowej, bezpieczeństwie i higienie pracy lub przepisów wyznaczających sposób eksploatacji ubezpieczonych urządzeń technicznych.

Według A. Wąsiewicza rola takich postanowień zależy od tego, czy określają one zakres ochrony ubezpieczeniowej, czy też nakładają na 
ubezpieczającego określone powinności z ujemnym dla niego skutkiem. W pierwszym przypadku chodzi o uregulowania, z których wynika, że w razie niespełnienia określonych w OWU wymagań (w tym także obowiązków wynikających np. ze wskazanych w tych warunkach przepisów) nie zachodzi w ogóle wypadek ubezpieczeniowy. Właśnie treść OWU decyduje bowiem o tym, jakie zdarzenia łącznie z ich uwarunkowaniami zaliczane są do wypadków ubezpieczeniowych.

W drugim przypadku chodzi o postanowienia nakładające na ubezpieczającego określone obowiązki umieszczone w ramach systematyki OWU w regulacjach dotyczących obowiązków ubezpieczającego, łączące $\mathrm{z}$ ich niedopełnieniem $\mathrm{w}$ razie zajścia wypadku ubezpieczeniowego niekorzystne dla ubezpieczającego skutki w postaci odmowy wypłaty odszkodowania lub zmniejszenia jego wartości. Uchybienie takim obowiązkom może wywierać wskazane niekorzystne dla ubezpieczającego skutki wyłącznie w sytuacji, gdy było powodem powstania lub zmniejszenia szkody oraz nosi cechy winy umyślnej lub rażącego niedbalstwa. Postanowienia tego rodzaju podlegają bowiem ocenie na podstawie treści art. 827 k.c. $^{68}$

Rozróżnienie zaproponowane przez A. Wąsiewicza poparł m.in. S. Byczko, sugerując wzorem orzecznictwa niemieckiego oparcie kryteriów na prostej zasadzie: jeżeli treść OWU dotyczy zachowania ubezpieczającego, zawsze wprowadza obowiązek dodatkowy; natomiast gdy dotyczy obiektywnej okoliczności niebędącej zachowaniem człowieka, formułuje klauzulę opisującą ryzyko. Autor ten, przywołując przykład prowadzenia pojazdu w stanie nietrzeźwości, zwrócił jednak uwagę, że w praktyce nie zawsze łatwo będzie zaliczyć pewne postanowienia OWU do odpowiedniej kategorii ${ }^{69}$.

68 A. Wąsiewicz, Przyczynienie..., s. 83-84.

69 Sz. Byczko, Obowiązki dodatkowe ubezpieczajacego w umowie ubezpieczenia mienia - niepublikowana praca doktorska obroniona na Uniwersytecie Łódzkim w 2003 r., s. 254, Naruszenie powinności ocenia przez pryzmat art. 827 k.c. również K. Malinowska, Konsekwencje niedochowania powinności ubezpieczeniowych w świetle art. 827 k.c., PA 2013, nr 3. 
Zwolennikiem opisywanego rozróżnienia jest również J.M. Kondek. Wskazuje on, że czym innym jest uzależnienie powstania odpowiedzialności od stopnia winy osoby ubezpieczonej, a czym innym precyzyjne określenie wypadku ubezpieczeniowego. W drugiej sytuacji w ogóle nie chodzi o winę ubezpieczającego, lecz o to, że określone zdarzenie (np. kradzież niezamkniętego samochodu) nie jest przewidzianym w umowie wypadkiem ubezpieczeniowym. Według cytowanego autora, o ile nakładanie w umowie ubezpieczenia dodatkowych obowiązków, których niedochowanie wyłączać będzie odpowiedzialność, jest w myśl art. 827 w zw. z art. 807 k.c. niedopuszczalne, o tyle mieścić się będzie w zakresie swobody kształtowania treści umowy ubezpieczenia możliwość dowolnego kształtowania okoliczności stanowiących wypadek ubezpieczeniowy. Przeciwny pogląd prowadziłby do wniosku, że ubezpieczyciel w zasadzie odpowiadałby za każdy przypadek uszczerbku w interesie objętym ubezpieczeniem (a zatem że wypadkiem ubezpieczeniowym byłaby każda szkoda wyrządzona osobie ubezpieczonej w jej ubezpieczonym interesie), co jest zbyt radykalne ${ }^{70}$.

Przychylając się przed kilku laty do poglądu A. Wąsiewicza, zaproponowałem szereg kryteriów uściślających rozróżnienie ${ }^{71}$. Po pierwsze, jeżeli treść OWU nakłada na ubezpieczającego obowiązek określonego zachowania, to wprowadza obowiązek prewencyjny, jeżeli natomiast wskazuje na obiektywną okoliczność niebędącą zachowaniem człowieka, formułuje ograniczenie odpowiedzialności. Decydujące znaczenie należy przy tym przypisać nie użytym sformułowaniom oraz systematyce OWU, ale kryteriom obiektywnym (kryterium tradycyjne). Po drugie, treść OWU może wyłączać odpowiedzialność ubezpieczyciela w sytuacjach sprzecznych z porządkiem prawnym i niepoddających się subiektywnym ocenom (np.: brak uprawnień do prowadzenia pojazdów, prowadzenie pojazdu w stanie nietrzeźwości lub pod wpływem środka odurzającego). Po trzecie, klauzule o treści wątpliwej należy wykładać zgodnie z zasadą in dubio contra proferentem, jako nakładające na ubezpieczającego powinności, których uchybienie powinno być oceniane

70 J.M. Kondek [w:] Kodeks cywilny. Komentarz, t. 2, Zobowiązania, red. K. Osajda, Warszawa 2013, s. 1689.

71 B. Kucharski, Powinność... 
przez pryzmat art. 827 k.c. Po czwarte, wyłączenia odpowiedzialności nie mogą wykraczać poza granice swobody umów określone w art. $353^{1}$ k.c., tj. nie mogą być sprzeczne z prawem, właściwościami i celem stosunku ubezpieczenia ani zasadami współżycia społecznego. W szczególności nie mogą przekreślać ochronnej funkcji ubezpieczenia.

Pogląd, zgodnie z którym uchybienie powinności ubezpieczeniowej może wyłączać odpowiedzialność ubezpieczyciela niezależnie od stopnia winy, prowadzi do wniosku, że ubezpieczający, który swoim zachowaniem doprowadził do szkody, byłby w lepszej sytuacji niż ubezpieczający, który nie dochowując określonych obowiązków, ułatwił wyrządzenie szkody komuś innemu. Ten pierwszy zgodnie z art. 827 k.c. otrzymałby bowiem odszkodowanie, choćby jego uchybienia miały cechy rażącego niedbalstwa, jeżeli tylko przemawiałyby za tym względy słuszności. Ten drugi natomiast byłby pozbawiony odszkodowania, nawet jeżeli zawinił w lekkim stopniu.

Ponadto ubezpieczający, który nie dochował powinności umownej, byłby traktowany gorzej niż ubezpieczający, który nie dopełnił powinności ustawowej. Trudno zrozumieć, dlaczego naruszenie powinności umownej miałoby skutkować wyłączeniem odpowiedzialności niezależnie od stopnia winy w sytuacji, gdy naruszenie powinności ustawowej wywołuje taki skutek jedynie w razie winy umyślnej lub rażącego niedbalstwa. Dotyczy to nie tylko obowiązku niewyrządzania szkody własnym działaniem (art. 827 k.c.), ale również obowiązku ratowania mienia przed szkodą, którego naruszenie sankcjonowane jest jedynie w razie kwalifikowanego stopnia winy (art. 826 k.c.).

Przydatność rozróżnienia między wyłączeniami odpowiedzialności a powinnościami umownymi konsekwentnie neguje M. Krajewski. Jego zdaniem podział zaproponowany przez A. Wąsiewicza opiera się na przypadkowym kryterium, jakim są użyte sformułowania lub też systematyka OWU. Różnica między postanowieniami pierwszego i drugiego typu istnieje jedynie na płaszczyźnie werbalnej i nie może stanowić 
podstawy dla różnej oceny prawnej ${ }^{72}$. Zdaniem M. Krajewskiego zasada swobody umów oraz kompetencja stron umowy ubezpieczenia do dowolnego określenia w OWU zakresu ochrony ubezpieczeniowej prowadzą do wniosku, że postanowienia nakładające na ubezpieczającego określone obowiązki prewencyjne z zagrożeniem utraty prawa do świadczenia w razie ich niedopełnienia są w pełni skuteczne, niezależnie od tego, czy niewykonanie tych obowiązków było przejawem winy umyślnej lub rażącego niedbalstwa, co zresztą znajduje potwierdzenie w orzecznictwie ${ }^{73}$.

Zaproponowane przeze mnie kryteria uściślające M. Krajewski określił jako arbitralne i nieprecyzyjne. Jego zdaniem nietrafny jest również argument, zgodnie z którym niekonsekwencją byłoby uznanie, że w przypadku powinności niepowodowania wypadku nałożonej na ubezpieczającego przez art. 827 k.c. ubezpieczyciela zwalnia jedynie wina umyślna i rażące niedbalstwo, a w przypadku powinności umownej miałoby to następować niezależnie od stopnia winy. Artykuł 827 k.c. ma bowiem znaczenie bezwzględnie obowiązujące jedynie w tym znaczeniu, że wyklucza postanowienia przewidujące bezwarunkowy obowiązek wypłaty odszkodowania w razie winy umyślnej lub rażącego niedbalstwa ubezpieczającego lub innych osób, za które ponosi on odpowiedzialność. Norma, zgodnie z którą lżejsze stopnie winy nie zwalniają ubezpieczyciela $\mathrm{z}$ odpowiedzialności, została wyprowadzona $\mathrm{z}$ art. 827 k.c. w drodze rozumowania a contrario i nie jest tą samą normą, która została bezpośrednio wyrażona w przepisie ${ }^{74}$.

Orzecznictwo Sądu Najwyższego dotyczące omawianych zagadnień jest chwiejne, co zapewne wiąże się z niedostrzeganiem przez SN rozróżnienia między wyłączeniami odpowiedzialności a dodatkowymi obowiązkami prewencyjnymi. Sąd Najwyższy przyjmuje, że ubezpieczyciel ma prawo nakładać na ubezpieczającego konkretne nieprzewidziane przez

72 Można wskazać, że w przykładzie kradzieży niezamkniętego samochodu traktowanym przez M. Kondka jako wyłączenie odpowiedzialności OWU w istocie nakładają na ubezpieczającego obowiązek zamknięcia samochodu przed jego opuszczeniem.

73 M. Krajewski, Umowa ubezpieczenia. Art. 805-834 KC..., 2004, s. 253-254.

74 M. Krajewski, Umowa ubezpieczenia. Art. 805-834 KC..., 2016, s. 622-623. 
kodeks obowiązki prewencyjne ${ }^{75}$. Problem sprowadza się do tego, czy uchybienie owym umownym obowiązkom prewencyjnym może być sankcjonowane niezależnie od winy kwalifikowanej ubezpieczającego oraz związku przyczynowego między uchybieniem a wypadkiem ubezpieczeniowym i szkodą. Wyroki dotyczą przede wszystkim przewidywanego powszechnie przez OWU AC polskich ubezpieczycieli obowiązku zabezpieczenia z należytą starannością kluczyków i dokumentów samochodowych poza pojazdem ${ }^{76}$.

Sąd Najwyższy często przyjmuje, że art. 827 k.c. w ogóle nie odnosi się do uchybienia obowiązkom prewencyjnym. Według SN przewidziane w art. 827 k.c. przesłanki wyłączenia odpowiedzialności ubezpieczyciela oraz zwolnienia go z obowiązku wypłaty odszkodowania odnoszą się tylko do takich sytuacji, w których sprawcą szkody był wyłącznie ubezpieczający albo osoba, z którą ubezpieczający pozostaje we wspólnym gospodarstwie domowym lub za którą ponosi odpowiedzialność, nie dotyczą natomiast sytuacji, gdy ubezpieczający, nie przestrzegając obowiązków prewencyjnych, jedynie przyczynił się do zajścia szkody wywołanej przez określone zdarzenie lub osobę trzecią ${ }^{77}$.

Argument ten prowadzi nierzadko do rozstrzygnięć kontrowersyjnych. Przykładowo w wyroku z 8.10.2004 r., V CK 70/0478, Sąd Najwyższy zaakceptował rozstrzygnięcie sądu drugiej instancji odmawiające prawa do odszkodowania ubezpieczającemu, który umieścił kluczyki samochodowe i dokumenty w teczce postawionej za biurkiem w swoim

75 Wyrok SN z 17.06.1983 r., I CR 189/83.

76 Co do tej kwestii, zob. również A. Daszewski, Problemy konsumentów usług ubezpieczeniowych z kluczykami do pojazdów w umowach ubezpieczenia autocasco, RU 2009/1, s. 97 i n.

77 Wyrok SN z 30.11.2000 r., I CKN 970/98; wyrok SN z 20.05.2004 r., II CK 341/03; wyrok SN z 8.08.2003 r., V CK 169/02, OSP 2004/10, poz. 121, z aprobującą glosą M. Krajewskiego; wyrok SN z 26.05.2006 r., V CSK 109/06, LEX nr 200945; wyrok SN z 14.07.2006 r., II CSK 60/06, LEX nr 450174; wyrok SN z 4.12.2008 r., I CNP 72/08, LEX nr 484692. Pośrednio wniosek ten wynika również z wyroków SN: z 16.07.2004 r., I CK 11/04, OSP 2005/6, poz. 78, z aprobującą glosą M. Krajewskiego; z 7.07.2005 r., V CK 870/04, LEX nr 152461; z 20.07.2000 r., V CKN 88/00, LEX 52586; z 6.05.1998 r., II CKN 731/97, LEX nr 50738; z 20.05.2015 r., I CSK 479/14, LEX nr 1747345.

78 LEX nr 146334. 
pokoju biurowym, a następnie, nie zamykając pokoju, wyszedł z niego, udając się na dwie minuty do sąsiedniego pomieszczenia. Teren zakładu pracy ochraniany był przez firmę ochroniarską i pracownicy ochrony mieli między innymi obowiązek sprawdzenia tożsamości osób wchodzących na teren zakładu oraz wpisywania ich do rejestru. Według SN pozostawienie przez ubezpieczającego teczki z dokumentami i kluczykami samochodu w niezamkniętym na czas jego opuszczenia pokoju biurowym, do którego był możliwy dostęp w sposób niezauważony, nie oznacza wymaganego przez OWU AC zachowania należytej staranności w zabezpieczeniu kluczyków i dokumentów poza pojazdem.

Z kolei w wyroku z 8.08.2008 r., V CSK 87/0879, Sąd Najwyższy uchylił do ponownego rozpoznania rozstrzygnięcie sądu apelacyjnego przyznające odszkodowanie za kradzież pojazdu, którego kluczyki i dokumenty wcześniej skradziono z kieszeni spodenek pozostawionych na plaży na czas kąpieli. W stanie faktycznym sprawy powód, jego syn, przyjaciółka oraz jej siostra na zmianę pilnowali rzeczy pozostawionych na plaży, choć mogło się zdarzyć, że wszyscy przebywali w jeziorze. W takich razach powód starał się obserwować pozostawione rzeczy z odległości 10-20 metrów. W dniu kradzieży kluczyków i dokumentów powód próbował zgłosić zdarzenie policji, jednak pobliski komisariat był zamknięty. W nocy na dzień następny skradziono samochód zaparkowany na terenie ośrodka wypoczynkowego z uruchomionymi fabrycznymi zabezpieczeniami. W tej sprawie zarzut naruszenia art. 827 k.c. nie był przedmiotem rozważań SN. Podstawę rozstrzygnięcia stanowiły uwagi dotyczące wykładni postanowień OWU nakładających na ubezpieczającego obowiązek zabezpieczenia kluczyków i dokumentów poza pojazdem z należytą starannością oraz powszechnych zwyczajów. Według SN zwyczaje takie powinny być zgodne z zasadami współżycia społecznego i nie mogą być contra legem.

Można odnieść wrażenie, że w sprawach tego rodzaju wszystko zależy od składu. Równolegle bowiem rozwija się druga linia orzecznicza, zgodnie z którą uchybienie obowiązkom prewencyjnym winno być oceniane w świetle art. 827 k.c. W orzeczeniach z tego cyklu Sąd Najwyższy często

79 OSNC-ZD 2009/2, poz. 57. 
szerzej nie uzasadnia kwestii stosowania art. 827 k.c., traktując ją jako pewną oczywistośćc ${ }^{80}$, albo posługuje się argumentem, według którego postanowienia OWU AC uzależniające wypłatę odszkodowania od określonych zachowań ubezpieczającego, bez potrzeby dokonywania oceny ich zaniechania pod kątem rażącego niedbalstwa, wykraczają poza granice dopuszczalnej swobody umów jako bardziej restryktywne dla ubezpieczającego aniżeli regulacja wynikająca $\mathrm{z}$ imperatywnej normy art. $827 \$ 1$ k.c. $^{81}$

Niekiedy również Sąd Najwyższy podkreśla, że wykładnia postanowień umowy ubezpieczenia ze względu na funkcję ochronną tej umowy musi uwzględniać jako zasadę odpowiedzialność zakładu ubezpieczeń przy jednoczesnym ograniczonym rozumieniu przesłanek odpowiedzialność tę wyłączających. Ma to szczególne znaczenie dla interpretacji postanowień nieostrych, wprowadzających kryteria ocenne, do jakich należy rozważany obowiązek zabezpieczenia kluczyków „,z należytą starannością?. W wypadku zamieszczenia takich postanowień wykładnia umowy nie może dążyć do zaostrzenia wymagań stawianych ubezpieczającemu i ograniczania obowiązków ubezpieczyciela ${ }^{82}$.

Przechodząc do konkluzji, należy wskazać, że pogląd, wedle którego art. 827 k.c. nie znajduje zastosowania do naruszenia umownych powinności ubezpieczeniowych, wydaje się być niezgodny z powszechnie przyjmowanym w doktrynie i orzecznictwie stanowiskiem o uregulowaniu w tym przepisie kwestii przyczynienia się ubezpieczającego do powstania szkody. Jak wskazano wcześniej, art. 827 k.c. wyklucza stosowanie art. 362 k.c., ponieważ istota ubezpieczenia polega na tym, że chroni ono ubezpieczającego nie tylko przed skutkami zdarzeń od niego niezależnych, ale również przed skutkami jego działań lub zaniechań sprowadzających szkodę bądź wpływających na jej rozmiary. Możliwość uwzględnienia przyczynienia na ogólnych zasadach, podobnie jak nie-

${ }^{80}$ Wyrok SN z 11.12.2007 r., II CSK 375/07, LEX nr 492168; wyrok SN z 30.01.2013 r., V CSK 75/12; wyrok SN z 13.01.2016 r., II CSK 37/15, LEX nr 1974074.

81 Wyrok SN z 29.01.2009 r., V CSK 291/08, z glosą P. Hyrlika, s. 68 i n.

82 Wyrok SN z 10.01.2014 r., I CSK 155/13, LEX nr 1523347. Podobnie wyrok z 23.01.2015 r., V CSK 217/14, LEX nr 1650306. Podobnie wyrok SN z 11.12.2007 r., II CSK 375/07. 
ograniczona swoboda w nakładaniu na ubezpieczającego obowiązków prewencyjnych, których naruszenie wywoływałoby niekorzystne skutki niezależnie od stopnia winy, prowadzi do unicestwienia podstawowych cech ubezpieczenia w postaci jego funkcji ochronnej i kompensacyjnej ${ }^{83}$.

Twierdzenie, że ubezpieczyciel może nakładać na ubezpieczającego obowiązki prewencyjne, których uchybienie skutkuje zwolnieniem ubezpieczyciela $\mathrm{z}$ odpowiedzialności niezależnie od stopnia winy, jest sprzeczne $\mathrm{z}$ istotą ubezpieczenia jako umowy, która ma chronić ubezpieczającego również przed skutkami jego własnych zaniedbań. Jaki jest sens ubezpieczenia, które z jednej strony chronić ma ubezpieczającego przed jego własnym niedbalstwem, z drugiej zaś wyłącza odpowiedzialność w razie niedbalstwa? Niezwykle trafnie kwestię tę ujęto w orzecznictwie angielskim. Sprawa Woolfar \& Rimmer Ltd v. Moyle dotyczyła ubezpieczenia pracodawcy w zakresie odpowiedzialności cywilnej. Jeden z pracowników stracił rękę, która dostała się w tryby maszyny. Ubezpieczyciel próbował uniknąć odpowiedzialności, powołując się na niedbalstwo pracodawcy, który nie zapewnił odpowiednich barier ochronnych. Sędzia Goddard stwierdził, że zgoda na takie postawienie sprawy przez ubezpieczyciela byłaby równoznaczna ze zgodą na zaaprobowanie obietnicy: „Ubezpieczamy twoją odpowiedzialność za niedbalstwo pod warunkiem, że nie będziesz niedbały" ${ }^{84}$.

Logicznie rzecz ujmując, na gruncie prawa polskiego nie można bez popadania w sprzeczność jednocześnie twierdzić, że:

1) zagadnienie zawinionego wyrządzenia szkody przez ubezpieczającego jest uregulowane kompleksowo w art. 827 k.c., który wyklucza odpowiedzialność ubezpieczyciela wyłącznie za winę umyślną i rażące niedbalstwo ubezpieczającego, wobec czego niedopuszczalne jest powoływanie się ubezpieczyciela na przyczynienie się ubezpieczającego do powstania szkody niemające cech winy umyślnej ani rażącego niedbalstwa oraz

83 Por. wcześniejsze uwagi dotyczące niestosowania w ubezpieczeniach mienia przepisów o przyczynieniu poszkodowanego B. Kucharski, Powinność..., s. 56-58.

84 Za M. Clarke, Policies and Perceptions of Insurance Law..., s. 166. 
2) norma, zgodnie z którą lżejsze stopnie winy nie zwalniają ubezpieczyciela $\mathrm{z}$ odpowiedzialności, została wyprowadzona $\mathrm{z}$ art. 827 k.c. w drodze rozumowania a contrario i nie jest tą samą normą, która została bezpośrednio wyrażona w przepisie (pogląd M. Krajewskiego) lub też

3) art. 827 k.c. nie dotyczy sytuacji, gdy szkodę wyrządziła osoba trzecia lub siły przyrody, a ubezpieczający jedynie się do niej przyczynił (pogląd SN).

Jak wskazywano, trudno uzasadnić tezę, że ubezpieczający, który naruszając umowną powinność prewencyjną swoim działaniem, jedynie ułatwił wyrządzenie szkody przez osobę trzecią lub zaistnienie szkody na skutek działania sił przyrody, miałby być traktowany gorzej niż ubezpieczający, który swoim działaniem bezpośrednio sprowadził szkodę (art. $827 \$ 1$ k.c.), albo gorzej niż ubezpieczający, który poprzez niedochowanie ustawowego obowiązku ratowania mienia doprowadził do rozszerzenia zakresu szkody już powstałej (art. $826 \$ 1$ i 3 k.c.), czy też ubezpieczający, który nie zabezpieczył roszczeń regresowych ubezpieczyciela, co w ogóle nie jest sankcjonowane (art. $826 \$ 2$ i 3 k.c.).

Powołane argumenty prowadzą również do wniosku, że naruszenie powinności prewencyjnej może prowadzić do wyłączenia odpowiedzialności ubezpieczyciela jedynie wtedy, gdy można je zakwalifikować co najmniej jako rażące niedbalstwo stanowiące przyczynienie się ubezpieczającego do powstania szkody. Wina kwalifikowana ubezpieczającego musi zatem dotyczyć nie tylko naruszenia powinności jako takiej, ale być nakierowana na spowodowanie wypadku ${ }^{85}$. Wziąwszy pod uwagę, że nakładanie dodatkowych powinności jest dopuszczalne, tylko gdy ma na celu ograniczenie ryzyka ponoszonego przez ubezpieczyciela, trudno zresztą wyobrazić sobie sytuację, w której umyślne lub rażąco niedbałe naruszenie powinności nie miałoby związku z przewidywaniem lub powinnością przewidywania zajścia wypadku ubezpieczeniowego. Omawiana kwestia łączy się z zagadnieniem związku przyczynowego między

85 Wagę tego rozróżnienia podkreśla M. Krajewski. Zob. M. Krajewski, Umowa ubezpieczenia. Art. 805-834 KC..., 2016, s. 621. 
niedochowaniem powinności a zajściem wypadku ubezpieczeniowego, pozwalając przejść do omówienia tego zagadnienia.

Pogląd M. Krajewskiego o możliwości wprowadzania powinności, których naruszenie nie musi być oceniane przez pryzmat art. 827 k.c., prowadzi tego autora do wniosku, że wyłączenie odpowiedzialności ubezpieczyciela możliwe jest nie tylko wtedy, gdy naruszenie powinności nie było skutkiem winy umyślnej i rażącego niedbalstwa, ale również wtedy, gdy zaistnienie wypadku nie miało związku z niedochowaniem powinności. Według M. Krajewskiego wszystko zależy od postanowień umowy lub OWU, których treść jedynie w razie wątpliwości należy interpretować na korzyść istnienia związku przyczynowego ${ }^{86}$.

Podobne tezy prowadzą zawsze do rozstrzygnięć surowych dla ubezpieczających. Niektóre z nich można uzasadniać interesem publicznym i względami prewencyjno-wychowawczymi. Dotyczy to przede wszystkim wyłączeń odpowiedzialności ubezpieczyciela w ubezpieczeniu AC za szkody spowodowane przez posiadacza pojazdu lub kierowcę w stanie nietrzeźwości, ewentualnie przez posiadacza lub kierowcę nieposiadającego wymaganych prawem polskim uprawnień do prowadzenia pojazdu. W wielu sytuacjach jednak postanowienia tego rodzaju prowadzić będą do rezultatów trudnych do zaakceptowania, nie tylko biorąc pod uwagę wzgląd na funkcję ochronną ubezpieczenia, ale również interes społeczny. Przykładowo można postawić pytanie, dlaczego ubezpieczający, który nie zabezpieczył należycie poza pojazdem kluczyków i dokumentów samochodowych, miałby tracić prawo do odszkodowania w sytuacji, gdy inny kierowca uderzył w jego stojący przy drodze samochód, ewentualnie gdy ktoś wybił szybę lub urwał w samochodzie lusterko, albo dlaczego ubezpieczający, który wbrew postanowieniom umownym nie włączył systemu antynapadowego, miałby tracić prawo do odszkodowania za szkody wywołane przez trzęsienie ziemi, obsunięcie gruntu lub powódź.

86 M. Krajewski, Umowa ubezpieczenia. Art. 805-834 KC..., 2016, s. 626-627. 
Kwestia związku przyczynowego została dostrzeżona w orzecznictwie. W wyrokach z 20.10.1977 r., IV CR 381/777, oraz z 29.05.1979 r., II CR $114 / 79^{88}$, stwierdzono, że wyłączenie odpowiedzialności za skutki wypadków spowodowanych w stanie nietrzeźwości działa bez względu na istnienie związku przyczynowego między stanem nietrzeźwości a wypadkiem. W pierwszej sprawie samochód prowadzony przez pijanego kierowcę podczas pokonywania zakrętu przewrócił się i dachował na skutek awarii układu kierowniczego. W drugiej dwóch pijanych mężczyzn jechało Fiatem 125 p. Mężczyzna zajmujący siedzenie pasażera złapał za kierownicę, powodując zderzenie z przydrożnym drzewem.

Obydwa wyroki zapadły na gruncie rozporządzenia Rady Ministrów w sprawie obowiązkowych ubezpieczeń komunikacyjnych z 1974 r. ${ }^{89}$ Rozporządzenie, o którym mowa, w odniesieniu do ubezpieczenia nieszczęśliwych wypadków wprowadzało rozróżnienie między sytuacją, gdy stan nietrzeźwości miał wpływ na powstanie wypadku, oraz sytuacją, w której takiego wpływu nie było, wyłączając odpowiedzialność ubezpieczyciela jedynie w pierwszej z nich. Gdy chodzi o ubezpieczenie AC, takiego rozróżnienia nie było, wobec czego SN motywował swe rozstrzygnięcia wykładnią gramatyczną, logiczną i systemową. Rozstrzygnięcie w pierwszej sprawie zaaprobowali w glosach J. Ławrynowicz oraz A. Wąsiewicz i T. Kwieciński. Glosatorzy zwracali uwagę, że choć sformułowanie „szkody spowodowane” mogłoby przemawiać za koniecznością wystąpienia związku przyczynowego, to wykładnia systemowa oraz względy prewencyjno-represyjne przemawiają za stanowiskiem $\mathrm{SN}^{90}$.

87 Wyrok z 20.10.1977 r., IV CR 381/77, z glosami J. Ławrynowicza oraz W. Kwiecińskiego i A. Wąsiewicza, OSPiKA 1979/6, poz. 105.

${ }^{88}$ Wyrok z 29.05.1979 r., II CR 114/79, OSNCP 1980/1-2, poz. 24, z glosą W. Marka, NP 1981/2, s. 126.

89 Rozporządzenie Rady Ministrów z 28.11.1974 r. w sprawie obowiązkowych ubezpieczeń komunikacyjnych (Dz.U. Nr 46, poz. 274 ze zm.).

90 Zob. w szczególności A. Wąsiewicz i T. Kwieciński w cytowanej glosie na s. 266 i 267. Glosa W. Marka jest natomiast glosą krytyczną. Co ciekawe, dla uzasadnienia swojego poglądu W. Marek powołuje się na A. Wąsiewicza, nie dostrzegając aprobującej glosy tego autora do pierwszego z powołanych wyroków. 
Jeżeli chodzi o szkody powstałe podczas prowadzenia pojazdu przez posiadacza lub kierowcę nieposiadającego uprawnień do prowadzenia pojazdu, podobne stanowisko Sąd Najwyższy zajął w wyroku z 29.11.1999 r., III CKN 475/98 ${ }^{91}$. W sprawie tej ubezpieczony prowadził samochód Ford Transit $\mathrm{z}$ doczepioną lawetą, posiadając prawo jazdy kat. A i B, a szkoda powstała na skutek zerwania wahacza i doszłoby do niej również, gdyby samochód Ford poruszał się bez przyczepy. Pozwany ubezpieczyciel odmówił wypłaty odszkodowania, wskazując, że ubezpieczony nie posiadał uprawnień do kierowania zestawem pojazdów.

Uzasadniając to ostatnie rozstrzygnięcie, Sąd Najwyższy powołał przytoczone wyżej wcześniejsze wyroki oraz trzy argumenty. Po pierwsze, pozwany ubezpieczyciel w $\$ 5$ OWU wyłączył swoją odpowiedzialność za szkody powstałe podczas prowadzenia pojazdu w stanie nietrzeźwości, po spożyciu alkoholu lub narkotyków albo bez wymaganych prawem uprawnień i nie ma żadnego uzasadniania stanowisko sprowadzające się do wybiórczej oceny wymienionych okoliczności. Po drugie, OWU pozwanego w sposób zróżnicowany określały związek przyczynowy między okolicznością, która wyłącza odpowiedzialność ubezpieczyciela, a szkodą. Wymóg związku przyczynowego znajdował wyraz w użyciu formuły „spowodowane” w odniesieniu do szkód wywołanych umyślnie, działaniami wojennymi lub rozruchami. Tymczasem w $\$ 5$ mowa była o szkodach powstałych podczas prowadzenia pojazdu bez wymaganych uprawnień. Po trzecie, o jednakowym traktowaniu wszystkich przesłanek wyłączających odpowiedzialność wymienionych w $₫ 5$ OWU pozwanego przemawiać miały względy prewencji ogólnej.

W nowszym orzecznictwie Sąd Najwyższy zdaje się odchodzić od powyższego stanowiska. W wyroku z 12.09.2000 r., II CKN 1120/9892, stwierdzono, że naruszenie przepisów przeciwpożarowych może skutkować wyłączeniem odpowiedzialności ubezpieczyciela jedynie, gdy pozostaje w związku przyczynowym z powstałą szkodą. W stanie faktycznym sprawy ubezpieczający naprawiał bezpieczniki przez tzw. watowanie ich drutem, co mogło mieć wpływ na powstanie pożaru, jednak w konkret-

\footnotetext{
91 OSNC 2000/5, poz. 103.

92 LEX nr 50883.
} 
nej sytuacji biegły taki związek wykluczył. Sąd Najwyższy stwierdził, że ubezpieczyciel ma prawo wprowadzać w OWU klauzule prewencyjne wyłączające jego odpowiedzialność bez względu na istnienie związku przyczynowego, takie wyłączenia muszą mieć charakter wyjątkowy i powinny być sformułowane w sposób precyzyjny, wykluczający dowolność ocen, działają bowiem niejako mechanicznie. Obowiązek przestrzegania przepisów przeciwpożarowych miał jednak zdaniem SN charakter zbyt ogólny, by odrywać go od zasady przyczynowości. Obiter dictum SN wyraził przy tym bardzo wątpliwy pogląd, że charakter działającego obiektywnie wyłączenia odpowiedzialności mogłaby spełniać formuła OWU, wedle której ubezpieczający powinien zawiadomić ubezpieczyciela o pożarze „niezwłocznie, nie później jednak niż w ciągu 24 godzin od powstania szkody".

Sąd Najwyższy w wyroku z 7.05.2009 r., IV CSK 16/09, zajął stanowisko pośrednie, uznając za skuteczne wyłączenie odpowiedzialności ubezpieczyciela za szkody w budynku wyłączonym z eksploatacji oraz przyjmując, że obowiązek eksploatowania budynku oraz zabezpieczenia go przed dostępem osób trzecich należał do grupy powinności prewencyjnych, w związku z czym do zastosowania sankcji w postaci wyłączenia odpowiedzialności ubezpieczyciela w razie niedopełnienia omawianej powinności wystarczało ustalenie, że niedopełnienie powinności zwiększało ryzyko wypadku ubezpieczeniowego w postaci pożaru.

Stanowisko o konieczności istnienia związku przyczynowego między naruszeniem powinności określonych w OWU AC a wypadkiem ubezpieczeniowym pojawiło się również w orzecznictwie Sądu Ochrony Konkurencji i Konsumentów. Przykładowo pod nr 1315 do prowadzonego przez Prezesa Urzędu Konkurencji i Konsumentów rejestru klauzul niedozwolonych wpisano klauzulę, na mocy której „Warta nie odpowiada za szkody (...) zaistniałe w sytuacji, gdy poszkodowany był pod wpływem alkoholu, narkotyków lub innych środków odurzających. Zdaniem SOKiK zakwestionowane postanowienie mogło doprowadzić do odmowy wypłaty odszkodowania w razie zajścia zdarzenia, bez względu na istnienie związku przyczynowego pomiędzy spożyciem wskazanych substancji, a zaistniałą szkodą. Dlatego zakwestionowaną 
klauzulę uznano za sprzeczną z dobrymi obyczajami i rażąco naruszająco interes konsumentów"93.

Wyżej wymienione wyłączenie nie odnosiło się do stanu kierującego pojazdem mechanicznym, ale do stanu poszkodowanego. Klauzulę, którą ubezpieczyciel wyłączał swą odpowiedzialność za szkody w pojeździe prowadzonym przez osobę znajdującą się w chwili wypadku w stanie nietrzeźwości, w stanie wskazującym na spożycie alkoholu, pod wpływem narkotyków lub środków psychotropowych, wpisano jednak również do rejestru pod nr 2008. Zdaniem SOKiK sam fakt, że powyższe unormowanie miało pełnić funkcję prewencyjną, nie stanowi wystarczającego uzasadnienia do uchylenia się ubezpieczającego od obowiązku naprawienia szkody, jeżeli pozostaje ona w całkowitym oderwaniu od zachowania kierującego pojazdem ${ }^{94}$.

Z podobnych względów pod nr 1358 do rejestru wpisano klauzulę, według której: „Zakres ochrony ubezpieczeniowej nie obejmuje szkód powstałych wskutek pozostawienia pojazdu bez nadzoru lub zapewnienia dostatecznego zabezpieczenia podczas postoju pojazdu (zgodnie z instrukcją stanowiącą integralną część niniejszych OWU)". W uzasadnieniu SOKiK zważył, że zakład ubezpieczeniowy ma prawo do określenia katalogu obowiązków, których musi przestrzegać podmiot podlegający ochronie ubezpieczeniowej, jak również prawo do określenia sankcji na wypadek niewywiązywania się z tych obowiązków. Jednakże zastosowanie tak surowej sankcji, jak odmowa wypłaty odszkodowania czy też zmniejszenie jego wysokości, każdorazowo warunkowane być musi istnieniem związku przyczynowo-skutkowego pomiędzy niedopełnieniem obowiązku a zaistnieniem szkody ${ }^{95}$.

Podobne rozstrzygnięcia SOKiK zapadły wobec klauzuli przewidującej wyłączenie odpowiedzialności ubezpieczyciela za szkody powstałe wskutek kradzieży radia lub radioodtwarzacza z odejmowanym panelem czołowym, gdy ubezpieczający nie może przedstawić ubezpieczycielowi

\footnotetext{
93 Wyrok SOKiK z 11.10.2007 r., XVII AmC 68/06, MSiG 2008/43, poz. 2772.

94 Wyrok SA w Warszawie z 9.02.2010 r., VI ACa 782/09, LEX nr 844686.

95 Wyrok SOKiK z 30.01.2007 r., XVII AmC 30/06, LEX nr 1724302.
} 
tego panelu, w której ubezpieczyciel nie uzależniał odmowy wypłaty odszkodowania od wystąpienia związku przyczynowego między brakiem możliwości dostarczenia panelu i dokonaną kradzieżą ${ }^{96}$ oraz wobec klauzuli wyłączającej odpowiedzialność za szkody powstałe w czasie ruchu pojazdu, gdy pojazd nie był dopuszczony do ruchu, a w przypadku pojazdów podlegających rejestracji - gdy w chwili zaistnienia szkody pojazd nie był zarejestrowany lub nie posiadał ważnego badania technicznego. Zdaniem SOKiK wyłączenie byłoby uzasadnione, gdyby zaniedbanie stanu technicznego pozostawało w związku przyczynowym z powstaniem szkody lub zwiększeniem jej rozmiarów ${ }^{97}$.

Przytoczone wyżej przykłady z orzecznictwa dodatkowo przemawiają w moim przekonaniu za celowością rozróżnienia między nakładaniem dodatkowych obowiązków umownych, których niedochowanie może wyłączać odpowiedzialność ubezpieczyciela wyłącznie w razie winy umyślnej lub rażącego niedbalstwa ubezpieczającego i w razie wystąpienia związku przyczynowego między niedochowaniem powinności a wypadkiem oraz z drugiej strony formułowaniem klauzul wyłączających ryzyko, które mogą dowolnie kształtować zakres wypadku ubezpieczeniowego. Prezentowany pogląd wydaje się stanowić rozsądny kompromis między swobodą wyznaczania przez ubezpieczyciela granic przejmowanego ryzyka ubezpieczeniowego oraz funkcją ochronną ubezpieczenia, która nakazuje baczyć na interes ubezpieczających ${ }^{98}$. Argumenty krytyczne M. Krajewskiego wobec sformułowanych wcześniej kryteriów rozróżnienia zmuszają jednak, by powrócić do kwestii tychże kryteriów. Przed ich sformułowaniem warto przyjrzeć się, jak zagadnienie przedstawia się w obcych porządkach prawnych.

Niemiecka VVG z 2006 r. stanowi w art. 28, że w razie niedochowania dodatkowego obowiązku przez ubezpieczającego względem ubezpieczyciela przed zajściem wypadku ubezpieczeniowego ubezpieczyciel może rozwiązać umowę bez wypowiedzenia w ciągu miesiąca od naruszenia

96 Klauzula nr 2009, wyrok SA w Warszawie z 9.02.2010 r., VI ACa 782/09.

97 Klauzula nr 2560, wyrok SOKiK z 7.04.2011 r., XVII AmC 1509/10, MSiG 2012/64, poz. 4267.

98 Por. J. Kondek [w:] Kodeks..., t. 2, red. K. Osajda, 2013, s. 1689. 
obowiązku, jeżeli uchybienie było umyślne lub rażąco niedbałe. Jeżeli umowa stanowi, że ubezpieczyciel zwolniony jest $\mathrm{z}$ odpowiedzialności w razie naruszenia dodatkowych obowiązków, ubezpieczyciel jest zwolniony, o ile naruszenie było umyślne. W wypadku rażącego niedbalstwa ubezpieczyciel może zmniejszyć świadczenie należne ubezpieczającemu stosownie do stopnia jego winy. Ciężar dowodu, że naruszenie obowiązku nie było skutkiem rażącego niedbalstwa, spoczywa na ubezpieczającym. Niezależnie od powyższej regulacji, ubezpieczyciel odpowiada w braku związku przyczynowego między naruszeniem obowiązku a zajściem wypadku ubezpieczeniowego lub zakresem szkody. Brak związku przyczynowego nie jest przeszkodą dla zwolnienia ubezpieczyciela z odpowiedzialności tylko wtedy, gdy naruszenie było umyślne.

Jak już wskazywano, rozróżnienie między dodatkowymi obowiązkami prewencyjnymi a wyłączeniem odpowiedzialności, które może być skuteczne niezależnie od związku przyczynowego i winy, jest w prawie niemieckim stosowane i opiera się na okolicznościach obiektywnych. Według orzecznictwa Federalnego Trybunału Sprawiedliwości decydujące znaczenie mają nie użyte sformułowania i systematyka ogólnych warunków, ale ogólny sens klauzuli. Jeżeli nakłada ona na ubezpieczającego obowiązek określonego działania lub zaniechania, interpretuje się ją jako obowiązek prewencyjny. Jeżeli natomiast klauzula wyklucza pewne zdarzenie spod zakresu ochrony ubezpieczeniowej, interpretuje się ją jako wyłączenie odpowiedzialności. Sytuacje, w których ubezpieczyciel próbuje wyłączyć odpowiedzialność w okolicznościach zależnych w istocie od sposobu zachowania ubezpieczającego, określa się mianem ukrytych powinności ${ }^{99}$.

Manfred Wandt zwraca uwagę, że z jednej strony regulacji dotyczącej powinności nie można próbować obchodzić, starając się przekształcać powinności w wyłączenia ryzyka. Z drugiej strony ubezpieczyciel powinien mieć możliwość sprecyzowania ryzyka nieobjętego umową także wtedy, gdy ma ono związek ze sferą postępowania ubezpieczającego. Opisana dwoistość tłumaczy, dlaczego dotąd nie udało się sprecyzować

99 M. Wandt, Versicherungsrecht, s. 235-236. P. Schimikowski, Versicherungsvertragsrecht, s. 134 . 
jasnych kryteriów odróżnienia, a orzecznictwo bywa rozbieżne. Według tego autora klauzulę należy interpretować jako powinność, ilekroć zachowanie ubezpieczającego wysuwa się na pierwszy plan lub jest tak samo istotne jak obiektywne okoliczności (np.: usytuowanie lub stan ubezpieczonej rzeczy). Jeżeli natomiast ochrona ubezpieczeniowa jest z góry zagwarantowana jedynie w pewnym zakresie i nie może być uchylona przez nieostrożne zachowanie ubezpieczającego, w grę wchodzi opis ryzyka (wyłączenie odpowiedzialności). Dodatkowo wobec kłopotów dotyczących odróżnienia M. Wandt wskazuje, że niezmiernie istotny przy interpretowaniu określonych klauzul winien być wzgląd na uzasadnione oczekiwania ubezpieczającego ${ }^{100}$.

Podobnie wypowiada się P. Schimikowski. Podawane przez tego autora przykłady z orzecznictwa wskazują na interpretowanie wszelkich wątpliwych postanowień na niekorzyść ubezpieczyciela jako powinności. Sądy niemieckie przyjmowały między innymi, że powinność została ukryta w klauzuli wyłączającej odpowiedzialność za kosztowności pozostawione w samochodzie znajdującym się bez nadzoru, w klauzuli wyłączającej odpowiedzialność za szkody wynikającego ze złego stanu technicznego pojazdu, w klauzuli wyłączającej odpowiedzialność za bagaż nienależycie opakowany albo niedokładnie zamknięty, jak również w klauzuli wyłączającej odpowiedzialność w ubezpieczeniu OC za szkody powstałe podczas pilotowania samolotu przez osobę nieposiadającą wymaganych uprawnień lub dokumentów potwierdzających umiejętności pilotażu ${ }^{101}$.

Autorzy niemieccy wskazują, że reformując niemieckie prawo w zakresie powinności ubezpieczeniowych przez uchwalenie nowej ustawy o umowie ubezpieczenia z 2007 r., ustawodawca niemiecki celowo nie odniósł się do kwestii omawianego odróżnienia. O ile jednak na gruncie art. 6 poprzedniej ustawy o umowie ubezpieczenia, według communis opinio, ukryte powinności traktować należało po prostu jako powinności i oceniać skutki ich naruszenia przez pryzmat winy i związku przyczynowego, o tyle na gruncie nowej ustawy dopuszczalność tego rodzaju praktyki jest wątpliwa. Klauzule OWU winy podlegają interpretacji

100 M. Wandt, Versicherungsrecht, s. 237.

101 P. Schimikowski, Versicherungsvertragsrecht, s. 135. 
zgodnie z regułami BGB dotyczącymi wzorców umownych. Wszystkie klauzule, w których ubezpieczyciel w istocie wyłącza odpowiedzialność w okolicznościach uzależnionych od określonego działania lub zaniechania ze strony ubezpieczającego bez względu na kwalifikowaną winę lub związek przyczynowy, należy uznać za sprzeczne z art. 28 nowej VVG i przez to nieważne. Semiimperatywny charakter tego przepisu sprawia więc ostatecznie, że rezultaty ukrywania powinności pod postacią klauzul opisujących ryzyko są dla ubezpieczycieli znacznie surowsze niż na gruncie VVG z 1908 r. $^{102}$

W prawie francuskim według art. L113-1 Code des assurances, z zastrzeżeniem wyraźnych i precyzyjnych zastrzeżeń w polisie ubezpieczeniowej, ubezpieczyciel odpowiada za szkody spowodowane nieprzewidzianymi zdarzeniami stanowiącymi skutek winy ubezpieczającego. Jednakże ubezpieczyciel nie odpowiada za szkody będące skutkiem umyślnych bezprawnych działań ubezpieczającego lub jego oszustwa. Jednocześnie, zgodnie z art. L113-11 Code des assurances, wszelkie postanowienia przewidujące utratę prawa do świadczenia ubezpieczeniowego w razie uchybienia obowiązującym przepisom lub regulacjom są nieważne, chyba że uchybienie stanowi przestępstwo lub umyślne wykroczenie.

W praktyce skuteczność wyłączenia zależy od kwalifikacji określonych w OWU okoliczności działania lub zaniechanie jako przesłanki ochrony ubezpieczeniowej albo jako klauzuli zwalniającej ubezpieczyciela z odpowiedzialności. Niewypełnienie przesłanki ochrony ubezpieczeniowej powoduje permanentny wzrost ryzyka ubezpieczeniowego. Przykładowo niezainstalowanie systemu alarmowego powoduje wzrost ryzyka kradzieży i skutkuje niezależnie od związku przyczynowego między uchybieniem a konkretną szkodą oraz winą ubezpieczającego. W odniesieniu do klauzul zwalniających $\mathrm{z}$ odpowiedzialności wymaga się związku przyczynowego oraz winy. Jak widać, inaczej niż w prawie niemieckim, klauzule wyłączające odpowiedzialność stanowią postać opisu ryzyka mniej restryktywną dla ubezpieczającego. Wziąwszy pod uwagę dotkliwość traktowania określonych klauzul jako przesłanek

102 M. Wandt, Versicherungsrecht, s. 250-251; P. Schimikowski, Versicherungsvertragsrecht, s. 135-136. 
ochrony ubezpieczeniowej, w orzecznictwie zaznacza się tendencja do interpretacji wszystkich postanowień jako wyłączeń odpowiedzialności, co skutkuje wymaganiem związku przyczynowego lub winy ubezpieczającego, przy czym warunek winy zdaje się obejmować wszystkie jej $\operatorname{postaci}^{103}$.

W prawie angielskim, podobnie jak we francuskim, decydujące znaczenie ma kwalifikacja określonego postanowienia jako przesłanki ochrony ubezpieczeniowej (warranty) bądź też jako zwykłego wyłączenia odpowiedzialności. Malcolm Clarke zwraca uwagę, że odróżnienie w wielu przypadkach może rodzić problemy, jednak warranties co do zasady dotyczą zdarzeń powodujących permanentny wzrost ryzyka ubezpieczeniowego, podczas gdy wyłączenia odpowiedzialności zdarzeń zwiększających ryzyko jedynie czasowo ${ }^{104}$. Naruszenie warranties skutkować może nie tylko zwolnieniem z odpowiedzialności, ale zakończeniem stosunku ubezpieczenia, i to niezależnie od związku przyczynowego oraz winy ubezpieczającego. Wyłączenie odpowiedzialności wstrzymuje natomiast ochronę ubezpieczeniową w ściśle określonych sytuacjach, działając przy tym zależnie od związku przyczynowego oraz stopnia winy ubezpieczającego. Zmiany dokonane przez Insurance Act 2015 zmierzają do rezygnacji z powyższego rozróżnienia. Zamiast zwykłego testu przyczynowości wprowadza się również zasadę, że ubezpieczyciel nie zwolni się z odpowiedzialności, jeżeli ubezpieczający wykaże, że naruszenie obowiązku w okolicznościach sprawy nie zwiększało prawdopodobieństwa zajścia wypadku, który miał miejsce ${ }^{105}$.

W prawie angielskim dużo zależy od rodzaju ubezpieczenia, sformułowania klauzuli oraz okoliczności konkretnego przypadku. Przykładowo, by uniezależnić działanie klauzuli od związku przyczynowego, ubezpieczyciele starają się wyłączać odpowiedzialność za wypadki, które

103 Y. Lambert-Faivre, L. Leveneur, Droit..., s. 336.

104 M. Clarke, The Law..., s. 637.

105 Zob. section 10 i 11 Insurance Act 2015. Zmiany dotyczące przekształcenia tzw. warranties $\mathrm{w}$ suspensive conditions stanowią efekt rozstrzygnięć $\mathrm{w}$ takich sprawach jak: Kler Knitwear Ltd v. Lombard General Insurance Co Ltd, [2000] Lloyd's Law Rep 47, oraz Sugar Hut Group Ltd \& Others v. Great Lakes Reinsurance (UK) PPlc \& Others, [2010] EWHC 2636, [2011] Lloyd's Rep I.R. 198, QBD. Zob. J. Birds, Birds'..., s. 176-177. 
wydarzyły się, gdy ubezpieczający był w stanie odurzenia, zamiast za wypadki wywołane stanem odurzenia, co niekiedy prowadzi do absurdalnych konsekwencji. Malcolm Clarke podaje przykład sprawy Kennedy v. Smith, w której pełnomocnik ubezpieczyciela argumentował, że wyłączenie działa w odniesieniu do wypadku, który wydarzył się w Szkocji, gdy samochód prowadziła trzeźwa żona ubezpieczającego, natomiast sam ubezpieczający w tym czasie raczył się drinkami na plaży w Hiszpanii ${ }^{106}$.

W odniesieniu do klauzul zobowiązujących ubezpieczającego do przedsiębrania rozsądnych środków zabezpieczenia mienia leading case stanowi omówiona wcześniej sprawa Sofi v. Prudential Assurance Co Ltd ${ }^{107}$ dotycząca kradzieży biżuterii z samochodu pozostawionego na przydrożnym parkingu. Wyrok okazał się korzystny dla ubezpieczającego, ponieważ w okolicznościach sprawy nie można było mu przypisać rażącego niedbalstwa przy naruszeniu obowiązku.

Inny przykład przemawiający za argumentem, że naruszenie powinności zwolni ubezpieczyciela jedynie, gdy ciężar winy ubezpieczającego jest odpowiednio wysoki, stanowi dotycząca wprawdzie ubezpieczenia na życie, ale instruktywna sprawa Morley v. Insurance Friendly Ins ${ }^{108}$. Ubezpieczyciel zakazywał ubezpieczającemu dobrowolnego narażania się na niepotrzebne niebezpieczeństwo. Ubezpieczający wypiwszy kilka piw, wskoczył na zderzak samochodu prowadzonego przez narzeczoną, która nie mogąc się nań doczekać, zaczęła powoli odjeżdżać spod jego domu. Niestety narzeczona przyśpieszyła, ubezpieczający spadł i się zabił, a ubezpieczyciel odmówił wypłaty świadczenia. Uzasadniając wyrok na niekorzyść ubezpieczyciela, sąd uznał, że ubezpieczający zachował się wysoce nierozsądnie, nie mógł jednak przewidzieć, że jego narzeczona będzie nierozsądna w stopniu niepomiernie większym.

Redaktorzy Principles of European Insurance Contract Law podkreślają znaczenie odróżniania między klauzulami zwalniającymi z odpowie-

\footnotetext{
106 M. Clarke, The Law..., s. 600.

107 [1993] 2 Lloyd's Rep 559.

108 Morley v. United Friendly Insurance plc [1993] 3 All ER, 47.
} 
dzialności ubezpieczyciela w wypadku nałożenia na ubezpieczającego określonych obowiązków oraz wyłączeniami odpowiedzialności. Wskazują, że pierwsze działają zależnie od winy i związku przyczynowego, drugie co do zasady nie wymagają ani związku przyczynowego, ani winy. Zwracają jednak uwagę, że obydwie techniki w praktyce prowadzą do podobnych rezultatów i pozwalają ubezpieczycielowi w całości albo części uniknąć odpowiedzialności ${ }^{109}$.

Z przytoczonych względów proponowany kształt art. 4:103 PEICL stanowi, że postanowienie, według którego niedochowanie przez ubezpieczającego środków prewencyjnych w całości lub w części zwalnia ubezpieczyciela z odpowiedzialności, jest skuteczne, jeżeli szkoda została spowodowana przez niedochowanie powinności umyślnie albo rażąco niedbale (recklessly ${ }^{110}$ ze świadomością, że szkoda prawdopodobnie nastąpi. Z zastrzeżeniem postanowień przewidujących wyraźnie zmniejszenie odszkodowania ubezpieczeniowego stosownie do stopnia winy, ubezpieczający jest uprawniony do odszkodowania także za szkody wywołane niedbałym niedochowaniem powinności.

Innymi słowy, naruszenie umownych powinności prewencyjnych wyłącza odpowiedzialność ubezpieczyciela jedynie, gdy było przyczyną szkody i ubezpieczającemu można zarzucić winę umyślną bądź rażące niedbalstwo. Jeżeli ubezpieczającemu można zarzucić jedynie zwykłe niedbalstwo, zachowuje on prawo do całego odszkodowania ubezpieczeniowego, chyba że strony wyraźnie przewidziały możliwość zmniejszenia odszkodowania odpowiednio do stopnia winy ubezpieczającego i wpływu naruszenia powinności na powstanie szkody. Jeżeli zatem stopień zawinienia jest niewielki, nie ma zwolnienia, choćby w części, jeżeli natomiast jest bliski rażącemu niedbalstwu, zwolnienie może być niemal całkowite ${ }^{111}$. Warto przy tym zwrócić uwagę, że stopień

109 Principles..., s. 177.

110 Jak wcześniej wskazano, na określenie rażącego niedbalstwa używa się w prawie angielskim również sformułowania gross negligence. Recklessness stanowiłoby zatem właściwie kwalifikowaną postać niedbalstwa bliską niedbalstwu w stopniu rażącym. Granice między recklessness i gross negligence nie wydają się jednak jasne. Por. Oxford Dictionary of Law, red. E. Martin, Oxford 1994 - hasła jw., s. 179 oraz 328 i 329.

111 Principles..., s. 177. 
winy ubezpieczającego odnoszony jest nie do naruszenia powinności samej w sobie, ale do wpływu, jaki naruszenie powinności może mieć na zajście wypadku.

Powyższe uwagi prawnoporównawcze ukazują, jak bardzo skomplikowana jest omawiana kwestia. Wydaje się, że można mówić nie tyle o precyzyjnych kryteriach odróżnienia powinności prewencyjnych i klauzul wyłączających odpowiedzialność, ile raczej o regułach interpretacyjnych ułatwiających takie odróżnienie. Ostatecznie można zaproponować następujące reguły:

1) jeżeli klauzula nakłada na ubezpieczającego dodatkowe obowiązki, stanowi powinność prewencyjną, jeżeli natomiast wyłącza określone zdarzenia spod ochrony przejmowanej przez ubezpieczyciela, stanowi wyłączenie ryzyka,

2) jeżeli określone zabezpieczenia lub środki prewencyjne stanowią przesłankę udzielenia ochrony ubezpieczeniowej, a ich zaniechanie permanentnie zwiększa ryzyko zajścia wypadku, to kreuje wyłączenie odpowiedzialności, jeżeli natomiast można ich wymagać jedynie czasowo w określonych okolicznościach, chodzi o powinność prewencyjną,

3) jeżeli określone zachowanie lub zaniechanie jest zabronione przez prawo powszechne, stanowiąc przestępstwo lub wykroczenie, klauzulę należy interpretować jako wyłączenie odpowiedzialności,

4) wątpliwości do treści klauzuli należy zgodnie z zasadą in dubio contra proferentem interpretować na korzyść ubezpieczającego, przyjmując, że nakłada ona na niego określone powinności,

5) uwzględniać należy kryteria interpretacji oświadczeń woli z art. 65 k.c., tzn. okoliczności konkretnej sprawy, zasady współżycia społecznego, ustalone zwyczaje, przede wszystkim zaś gospodarczy cel umowy. Jako ostateczne remedium zaproponować można test zdrowego rozsądku przy uwzględnieniu rodzaju ubezpieczenia i ubezpieczanego ryzyka oraz uzasadnionych oczekiwań ubezpieczającego.

Pierwsze kryterium zostało wcześniej omówione. Przy określeniu, czy chodzi o zachowanie, czy obiektywne zdarzenie, należy brać pod uwagę 
samo sformułowanie klauzuli i systematykę OWU. Decydujące znaczenie powinny mieć jednak okoliczności obiektywne. Jak już wskazano, nie powinno budzić wątpliwości, że zabezpieczenie z należytą starannością kluczyków i dokumentów poza pojazdem jest obowiązkiem prewencyjnym, natomiast wskazanie, że ochrona nie obejmuje kradzieży określonego rodzaju albo wybuchu, stanowi klauzule wyłączające ryzyko. Ten drugi rodzaj postanowień działa oczywiście obiektywnie. W najbardziej oczywistych przypadkach pytania o związek przyczynowy albo winę ubezpieczającego nie mają w ogóle sensu.

Druga reguła interpretacyjna odróżniająca permanentną przesłankę odpowiedzialności od obowiązków incydentalnych pozwala przykładowo wskazać, że jeżeli OWU wymagają krat w oknach, określonej liczby zamków, systemu alarmowego albo grodzi przeciwpożarowych i ubezpieczający w ogóle zaniechał zastosowania określonych zabezpieczeń, warunki te należy interpretować nie jako powinności prewencyjne, ale jako klauzule wyłączające odpowiedzialność. W sytuacji gdy ubezpieczający zawarł umowę, wiedząc, że przesłanką odpowiedzialności ubezpieczyciela jest zastosowanie określonego rodzaju zabezpieczeń i zabezpieczeń tych w ogóle nie zastosował, pytanie o ciężar winy nie ma większego sensu. Nieco bardziej skomplikowana jest sprawa związku przyczynowego. Wydaje się, że ubezpieczyciel nie musi udowadniać związku przyczynowego w konkretnym przypadku, wystarczy potencjalny związek przyczynowy, innymi słowy - wzrost ryzyka wypadku określonego rodzaju w razie niezastosowania zabezpieczeń.

Pewne kwestie będą oczywiście budzić wątpliwości. Można przykładowo zapytać, czy ubezpieczyciel odpowiada za kradzież w sytuacji, gdy nie zastosowano uzgodnionego rodzaju drzwi i zamków, jednak ubezpieczający jest w stanie wykazać, że złodzieje weszli przez okno. Odpowiedź dyktuje w tym przypadku warunek choćby potencjalnego związku przyczynowego. Ryzyko pokonania przez złodzieja zapory w postaci okna nie zwiększa się przez niezastosowanie określonych zamków. Inna wątpliwość może dotyczyć sytuacji, gdy ubezpieczający zastosował określone zabezpieczenia, ale nie uruchomił ich w konkretnej sytuacji. Przykładowo ubezpieczający opuszczając dom na kwadrans, zamknął drzwi na jeden spośród dwóch wymaganych zamków albo nie 
załączył systemu alarmowego. Wydaje się, że w przytoczonym przykładzie zastosowanie istniejącego zabezpieczenia należy już traktować jako powinność prewencyjną, której złamanie może skutkować wyłączeniem odpowiedzialności, jeżeli istnieje związek przyczynowy między niezastosowaniem zabezpieczenia i szkodą oraz jednocześnie ubezpieczającemu można postawić przynajmniej zarzut rażącego niedbalstwa.

Kryterium trzecie dotyczyło popełnienia przez ubezpieczającego przestępstwa lub wykroczenia. Spośród omówionych obcych prawodawstw wyraźnie przewiduje je jedynie prawo francuskie. W prawie niemieckim do podobnych rezultatów dochodzi się jednak, stosując reguły przyczynowości ${ }^{112}$. Można oczywiście twierdzić, że postanowienia wyłączające odpowiedzialność ubezpieczyciela za szkody powstałe podczas prowadzenia pojazdu w stanie odurzenia albo bez wymaganych uprawnień nakładają w istocie na ubezpieczającego powinność niewprowadzania się w stan odurzenia przed zajęciem miejsca za kierownicą albo zdobycia wcześniej określonych uprawnień. Wyolbrzymiana w czasach realnego socjalizmu funkcja prewencyjno-wychowawcza ubezpieczeń ma obecnie znaczenie pomocnicze, nie należy jej jednak zupełnie lekceważyć. Truizmem jest stwierdzenie, że ryzyko spowodowania wypadku przez kierowcę pijanego albo nieposiadającego uprawnień jest daleko większe niż ryzyko spowodowania wypadku przez kierowcę trzeźwego i mającego uprawnienia. Z powyższych względów skłonny byłbym przyjąć, że jeżeli zakład ubezpieczeń, formułując klauzule, zaznaczy, że nie odpowiada za szkody powstałe podczas prowadzenia pojazdu w stanie nietrzeźwości, zamiast za szkody spowodowane przez kierowcę nietrzeźwego, to postanowienia takie należy respektować, traktując je jako wyłączenia odpowiedzialności. Orzecznictwo SOKiK wykluczające skuteczność podobnych klauzul w oderwaniu od związku przyczynowego wydaje się w tym kontekście zbyt daleko idące ${ }^{113}$.

Również w odniesieniu do tej kwestii pewne sytuacje mogą budzić wątpliwości. Orzecznictwo Sądu Najwyższego uniezależniające skuteczność klauzul wyłączających odpowiedzialność za szkody wywołane w stanie

112 Por. M. Wandt, Versicherungsrecht, s. 356-357.

113 Por. cytowany już wyrok SA w Warszawie z 9.02.2009 r., VI ACa 782/09. 
odurzenia od związku przyczynowego między tym stanem a zajściem wypadku dotyczy przykładowo jedynie stanu nietrzeźwości. W wyroku z 21.03.1977 r., III CZP 9/77114, Sąd Najwyższy wskazał, że stan nietrzeźwości wyłączający odpowiedzialność ubezpieczyciela bez względu na związek przyczynowy między tym stanem a wypadkiem nie obejmuje stanu wskazującego na użycie alkoholu. Z drugiej strony w wyroku z 13.05.2004 r., V CK 489/03 ${ }^{115}$, sąd ten stwierdził, że pojęcie uprawnień do prowadzenia pojazdu, których brak wykluczał odpowiedzialność ubezpieczyciela niezależnie od ewentualnego związku przyczynowego, obejmował nie tyko dokument uprawniający do prowadzenia pojazdu w myśl prawa o ruchu drogowym, tj. prawo jazdy odpowiedniej kategorii, ale również świadectwo kwalifikacji. Świadectwo to nie było wprawdzie objęte normą art. 88 ust. 2 p.r.d. określającą dokumenty uprawniające do prowadzenia pojazdu, było jednak wymagane od określonych kategorii kierowców celem wykazania, że nie mają przeciwwskazań zdrowotnych do wykonywania zawodu kierowcy. W stanie faktycznym sprawy przyczyną szkody nie był stan zdrowia kierowcy, ale niewłaściwe zabezpieczenie przewożonego ładunku ${ }^{116}$.

Z pierwszym z cytowanych wyroków łatwiej się zgodzić niż z drugim. Próg stanu po spożyciu alkoholu w prawie polskim jest tak niski, że trudno potwierdzić negatywny wpływ tego stanu na sprawność psychomotoryczną przeciętnego kierowcy ${ }^{117}$. Z drugiej strony, jeżeli ustawodawca lub ubezpieczyciel nie wskazał, że używane przezeń pojęcie dokumentu uprawniającego do prowadzenia pojazdu ma szerszy zakres niż pojęcie ustawowe, wykładnia in dubio contra proferentem powinna się sprzeciwiać objęciu tym terminem świadectwa kwalifikacji, które nie jest objęte ustawowym określeniem dokumentu uprawniającego do

114 OSNC 1977/10, poz. 177.

115 LEX nr 188492.

116 Rozstrzygnięcie dotyczyło obowiązkowego ubezpieczenia OC. Autorowi znane są z praktyki odmienne rozstrzygnięcia dotyczące ubezpieczenia autocasco.

117 Rezygnacja z tzw. reguły „wszystko albo nic” w art. 28 niemieckiej VVG z 2007 r. $\mathrm{w}$ porównaniu $\mathrm{z}$ art. 6 starej ustawy pozwala $\mathrm{w}$ takich przypadkach na zmniejszenie odszkodowania stosownie do stopnia rażącego niedbalstwa. Por. M. Wandt, Versicherungsrecht, s. 262-263. Stopniowanie rażącego niedbalstwa wydaje się jednak pomysłem wątpliwym. 
prowadzenia pojazdu, nawet jeżeli kierowca powinien takie świadectwo posiadać. Mając powyższe na uwadze, warunki niepozostawania w stanie wskazującym na spożycie alkoholu oraz posiadania świadectwa kwalifikacji skłonny byłbym traktować w okolicznościach wyżej przytoczonych spraw jako powinności prewencyjne, a nie klauzule wyłączające odpowiedzialność.

Wyrok dotyczący świadectwa kwalifikacji pozwala płynnie przejść do reguły nakazującej interpretowanie postanowień wątpliwych na niekorzyść ubezpieczyciela jako powinności prewencyjnych. W tym kontekście można przytoczyć wyrok Sądu Najwyższego z 13.05.2004 r., V CK $481 / 03^{118}$, w którym za nieskuteczne uznano wyłączenie odpowiedzialności za szkody wynikające z braku konserwacji budynku albo z faktu, że budynek nie odpowiadał normom występującym w budownictwie. Powołując się na tę klauzulę, ubezpieczyciel chciał uniknąć odpowiedzialności za katastrofę budowlaną w objętym ubezpieczeniem pawilonie handlowym. Sądy dwóch pierwszych instancji uznały ekscepcje ubezpieczyciela za skuteczną, wskazując, że pojęciem norm budowlanych należy objąć normy wynikające z ustawy - Prawo budowlane i z rozporządzeń wydanych na jej podstawie. Sąd Najwyższy nie zgodził się z tym rozstrzygnięciem, wskazując, że pojęcie norm obowiązujących w budownictwie nie zostało przez ubezpieczyciela zdefiniowane i było tak ogólne, że ubezpieczający nie znał zakresu ochrony ubezpieczeniowej. Klauzule o treści podobnej do wyżej wskazanej wpisane są również do rejestru klauzul niedozwolonych prowadzonego przez SOKiK pod numerami 1223 i $1224^{119}$.

Z ostatniego rozstrzygnięcia Sądu Najwyższego wynika, że norm nakładających na ubezpieczającego obowiązek przestrzegania pewnych bliżej niesprecyzowanych reguł często nie można nawet traktować jako skutecznych powinności prewencyjnych, w żadnym razie nie mogą one stanowić działających obiektywnie wyłączeń odpowiedzialności. Innymi słowy, jeżeli OWU nakładają na ubezpieczającego obowiązek podjęcia pewnych nieprecyzyjnie sformułowanych działań albo prze-

118 LEX nr 183801.

119 Wyrok SOKiK z 21.12.2006 r., XVII AmC 103/05, MSiG 2007/213, poz. 13699. 
strzegania ogólnie określonych norm, można co najwyżej rozważać obowiązek prewencyjny, nigdy zaś działające obiektywnie wyłączenie odpowiedzialności. Odmienny skutek może ewentualnie wchodzić w grę w odniesieniu do wymagania spełnienia norm ściśle określonych, których nieprzestrzeganie powoduje zagrożenie życia ludzkiego i stanowi przestępstwo.

Wyżej wskazane reguły interpretacyjne oczywiście nie wyjaśniają wszelkich wątpliwości. Prawnicy, w szczególności prawnicy kontynentalni, przyzwyczajeni są oczekiwać ogólnych recept pozwalających rozstrzygać wszelkie zbliżone do siebie sytuacje. W odniesieniu do odróżnienia klauzul wyłączających odpowiedzialność oraz umownych obowiązków prewencyjnych trudno zaproponować precyzyjną receptę. Oczywiście kryteria interpretacji określone w art. 65 k.c. mogą być przydatne również przy interpretacji danego postanowienia jako powinności prewencyjnej albo wyłączenia odpowiedzialności. Jako ostateczne remedium zastosowano test zdrowego rozsądku przy uwzględnieniu wszelkich okoliczności sprawy ze szczególnym uwzględnieniem rodzaju ubezpieczenia oraz ubezpieczanego ryzyka, a także uzasadnionych oczekiwań ubezpieczającego. Testu zdrowego rozsądku nie należy przy tym de lege lata traktować jako samodzielnej dodatkowej klauzuli generalnej niemającej umocowania w ustawie, ale jako kryterium wspomagające, mające znaczenie przede wszystkim w zakresie wykładni oświadczenia woli. Na podstawie art. $65 \$ 1$ k.c. można wskazać, że wykładnia oświadczenia woli zgodna $\mathrm{z}$ okolicznościami oraz uwzględniająca zasady współżycia społecznego to wykładnia respektująca rozumienie tego oświadczenia przez rozsądnego uczestnika obrotu znajdującego się w analogicznej sytuacji jak adresat danego oświadczenia, w szczególności dysponującego takim samym zakresem wiedzy o oświadczeniach i okolicznościach jego złożenia ${ }^{120}$.

Warto wskazać, że podobną receptę stosuje prawo amerykańskie, uznając za skuteczne nakładanie na ubezpieczającego obowiązków prewencyjnych, których można od niego w określonych okolicznościach roz-

${ }_{120}$ Zob. szerzej E. Rott-Pietrzyk, Klauzula generalna rozsądku de lege ferenda [w:] Europeizacja prawa prywatnego, t. 2, red. M. Pazdan i in., Warszawa 2008, s. 291-293. 
sądnie wymagać, albo stosowanie wyłączeń, których ubezpieczający w określonych okolicznościach mógł się rozsądnie spodziewać. Innymi słowy, według amerykańskiego podejścia zastrzeżenia ograniczające lub wyłączające odpowiedzialność ubezpieczyciela powinny odpowiadać rozsądnym oczekiwaniom ubezpieczającego (tzw. reasonable expectations test $)^{121}$. Również w prawie niemieckim cytowany wyżej M. Wandt odwołuje się do uzasadnionych oczekiwań ubezpieczającego.

W prawie angielskim z kolei OWU często wprost wymagają od ubezpieczającego rozsądnych środków zabezpieczających. Przy interpretacji podobnych postanowień kładzie się nacisk właśnie na rodzaj ubezpieczenia i ubezpieczane ryzyko. Raz jeszcze można przypomnieć powoływaną sprawę Sofi v. Prudential Assurance Co Ltd. Dodatkowo wskazać można sprawę Fraser v. Furman, w której Lord Diplock stwierdził wyraźnie, że klauzule wymagające od ubezpieczającego rozsądnych środków zapobiegawczych należy interpretować w kontekście rodzaju polisy zabezpieczającej przed określonym ryzykiem oraz gospodarczego celu umowy, dochodząc ostatecznie do wniosku, że niedochowanie podobnego obowiązku może zwalniać ubezpieczyciela z odpowiedzialności, tylko gdy było wynikiem co najmniej rażącego niedbalstwa ${ }^{122}$.

\subsubsection{Skuteczność oraz interpretacja umownych wyłączeń odpowiedzialności}

Treść umowy ubezpieczenia może być przez strony kształtowana dowolnie w granicach wyznaczających zakres swobody umów. Dotyczy to również wyłączeń odpowiedzialności, których dopuszczalność będzie zależała od tego, czy nie pozostają one w sprzeczności z przepisami ustawy, z właściwością i naturą stosunku prawnego ubezpieczenia oraz z zasadami współżycia społecznego. Dodatkowo w stosunkach z konsumentami oraz z osobami fizycznymi prowadzącymi działalność gospodarczą należy rozważyć uznanie określonych wyłączeń odpowie-

121 J. Birds, Birds'..., s. 233-234.

122 M. Clarke, The Law..., s. 593. Fraser v. B.N. Furman (Productions) Ltd [1967] 1 WLR 898 (CA), s. 905. 
dzialności za klauzule niedozwolone. Odrębną kwestią jest znaczenie dla interpretacji oraz ważności wyłączeń odpowiedzialności ubezpieczyciela przepisów ustawy o dystrybucji ubezpieczeń, w szczególności art. 8 tej ustawy. Celem rozważań nie jest oczywiście przypominanie ogólnych wiadomości dotyczących granic swobody umów, ochrony konsumenta przed narzuceniem nieuczciwych wzorców umownych ani szczegółowa analiza przepisów ustawy o dystrybucji ubezpieczeń, ale sprecyzowanie warunków, które muszą spełniać klauzule wyłączające odpowiedzialność ubezpieczyciela dla swej skuteczności.

Rozpoczynając od pierwszej kategorii ograniczeń swobody umów, a mianowicie sprzeczności z ustawą, trzeba pamiętać, że przepisy o umowie ubezpieczenia z zastrzeżeniem wyjątków z nich wynikających mają bezwzględnie obowiązujący charakter ${ }^{123}$. Zasadę tę potwierdza art. 807 k.c., wskazując, że postanowienia ogólnych warunków ubezpieczenia lub postanowienia umowy ubezpieczenia sprzeczne z przepisami niniejszego tytułu są nieważne, chyba że dalsze przepisy przewidują wyjątki. Przepis odwołuje się wprawdzie expressis verbis wyłącznie do sprzeczności OWU z przepisami Kodeksu cywilnego o umowie ubezpieczenia, nie powinno jednak budzić wątpliwości, że nieważne będą również postanowienia OWU sprzeczne z innymi bezwzględnie obowiązującymi przepisami prawa.

Swoboda umów w zakresie pozostających w kręgu rozważań dobrowolnych ubezpieczeń mienia idzie oczywiście znacznie dalej niż swoboda dotycząca ubezpieczeń obowiązkowych, które uregulowane są przepisami ustawy o ubezpieczeniach obowiązkowych, Ubezpieczeniowym Funduszu Gwarancyjnym i Polskim Biurze Ubezpieczycieli Komunikacyjnych oraz rozporządzeniami wydanymi na podstawie delegacji ustawowej. W zakresie ubezpieczeń dobrowolnych wśród przepisów wyznaczających granice swobody poza przepisami umowy Kodeksu cywilnego o umowie ubezpieczenia, przepisami części ogólnej kodeksu oraz ogólnymi przepisami o zobowiązaniach wchodzą w grę przede wszystkim przepisy ustawy o działalności ubezpieczeniowej i reasekuracyjnej.

123 Co do tej kwestii, zob. w szczególności M. Orlicki, Regulacja... 
Warto przypomnieć, że normę wyznaczającą wyraźnie reguły dotyczące sposobu formułowania wyłączeń odpowiedzialności zawierają przepisy francuskie. Artykuł L113-1 Code des assurances wskazuje, że ubezpieczyciel ponosi odpowiedzialność za szkody będące skutkiem zdarzeń losowych, a także wywołane przez ubezpieczającego sauf exclusion formelle et limitée contenue dans la police. Ze sformułowania formelle wywodzi się warunek, by wyłączenia były jasne, precyzyjne i niedwuznaczne, niezależnie od tego, czy zostały zawarte w umowie, czy ogólnych warunkach ubezpieczenia, oraz niezależnie od tego, czy wynikają z treści wprost, czy też można je wywieść w drodze rozumowania a contrario, analizując postanowienia wyznaczające granice ponoszonego przez ubezpieczyciela ryzyka od strony pozytywnej. Warunek, by wyłączenia były limitée, czyli ograniczone, wyklucza przykładowo ważność wyłączenia odwołującego się do nieprzestrzegania przepisów i reguł ${ }^{124}$. Dodatkowo sama redakcja przepisu wskazuje, że zasadą jest odpowiedzialność ubezpieczyciela, natomiast wyłączenie odpowiedzialności wyjątkiem.

Polskie przepisy nie regulują w podobny sposób redakcji postanowień wyłączających odpowiedzialność, można z nich jednak wywieść pewne reguły w tym zakresie. Pierwszorzędne znaczenie ma art. 15 ust. 3 u.d.u.r. nakazujący formułować umowę ubezpieczenia, ogólne warunki ubezpieczenia oraz inne wzorce jednoznacznie i w sposób zrozumiały, oraz art. 15 ust. 5 u.d.u.r. rozciągający regułę in dubio contra proferentem $\mathrm{w}$ odniesieniu do OWU na stosunki pozakonsumenckie. Ponadto z powoływanych w toku wcześniejszych wywodów art. 16 pkt 1 oraz art. 17 ust. 1 pkt 2 u.d.u.r. wynika odpowiednio konieczność określenia w OWU zakresu odpowiedzialności ubezpieczyciela oraz informacji o postanowieniach zawierających ograniczenia i wyłączenia odpowiedzialności uprawniające ubezpieczyciela do odmowy wypłaty odszkodowania i innych świadczeń lub ich obniżenia. Dodatkowo art. 8 ust. 6 pkt 4 u.d.u. nakłada na dystrybutora obowiązek zawarcia głównych wyłączeń odpowiedzialności uprawniających ubezpieczyciela do odmowy wypłaty odszkodowania i innych świadczeń w dokumencie informującym o produkcie ubezpieczeniowym.

124 Y. Lambert-Faivre, L. Leveneur, Droit..., s. 331-334. 
Powołane przepisy pozwalają wywieść przynajmniej cztery reguły w zakresie formułowania wyłączeń odpowiedzialności. Po pierwsze, ogólne warunki umów powinny być zredagowane w sposób opisujący zakres odpowiedzialności ubezpieczyciela od strony pozytywnej oraz negatywnej. Wyłączenia odpowiedzialności powinny być zatem wyraźnie wyodrębnione w treści OWU. Po drugie, OWU oraz wszelkie wzorce mają być sformułowane jednoznacznie i w sposób zrozumiały. Warunek powyższy dotyczy oczywiście również, a może nawet w szczególności, postanowień ograniczających lub wyłączających odpowiedzialność ubezpieczyciela ${ }^{125}$. Po trzecie, OWU muszą zawierać informacje, w których postanowieniach zawarte są wyłączenia odpowiedzialności. Po czwarte, ważniejsze wyłączenia odpowiedzialności muszą zostać umieszczone w ustandaryzowanym dokumencie informującym o produkcie ubezpieczeniowym.

Pierwsze z omawianych wymagań, tj. konieczność wyraźnego zastrzeżenia wyłączenia odpowiedzialności, wyrażane było już w orzeczeniach dawnej Głównej Komisji Arbitrażowej na długo przed pojawieniem się odpowiednich regulacji. W stanie faktycznym orzeczenia z 5.02.1973 r. ${ }^{126}$ chodziło o ubezpieczenie od ognia i zdarzeń losowych, którym objęte były m.in. budowle wodne wznoszone przez powodowe Przedsiębiorstwo Budownictwa Wodno-Inżynieryjnego. Budowle zostały uszkodzone na skutek wynikającego z gwałtownych opadów przyboru wód potoku i w rzece, powodującego wylew wód z naturalnych łożysk. Ubezpieczyciel twierdził, że wszelkie budowle wodne umiejscowione w zbiornikach wodnych w obrębie ich naturalnych lub sztucznych łożysk nie są ubezpieczone od skutków działania powodzi. Główna Komisja Arbitrażowa nie podzieliła tego stanowiska, wskazując, że w mających w owym czasie postać rozporządzenia postanowieniach OWU, dotyczących ograniczeń zakresu odpowiedzialności PZU, wśród szkód wyłączonych z tej odpowiedzialności nie wymieniono szkód po-

125 Warunki, którym odpowiadać mają wyłączenia odpowiedzialności w prawie polskim, formułuje M. Serwach, Wykładnia postanowień wyłaczających lub ograniczajacych odpowiedzialność zakładu ubezpieczeń w ubezpieczeniach majątkowych [w:] Odpowiedzialność cywilna. Księga pamiątkowa ku czci Profesora Adama Szpunara, red. M. Pyziak-Szafnicka, Kraków 2004, s. 422.

126 Orzeczenie GKA z 5.02.1973 r., BO-13004/72, OSP 1974/2, poz. 39. 
wodziowych w budowlach umiejscowionych w łożyskach zbiorników wodnych. Podobnego wyłączenia nie zastrzeżono również w zawartej przez strony umowie ubezpieczenia od ognia i innych zdarzeń losowych. Zdaniem GKA ze względu na istotę ochrony ubezpieczeniowej wyłączenie odpowiedzialności PZU musi być wyraźne; po zawarciu umowy ubezpieczenia na określonych warunkach ubezpieczający się nie powinien być narażony na odmowę pokrycia szkody przez PZU na podstawie swobodnej interpretacji postanowień regulujących różne kwestie związane $\mathrm{z}$ ubezpieczeniem.

Podobnie w orzeczeniu z 12.11.1987 r. ${ }^{127}$ GKA stwierdziła, że gdy towar wysyłany za granicę statkiem został ubezpieczony „od wszelkich ryzyk”, ubezpieczyciel ponosi odpowiedzialność także za zamarznięcie towaru, gdyż w ubezpieczeniu tym zamarznięcie towaru nie stanowiło ryzyka pozataryfowego, wymagającego rozszerzenia warunków ubezpieczenia za dodatkową opłatą. Dalej GKA wskazała, że gdyby celem regulacji zawartej w taryfie za ubezpieczenie ładunków w przewozach morskich ustalonej przez TUiR Warta SA było nadanie konkretnym ryzykom charakteru ryzyk pozataryfowych, to niezbędne byłoby enumeratywne wskazanie tych ryzyk.

Drugi warunek sformułowania wzorca jednoznacznie oraz w sposób zrozumiały wynika nie tylko z ustawy o działalności ubezpieczeniowej i reasekuracyjnej, ale również z art. $385 \$ 2$ k.c. Orzecznictwo dotyczące tych kwestii jest niezmiernie bogate. Podkreślić można, że również to wymaganie wraz z regułą nakazującą interpretację postanowień niejednoznacznych na niekorzyść ubezpieczyciela, który jest ich autorem, było formułowane przez Sąd Najwyższy na długo przed wejściem w życie odpowiednich przepisów. Przykładowo można wskazać, że w wyroku z 14.07.1959 r. ${ }^{128}$ Sąd Najwyższy zajął się zakresem ubezpieczenia od strony pozytywnej, interpretując pojęcie zapasów, które zdaniem powódki obejmowały m.in. skradzione materiały kosmetyczne i dentystyczne, natomiast zdaniem pozwanego ubezpieczyciela wyłącznie zgromadzone

127 Orzeczenia GKA z 12.11.1987 r., IP-6911/87, OSP 1989/7-12, poz. 159. Obydwa orzeczenia omawia M. Serwach w cytowanym wyżej artykule.

128 Orzeczenie SN z 24.07.1959 r., IV CR 1027/58, LEX nr 1634349. 
przedmioty przeznaczone na zaspokojenie bieżących osobistych potrzeb konsumpcyjnych ubezpieczającego i jego domowników. Sąd Najwyższy stwierdził, że zasady współżycia społecznego wymagają, by oświadczenia woli pozwanego zakładu ubezpieczeń tłumaczone były zgodnie $\mathrm{z}$ ich treścią $\mathrm{w}$ ten sposób, jak je mogli i powinni rozumieć adresaci, do których były skierowane. Byłoby sprzeczne z tymi zasadami, gdyby niejasności wywołane wadliwą i niedbałą redakcją takich oświadczeń woli były tłumaczone na niekorzyść kontrahenta zakładu, który nie ma żadnego wpływu na treść zawieranej umowy i działa w zaufaniu do zakładu ${ }^{129}$.

Jeszcze bardziej instruktywny jest znany wyrok z 28.02.1996 r. ${ }^{130}$, w którym Sąd Apelacyjny w Łodzi zajmował się sprawą szkód powstałych na skutek włamania do lokalu wiejskiej dyskoteki. Przedmiotem wątpliwości było postanowienie OWU pozwanego ubezpieczyciela wyłączające odpowiedzialność za szkody wynikłe po upływie pewnego czasu od chwili zamknięcia i nieużytkowania lokalu, w którym znajduje się ubezpieczone mienie. W ciągu miesiąca przed włamaniem w lokalu rzeczywiście nie były organizowane dyskoteki z uwagi na Wielki Post, jednak powód sporadycznie prowadził działalność gastronomiczną. Sąd Apelacyjny w Łodzi wskazał, że sformułowanie „zamknięcie i nieużytkowanie lokalu" nie jest sformułowaniem jednoznacznym. Może oznaczać - jak to sugeruje pozwany zakład - każdą przerwę w prowadzeniu działalności gospodarczej, trwającą dłużej niż 14 dni, ale może także oznaczać - zgodnie z twierdzeniem powoda - zakończenie działalności gospodarczej. Sąd stwierdził, że przy formułowaniu OWU zachowana powinna być bardzo staranna i precyzyjna redakcja zawartych w nich postanowień, zwłaszcza co do zakresu ochrony ubezpieczeniowej. Dotyczy to zarówno formy tych postanowień, jak również systematyki i terminologii. Ujemne skutki wadliwie opracowanych ogólnych warunków ubezpieczeń, polegające na możliwości dowolnej ich interpretacji, powinny obciążać ubezpieczyciela jako profesjonalistę i autora tych warunków.

129 Ostatnio podobnie wyrok SN z 14.03.2018 r., II CSK 445/17, LEX nr 2486131.

130 Wyrok SA w Łodzi z 28.02.1996 r., I ACr 37/96, OSA 1996/9, poz. 43. 
Trzeci warunek, a mianowicie zawarcie w OWU informacji, które postanowienia określają ograniczenia oraz wyłączenia odpowiedzialności zakładu ubezpieczeń uprawniające do odmowy wypłaty odszkodowania i innych świadczeń lub ich obniżenia, stanowi nowy warunek wynikający z art. 17 u.d.u.r. Należy przychylić się do poglądu, że niewypełnienie tego warunku nie powoduje samo przez się uznania wyłączenia bądź ograniczenia odpowiedzialności za nieważne. W niektórych sytuacjach wyłączenie lub ograniczenie, o którego usytuowaniu nie poinformowano, może okazać się niejednoznaczne, jednak wszystko będzie zależeć od okoliczności konkretnego przypadku. Rację zdaje się mieć M. Krajewski, który stwierdza, że przepis nie doprowadził do celu zamierzonego przez ustawodawcę, a jego praktyczny skutek jest nawet odwrotny od zamierzonego. W praktyce spełnienie wynikających $\mathrm{z}$ art. 17 u.d.u.r. wymagań sprowadza się do zamieszczenia w ogólnych warunkach ubezpieczenia tabelki, w której poszczególne jednostki redakcyjne wzorca wpisywane są do jednej z rubryk. Taka tabelka niczego nie wyjaśnia, a dla adresata wzorca, który nie zna powodu jej zamieszczenia, przyczynia się raczej do pogłębienia przekonania, że próba zrozumienia ogólnych warunków ubezpieczenia jest dla laika z góry skazana na niepowodzenie.

Jeszcze nowszy jest warunek czwarty, nakazujący umieszczenie informacji o ważniejszych wyłączeniach odpowiedzialności w ustandaryzowanym dokumencie ubezpieczeniowym. Artykuł 8 ust. 6 u.d.u. nie precyzuje, które wyłączenia należy uznać za ważniejsze. Marcin Orlicki wskazuje, że chodzi o te wyłączenia, które według statystyk likwidacyjnych najczęściej stanowią podstawę do odmowy wypłaty odszkodowania lub zmniejszenia jego wysokości, jak również wyłączenia zaskakujące klienta, które są niezgodne ze stereotypowym sposobem myślenia klientów o zakresie ochrony w produktach ubezpieczeniowych danego rodzaju. Autor nie precyzuje jednak, jaki jest skutek nieumieszczenia określonego wyłączenia w ustandaryzowanym dokumencie. Wydaje się, że w tym zakresie można odwołać się do uwag dotyczących art. 17 u.d.u.r. ${ }^{131}$ Niewywiązanie się przez dystrybutora z obowiązku wręczenia ustandaryzowanego dokumentu, ewentualnie sformułowanie

${ }^{131}$ M. Orlicki, Ustandaryzowany dokument według ustawy o dystrybucji ubezpieczeń - zasady tworzenia i znaczenie prawne, PA 2017/4. 
tego dokumentu w sposób sprzeczny z ustawą o dystrybucji ubezpieczeń oraz z rozporządzeniem wykonawczym Komisji (UE) 2017/1469 z 11.08.2017 r. ustanawiającym ustandaryzowany format prezentacji dokumentu zawierającego informacje o produkcie ubezpieczeniowym ${ }^{132}$, nie skutkuje automatycznie nieważnością wyłączenia odpowiedzialności, ale może co najwyżej w określonych wypadkach doprowadzić do uznania wyłączenia za niejednoznaczne.

Wyjaśnienie powyższych kwestii pozwala na przejście do omówienia przepisów Kodeksu cywilnego, z którymi wyłączania nie mogą być sprzeczne. W tym zakresie należy podkreślić znaczenie art. 827 k.c., który był analizowany wcześniej. Zdaniem autora niniejszej pracy nieważne będą w szczególności postanowienia przewidujące nieodpowiedzialność ubezpieczyciela w razie naruszenia przez ubezpieczającego wynikających z ustawy lub z umowy obowiązków prewencyjnych niezależnie od ciężaru winy oraz związku przyczynowego między naruszeniem a szkodą. To samo dotyczy postanowień przewidujących nieodpowiedzialność ubezpieczyciela w razie naruszenia przewidzianego w art. 826 k.c. obowiązku ratowania mienia już dotkniętego wypadkiem oraz zabezpieczenia roszczeń regresowych ubezpieczyciela. Jak już wskazywano, przepis przewiduje bowiem brak odpowiedzialności ubezpieczyciela za szkody będące konsekwencją zaniechań ubezpieczającego w zakresie użycia dostępnych środków mających na celu ratowanie przedmiotu ubezpieczenia, zapobieżenie szkodzie oraz zmniejszenie jej rozmiarów wyłącznie w razie winy umyślnej lub rażącego niedbalstwa ubezpieczającego. $\mathrm{Z}$ kolei naruszenie obowiązku zabezpieczenia roszczeń regresowych ubezpieczyciela nie jest zagrożone żadną sankcją, z czego wywodzić można co najwyżej ewentualną odpowiedzialność odszkodowawczą ubezpieczającego na ogólnych zasadach.

Drugim oraz, jak się wydaje, najistotniejszym kryterium warunkującym skuteczność wyłączenia odpowiedzialności będzie właściwość (natura) stosunku prawnego ubezpieczenia. Dekodowanie właściwości i natury konkretnego stosunku prawnego ubezpieczenia jako kryterium warunkującego skuteczność wyłączeń odpowiedzialności

132 Dz.Urz. UE L 209, s. 19. Rozporządzenie weszło w życie 1.09.2017 r. 
powinno przebiegać przynajmniej w czterech etapach. Pierwszy etap polega na poddaniu wyłączeń ocenie pod kątem właściwości (natury) każdego obligacyjnego stosunku prawnego. Dopiero w drugim etapie należy zwrócić uwagę na cechy charakterystyczne ubezpieczenia jako instytucji prawnej. W literaturze zwrócono w tym zakresie uwagę na konieczność występowania ryzyka oraz związaną z tym subiektywną niepewność wypadku ubezpieczeniowego, a także trwałość jako cechę charakterystyczną umowy ubezpieczenia ${ }^{133}$. Wziąwszy jednak pod uwagę kwestię będącą przedmiotem rozważań, największe znaczenie będzie mieć podkreślany w licznych orzeczeniach przez Sąd Najwyższy ochronny cel umowy ubezpieczenia oraz oparcie umowy ubezpieczenia na wzajemnym zaufaniu stron. Zdaniem autora niniejszej pracy bardzo istotne znaczenie w tym zakresie będzie mieć również zakwalifikowanie ubezpieczenia jako umowy wzajemnej. Trzecim etapem powinna być weryfikacja wyłączenia w świetle konkretnego rodzaju ubezpieczenia. Wiadomo przykładowo, że zawierając ubezpieczenie AC, ubezpieczający chce zyskać ochronę przede wszystkim na wypadek zniszczenia pojazdu wskutek wypadku drogowego, niekorzystnych zjawisk przyrodniczych, działań osób trzecich, a także na wypadek utraty pojazdu na skutek kradzieży oraz własnej lekkomyślności. W ostatniej kolejności należy wziąć pod uwagę właściwość (naturę) konkretnego stosunku prawnego z uwzględnieniem wszystkich znanych obydwu stronom okoliczności zawarcia umowy.

Mając na uwadze właściwość (naturę) stosunku prawnego ubezpieczenia jako kryterium ograniczające swobodę kształtowania treści postanowień wyłączających odpowiedzialność ubezpieczyciela, M. Serwach formułuje warunek ich ograniczonego charakteru znów zbieżny z warunkiem formułowanym wprost przez prawo francuskie. Zbyt szeroki charakter wyłączeń odpowiedzialności może sprawiać, że zasadą w konkretnym stosunku ubezpieczenia będzie brak odpowiedzialności ubezpieczyciela zamiast jego odpowiedzialności, a wyjątkiem odpowiedzialność zamiast braku odpowiedzialności. W tych sytuacjach ochronny dla ubezpieczającego cel stosunku prawnego ubezpieczenia nie zostanie osiągnięty. Dodatkowo zaburzona zostanie ekwiwalentność świadczeń stron

133 P. Sukiennik, Ubezpieczeniowy wymiar zasady swobody umów, PA 2000/3, s. 32. 
tego stosunku, ubezpieczający w zamian za składkę mającą wymierną wartość uzyska bowiem ochronę ubezpieczeniową mającą $\mathrm{w}$ istocie charakter czysto iluzoryczny. Formułując w podobny sposób warunki ubezpieczenia, ubezpieczyciel wykorzysta swój profesjonalizm oraz doświadczenie oraz brak znajomości rzeczy po stronie ubezpieczającego, naruszając także zasadę najwyższej dobrej wiary stosunku prawnego ubezpieczenia. W skrajnych przypadkach ubezpieczenie mające być z punktu widzenia ubezpieczającego pełne, tj. gwarantujące pewność kompensacji na wypadek niekorzystnych zdarzeń losowych, będzie $\mathrm{w}$ istocie puste niczym wydmuszka.

Jest charakterystyczne, że podobnie jak wymagania wyraźnego oraz precyzyjnego formułowania wyłączeń odpowiedzialności łączące się obecnie z postulatem ich niesprzeczności z ustawą przenikały się z regułą interpretowania wzorca na niekorzyść proferenta, czyli ubezpieczyciela, tak warunek niesprzeczności wyłączenia z właściwością (naturą) stosunku prawnego przenika się $\mathrm{z}$ regułami interpretowania umowy zgodnie z celem, który przyświecał zawierającym ją stronom, oraz $\mathrm{z}$ regułą preponderancji umowy w razie jej sprzeczności z ogólnymi warunkami. Właściwość i natura stosunku prawnego muszą bowiem brać pod uwagę jego cel gospodarczy oraz okoliczności towarzyszące zawarciu umowy rodzącej ten stosunek. Dwa ostatnie kryteria stanowią zaś podstawowe reguły wykładni oświadczeń woli w świetle art. 65 k.c. Pierwszeństwo konkretnej umowy w zderzeniu z wzorcem stanowi zaś podstawowe kryterium interpretacji wzorca zgodnie $\mathrm{z}$ art. $385 \$ 1$ k.c. W tych okolicznościach trudno się dziwić, że większość orzeczeń dotyczących omawianej kwestii skupia się na interpretacji ogólnych warunków ubezpieczenia.

Omawiane kwestie dobrze ilustrują dwa znane orzeczenia Sądu Najwyższego. Uchwała z 12.12.1997 r., III CZP 65/97134, dotyczyła zawładnięcia przez osobę posługującą się fałszywym dowodem tożsamości przyczepy samochodowej przeznaczonej do zarobkowego wynajmu. Ubezpieczenie zawarto na wypadek kradzieży, przy czym OWU pozwanego wyłączały jego odpowiedzialność za szkody powstałe na skutek kradzieży pojazdu

134 OSNC 1998/4, poz. 55. 
przez najemcę nieuczestniczącego w sporze, jak również za szkody polegające na utracie pojazdu wskutek kradzieży, jeżeli nie zabezpieczono z należytą starannością poza pojazdem kluczyków i dokumentów pojazdu. Sąd pierwszej instancji oddalił powództwo, uznając, że w sprawie nie doszło do kradzieży. Sąd drugiej instancji zwrócił się do Sądu Najwyższego z pytaniem, jak rozumieć postanowienia OWU pozwanego w opisanej sytuacji.

Sąd Najwyższy zauważył, że OWU pozwanego były sprzeczne z zawartą umową, oraz powołał się na regułę in dubio contra proferentem. Wychodząc z tych założeń, SN wskazał, że nie ma podstaw do przyjęcia, że pozwany posłużył się w OWU terminologią w pełni zbieżną z odpowiednimi instytucjami prawa karnego materialnego, w szczególności że terminu „kradzież pojazdu” użył wyłącznie w rozumieniu art. 203 $\$ 1$ k.k. z 1969 r. Gdyby bowiem taka była wola pozwanego, to powinien on wyraźnie zastrzec to w treści wzorca, czego nie uczynił. Ponadto Sąd Najwyższy wskazał, że istotą działalności polegającej na odpłatnym wynajmowaniu przyczep samochodowych jest oddawanie ich do używania osobom trzecim wraz z kluczykami i dokumentami. Przyjęcie zatem interpretacji proponowanej przez ubezpieczyciela prowadziłoby do kuriozalnych wręcz wniosków sprowadzających się do wyłączenia odpowiedzialności ubezpieczyciela za utratę wskutek kradzieży każdego służącego do odpłatnego wynajmowania ubezpieczonego pojazdu.

W wyroku z 12.01.2007 r., IV CSK 307/06 ${ }^{135}$, Sąd Najwyższy zajął się kradzieżą Renault Megane. Nieznana osoba, przechodząc obok unieruchomionego pojazdu, w którym siedziała powódka, zawadziła o lusterko. Gdy powódka wyszła poprawić lusterko, ktoś wtargnął do pojazdu, zablokował drzwi od wewnątrz, a następnie odjechał, wykorzystując pozostawione w środku sterowniki. Ubezpieczyciel odmówił wypłaty odszkodowania, wskazując, że ubezpieczenie nie obejmowało kradzieży rozbójniczej, przy czym kradzież była zdefiniowana w OWU przez odwołanie się do przepisów Kodeksu karnego, natomiast kradzież rozbójnicza jako kradzież przez zaskoczenie właściciela pojazdu, podczas gdy kradzież przez zaskoczenie jest zwykłą kradzieżą z art. 278 k.k. Sąd

135 LEX nr 238967. 
Najwyższy uchylił do ponownego rozpoznania wyrok sądu apelacyjnego oddalający powództwo, powołując się na sprzeczność między OWU a formularzem wniosku ubezpieczeniowego, który określał ubezpieczenie jako pełne i sugerował, że dotyczy najszerszego z możliwych ubezpieczeń, obejmującego wszelkie rodzaje kradzieży.

Sąd Najwyższy wskazał również, że umowa ubezpieczenia należy do umów szczególnego zaufania, w której działania kontrahentów powinny być lojalne, a postanowienia umowy jasne, zrozumiałe i jednoznaczne dla osób bez szczególnego przygotowania i bez konieczności sięgania do innych uregulowań. Dotyczy to w szczególności wszelkiego rodzaju wyłączeń i ograniczeń odpowiedzialności zakładu ubezpieczeń, co do których nie może być żadnych wątpliwości już przy zawieraniu umowy. Także funkcja ochronna umowy ubezpieczenia wymaga, by przed jej zawarciem ubezpieczający miał świadomość, jakie wypadki nie są objęte ubezpieczeniem lub ograniczają albo wyłączają odpowiedzialność ubezpieczyciela ${ }^{136}$. Dodatkowo w świadomości społecznej ukształtowało się rozumienie umowy ubezpieczenia autocasco jako ubezpieczenia szerokiego, obejmującego z reguły wszystkie zdarzenia określone mianem kradzieży, co sprawia, że wszelkie wyłączenia takiej odpowiedzialności powinny być jednoznacznie i wyraźnie określone ${ }^{137}$.

Trzecie ograniczenie zasady swobody umów z art. $353^{1}$ k.c., które może mieć znaczenie przy uznaniu wyłączenia odpowiedzialności za nieważne, stanowią zasady współżycia społecznego. Zagadnienie to samo w sobie nie wymaga szerszego omówienia. Wynika to przede wszystkim stąd, że potrzeba oceny umowy z punktu widzenia zasad współżycia społecznego jest uzasadniona tylko wówczas, gdy umowa przeszła już pozytywnie weryfikację z punktu widzenia zgodności z ograniczeniami płynącymi z ustawy lub natury stosunku prawnego ${ }^{138}$. Trudno znaleźć wyłączenie odpowiedzialności ubezpieczyciela, które było w pełni zgod-

136 Wyrok SN z 13.05.2004 r., V CK 481/03.

137 Wyrok SN z 2.12.1998 r., I CKN 278/98, LEX nr 50692.

138 R. Trzaskowski, Granice swobody kształtowania treści i celu umów obligacyjnych, Kraków 2005, s. 426-427. Cytowany autor powołuje się na wypowiedzi M. Safjana i P. Machnikowskiego. 
ne $\mathrm{z}$ ustawą, przede wszystkim zaś z właściwością (naturą) stosunku prawnego ubezpieczenia (w szczególności z jej ochronnym celem oraz postulatem ekwiwalentności świadczeń stron) i jednocześnie sprzeczne z zasadami współżycia społecznego.

Wśród przykładów umów sprzecznych z zasadami współżycia społecznego podaje się przede wszystkim umowy sprzeczne z panującymi zapatrywaniami moralnymi dotyczącymi sfery seksualności, umowy sprzeczne z uczciwością i lojalnością oraz umowy związane z pogwałceniem etyki zawodowej ${ }^{139}$. Pierwsza i trzecia grupa przykładów nie będzie raczej dotyczyć wyłączeń odpowiedzialności w umowie ubezpieczenia. Sprzeczność z zasadami uczciwości i lojalności mogłaby mieć odrębne znaczenie przy przyjęciu tezy, że zasada najwyższego dobrej wiary czy też najwyższego zaufania nie należy do natury stosunku prawnego ubezpieczenia. Jak wyżej wskazano, Sąd Najwyższy prezentuje pogląd odmienny. Pogląd ten został uznany za słuszny. Podkreślić należy przy tym, że oparcie ubezpieczenia na najwyższym zaufaniu nie powinno być łączone wyłącznie z zaufaniem ubezpieczyciela do informacji, jakie uzyskuje od ubezpieczającego ${ }^{140}$. Drugim, obecnie być może nawet ważniejszym aspektem, jest zaufanie ubezpieczającego do kontrahenta, który przecież ma stać na straży jego istotnych interesów majątkowych.

Ocena zgodności wyłączenia odpowiedzialności z zasadami uczciwości i lojalności mogłaby mieć ewentualnie znaczenie przede wszystkim, gdy w odniesieniu do określonego stosunku ubezpieczenia nie będą mogły znaleźć zastosowania przepisy dotyczące ochrony przed narzucaniem nieuczciwych klauzul umownych $\mathrm{z}$ uwagi na status podmiotowy ubezpieczającego. Jak wiadomo, rozszerzenie takiej ochrony w umowie ubezpieczenia poza konsumentów objęło jedynie osoby fizyczne mające status przedsiębiorców, nie objęło natomiast małych spółek handlowych, innych podmiotów mogących choćby ubocznie prowadzić działalność gospodarczą (fundacje, stowarzyszenia ${ }^{141}$ itp.) ani podmiotów prawa

139 R. Trzaskowski, Granice..., s. 433-437.

140 Aktualność doktryny najwyższej dobrej wiary w umowie ubezpieczenia kwestionuje J. Łopuski. Odmiennie przykładowo K. Malinowska, Umowa...

141 Zob. przykładowo W.J. Katner, Pojęcie... 
o charakterze non profit. Wszystkie wymienione kategorie w relacji z ubezpieczycielem jako profesjonalistą o wysokiej pozycji rynkowej mogą w konkretnych okolicznościach zasługiwać na ochronę. Nadto kontrola wyłączenia odpowiedzialności w świetle zasad współżycia społecznego mogłaby mieć znaczenie w zakresie, w jakim wyłączenie zostałoby uznane za dotyczące głównych świadczeń stron.

Ocena wyłączenia przez pryzmat jego zgodności z zasadami współżycia społecznego łączy się zatem z bardziej skomplikowaną kwestią klauzul niedozwolonych w umowach konsumenckich ${ }^{142}$, które definiowane są przez odwołanie się między innymi do kategorii dobrych obyczajów, mających zdaniem większości doktryny znaczenie zbliżone do zasad współżycia społecznego. Zgodnie z art. $385^{1} \$ 1$ k.c. klauzulą niedozwoloną jest postanowienie umowy nieuzgodnione z konsumentem kształtujące jego prawa i obowiązki w sposób sprzeczny z dobrymi obyczajami, rażąco naruszając jego interesy. Odpowiedź na pytanie, czy wyłączenie odpowiedzialności ubezpieczyciela może być uznane za klauzulę niedozwoloną, nie jest zupełnie oczywista z uwagi na zastrzeżenie zawarte $\mathrm{w}$ zdaniu drugim $\mathrm{z}$ art. $385^{1} \$ 1$ k.c. Przy przyjęciu teorii ponoszenia ryzyka, niezależnie od treści przypisywanej świadczeniu ubezpieczyciela w postaci ponoszenia ryzyka, wyłączenia odpowiedzialności zdają się stanowić postanowienia wyznaczające charakter głównych świadczeń stron, które nie mogą być uznane za klauzule niedozwolone, jeżeli tylko zostały sformułowane w sposób jednoznaczny ${ }^{143}$. Kwestia ta została postawiona wcześniej przy okazji omawiania orzecznictwa SN dotyczącego klauzuli proporcji. Wypada przypomnieć, że za główne świadczenie w rozumieniu art. $385^{1} \S$ k.c. uznano wtedy świadczenie spełnianie przez ubezpieczyciela w razie zajścia wypadku ubezpieczeniowego, pomimo że zdaniem autora ubezpieczyciel co do zasady świadczy także, gdy wypadek ubezpieczeniowy nie następuje.

142 Co do mechanizmów ochrony konsumenta w umowie ubezpieczenia, zob. M. Więcko-Tułowiecka, Ochrona...

143 Podobnie M. Krajewski, Umowa ubezpieczenia a niedozwolone postanowienia umowne [w:] Niedozwolone postanowienia umowne w umowach ubezpieczenia, red. K. Zaradkiewicz, Warszawa 2013, s. 38 i 39, oraz M. Krajewski, Umowa ubezpieczenia. Art. 805-834 KC..., 2016, s. 76-77. 
Powyższy pogląd wymaga obecnie szerszego uzasadnienia. Jak wskazuje M. Ziemiak, w celu efektywnej realizacji uprawnień wynikających z przepisów o klauzulach abuzywnych, pojęcie świadczenia głównego ubezpieczyciela powinno być rozumiane wąsko i obejmować jego podstawową charakterystykę i parametry (ale już nie np. szczegółowe zasady ustalania odszkodowania czy wspomniane postanowienia określające ograniczenia zakresu czy wyłączenia odpowiedzialności) ${ }^{144}$. W uzasadnieniu autor powołuje postanowienie Sądu Najwyższego z 6.01.2005 r., III CZP 76/04 ${ }^{145}$, oraz uchwałę tego sądu z 29.06.2007 r., III CZP 62/07 ${ }^{146}$, w której expressis verbis przytacza się postulat doktryny, aby: „pojęcie postanowień określających główne świadczenia stron rozumieć wąsko jako obejmujący jedynie klauzule odnoszące się wprost do obowiązku głównego, realizowanego w ramach umowy, przez określenie jego zakresu, a wszelkie wątpliwości należy rozstrzygać na rzecz objęcia klauzuli kontrolą merytoryczną".

Na przeciwnym stanowisku stoi M. Pokrzywniak, który aprobując teorię ponoszenia ryzyka oraz łącząc ją z wzajemnością umowy ubezpieczenia, uważa, że postanowienia wyłączające pewne ryzyka z zakresu ochrony ubezpieczeniowej określają treść świadczenia głównego ubezpieczyciela i dlatego wymykają się kontroli abstrakcyjnej wzorca umownego, jeżeli są jednoznaczne. Autor ten powołuje w uzasadnieniu preambułę dyrektywy 93/13/EWG o niedozwolonych klauzulach w umowach konsumenckich, gdzie wskazano, że „postanowienia umowy ubezpieczenia, w których jasno określono ryzyko ubezpieczeniowe oraz odpowiedzialność ubezpieczyciela nie będą podlegały kontroli, ponieważ takie ograniczenia brane są pod uwage przy obliczaniu składki opłacanej przez konsumenta"147.

144 M. Ziemiak, Klauzule abuzywne w Restatement of European Insurance Contract Law a prawo polskie, RU 2010/2, s. 164-165. Zob. również M. Ziemiak, Postanowienia..., s. 345 i n.

145 Prok. i Pr.-wkł. 2005/11, s. 40.

146 OSNC 2008/7-8, poz. 87.

147 J. Pokrzywniak, Regulacja... Podobnie, jak się zdaje, choć bez jednoznacznego stanowiska, Z. Długosz, Niedozwolone postanowienia umowne w umowach ubezpieczenia [w:] Kierunki rozwoju ubezpieczeń gospodarczych w Polsce. Wybrane zagadnienia prawne, 
Obydwa orzeczenia przytoczone przez M. Ziemiaka jako argumenty na rzecz wąskiego rozumienia terminu „postanowienia określające główne świadczenia stron" dotyczą waloryzacji sumy ubezpieczenia w umowie ubezpieczenia na życie. Sąd Najwyższy nie rozważał w nich teorii ponoszenia ryzyka, zawężając jedynie pojęcie świadczenia pieniężnego ubezpieczyciela przez wskazanie, że umowna klauzula waloryzacyjna nie określa bezpośrednio świadczenia głównego (np. świadczenia ubezpieczeniowego), ale jedynie wprowadza umowny reżim jego podwyższania. W ujęciu Sądu Najwyższego zatem jedynie wysokość nominalnej sumy ubezpieczenia stanowi świadczenie główne w umowie ubezpieczenia. Nie stanowi natomiast świadczenia głównego określenie sposobu modyfikacji pierwotnej sumy ubezpieczenia przez wprowadzenie klauzuli indeksowej ${ }^{148}$. W zakresie tej drugiej części postanowienia umowy ubezpieczenia podlegać mogą kontroli w świetle przepisów o niedozwolonych klauzulach umownych.

Dokładniej omawianą kwestią Sąd Najwyższy zajął się w wyroku z 30.09.2015 r., I CSK 800/14 ${ }^{149}$, dotyczącym klauzuli ograniczającej odpowiedzialność ubezpieczyciela w umowie ubezpieczenia kosztów leczenia przez wprowadzenie maksymalnego okresu hospitalizacji limitującego obowiązek świadczenia pieniężnego ubezpieczyciela. Sąd Najwyższy przypomniał omówione we wcześniejszej części pracy orzecznictwo, w którym klauzulę proporcjonalności uznano za określającą główne świadczenia stron, oraz na orzecznictwo odmawiające takiego charakteru postanowieniom wprowadzającym umowne klauzule waloryzacyjne. Następnie SN, powołując się na obowiązek wykładni prounijnej, rozważył stanowisko Europejskiego Trybunału Sprawiedliwości (Trybunału Sprawiedliwości Unii Europejskiej), zajęte w związku z interpretacją terminu „główny przedmiot umowy” zawartego w art. 4 ust. 2 dyrektywy Rady 93/13/EWG.

red. B. Gnela, M. Szaraniec, Warszawa 2013, s. 73-74. Autor ten zdaje się łączyć główne świadczenia stron z essentialia negotii umowy ubezpieczenia.

148 Por. również M. Szczepańska w glosie do uchwały SN z 29.06.2007 r., III CZP 62/07, LEX/el. 2009. Stanowisko to zostało powtórzone w wyroku SN z 2.04.2015 r., I CSK 257/14, LEX nr 1710338.

149 OSNC 2016/9, poz. 105. 
Zgodnie z powołanym przepisem ocena nieuczciwego charakteru warunków nie dotyczy ani określenia głównego przedmiotu umowy, ani relacji ceny i wynagrodzenia do dostarczonych w zamian towarów i usług, jeżeli warunki te zostały wyrażone prostym i zrozumiałym językiem. Interpretacji postanowień umowy ubezpieczenia w świetle tego przepisu Trybunał Sprawiedliwości Unii Europejskiej dokonał w wyroku z 23.04.2015 r., C-96/14, Jean-Claude van Hove przeciwko CNP Assurances $\mathrm{SA}^{150}$. Uwzględniono przy tym treść motywu 19 dyrektywy, odnoszącego się do umowy ubezpieczenia, w myśl którego umowy ubezpieczenia, które jasno określają ryzyko ubezpieczeniowe (lub zakreślają jego granice) oraz określają odpowiedzialność ubezpieczyciela, nie będą podlegały wskazanej ocenie, ponieważ takie ograniczenia brane są pod uwagę przy obliczaniu składki opłacanej przez konsumenta.

Trybunał, odwołując się do swego wcześniejszego orzecznictwa, stwierdził, że transakcja ubezpieczeniowa charakteryzuje się tym, że ubezpieczyciel zobowiązuje się w zamian za uprzednią zapłatę składki do świadczenia ubezpieczonemu, w przypadku realizacji ryzyka ubezpieczeniowego, usługi uzgodnionej przy zawarciu umowy. Trybunał orzekł, że warunek ustanowiony w umowie ubezpieczenia jest objęty zakresem wyjątku zawartego w art. 4 ust. 2 dyrektywy tylko wtedy, gdy sąd odsyłający stwierdzi, że w świetle charakteru, ogólnej systematyki i postanowień całości stosunku umownego, w którą ten warunek się wpisuje, a także kontekstu prawnego i faktycznego tego stosunku, wspomniany warunek określa podstawowy element wspomnianej całości, który jako taki ją charakteryzuje, oraz że warunek jest sporządzony prostym i zrozumiałym językiem, czyli że jest nie tylko zrozumiały dla konsumenta pod względem gramatycznym, ale też że umowa wyjaśnia w sposób przejrzysty konkretne funkcjonowanie mechanizmu, do którego odnosi się dany warunek, a także stosunek pomiędzy tym mechanizmem a mechanizmem przewidzianym w innych warunkach, tak aby konsument był w stanie przewidzieć, na podstawie jednoznacznych i zrozumiałych kryteriów, konsekwencje ekonomiczne wynikające dla niego $\mathrm{z}$ ustanowienia tego mechanizmu.

150 EU:C:2015:262. 
W dalszej kolejności Sąd Najwyższy zwrócił uwagę na dwoistość świadczenia ubezpieczeniowego, stwierdzając, że zakład ubezpieczeń na podstawie umowy ubezpieczenia świadczy usługę udzielenia ochrony ubezpieczonemu, ponosząc ryzyko zapłaty w razie zajścia wypadku ubezpieczeniowego, ale gdy do niego dojdzie, wypełnienie zobowiązania następuje przez zapłatę sumy pieniężnej, która staje się świadczeniem głównym. Ostatecznie odnosząc powyższe do okoliczności rozpatrywanej sprawy, SN uznał, że za postanowienie wzorca wyznaczające główne świadczenie zakładu ubezpieczeń nie można uznać klauzuli, która dookreśla zakres obowiązku świadczenia przez wprowadzenie jego ograniczeń limitowanych terminem hospitalizacji. Warunki mające charakter posiłkowy względem postanowień umowy definiujących samą istotę obowiązku dłużnika $\mathrm{z}$ danego stosunku prawnego nie mogą być objęte pojęciem głównych świadczeń w rozumieniu art. $385^{1} \$ 1$ zdanie drugie k.c. Sporne postanowienie nie charakteryzuje i nie oznacza zobowiązania dłużnika, lecz go „dotyczy”, stanowiąc jedno z wielu ograniczeń zakresu obowiązku świadczenia ciążącego na zakładzie ubezpieczeń w razie zaistnienia wypadku ubezpieczeniowego. Nie można mu także przypisać znaczenia podstawowego w omawianym stosunku prawnym.

Podkreślić należy, że w cytowanym wyroku Sąd Najwyższy de facto zaaprobował teorię ponoszenia ryzyka, wskazując, że ubezpieczyciel świadczy usługę udzielenia ochrony ubezpieczonemu, ponosząc ryzyko zapłaty w razie zajścia wypadku ubezpieczeniowego. Jednocześnie jednak wskazał, że jeżeli do wypadku ubezpieczeniowego nie dojdzie, wypełnienie zobowiązania następuje przez zapłatę sumy pieniężnej, która staje się świadczeniem głównym. Stanowisko to jest zbieżne z zaproponowanym wcześniej przy okazji omawiania niedozwolonego charakteru klauzuli proporcjonalności. Wbrew stanowisku M. Ziemiaka nie trzeba zatem rezygnować z teorii ponoszenia ryzyka, by poddać kontroli jedynie świadczenie spełniane w razie zajścia wypadku ubezpieczeniowego. Przyjąć można, że ustawodawca, używając w zdaniu drugim art. $385^{1}$ $\$ 1$ k.c. kwantyfikatora "główne”, zmierzał do zawężenia zastrzeżenia tam zawartego jedynie do konkretnych i najistotniejszych obowiązków składających się na świadczenie w szerokim znaczeniu. Świadczeniem głównym ubezpieczyciela w umowie ubezpieczenia na gruncie art. $358^{1}$ $\$ 1$ k.c. byłaby w takim ujęciu jedynie zapłata określonego w umowie 
odszkodowania oraz zapłata umówionej sumy pieniężnej, wymienione w art. $805 \$ 2$ k.c. po słowach „W szczególności”.

Nieco inaczej podchodzą do sprawy autorzy Principles of European Insurance Contract Law. Zgodnie z art. 2-304:1 PEICL warunki umowy, które nie były indywidualnie negocjowane, nie wiążą ubezpieczającego, ubezpieczonego lub beneficjenta, jeżeli stoją w sprzeczności z wymogami dobrej wiary i dobrych praktyk rynkowych, powodują znaczącą nierównowagę wynikających dla nich z umowy praw i obowiązków, biorąc pod uwagę istotę umowy ubezpieczenia, a także pozostałe postanowienia umowy oraz okoliczności, w których została zawarta. Ustęp 3 zastrzega, że przepis stosuje się do warunków, które ograniczają lub zmieniają zakres ochrony ubezpieczeniowej, jednakże ocena nieuczciwego charakteru warunków nie dotyczy: (a) relacji wartości ochrony ubezpieczeniowej do składki ubezpieczeniowej ani (b) określenia głównego przedmiotu udzielanej ochrony ubezpieczeniowej i uzgodnionej składki ubezpieczeniowej, o ile warunki te zostały wyrażone prostym i zrozumiałym językiem.

Autorzy przytoczonej normy wskazują wyraźnie, że wyłączenie kontroli niedozwolonego charakteru dotyczy jedynie zasadniczych postanowień umowy (core terms), opisując postanowienia zasadnicze jako te, które rozstrzygają o typie i przedmiocie ubezpieczenia, ubezpieczonym ryzyku, odpowiedzialności ubezpieczyciela, korzyści uzyskiwanej przez ubezpieczającego, sumie ubezpieczenia, interesie oraz wartości ubezpieczenia. Jednocześnie autorzy PEICL zastrzegają, że postanowienia ograniczające, zmieniające, opisujące albo modyfikujące obowiązek świadczenia po stronie ubezpieczyciela nie stanowią postanowień zasadniczych w rozumieniu przepisu. Przykładowo wskazują, że w ubezpieczeniu odpowiedzialności cywilnej postanowienie przewidujące wyłączenie odpowiedzialności za szkodę czysto majątkową może podlegać kontroli jako klauzula niedozwolona ${ }^{151}$.

Dodać można, że podobnie omawianą kwestie ujmuje się w prawie niemieckim. Według orzecznictwa nie podlegają kontroli tylko takie

151 Principles..., s. 117. 
postanowienia, które opisują bezpośrednio przedmiot należnego świadczenia (rodzaj, wartość i zakres należnego świadczenia). Klauzule, które ograniczają, zmieniają, przeformułowują lub modyfikują obietnice głównego świadczenia, mogą być poddane kontroli treściowej. Do bardzo wąskiego zakresu klauzul, które nie podlegają kontroli treściowej, należą klauzule, które bezpośrednio ustalają cenę głównego świadczenia wynikającego z umowy. Do postanowień podlegających kontroli należą w szczególności te, które formułują wyłączenia odpowiedzialności, powinności ubezpieczeniowe, terminy realizacji konkretnych obowiązków, a także uregulowane w ogólnych warunkach ubezpieczenia prawa kształtujące ${ }^{152}$.

W literaturze polskiej wskazano, że klauzule niedozwolone w obrocie ubezpieczeniowym Polski, Niemiec i Francji dotyczą tych samych elementów stosunku ubezpieczenia, w szczególności zaś właśnie nadmiernych i nieuzasadnionych wyłączeń bądź ograniczeń odpowiedzialności ubezpieczyciela ${ }^{153}$. Wielu przykładów w tym zakresie dostarcza orzecznictwo polskiego Sądu Ochrony Konkurencji i Konsumentów. Poza klauzulami nakładającymi na ubezpieczającego przestrzeganie określonych obowiązków, których niedochowanie skutkować miało zwolnieniem ubezpieczyciela z odpowiedzialności, za niedozwolone uznawano m.in.:

- klauzule wyłączające odpowiedzialność za szkody w budynku wynikające z faktu, że jego konstrukcja lub wykonanie nie odpowiadają normom obowiązującym w budownictwie ${ }^{154}$,

- klauzule wyłączające odpowiedzialność za szkody powstałe w innych okolicznościach niż podane w zgłoszeniu szkody ${ }^{155}$,

152 Zob. M. Wandt, Versicherungsrecht, s. 100-101.

153 M. Ziemiak, Klauzule abuzywne w polskim obrocie ubezpieczeniowym. Ocena mechanizmów ochrony konsumenta w Polsce na tle rozwiązań niemieckich i francuskich, RU 2008/4, s. 98.

154 Klauzula nr 1223 i 1224, wyrok SOKiK z 21.12.2006 r., XVII AmC 103/05.

155 Klauzula nr 1291, wyrok SOKiK z 6.03.2008 r., XVII AmC 123/07, MSiG 2008/47, poz. 2969. Klauzula nr 1654, wyrok SOKiK z 25.02.2009 r., XVII AmC 252/08, MSiG 2009/201, poz. 12815. Klauzula nr 1719, wyrok SOKiK z 3.08.2009 r., XVII AmC 249/08, Klauzule..., 2012, s. 98. Klazula nr 2010, wyrok SOKiK z 9.02.2010 r., XVII AmC 155/09, Klauzule... 2012, s. 114-115. Klauzula nr 2526, wyrok SOKiK z 20.05.2011 r., XVII AmC 1153/09, MSiG 2012/42, poz. 2754. 
- klauzule wyłączające odpowiedzialność za szkody zaistniałe w sytuacji, gdy ubezpieczający był pod wpływem alkoholu, narkotyków lub innych środków odurzających ${ }^{156}$,

- klauzule wyłączające odpowiedzialność za szkody wynikłe z powodu działania hałasu, wibracji, ciepła, wody lub innych podobnych czynników ${ }^{157}$,

- klauzule wyłączające odpowiedzialność za szkody powstałe podczas ruchu pojazdu, który nie był dopuszczony do ruchu, nie był zarejestrowany lub nie posiadał ważnego badania technicznego ${ }^{158}$,

- klauzule wyłączające odpowiedzialność za szkody w pojeździe nielegalnie wprowadzonym za obszar celny UE, tj. wówczas, gdy pojazd nie został dostarczony lub zgłoszony do miejsca kontroli celnej albo w zgłoszeniu celnym lub innym dokumencie podano nieprawdziwe dane ${ }^{159}$,

- klauzule wyłączające odpowiedzialność w razie zawarcia ubezpieczenia wielokrotnego $\mathrm{z}$ tytułu umów ubezpieczenia poza umową zawartą najwcześniej ${ }^{160}$.

Kwestia, czy przytaczane wyżej postanowienia określały główne świadczenia stron, zwykle w ogóle nie była przedmiotem rozważań, co przynajmniej częściowo można tłumaczyć ich niejednoznacznością (użycie sformułowań: normy obowiązujące w budownictwie, inne środki odurzające, inne podobne czynniki, inne dokumenty ${ }^{161}$. W wyroku dotyczącym ubezpieczenia podwójnego SOKiK potraktował sprawę jako oczywistą, wskazując, że postanowienie nie określało w żaden sposób świadczenia strony pozwanej, a wyłączało jego odpowiedzialność (zwalniało go z obowiązku zapłaty) z tytułu kolejnych umów, gdy zawarta

156 Klauzula nr 1315, wyrok SOKiK z 11.10.2007 r., XVII AmC 68/06. Klauzula nr 2008, wyrok SOKiK z 9.02.2010 r., XVII AmC 782/09, Klauzule..., 2012, s. 112-113.

157 Klauzula nr 1426, wyrok SOKiK z 30.10.2007 r., XVII AmC 86/06, MSiG 2008/117, poz. 8166 .

158 Klauzula nr 2560, wyrok SOKiK z 7.04.2011 r., XVII AmC 1509/10.

159 Klauzula nr 3035, wyrok SOKiK z 18.01.2011 r., XVII AmC 37/10, MSiG 2012/144, poz. 10156.

160 Klauzula nr 3461, wyrok SOKiK z 19.09.2011 r., XVII AmC 145/10.

161 Na brak spójnej koncepcji w orzecznictwie SOKiK zwraca uwagę M. Krajewski, Umowa ubezpieczenia. Art. 805-834 KC..., 2016, s. 77-78. 
została więcej niż jedna umowa. Ostatecznie zaś stwierdził, że klauzula przewidywała obowiązek wykonania zobowiązania przez konsumenta mimo niewykonania zobowiązania przez jego kontrahenta (art. $385^{3}$ pkt 22 k.c.) ${ }^{162}$.

Nieco więcej uwagi rozumieniu sformułowania „główne świadczenia stron" poświęcono w wyroku SOKiK z 23.01.2017 r., XVII AmC 109/15 163 , dotyczącym arbitralnego ustalenia przez ubezpieczyciela wartości wykupu w kolejnych latach obowiązywania umowy ubezpieczenia na życie. W uzasadnieniu tego wyroku stwierdzono, że pojęcie "głównych świadczeń stron" nie zostało w żaden sposób sprecyzowane przez ustawodawcę, jednakże należałoby sądzić, że z reguły obejmuje ono elementy konstrukcyjne umowy, bez których uzgodnienia nie doszłoby do jej zawarcia, czyli tzw. essentialia negotii. W niniejszym przypadku są to: ze strony pozwanej - świadczenie usług ubezpieczeniowych na rzecz konsumentów, ze strony zaś konsumenta - zapłata ceny za świadczone przez pozwanego usługi. Następnie przywołano stanowisko Sądu Najwyższego zawarte w przytoczonej wyżej uchwale tego sądu z 29.06.2007 r., że rozpatrywane pojęcie należy rozumieć wąsko, rozstrzygając wszelkie wątpliwości na rzecz objęcia klauzuli kontrolą merytoryczną. Zdaniem SOKiK nie bez powodu ustawodawca posłużył się sformułowaniem "postanowienia określające główne świadczenia stron”, nie zaś „dotyczące” ich, które może mieć szerszy zakres interpretacyjny.

Podsumowując powyższe uwagi, wydaje się, że głównym świadczeniem ubezpieczyciela $\mathrm{z}$ umowy ubezpieczenia w rozumieniu art. $385^{1} \$ 1$ k.c. nie jest ochrona ubezpieczeniowa, ale świadczenie spełniane w razie zajścia wypadku ubezpieczeniowego. Dzięki użyciu przez ustawodawcę określenia „główne” poglądu tego można bronić, także aprobując tzw. teorię ponoszenia ryzyka w zakresie tezy, że ubezpieczyciel spełnia świadczenie z umowy ubezpieczenia w sytuacji, gdy wypadek ubezpieczeniowy nie występuje. Ujęcie takie pozwala poddać wyłączenia

162 Aneks do raportu Rzecznika Praw Ubezpieczonych. Klauzule abuzywne $w$ działalności ubezpieczeniowej, Warszawa 2014, s. 71.

163 LEX nr 2246437. 
odpowiedzialności kontroli przez pryzmat przepisów o klauzulach niedozwolonych, choćby były sformułowane jednoznacznie. Pozostawienie wyłączeń odpowiedzialności poza zakresem tej kontroli pozostawałoby zresztą w jaskrawej sprzeczności z celem przepisów mających chronić konsumenta przed narzucaniem nieuczciwych warunków umownych. Pozostawienie wyłączenia poza zakresem kontroli można zatem rozważać jedynie wyjątkowo, gdy należy ono do samej istoty określenia w danej umowie wypadku ubezpieczeniowego oraz pozostaje w bezpośredniej relacji z wymiarem składki ubezpieczeniowej.

Odrębną zasygnalizowaną na wstępie kwestię stanowi znaczenie dla ważności oraz interpretacji wyłączeń odpowiedzialności ubezpieczyciela przepisów ustawy o dystrybucji ubezpieczeń w szczególności art. 8 tej ustawy. Poza omówionym już wcześniej warunkiem ujęcia ważniejszych wyłączeń odpowiedzialności w dokumencie zawierającym informację o produkcie ubezpieczeniowym (art. 8 ust. 6 u.d.u.), wskazany przepis obciąża dystrybutora ubezpieczeń obowiązkiem przeprowadzenia testu wymagań i potrzeb klienta (art. 8 ust. 1 u.d.u.) oraz stanowi, że proponowana umowa ubezpieczenia lub gwarancji ubezpieczeń powinna być zgodna $\mathrm{z}$ tymi wymaganiami i potrzebami (art. 8 ust. 3 u.d.u.). Jawi się pytanie, czy wyłączenia sprzeczne $\mathrm{z}$ wymaganiami i potrzebami klienta, które ostatecznie znalazły się w zawartej umowie ubezpieczenia, mogą być uznane za nieważne, ewentualnie czy wymagania i potrzeby klienta mogą mieć znaczenia dla ich interpretacji.

Ustawa o dystrybucji ubezpieczeń rodzi oczywiście cały szereg problemów szczególnych, których analiza wykracza poza zakres niniejszej pracy. Rozważania dotyczące związanych $\mathrm{z}$ nią kwestii będą zatem $\mathrm{z}$ konieczności skrótowe ${ }^{164}$. Należy mieć na uwadze, że ustawa skierowana jest do dystrybutorów ubezpieczeń rozumianych najogólniej jako sprzedawcy produktów ubezpieczeniowych. Zasadniczym celem ustawy jest ochrona klientów dystrybutorów przed tzw. misselingiem ${ }^{165}$.

164 Na rynku jest obecnie dostępny jeden komentarz do ustawy. Zob. Ustawa o dystrybucji ubezpieczeń. Komentarz, red. P. Czublun, Warszawa 2017. Powstają jednak kolejne.

165 Pojęcia dystrybutorów i klientów ubezpieczeń zdefiniowane są w art. 3 ustawy zawierającym tzw. słowniczek. Pojęcie produktu ubezpieczeniowego nie ma definicji 
Użycie żargonu ubezpieczeniowego w powyższych zdaniach jest celowe. $Z$ ubolewaniem należy bowiem stwierdzić, że ustawa o dystrybucji jest przykładem wpływu prawa unijnego na ekonomizację polskiego języka prawnego ${ }^{166}$.

Dodatkowo wypada zauważyć, że choć polski ustawodawca zdecydował się uznać za twórców produktów ubezpieczeniowych również pośredników ubezpieczeniowych ${ }^{167}$, w praktyce osoby zaangażowane w czynności dystrybucyjne jedynie wyjątkowo mają wpływ na kształt konkretnych postanowień ogólnych warunków ubezpieczenia, częściej zaś zajmują się dystrybucją produktów o kształcie zawczasu określonym przez odpowiednie służby zakładów ubezpieczeń. Wyjątki dotyczą przede wszystkim klientów o dużym potencjale ekonomicznym mających odpowiednią siłę negocjacyjną. Niezależnie od powyższego należy powątpiewać, czy każda modyfikacja zastanych warunków z uwagi na potrzeby konkretnego klienta powinna być uznana za utworzenie nowego produktu ubezpieczeniowego.

Mając na uwadze powyższe spostrzeżenia, wydaje się, że niedostosowanie zastanych warunków ubezpieczenia do wymagań i potrzeb konkretnego klienta może bezpośrednio prowadzić do nieważności czy bezskuteczności określonych postanowień jedynie wyjątkowo. Dotyczyć to będzie w szczególności sytuacji, gdy test wymagań i potrzeb klienta można uznać za element wniosku ubezpieczeniowego i ubezpieczyciel doręczy ubezpieczającemu dokument ubezpieczenia zawierający postanowienia ${ }^{168}$, które odbiegają na niekorzyść ubezpieczającego od

ustawowej. Odnosi się do niego przede wszystkim rekomendacja KNF w sprawie zarządzania produktem ubezpieczeniowym z 22.03.2016 r., jedna z rekomendacji KNF, które oczywiście nie mają mocy powszechnie obowiązującej. Zob. przykładowo K. Malinowska, Pojęcie zarządzania produktem ubezpieczeniowym $w$ świetle dyrektywy o dystrybucji ubezpieczeń i przepisów implementacyjnych, WU 2017/1, s. 9-10.

166 Zob. K. Malinowska i in., Koncepcja rynku pośrednictwa ubezpieczeniowego (projekt ustawy o pośrednictwie ubezpieczeniowym), Warszawa 2017, s. 25.

167 Zob. uzasadnienie rządowego projektu ustawy o dystrybucji ubezpieczeń, VIII kadencja, druk sejm. nr 1781. Porównaj K. Malinowska i in., Koncepcja..., s. 24.

168 Propozycję traktowania ankiety oceniającej potrzeby i wymagania klienta jako elementów wniosku ubezpieczeniowego i oferty ubezpieczającego formuje D. Maśniak. Zob. D. Maśniak, Czy test wymagań i potrzeb to wniosek ubezpieczeniowy [w:] Dystrybucja 
treści złożonego przez niego wniosku, zaniedbując przy tym obowiązek zwrócenia na to uwagi ubezpieczającego na piśmie i wyznaczenia mu przynajmniej 7-dniowego terminu na złożenie sprzeciwu. W tym przypadku zmiany dokonane na niekorzyść ubezpieczającego okażą się nieskuteczne, a umowa dojdzie do skutku na warunkach określonych we wniosku ubezpieczeniowym (art. 811 k.c.).

W innych sytuacjach sprecyzowanie konkretnych wymagań i potrzeb powinno natomiast wpływać na interpretację określonych postanowień umownych w kierunku odpowiadającym tymże wymaganiom i potrzebom. Można w tym miejscu odwołać się do przytoczonego wyżej przykładu z orzecznictwa, gdy ubezpieczający prowadzący działalność gospodarczą polegającą na wynajmie pojazdów mechanicznych zawiera ostatecznie umowę ubezpieczenia, która zdaje się wyłączać odpowiedzialność ubezpieczyciela za kradzież lub przywłaszczenie pojazdu oddanego do używania osobie trzeciej. Niejednoznaczne postanowienia umowy należy w tej sytuacji wykładać w kierunku pozwalającym na przypisanie ubezpieczycielowi odpowiedzialności.

Należy podkreślić, że uwzględnienie wymagań i potrzeb konkretnego klienta przy interpretacji zaproponowanych mu warunków umowy ubezpieczenia pozostaje w bezpośrednim związku z wcześniej omówionym ograniczeniem swobody umów w postaci właściwości i natury stosunku ubezpieczenia, w szczególności zaś z ochronnym celem tego stosunku, jak również z regułą wykładni ogólnych warunków umowy ubezpieczenia contra proferentem. Wypada przy tej okazji wyrazić ubolewanie, że przepisy ograniczające swobodę ubezpieczyciela w zakresie formułowania warunków konkretnego stosunku ubezpieczenia rozsiane są obecnie w kilku różnych ustawach (w szczególności w Kodeksie cywilnym, ustawie o działalności ubezpieczeniowej i reasekuracyjnej oraz ustawie o dystrybucji ubezpieczeń).

usług ubezpieczeniowych, red. B. Gnela, M. Szaraniec, Warszawa 2017, s. 44-45. Problem wydaje się jednak polegać na tym, że sprecyzowanie konkretnych wymagań i potrzeb tylko w niektórych sytuacjach stanowić będzie stanowczą propozycję zawarcia umowy. 
W pozostałych sytuacjach, tzn. przede wszystkim wtedy, gdy sformułowanie wymagań i potrzeb nie pozwoli na uznanie ich za część oferty przedstawionej zakładowi ubezpieczeń, natomiast jednoznaczne sformułowanie postanowień umowy lub ogólnych warunków ubezpieczeń wykluczy możliwość korzystnej dla ubezpieczającego ich interpretacji, regulacja $z$ art. 8 u.d.u. nie wywrze skutku w sferze zawartej umowy ubezpieczenia. Klient dystrybutora nie będzie jednak pozbawiony ochrony, będzie mógł bowiem na podstawie art. 8 u.d.u. formułować względem niego roszczenia odszkodowawcze. Prima facie wydaje się, że odpowiedzialność ubezpieczyciela za działania jego pracowników i agentów, jak również odpowiedzialność samych agentów będzie mieć naturę deliktową, natomiast odpowiedzialność brokerów naturę kontraktową. We wszystkich przypadkach dystrybutorzy mogą odpowiadać za szkodę poniesioną przez ubezpieczającego lub ubezpieczonego na skutek nieuzyskania konkretnego odszkodowania ubezpieczeniowego.

W konkluzji, rozpatrując szeroko zagadnienie kryteriów formułowania skutecznych wyłączeń odpowiedzialności w świetle ograniczeń swobody umów oraz ochrony konsumenta przed narzucaniem nieuczciwych warunków umownych, można zaaprobować wymagania sformułowane przez M. Serwach. Po pierwsze, wyłączenia odpowiedzialności powinny być wyraźne, tj. nazwane oraz wyodrębnione jako wyłączenia w strukturze wewnętrznej ogólnych warunków ubezpieczenia. Po drugie, wyłączenia mają być jednoznaczne i precyzyjne. Ubezpieczający niezależnie od swoich kwalifikacji podmiotowych winien mieć możliwość zapoznania się z nimi oraz zrozumienia ich zakresu w chwili zawierania umowy ubezpieczenia. Po trzecie wyłączenia nie mogą być zbyt szerokie, wziąwszy pod uwagę przede wszystkim ochronny cel każdej umowy ubezpieczenia oraz cel, który przyświecał ubezpieczającemu, gdy zawierał konkretną umowę ubezpieczenia. W tym zakresie należy właśnie brać pod uwagę wymagania i potrzeby konkretnego klienta, które winny być ustalone przez dystrybutora zgodnie $\mathrm{z}$ art. 8 u.d.u.

Dodatkowo, po czwarte, należy podkreślić znaczenie formułowanego w doktrynie oraz orzecznictwie obowiązku uprzedzenia ubezpieczającego, w szczególności mającego status konsumenta lub będącego osobą fizyczną prowadzącą działalność gospodarczą, o wyłączeniach oraz 
ograniczeniach odpowiedzialności. Obowiązek taki jest aktualny przede wszystkim w sytuacji, gdy w świadomości społecznej ukształtował się stereotyp szerokiego czy pełnego zakresu ochrony ubezpieczeniowej w konkretnym rodzaju ubezpieczenia ${ }^{169}$. Realizacja wskazanego wyżej obowiązku przez ubezpieczycieli w praktyce ubezpieczeniowej przyczyniłaby się z całą pewnością do usunięcia jednej z podstawowych przyczyn negatywnej oceny konkretnych postanowień ogólnych warunków ubezpieczenia, a mianowicie zaskoczenia ubezpieczającego konkretną klauzulą. Dodać można, że w prawie niemieckim element obiektywnego oraz subiektywnego zaskoczenia wprost decyduje o nieważności konkretnych klauzul ${ }^{170}$. W pewnym zakresie rolę takiego uprzedzenia mogą pełnić informacje zawarte na pierwszej stronie OWU zgodnie $\mathrm{z}$ art. 17 u.d.u.r. oraz $\mathrm{w}$ ustandaryzowanym dokumencie informującym o produkcie ubezpieczeniowym zgodnie $\mathrm{z}$ art. 8 ust. 6 u.d.u. Jaką rolę odegrają obydwa wskazane przepisy, pokaże praktyka.

169 Zob. B. Kęszycka, Dobre obyczaje jako kryterium oceny ubezpieczeniowego wzorca umownego, PA 2009/1, s. 33-34. Autorka ta postuluje nawet wprowadzenie do polskiego porządku prawnego, istniejącego w prawie włoskim oraz hiszpańskim, obowiązku uzyskania przez ubezpieczyciela potwierdzenia przyjęcia przez konsumenta do wiadomości klauzul szczególnie dotkliwych, co do których należy w myśl rzetelności kontraktowej upewnić się, czy zostały przez kontrahenta uświadomione i zrozumiane. Klauzule te winny być dla swej skuteczności wyraźnie wskazane konsumentowi przed zawarciem umowy, wyeksponowanie i przez konsumenta podpisane.

170 Zob. M. Wandt, Versicherungsrecht, s. 96-97. 

Rozdział 7

\section{NAPRAWIENIE SZKODY PRZEZ UBEZPIECZYCIELA W DRODZE RESTYTUCJ NATURALNEJ}

\subsection{Wprowadzenie}

Przepisy ogólne o naprawieniu szkody pozwalają poszkodowanemu wybrać między restytucją naturalną a odszkodowaniem pieniężnym (art. 363 k.c.). Odszkodowanie ubezpieczeniowe intuicyjnie traktowane jest zwykle jako odszkodowanie pieniężne. Rozwój różnego rodzaju ubezpieczeń assistance zdaje się jednak wskazywać na możliwość spełnienia przez ubezpieczyciela świadczenia w naturze. Także w innych ubezpieczeniach rozwiązanie takie mogłoby mieć swoje zalety dla obu stron stosunku ubezpieczenia: ubezpieczającemu, który doznał szkody wskutek zajścia wypadku ubezpieczeniowego, powinno wszak zależeć nie tyle na uzyskaniu pieniędzy, ile na przywróceniu do stanu sprzed jej wystąpienia i zaoszczędzeniu sobie kłopotów, ubezpieczycielowi zaś na tym, by restitutio in integrum odbyło się jak najmniejszym kosztem.

Odpowiedź na pytanie, czy świadczenie ubezpieczyciela może być świadczeniem niepieniężnym, trzeba poprzedzić wyjaśnieniem kilku kwestii wstępnych, które pozwolą zrozumieć sens pytania. Po pierwsze, niniejszy rozdział nie dotyczy sporu między zwolennikami teorii świadczenia pieniężnego i zwolennikami teorii ponoszenia ryzyka. Tezą pracy jest, że ubezpieczyciel świadczy także, jeżeli nie zachodzi wypadek 
ubezpieczeniowy, natomiast roszczenie jako instrument pozwalający na przymusową realizację świadczenia pojawia się dopiero w razie zajścia wypadku, kiedy świadczenie przybiera co do zasady postać świadczenia pieniężnego. Sprawa została już wyjaśniona we wcześniejszej części pracy.

Po drugie, odpowiedzialność gwarancyjno-repartycyjną ubezpieczyciela wynikającą z zawartej umowy ubezpieczenia odróżnić trzeba od odpowiedzialności odszkodowawczej za niewykonanie tej umowy. Ubezpieczyciel, płacąc odszkodowanie, spełnia zatem świadczenie wynikające z zawartej umowy. W razie niespełnienia tego świadczenia, to jest w razie niewykonania umowy, ubezpieczający ma roszczenie o jej wykonanie in natura. W tym przypadku wykonanie umowy polega na żądaniu od ubezpieczyciela odszkodowania, do którego zapłacenia był zobowiązany. Ubezpieczający może oczywiście wybrać również żąanie zapłaty odszkodowania za niewykonanie umowy. Analiza odpowiedzialności gwarancyjno-repartycyjnej ubezpieczyciela jako trzeciego, poza odpowiedzialnością ex contractu i ex delicto, reżimu odpowiedzialności odszkodowawczej również została przeprowadzona wcześniej.

Po trzecie, właśnie w odniesieniu do odpowiedzialności gwarancyjno-repartycyjnej ubezpieczyciela oraz podstawowego świadczenia ubezpieczyciela wynikającego z zawartej umowy ubezpieczenia rodzi się pytanie, czy naprawienie szkody powstałej wskutek zajścia wypadku ubezpieczeniowego może nastąpić jedynie przez zapłatę odszkodowania ubezpieczeniowego, czy też ubezpieczający ma prawo domagać się od ubezpieczyciela przywrócenia stanu poprzedniego na ogólnych zasadach, ewentualnie czy ubezpieczyciel, zamiast zapłaty odszkodowania, może zwolnić się ze zobowiązania, wybierając przywrócenie do stanu poprzedniego. Innymi słowy, chodzi o pytanie, czy dopuszczalne jest spełnienie świadczenia $\mathrm{z}$ umowy ubezpieczenia $\mathrm{w}$ drodze restytucji naturalnej, a nie poprzez zapłacenie odszkodowania.

Po czwarte, istnieją rodzaje ubezpieczeń majątkowych, w których umowa lub ogólne warunki ubezpieczenia zdają się określać treść świadczenia ubezpieczyciela inaczej niż przez zapłatę odszkodowania. Zamiast dania określonej sumy pieniężnej, tj. świadczenia w formie dare, ubez- 
pieczyciel zobowiązuje się do wykonania określonej czynności, czyli do świadczenia w formie facere. Przykładowo w ubezpieczeniu car assistance do zaholowania samochodu i zapewnienia samochodu zastępczego, natomiast w ubezpieczeniach home assistance do naprawy zepsutego sprzętu gospodarstwa domowego. Rodzi się pytanie, czy w tych ubezpieczeniach ubezpieczyciel w istocie zobowiązuje się wyświadczyć określoną usługę, której ubezpieczający poszukuje ze względu za zaistniały wypadek ubezpieczeniowy, czy może zobowiązuje się jedynie pokryć koszty takiej usługi wyświadczonej przez podmiot trzeci.

Niniejszy rozdział dotyczyć ma właśnie dwóch ostatnich pytań. Należy przy tym zastrzec, że kwestia, czy ubezpieczyciel może naprawić szkodę w drodze restytucji naturalnej, wydaje się istotniejsza. Zagadnienie natury świadczenia ubezpieczyciela w ubezpieczeniach assistance (ewentualnie w niektórych innych ubezpieczeniach) jawi się w odpowiednim świetle jako pochodna tej pierwszej kwestii. Niewykluczone wydaje się bowiem ujęcie niektórych rodzajów ubezpieczenia postrzeganych często jako odstępstwo od pieniężnego charakteru odszkodowania ubezpieczeniowego jako zobowiązujących ubezpieczyciela do zapłaty odszkodowania za szkody w postaci dodatkowych wydatków, których konieczność poniesienia powstaje w związku $\mathrm{z}$ wypadkiem ubezpieczeniowym.

Odpowiedzialność ubezpieczeniowa ma oczywiście szereg cech swoistych, które zostały wyjaśnione w pierwszym rozdziale. Przede wszystkim odpowiedzialność ubezpieczeniowa ujmowana jest jako trzeci reżim odpowiedzialności, różny od odpowiedzialności ex delicto i ex contractu ${ }^{1}$. Ponadto pominąwszy ubezpieczenie OC, gdzie zakres odpowiedzialności ubezpieczyciela ma charakter akcesoryjny wobec odpowiedzialności sprawcy, odszkodowanie ubezpieczeniowe może być w różny sposób ograniczone. W ubezpieczeniach nie obowiązuje zatem zasada pełnego odszkodowania ${ }^{2}$. Nie można jednak pomijać, że umowa ubezpieczenia

\footnotetext{
1 Przesądza o tym sam ustawodawca, choć istnieją głosy, że pojęciem odpowiedzialności odszkodowawczej należy obejmować jedynie odpowiedzialność mającą charakter sankcyjny. Zob. przykładowo B. Kucharski, Odpowiedzialność ubezpieczyciela..., s. 49.

2 Co do tych kwestii, zob. rozważania we wcześniejszych rozdziałach. Z literatury zob. przede wszystkim M. Kaliński, Zasada..., cz. 1, s. 40 i n., oraz cz. 2, s. 29 i n. oraz podana tam literatura; A. Wąsiewicz, Odszkodowanie..., s. 21 i n.; E. Kowalewski, Od-
} 
jest jedną z umów obligacyjnych uregulowanych w Kodeksie cywilnym, a odpowiedzialność gwarancyjno-repartycyjna ubezpieczyciela w ubezpieczeniach majątkowych - postacią cywilnej odpowiedzialności odszkodowawczej. Z powyższych względów rozważania dotyczące form naprawienia szkody przez ubezpieczyciela trzeba poprzedzić uwagami dotyczącymi ogólnych zasad naprawienia szkody w prawie cywilnym.

\subsection{Sposoby naprawienia szkody w prawie cywilnym}

Podstawowe reguły prawa polskiego dotyczące naprawienia szkody sformułowane są $\mathrm{w}$ art. 363 k.c. Zagadnienie ma charakter zupełnie podstawowy, a literatura jest niezmiernie bogata ${ }^{3}$. Od czasów wypowiedzi A. Szpunara większość autorów powtarza podobne stwierdzenia ${ }^{4}$. Z nowszej literatury zwraca uwagę obszerna monografia M. Kalińskiego podsumowująca wcześniejsze wypowiedzi doktryny ${ }^{5}$. W sprawie trudno powiedzieć coś nowego. Niniejsze rozważania wydają się niezbędne, ale nie pretendują do miana nowości. Można je uporządkować według kilku najistotniejszych zagadnień. Po pierwsze, przypomnienia wymaga przyjęte przez polskiego ustawodawcę rozwiązanie co do sposobów naprawienia szkody na tle rozwiązań możliwych. Po drugie, należy wyjaśnić charakter prawny wyboru między restytucją naturalną a świadczeniem pieniężnym. Po trzecie, ze względu na tytuł podrozdziału istotne jest przeanalizowanie samego pojęcia i możliwych form restytucji naturalnej.

szkodowanie ubezpieczeniowe za utracone korzyści, s. 45 i n. Pionierski charakter miały oczywiście w tym zakresie prace W. Warkałły: Odpowiedzialność..., Zasada..., s. 430 i n., oraz Ubezpieczenie utraconych korzyści..., s. 43 i n.

${ }^{3}$ Poza komentarzami do art. 362 k.c. oraz przytaczanymi w kolejnych przypisach wypowiedziami A. Szpunara i M. Kalińskiego można wskazać przede wszystkim następujące pozycje: A. Winiarz, Obowiązek...; T. Dybowski Naprawienie..., s. 284.

${ }^{4}$ A. Szpunar, Ustalenie odszkodowania w prawie...; A. Szpunar, Odszkodowanie...; A. Szpunar, O sposobach naprawienia szkody na mieniu, NP 1971/11; A. Szpunar, Restytucja naturalna jako sposób naprawienia szkody, NP 1985/1.

${ }_{5}^{5}$ M. Kaliński, Szkoda..., 2008. Zob. również M. Kaliński [w:] System..., t. 6, 2009. 
Co do pierwszej kwestii, można powtórzyć za T. Dybowskim, że badania prawnoporównawcze wskazują na cztery możliwe rozwiązania w zakresie wyboru między odszkodowaniem pieniężnym a restytucją naturalną jako sposobami naprawienia szkody:

1) odszkodowanie pieniężne jest jedyną formą naprawienia szkody,

2) odszkodowanie pieniężne jest podstawową formą naprawienia szkody, a inne formy są dopuszczalne wyjątkowo, jeżeli sąd uzna to za konieczne,

3) podstawową formą naprawienia szkody jest restytucja naturalna, a odszkodowanie pieniężne jedynie formą zastępczą, gdy restytucja nie da się zrealizować,

4) obie formy naprawienia szkody są dopuszczalne, a wybór należy do poszkodowanego ${ }^{6}$.

Treść art. $363 \$ 1$ k.c. wskazuje, że prawo polskie przyjmuje obecnie z zastrzeżeniami rozwiązanie ostatnie. Roszczenie poszkodowanego ogranicza się do świadczenia w pieniądzu, po pierwsze, gdy przywrócenie stanu poprzedniego jest niemożliwe oraz po drugie, gdy pociąga dla zobowiązanego nadmierne trudności. Odnośnie do pierwszego ograniczenia, wskazuje się m.in., że restytucja jest wyłączona, gdy ze względu na przedmiot uszczerbku kwota pieniężna jest jedyną możliwą do zastosowania postacią naprawienia szkody. Odnośnie do drugiego ograniczenia, powołuje się m.in. sytuacje, w których koszt naprawy rzeczy przekracza jej wartość sprzed uszkodzenia

Trzecie ograniczenie polega na tym, że przepisy szczególe wobec art. 363 k.c. mogą przewidywać określoną formę naprawienia szkody. W przeszłości jako przykład ustawy wprowadzającej pierwszeństwo restytucji podawano zwykle Prawo geologiczne i górnicze z 1994 r. ${ }^{8}$ Aktualnie obowiązujące Prawo geologiczne i górnicze z 2011 r. ${ }^{9}$ również

6 T. Dybowski, Naprawienie..., s. 170.

7 M. Kaliński, Szkoda..., s. 486 i 489.

8 Art. 94 ust. 1 ustawy z 4.02.1994 r. - Prawo geologiczne i górnicze (Dz.U. z 2005 r. $\mathrm{Nr} 228$, poz. 1947 ze zm.) stanowił wprost, że naprawienie szkody powinno nastąpić przez przywrócenie stanu poprzedniego.

9 Por. art. 147 ustawy z 9.06.2011 r. - Prawo geologiczne i górnicze (Dz.U. z 2017 r. poz. $2126 \mathrm{ze} \mathrm{zm}$.). 
zdaje się przyznawać pierwszeństwo restytucji naturalnej. Restytucja jako sposób naprawienia szkody jest natomiast wyraźnie wyłączona m.in. przez przepisy Prawa przewozowego ${ }^{10}$ oraz przepisy Konwencji wiedeńskiej o umowach międzynarodowej sprzedaży towarów ${ }^{11}$. Jako typowy przykład przepisów wprowadzających wyłączność świadczenia pieniężnego wskazywane są również przepisy Kodeksu cywilnego o umowie ubezpieczenia (art. 805 i 822) ${ }^{12}$. Właśnie ta ostania kwestia zostanie poddana bardziej wnikliwej analizie w kolejnym podrozdziale.

Odnośnie do drugiego wskazanego we wstępie zagadnienia, a mianowicie kwalifikacji prawnej uprawnienia poszkodowanego do wyboru restytucji naturalnej albo świadczenia pieniężnego, w doktrynie ścierają się dwa poglądy. Według tradycyjnego zapatrywania sytuację poszkodowanego należy ujmować jako zobowiązanie przemienne z prawem wyboru służącym wierzycielowi ${ }^{13}$. Przy przyjęciu tego stanowiska zastosowanie znajduje art. 365 k.c., a w szczególności zaś jego $\$ 3$, przewidujący przejście prawa wyboru na dłużnika w razie nieskorzystania z wyboru przez wierzyciela.

Pogląd konkurencyjny, wyrażony po raz pierwszy przez A. Ohanowicza, wskazuje na zbieg roszczeń ${ }^{14}$. Autor ten podnosi dwa argumenty mające przemawiać przeciwko konstrukcji zobowiązania przemiennego. Po pierwsze, art. 363 k.c. przewidujący równorzędność obu form

10 Por. art. 80 i n. pr. przew.

11 Art. 74 Konwencji Narodów Zjednoczonych o umowach międzynarodowej sprzedaży towarów, sporządzonej w Wiedniu dnia 11 kwietnia 1980 r. (Dz.U. z 1997 r. $\mathrm{Nr}$ 45, poz. 286 ze zm.).

12 Zob. przykł. M. Orlicki [w:] System..., t. 8.

13 A. Szpunar, Ustalenie odszkodowania w prawie..., s. 145; W. Czachórski, A. Brzozowski, M. Safjan, E. Skowrońska-Bocian, Zobowiązania..., s. 98; A. Olejniczak [w:] Kodeks cywilny. Komentarz, t. 3, Zobowiązania - część ogólna, red. A. Kidyba, Warszawa 2010, s. 100; Z. Banaszczyk [w:] Kodeks cywilny, t. 1, Komentarz. Art. 1-449 $9^{11}$, red. K. Pietrzykowski, Warszawa 2008, s. 1015-1016.

14 A. Ohanowicz, Zobowiązania przemienne [w:] A. Ohanowicz, Wybór prac, Warszawa 2007, s. 656-659. Pogląd ten aprobują m.in. T. Dybowski, Naprawienie..., s. 287. Niezupełnie jasno K. Zagrobelny [w:] Kodeks cywilny. Komentarz, red. E. Gniewek, P. Machnikowski, Warszawa 2013, s. 2013, który z jednej strony twierdzi, że nie da się konsekwentnie przyjmować, że chodzi o zobowiązanie przemienne, z drugiej zaś dopuszcza stosowanie art. $365 \$ 3$ k.c. 
naprawienia szkody z prawem wyboru wierzyciela ma na celu ochronę interesu tego ostatniego. Interes wierzyciela jest znacznie donioślejszy niż interes dłużnika. W tych warunkach przyjęcie konstrukcji zobowiązania przemiennego z przejściem prawa wyboru na dłużnika ma tego ostatniego nadmiernie uprzywilejowywać.

Po drugie, w zobowiązaniu przemiennym, z chwilą zawiadomienia dłużnika o wyborze, następuje koncentracja, czyli zobowiązanie o świadczeniu nieokreślonym zmienia się na zobowiązanie o świadczeniu wybranym przez uprawnionego ze skutkiem ex tunc. Zobowiązanie, które po dokonaniu wyboru stałoby się niemożliwe z przyczyn, za które dłużnik nie odpowiada, wygasłoby zgodnie z art. 475 k.c., choćby inne świadczenie, na które zobowiązanie przemienne opiewało, wciąż było możliwe do spełnienia. W zobowiązaniu odszkodowawczym jest inaczej, bo wierzyciel także po wyborze restytucji naturalnej może swój wybór zmienić, jeżeli sposób ten okaże się niemożliwy lub nadmiernie uciążliwy dla dłużnika, bez względu na to, czy dłużnik za zaistniały stan rzeczy odpowiada. Tego rodzaju skutek można zdaniem A. Ohanowicza osiągnąć, jedynie przyjmując konstrukcję zbiegu roszczeń.

Argumenty te przekonująco zwalcza A. Szpunar, odnośnie do pierwszego z nich wskazując, że choć preponderancja interesu wierzyciela nie może być kwestionowana, należy brać pod uwagę także usprawiedliwiony interes dłużnika, który nie pozwala na przeciąganie stanu niepewności zbyt długo. Odnośnie do drugiego argumentu, a mianowicie zasady koncentracji, A. Szpunar twierdzi, że nie przemawia ona przeciw konstrukcji zobowiązania przemiennego. Restytucja naturalna ze swej istoty może stać się niemożliwa. W tej zaś sytuacji roszczenie poszkodowanego ogranicza się do świadczenia w pieniądzu z mocy art. 363 k.c. Konstrukcja zbiegu roszczeń sama przez się niczego nie tłumaczy i nie należy jej nadużywać, szczególnie że zgodnie z art. 363 k.c. poszkodowanemu przysługuje tylko jedno roszczenie odszkodowawcze. Poza tym art. 365 k.c. podaje cechy strukturalne zobowiązania przemiennego, regulując jedynie to, komu przysługuje wybór i jakie są jego skutki. Możliwe są daleko idące różnice w kształtowaniu zobowiązań przemiennych. Artykuł 363 k.c., będąc normą szczególną wobec art. 365 k.c., pozwala 
wierzycielowi zmienić wybór, gdyby restytucja okazała się niemożliwa lub nadmiernie uciążliwa dla dłużnika.

Pogląd A. Szpunara aprobuje M. Kaliński, wskazując, że koncepcja A. Ohanowicza pomija relację między art. $475 \$ 1$ k.c. i art. $363 \$ 1$ k.c. Drugi z przepisów wyłącza zastosowanie przewidzianego w pierwszym skutku następczej niemożliwości świadczenia ${ }^{15}$.Zarówno A. Szpunar, jak i M. Kaliński zwracają uwagę na celowość sformułowania przez powoda żądania powództwa w sposób ewentualny celem uniknięcia ryzyka jego oddalenia w wypadku, gdyby w toku procesu restytucja naturalna okazała się niemożliwa ${ }^{16}$. Maciej Kaliński wskazuje również, że należy dopuścić żądanie alternatywne. Wyrok winien w takim przypadku zasądzać oba świadczenia alternatywnie. W postępowaniu egzekucyjnym należałoby stosować art. 786 k.p.c., uznając, że sąd może nadać wyrokowi klauzulę wykonalności po przedstawieniu przez wierzyciela dowodu wyboru świadczenia w formie pisemnej z podpisem urzędowo poświadczonym ${ }^{17}$.

Ostatnią kwestią wymagającą przypomnienia w zakresie reguł ogólnych jest samo pojęcie restytucji naturalnej. W literaturze wskazuje się, że pojmowanie naprawienia szkody jako przywrócenia stanu sprzed oddziaływania zdarzenia szkodzącego jest nadmiernym uproszczeniem. Przede wszystkim szkoda ma charakter płynny w czasie, a decydującą chwilą dla oceny rozmiarów uszczerbku jest chwila orzekania. Ponadto raz doznany uszczerbek jest nieodwracalny, bo czasu nie można cofnąć. Z tych względów przywrócenie stanu poprzedniego określane mianem restytucji musi być pojmowane funkcjonalnie jako stworzenie stanu gospodarczego, który istniałby w braku zdarzenia szkodzącego ${ }^{18}$. W przypadku restytucji naturalnej niezmiernie istotna jest nadto kwestia lokalizacji szkody. Działanie zobowiązanego ma być skierowane na konkretne dobro lub interes, w którym pojawił się uszczerbek, nie

15 M. Kaliński, Szkoda..., s. 502-503.

16 A. Szpunar, Restytucja..., s. 10-11; M. Kaliński, Szkoda..., s. 501.

17 M. Kaliński, Szkoda..., s. 503.

18 Tak przykł. A. Szpunar, Restytucja..., s. 8-9; A. Szpunar, O sposobach..., s. 1599; M. Kaliński, Szkoda..., s. 485. 
zaś całą sferę majątkową poszkodowanego ${ }^{19}$. Przywrócenie do stanu poprzedniego nie zostało przez ustawodawcę zdefiniowane. Sposób przywrócenia do stanu poprzedniego zależy zatem od charakteru zdarzenia szkodzącego oraz postaci uszczerbku.

Skatalogowanie możliwych form restytucji naturalnej rodzi trudności. Krzysztof Zagrobelny stwierdza nawet, że ze względu na pojemność samej formuły restytucji sformułowanie pełnego wyliczenia nie jest możliwe ani potrzebne $e^{20}$. Bogactwo życia wydaje się niezmierzone, prawnik zawczasu nie przewidzi wszystkich sytuacji. Dodatkowo zagadnienie komplikuje okoliczność, że nawet najbardziej typowe przykłady restytucji budzą wątpliwości zasadniczej natury. Wśród tych typowych przykładów wymienia się zwykle: naprawienie rzeczy uszkodzonej, zwrot poszkodowanemu rzeczy, nad którą utracił władztwo, oraz dostarczenie rzeczy zamiennych w takiej samej ilości zamiast rzeczy zniszczonych lub utraconych. Problemy wypada przypomnieć po kolei.

W odniesieniu do naprawy uszkodzonej rzeczy pojawia się pytanie, czy sytuację, gdy naprawy dokonuje sam poszkodowany, następnie domagając się zwrotu kosztów z robocizną, należy kwalifikować jako restytucję naturalną czy zapłatę odszkodowania w pieniądzu. Adam Szpunar zwracał uwagę, że w tej sytuacji granice między obydwiema formami naprawienia szkody zacierają się. Autor początkowo twierdził, że skoro zobowiązany do naprawienia szkody nie podjął żadnego działania, to w rachubę wchodzi zapłata odszkodowania ${ }^{21}$. Kilka lat później zmodyfikował jednak swoje stanowisko, stwierdzając, że zachodzi tu szczególny rodzaj przywrócenia stanu poprzedniego ${ }^{22}$.

Różnice podkreśla M. Kaliński, wskazując, że podział z art. 363 k.c. ma charakter dychotomiczny. Cel zapłaty odszkodowania, jakim jest restytucja w znaczeniu gospodarczym, nie przesądza o nieistotności

19 Tak. przykładowo A. Olejniczak [w:] Kodeks..., red. A. Kidyba, s. 102.

20 K. Zagrobelny [w:] Kodeks..., 2013, s. 599. Katalog próbuje formułować M. Kaliński. Na kolejnych stronach swej monografii analizuje jednak szereg form nieujętych w katalogu. Zob. M. Kaliński, Szkoda..., s. 504 i n.

21 A. Szpunar, O sposobach..., s. 1599.

22 A. Szpunar, Restytucja..., s. 12. 
kwalifikacji prawnej świadczenia jako restytucji naturalnej lub odszkodowania. Według tego autora w przypadku, gdy zapłata odszkodowania w pieniądzu ma na celu przywrócenie stanu poprzedniego, świadczenie wciąż ma postać świadczenia pieniężnego, nie zaś restytucji naturalnej. Jego zdaniem sedno problemu sprowadza się do odpowiedzi na pytanie, czy poszkodowany może domagać się zapłaty sumy potrzebnej do naprawienia rzeczy przed poniesieniem $\mathrm{z}$ tego tytułu wydatkó $w^{23}$.

Ostatnia kwestia zostanie przeanalizowana $\mathrm{w}$ jednym $\mathrm{z}$ kolejnych podrozdziałów, ponieważ w orzecznictwie pojawiała się ona na gruncie obowiązkowego ubezpieczenia OC posiadaczy pojazdów mechanicznych. Na podstawowe pytanie, czy właściciel, domagając się zwrotu kosztów wykonanej przez siebie naprawy, wybiera restytucję naturalną, należy udzielić odpowiedzi negatywnej zgodnej z poglądem M. Kalińskiego i pierwotnym poglądem A. Szpunara. Jak wskazuje się powszechnie, restytucja naturalna w przypadku naprawy rzeczy polega na dokonaniu naprawy przez sprawcę samodzielnie, ewentualnie na zleceniu przezeń naprawy osobie trzeciej. Jeżeli sprawca nie robi nic, by przywrócić stan poprzedni, zwracając jedynie koszty poniesione na naprawę przez poszkodowanego, świadczenie ma wciąż postać świadczenia pieniężnego.

W przykładzie restytucji wymienionym jako drugi, to jest w razie zwrotu poszkodowanemu zabranej rzeczy, zachodzi zbieg roszczeń rzeczowych i windykacyjnych. Jest jednak kwestią sporną, czy zbieg taki zachodzi również wówczas, gdy rzecz została zabrana posiadaczowi, który nie potrafi udowodnić swoich roszczeń. Zdaniem A. Szpunara w razie udowodnienia praw do rzeczy występuje zbieg roszczeń odszkodowawczych i windykacyjnych, natomiast $\mathrm{w}$ razie niemożności udowodnienia praw zbieg roszczeń odszkodowawczych i posesoryjnych ${ }^{24}$. Odmiennego zdania jest T. Dybowski, według którego w ostatniej sytuacji restytucja naturalna nie jest możliwa ${ }^{25}$.

23 M. Kaliński, Szkoda..., s. 496.

24 A. Szpunar, Restytucja..., s. 7; K. Zagrobelny [w:] Kodeks..., 2013, s. 600.

25 T. Dybowski, Odszkodowanie za naruszenie..., s. 3; T. Dybowski, Odszkodowanie należne posiadaczowi za utracone pożytki z rzeczy, NP 1977, Nr 4, s. 461 i n. 
Wydaje się, że bez zastrzeżeń nie można przyjąć żadnego z przytoczonych stanowisk. W przypadku bowiem zabrania rzeczy przez właściciela po stronie nieuprawnionego nie występuje szkoda, nie może on zatem żądać przywrócenia do stanu poprzedniego. W sytuacji natomiast, gdy rzecz zostanie zabrana przez inną osobę niż właściciel i władztwo nad nią utraci samoistny posiadacz, który mógłby nabyć własność przez zasiedzenie lub wskutek upływu terminu $\mathrm{z}$ art. $169 \$ 2$ k.c., roszczenia restytucyjnego nie można wykluczyć ${ }^{26}$.

Odnośnie do trzeciego przykładu restytucji, a mianowicie dostarczenia takiej samej ilości rzeczy zamiennych, wystąpiły w doktrynie kontrowersje, czy wskazana forma restytucji jest w ogóle dopuszczalna. Przeciwko wypowiadał się W. Czachórski, wskazując, że art. 363 k.c. w odróżnieniu do art. $561 \S 1$ k.c., nie wymienia uprawnienia do żądania dostarczenia nieuszkodzonej rzeczy zamiennej. Pogląd dopuszczający w tym wypadku rekompensatę naturalną konsekwentnie prezentował A. Szpunar, powołując się na argumenty natury funkcjonalnej, w szczególności na rozumienie przywrócenia stanu faktycznego jako stworzenie stanu gospodarczego zbliżonego do tego, jaki istniał przed zajściem zdarzenia szkodzącego ${ }^{27}$.

Argumentację opowiadającą się za drugim poglądem trafnie uzupełnia M. Kaliński, wskazując, że art. 561 \$ 1 k.c. odnosi się do szczególnych konsekwencji dostarczenia przez sprzedawcę rzeczy obarczonych wadą, trudno wobec tego wnioskować zeń a contrario, gdy chodzi o ogólne zasady odpowiedzialności odszkodowawczej ${ }^{28}$. Dodać można, że wnioskowanie a contrario jest zwykle zawodne samo w sobie oraz że art. 561 k.c. musi zawierać dokładne i zamknięte wyliczenie uprawnień z tytułu rękojmi, ponieważ dotyczy wyjątkowego przypadku odpowiedzialności na zasadzie ryzyka.

26 Podobnie: K. Zagrobelny [w:] Kodeks..., 2013, s. 600-601.

27 A. Szpunar, Ustalenie odszkodowania w prawie..., s. 144; A. Szpunar, Restytucja..., s. 8-9; A. Szpunar, O sposobach..., s. 1608.

28 M. Kaliński, Szkoda.... s. 506-507. 


\subsection{Dopuszczalność naprawienia szkody przez ubezpieczyciela $\mathbf{w}$ drodze restytucji naturalnej}

Jak wskazano we wprowadzeniu do niniejszego rozdziału, działalność ubezpieczeniowa kojarzy się ze spełnianiem świadczeń w pieniądzu. W odniesieniu do ubezpieczeń osobowych jest to oczywiste. Ubezpieczenia te, jak wiadomo, zwane są ubezpieczeniami sum. Nie chodzi w nich o naprawienie szkody i przepis art. 363 k.c. nie może znajdować zastosowania $^{29}$. Ponadto $\mathrm{w}$ ubezpieczeniach na życie $\mathrm{z}$ istoty wypadku ubezpieczeniowego wynika, że przywrócenie stanu poprzedniego jest niemożliwe. Ubezpieczyciel zmarłego nie wskrzesi.

Działalność ubezpieczeniowa wywołuje asocjację z wypłacaniem świadczeń w pieniądzu nie tylko jednak, gdy chodzi o ubezpieczenia osobowe. Te naturalne skojarzenia zdaje się potwierdzać ustawa o działalności ubezpieczeniowej i reasekuracyjnej. Zgodnie z tą ustawą działalność ubezpieczeniowa polega na wykonywaniu czynności ubezpieczeniowych związanych z oferowaniem i udzielaniem ochrony na wypadek ryzyka wystąpienia skutków zdarzeń losowych. Zakład ubezpieczeń nie może wykonywać innej działalności poza działalnością ubezpieczeniową i bezpośrednio z nią związaną. Sformułowany w ustawie o działalności ubezpieczeniowej i reasekuracyjnej katalog czynności ubezpieczeniowych wymienia w szczególności zawieranie i wykonywanie umów ubezpieczenia oraz wypłacanie odszkodowań i świadczeń z tychże umów. Wypada podkreślić, że wśród czynności ubezpieczeniowych nie wymieniono natomiast świadczenia przez ubezpieczycieli usług mających na celu doprowadzenie sytuacji ubezpieczonego do stanu sprzed zajścia wypadku. Obecna ustawa zawiera wprawdzie również art. 2, z którego wynika expressis verbis, że ubezpieczyciele mogą świadczyć pomoc w zakresie tzw. assistance samochodowego ${ }^{30}$, jednak poprzednia ustawa o działalności ubezpieczeniowej nie zawierała odpowiednika tego przepisu ${ }^{31}$.

${ }^{29}$ Pewne wątpliwości jawią się w odniesieniu do ubezpieczeń wypadkowych w zakresie, w jakim mają one na celu zwrot kosztów leczenia.

30 Por. art. 4 ust. 1 oraz $7-11$ u.d.u.r.

31 Ustawa z 22.05.2003 r. o działalności ubezpieczeniowej. 
Mając na uwadze powyższe, nie dziwi, że zgodnie z tradycyjnym przeważającym w doktrynie stanowiskiem świadczenie ubezpieczyciela polega zawsze na zapłacie świadczenia pieniężnego ${ }^{32}$. Autorzy wyrażający to stanowisko bywali wprawdzie niekonsekwentni wtedy, gdy wskazywali, że zapłacenie przez ubezpieczyciela kosztów naprawy rzeczy uszkodzonej w wyniku wypadku ubezpieczeniowego jest w istocie formą przywrócenia do stanu poprzedniego, wprost jednak nie mówili o świadczeniu ubezpieczyciela polegającym na restytucji naturalnej.

Poruszony problem, co może wydać się dziwne, biorąc pod uwagę jego znaczenie, nie ma bogatej literatury. Najstarsza i najbardziej radykalna wypowiedź dopuszczająca restytucję naturalną jako sposób naprawienia szkody przez ubezpieczyciela została wyrażona w 1998 r. przez B. Balas-Noszczyk i K. Malinowskąa ${ }^{33}$. Jest cytowana przez wszystkich autorów, którzy zajmują się poruszoną kwestią, trudno jednak znaleźć takich, którzy zgadzają się z nią bez zastrzeżeń ${ }^{34}$.

Argumenty B. Balas-Noszczyk i K. Malinowskiej można ująć w dwóch punktach. Pierwszy dotyczy brzmienia przepisów Kodeksu cywilnego o umowie ubezpieczenia, drugi ogólnych zasad odpowiedzialności odszkodowawczej. Zgodnie art. $805 \$ 2$ k.c. świadczenie ubezpieczyciela polega w szczególności na zapłacie:

1) przy ubezpieczeniu majątkowym - określonego odszkodowania za szkodę powstałą wskutek przewidzianego w umowie wypadku;

2) przy ubezpieczeniu osobowym - umówionej sumy pieniężnej, renty lub innego świadczenia $\mathrm{w}$ razie zajścia przewidzianego w umowie wypadku w życiu osoby ubezpieczonej.

Zdaniem autorek zwolennicy stanowiska o wyłącznie pieniężnym charakterze świadczenia zakładu ubezpieczeń pomijają zawarty w przepisie zwrot „W szczególności”, który z ogólnie przyjętymi regułami wykład-

32 Zob. przykładowo W. Warkałło, Zasada..., s. 426; A. Wąsiewicz, Odszkodowanie..., s. 35 i n.; M. Orlicki, Umowa ubezpieczenia [w:] System..., t. 8, s. 858-959; L. Ogiegło [w:] Kodeks...

33 B. Balas-Noszczyk, K. Malinowska, W sprawie..., s. 17 i n.

34 M. Orlicki, Umowa ubezpieczenia, 2002, s. 189 i n.; M. Krajewski, Umowa ubezpieczenia. Art. 805-834 KC..., 2016, s. 59-60, oraz M. Kaliński, Szkoda..., s. 494. 
ni prawa zaprzecza zamkniętemu katalogowi możliwości spełnienia świadczenia. B. Balas-Noszczyk i K. Malinowska wskazują również, że ogólna zasada odpowiedzialności odszkodowawczej sformułowana w art. 363 k.c. przewiduje dwa równorzędne sposoby naprawienia szkody, przyznając wybór poszkodowanemu. Umowa ubezpieczenia, która powinna spełniać funkcję ochronną wobec osób poszkodowanych wskutek wystąpienia przewidzianego w niej zdarzenia, nie powinna ograniczać praw przyznanych tym osobom przez przepisy ogólne.

Dodatkowo zdaniem autorek należy respektować zasadę autonomii woli stron mogących w myśl art. $353^{1}$ k.c. ułożyć stosunek prawny według swego uznania, byleby jego treść lub cel nie sprzeciwiały się właściwości (naturze) stosunku, ustawie ani zasadom współżycia społecznego. Żadne z wymienionych w przepisie ograniczeń nie wyklucza zawarcia w umowie ubezpieczenia mienia lub ogólnych warunkach postanowień przewidujących naprawienie szkody w drodze restytucji naturalnej ${ }^{35}$.

Podobnie przebiega argumentacja autorek w odniesieniu do ubezpieczenia odpowiedzialności cywilnej. Sprawa jest o tyle trudniejsza, że art. 822 k.c. wskazuje wyraźnie, że na mocy ubezpieczenia OC ubezpieczyciel zobowiązuje się do zapłacenia określonego w umowie odszkodowania za szkody wyrządzone osobom trzecim. Ze sformułowania „zapłacenie odszkodowania” przynajmniej prima facie nie sposób wywieść, że naprawienie szkody wyrządzonej przez ubezpieczonego osobie trzeciej może nastąpić poprzez przywrócenie stanu poprzedniego.

Autorki argumentują, że w ubezpieczeniu OC odpowiedzialność ubezpieczyciela jest akcesoryjna w stosunku do odpowiedzialności sprawcy szkody, ten zaś odpowiada na zasadach ogólnych. Poszkodowany może zatem wybierać między odszkodowaniem pieniężnym a restytucją naturalną. Na mocy specjalnego przepisu ustawy (obecnie art. $822 \$ 4$ k.c.) poszkodowany ma prawo dochodzić roszczenia służącego mu wobec sprawcy bezpośrednio od ubezpieczyciela, z którym sprawca miał zawartą umowę ubezpieczenia odpowiedzialności cywilnej.

35 B. Balas-Noszczyk, K. Malinowska, W sprawie..., s. 20-21. 
Wyraźne sformułowanie, wedle którego „ubezpieczyciel zobowiązuje się do zapłacenia odszkodowania", autorki tłumaczą, wskazując, że rekompensata oznacza nie tylko przywrócenie do stanu poprzedniego, lecz również stworzenie takiego stanu, który w przybliżony sposób zaspokajałby naruszone potrzeby poszkodowanego. Idąc dalej tym torem rozumowania, należy, zdaniem autorek, przyjąć, że w rozumieniu art. 822 k.c. zapłata odszkodowania może służyć przywróceniu stanu poprzedniego wtedy, gdy poszkodowany zamierza ją przeznaczyć na naprawę pojazdu. Pieniężna forma odszkodowania jest w tej sytuacji jedynie stanem pozornym, w istocie zaś naprawienie szkody następuje $\mathrm{w}$ drodze przywrócenia stanu poprzedniego. Skoro remont samochodu ma na celu przywrócenie do stanu, jaki istniał przed wyrządzeniem szkody, to trzeba uznać, że świadczenie ubezpieczyciela ma postać restytucji naturalnej ${ }^{36}$.

Podobną argumentację dla uzasadnienia dopuszczalności naprawienia przez ubezpieczyciela szkody w naturze prezentuje J. Nawracała. Zdaniem tego autora teza, że świadczenie ubezpieczyciela polegać może na wyświadczeniu na rzecz ubezpieczającego jakiegoś rodzaju usługi, wynika z wykładni językowej art. $805 \$ 2$ k.c. Przemawiają za tym sformułowania „w szczególności” oraz „lub innego świadczenia” ${ }^{37}$. Dodatkowo przyjęcie szerokiej koncepcji świadczenia ubezpieczyciela w razie zajścia wypadku odpowiada wymaganiom rynku. Postępująca komplikacja i zaawansowanie stosunków gospodarczych rzutuje z jednej strony na drobiazgową specjalizację w określonych sferach oraz z drugiej strony na coraz większą kompleksowość usług świadczonych w określonych sektorach. Jednym z przejawów tej drugiej tendencji w sektorze finansowym jest proponowanie ubezpieczeń, w których świadczenie polega nie tylko na wypłacie pieniędzy w razie zajścia wypadku. Żadne względy aksjologiczne również nie przemawiają za wyłączeniem dopuszczalności zawierania tego rodzaju ubezpieczen ${ }^{38}$.

36 B. Balas-Noszczyk, K. Malinowska, W sprawie..., s. 22-23.

37 J. Nawracała, Nie tylko..., s. 5-7. Pogląd o dopuszczalności spełnienia świadczenia w formie niepieniężnej akceptuje również E. Kowalewski [w:] Prawo ubezpieczeń gospodarczych, red. E. Kowalewski, s. 209.

38 J. Nawracała, Nie tylko..., s. 5. 
Stanowczym przeciwnikiem możliwości naprawienia przez ubezpieczyciela szkody w drodze restytucji naturalnej jest M. Orlicki. Według tego autora stanowisko B. Balas-Noszczyk i K. Malinowskiej nie uwzględnia wyraźnego brzmienia art. $805 \$ 2$ k.c., wedle którego świadczenie ubezpieczyciela polega na zapłacie. Tylko świadczenie pieniężne polegać może na zapłacie. Wniosku tego nie może, zdaniem M. Orlickiego, zmienić akcentowane przez zwolenników przeciwnego poglądu sformułowanie „w szczególności”. Tezę o możliwości naprawienia szkody $\mathrm{w}$ formie restytucji naturalnej należy natomiast odrzucić, ponieważ art. $822 \$ 1$ k.c. wspomina wyłącznie o zapłacie odszkodowania ${ }^{39}$.

Kolejnym argumentem przeciwko koncepcji o dopuszczalności spełnienia świadczenia ubezpieczyciela w drodze restytucji naturalnej ma być treść art. $824^{1} \$ 1$ k.c. Przepis ten, dotyczący zasady odszkodowania, mówi o sumie pieniężnej jako o świadczeniu ubezpieczyciela. Jego dyspozytywny charakter dotyczy wyłącznie wysokości wypłacanej przez ubezpieczyciela sumy pieniężnej, w żadnym zaś razie samego spełnienia przez ubezpieczyciela świadczenia w pieniądzu ${ }^{40}$.

Według M. Orlickiego zasada wolności umów proklamowana $\mathrm{w}$ art. $353^{1}$ k.c. nie pozwala na umowne zastrzeżenie możliwości spełnienia świadczenia przez ubezpieczyciela $\mathrm{w}$ formie restytucji naturalnej, takie zastrzeżenie byłoby bowiem sprzeczne $\mathrm{z}$ bezwzględnie obowiązującymi przepisami art. $805 \$ 2$ i art. 822 k.c. Dodatkowo pogląd dopuszczający taką możliwość prowadziłby do chaosu w praktyce stosowania prawa ubezpieczeniowego ${ }^{41}$. Pojęcia sumy ubezpieczeniowej, sumy gwarancyjnej oraz techniczno-ubezpieczeniowych ograniczeń odszkodowania straciłyby rację bytu, w najlepszym zaś razie ich stoso-

39 M. Orlicki, Umowa ubezpieczenia, 2002, s. 190; M. Orlicki, Umowa ubezpieczenia [w:] System..., t. 8, s. 730.

40 M. Orlicki, Umowa ubezpieczenia [w:] System..., t. 8, s. 730.

${ }^{41}$ Kwestie te dostrzega się w prawie francuskim, co jednak nie stanowi tam przeszkody do kwalifikowania umów assistance jako ubezpieczenia; por. S. Beaugendre, Contrat..., s. 157 i n. 
wanie wymagałoby ciągłego szacowania wartości dokonanych w ramach restytucji naturalnej zakupów towarów i świadczenia usług ${ }^{42}$.

Nieco łagodniejsze stanowisko zajmuje M. Krajewski, którego zdaniem koncepcja dopuszczająca spełnienie przez ubezpieczyciela świadczenia w drodze restytucji naturalnej może wydawać się atrakcyjna, jest jednak niedostosowana do brzmienia przepisów Kodeksu cywilnego. Wprawdzie brzmienie art. $805 \$ 2$ k.c. jej nie wyklucza, jednak inne przepisy Kodeksu cywilnego nie zakładają takiej możliwości. Wśród przepisów mówiących wyraźnie o wypłacie lub zapłacie M. Krajewski wymienia art. $822,824^{1} \S 1$ i 3 , art. $826 \$ 2$, art. $827 \$ 1$ i art. 828 k.c., a także art. 3 ust. 8 pkt 2 i art. 28 u.d.u.r. oraz art. 13 i 14 u.u.o. ${ }^{43}$

Dodatkowo M. Krajewski powtarza argument M. Orlickiego dotyczący chaosu w stosowaniu przepisów o umowie ubezpieczenia, wskazując, że dopuszczenie restytucji naturalnej mogłoby prowadzić do trudnych do przewidzenia komplikacji związanych z faktem, że odszkodowanie ubezpieczeniowe często jest niższe od poniesionej szkody. Niemożliwe byłoby potrącenie franszyzy albo udziału własnego. Występowałyby wątpliwości, gdyby koszty przywrócenia stanu poprzedniego przewyższały sumę ubezpieczenia. Niejasności rodziłoby również stosowanie art. $828 \$ 1$ k.c., zgodnie z którym roszczenie ubezpieczającego przeciwko sprawcy przechodzi na ubezpieczyciela do wysokości zapłaconego odszkodowania ${ }^{44}$.

Ostatecznie M. Krajewski dochodzi jednak do odmiennego niż M. Orlicki wniosku, stwierdzając, że przytoczone przepisy wskazują jedynie, że ustawodawca zakładał, że strony w typowej sytuacji nie umówią się o naprawienie szkody w drodze restytucji naturalnej, możliwości takiej jednak nie wykluczają. Strony na zasadzie swobody umów mogą zatem umówić się o naprawienie szkody w drodze restytucji naturalnej. W niektórych sytuacjach, przykładowo w ubezpieczeniu assistance,

42 M. Orlicki, Umowa ubezpieczenia, 2002, s. 191; M. Orlicki, Umowa ubezpieczenia [w:] System..., t. 8, s. 730-731.

${ }^{43}$ M. Krajewski, Umowa ubezpieczenia. Art. 805-834 KC..., 2016, s. 60-63.

44 M. Krajewski, Umowa ubezpieczenia. Art. 805-834 KC..., 2016, s. 60-63. 
umówione świadczenia ubezpieczyciela mogą mieć charakter niepieniężny. Dodatkowo M. Krajewski przywołuje wyrok SN z 29.01.2002 r., V CKN 682/00 ${ }^{45}$, w którego uzasadnieniu wyrażono zbliżony pogląd ${ }^{46}$. Zdaniem M. Krajewskiego strony mogą umówić się po zajściu wypadku ubezpieczeniowego, że naprawienie szkody nastąpi w drodze restytucji naturalnej. W takim przypadku zastosowanie jednak znajduje konstrukcja datio in solutum z art. 453 k.c. Ze względu na odpowiedzialność zakładu ubezpieczeń za jakość spełnionego świadczenia sytuacja taka jest jednak prawdopodobna ${ }^{47}$.

Podobnie wypowiada się M. Kaliński. Jego zdaniem w ubezpieczeniach regułą jest naprawienie szkody w pieniądzu. Pojemna formuła art. 805 $\$ 2$ k.c. pozwala jednak zastrzec w umowie ubezpieczenia, że naprawienie szkody przybierze postać restytucji, co w praktyce stanowi rzadkość. Zastrzeżenie takie jest wykluczone w ubezpieczeniu OC, art. 822 k.c. nie dopuszcza bowiem wyjątków od „zapłacenia odszkodowania”. Poprawność formułowanych w doktrynie kategorycznych poglądów, że roszczenie o restytucję jest w ubezpieczeniach majątkowych wykluczone, zależy od tego, czy uznać je za konstatację ilościową, czy jakościową ${ }^{48}$. Nie ma charakteru restytucji zapłata przez ubezpieczyciela odszkodowania w celu przywrócenia do stanu poprzedniego ${ }^{49}$.

Przedstawienie poglądów doktryny pozwala przejść do prezentacji własnego stanowiska. Gdy chodzi o ubezpieczenie OC, art. 822 k.c. wyraźnie mówiący o odszkodowaniu wydaje się przemawiać na rzecz zwolenników poglądu konserwatywnego. Dodać jednak należy, że wnioskowanie w tym zakresie opiera się wyłącznie na zawodnym rozumowaniu a contrario $\mathrm{z}$ art. 822 k.c. W Kodeksie cywilnym nie ma przepisów formułujących zakaz naprawienia szkody przez ubezpieczyciela w drodze restytucji naturalnej. Zaznaczyć przy tym wypada, że akcesoryjność odpowiedzialności ubezpieczyciela w ubezpieczeniu odpowiedzialności

45 LEX nr 54343.

${ }^{46}$ M. Krajewski, Umowa ubezpieczenia. Art. 805-834 KC..., 2016, s. 60-63.

47 M. Krajewski, Umowa ubezpieczenia. Art. 805-834 KC..., 2016, s. 63-64.

48 M. Kaliński, Szkoda..., s. 494 i wskazana tam literatura.

49 M. Kaliński, Szkoda..., s. 495-496; M. Kaliński, Zasada..., cz. 1, s. 57 i wskazana tam literatura. 
cywilnej względem odpowiedzialności sprawcy przemawia raczej za bezpośrednim stosowaniem art. 363 k.c. w ubezpieczeniu OC.

Nawet przyjąwszy, że wnioskowanie a contrario z art. 822 k.c. prowadzi do zakazu naprawienia szkody w drodze restytucji naturalnej w ubezpieczeniach OC, przyznać trzeba, że w odniesieniu do innych ubezpieczeń majątkowych nie istnieją przepisy Kodeksu cywilnego, które wskazywałyby w sposób wyraźny, że świadczenie ubezpieczyciela musi być spełnione $\mathrm{w}$ formie pieniężnej. Argumenty przedstawione przez M. Orlickiego oraz po części przez M. Krajewskiego wskazują jedynie na to, że ustawodawca kojarzył świadczenie ubezpieczyciela $\mathrm{w}$ ubezpieczeniu majątkowym ze świadczeniem pieniężnym. Trudno jednak znaleźć przepisy, z których wynikałby bezwzględny zakaz naprawienia szkody w drodze restytucji naturalnej.

Wbrew stanowisku M. Orlickiego zakaz tego rodzaju nie wynika $\mathrm{z}$ art. 805 ani $\mathrm{z}$ art. $824^{1}$ k.c. Przepis art. $805 \mathrm{w} \$ 1$ mówi o spełnieniu przez ubezpieczyciela określonego świadczenia, zaś w $\$ 2$ o tym, że świadczenie ubezpieczyciela polega w szczególności na zapłacie określonego odszkodowania lub świadczenia. Pogląd M. Orlickiego dotyczący wykładni tego ostatniego przepisu byłby trafny, gdyby norma $\mathrm{z} \$ 2$ stanowiła, że świadczenie polega na zapłacie w szczególności odszkodowania lub świadczenia. Norma mówi jednak, że świadczenie polega w szczególności na zapłacie odszkodowania lub świadczenia. Innymi słowy, szyk wyrazów w zdaniu, inaczej niż chce M. Orlicki, nie wyklucza świadczeń innych niż polegające na zapłacie sumy pieniężnej. Sformułowanie „W szczególności” wydaje się mieć zatem znaczenie kluczowe ${ }^{50}$.

Przepis art. $824^{1}$ k.c. formułuje tzw. zasadę odszkodowania. Z $\$ 1$ art. $824^{1}$ k.c. wynika, że o ile nie umówiono się inaczej, suma pieniężna wypłacona przez ubezpieczyciela $z$ tytułu ubezpieczenia nie może być wyższa od poniesionej szkody. Z przepisu tego nie można wywodzić zakazu naprawienia przez ubezpieczyciela szkody w drodze restytucji

50 Tak. B. Balas-Noszczyk, M. Malinowska, W sprawie..., s. 20-21; J. Nawracała, Nie tylko..., s. 5. Podobnie M. Krajewski, Umowa ubezpieczenia. Art. 805-834 KC..., 2016, s. 59-60, oraz M. Kaliński, Szkoda..., s. 494. 
naturalnej. Przepis wskazuje jedynie, że w sytuacji, gdy świadczenie ubezpieczyciela polega na zapłacie sumy pieniężnej, nie może ono przekraczać wysokości poniesionej szkody. Oczywiście zasada odszkodowania należy do istoty ubezpieczeń majątkowych, wydaje się zatem, że nawet gdyby restytucję naturalną dopuścić, zasada odszkodowania winna mieć zastosowanie. Przepis art. $824^{1}$ k.c. powinien zatem znaleźć w tym zakresie zastosowanie per analogiam.

Symptomatyczne jest nadto, że przepis, o którym mowa, rozpoczyna się od zastrzeżenia: „O ile nie umówiono się inaczej”. Wbrew stanowisku M. Orlickiego niewykluczona wydaje się argumentacja, że zastrzeżenie to dotyczy nie tylko możliwości świadczenia przez ubezpieczyciela sumy pieniężnej przekraczającej wysokość szkody (odszkodowanie w wartości nowej i odszkodowanie w wartości otaksowanej $)^{51}$, ale również możliwości spełnienia świadczenia w drodze restytucji naturalnej. Dodać można, że $\$ 2$ art. $824^{1}$ k.c. sformułowany jest w sposób pozwalający objąć jego dyspozycją także świadczenia spełniane w drodze restytucji naturalnej, natomiast $\$ 3$ znów powraca do sformułowań sugerujących pieniężną formę świadczenia ubezpieczyciela. Jakkolwiek by nie wykładać zastrzeżenia „o ile nie umówiono się inaczej”, niewątpliwe jest jedynie to, na co wskazuje M. Krajewski, a mianowicie że przepis art. $824^{1}$ k.c., podobnie jak przepisy art. $822 \$ 1$, art. $826 \$ 2$, art. $827 \$ 1$ i art. 828 k.c., stanowią wyraz, będącego zapewne wynikiem tradycji, założenia ustawodawcy, że ubezpieczyciel świadczy, spełniając świadczenie pieniężne.

Twierdzenie M. Orlickiego, że przepisy o sumie ubezpieczenia, nadubezpieczeniu i podubezpieczeniu nie nadają się do stosowania przy świadczeniu ubezpieczyciela polegającym na świadczeniu niepieniężnym, również nie przesądza o niedopuszczalności takiego sposobu naprawienia szkody. Nadto twierdzenie to jest wątpliwe. Ogólne warunki ubezpieczenia mogą bowiem wskazywać, według jakich cen obliczana będzie wartość świadczenia ubezpieczeniowego niepolegająca na zapłacie sumy pieniężnej. Można powiedzieć, że stosowanie tych przepisów byłoby nawet łatwiejsze niż przy tzw. naprawie bezgotówkowej, bo

${ }^{51}$ Co do tych kwestii, zob. w szczególności W. Warkałło, Ubezpieczenie utraconych korzyści..., oraz E. Kowalewski, Odszkodowanie ubezpieczeniowe za utracone korzyści. 
ubezpieczyciel, zobowiązując się naprawiać rzeczy we własnym zakresie, musiałby znać wartość świadczonych przez siebie usług i swoje cenniki lepiej niż cenniki zakładów mechanicznych i innych usługodawców, z którymi współpracuje w ramach tzw. bezgotówkowej likwidacji szkód.

Jeszcze bardziej wątpliwe są argumenty dotyczące niemożności stosowania technicznych ograniczeń odpowiedzialności. Ograniczenia te wynikają jedynie $\mathrm{z}$ tradycji. Nie ma o nich mowy w przepisach rangi ustawowej, w szczególności w Kodeksie cywilnym. Kodeks nie wspomina ani o franszyzie redukcyjnej, ani o franszyzie integralnej, ani o udziale własnym. Ograniczenia te są przede wszystkim wykwitem praktyki ubezpieczeniowej, a doktryna je dopuszcza, nie próbując interpretować przemilczenia ustawodawcy jako zakazu ich stosowania ${ }^{52}$. Wskazane ograniczenia można by zresztą stosować na dokładnie tych samych zasadach, co przepisy o sumie ubezpieczenia, tzn. precyzyjnie wskazując w ogólnych warunkach umów reguły, według których wyceniana będzie wartość usług świadczonych przez ubezpieczyciela. Wszystko wydaje się być zatem kwestią odpowiedniego ukształtowania ogólnych warunków ubezpieczenia.

Twierdzi się również, że naprawienie szkody w drodze restytucji naturalnej jest sprzeczne $z$ istotą i tradycją ubezpieczeń. Poglądy te pozornie wydają się uzasadnione. Zakłady ubezpieczeń to przecież instytucje finansowe, a nie warsztaty naprawcze lub przedsiębiorstwa budowlane. Jest jednak oczywiste, że zakład ubezpieczeń nie będzie sam naprawiał samochodów ani remontował domów, będzie natomiast zamiast tego posługiwał się podwykonawcami. Twierdzenie, że ubezpieczyciel może zwrócić koszty naprawy zleconej przez ubezpieczającego, nie może jednak sam zlecić naprawy, wydaje dość trudne do obrony w sytuacji, gdy ubezpieczenie ma na celu właśnie naprawienie szkody, czyli w istocie przywrócenie do stanu poprzedniego.

52 Z.K. Nowakowski, A. Wąsiewicz, Prawo ubezpieczeń majątkowych i osobowych, Warszawa-Poznań 1973, s. 50-52; W. Warkałło, Prawo..., s. 70-71; Prawo ubezpieczeń gospodarczych, red. E. Kowalewski, s. 220; M. Orlicki, Umowa ubezpieczenia, 2002, s. 167-168; M. Krajewski, Umowa ubezpieczenia. Art. 805-834 KC..., 2016, s. 213-214. 
Stwierdzenie M. Orlickiego, że dopuszczenie spełnienia przez ubezpieczyciela świadczenia w naturze może powodować pewne kłopoty, jest niewątpliwie słuszne. Kłopoty te jednak da się rozwiązać, odpowiednio interpretując przepisy. Ilustrację w tym zakresie stanowić może uchwała Sądu Najwyższego z 30.11.2016 r., III CZP 74/1653, gdzie uznano, że roszczenie regresowe wobec ubezpieczyciela sprawcy szkody służy ubezpieczycielowi, który pokrył koszty najmu pojazdu zastępczego w ramach ubezpieczania assistance. Pozwane Polskie Biuro Ubezpieczycieli Komunikacyjnych podnosiło, że takie roszczenie powodowemu ubezpieczycielowi nie służy, nie zapłacił on bowiem odszkodowania stosownie do art. 828 k.c., mającego stanowić podstawę regresu, ale zapłacił wynagrodzenie na podstawie umowy, którą zawarł z wynajmującym. Według Sądu Najwyższego w sytuacji, gdy sprawcą szkody wyrządzonej ubezpieczonemu jest osoba trzecia, rolą ubezpieczyciela assistance jest podniesienie komfortu ubezpieczonego przez jak najszybsze spełnienie jego świadczenia i „wzięcie na siebie” trudu ustalenia osoby za nie odpowiedzialnej oraz dochodzenia od niej odszkodowania.

Zdaniem Sądu Najwyższego, spełniając swoje świadczenie z umowy ubezpieczenia assistance za pośrednictwem osoby trzeciej, ubezpieczyciel de facto wypłaca na rzecz poszkodowanego odszkodowanie in naturam, co jest możliwe na podstawie przepisów ogólnych. Z perspektywy ubezpieczyciela zawsze dochodzi do zapłaty albo bezpośrednio odszkodowania na rzecz poszkodowanego, albo na rzecz osoby trzeciej za naprawienie szkody w naturze. W tym sensie ubezpieczyciel zawsze płaci odszkodowanie, także gdy szkoda w majątku poszkodowanego naprawiana jest $w$ naturze. Wobec tego, że umożliwienie poszkodowanemu w wypadku komunikacyjnym korzystania z samochodu zastępczego jest postacią wypłaty na jego rzecz odszkodowania, to dla spełnienia przesłanki „zapłacenia odszkodowania” warunkującej powstanie na rzecz ubezpieczyciela roszczenia regresowego, o którym mowa w art. 828 $\$ 1$ k.c., bez znaczenia jest to, w jaki sposób ubezpieczyciel dochodzący tego roszczenia spełnił świadczenie wobec poszkodowanego, a więc czy dostarczył - bezpośrednio albo za pośrednictwem innego podmiotu - taki samochód, czy też wypłacił w pieniądzu odszkodowanie

53 OSNC 2017/7-8, poz. 82. 
pokrywające koszty poniesione przez poszkodowanego na wynajęcie takiego samochodu. Ewentualne zawarcie umowy z osobą trzecią mającą bezpośrednio spełnić takie świadczenie na rzecz poszkodowanego jest sprawą ubezpieczyciela.

Z wnioskiem Sądu Najwyższego, że art. 828 k.c. może stanowić podstawę regresu dla ubezpieczyciela assistance, oczywiście należy się zgodzićs4. W uzasadnieniu jednak jest trochę chaosu. Sąd Najwyższy nie zajmuje jednoznacznego stanowiska co do tego, czy świadczenie z ubezpieczenia assistance ma postać pieniężną, czy niepieniężną. Umowę zawartą przez ubezpieczyciela z wypożyczalnią samochodów zdaje się traktować jako umowę najmu, nie zastanawiając się nad tym, czy jakikolwiek stosunek prawny istnieje między wypożyczalnią a ubezpieczonym. Wynika to zapewne stąd, że Sąd Najwyższy słusznie skoncentrował się na kwestii regresu oraz na jego podstawach. Uchwała ma z pewnością szerszy walor i można ją odnieść nie tylko do poniesienia przez ubezpieczyciela kosztów wynajmu, ale również innych usług, które starał się on zapewnić na mocy zawartej umowy ubezpieczenia.

Być może niechęć do naprawienia przez ubezpieczyciela szkody w drodze restytucji naturalnej wynika $z$ tradycyjnej niechęci prawa brytyjskiego, gdzie przecież wykształciło się ubezpieczenie jako instytucja prawna do takiej formy naprawienia szkody. Jak wiadomo, common law $\mathrm{w}$ ramach tzw. remedies, czyli roszczeń przysługujących w razie wyrządzenia szkody, jedynie wyjątkowo dopuszcza tzw. specific performance, poprzestając zwykle na świadczeniach odszkodowawczych. Tendencja do coraz powszechniejszego stosowania specific performance jest jednak zauważalna. Dotyczy to przede wszystkim innych niż Wielka Brytania przedstawicieli rodziny common law, w szczególności Stanów Zjednoczonych Ameryki Północnej, Kanady i Australii ${ }^{5}$.

Bliższe spojrzenie na prawo anglosaskie wskazuje jednak, że tradycyjnie restrykcyjne stanowisko w przedmiocie specific performance nie jest po-

54 Stosowanie regulacji dotyczących regresu w ubezpieczeniach assistance nie budzi również wątpliwości w prawie francuskim - por. S. Beaugendre, Contrat..., s. 157.

55 K. Zweigert, H. Kötz, An Introduction..., s. 479 i n. oraz 484. 
strzegane jako przeszkoda dla naprawienia przez ubezpieczyciela szkody $\mathrm{w}$ drodze przywrócenia do stanu poprzedniego. W istocie dopuszczalność restitutio in integrum nie budzi w angielskim prawie ubezpieczeniowym wątpliwości ${ }^{56}$. Opcja taka istnieje jedynie w ubezpieczeniach mienia i musi wyraźnie wynikać z treści polisy, postrzegana jest jednak jako prawo ubezpieczyciela, nie zaś ubezpieczającego ${ }^{57}$. Wybór między naprawieniem szkody przez przywrócenie do stanu poprzedniego należy wyłącznie do ubezpieczyciela, który jest swoim wyborem związany i nie może się z niego wycofać. Zastrzeżenia dotyczące przywrócenia stanu poprzedniego czynione są przez ubezpieczycieli od dawna w ich własnym interesie ${ }^{58}$. Mają chronić przed wygórowanymi roszczeniami ubezpieczających, a także przeciwdziałać oszustwom ubezpieczeniowym.

W razie skorzystania z prawa do przywrócenia do stanu poprzedniego umowa ubezpieczenia przekształca się zależnie od okoliczności w umowę o naprawę albo umowę o roboty budowlane ze wszystkimi tego konsekwencjami ${ }^{59}$. Jeżeli polisa nie zawiera stosownych zastrzeżeń, ubezpieczyciel będzie musiał wywiązać się z takiej umowy, choćby koszty przywrócenia do stanu poprzedniego przekraczały sumę ubezpieczenia albo wartość rzeczy naprawionej przekroczyła jej wartość przed szkodą. Następcza niemożliwość świadczenia może zwolnić ubezpieczyciela z obowiązku przywrócenia do stanu poprzedniego, przekształcając na powrót stosunek prawny w umowę ubezpieczenia, jedynie jeżeli zadziała doktryna frustration of contract. Ubezpieczyciel poniesie również odpowiedzialność za wadliwą naprawę lub wadliwie wzniesiony budynek ${ }^{60}$.

56 Każda licząca się książka o ubezpieczeniach zawiera oddzielny rozdział poświęcony tej kwestii. Zob. J. Birds, Birds'..., rozdz. 16, s. 319 i n.; E.R. Hardy-Ivamy, General Principles..., rozdział 45, s. 483 i n., MacGillivray..., rozdz. 22 i n.; J. Lowry, P. Rawlings, R. Merkin, Insurance Law..., rozdz. 10 C, s. 344 i n.; A. McGee, The Modern..., rozdz. 23, s. 319 i n.; M. Clarke, The Law of Insurance Contract, London-Hong-Kong 1997, rozdz. 29, s. 791 i n.

57 E.R. Hardy-Ivamy, General Principles..., s. 484; Colinvaux's..., s. 359.

58 J. Birds, Birds'..., s. 319-321. Redaktorzy MacGillivray zwracają uwagę, że tego rodzaju klauzule chronią nadto ubezpieczyciela przed wypłatą sum przekraczających wartość przywrócenia do stanu poprzedniego wtedy, gdy wiele osób ma interesy ubezpieczeniowe o różnej wartości; MacGillivray..., s. 673.

59 J. Birds, Birds'..., s. 320; E.R. Hardy-Ivamy, General Principles..., s. 465.

60 J. Birds, Birds'..., s. 320. 
Poza umownym prawem przywrócenia do stanu poprzedniego wyróżnia się również ustawowy obowiązek przywrócenia wynikający z art. 83 Fire Prevention (Metropolis) Act 1774 dotyczącego ubezpieczeń ogniowych budynków. Należy podkreślić, że podobnie jak w przypadku klauzul umownych, obowiązek ten nie został wprowadzony w interesie ubezpieczających. Przywrócenia do stanu poprzedniego może zażądać od ubezpieczyciela osoba niebędąca ubezpieczającym, która ma interes $\mathrm{w}$ trwaniu budynku w stanie niepogorszonym ${ }^{61}$. Przykładowo prawo takie wykonywać mogą skutecznie wierzyciele hipoteczni, a także najemcy czy kupujący przed sfinalizowaniem sprzedaży budynku ${ }^{62}$. Rozwiązanie to przypomina nieco regulację z art. 89 polskiej ustawy o księgach wieczystych i hipotece, która zakazuje ubezpieczycielowi budynku wypłaty pieniędzy ubezpieczającemu na inne cele niż przywrócenie do stanu poprzedniego, jeżeli nie wyrazi na to zgody wierzyciel hipoteczny ${ }^{63}$.

Angielska Komisja ds. Reformy Prawa rozważała zmianę art. 83 Fire Prevention (Metropolis) Act 1774 lub jego uchylenie, ponieważ jest wykorzystywany w innych celach niż te, którym miał służyć. Z przepisu korzystają obecnie przede wszystkim osoby trzecie w różnym stopniu zainteresowane utrzymaniem budynku w stanie niepogorszonym, podczas gdy chodziło o zapobieganie podpaleniom ze strony samych ubezpieczających. Ostatecznie uznano, że problem nie jest wystarczająco poważny, by zmieniać prawo ${ }^{64}$.

Powołując argumenty prawnoporównawcze, warto zaznaczyć, że francuskie prawo ubezpieczeniowe nie wskazuje w ogóle na to, że ubezpieczyciel ma zapłacić odszkodowanie. Dotyczący tej kwestii art. L113-5 Code des assurances przeszedł znamienną zmianę. Przed 1981 r. stanowił, że w razie zajścia wypadku ubezpieczyciel wypłaca odszkodowanie lub

61 J. Lowry, P. Rawlings, R. Merkin, Insurance Law..., s. 346; J. Birds, Birds'..., s. 321.

62 Co do osób zainteresowanych zob. przykładowo MacGillivray..., s. 684; A. McGee, The Modern..., s. 321.

63 Przy czym polski przepis nie zobowiązuje ubezpieczyciela do przywrócenia do stanu poprzedniego, ale jedynie do przeznaczenia odszkodowania na ten cel. Odszkodowanie może być wypłacane w ratach stosownie do postępu robót.

${ }^{64}$ J. Lowry, P. Rawlings, R. Merkin, Insurance Law..., s. 348; J. Birds, Birds'..., s. 323; MacGillivray..., s. 688. 
sumę wskazaną w umowie („est tenu de payer dans le délai convenu l'indemnité ou la somme déterminée par la contrat"). Obecnie wskazany przepis stanowi, że w razie zajścia wypadku ubezpieczyciel spełnia oznaczone w umowie świadczenie („doit exécuter dans le délai convenu la prestation déterminée par la contrat”). Zmiana miała na celu właśnie legalizację świadczenia przez ubezpieczycieli różnego rodzaju usług $\mathrm{w}$ ubezpieczeniach assistance i ochrony prawnej ${ }^{65}$.

Nieco inaczej sytuacja przedstawia się w prawie niemieckim, jednak i tu trudno przyjąć, że naprawienie szkody w drodze restytucji naturalnej jest wyłączone. Ustawodawca niemiecki, podobnie jak polski, zdaje się zakładać, że będzie ono polegało na zapłacie sumy pieniężnej, nie formułuje jednak zakazów naprawienia przez ubezpieczyciela szkody $\mathrm{w}$ drodze restytucji naturalnej ${ }^{66}$. Możliwość spełniania świadczenia przez ubezpieczyciela w naturze była dostrzegana jeszcze na gruncie VVG z 1902 r. ${ }^{67}$ Podobne poglądy formułowane są również obecnie. Przykładowo według M. Wandta sam fakt, że zamiast świadczenia pieniężnego obiecuje się świadczenie spełniane w formie naturalnej (np. naprawę rzeczy w razie jej uszkodzenia w zamian za określoną opłatę), nie przesądza o wyłączeniu określonych umów ze sfery zainteresowań nadzoru ubezpieczeniowego ${ }^{68}$. Autor ten podkreśla również możliwość spełnienia świadczenia w formie naturalnej w ubezpieczeniach zdrowotnych ${ }^{69}$.

Problem jest dostrzegany również w innych systemach prawnych. Przykładowo art. 7:925 holenderskiego kodeksu cywilnego definiuje umowę ubezpieczenia między innymi przez wskazanie, że świadczenie ubezpieczyciela polega na wykonaniu na rzecz drugiej strony jednej lub wielu płatności. Tego rodzaju sformułowaniem nie mogłoby być oczywiście objęte zapewnienie przez ubezpieczyciela w ubezpieczeniu odpowiedzialności cywilnej albo ochrony prawnej porad prawnych na

65 J. Bigot [w:] Traité de Droit..., s. 48; Y. Lambert-Faivre, L. Leveneur, Droit..., s. 189; S. Beaugendre, Contrat..., s. 45 oraz 150.

66 Zob. m.in. art. 16, 78, 100, 137 VVG.

67 Bruck E., Möller H., Kommentar zum Versicherungsvertragsgesetz, Berlin, New York 1980, s. 7-8.

68 M. Wandt, Versicherungsrecht, s. 11, 26.

69 M. Wandt, Versicherungsrecht, s. 477. 
rzecz ubezpieczającego albo w ubezpieczeniu medycznym zapewnienie, zamiast zwrotu kosztów leczenia poniesionych przez ubezpieczającego, usług lekarzy i szpitali działających na podstawie umów z ubezpieczycielem. Z tego powodu art. 7:926 ustęp 1 holenderskiego kodeksu cywilnego precyzuje, że przez płatność w rozumieniu holenderskiego prawa umów rozumie się również świadczenia inne niż wypłacane w pieniądzach.

Właśnie z opisanych względów art. 1:201 PEICL stanowi jedynie, że ubezpieczyciel przyrzeka ubezpieczającemu ochronę na wypadek określonego ryzyka w zamian za zapłatę składki. Sformułowanie ma być inspirowane ustawami belgijską oraz luksemburską, które wskazują po prostu, że ubezpieczyciel ma wykonać świadczenie wskazane w umowie. Przyjęta redakcja art. 1:201 PEICL ma pozwolić stronom na ustalenie, czy świadczenie spełniane przez ubezpieczyciela ma mieć formę pieniężną, czy niepieniężną. Twórcy PEICL wskazują również, że zastrzeżenie tego rodzaju wynika wprost $\mathrm{z}$ art. 1 greckiej ustawy o umowie ubezpieczenia ${ }^{70}$. Ich zdaniem w Polsce podobna możliwość wynikała z nieobowiązującej już ustawy o działalności ubezpieczeniowej z 2003 r., która w zakresie określenia działalności ubezpieczeniowych i reasekuracyjnych zawierała podobną regulację do obecnie obowiązującej ustawy o działalności ubezpieczeniowej i reasekuracyjnej (por. art. 3 ust. 1 oraz ust. 4 pkt 2 u.d.u. z 2003 r.) $)^{71}$.

W moim przekonaniu ani przepisy Kodeksu cywilnego, ani ustawy o działalności ubezpieczeniowej i reasekuracyjnej nie dostarczają mocnych argumentów przemawiających przeciwko dopuszczalności spełnienia świadczenia w drodze restytucji naturalnej. Jak wcześniej wskazano, ustawa o działalności ubezpieczeniowej i reasekuracyjnej wyraźnie odnosi się do assistance samochodowego w art. 2. Zgodnie z tym przepisem zakład ubezpieczeń, który otrzymał zezwolenie na wykonywanie działalności ubezpieczeniowej w zakresie ubezpieczeń, o których mowa w dziale II w grupie 18 załącznika do ustawy, może

70 Principles..., s. 52.

71 Pogląd ten pochodzi od D. Fuchsa będącego członkiem Project Group „Restatement of European Insurance Contract Law” oraz popierającego stanowczo teorię ponoszenia ryzyka. Por. D. Fuchs, Ochrona..., s. 40. 
świadczyć pomoc w razie wypadku lub awarii pojazdu mechanicznego w rozumieniu ustawy o ubezpieczeniach obowiązkowych, Ubezpieczeniowym Funduszu Gwarancyjnym i Polskim Biurze Ubezpieczycieli Komunikacyjnych na terytorium państwa członkowskiego Unii Europejskiej przedsiębiorstwa udzielającego ochrony. Odpowiedzialność z tytułu świadczonej pomocy ogranicza się do:

a) usuwania awarii pojazdu na miejscu $\mathrm{z}$ wykorzystaniem, w większości przypadków, przez przedsiębiorstwo udzielające ochrony własnego personelu i sprzętu,

b) przewiezienia pojazdu mechanicznego do najbliższego lub najbardziej odpowiedniego miejsca, w którym mogą być wykonane naprawy, oraz ewentualnego przewiezienia kierowcy i pasażerów, w normalnych okolicznościach za pomocą tego samego środka transportu, do najbliższego miejsca, z którego osoby te mogą kontynuować podróż innymi środkami,

c) transportowania pojazdu mechanicznego, ewentualnie wraz z kierowcą i pasażerami, do miejsca zamieszkania kierowcy lub pasażerów, miejsca rozpoczęcia podróży lub pierwotnego celu podróży w tym samym państwie.

W tym zakresie stosuje się przepisy ustawy o działalności ubezpieczeniowej i reasekuracyjnej.

$\mathrm{Z}$ drugiej strony jednak art. 4 u.d.u.r. utożsamia działalność ubezpieczeniową z wykonywaniem czynności ubezpieczeniowych związanych z oferowaniem i udzielaniem ochrony na wypadek ryzyka wystąpienia skutków zdarzeń losowych. Wyliczenie czynności ubezpieczeniowych wydaje się wyczerpujące (pominąwszy wynikającą z art. 4 ust. 8 pkt 7 możliwość wykonywania przez zakłady ubezpieczeń innych czynności przewidzianych przepisami odrębnych ustaw) i nie obejmuje świadczenia przez zakłady ubezpieczeń usług naprawczych, hotelowych, gastronomicznych, prawnych, leczniczych itp. Dodatkowo art. 4 ust. 3 u.d.u.r. zakazuje zakładom ubezpieczeń wykonywania innej działalności poza działalnością ubezpieczeniową i bezpośrednio z nią związaną.

Z zestawienia art. 2 oraz art. 4 u.d.u.r. można wprawdzie próbować wysnuć wniosek, że świadczenie pomocy przybierającej postać określonego 
rodzaju usług zamiast wypłaty odszkodowania pieniężnego jest dopuszczalne wyłącznie w zakresie określonym wyraźnie w art. 2 u.d.u.r. Tego rodzaju ujęcie ograniczałoby jednak wydatnie nawet dopuszczalny zakres pomocy niepieniężnej w ubezpieczeniu assistance samochodowym, które w praktyce poza usługami określonymi w art. 2 u.d.u.r. obejmuje przynajmniej zapewnienie ubezpieczającemu noclegu poza miejscem zamieszkania. Usługi świadczone w ramach tzw. medical, legal albo home assistance byłyby natomiast zupełnie wykluczone. Za opisanym wyżej stanowiskiem, ograniczającym zakres świadczeń niepieniężnych ubezpieczyciela do usług wymienionych w art. 2, nie przemawiają żadne racje poza niezupełnie jednoznacznym brzmieniem ustawy. W szczególności wydaje się ono nie do pogodzenia z względami celowości oraz potrzebami obrotu.

Jest nadto przynajmniej wątpliwe, czy ustawa o działalności ubezpieczeniowej i reasekuracyjnej, nieokreślająca prywatnoprawnej natury ubezpieczania oraz mająca ze swej istoty charakter przede wszystkim administracyjnoprawny, może przesądzać o dopuszczalnej treści świadczenia ubezpieczyciela tylko dlatego, że zamiast o wykonywaniu umów ubezpieczenia wspomina o wypłacaniu odszkodowań i innych świadczeń. Można również argumentować, że nawet jeśli naprawianie szkód poprzez przywrócenie do stanu poprzedniego nie stanowi działalności ubezpieczeniowej w rozumieniu ustawy, to jest jednak objęte spektrum kompetencji zakładów ubezpieczeń jako działalność pozostająca z działalnością ubezpieczeniową w bezpośrednim związku (art. 4 ust. 3 i 5 in fine u.d.u.r.).

Dodać należy, że choć ustawa o działalności ubezpieczeniowej i reasekuracyjnej, wyliczając czynności ubezpieczeniowe, nie obejmuje działalności usługowej, to jednak wcześniej określa działalność ubezpieczeniową jako działalność polegającą na wykonywaniu czynności ubezpieczeniowych związanych $\mathrm{z}$ oferowaniem i udzielaniem ochrony na wypadek ryzyka wystąpienia skutków zdarzeń losowych. W moim przekonaniu można stąd wysnuć wniosek, że dopóki świadczenie określonego rodzaju usług przy pomocy współpracujących z ubezpieczycielem podwykonawców wiąże się z udzielaniem ochrony na wypadek 
ryzyka wystąpienia skutków zdarzeń losowych, dopóty jest niesprzeczne $\mathrm{z}$ istotą ubezpieczenia.

Uzupełniająco wypada wskazać, że zgodnie z art. 5 u.d.u.r. ustala się podział ubezpieczeń według działów, grup i rodzajów ryzyka określony w załączniku do ustawy. Konstatacja sugerująca niedopuszczalność spełniania przez ubezpieczycieli świadczeń niepieniężnych pozostałaby w rozdźwięku z załącznikiem do ustawy. W załączniku, wśród ubezpieczeń innych niż ubezpieczenia na życie, wymienia się bowiem ubezpieczenia świadczenia pomocy na korzyść osób, które popadły w trudności w czasie podróży lub podczas nieobecności w miejscu zamieszkania, a także ubezpieczenia pomocy prawnej. Ogólne warunki ubezpieczenia największych polskich ubezpieczycieli zdają się wskazywać, że na mocy tego rodzaju ubezpieczeń ubezpieczyciele zobowiązują się świadczyć na rzecz ubezpieczonych pomoc polegającą na świadczeniu różnego rodzaju usług.

Kolejny argument na rzecz dopuszczalności spełnienia przez ubezpieczyciela świadczeń $\mathrm{w}$ formie niepieniężnej stanowi prawo unijne. Ustawodawca europejski przewiduje, że świadczenie ubezpieczyciela w ubezpieczeniu assistance nie polega tylko na pośredniczeniu między ubezpieczającym usługodawcą i pokryciu kosztów usługi, ale właśnie na jej wykonaniu. Zgodnie z art. 2 ust. 2 dyrektywy Wypłacalność $\mathrm{II}^{72}$ „ubezpieczenie inne niż na życie obejmuje działalność polegającą na pomocy udzielanej osobom, które popadły w trudności w czasie podróży, podczas nieobecności w miejscu zamieszkania lub miejscu zwykłego pobytu. Działalność ta polega na zobowiązaniu, w zamian za zapłaconą uprzednio składkę, do niezwłocznego zapewnienia pomocy osobie uprawnionej na podstawie umowy o świadczenie pomocy, kiedy osoba ta znajdzie się w trudnej sytuacji w następstwie zdarzenia losowego - w przypadkach i zgodnie $\mathrm{z}$ warunkami określonymi w umowie. Pomoc może polegać na udzielaniu świadczeń pieniężnych lub w naturze. Udzielanie świadczeń w naturze może być również realizowane przy pomocy personelu i sprzętu osoby, która ich udziela. Działalność w zakresie pomocy nie obejmuje serwisu, konserwacji, obsługi posprzedaż-

72 Dyrektywa Parlamentu Europejskiego i Rady 2009/138/WE. 
nej lub samego wskazywania lub świadczenia pomocy w charakterze pośrednika”. Artykuł 2 u.d.u.r. stanowi implementację wyżej opisanej regulacji unijnej.

Zainteresowanie ustawodawcy europejskiego ubezpieczeniem assistance jest łatwo zrozumiałe w świetle immanentnej międzynarodowości najważniejszego z nich, to jest assistance samochodowego. Nie należy zatem dziwić się, że podobne postanowienia zawierała już nieobowiązująca obecnie dyrektywa Rady z 10.12.1984 r. (84/641/EWG) zmieniająca, szczególnie w zakresie ubezpieczenia świadczenia pomocy turystycznej, pierwszą dyrektywę (73/239/EWG) w sprawie koordynacji przepisów ustawowych, wykonawczych i administracyjnych odnoszących się do podejmowania i prowadzenia działalności w dziedzinie ubezpieczeń bezpośrednich innych niż ubezpieczenia na życie ${ }^{73}$. Właśnie na mocy dyrektywy z 1984 r. utworzono branżę 18 ubezpieczeń, tj. ubezpieczenie świadczenia pomocy na korzyść osób, które popadły w trudności w czasie podróży, podczas nieobecności w miejscu zamieszkania lub miejscu stałego pobytu, wymienioną również w załączniku do polskiej ustawy o działalności ubezpieczeniowej i reasekuracyjnej ${ }^{74}$.

W świetle powyższych uwag oraz współczesnych tendencji do poszerzania ochrony ubezpieczeniowej regulacja ustawy o działalności ubezpieczeniowej i reasekuracyjnej, nieuwzględniająca wśród czynności ubezpieczeniowych usług mających na celu przywrócenie stanu poprzedniego, wydaje się nieco anachroniczna. Klasyfikacja rodzajów ubezpieczenia wymieniająca m.in. ubezpieczenia świadczenia pomocy na korzyść osób, które popadły w trudności w czasie podróży lub podczas nieobecności w miejscu zamieszkania, nie koresponduje z wyliczeniem czynności ubezpieczeniowych. Wyliczenie to w moim przekonaniu powinno zostać rozszerzone w taki sposób, by zagwarantować ubezpieczycielom możliwość świadczenia usług zmierzających do naprawienia szkody wywołanej zdarzeniem losowym.

73 Dz.Urz. UE L 339, s. 21.

74 Zob. S. Beaugendre, Contrat..., s. 32 i n. 
W ramach konkluzji można przypomnieć uwagę A. Szpunara, że różnica między restytucją naturalną a zapłaceniem w pieniądzu odszkodowania mającego pokryć koszty przywrócenia do stanu poprzedniego często zaciera się. Uwaga ta będzie przedmiotem szerszych rozważań w kolejnym podrozdziale. Na obecnym etapie trudno jednak zrozumieć, jakie racje miałyby sprzeciwiać się zlecaniu przez ubezpieczycieli we własnym imieniu, ale na rachunek ubezpieczonych usług zmierzających do naprawienia poniesionych przez tych ostatnich szkód przy jednoczesnym dopuszczeniu pokrywania, także w drodze bezgotówkowej, kosztów usług zleconych we własnym imieniu przez ubezpieczonych.

\subsection{Zapłata odszkodowania w celu przywrócenia stanu poprzedniego a restytucja naturalna}

Pogląd, że zapłata przez ubezpieczyciela odszkodowania w celu przywrócenia uszkodzonej rzeczy do stanu poprzedniego jest równoznaczna $\mathrm{z}$ restytucją naturalną, prezentuje szereg autorów, powołując się przy tym na orzecznictwo Sądu Najwyższego. Wprawdzie wypowiadany jest on na gruncie ubezpieczenia OC, jednak w odniesieniu do ubezpieczeń majątkowych problem wydaje się również aktualny.

Wcześniej przytaczane były zmieniające się poglądy A. Szpunara. Autor ten ostatecznie stwierdził, że zapłata odpowiedniej sumy pieniężnej - w pewnym sensie - także służy przywróceniu stanu poprzedniego w znaczeniu gospodarczym i wyprowadził stąd wniosek, że chodzi o szczególny rodzaj przywrócenia stanu poprzedniego ${ }^{75}$. Z powołanej konkluzji A. Szpunara B. Balas-Noszczyk i K. Malinowska wywiodły, że art. 822 k.c. mówiący o zapłaceniu przez ubezpieczyciela odszkodowania za szkody wyrządzone osobom trzecim, za które odpowiedzialność ponosi ubezpieczający lub ubezpieczony, nie wyklucza restytucji naturalnej w sytuacjach, gdy odszkodowanie ma pokryć przywrócenie do stanu

75 A. Szpunar, Restytucja..., s. 12; A. Szpunar, Ustalenie odszkodowania z tytułu..., s. $31 \mathrm{i} \mathrm{n.}$ 
poprzedniego. Jak wskazano, według tych autorek w omawianych sytuacjach pieniężna forma odszkodowania jest jedynie stanem pozornym ${ }^{76}$.

Stanowisko, wedle którego zapłata sumy pieniężnej służy przywróceniu stanu poprzedniego, prezentuje również J. Kufel, szerzej go nie uzasadniając $c^{77}$. Podobnie wypowiadają się E. Kowalewski i M. Nesterowicz w glosie do uchwały Sądu Najwyższego z 12.10.2001 r., III CZP $57 / 01^{78}$. Autorzy ci krytykują wyrażony w cytowanej uchwale pogląd, wedle którego odszkodowanie za uszkodzenie samochodu może objąć, oprócz kosztów naprawy, także zapłatę sumy pieniężnej, odpowiadającej różnicy między wartością tego samochodu przed uszkodzeniem i po naprawie. Ich zdaniem, skoro poszkodowany wybiera naprawę, czyli naprawienie szkody w drodze restytucji naturalnej, to nie może domagać się dodatkowo naprawienia tzw. szkody handlowej, konstrukcja z art. 363 k.c. opiera się bowiem na zobowiązaniu przemiennym. Wybór poszkodowanego prowadzi do koncentracji i obejmuje wybór między całymi świadczeniami, innymi słowy, nie może dotyczyć części jednego świadczenia i części drugiego. Uprawnienie poszkodowanego ogranicza się do wyboru tylko jednego z roszczeń. Zaspokojenie tego roszczenia oznacza wygaśnięcie drugiego ${ }^{79}$. Sam pogląd, że w przypadku zwrotu przez ubezpieczyciela kosztów naprawy chodzi o restytucję naturalną, nie zostaje przez autorów uzasadniony. Stanowisko wykluczające domaganie się uzupełniającego odszkodowania pieniężnego wtedy, gdy restytucja nie pozwala na przywrócenie wszystkich cech rzeczy uszkodzonej, jest zaśkontestowane przez większość doktryny i orzecznictwo ${ }^{80}$.

76 B. Balas-Noszczyk, K. Malinowska, W sprawie..., s. 23.

77 J. Kufel [w:] Ubezpieczenia gospodarcze, red. T. Sangowski, Warszawa 2001, s. 142.

78 Krytyczna glosa E. Kowalewskiego i M. Nesterowicza, s. 69 i n., aprobująca glosa A. Szpunara.

79 E. Kowalewski, M. Nestrowicz, Glosa..., s. 73.

80 Stanowisko odmienne prezentują m.in. T. Wiśniewski [w:] Kodeks cywilny..., komentarz do art. 363, teza 4; Z. Banaszczyk [w:] Kodeks..., t. 1, red. K. Pietrzykowski, s. 1017-1018; K. Zagrobelny [w:] Kodeks..., 2013, s. 507; M. Kaliński Odpowiedzialność odszkodowawcza [w:] System..., s. 178-179. Stanowisko to, co ciekawe, stanowczo popierał również A. Szpunar, którego M. Nesterowicz i E. Kowalewski powołują na poparcie swego poglądu. Por. A. Szpunar, Ustalenie odszkodowania w prawie..., s. 143. Przeciwnie m.in. A. Olejniczak [w:] Kodeks..., red. A. Kidyba, s. 100. 
Pogląd, że bezgotówkowa likwidacja szkód nie polega na spełnieniu przez ubezpieczyciela świadczenia $\mathrm{w}$ formie niepieniężnej, prezentują M. Orlicki i M. Krajewski. Zdaniem tego pierwszego zamiast ustalać, że naprawienie szkody odbywać się będzie w drodze restytucji naturalnej, strony mogą zastrzec, że w razie zajścia wypadku ubezpieczeniowego zakład ubezpieczeń ma spełnić świadczenie ubezpieczeniowe w pieniądzu, ale jednocześnie jest uprawniony i zobowiązany do zawarcia z warsztatem naprawczym umowy mającej na celu przywrócenie stanu poprzedniego. Na mocy umocowania i zlecenia ubezpieczającego ubezpieczyciel dokonuje $\mathrm{w}$ ten sposób przywrócenia stanu poprzedniego przy pomocy zewnętrznych wykonawców.

Stanowisko M. Orlickiego nie jest zupełnie jasne. Jeżeli bowiem z umowy ubezpieczenia płynąć miałoby zobowiązanie zakładu ubezpieczeń do zawarcia umowy o przywrócenie do stanu poprzedniego, to świadczenie ubezpieczyciela w razie zajścia wypadku nie przybierałoby wyłącznie formy pieniężnej. W każdym razie na gruncie jego ujęcia umowa o naprawę pojazdu jest zawierana w imieniu ubezpieczającego i ubezpieczyciel nie jest jej stroną. Wynagrodzenie podmiotów dokonujących restytucji to świadczenie pieniężne ubezpieczyciela spełniane bez pośrednictwa ubezpieczającego, lecz za jego zgodą i na jego zlecenie. Opisana konstrukcja bezgotówkowej likwidacji szkód jest według M. Orlickiego zgodna $\mathrm{z}$ ustawą i naturą stosunku ubezpieczenia, w przeciwieństwie do koncepcji spełnienia świadczenia przez ubezpieczyciela w drodze restytucji naturalnej ${ }^{81}$.

Również według M. Krajewskiego tzw. bezgotówkowe rozliczenia z zakładem naprawczym polegają na spełnieniu przez ubezpieczyciela świadczenia w formie pieniężnej, tyle że nie na rzecz ubezpieczającego, ale na rzecz warsztatu naprawczego. Do zawarcia umowy, której przedmiotem jest naprawa, dochodzi pomiędzy podmiotem prowadzącym zakład naprawczy a poszkodowanym posiadaczem pojazdu. Ubezpieczyciel spełnia jedynie świadczenie w imieniu i na rzecz tego ostatniego.

81 M. Orlicki, Umowa ubezpieczenia, 2002, s. 191; M. Orlicki, Umowa ubezpieczenia [w:] System..., t. 8, s. 731. 
Podstawowa konkluzja w przedstawionym sporze została już w zasadzie sformułowana wcześniej. Jakkolwiek A. Szpunar ma rację, że w omawianym przypadku granica między restytucją naturalną a odszkodowaniem pieniężnym zaciera się, to jednak, próbując dokonać kwalifikacji świadczenia spełnianego przez ubezpieczyciela na gruncie art. 363 k.c., który przewiduje dwie ekskluzywne formy naprawienia szkody, trudno nie dostrzec, że ubezpieczyciel w każdym przypadku płaci odszkodowanie, nie zaś naprawia samochód. Odszkodowanie, o którym mowa, może być wypłacone na podstawie kalkulacji dokonanej zawczasu przez ubezpieczyciela, niekiedy zaś na podstawie faktur przedstawionych przez ubezpieczającego lub nawet bezgotówkowo, bezpośrednio na konto zakładu naprawczego, tym niemniej pozostaje odszkodowaniem pieniężnym.

Ubezpieczyciel nie zobowiązuje się do przywrócenia stanu poprzedniego, ale do pokrycia kosztów przywrócenia stanu poprzedniego. Powództwo, w którym ubezpieczający domagałby się od ubezpieczyciela restytucji naturalnej, powinno zostać oddalone, pominąwszy może przypadki, gdy ogólne warunki ubezpieczenia wyraźnie przewidują, że świadczenie ubezpieczyciela będzie przybierać postać restytucji naturalnej. Tylko w takiej sytuacji można w ogóle rozważać roszczenie ubezpieczającego wobec ubezpieczyciela o przywrócenie stanu poprzedniego. Możliwość takiego zastrzeżenia była przedmiotem rozważań.

Oczywiście restytucja naturalna nie musi przybierać postaci usług świadczonych przez zobowiązanego osobiście. Może on również powierzyć naprawę osobie trzeciej. Jednakże, wtedy gdy ubezpieczyciel zwraca koszty naprawy, nawet w ramach tzw. bezgotówkowej likwidacji szkód, umowę, której przedmiotem jest naprawa samochodu zawiera z zakładem naprawczym poszkodowany. Ubezpieczyciel ma jedynie umowy z wybranymi przez siebie zakładami naprawczymi, na podstawie których rozlicza się z nimi bezgotówkowo. Z takiego ukształtowania stosunków umownych płyną przynajmniej dwie istotne konsekwencje. Po pierwsze, kiedy koszty naprawy oszacowane przez zakład naprawczy przekraczają odszkodowanie wypłacone przez ubezpieczyciela, roszczenie o wypłatę nadwyżki zakład kierować będzie do poszkodowanego, a dopiero ten może próbować domagać się uzupełniającego odszkodowania od ubezpieczyciela. Po drugie, co podkreślają S. Reps oraz M. Krajewski, 
ubezpieczyciel nie będzie odpowiadał za niewłaściwie wykonaną naprawę, choćby została ona wykonana w autoryzowanym przezeń serwisie. Roszczenia stąd wynikające poszkodowany kierować może wyłącznie do podmiotu prowadzącego zakład naprawczy ${ }^{82}$.

Zjawisko bezgotówkowej likwidacji szkód samochodowych polegające na tym, że odszkodowanie obejmujące koszty naprawy trafia bezpośrednio na rachunek warsztatu, który dokonał naprawy, przypomina konstrukcję przekazu ${ }^{83}$. Ubezpieczający będący przekazującym udziela podwójnego upoważnienia. Osobę prowadzącą zakład naprawczy (odbiorcę przekazu) upoważnia do przyjęcia świadczenia. Ubezpieczyciela (przekazanego) upoważnia natomiast do spełnienia świadczenia odszkodowawczego z umowy ubezpieczenia na rachunek ubezpieczającego.

Prawny i gospodarczy sens przysporzenia uzyskiwanego przez osobę prowadzącą zakład naprawczy uzasadnia umowa o naprawę pojazdu łącząca tego ostatniego $\mathrm{z}$ ubezpieczającym i stanowiąca stosunek waluty. Stosunek pokrycia zachodzi między ubezpieczającym a zakładem ubezpieczeń i ma podstawę w łączącej ich umowie ubezpieczenia. W tym stosunku dochodzi do przekazu w dług: ubezpieczyciel, spełniając świadczenie do rąk osoby prowadzącej zakład naprawczy, zwolni się z obowiązku zapłaty odszkodowania ubezpieczeniowego względem ubezpieczającego. Wreszcie między ubezpieczycielem a osobą prowadzącą zakład naprawczy zachodzi stosunek zapłaty. Świadczenie spełnione $\mathrm{w}$ tym stosunku zostaje odpowiednio zarachowane na stosunek waluty, zwalniając ubezpieczającego z długu względem osoby prowadzącej zakład naprawczy oraz na stosunek pokrycia, zwalniając ubezpieczyciela z długu względem ubezpieczającego.

Pozornie przedstawiony układ stosunków odpowiada zatem przekazowi. Podobnie jak przy przekazie, ale inaczej niż przy umowie na rzecz osoby trzeciej, osoba prowadząca zakład naprawczy nie ma własnego

82 S. Reps, J. Reps, Ubezpieczenia majątkowe przedsiębiorców, s. 107-108. M. Krajewski, Umowa ubezpieczenia. Art. 805-834 KC..., 2016, s. 64.

83 Pogląd, że w opisanej sytuacji w istocie dochodzi do przekazu, wyraził na seminarium doktorskim w Katedrze Prawa Gospodarczego i Handlowego UŁ Szymon Byczko. 
roszczenia o zapłatę odszkodowania do ubezpieczyciela. Ewentualne argumenty sceptyków wskazujących, że ubezpieczyciel może wobec zakładu podnosić zarzuty ze stosunku pokrycia i waluty, podczas gdy przekaz jest abstrakcyjny, można zwalczać, wskazując, że abstrakcyjność przekazu jest jedynie względna i przepisy o przekazie nie wykluczają podania w treści przekazu stosunku waluty lub pokrycia. Nadto zakres zarzutów służących przekazanemu względem odbiorcy ulega ograniczeniu dopiero z chwilą przyjęcia przekazu.

Wymieniani wyżej autorzy wypowiadający się na temat konstrukcji prawnej bezgotówkowej likwidacji szkód wskazują wprawdzie, że ubezpieczyciel spełnia świadczenie pieniężne na rzecz zakładu naprawczego w imieniu ubezpieczającego, nie zaś w swoim własnym. Działania ubezpieczyciela w stosunku zapłaty w cudzym imieniu zamiast w imieniu własnym odróżniałoby zachodzący układ stosunków od przekazu, zbliżając go do podwójnego pełnomocnictwa, nie wydaje się jednak, by mogło stanowić argument na rzecz zupełnego odrzucenia przekazu. Przyjęta przez ustawodawcę konstrukcja przekazu odchodzi wprawdzie od starszych koncepcji, wypada jednak odnotować, że teoria podwójnego pełnomocnictwa odegrała niebagatelną rolę w kształtowaniu się konstrukcji przekazu. Różnica między działaniem ubezpieczyciela w swoim własnym imieniu a działaniem w imieniu ubezpieczającego jest zresztą trudno uchwytna. W zasadzie nic nie stoi na przeszkodzie, by odwrócić kierunek myślenia, wskazując, że ubezpieczający, jeżeli nie wyraźnie, to przynajmniej per facta concludentia, dokonuje przekazu, ubezpieczyciel zaś, spełniając świadczenie pieniężne na rzecz zakładu naprawczego, działa w imieniu własnym, ale jedynie na rachunek ubezpieczającego.

Do odejścia od przekazu skłania raczej inny argument streszczający się w lapidarnym pytaniu: po co? Ujęcie bezgotówkowej naprawy samochodów jako przekazu jest nęcące, ponieważ przekaz sam w sobie stanowi dla prawnika konstrukcję ciekawą teoretycznie, a jego zastosowanie w czystej postaci, pominąwszy instytucje pochodne, jest skromne, jednakże raz jeszcze powtórzyć można: po co? Bliższa analiza wskazuje, że wikłanie przekazu w bezgotówkową naprawę samochodów jest jednak zbędne i niewiele wyjaśnia. Jak już wskazano, w przedstawionym układzie przekaz od samego początku wiązałby się z podaniem stosunków 
waluty oraz pokrycia. Przyjęcie upoważnienia przez ubezpieczyciela nie wykluczałoby powoływania się przezeń wobec osoby prowadzącej zakład naprawczy na zarzuty z umowy ubezpieczenia, i to zapewne stanowi argument przesądzający przeciwko przekazowi (por. art. $921^{2} \$ 2$ k.c.).

Umorzenie zobowiązania ubezpieczyciela $\mathrm{z}$ umowy ubezpieczenia (w stosunku pokrycia) można osiągnąć przez samo porozumienie między ubezpieczającym a ubezpieczonym, że spełnienie świadczenia nastąpi do rąk osoby trzeciej. Do umorzenia zobowiązania zamawiającego wobec zakładu naprawczego (stosunek waluty) wystarcza podanie przez ubezpieczyciela stosownego tytułu w treści przelewu bankowego. Zgodnie z art. 356 k.c. osoba prowadząca zakład naprawczy nie może żądać świadczenia osobistego, a jeżeli jej wierzytelność wobec zamawiającego naprawę stała się wymagalna, nie może odmówić przyjęcia świadczenia spełnianego przez ubezpieczyciela, choćby ten działał bez zgody dłużnika. Cała operacja bardziej niż przekaz przypomina tak zwaną niewłaściwą umowę na rzecz osoby trzeciej, w której osoba trzecia nie ma bezpośredniego roszczenia wobec dłużnika. Różnic wobec takiej umowy upatrywać można w tym, że porozumienie między ubezpieczającym a ubezpieczycielem, na mocy którego odszkodowanie z umowy ubezpieczenia ma być zapłacone do rąk osoby prowadzącej zakład naprawczy, zawierane jest nie w interesie tej osoby, ale w interesie ubezpieczającego i jak się wydaje, nawet oświadczenie zakładu naprawczego, że chce skorzystać z zastrzeżenia płatności na jej rzecz, nie wyklucza zmiany albo odwołania takiego zastrzeżenia przez strony porozumienia.

Podsumowując, tzw. bezgotówkowa likwidacja szkód nie polega na zobowiązaniu się przez ubezpieczyciela do spełnienia świadczenia $\mathrm{z}$ umowy ubezpieczenia $\mathrm{w}$ formie niepieniężnej, ale jedynie na następczym porozumieniu między ubezpieczycielem a ubezpieczającym, że odszkodowanie ubezpieczeniowe zostanie zapłacone na rzecz zakładu naprawczego. Nie dochodzi w tej sytuacji ani do przekazu, ani do umowy na rzecz osoby trzeciej. Ubezpieczyciel nie jest zobowiązany wobec osoby prowadzącej zakład naprawczy, ale jedynie wobec ubezpieczającego, a nadto podnosić może wszelkie zarzuty z umowy ubezpieczenia związane w szczególności z granicami odszkodowania ubezpieczeniowego. 


\subsection{Charakter świadczenia ubezpieczyciela w ubezpieczeniach assistance i ubezpieczeniu ochrony prawnej}

Powyższe uwagi pozwalają przejść do analizy powoływanych wcześniej rodzajów ubezpieczenia, które najwcześniej opisywane są jako przykłady zobowiązania się przez ubezpieczyciela do świadczenia określonych usług. Dotyczy to przede wszystkim różnego rodzaju ubezpieczeń assistance, z których najbardziej popularne jest ubezpieczenie assistance car. W ramach takiego ubezpieczenia ubezpieczyciele zapewniają nie tylko pokrycie kosztów otwarcia, holowania i parkowania pojazdów, kosztów naprawy pojazdu w miejscu zdarzenia, a także kosztów przejazdu kierowcy i pasażerów oraz ich zakwaterowania, ale również organizację wszystkich wymienionych usług ${ }^{84}$. Poza tym w grę wchodzą ubezpieczenie ochrony prawnej. Jako przykład ubezpieczenia, w którym ubezpieczyciel spełnia świadczenie w naturze, powoływane są również niekiedy ubezpieczenia medyczne. W istocie chodzi, jak się zdaje, o tzw. ubezpieczenie medical assistance, gdzie ubezpieczyciel zapewnia ubezpieczonemu nieodpłatny natychmiastowy dostęp do określonych usług medycznych.

Starając się umiejscowić ubezpieczenia assistance w systematyce załącznika do ustawy o działalności ubezpieczeniowej i reasekuracyjnej - Podział ryzyka według działów, grup i rodzajów ubezpieczeń, A. Raczyński dochodzi do wniosku, że ubezpieczenie assistance car należy uznać za ubezpieczenie świadczenia pomocy na korzyść osób, które popadły w trudności w czasie podróży lub podczas nieobecności w miejscu zamieszkania (dział II, grupa 18), ubezpieczenie medical assistance za ubezpieczenie choroby (dział II, grupa 2), natomiast ubezpieczenie home assistance, zależnie od przypadku, za inne ubezpieczenie szkód rzeczowych wywołanych przez żywioły (dział II, grupa 8) lub ubezpieczenie

${ }^{84}$ Por. przykładowo OWU ubezpieczenia „PZU Pomoc - Pomoc na drodze” PZU SA, OWU „Warta Moto-Assistance” TUiR Warta SA, OWU Car Assistance TU Allianz Polska SA oraz OWU Kosztów Udzielenia Natychmiastowej Pomocy Hestia Car Assistance dla Klientów Indywidualnych oraz małych i średnich przedsiębiorców STU ERGO Hestia SA. 
szkód rzeczowych wywołanych przez grad, mróz oraz inne wcześniej niewymienione przyczyny (dział II, grupa 9).

Z powyższą klasyfikacją trudno się nie zgodzić. Warto przy tym zwrócić uwagę, że tzw. ubezpieczenie medical assistance, będące postacią ubezpieczenia chorobowego, według systematyki Kodeksu cywilnego zaliczone powinno być nie do ubezpieczeń osobowych, ale majątkowych, ściślej zaś do ubezpieczeń mienia, ponieważ stoi na straży interesu majątkowego, któremu zagrażają wydatki związane z kosztami ewentualnego leczenia. Do ubezpieczenia tego odnosić się będą odpowiednio uwagi dotyczące innych ubezpieczeń assistance. Prostsza jest kwalifikacja ubezpieczenia ochrony prawnej, które zostało wyraźnie wyodrębnione w systematyce powołanego wyżej załącznika do ustawy o działalności ubezpieczeniowej (dział II, grupa 17), a nawet w samym tekście ustawy (art. 27 u.d.u.r.), pomimo że w praktyce, gdy chodzi o pomoc ubezpieczonemu na wypadek wystąpienia wobec niego z roszczeniem przez osobę trzecią, ubezpieczenie to bardzo często traktowane jest jako dodatkowe ryzyko w ubezpieczeniu $\mathrm{OC}^{85}$. $Z$ prawnego punktu widzenia ma ono jednak niewątpliwie charakter odrębny choćby dlatego, że suma gwarancyjna w ubezpieczeniu OC powinna odnosić się do świadczenia należnego poszkodowanej osobie trzeciej.

W pierwszym rzędzie należy jednak zastanowić się, czy w ubezpieczeniach assistance oraz ochrony prawnej ubezpieczyciele w istocie zobowiązują się do świadczenia niepieniężnego, czy może, podobnie jak w przypadku bezgotówkowej likwidacji szkód mechanicznych, jedynie porozumiewają się z ubezpieczającym co do bezpośredniej zapłaty za usługi wyświadczone mu w następstwie wypadku przez innych usługodawców.

W doktrynie brak pogłębionej dyskusji na omawiany temat. Eugeniusz Kowalewski w swoim podręczniku w formie slajdów wskazuje, że świadczenie ubezpieczyciela może przybierać postać świadczenia niepieniężnego, wymieniając: assistance, pomoc prawną, windykację roszczeń

${ }^{85}$ Co do tej kwestii, zob. w szczególności M. Orlicki, O łączeniu w jednej umowie różnych rodzajów ubezpieczeń, PA 2010/2. 
i ocenę ryzyka (państw, pomocy, kontraktów). Autor ten, nawiązując do swoich wcześniejszych wypowiedzi, wskazuje również, że w ubezpieczeniu OC osoba ubezpieczona nie otrzymuje odszkodowania do swoich rąk, wypłacane jest ono bezpośrednio osobie poszkodowanej (actio directa). Ubezpieczony otrzymuje zatem świadczenie w postaci zwolnienia z długu odszkodowawczego ${ }^{86}$. Nie wdając się w rozważania co do trafności tego ostatniego stanowiska, z którym zresztą w innym miejscu polemizuje sam E. Kowalewski ${ }^{87}$, wypada skoncentrować się na ubezpieczeniach assistance i podobnych.

Więcej uwagi zagadnieniu poświęca A. Raczyński. Autor ten, powołując się na dostępne OWU, wskazuje, jakie usługi oferują ubezpieczyciele na polskim rynku w ramach ubezpieczeń car assistance, medical assistance oraz home assistance. Jego zdaniem specyfika świadczenia ubezpieczyciela w ubezpieczeniu assistance polega nie tylko na pokryciu w zastępstwie ubezpieczonego kosztów określonych dóbr czy usług, ale również (o ile nie przede wszystkim) na zapewnieniu ich natychmiastowej dostępności poprzez sieć podmiotów współpracujących w tym zakresie z ubezpieczycielem. Innymi słowy, istota omawianego ubezpieczenia sprowadza się zatem do zapewnieniu ubezpieczonemu dostępu do określonych świadczeń niepieniężnych ${ }^{88}$. Konfrontując tak opisane świadczenia w różnego rodzaju ubezpieczeniach assistance z przepisami ustawy o działalności ubezpieczeniowej i reasekuracyjnej, A. Raczyński stwierdza, że konstrukcja ubezpieczenia assistance na pierwszy rzut oka nie pasuje do ustawowego schematu ubezpieczenia. Autor ten ponadto zauważa, podobnie jak E. Kowalewski, że w ubezpieczeniu OC oraz ubezpieczeniu ochrony prawnej świadczenie należne ubezpieczonemu również nie polega na zapłaceniu odszkodowania.

Stanowisko o niepieniężnym charakterze świadczenia ubezpieczyciela w ubezpieczeniu assistance prezentuje również M. Krajewski. Zdaniem

${ }^{86}$ Prawo ubezpieczeń gospodarczych, red. E. Kowalewski, s. 209.

87 E. Kowalewski, Teoretyczny..., s. 205 i n.

88 A. Raczyński, Świadczenie ubezpieczyciela w ubezpieczeniu assistance [w:] Kierunki rozwoju ubezpieczeń gospodarczych w Polsce. Wybrane zagadnienia prawne, red. B. Gnela, Warszawa 2013, s. 183. 
tego autora ubezpieczyciele przeważnie nie określają swego świadczenia wprost jako wykonanie określonej usługi, preferując zapewnienie organizacji i pokrycie kosztów takiej usługi. Użycie opisanego sformułowania zwykle nie prowadzi jednak do zmiany merytorycznej, trzeba zatem przyjąć, że świadczenie w postaci usługi spełnia ubezpieczyciel, a nie podmiot bezpośrednio dokonujący określonej czynności. Na wybór tego ostatniego ubezpieczający nie ma żadnego wpływu i nie sposób uznać, by łączył go z nim jakikolwiek stosunek umowny (np. nie można przyjąć, by ubezpieczający obowiązany był do zapłaty wynagrodzenia, gdyby wynagrodzenia z jakichś powodów nie zapłacił ubezpieczyciel). Wykonawca usługi jest zatem jedynie podmiotem, któremu ubezpieczyciel powierza wykonanie zobowiązania i za którego odpowiada na zasadzie art. 474 k.c. ${ }^{89}$

Wbrew pozorom, sprawa nie zawsze przedstawia się tak, jak opisuje ją M. Krajewski. Jedną z typowych usług gwarantowanych w ramach ubezpieczenia assistance jest zapewnienie samochodu zastępczego. W praktyce skorzystanie z tej usługi odbywa się w taki sposób, że ubezpieczający uzyskuje (zwykle przez infolinię ubezpieczyciela) kontakt ze współpracującą z tym ostatnim tzw. wypożyczalnią samochodów, która podstawia samochód we wskazane przezeń miejsce. Ubezpieczający, biorąc samochód w posiadanie, podpisuje z wypożyczalnią umowę najmu, na mocy której w szczególności odpowiada bezpośrednio względem wypożyczalni za określone uszkodzenia samochodu. Opłatę za najem pokrywa oczywiście ubezpieczyciel, który wcześniej wskazał ubezpieczającemu wynajmującego, najemcą w podpisywanej umowie nie jest jednak ubezpieczyciel, ale ubezpieczający.

Organizacja kosztów ewentualnego noclegu przedstawia się analogicznie: ubezpieczający uzyskuje od ubezpieczyciela adres hotelu, a następnie udaje się do tego hotelu i zawiera umowę, nie płaci jednak za nocleg, ponieważ koszty wynajmu pokoju pokrywa ubezpieczyciel. W obydwu opisanych sytuacjach ubezpieczyciela obciąża organizacja usługi oraz pokrycie jej kosztów. Pierwszą część zobowiązania ubezpieczyciel spełnia w ten sposób, że znajduje usługodawcę mogącego zaoferować usługę

89 M. Krajewski, Umowa ubezpieczenia. Art. 805-834 KC..., 2016, s. 64-65. 
we wskazanym miejscu i czasie oraz kontaktuje z nim ubezpieczającego. Ubezpieczyciel pełni w tym zakresie jedynie funkcję pośrednika. Z prawnego punktu widzenia cała sytuacja przedstawia się zatem bardzo podobnie jak przy tzw. bezgotówkowej likwidacji szkód mechanicznych.

Podobnie kwestia wygląda w ubezpieczeniach ochrony prawnej ${ }^{90}$. Świadczenie ubezpieczyciela określane jest tu przede wszystkim jako refundacja wydatków dotyczących obrony interesów prawnych ubezpieczonego oraz zagwarantowanie porad prawnych na etapie przedsądowym. Pomoc prawną na rzecz ubezpieczonego świadczą przede wszystkim współpracujące z ubezpieczycielami oraz przez nich rekomendowane kancelarie prawne. Ubezpieczony ma przy tym, inaczej niż w ubezpieczeniach assistance, prawo wyboru innego usługodawcy - w tym przypadku prawnika - niż rekomendowany przez ubezpieczyciela ${ }^{91}$. Prawo to gwarantowane jest przez dyrektywę 87/344/EWG z 22.06.1987 r. oraz art. 27 ust. 3 u.d.u.r. ${ }^{92}$ Ogólne warunki ubezpieczenia ochrony prawnej zastrzegają przy tym, że prawnik świadczący pomoc na rzecz ubezpieczonego, nawet ten rekomendowany przez ubezpieczyciela, ponosi odpowiedzialność wyłącznie wobec niego, ubezpieczyciel nie ponosi żadnej odpowiedzialności za czynności prawnika ${ }^{93}$.

Jak widać, również w przypadku ubezpieczenia ochrony prawnej usługa ubezpieczyciela polega zatem przede wszystkim na skontaktowaniu ubezpieczającego lub ubezpieczonego z prawnikiem mogącym w od-

90 Co do tej kwestii, zob. J. Vassel, P. Mierzejewski, Ubezpieczenie ochrony prawnej $w$ Europie $i$ w Polsce, PA 2005/1; S. Szmak, Ubezpieczenia ochrony prawnej $w$ systemie niemieckim - wybrane problemy, WU 2014/1; M. Pabiś, Ubezpieczenie ochrony prawnej - konstrukcja produktu i likwidacja szkód w praktyce ubezpieczeniowej, WU 2016/1.

${ }_{11}$ Zob. szerzej S. Szmak, Wybór prawnika w ubezpieczeniu ochrony prawnej-regulacje wybranych państw europejskich oraz orzecznictwo Trybunału Sprawiedliwości UE, PA 2012/2, s. 75 i n.

92 Dyrektywa Rady z 22.06.1987 r. w sprawie koordynacji przepisów ustawowych, wykonawczych i administracyjnych odnoszących się do ubezpieczenia ochronny prawnej (87/344/EWG), Dz.Urz. WE L 185, s. 77.

93 Por. przykładowo $\$ 18$ ust. 3 OWU Ochrony prawnej Concordia SA obowiązujących od 1.04.2016 r. oraz $\$ 27$ ust. 3 OWU „Ochrona prawna w życiu prywatnym” (OPŻP/ OPP/2017) DAS Towarzystwa Ubezpieczeń Ochrony Prawnej SA przyjęte uchwałą Zarządu tegoż towarzystwa nr 12/12/2016 z 2.12.2016 r. 
powiednim miejscu i czasie zapewnić pomoc prawną oraz na pokryciu kosztów usług prawnych świadczonych przez tego prawnika. Ubezpieczyciel jest natomiast pośrednikiem sensu stricto oraz płatnikiem. Usługi zapewniane przezeń w ramach pośrednictwa ograniczają się zatem do tego, co art. 517 k.z. określał mianem nastręczenia sposobności do zawarcia umowy i ewentualnie pośredniczenia przy jej zawarciu. Nawet jeśli przyjąć, że pośredniczenie, o którym mowa, obejmuje również doradztwo w zakresie wyboru prawnika, to ubezpieczyciel wyraźnie wyłącza swoją odpowiedzialność za sposób wykonania usługi tego ostatniego, w szczególności zaś błędy w sztuce, co de lege lata wydaje się dopuszczalne.

Powyższe uwagi wskazują, że w wielu sytuacjach użycie sformułowania „organizacja i pokrycie kosztów” oraz doprecyzowanie zakresu świadczenia ubezpieczyciela w OWU w istotny sposób zmienia sytuację. Organizacja oznacza jedynie pośredniczenie w zawarciu umowy z podmiotem, który jest w stanie zapewnić ubezpieczającemu natychmiast odpowiednią usługę. Podmiot ten nie jest osobą, za pomocą której ubezpieczyciel wykonywa własne zobowiązanie w rozumieniu art. 474 k.c., zobowiązanie ubezpieczyciela ogranicza się bowiem do pośredniczenia w zawarciu umowy oraz zapłacenia wynagrodzenia podmiotowi, który ją wyświadczył w granicach odpowiedzialności przyjętej na siebie w umowie ubezpieczyciela. Usługodawca wyświadcza ubezpieczającemu usługę na swój własny rachunek, a nie na rachunek ubezpieczyciela. Ubezpieczyciel nie odpowiada za jakość świadczenia mającego postać specjalistycznej usługi (innej niż ubezpieczeniowa).

W opisywanej sytuacji stanowisko M. Orlickiego, dosyć kategorycznie odrzucające możliwość spełnienia przez ubezpieczyciela świadczenia w razie zajścia wypadku w formie restytucji naturalnej, broni się. Autor ten wyraźnie pozostaje pod wpływem prawa niemieckiego, które nawet jeśli nie wyłącza świadczenia ubezpieczyciela w formie restytucji naturalnej, to wyraźnie preferuje zapłatę odszkodowania pieniężnego. $\mathrm{Na}$ nieco innej pozycji stoi, jak wcześniej wskazano, ustawodawca angielski, dopuszczający restytucję naturalną jako prawo i wybór ubezpieczyciela, ze wszystkimi jednak tego konsekwencjami, w szczególności dotyczącymi przekształcenia umowy ubezpieczenia w umowę o określoną usługę 
(zwykle repair contract). Zupełnie inaczej przedstawia się natomiast stanowisko prawa francuskiego, gdzie spełnienie przez ubezpieczyciela świadczenia $\mathrm{w}$ formie restytucji naturalnej dopuszczone jest bardzo wyraźnie i gdzie wyrażane są poglądy, według których umowa ubezpieczenia przybiera w wielu wypadkach charakter umowy mieszanej z elementami umowy o świadczenie usług ${ }^{94}$.

Mogłoby się zdawać, że ubezpieczenia assistance oraz ochrony prawnej w prawie polskim przy odpowiednim ujęciu przestają być argumentem na rzecz dopuszczalności spełnienia świadczenia $\mathrm{w}$ formie restytucji naturalnej. Rzadko jednak zdarza się, by świadczenie ubezpieczyciela w ubezpieczeniu assistance ograniczało się do wąsko rozumianej organizacji i pokrycia kosztów określonych usług. Jak już wskazano, omawiane ostatnio ubezpieczenie ochrony prawnej polega nie tylko na zagwarantowaniu pokrycia kosztów szeroko rozumianych usług prawnych świadczonych przez radców prawnych i adwokatów, ale również na zapewnieniu porad prawnych na etapie przedsądowym. Porada potrzebna na etapie wstępnym służy określeniu problemu ubezpieczającego choćby w przybliżeniu, by zdecydować o ewentualnej potrzebie bezpośredniego kontaktu z prawnikiem ${ }^{95}$. Niezależnie od powyższego szereg prostych i błahych kwestii prawnych może być rozwiązanych na odległość bez konieczności bezpośredniego kontaktu z prawnikiem. $\mathrm{Z}$ opisanych względów dostępne na rynku warianty ubezpieczenia ochrony prawnej poza pokryciem kosztów usług prawnych świadczonych przez wyspecjalizowanych prawników zawierają zwykle również, określany mianem assistance prawnego, element infolinii prawnych zapewniających dostęp do prostej i szybkiej porady prawnej ${ }^{96}$. Również $\mathrm{w}$ ramach typowych ubezpieczeń assistance ubezpieczyciel poza samym pośredniczeniem między ubezpieczającym i usługodawcą oraz pokryciem wynagrodzenia tego ostatniego zapewnia zwykle dostęp do infolinii, gdzie ubezpieczający może uzyskać informacje i porady potrzebne doraźnie w określonych objętych ubezpieczeniem wypadkach.

\footnotetext{
94 Zob. w szczególności S. Beaugendre, Contrat..., s. 47-48 oraz 222-224.

95 S. Szmak, Wybór..., s. 75.

96 M. Pabiś, Ubezpieczenie..., s. 17-18.
} 
Oczywiście infolinie te obsługiwane będą przez niezależnych przedsiębiorców, którym ubezpieczyciele zlecają ich prowadzenie na zasadach outsourcingu, tym niemniej w sytuacji, gdy ubezpieczający, zadzwoniwszy pod telefon wskazany w OWU, od razu uzyskuje potrzebne mu informacje, trudno dopatrzyć się umowy między nim a podmiotem tych informacji udzielającym. Umowa ubezpieczenia istnieje między ubezpieczycielem a ubezpieczającym, umowa outsourcingu między ubezpieczycielem a podmiotem prowadzącym infolinię. Nie budzi wątpliwości, że ubezpieczyciel będzie ponosił względem ubezpieczającego odpowiedzialność za funkcjonowanie infolinii na zasadzie art. 474 k.c. Ewentualne roszczenia regresowe ubezpieczyciela wobec podmiotu prowadzącego infolinię pozostają poza zakresem rozważań.

Niezależnie od powyższego, choć zwykle ubezpieczyciele z oczywistych względów starają się, by ich pomoc w ramach ubezpieczenia assistance ograniczała się do pośredniczenia polegającego wyłącznie na skontaktowaniu ubezpieczającego $\mathrm{z}$ odpowiednim usługodawcą oraz zapłaty temu ostatniemu wynagrodzenia, $\mathrm{z}$ teoretycznego punktu widzenia nie ma przeszkód, by świadczenie ubezpieczyciela miało zakres szerszy. Kwestia była przedmiotem rozważań w poprzednim podrozdziale, gdzie sformułowano konkluzję, że sformułowania Kodeksu cywilnego preferujące zapłatę odszkodowania, występowanie w ubezpieczeniu sumy pieniężnej, a także powszechne stosowanie w praktyce tzw. techniczno-ubezpieczeniowych ograniczeń odszkodowania ubezpieczeniowego nie stanowią argumentów, które wykluczałyby naprawienie przez ubezpieczyciela szkody w formie restytucji naturalnej. Jeżeli umowa lub ogólne warunki umów tak stanowią, ubezpieczyciel może zatem spełnić swoje świadczenie w razie zajścia wypadku in natura, w szczególności zamiast dania pieniędzy (dare) może przy pomocy podwykonawców podjąć określone czynności mające na celu przywrócenie stanu poprzedniego $\left(\right.$ facere $^{97}$. Przy takim sformułowaniu umowy ubezpieczyciel powinien jednak liczyć się z odpowiedzialnością za jakość świadczenia. Dwoistość

97 Takie ujęcie umowy ubezpieczenia assistance dominuje w prawie francuskim, choć zaznacza się, że rola ubezpieczyciela może zostać również ograniczona do roli pośrednika nieodpowiedzialnego za jakość świadczenia podwykonawcy, co będzie oczywiście mniej korzystne dla ubezpieczającego; por. S. Beaugendre, Contrat..., s. 189-190. 
charakteru świadczenia ubezpieczyciela w ubezpieczeniu assistance sankcjonuje ustawodawca europejski, ujmując zobowiązanie ubezpieczyciela jako zapewnienie pomocy osobie uprawnionej, kiedy osoba ta znajdzie się $\mathrm{w}$ trudnej sytuacji $\mathrm{w}$ następstwie zdarzenia losowego - w przypadkach i zgodnie $\mathrm{z}$ warunkami określonymi w umowie, i wskazując, że pomoc może być udzielona przez świadczenie w pieniądzu i naturze (art. 1 ust. 2 dyrektywy Wypłacalność II).

Dodać należy, że umowy ubezpieczenia assistance wszelkiego typu (samochodowe, domowe, prawne, medyczne itd.) stanowią odrębne zagadnienie same w sobie. Ich szczególna cecha polega nie tylko na dopuszczeniu świadczenia w naturze, ale również na odejściu od zasady lokalizacji szkody. Ubezpieczeniem objęte jest ryzyko kosztów, jakie spotkać mogą ubezpieczającego w przyszłości w związku z zajściem zdarzenia losowego. W tym sensie ubezpieczenia te zbliżają się do ubezpieczenia odpowiedzialności cywilnej, obejmując sferę pasywów ubezpieczającego. $Z$ tego względu niektórzy skłaniają się do wyodrębnienia odrębnej grupy ubezpieczeń zwanych ubezpieczeniami kosztów ${ }^{98}$. Powiedzieć można, że w pewnym zakresie trafna była intuicja W. Warkałły, który inspirując się ubezpieczeniami, twierdził, że w obrębie szkody poza szkodą efektywnie poniesioną oraz utraconym zyskiem należy wyróżnić wydatki związane z poniesieniem szkody99.

Inną szczególną cechą ubezpieczeń przewidujących świadczenie różnego rodzaju pomocy jest ich nakładanie się na tradycyjne ubezpieczenia mienia, w szczególności w zakresie, w jakim ubezpieczenia te obejmują wydatki poniesione przez ubezpieczającego na ratowanie mienia, zapobieżenie szkodzie i jej zmniejszenie. Widać to dobrze już w assistance samochodowym, gdzie koszt odholowania samochodu przynajmniej do najbliższego warsztatu może być objęty ubezpieczeniem autocasco. Ubezpieczenia assistance z pewnością zasługują na odrębne opracowanie. W pracy niniejszej nie ma miejsca na wyjaśnienie wszystkich pojawiających się w tym zakresie wątpliwości.

\footnotetext{
98 S. Beaugendre, Contrat..., s. 31.

99 W. Warkałło, Odpowiedzialność..., s. 131.
} 


\subsection{Dopuszczalny zakres pomocy świadczonej przez ubezpieczyciela}

Odpowiedź na pytanie dotyczące dopuszczalności naprawienia przez ubezpieczyciela szkody $\mathrm{w}$ formie restytucji naturalnej oraz charakteru świadczenia w ubezpieczeniu assistance rodzi kwestię dopuszczalnego zakresu ubezpieczenia assistance. Dokładnie rzecz ujmując, sprowadza się ona do pytania, jakie zdarzenia oraz usługi mogą być objęte różnymi postaciami ubezpieczenia assistance.

Powoływany już A. Raczyński, analizując przytaczane przez siebie postanowienia OWU różnych ubezpieczycieli w świetle zasady swobody umów, dochodzi do wniosku, że wszystkie zdarzenia obejmowane w praktyce ubezpieczeniem assistance spełniają kryteria losowości oraz legalności przedmiotu ubezpieczenia majątkowego. Mieszczą się one również w definicji zdarzenia losowego, które ustawa o działalności ubezpieczeniowej i reasekuracyjnej określa jako niezależne od woli ubezpieczającego zdarzenie przyszłe i niepewne, którego nastąpienie powoduje uszczerbek w dobrach osobistych lub dobrach majątkowych albo zwiększenie potrzeb majątkowych po stronie ubezpieczającego lub innej osoby objętej ochroną ubezpieczeniową art. 3 ust. 1 pkt 57 u.d.u.r. ${ }^{100}$

Z całą pewnością dopuszczalność spełnienia przez ubezpieczyciela świadczenia $\mathrm{w}$ drodze restytucji naturalnej należy badać przez pryzmat kryteriów legalności oraz możliwości wyceny w pieniądzu przedmiotu ubezpieczenia, a także zasady losowości. Zgodnie ze znowelizowanym art. 821 k.c. przedmiotem ubezpieczenia majątkowego może być każdy interes majątkowy, który nie jest sprzeczny z prawem oraz daje się ocenić w pieniądzu ${ }^{101}$. Kwestię przedmiotu ubezpieczenia uzupełniają przytoczone wyżej definicje zdarzenia losowego oraz działalności ubezpieczeniowej polegającej na wykonywaniu czynności związanych z udzielaniem ochrony na wypadek ryzyka wystąpienia skutków zdarzeń losowych. Negatywem interesu ubezpieczeniowego jest ryzyko

100 A. Raczyński, Świadczenie...

101 Co do tych kwestii, zob. S. Byczko, Interes..., passim; B. Kucharski, Przeniesienie..., s. 107 i n.; S. Byczko, Interes... 
ubezpieczeniowe. Istnienie ryzyka oraz interesu bezsprzecznie należą do istoty ubezpieczenia majątkowego jako umowy mającej chronić przed uszczerbkiem mogącym powstać w mieniu osoby ubezpieczonej wskutek wystąpienia zdarzenia losowego opisanego w umowie ubezpieczenia.

Jak wskazuje się w literaturze, losowość ubezpieczenia powinna być rozumiana szczególnie. Ubezpieczenie nie dotyczy bowiem ryzyk spekulatywnych, tworzonych przez człowieka z chęci zysku, trójwariantowych, gdzie pierwszym wariantem jest szkoda, drugim jej brak, a trzecim korzyść. Ubezpieczenie dotyczy ryzyk czystych, tzn. istniejących pierwotnie, niezależnie od woli człowieka i wiążących się z wariancją alternatywną, gdzie jednym wariantem jest szkoda, drugim jej brak, nie występuje zaś wariant trzeci w postaci spodziewanej korzyści ${ }^{102}$. Niekiedy obrazowo i jednocześnie trafnie mówi się nie o losowości, ale wręcz o antylosowości ubezpieczenia ${ }^{103}$.

Interes ubezpieczeniowy opisywany jest zwykle jako stosunek między poszukującym ubezpieczenia a wypadkiem ubezpieczeniowym, polegający na tym, że zajście wypadku powoduje dla poszukującego ochrony ubezpieczeniowej uszczerbek ${ }^{104}$. $Z$ tego powodu do istoty ubezpieczenia majątkowego należy również zasada odszkodowania wyrażona obecnie w art. $824^{1}$ k.c. ${ }^{105}$ Dla jasności wywodu raz jeszcze można przypomnieć, że zgodnie z tym przepisem suma pieniężna wypłacona przez ubezpieczyciela $z$ tytułu ubezpieczenia nie może być wyższa od poniesionej szkody, jeżeli nie umówiono się inaczej. Zastrzeżenie „jeżeli nie umówiono się inaczej" nie oznacza dopuszczalności kreowania ubezpieczeń majątkowych prowadzących w sposób oczywisty do wzbogacenia ubezpieczonego.

102 E. Kowalewski, Wprowadzenie do teorii ryzyka..., s. 25-26.

103 M. Picard, A. Besson, Les assurances..., s. 67.

104 Tak B. Kucharski, Przeniesienie..., s. 109. Podobnie B. Hełczyński, Ubezpieczenie..., s. 25-26; E. Kowalewski, Wprowadzenie do teorii interesu..., s. 77. Nieco inaczej S. Byczko, Interes..., s. 229.

105 Co do relacji między interesem ubezpieczeniowym a zasadą odszkodowania, zob. S. Byczko, Interes..., s. 147 i n. oraz wskazana tam literatura. 
Zastrzeżenie, o którym mowa, dotyczy tzw. ubezpieczenia w wartości nowej oraz ubezpieczenia w wartości otaksowanej. Istotą tych ubezpieczeń jest również przywrócenie do stanu poprzedniego w znaczeniu gospodarczym. Upraszczając nieco, dzięki ubezpieczeniu w wartości nowej lub w wartości otaksowanej, poszkodowany jest w stanie odbudować dom albo zakupić taki samochód, jaki utracił, nie musi natomiast odbudowywać domu identycznego ani kupować identycznego samochodu przy uwzględnieniu częściowego zużycia utraconego mienia.

Jak już wskazano, nawet przyjąwszy, że możliwe jest spełnienie świadczenia ubezpieczeniowego w naturze, zasada odszkodowania musi być stosowana przynajmniej odpowiednio. Względnie obowiązujący charakter normy z art. $824^{1} \$ 1$ k.c. nie upoważnia do przyjęcia pełnej dowolności w kwestii ustalenia wysokości świadczenia ubezpieczyciela. Umowa ubezpieczenia stawałaby się bowiem umową typowo hazardową, zbliżoną do gry lub zakładu, to zaś należałoby uznać za sprzeczne $z$ naturą ubezpieczeń ${ }^{106}$. Oderwanie ubezpieczenia od kwestii interesu, ryzyka, losowości, ale również od zasady odszkodowania jest sprzeczne z właściwością, naturą kreowanego stosunku prawnego i jako takie wykracza poza dopuszczalny zakres zasady swobody umów (art. $353^{1}$ k.c.).

Konstatacja powyższa każe z rezerwą podchodzić do poglądów, wedle których ubezpieczyciel ma pełną dowolność w oferowaniu w ramach ubezpieczenia assistance różnego rodzaju dodatkowych świadczeń. Wyobraźnia ubezpieczycieli mających nadzieję na dodatkowe zyski jest w tych kwestiach bardzo bogata, choć zapewne nie dorównuje wyobraźni potencjalnych klientów, którym nie brakuje grosza. Tytułem przykładu można wskazać, że ubezpieczyciele w ramach dodatkowych opcji ubezpieczenia assistance oferują m.in.:

- zorganizowanie przechowania opon letnich i zimowych,

- zorganizowanie i pokrycie kosztów dekoracji pojazdu do uroczystości,

106 Tak m.in. M. Krajewski, Umowa ubezpieczenia. Art. 805-834 KC..., 2016, s. 218-219; H. Ciepła [w:] Kodeks cywilny. Komentarz. Księga trzecia..., komentarz do art. $824^{1}$ k.c., teza 2. 
- zorganizowanie zakupu oraz dowóz bagażnika do rowerów lub na narty,

- organizację wypożyczenia przyczepy kempingowej lub samochodu kempingowego oraz rezerwację miejsca pobytu na kampingu,

- organizację wypożyczenia przyczep do łodzi, quadów, motocykli itp.,

- udzielenie informacji dotyczącej zabiegów, których auto wymaga w danym okresie,

- udzielenie informacji o pralniach tapicerki,

- udzielenie telefonicznej informacji o miejscach na pikniki i majówki,

- udzielenie telefonicznej informacji na temat tras narciarskich w Polsce i Europie ${ }^{107}$,

- pokrycie kosztów przejazdu taksówką w okresie 24 godzin od momentu realizacji świadczenia $z$ ubezpieczenia assistance,

- dostęp do infolinii „Twój dom i ogród” obejmującej instrukcje dotyczące zakładania ogrodu, pielęgnacji roślin, zakładania oczek wodnych,

- dostęp do infolinii „remontowo-budowlanej” służącej w szczególności informacjami w zakresie formalności związanych z remontem mieszkania, wysokości podatków i innych informacji formalnoprawnych,

- dostęp do infolinii „baby assistance” zapewniającej informacje w zakresie objawów ciąży, wskazówek w zakresie przygotowania się do porodu, karmienia i pielęgnacji noworodka,

- dostęp do „infolinii podróżnej” obejmującej zagadnienia związane $\mathrm{z}$ obowiązkami wizowymi, panującymi w danym miejscu zwyczajami i świętami państwowymi oraz informacjami teleadresowymi na temat najdogodniejszej trasy przejazdu i połączeń komunikacyjnych, atrakcji turystycznych,

- organizację rezerwacji biletów lotniczych, kolejowych i autobusowych,

- rezerwację i dostarczenie biletów na imprezy masowe,

- rezerwację jazd próbnych organizowanych przez dealerów samochodowych, rezerwację hoteli i miejsc w restauracji, 
- rezerwację taksówki,

- opiekę nad dziećmi,

- dostawę pod wskazany adres prezentów, zakupów czy kwiatów ${ }^{108}$.

Wbrew stanowisku A. Raczyńskiego zdecydowana większość wypadków objętych tymi dodatkowymi świadczeniami nie ma charakteru zdarzeń losowych. Niektórym brakuje cechy niepewności, innym niezależności od woli człowieka, większości z nich zaś obydwu tych cech. Nie narusza istoty ubezpieczenia zorganizowanie przez ubezpieczyciela naprawy zepsutego sprzętu AGD, RTV, podobnie jak zorganizowanie naprawy samochodu. Jednak usługi polegające na zorganizowaniu specjalnego bagażnika samochodowego albo przyczepy, większość wyżej wymienionych usług informacyjnych i doradczych, z pewnością zaś usługi polegające na rezerwacji miejsc kampingowych, rezerwacji biletów uprawniających do uczestnictwa w wydarzeniach artystycznych, sportowych itp. lub dostarczeniu kwiatów wykraczają poza usługi, które ubezpieczyciel w ramach prowadzonej przez siebie działalności ubezpieczeniowej może zlecać podmiotom trzecim.

Dodać należy, że istnieją wykwalifikowane przedsiębiorstwa zajmujące się świadczeniem tego rodzaju usług. Usługi te określane mianem usług concierge nie mają jednak dużo wspólnego z działalnością ubezpieczeniową. Jak już wskazano świadczone są one bowiem w sytuacjach niemających cech zdarzeń losowych, w wypadkach, którym brakuje cechy niepewności albo cechy niezależności od woli człowieka. Dodatkowo świadczenie tego rodzaju usług przez ubezpieczycieli jest niezgodnie $\mathrm{z}$ wpisanymi w istotę prawnej instytucji ubezpieczenia zasadami interesu ubezpieczeniowego, przede wszystkim zaś z zasadą odszkodowania. Świadczenie tego rodzaju usług nie polega bowiem na naprawieniu szkody w drodze restytucji naturalnej.

108 Przykłady te podaje na podstawie analizy warunków ubezpieczenia różnych ubezpieczycieli A. Raczyński, Świadczenie..., s. 181-183. 


\section{PODSUMOWANIE}

\section{Główne tezy oraz perspektywy rozwoju świadczenia ubezpieczyciela w ubezpieczeniu mienia}

Odpowiedzialność ubezpieczyciela z umowy ubezpieczenia mienia jest postacią cywilnej odpowiedzialności odszkodowawczej. W świetle wciąż aktualnych sporów doktrynalnych dotyczących natury odpowiedzialności ubezpieczeniowej ${ }^{1}$ konstatacja ta nie jest tak oczywista, jak mogłoby się prima facie wydawać. Potwierdza ona zakorzenienie instytucji ubezpieczenia w prawie obligacyjnym i nakazuje tam, gdzie prawo o umowie ubezpieczenia nie przewiduje wyjątków, stosować do naprawienia szkody przez ubezpieczyciela ogólne reguły dotyczące prawa odszkodowawczego. Wyjątki wynikające ze szczególnych cech ubezpieczenia są bardzo istotne, tym niemniej jako ogólną regułę interpretacyjną należy przyjąć odwoływanie się do zasad ogólnych.

Ze względu na źródło odpowiedzialności oraz zasady obowiązujące przy jej ustalaniu, odpowiedzialność ubezpieczeniową należy umieścić w odrębnym od odpowiedzialności ex delicto i ex contractu reżimie odpowiedzialności gwarancyjnej. Reguły tej odpowiedzialności wynikają przede wszystkim z regulacji kodeksowej dotyczącej umowy ubezpieczenia oraz postanowień konkretnej umowy i ogólnych warunków ubezpieczenia. Nie oznacza to, że ubezpieczyciel nie ponosi odpowiedzialności z tytułu niewykonania umowy. Jest wręcz przeciwnie i odpowiedzialność ta może być bardziej dotkliwa od samej odpowiedzialności z umowy.

1 Por. S. Byczko, Świadczenie..., passim. 
Sytuację, w której ubezpieczyciel świadczy pierwotne świadczenie odszkodowawcze na warunkach wynikających z umowy, należy jednak odróżnić od sytuacji, w której odpowiadać będzie za niespełnienie tego świadczenia, narażając się na wypłatę wtórnego odszkodowania związanego z niewykonaniem umowy.

Trudna do utrzymania jest natomiast koncepcja upatrująca w odpowiedzialności ubezpieczeniowej odpowiedzialności absolutnej². Przy bliższym spojrzeniu wyróżnienie poza odpowiedzialnością na zasadzie winy, ryzyka i na zasadzie słuszności odrębnej zasady odpowiedzialności absolutnej staje się bardzo wątpliwe. Odpowiedzialność ubezpieczyciela wydaje się być najbliższa odpowiedzialności na zasadzie ryzyka, natomiast jej granice oraz okoliczności zwalniające wyznaczają reguły prawa powszechnego o umowie ubezpieczenia, jak również, w dozwolonych granicach, postanowienia konkretnej umowy i ogólnych warunków ubezpieczenia. Można zatem skonstatować, że wprowadzanie różnego rodzaju okoliczności egzoneracyjnych jest dozwolone w granicach przewidzianych przez prawo powszechne. Granic tych nie należy jednak upatrywać w kwalifikowaniu ubezpieczenia jako odpowiedzialności absolutnej, ale raczej poszukiwać ich, uwzględniając funkcję ochronną ubezpieczenia. Zupełnie inną kwestią jest odpowiedzialność ubezpieczyciela $\mathrm{z}$ tytułu niewykonania umowy, która na zasadach ogólnych ukształtowana jest jako odpowiedzialność na zasadzie winy. Mając jednak na uwadze poziom staranności wymagany od ubezpieczyciela jako profesjonalisty, należy stwierdzić, że ubezpieczyciel, odmawiając wypłaty świadczenia, działa w pewnym sensie na swoje ryzyko, ponieważ wykazanie, że niewykonanie umowy ubezpieczenia w terminie jest konsekwencją okoliczności, za które ubezpieczyciel nie odpowiada, możliwe będzie wyjątkowo, przede wszystkim w sytuacjach braku współdziałania ubezpieczającego w likwidacji szkody ${ }^{3}$.

Przy ocenie typu odpowiedzialności ubezpieczeniowej najwięcej trudności wywołuje kryterium sprawstwa. Wbrew twierdzeniom W. Warkałły

2 Lansowana dawniej przede wszystkim przez W. Warkałłę, Odpowiedzialność..., s. 172 i n.

3 B. Kucharski, Odpowiedzialność ubezpieczyciela..., s. 56-57. 
wskazanie, że odpowiedzialność ubezpieczeniowa jest przypadkiem odpowiedzialności gwarancyjnej, którą należy odróżnić od odpowiedzialności sprawczej, nie wnosi wiele więcej niż wyróżnienie odrębnego reżimu odpowiedzialności gwarancyjnej. Istota rzeczy sprowadza się bowiem w obu przypadkach do tego, że ubezpieczyciel odpowiada, chociaż nie można przypisać mu choćby najszerzej rozumianego sprawstwa szkody podlegającej kompensacji. Wyróżnienie typu odpowiedzialności gwarancyjnej, odrębnego od odpowiedzialności sprawczej, ma sens przede wszystkim, jeżeli odnosić oba typy nie tylko do przypadków odpowiedzialności za szkodę, ale szerzej do odpowiedzialności za dług. Pozwala to umieścić w obrębie typu odpowiedzialności gwarancyjnej nie tylko przypadki sytuowane w ramach reżimu odpowiedzialności gwarancyjnej wynikające z zawarcia umów określanych szeroko mianem umów gwarancyjnych, ale również wynikające z ustawy różnego rodzaju przypadki odpowiedzialności subsydiarnej, polegającej często na przystąpieniu do cudzego długu.

Wyróżnienie typów odpowiedzialności ze względu na kryterium ekonomicznego rozkładu odpowiedzialności, prima facie bardzo kontrowersyjne oraz zdaniem niektórych w ogóle nie mające charakteru prawnego, przy bliższym spojrzeniu okazuje się zapewne bardziej użyteczne niż wyróżnienie typu odpowiedzialności gwarancyjnej. Umieszczenie odpowiedzialności ubezpieczeniowej w obrębie typu odpowiedzialności repartycyjnej pozwala zwrócić uwagę na szczególne cechy świadczenia ubezpieczyciela z umowy ubezpieczenia. Zespół obowiązków dłużnika, określanych mianem świadczenia, ściśle łączy się bowiem w tym przypadku z charakterem prowadzonego przezeń przedsiębiorstwa i obejmuje utworzenie oraz utrzymywanie wspólnoty osób płacących składki ubezpieczeniowe, a także zarządzanie nią. Dodatkowo wskazanie, że odpowiedzialność ubezpieczeniowa jest odpowiedzialnością repartycyjną, pozwala również uzasadnić, dlaczego na gruncie ubezpieczeń kompensacji podlegać mogą niekiedy szkody niepodlegające naprawieniu w świetle reguł ogólnych. Ostatecznie wyróżnienie odrębnego typu odpowiedzialności ze względu na kryterium sprawstwa szkody ma sens przede wszystkim przy połączeniu tego kryterium z kryterium ekonomicznego rozkładu odpowiedzialności, co uzasadnia powszechne 
charakteryzowanie odpowiedzialności ubezpieczeniowej jako odpowiedzialności gwarancyjno-repartycyjnej.

Ujęcie odpowiedzialności ubezpieczeniowej jako odpowiedzialności ograniczonej wydaje się prima facie dosyć oczywiste. Jak często podkreśla się w literaturze, odszkodowanie ubezpieczeniowe jest odszkodowaniem umownym. Ubezpieczenie obejmuje jedynie ściśle określony w umowie interes, a faktyczna wartość tego interesu jest pierwszym ograniczeniem zakresu odszkodowania. W związku z powyższym zasada pełności odszkodowania może być odnoszona nie do całego majątku ubezpieczającego, ale jedynie do ubezpieczonego interesu. Dodatkowo bezwzględnym limitem wysokości odszkodowania jest suma ubezpieczenia. W praktyce wiele zależy od przyjętego sytemu odpowiedzialności ubezpieczyciela. Ponadto powszechnie stosuje się techniczne ograniczenia odpowiedzialności w postaci udziału własnego oraz franszyzy. Zagadnienie ograniczonego zakresu odszkodowania ubezpieczeniowego ma jednak również drugi aspekt. Stwierdzenia, że odszkodowanie ubezpieczeniowe jest odszkodowaniem umownym, nie należy bowiem nadużywać w sposób prowadzący do wypaczenia znaczenia samego pojęcia odszkodowania oraz ochronnej funkcji ubezpieczenia. Świadczenie ubezpieczeniowe powinno zatem przynajmniej w zasadniczym zakresie kompensować szkodę poniesioną przez ubezpieczonego. Wątpliwa wydaje się natomiast dopuszczalność metod ustalania odszkodowania w sposób zupełnie abstrahujący od rzeczywistej wartości naruszonego interesu. Ten drugi aspekt ograniczoności odszkodowania ubezpieczeniowego stanowi konsekwencję „zakotwiczenia” prawa ubezpieczeń w ogólnych regułach prawa odszkodowawczego.

Zadawniony spór o treść świadczenia prawnego ubezpieczyciela między zwolennikami teorii świadczenia pieniężnego oraz zwolennikami teorii ponoszenia ryzyka wydaje się mieć charakter przede wszystkim teoretyczny. Argumenty prawnoporównawcze wskazują, że obecnie coraz częściej podkreśla się rolę samego przejęcia przez ubezpieczyciela ryzyka zajścia wypadku. Szczególnie wyraźne sygnały stanowić mogą uwzględnienie tego elementu w niemieckiej VVG z 2008 r. oraz w Zasadach Europejskiego Prawa o Umowie Ubezpieczenia. Tendencji tych nie uwzględnia art. $805 \$ 1$ k.c. wskazujący, że ubezpieczyciel 
spełnia świadczenie w razie zajścia wypadku. Przepis ten stanowi na gruncie prawa polskiego podstawowy argument zwolenników teorii świadczenia pieniężnego. We współczesnej polskiej doktrynie wyraźnie dominuje jednak teoria ponoszenia ryzyka, natomiast orzecznictwo Sądu Najwyższego jest rozbieżnie. Zdaniem autora kostyczne ujęcie umowy ubezpieczenia jako umowy, w której ubezpieczyciel świadczy jedynie w razie zajścia przewidzianego w umowie wypadku, prowadzi do zakwalifikowania jej jako umowy jednostronnie lub dwustronnie zobowiązującej zależnie od tego, czy wypadek zaszedł. Ujęcie takie nie oddaje ani gospodarczej, ani prawnej istoty umowy ubezpieczenia. $\mathrm{Z}$ drugiej strony teoria ponoszenia ryzyka ma istotne mankamenty, polegające, zależnie od przyjmowanego jej wariantu, na upatrywaniu treści świadczenia ubezpieczyciela w samej gotowości do jego spełnienia albo w zespole czynności, które składają się na działalność prowadzonego przezeń przedsiębiorstwa i podejmowane są bez związku z konkretną umową ubezpieczenia.

W pracy wyrażono pogląd, według którego poszukiwanie prawnego desygnatu pojęcia ubezpieczenia nie może odbywać się jednak przy całkowitym pomijaniu ubezpieczenia jako instrumentu ekonomicznego. Istota działalności ubezpieczyciela będącej działalnością repartycyjną polega wszak na tym, że świadczenia pieniężne spełniane w razie zajścia zdarzeń losowych finansowane są z funduszu tworzonego ze składek uiszczanych przez jednostki zagrożone tymi zdarzeniami. Zapewnienie istnienia i funkcjonowania tego funduszu przekłada się zatem na świadczenie w każdej konkretnej umowie 4 . Odszkodowanie wypłacane przez ubezpieczyciela w razie zajścia wypadku stanowi jedynie ewentualną konkretyzację wszystkich obowiązków ubezpieczyciela składających się na spełniane przez niego świadczenie. Jednocześnie jednak, z perspektywy konkretnego ubezpieczającego, inne obowiązki ubezpieczyciela mają sens i znaczenie jedynie ze względu na obowiązek dania odszkodowania w razie zajścia wypadku. Koncepcję tę wspiera ujmowanie ubezpieczenia jako umowy wzajemnej, niezależnie od tego, czy w konkretnym stosunku ubezpieczeniowym obowiązek dania przez ubezpieczyciela odszkodowania w ogóle się pojawia. Wbrew powszechnym w polskiej

${ }^{4} \mathrm{~W}$ tym kierunku ostatnio również J. Jastrzębski, Nieubezpieczeniowe..., s. 15. 
doktrynie poglądom wzajemność umowy nie jest immanentnie powiązana $\mathrm{z}$ koncepcją ponoszenia ryzyka jako świadczenia ubezpieczyciela. Wzajemność jest bowiem obiektywnym elementem konstrukcyjnym umowy danego typu i należy ją oceniać w chwili wymiany przez strony obietnic, nie zaś dopiero po zakończeniu stosunku prawnego powstałego wskutek zawarcia umowy. Wzajemność ubezpieczenia nie przekłada się przy tym na zastosowanie do tej umowy przepisów o wykonaniu zobowiązań wzajemnych ${ }^{5}$. Przepisy te nie nadają się do zastosowania w ubezpieczeniu, ponieważ specyfika świadczenia ubezpieczyciela polega na tym, że jedynym obowiązkiem składającym się na to świadczenie, któremu odpowiada roszczenie po stronie ubezpieczającego, jest właśnie zależący od zajścia wypadku niepewny obowiązek dania odszkodowania. Kwalifikacja umowy ubezpieczenia jako umowy wzajemnej nie jest jednak pozbawiona znaczenia praktycznego, w wielu wypadkach może bowiem stanowić istotną dyrektywę interpretacyjną przy wykładni oraz ocenie ważności konkretnych postanowień tej umowy.

Obowiązek dania odszkodowania, stanowiąc jednocześnie niepewny oraz centralny obowiązek ubezpieczyciela, pojawia się jedynie przy spełnieniu określonych przesłanek. Pierwszą z nich jest trwanie materialnego okresu ubezpieczenia, co uzależnione jest przede wszystkim od zawarcia umowy ubezpieczenia i zwykle od zapłaty przez ubezpieczającego składki lub jej pierwszej raty. Drugą przesłankę stanowi zajście przewidzianego w umowie wypadku, mającego charakter zdarzenia losowego. Trzecia przesłanka polega na wystąpieniu szkody, czwarta zaś na związku przyczynowym między wypadkiem a szkodą. Na gruncie ubezpieczeń mienia nieuprawnione jest utożsamianie wypadku ubezpieczeniowego ze szkodą. Wbrew spotykanym w praktyce określeniom (all risk insurance itp.) nie ma bowiem ubezpieczeń chroniących od wszystkich ryzyk ${ }^{6}$. Szkoda ubezpieczeniowa jedynie do pewnego stopnia może być utożsamiana ze szkodą w znaczeniu ogólnym, co wynika ze wspomnianej wcześniej zasady jej zlokalizowania w konkretnym interesie. Wbrew pojawiającym się wątpliwościom, słuszne jest zatem

5 Inaczej M. Orlicki, Umowa ubezpieczenia, 2002, s. 145 i n., oraz M. Orlicki, Umowa ubezpieczenia [w:] System..., t. 8, s. 707 i n.

6 Zob. jednak M. Krajewski, Wypadek..., passim. 
stwierdzenie, że szkoda ubezpieczeniowa nie obejmuje co do zasady utraconych zysków, chyba że chroniony ubezpieczeniem interes polegał właśnie na ich utracie ${ }^{7}$. Z drugiej strony szerokie ujęcie interesu ubezpieczeniowego, zdające się abstrahować od możności jego ujęcia w ramy prawa podmiotowego, pozwala objąć ubezpieczeniem szkody niepodlegające naprawieniu na zasadach ogólnych. Kwestia charakteru związku przyczynowego, jaki musi wystąpić między wypadkiem ubezpieczeniowym a szkodą, należy do kontrowersyjnych. Określenie tego związku w dużej mierze jest sprawą redakcji ogólnych warunków ubezpieczenia. Redakcja tych warunków powinna sprawiać, że dla ustalenia istnienia związku przyczynowego wystarczające będzie przeprowadzenie testu conditio sine qua non. Nieuprawnione jest rozszerzanie na ubezpieczenia lądowe, w braku wyraźnych zastrzeżeń umownych, kryterium bezpośredniości następstw, obowiązującego co do zasady w ubezpieczeniach morskich. Niezależnie od umownego przyjęcia takiego kryterium lub jego braku, w przypadkach wątpliwych należy odpowiedzieć na pytanie, czy szkoda jest normalnym następstwem przewidzianego w umowie wypadku. Wynika to po pierwsze, stąd, że kryteria bezpośredniości i adekwatności następstw stanowią co do zasady dwa różne kryteria (pierwsze odnosi się przede wszystkich od długości łańcucha związku przyczynowego, drugie zaś do siły związania poszczególnych ogniw). Po drugie, odwołanie do kryterium normalności stanowi konsekwencję kwalifikacji odpowiedzialności ubezpieczyciela jako cywilnej odpowiedzialności odszkodowawczej. W praktyce, na co w prawie angielskim zwracał uwagę Lord Denning, ocena istnienia związku przyczynowego między wypadkiem a szkodą jest często sprawą zdrowego rozsądku ${ }^{8}$.

Jak wskazano, ograniczony charakter odszkodowania ubezpieczeniowego wynika przede wszystkim z roli, jaką odgrywają pojęcia wartości i sumy ubezpieczenia oraz relacji między nimi. Według autora możliwości ustalenia wartości ubezpieczenia na poziomie istotnie odbiegającym

7 Tak w szczególności E. Kowalewski, Odszkodowanie ubezpieczeniowe za utracone korzyści, s. 43-44; M. Orlicki, Umowa ubezpieczenia [w:] System..., t. 8, s. 723; Inaczej M. Kaliński, Zasada..., cz. 1, s. 43, oraz M. Krajewski, Umowa ubezpieczenia. Art. 805-834 KC..., 2016, s. 565.

8 M. Clarke, Policies and Perceptions of Insurance Law..., s. 185-187. 
od wartości rzeczywistej ograniczone są przez zasadę odszkodowania, i to zarówno, gdy chodzi o ustalenie, że wartość ubezpieczenia będzie szacowana w sposób prowadzący do jej zaniżenia względem wartości rzeczywistej, jak również do jej zawyżenia. Ubezpieczenia w wartości nowej oraz w wartości otaksowanej nie powinny być ujmowane jako wyjątki od zasady odszkodowania, ale raczej jako jej potwierdzenie, pozwalające na przywrócenie stanu sprzed szkody w sensie gospodarczym. Wydaje się, że w rozwoju ubezpieczeń nie należy rezygnować $\mathrm{z}$ warunku interesu ubezpieczeniowego oraz $\mathrm{z}$ będącej jego konsekwencją zasady odszkodowania. Pojawiające się ostatnio głosy, wedle których w ubezpieczeniach zasada odszkodowania nie obowiązuje, wobec czego wartość otaksowania powinna być zawsze bezwzględnie wiążąca dla stron $^{9}$, ignorują genezę ubezpieczenia w wartości otaksowanej. Prowadzą również do wypaczenia istoty ubezpieczenia jako umowy antylosowej, zbliżając ją do umów hazardowych, a nadto mogą prowadzić do zjawisk kryminogennych. Obowiązywanie zasady odszkodowania ujawnia się z całą ostrością przy tzw. ubezpieczeniu podwójnym, którego znaczenie, w związku z coraz lepszym doinformowaniem stron umowy ubezpieczenia, będzie jednak, jak się zdaje, maleć. Zmiany dokonane w tym ostatnim zakresie w prawie polskim nowelą z 2007 r. należy ocenić pozytywnie z tym zastrzeżeniem, że rozliczenia regresowe między ubezpieczycielami powinny zostać oparte na zasadzie określanej w prawie anglosaskim zasadą odpowiedzialności niezależnej, zamiast na zasadzie odpowiedzialności maksymalnej ${ }^{10}$. Polskie rozwiązanie wydaje się niezgodne z prawem obowiązującym w wiodących krajach Europy.

Co do znaczenia pełnionego przez sumę ubezpieczenia należy zaaprobować pogląd, wedle którego suma ta, w braku odmiennych ustaleń, winna być odnoszona do każdej szkody z osobna. Pogląd ten jest zgodny zarówno z losowym charakterem ubezpieczenia, jego funkcją ochronną, jak również z prokonsumenckim kierunkiem ewolucji prawa umów. Suma ubezpieczenia nie może być także postrzegana jako limit bezwzględny i niezmienny niezależnie od wszystkich okoliczności. Skoro stanowi ona

9 M. Wandt, Versicherungsrecht, s. 300.

10 B. Kucharski, Odpowiedzialność ubezpieczycieli w ubezpieczeniu podwójnym, s. $287-288$. 
z góry przyjęty limit, mogący prowadzić do ustalania odszkodowania w sposób odbiegający od zasad ogólnych, nie można wykluczyć możliwości jej waloryzowania przez sąd w razie istotnej zmiany siły nabywczej pieniądza. Szczególne cechy umowy ubezpieczenia, w szczególności zaś jego losowość, nie wykluczają również podwyższenia sumy ubezpieczenia w razie zajścia okoliczności nadzwyczajnych, których strony nie mogły przewidzieć na podstawie art. $357^{1}$ k.c. Wziąwszy pod uwagę względnie stabilną sytuację gospodarczą w ostatnim czasie, znaczenie praktyczne wskazanych możliwości winno być znikome. Aktualne są w tej mierze głosy opowiadające się za względnie restryktywną wykładnią okoliczności nadzwyczajnych jako przesłanki zastosowania klauzuli rebus sic stantibus.

Ewolucja umowy ubezpieczenia w kierunku łagodzącym działanie zasady najwyższego zaufania ubezpieczyciela do ubezpieczającego, wynikająca $z$ coraz lepszego poinformowania ubezpieczyciela ${ }^{11}$, w szczególności zaś z jego rosnącej roli przy szacowaniu wartości początkowej ubezpieczenia, przemawia również za preponderancją systemu odpowiedzialności na pierwsze ryzyko względem systemu odpowiedzialności proporcjonalnej. Również w tym zakresie prawo polskie wydaje się zmierzać w kierunku zgodnym z tendencjami ogólnoeuropejskimi. Ubezpieczenie w systemie odpowiedzialności proporcjonalnej jest oczywiście dopuszczalne, powinno być jednak wybierane przez ubezpieczającego jako opcja korzystniejsza w danych okolicznościach, przy świadomości wszystkich związanych z tym konsekwencji. Ubezpieczenie w systemie odpowiedzialności proporcjonalnej nie może zaś być traktowane przez ubezpieczyciela jako wybieg mogący służyć przynajmniej ograniczeniu odpowiedzialności wtedy, gdy sama jej zasada nie może być kwestionowana. $\mathrm{Z}$ tych względów postulować należy, by zawarcie ubezpieczenia w systemie odpowiedzialności proporcjonalnej znajdowało odzwierciedlenie w treści polisy. Niedopuszczalne jest przy tym odnoszenie zasady proporcji do wartości należnego odszkodowania, zamiast do wielkości szkody podlegającej naprawieniu, w sposób pro-

11 Co do tej kwestii, zob. J. Łopuski, Doktryna najwyższej dobrej wiary w anglosaskim prawie ubezpieczeniowym, jej pochodzenie, znaczenie i krytyka [w:] Szkice o ubezpieczeniach, red. M. Kuchlewska, Poznań 2006. 
wadzący do tego, że ubezpieczyciel w ogóle nie ponosi ryzyka wypłaty całej sumy ubezpieczenia. Praktyki tego rodzaju należy postrzegać jako sprzeczne z istotą ubezpieczenia, w szczególności zaś z jego wzajemnością ${ }^{12}$. To samo dotyczy stosowania udziału własnego lub franszyzy redukcyjnej w przypadkach ustalenia składki od sumy ubezpieczenia niepomniejszonej o udział własny lub franszyzę.

Sposób ustalania odszkodowania ubezpieczeniowego wynika z nakładania się na siebie ogólnych reguł prawa odszkodowawczego, w szczególności samej zasady odszkodowania w ujęciu konkretnym, ograniczonym do interesu będącego przedmiotem ubezpieczenia oraz przedstawionych wcześniej specyficznych konstrukcji prawno-ubezpieczeniowych. Podstawowym składnikiem odszkodowania ubezpieczeniowego jest zwrot kosztów przywrócenia uszkodzonej rzeczy do stanu sprzed wypadku ubezpieczeniowego. Koszty te mogą być ustalane metodą serwisową albo kosztorysową. Pierwsza metoda polega na refundacji rachunków za naprawę rzeczy przedstawionych przez ubezpieczonego. Istotą drugiej metody jest przeprowadzenie swego rodzaju symulacji polegającej na wyliczeniu potencjalnych kosztów naprawy i ich wypłaceniu ubezpieczającemu niezależnie od tego, czy zostały faktycznie poniesione. Metoda taka nie wykracza poza granice swobody kształtowania przez strony sposobów wyliczania odszkodowania ubezpieczeniowego, niezależnie od wątpliwości dotyczących jej kwalifikacji jako jednej z dwóch ekskluzywnych form naprawienia szkody, przewidywanych przez art. 363 k.c. Nie prowadzi ona do naruszenia zasady interesu ubezpieczeniowego ani zasady odszkodowania, ponieważ funkcjonalnie stawia ubezpieczającego w sytuacji najbardziej zbliżonej do stanu sprzed wypadku ${ }^{13}$. Alternatywny wobec dwóch powyższych sposób wyliczania odszkodowania ubezpieczeniowego stosowany jest przy tzw. szkodach całkowitych. Ubezpieczyciel wypłaca odszkodowanie stanowiące różnicę między wartością rzeczy sprzed wypadku oraz wartością pozostałości. Ten ostatni sposób jest zwykle mniej korzystny dla ubezpieczającego, tym bardziej, że ubezpieczyciele mają tendencję do manipulowania obydwoma wartościami na swoją korzyść. Klauzule umowne narzuca-

12 Podobnie J. Nawracała, Odpowiedzialność..., s. 44-45.

13 B. Janiszewska, Nadmierne..., s. 58 oraz 66 i 67. 
jące ubezpieczającemu ten sposób w sytuacji, gdy koszt naprawy rzeczy nie przekracza $60-70 \%$ jej wartości, wydają się być niedopuszczalne. Odszkodowanie ubezpieczeniowe powinno co do zasady obejmować podatek VAT, jeżeli ubezpieczający nie byłby uprawniony do jego odliczenia. Ubezpieczyciel może jednak zastrzec, że będzie zwracał VAT, tylko jeżeli rzeczywiście został on zapłacony, albo nawet ograniczyć odszkodowanie do cen netto. W tym ostatnim przypadku nie można jednak pobierać składki od wartości powiększonej o VAT.

Ogólne warunki umów polskich ubezpieczycieli nie przewidują co do zasady kompensowania w ramach odszkodowania autocasco tzw. ubytku wartości handlowej. Pokrycie szkody w tym zakresie zaczyna być jednak standardem odszkodowawczym przy wyliczaniu odszkodowania na zasadach ogólnych i nie wykracza poza konkretne ujęcie szkody w ubezpieczeniach, wobec czego w określonych sytuacjach ubezpieczający może wywodzić, że pozbawienie go możliwości naprawienia szkody w tym zakresie przekracza granice swobody umów. Zasada lokalizacji szkody sprzeciwia się natomiast objęciu odszkodowaniem z ubezpieczenia mienia wynagrodzenia profesjonalnego pełnomocnika czy kosztów opinii rzeczoznawcy wydanej na zlecenie ubezpieczającego.

Odszkodowanie z ubezpieczenia mienia nie może być kumulowane z odszkodowaniem z innych źródeł, w tym zakresie bowiem znajduje zastosowanie zasada compensatio lucri cum damno. Odszkodowanie z ubezpieczenia nie może zatem przysługiwać, gdy szkoda, jaka spotkała ubezpieczonego, została naprawiona przez sprawcę. Nie powinno być również zgody na kumulowanie odszkodowania ubezpieczeniowego z nadzwyczajnymi świadczeniami pomocowymi ze strony państwa. Szafowanie tego rodzaju świadczeniami nie służy zresztą rozwojowi ubezpieczeń ani promowaniu ogólnej idei przezorności i ma wymiar czysto polityczny ${ }^{14}$. Zasada compensatio lucri cum damno jest ściśle powiązana z zasadą subrogacji ubezpieczyciela, który pokrył szkodę, w prawa poszkodowanego względem sprawcy. Naturalną konsekwencją zasady compensatio lucri cum damno jest potrącanie z odszkodowania wartości pozostałości w razie szkody całkowitej, natomiast w razie szko-

14 M. Orlicki, O zaliczaniu..., passim. 
dy częściowej tzw. amortyzacji części. Stosowanie przez ubezpieczycieli w ubezpieczeniu mienia współczynników amortyzacji części powinno być dopuszczalne, jednak tylko o tyle, o ile współczynniki te nie odbiegają istotnie od rzeczywistego spadku wartości części używanych. Podobne uwagi można odnieść do uregulowań dotyczących użycia do naprawy części zamiennych gorszej jakości niż pochodzące od producenta $^{15}$. Wobec faktu, że ubezpieczyciel nie może być osobą fizyczną, jego odpowiedzialność nie ma charakteru deliktowego, a prowadzone przez niego przedsiębiorstwo nastawione jest na wypłacanie odszkodowań, a limine można natomiast wykluczyć zastosowanie do odszkodowania $\mathrm{z}$ ubezpieczenia mienia sędziowskiego ius moderandi, o którym mowa w art. 440 k.c. ${ }^{16}$

Szczególnym składnikiem odszkodowania ubezpieczeniowego są koszty ratowania przedmiotu ubezpieczenia. Koszty te podlegają zwrotowi niezależnie od ich ostatecznej efektywności, jeżeli tylko w okolicznościach sprawy można je uznać za celowe. Należy z całą mocą podkreślić, że ewolucja prawa ubezpieczenia zmierza w kierunku objęcia odszkodowaniem nie tyko kosztów minimalizacji szkody już doznanej, ale również kosztów zapobieżenia szkodzie przewidywanej. Wspomniany warunek celowości tych kosztów w powiązaniu z koniecznością zajścia wypadku ubezpieczeniowego dla aktualizacji omawianego obowiązku ubezpieczyciela stanowi wystarczające zabezpieczenie jego interesów. Co więcej, przemiany świadczenia ubezpieczyciela powinny zmierzać do objęcia kosztów ratowania odszkodowaniem bez względu na przewidziany w umowie limit sumy ubezpieczeniowej. Przemawiają za tym zupełnie odrębny i zewnętrzny wobec szkody w ubezpieczonym mieniu charakter szkody obejmującej wydatki poniesione w celu ratowania ubezpieczeniowego mienia, jak również względy prewencji ubezpieczeniowej. Zwrot kosztów ratowania w żadnym razie nie powinien natomiast polegać na kompensacie wydatków mających charakter ekscesów ubezpieczającego. Prawidłowy kierunek w tym zakresie zdają się wyznaczać Zasady Europejskiego Prawa o Umowie Ubezpieczenia (PEICL).

15 Szerzej P. Wawszczak, Części zamienne...

16 W. Warkałło, Ubezpieczenie utraconych korzyści..., s. 59. 
$\mathrm{Na}$ atrakcyjność kompensacji ubezpieczeniowej wpływa regulacja dotycząca terminu wypłaty świadczenia przez ubezpieczyciela. Ocena polskiego rozwiązania wprowadzającego co do zasady 30-dniowy termin liczony od dnia zawiadomienia o wypadku wypada pozytywnie, szczególnie w porównaniu z rozwiązaniami nieprzewidującymi żadnej regulacji szczególnej albo proponującymi liczenie terminu dla ubezpieczyciela od chwili, kiedy zdołał on oszacować szkodę. Sam termin „Zawiadomienie” wskazuje, że ubezpieczający nie musi precyzować roszczeń co do wysokości, oszacowanie wysokości poniesionej szkody jest bowiem rolą ubezpieczyciela. $Z$ zawiadomienia musi natomiast wynikać chęć skorzystania z ubezpieczenia oraz w niektórych przypadkach, w szczególności gdy ubezpieczającemu służyć mogą alternatywnie wzajemnie wykluczające się roszczenia, sprecyzowanie roszczenia co do rodzaju. Konieczność aktywnej postawy ubezpieczyciela polega również na tym, że co do zasady winien on samodzielnie ustalić zasadę i zakres odpowiedzialności bez czekania na zakończenie innych postępowań, w szczególności karnego postępowania przygotowawczego, postępowań sądowych i administracyjnych. Oczywiście szybkie zakończenie postępowania likwidacyjnego wymaga współdziałania ze strony ubezpieczającego. Jest charakterystyczne, że w przeszłości nie tylko w Polsce pojawiały się kontrowersje co do odpowiedzialności ubezpieczyciela za zwłokę i opóźnienie. Współczesny ogólnoeuropejski trend polega na przypisaniu ubezpieczycielowi takiej odpowiedzialności na ogólnych zasadach, co przejawia się w szczególności tym, że wraz z uchybieniem terminu rozpoczynają bieg odsetki, a nadto ubezpieczyciel naraża się na odpowiedzialność odszkodowawczą o zakresie przekraczającym zakres pierwotnej odpowiedzialności gwarancyjno-repartycyjnej. Tendencja europejska polega również na zrównaniu odsetek należnych od ubezpieczyciela z poziomem odsetek w transakcjach handlowych ${ }^{17}$. W tym ostatnim zakresie polskie rozwiązanie zdaje się wymagać korekty.

Konsekwencją surowości oraz umownego charakteru odpowiedzialności gwarancyjno-repartycyjnej jest możliwość precyzowania jej zakresu nie tylko co do wysokości, ale również co do samego przedmiotu. Duża lista przedmiotowych wyłączeń jest charakterystyczna dla prawa ubezpie-

17 Principles..., s. 219. 
czeniowego. Część z nich wynika już z kodeksowej regulacji umowy ubezpieczenia. Zupełnie naturalne jest wyłączenie odpowiedzialności za szkody będące konsekwencją umyślnych działań ubezpieczającego. Zdarzenia spowodowane przez ubezpieczającego umyślnie, a w pewnym zakresie także przez osoby, nad którymi ubezpieczający powinien sprawować kontrolę, nie mają wymaganej od wypadku ubezpieczeniowego cechy losowości, a ich wyłączenie jest powszechne we wszystkich systemach prawnych.

Nieco inaczej przedstawia się zagadnienie szkód będących następstwem rażącego niedbalstwa ubezpieczającego. Przy objęciu tym pojęciem jedynie szczególnie ciężkich postaci winy, które mogą być zrównane ze złym zamiarem, ratio legis takiego rozwiązania jest zrozumiałe. Aktualne rozwiązanie kodeksowe, które pozwala objąć ubezpieczeniem szkody powstałe na skutek rażącego niedbalstwa ubezpieczającego $\mathrm{z}$ woli stron, a w pozostałych wypadkach wyłącza odpowiedzialność ubezpieczyciela, chyba że wypłata odszkodowania odpowiada względom słuszności, wydaje się wystarczająco elastyczne pod warunkiem właściwego wykładania pojęcia rażącego niedbalstwa. Orzecznictwo Sądu Najwyższego w tej mierze jest wyważone. Zyskujące popularność w Europie rozwiązania pozwalające ubezpieczycielowi ograniczyć wysokość odszkodowania proporcjonalnie do ciężaru winy ubezpieczającego wydają się natomiast wątpliwe ze względu na wąski zakres pojęcia rażącego niedbalstwa, które nie nadaje się do stopniowania. Stopniowanie tego rodzaju wiązać się może z rozszerzeniem znaczenia pojęcia rażącego niedbalstwa, co wydaje się zjawiskiem niepożądanym.

Nowelizacja art. 827 k.c. nie rozwiązała problemu dopuszczalnego zakresu tzw. klauzuli reprezentantów. Zastąpienie nieprecyzyjnej kategorii osób, za które ubezpieczający ponosi odpowiedzialność, kategorią osób pozostających z nim w gospodarstwie domowym prawidłowo ogranicza pole do interpretacji w odniesieniu do ubezpieczeń dotyczących mienia niewykorzystywanego w działalności gospodarczej. Problem pozostaje natomiast nadal aktualny w ubezpieczeniach przedsiębiorców. Lansowany przez niektórych autorów pogląd, zgodnie z którym, pomijając stosunki domowe, ubezpieczyciel ma całkowitą swobodę co do określenia zakresu klauzuli reprezentantów, jest wątpliwy jako rozszerzający 
potencjalny zakres tej klauzuli w porównaniu do stanu sprzed zmiany, a nadto niezgodny $\mathrm{z}$ rozwiązaniami przyjmowanymi w reprezentatywnych obcych systemach prawnych. Wydaje się, że klauzule statuujące nieodpowiedzialność ubezpieczyciela za osoby, względnie niezależne od ubezpieczającego, których ten żadną miarą nie jest w stanie nadzorować i których działania z punktu widzenia ubezpieczającego mają wszelkie cechy losowości, mogą być w określonych okolicznościach uznane za sprzeczne $\mathrm{z}$ właściwościami (naturą) stosunku prawnego ubezpieczenia lub z zasadami współżycia społecznego. Obecna regulacja art. 827 $\$ 3$ k.c., odnoszącego się do omawianej kwestii, ma również mankament polegający na nieuregulowaniu rażącego niedbalstwa osób zależnych od ubezpieczającego. Warto nadmienić, że omawianych problemów nie rozwiązują również powoływane wcześniej reguły PEICL.

Dopuszczalny zakres umownych wyłączeń odpowiedzialności ubezpieczyciela wydaje się być aktualnie centralnym problemem prawa ubezpieczeniowego. Nie dotyczy to wyłączeń za ubytki naturalne oraz inne zdarzenia, które nie mają cech zdarzeń losowych, ani pozbawionych istotnego znaczenia w krajach o stabilnej sytuacji politycznej i gospodarczej wyłączeń związanych z wojną, zamachem, zamieszkami itp. Kwestie te jako niebudzące większych wątpliwości zostały w pracy pominięte. Sprawą zasadniczą jest odróżnienie klauzul wyłączających odpowiedzialność od nakładania na ubezpieczającego umownych powinności prewencyjnych. Według stanowiska przyjętego w pracy wyłączenia odpowiedzialności mogą skutkować bez względu na zawinienie ubezpieczającego, a niekiedy nawet związek przyczynowy między określoną okolicznością a wypadkiem. Naruszenie powinności natomiast może prowadzić do zwolnienia ubezpieczyciela z odpowiedzialności, wyłącznie gdy było umyślne lub rażąco niedbałe i pozostawało w związku przyczynowym z wypadkiem. Zdumiewa, że problemu tego rozróżnienia w zasadzie nie podejmuje orzecznictwo Sądu Najwyższego. Pogląd negujący znaczenie omawianego rozróżnienia jako opartego na kryteriach czysto werbalnych ${ }^{18}$ odrzucono w pracy, zgadzając się ze stanowiskiem, że rozróżnienie pozwala na wyważenie interesów stron

18 M. Krajewski, Umowa ubezpieczenia. Art. 805-834 KC..., 2016, s. 624. 
umowy ubezpieczenia ${ }^{19}$. Ubezpieczyciel winien mieć względną swobodę w kształtowaniu zakresu swojej odpowiedzialności, ubezpieczający z kolei winien mieć gwarancję kompensacji szkód wynikających nie tylko z okoliczności zupełnie od niego niezależnych, ale również będących skutkiem uchybień z jego strony, niemających cech winy umyślnej oraz rażącego niedbalstwa. Omawiana kwestia ściśle wiąże się z ustawowym wyłączeniem odpowiedzialności ubezpieczyciela za szkody wyrządzone przez ubezpieczającego umyślnie lub będące skutkiem rażącego niedbalstwa. Funkcja ochronna ubezpieczenia jako instytucji dającej ubezpieczającemu prawo do wynagrodzenia szkód będących skutkiem jego roztargnienia czy niefrasobliwości sprzeciwia się zastosowaniu przepisów o przyczynieniu i wskazuje, że intencją ustawodawcy było uregulowanie omawianej kwestii w sposób kompleksowy w art. 827 k.c. Parafrazując słowa jednego $\mathrm{z}$ angielskich sędziów, obietnica ubezpieczyciela wobec ubezpieczającego: „ubezpieczę Cię również od skutków Twojego niedbalstwa, jednak pod warunkiem, że nie będziesz niedbały" jest dla tego ostatniego bezwartościowa ${ }^{20}$.

Omawiane rozróżnienie jest obecne w obcych systemach prawnych, a szczególną wagę przywiązuje się do niego w prawie niemieckim, tradycyjnie mającym największy wpływ na rozwiązania przyjmowane w polskim prawie ubezpieczeniowym. Przeprowadzona w Niemczech ustawą z 2007 r. reforma prawa powinności rezygnuje z tzw. reguły „wszystko albo nic", pozwalając ubezpieczycielowi obniżyć odszkodowanie w razie naruszenia powinności stosownie do stopnia rażącego niedbalstwa ze strony ubezpieczającego ${ }^{21}$. Rozwiązanie przyjmowane przez PEICL co do zasady sankcjonuje jedynie umyślne lub rażąco niedbałe naruszenie powinności, dopuszcza jednak wprowadzenie umownej regulacji pozwalającej na zmniejszenie odszkodowania proporcjonalnie do stopnia winy. Jak wskazano, rezygnacja $\mathrm{z}$ reguły „wszystko albo nic” w prawie polskim mogłaby doprowadzić do degeneracji (rozwodnienia) pojęcia

19 J.M. Kondek [w:] Kodeks..., t. 2, red. K. Osajda, 2013, s. 1689.

20 Sędzia Goddard w sprawie Woolfall \& Rimmer Ltd v. Moyle and Another [1942] $1 \mathrm{~KB}$ 66, 76 (CA) za M. Clarkiem, Policies and Perceptions of Insurance..., s. 166.

${ }^{21}$ M. Wandt, Versicherungsrecht, s. 242-243. Obecne reguły autor próbuje szczegółowo tłumaczyć dalej na s. 258-264. 
rażącego niedbalstwa, rozciągając je na uchybienia ubezpieczającego niemające wystarczającego ciężaru, przekreślając w praktyce zasadę niestosowania przepisów o przyczynieniu. W tych okolicznościach skupiono się na wskazaniu szeregu kryteriów pozwalających na odróżnienie wyłączeń odpowiedzialności od umownych powinności prewencyjnych. Kryteriów tych jest cały szereg, co wynika $\mathrm{z}$ wagi problemu, a nadto z dostrzeganego przez autora i obecnego również w prawie niemieckim problemu przekształcania przez ubezpieczycieli powinności w wyłączeniach odpowiedzialności przez wprowadzanie tzw. powinności ukrytych.

Skuteczność wyłączeń odpowiedzialności zależy od całego szeregu kryteriów formalnych i materialnych. Wśród tych pierwszych wskazać trzeba: po pierwsze, konieczność wyraźnego wyodrębnienia wyłączeń w treści OWU; po drugie, sformułowanie wyłączeń jednoznacznie i w sposób zrozumiały; po trzecie, zawarcie w OWU informacji, w których postanowieniach zawarte są wyłączenia odpowiedzialności. Po czwarte, od października 2018 r. konieczne jest umieszczenie ważniejszych wyłączeń w ustandaryzowanym dokumencie informującym o produkcie ubezpieczeniowym ${ }^{22}$. Wagi dwóch ostatnich, wprowadzonych w ostatnim czasie, warunków nie należy przeceniać. Praktyka pokazała, że warunek trzeci nie doprowadził do istotnej poprawy sytuacji ubezpieczających. Co do warunku czwartego, ograniczenia dotyczące sposobu redagowania ustandaryzowanego dokumentu informacyjnego mogą nie pozwolić na umieszczenie w nim wszystkich wyłączeń, które mogłyby okazać się dla ubezpieczającego istotne. Niedopełnienie dwóch ostatnich warunków nie prowadzi zresztą per se do nieważności postanowień przewidujących wyłączenie, ale może wpływać na ocenę ich jednoznaczności oraz interpretację.

Warunki materialne skuteczności wyłączeń odpowiedzialności sprowadzają się do kryteriów ograniczających swobodę umów zgodnie $\mathrm{z}$ art. $353^{1}$ k.c. oraz przesłanek uznania określonych klauzul w umowach $z$ konsumentami za niedozwolone. Pamiętać należy o rozszerzeniu stosowania przepisów o klauzulach niedozwolonych na przedsiębiorców będących osobami fizycznymi. Szczególnego znaczenia w zakresie

22 M. Orlicki, Ustandaryzowany... 
klauzul niedozwolonych nabiera uznanie określonych postanowień umowy ubezpieczenia za określające główne świadczenia stron. W pracy zaproponowano ujęcie wąskie, ograniczające znaczenie tzw. core terms jedynie do klauzul określających w sposób bezpośredni świadczenie pieniężne ubezpieczyciela. Przy takiej interpretacji wyłączenia odpowiedzialności podlegać będą co do zasady ocenie przez pryzmat przepisów o klauzulach niedozwolonych ${ }^{23}$.

Innym bardzo istotnym problemem, przed którym stoi współczesne prawo ubezpieczeniowe, jest dopuszczalność naprawienia przez ubezpieczyciela szkody w formie restytucji naturalnej zamiast przez wypłatę odszkodowania pieniężnego. Wiąże się to przede wszystkim z rozwijającym się rynkiem różnego rodzaju ubezpieczeń assistance, obejmującym nie tylko assistance samochodowe, ale również domowe, medyczne i prawne. Pomimo że sama kwestia dopuszczalności spełnienia przez ubezpieczyciela świadczenia $\mathrm{z}$ umowy ubezpieczenia $\mathrm{w}$ formie niepieniężnej wydaje się przesądzona przez ustawodawcę europejskiego ${ }^{24}$, obce reprezentatywne systemy prawne mają do niej zupełnie różny stosunek. Prawo niemieckie jest jej tradycyjnie niechętne, prawo francuskie wydaje się ją akceptować jako wygodną dla ubezpieczającego w określonych okolicznościach. Prawo angielskie z kolei od zawsze dopuszczało spełnienie przez ubezpieczyciela świadczenia przez przywrócenie do stanu poprzedniego, motywując to jednak jego własnym interesem, a nie interesem ubezpieczającego.

Zdaniem autora prawo polskie nie zakazuje dopuszczalności naprawienia przez ubezpieczyciela szkody in natura. Prawdą jest, że przepisy o umowie ubezpieczenia, tradycyjnie wzorowane na rozwiązaniach niemieckich, koncentrują się na świadczeniach pieniężnych. Jednym z problemów jest odpowiednia wykładnia art. 828 k.c., wyraźnie przewidującego wstąpienie w prawa ubezpieczającego względem sprawcy jedynie przez ubezpieczyciela, który wypłacił ubezpieczającemu należne

23 Takie ujęcie dominuje w prawie niemieckim. Zob. M. Wandt, Versicherungsrecht, s. 100-101. Inna jest jednak praktyka angielska pomimo krytycznych głosów w doktrynie - zob. M. Clarke, Policies and Perceptions of Insurance Law..., s. 269.

24 Por. art. 1 ust. 2 dyrektywy Parlamentu Europejskiego i Rady 2009/138/WE. 
mu odszkodowanie, nie zaś przez ubezpieczyciela, który zapłacił swojemu podwykonawcy wynagrodzenie za wykonanie usługi na rzecz ubezpieczającego. Sąd Najwyższy rozwiązał ten kłopot, wykładając przepis funkcjonalnie ${ }^{25}$, i wydaje się, że podobnie da się rozwiązać inne kwestie, które mogą pojawić się na gruncie przepisów Kodeksu cywilnego traktujących o zapłacie odszkodowania.

Ubezpieczyciel ma prawo zobowiązać się zarówno do pokrycia kosztów usług świadczonych ubezpieczającemu przez osoby trzecie, z którymi umowy zawierać będzie ubezpieczający, ale również do wyświadczenia potrzebnych usług ubezpieczającemu. W tym celu ubezpieczyciel zawiera umowy z podwykonawcami, ponosząc za nich odpowiedzialność. Sposób naprawienia szkody zależy zatem przede wszystkim od redakcji umowy oraz ogólnych warunków ubezpieczenia ${ }^{26}$. Istota ubezpieczenia w ogóle nie polega na tym, w jaki sposób ubezpieczyciel naprawi szkodę, ale na jego ochronnej funkcji pozwalającej na naprawienie szkód będących skutkami zdarzeń losowych. Ograniczeń co do dopuszczalności zobowiązywania się przez ubezpieczyciela do świadczeń niepieniężnych upatrywać należy właśnie w antylosowości ubezpieczenia. Obserwacja rynku wskazuje, że nie wszyscy ubezpieczyciele dostrzegają to ograniczenie, myląc swoje zadania z zadaniami, których podejmują się podmioty oferujące tzw. usługi concierge. Rola ubezpieczeń nie polega na zaspokajaniu rozmaitych coraz bardziej wyszukanych zachcianek i kaprysów ubezpieczających ani na oferowaniu świadczeń, których potrzeba pojawia się cyklicznie, przykładowo w związku z naturalną zmianą pór roku w określonym klimacie. Wydaje się, że cecha losowości powinna być również kryterium pozwalającym odróżnić umowy ubezpieczenia od różnego rodzaju umów polegających na gwarancji spełniania na rzecz kontrahenta świadczeń w zamian za określony abonament (przedłużone gwarancje, obsługa prawna itp.). Umowa ubezpieczenia jest bowiem losowa $\mathrm{z}$ definicji, natomiast w umowach o świadczenie usług w zamian za abonament losowość pojawiać się może z woli stron i ma charakter ekonomiczny, a nie prawny. Inaczej niż w przypadku tych umów losowość ubezpieczenia łączy się z wzajemnością w taki sposób, że koszt

${ }^{25}$ Uchwała SN z 30.11.2016 r., III CZP 74/16.

26 Tak w szczególności J. Nawracała, Nie tylko... 
usług nie przekłada się bezpośrednio na wysokość składki, która jest relatywnie niska ${ }^{27}$. Ostatnie zagadnienia, a mianowicie pojawienie się wyspecjalizowanych przedsiębiorstw świadczących usługi pomocowe zarówno na wypadek zdarzeń, które mają, jak i nie mają cech zdarzeń losowych, oraz odróżnienia ubezpieczenia od niektórych umów o usługi w zamian za abonament wydają się odrębnymi problemami, które prawo ubezpieczeniowe będzie musiało rozstrzygnąć w najbliższej przyszłości.

Ze spełnieniem przez ubezpieczyciela świadczenia in natura wiążą się oczywiście określone niebezpieczeństwa. Ubezpieczyciel będzie miał w szczególności tendencję do wymiany rzeczy na taką, którą oferuje jego dostawca, zamiast na taką, która została uszkodzona, ewentualnie do naprawienia uszkodzonej rzeczy najmniejszym kosztem, co z kolei może przekładać się na niską jakość oferowanych usług. Z tym wiąże się kwestia odpowiedzialności za jakość świadczenia. Będzie ona wyglądać inaczej w tych umowach, w których ubezpieczyciel przyjmuje jedynie rolę pośrednika, kontaktując ubezpieczającego z podmiotem spełniającym świadczenie, i zobowiązując się pokryć koszty usług tego podmiotu, oraz inaczej w umowach, na mocy których ubezpieczyciel bezpośrednio zobowiązuje się naprawić szkodę, a ubezpieczający nie zawiera żadnej umowy poza umową ubezpieczenia. Z drugiej strony jednak należy pamiętać o tendencji ubezpieczających do zawyżania roszczeń finansowych kierowanych względem ubezpieczycieli. Przejawiać się one mogą w zleceniu naprawy zakładom, których stawki są nieproporcjonalnie wysokie do jakości oferowanych usług, albo w domaganiu się pokrycia szczególnie wysokich kosztów przywrócenia rzeczy do stanu poprzedniego przy jednoczesnym zleceniu naprawy podmiotowi usuwającego usterki znacznie tańszym kosztem bądź też nawet przy rezygnacji z usunięcia usterek. Problemy te dostrzegano zawsze w prawie angielskim przyznającym ubezpieczycielowi prawo tzw. reinstatement, ale z narażeniem się na odpowiedzialność za jakość świadczenia ${ }^{28}$.

27 Szeroko co do tych kwestii S. Beaugendre, Contrat..., s. 52 i n. oraz 111 i n. Z nowszej polskiej literatury odnośnie odróżnienia umowy ubezpieczenia od różnego rodzaju umów gwarancji zob. ostatnio J. Jastrzębski, Nieubezpieczeniowe..., s. 4 i n.

28 Poza literaturą powołaną wcześniej w rozdziale dotyczącym możliwości naprawienia szkody przez ubezpieczyciela w drodze przywrócenia do stanu poprzedniego zob. M. Clarke, Policies and Perceptions of Insurance Law..., s. 214 oraz 227-228. 
Rozwój gospodarczy i kulturalny społeczeństw oraz konkurencja między ubezpieczycielami starającymi się sprostać rosnącym wymaganiom potencjalnych klientów w sposób bezpośredni wiąże się ze wzrostem znaczenia świadczeń niepieniężnych w umowie ubezpieczenia. Niektóre osoby uczestniczące przykładowo w wypadkach komunikacyjnych wolą samodzielnie zorganizować sobie zaholowanie uszkodzonego samochodu, jego naprawę oraz transport zastępczy przez czas naprawy, a następnie domagać się odszkodowania pozwalającego z nadwyżką skompensować poniesione wydatki. Taka mentalność zdaje się dominować w Niemczech i licuje z tamtejszą praktyką ubezpieczeniową. Dla innych osób z kolei istotne jest przede wszystkim zaoszczędzenie sobie kłopotów oraz czasu. W razie wypadku osoby takie wolą wykonać telefon do ubezpieczyciela, wsiąść w podstawiony przezeń samochód zastępczy, powierzyć mu samochód uszkodzony oraz czekać na informację, że ten ostatni samochód został naprawiony, w związku z czym należy udać się w określone miejsce, by go odebrać i zdać samochód zastępczy. Taka mentalność zdaje się dominować we Francji i licuje z tamtejszą praktyką. Nie należy jednak generalizować. Ubezpieczający niezależnie od kraju swego zamieszkania powinni mieć prawo zawarcia ubezpieczenia na warunkach niemieckich albo francuskich. Nie można również wykluczyć ubezpieczeń, których warunki będą przewidywać alternatywne sposoby naprawienia przez ubezpieczyciela szkody, przyznając jednak prawo wyboru ubezpieczającemu zamiast ubezpieczycielowi, jak czynią to warunki angielskie. Taka konstrukcja może mieć znaczenie dla społecznego odbioru ubezpieczycieli, którzy nie chcą być postrzegani po prostu jako podmioty wypłacające odszkodowania, ale raczej jako oferujący szeroki zakres usług doradcy risk management i w ten sposób zachęcają do korzystania ze swoich usług ${ }^{29}$.

29 S. Beaugendre, Contrat..., s. 41-44. 



\section{BIBLIOGRAFIA}

Bagińska E., Odpowiedzialność deliktowa w razie niepewności związk przyczynowego. Studium prawnoporównawcze, Torun 2013

Balas-Noszczyk B., Malinowska K., W sprawie dopuszczalności spetnienia świadczenia $z$ umowy ubezpieczenia $w$ drodze restytucji naturalnej (przywrócenia stanu poprzedniego), PA 1998/4

Beale H., Klauzule wyłączenia i ograniczenia odpowiedzialności odszkodowawczej w prawie angielskim, AUWr 2000, Nr 2244, Prawo CCLXXII

Beaugendre S., Contrat d'assistance et activiete d'assurance, Paris 2000

Berr C.J., Groutel H., Code des assurances, Dalloz 2000

Bieniek G., Odpowiedzialność cywilna za wypadki drogowe, Warszawa 2006

Birds J., Birds' Modern Insurance Law, London 2007

Birds J., Birds' Modern Insurance Law, London 2016

Borowiecka U., Rażące niedbalstwo i niedochowanie należytej staranności na tle orzecznictwa Sądu Najwyższego, sąów powszechnych i skarg wplywajacych do Rzecznika Ubezpieczonych, MU 2011/45

Brodecki Z., Kilka refleksji na temat związu przyczynowego, PA 1995/3

Brodecki Z., Prawo ubezpieczeń gospodarczych. Komentarz, Kraków 2005

Bruck E., Möller H., Kommentar zum Versicherungsvertragsgesetz, Berlin-New York 1980

Bruck E., Möller H., Versicherungsvertragsgesetz. Großkommentar, Berlin 2009

Brzozowski A., Wpływ zmiany okoliczności na zobowiązania [w:] System Prawa Prywatnego, red. Z. Radwański, t. 6, Prawo zobowiąań - część ogólna, red. A. Olejniczak, Warszawa 2014

Brzozowski Z., Zdarzenia losowe jako szczególny rodzaj faktów prawnych, WU 1963/10

Brzozowski Z., Przedmiot prawnego stosunku ubezpieczenia, WU 1972/11

Bucoń M., Odpowiedzialność cywilna uczestników wypadku komunikacyjnego, Warszawa 2008

Byczko S., Niektóre problemy prawne związane z umowa ubezpieczenia auto-casco na tle orzecznictwa Sądu Najwyższego, Pal. 1995/9-10 
Byczko S., Powinności ubezpieczającego w umowie ubezpieczenia mienia, niepublikowana praca doktorska napisana pod kierunkiem W.J. Katnera i obroniona w 2003 r. na Uniwersytecie Łódzkim

Byczko S., Powinności ubezpieczającego a inne obowiązi w umowie ubezpieczenia mienia [w:] Odpowiedzialność cywilna. Księga pamiątkowa ku czci Profesora Adama Szpunara, red. M. Pyziak-Szafnicka, Kraków 2004

Byczko S., Roszczenia uprawnionego w przypadku nienależytego wykonania umowy przez ubezpieczyciela [w:] Ubezpieczenia gospodarcze. Wybrane zagadnienia prawne, red. B. Gnela, Warszawa 2011

Byczko S., Interes ubezpieczeniowy. Aspekty prawne, Warszawa 2013

Byczko S., Prawo ubezpieczeń gospodarczych. Zarys wykładu, Warszawa 2013

Byczko S., Proces likwidacji szkody w kontekście świadczenia ubezpieczyciela [w:] Kierunki rozwoju ubezpieczeń gospodarczych w Polsce. Wybrane zagadnienia prawne, red. B. Gnela, M. Szaraniec, Warszawa 2013

Byczko S., Świadczenie pieniężne ubezpieczyciela na tle pojęcia odpowiedzialności cywilnej [w:] Prawo prywatne wobec wyzwań wspótczesności. Księga pamiątkowa dedykowana Profesorowi Leszkowi Ogiegle, red. M. Fras, P. Ślęzak, Warszawa 2017

Campbell N., The nature of insurer's obligation, „Lloyd's Maritime Commercial Law Quarterly" 2000/42

Chagny M., Perdrix L., Droit des Assurances, Paris 2009

Chłopecki M., Szkoda poniesiona przez spółkę akcyjna a szkoda poniesiona przez akcjonariusza w świetle przepisów kodeksu spółek handlowych i kodeksu cywilnego, PPH 2007/5

Chmielowiec B., Kilka uwag o pojęciu i praktyce tzw. szkody całkowitej w ubezpieczeniach komunikacyjnych, PUSiG 2010/01

Chmielowiec B., Praktyczne problemy zwiazane $z$ kwalifikacja szkody jako catkowitej i podejmowane w tym zakresie działania Rzecznika Ubezpieczonych, MU 2010/41

Chmielowiec B., Podatek VAT $w$ rozliczeniu kosztorysowym $w$ ramach ubezpieczenia autocasco, MU 2011/45

Chmielowiec B., Utrata wartości handlowej pojazdu, MU 2012/49

Chmielowiec B., Amortyzacja wartości części koniecznych do naprawy pojazdu w świetle uchwały Sądu Najwyższego z dnia 12 kwietnia 2012 r., RU 2013/1

Chmielowiec B., Podatek od towarów i ustug (VAT) przy wypłacie odszkodowań z umów ubezpieczenia w zakresie ubezpieczeń gospodarczych, RU 2014/2

Chróścicki A., Umowa ubezpieczenia po nowelizacji kodeksu cywilnego. Komentarz, Warszawa 2008

Clarke M., Policies and Perceptions of Insurance Law in The Twenty-First Century, Oxford 2005 
Clarke M., The Law of Insurance Contract, London 2009

Colinvaux's Law of Insurance, red. R. Merkin, London 2006

Cudna A., Ubezpieczenie odpowiedzialności cywilnej członków organów spółek kapitałowych, PUSiG 2001/8

Cudna-Wagner A., Odpowiedzialność odszkodowawcza ubezpieczyciela, Warszawa 2002

Czachórski W., Odpowiedzialność odszkodowawcza w ramach tzw. ujemnego interesu umowy, RPEiS 1968/3

Czachórski W., Zasady i funkcje odpowiedzialności cywilnej według kodeksu cywilnego - ich ewolucja [w:] Studia z prawa zobowiązań. Księga pamiątkowa ku czci Profesora Alfreda Ohanowicza, red. Z. Radwański, Warszawa-Poznań 1979

Czachórski W., Brzozowski A., Safjan M., Skowrońska-Bocian E., Zobowiązania. Zarys wykładu, Warszawa 2009

Daszewski A., Problemy konsumentów usług ubezpieczeniowych z kluczykami do pojazdów w umowach ubezpieczenia autocasco, RU 2009/1

Daszewski A., Zwrot kosztów ustanowienia pełnomocnika na etapie postępowania przedsądowego w świetle uchwały Sądu Najwyższego z dnia 13 marca 2012 r., RU 2012/2

Deutsch E., Versicherungsvertragsrecht. Ein Grundi $\beta$, Karlsruhe 2000

Długosz Z., Niedozwolone postanowienia umowne w umowach ubezpieczenia [w:] Kierunki rozwoju ubezpieczeń gospodarczych $w$ Polsce. Wybrane zagadnienia prawne, red. B. Gnela, M. Szaraniec, Warszawa 2013

Dmochowski S., Odszkodowania i świadczenia z ubezpieczeń gospodarczych, Warszawa 1983

Domański L., Instytucje Kodeksu Zobowiązań. Część ogólna, Warszawa 1936

Dreher M., Die Versicherung als Rechtsprodukt. Die Privatversicherung und ihre rechtliche Gestaltung, Tubingen 1991

Drzewiecki M., Ubezpieczenia gospodarcze. Przepisy. Komentarz, Jaktorów 2000

Duży A., Dyferencyjna metoda ustalania wysokości szkody, PiP 1983/10

Dybowski T., Adekwatny czy konieczny związek przyczynowy, Pal. 1961/5-6

Dybowski T., Odszkodowanie za naruszenie posiadania, NP 1973/1, s. 3

Dybowski T., Odszkodowanie należne posiadaczowi za utracone pożytki z rzeczy, NP 1977/4

Dybowski W., Naprawienie szkody [w:] System Prawa Cywilnego, t. 3, cz. 1, Prawo zobowiązań. Część ogólna, red. Z. Radwański, Ossolineum 1981

Dybowski T., Świadczenie [w:] System Prawa Cywilnego, t. 3, cz. 1, Prawo zobowiązań. Część ogólna, red. Z. Radwański, Ossolineum 1981

Dybowski T., Pyrzyńska A., Świadczenie [w:] System Prawa Prywatnego, red. Z. Radwański, t. 5, Prawo zobowiązań - część ogólna, red. E. Łętowska, Warszawa 2012 
Fendler Z., Prywatne prawo ubezpieczeniowe wraz z komentarzem i orzecznictwem sądów polskich, Kraków 1934

Fras M., Umowa ubezpieczenia grupowego. Aspekty prawne, Warszawa 2015

Fras M., O współczesnych tendencjach normatywnych $w$ ujęciu istoty $i$ typologii umów ubezpieczenia [w:] Prawo prywatne wobec wyzwań współczesności. Księga pamiątkowa dedykowana Profesorowi Leszkowi Ogiegle, red. M. Fras, P. Ślęzak, Warszawa 2017

Fuchs D., Umowa ubezpieczenia - umowa wzajemna czy tylko dwustronnie zobowiąującą?, WU 1995/7-9

Fuchs D., Wybrane cechy umowy ubezpieczenia majątkowego, PA 1999/4

Fuchs D., Zakres obowiązku prewencji w prawie ubezpieczeń gospodarczych. Uwagi na tle art. 826 k.c., PA 2004/2

Fuchs D., Charakter prawny art. 814 kodeksu cywilnego. Rozważania na temat czasowych aspektów odpowiedzialności zakładu ubezpieczeń, Pal. 2005/7-8

Fuchs D., Wpływ wejścia w życie pakietu ustaw ubezpieczeniowych na charakterystykę umowy ubezpieczenia [w:] Rozprawy prawnicze. Ksiega pamiątkowa Profesora Maksymiliana Pazdana, red. L. Ogiegło, W. Popiołek, M. Szpunar, Kraków 2005

Fuchs D., Podwójne (wielokrotne) ubezpieczenie de lege lata oraz de lege ferenda, PPH 2006/6

Fuchs D., Ochrona ubezpieczeniowa jako świadczenie główne ubezpieczyciela, PA 2006/2

Fuchs D., Implikacje spełnienia świadczenia kulancyjnego przez ubezpieczyciela w szczególności dla jego prawa regresu wobec sprawcy szkody, PPH 2009/7

Fuchs D., Obowiązki prewencyjno-ratownicze wspólnoty mieszkaniowej jako specyficznego podmiotu stosunku majątkowego w ubezpieczeniach majątkowych - uwagi na tle art. 826 k.c., RU 2010/1

Fuchs D., Odszkodowanie z tytułu ubezpieczenia OC posiadacza pojazdu a kwestia amortyzacji części zamiennych użytych do naprawy uszkodzonego pojazdu, WU 2012/1

Gandor K., Prawa podmiotowe tymczasowe. Ekspektatywy, Ossolineum 1968

Gawlik Z., Odpowiedzialność absolutna w polskim prawie odszkodowawczym [w:] Prace cywilistyczne. Księga pamiątkowa dla uczczenia 40-lecia pracy naukowej profesora Jana J. Winiarza, red. S. Wójcik, Warszawa 1990

Gęsikowska K., Istota i powstanie stosunku ubezpieczenia, WU 1993/10-12

Górski W., Umowa ubezpieczenia w nowym kodeksie cywilnym, PUG 1964/9

Górski W., Ubezpieczenie mienia $w$ transporcie (cargo) [w:] Ubezpieczenia $w$ gospodarce rynkowej, t. 2, red. A. Wąsiewicz, Bydgoszcz 1994

Górski W., Ubezpieczenia transportowe, Zielona Góra 1999

Grau J.B., Chiner N.L., Iglesia J.O., Insurance Law in Spain, The Netherlands 2014 
Grzybowski S., Zobowiązania w systemie prawa cywilnego [w:] System Prawa Cywilnego, t. 3, cz. 1, Prawo zobowiązań. Część ogólna, red. Z. Radwański, Ossolineum 1981

Guść J., O właściwości (naturze) stosunku prawnego, PiP 1997/4

Hardy Ivamy E.R., Chalmers' Marine Insurance Act 1906, London 1976

Hardy Ivamy E.R., General Principles of Insurance Law, London-Dublin-Edinburgh 1993

Hełczyński B., Ubezpieczenie na cudzy rachunek, Kraków 1927

Hodgin R.W., Problem in defining insurance contract, LMCLQ 1980

Hodgin R.W., Protection of the Insured, London-New York-Hamburg-Hong Kong 1987

Hofmann E., Privetversicherungsrecht, Munchen 1998

Huget M., Ubezpieczenia przewozów morskich, Gdynia 1960

Hyrlik P., Glosa do wyroku SN z 29.01.2009 r., V CSK 291/08, „Glosa” 2011/2

Hyrlik P., Kierunki wykładni przepisów o umowie ubezpieczenia na przykładzie art. 827 \$ 2, „Glosa” 2011/2

Ignatowicz J., Ochrona posiadania, Warszawa 1963

Janiszewska B., Nadmierne koszty restytucji a odpowiedzialność ubezpieczyciela za tzw. szkody komunikacyjne, SI 2007, t. 47

Janiszewska B., Uwagi o ustaleniu „szkody całkowitej” wobowiazkowych ubezpieczeniach komunikacyjnych, SI 2007, t. 47

Jastrzębski J., Nieubezpieczeniowe umowy gwarancyjne, PPH 2018/7

Jęksa Z., Ubezpieczenia majątku i zysku firmy, Warszawa 2000

Kaliński M., Zasada odszkodowania w ubezpieczeniach gospodarczych, cz. 1, PA 2002/1

Kaliński M., Zasada odszkodowania $w$ ubezpieczeniach gospodarczych, cz. 2, PA 2002/2

Kaliński M., O wadliwej obiektywizacji szkody, SI 2007, t. 47

Kaliński M., Szkoda na mieniu i jej naprawienie, Warszawa 2008

Kaliński M., Glosa do wyroku SN z 12.01.2006 r., II CK 327/05, PA 2009/7

Kaliński M., Szkoda na mieniu i jej naprawienie, Warszawa 2011

Kaliński M., Tak zwany ubytek wartości handlowej jako składnik odszkodowania ubezpieczeniowego, PS 2012/10

Kaliński M., Glosa do wyroku SN z 22.06.2012 r., V CSK 338/11, PiP 2013/2

Kaliński M., Odpowiedzialność odszkodowawcza [w:] System Prawa Prywatnego, t. 6, Prawo zobowiązań - część ogólna, red. A. Olejniczak, Warszawa 2014

Kappes A., Odpowiedzialność za cudzy dtug. Próba analizy pojęcia [w:] Europeizacja prawa prywatnego, red. M. Pazdan i in., Warszawa 2008

Kappes A., Odpowiedzialność członków zarządu za zobowiązania spółki z o.o., Warszawa 2009 
Kappes A., Czy ujmowanie szkody jako bezpośredniej uniemożliwia dochodzenie roszczeń odszkodowawczych przez wspólników spółek kapitałowych? [w:] Czynić postęp w prawie. Księga jubileuszowa dedykowana Profesor Birucie Lewaszkiewicz-Petrykowskiej, red. W. Robaczyński, Łódź 2017

Katner W.J., Pojęcie umowy nienazwanej [w:] System Prawa Prywatnego, red. Z. Radwański, t. 9, Prawo zobowiazań - umowy nienazwane, red. W.J. Katner, Warszawa 2015

Kęszycka B., Prawo ubezpieczeń gospodarczych, Poznań 1999

Kęszycka B., Dobre obyczaje jako kryterium oceny ubezpieczeniowego wzorca umownego, PA 2009/1

Kidyba A., Prawo handlowe, Warszawa 2017

Klein A., Przesłanki odpowiedzialności kontraktowej i deliktowej, SIS 1979/5

Klein A., Elementy zobowiazaniowego stosunku prawnego, Wrocław 2005

Koch A., Metodologiczne zagadnienia związku przyczynowego w prawie cywilnym, Poznań 1975

Koch A., Związek przyczynowy jako podstawa odpowiedzialności odszkodowawczej w prawie cywilnym, Warszawa 1975

Koch A., Zwiazek przyczynowy w ubezpieczeniach, PA 1993/5

Koch A., Umowa gwarancji bankowej [w:] System Prawa Prywatnego, red. Z. Radwański, t. 8, Prawo zobowiązań - część szczegółowa, red. J. Panowicz-Lipska, Warszawa 2011

Kodeks cywilny. Komentarz, red. E. Gniewek, P. Machnikowski, Warszawa 2011

Kodeks cywilny. Komentarz, t. 2, Warszawa 1972

Kodeks cywilny. Komentarz, t. 2, Zobowiązania, red. K. Osajda, Warszawa 2013

Kodeks cywilny. Komentarz, t. 3, Zobowiązania - częśćszczególna, red. A. Kidyba, Warszawa 2014

Kodeks cywilny. Komentarz, t. 3, Zobowiązania. Część ogólna, red. J. Gudowski, Warszawa 2018

Kodeks cywilny. Komentarz, t. 3B, Zobowiązania. Część szczegółowa. Ustawa o terminach zapłaty, red. K. Osajda, Warszawa 2017

Kodeks cywilny. Komentarz, t. 5, Zobowiązania. Część szczegółowa, red. J. Gudowski, Warszawa 2017

Kodeks cywilny, t. 1, Komentarz. Art. 1-449 ${ }^{11}$, red. K. Pietrzykowski, Warszawa 2008

Kodeks cywilny, t. 2, Komentarz. Art. 450-1088. Przepisy wprowadzajace, red. K. Pietrzykowski, Warszawa 2013

Komentarz do kodeksu cywilnego. Księga trzecia. Zobowiązania, t. 2, red. G. Bieniek, Warszawa 2002

Komentarz do niektórych przepisów ustawy - Kodeks cywilny, red. M. Serwach [w:] Prawo ubezpieczeń gospodarczych, t. 2, LEX/el. 2010 
Komosa T., Krauss J., Glosa do uchwały SN z 8.07.1992 r., III CZP 80/92, PPH 1992/2 Kościelniak M., Zakres obowiązku refundacji kosztów przewidzianych w art. 826 $\$ 1$ k.c. na przykładzie wybranych zapisów ogólnych warunków ubezpieczenia autocasco, MU 2012/51

Kotuk T., Glosa do uchwały SN z 17.11.2011 r., III CZP 5/11, LEX/el. 2012

Kowalewski E., Ubezpieczenie odpowiedzialności cywilnej. Funkcje i przemiany, Toruń 1981

Kowalewski E., Łopuski J., Przedawnienie roszczeń z ubezpieczenia gospodarczego, SU 1989, t. X

Kowalewski E., Teoretyczny model świadczenia ubezpieczeniowego w ubezpieczeniu odpowiedzialności cywilnej, „Acta Universitatis Nicolai Copernici” 1990, z. XXVIII

Kowalewski E., Prawo ubezpieczeń gospodarczych. Ewolucja i kierunki przemian, Bydgoszcz 1992

Kowalewski E., Wąsiewicz A., Postulowany kształt umowy ubezpieczenia w kodeksie cywilnym, PiP 1993/11-12

Kowalewski E., Wprowadzenie do teorii ryzyka ubezpieczeniowego [w:] Ubezpieczenia w gospodarce rynkowej, t. 2, red. A. Wąsiewicz, Bydgoszcz 1994

Kowalewski E., Ryzyko ubezpieczeniowe - podstawowe pojęcia i terminologia, PA 1996/2

Kowalewski E., Odszkodowanie ubezpieczeniowe za utracone korzyści, PA 1996/3

Kowalewski E., Wprowadzenie do teorii interesu ubezpieczeniowego [w:] Ubezpieczenia w gospodarce rynkowej, t. 3, A. Wąsiewicz, Bydgoszcz 1997

Kowalewski E., Ubezpieczeniowa zasada wzajemności. Jej istota i konsekwencje prawne, PA 1998/1

Kowalewski E., Ryzyko w działalności człowieka i możliwości jego ograniczenia [w:] Ubezpieczenia gospodarcze, red. T. Sangowski, Warszawa 2000

Kowalewski E., Istota ubezpieczenia odpowiedzialności cywilnej, PA 2002/3

Kowalewski E., Nestorowicz M., Glosa do uchwały SN z 12.10.2001 r., III CZP 57/01, PA 2003/3

Kowalewski E., Glosa do wyroku SN z 22 kwietnia 2004 r., II CK 144/03, PA 2005/1

Prawo ubezpieczeń gospodarczych, red. E. Kowalewski, Bydgoszcz-Toruń 2006

Kowalewski E., Serwach M., Kulancja ubezpieczeniowa, PA 2008/3

Kowalewski E., Ziemiak P., W sprawie wykładni art. 813 k.c., PA 2010/1

Kowalewski E., Odszkodowanie za ubytek wartości handlowej pojazdu poddanego naprawie, WU 2011/3

Kowalewski E., Nesterowicz M., Bagińska E., Wałachowska M., Ziemiak M.P., Mogilski W.W., Serwach M., W sprawie refundacji kosztów wynagrodzenia pełnomocnika w ubezpieczeniowym postępowaniu likwidacyjnym, WU 2011/4 
Kowalewski E., Deminuacja wartości handlowej pojazdu poddanego naprawie jako przedmiot odszkodowania - koincydencja czy alternatywność roszczeń poszkodowanego [w:] Odszkodowanie za ubytek wartości handlowej pojazdu poddanego naprawie, red. E. Kowalewski, Torun 2012

Kowalewski E., Ziemiak M.P., Kompensacja ubytku wartości handlowej po naprawie jako przedmiot odszkodowania - standard odszkodowawczy czy roszczenie ad casum? [w:] Odszkodowanie za ubytek wartości handlowej pojazdu poddanego naprawie, red. E. Kowalewski, Toruń 2012

Kowalewski E., Wałachowska M., Ziemiak M., Merkantylny ubytek wartości części zamiennych [w:] Kolokwium naukowe, dnia 5 kwietnia 2012 roku zorganizowane przez Polską Izbę Ubezpieczeń we wspólpracy z Uniwersytetem Mikołaja Kopernika w Toruniu oraz Uniwersytetem Kardynała Stefana Wyszyńskiego $w$ Warszawie, materiały powielone, Warszawa 2012

Kowalewski E., Co psychologia behawioralna dać może teorii ryzyka ubezpieczeniowego? [w:] Ryzyko ubezpieczeniowe. Wybrane zagadnienia teorii i praktyki, red. M. Serwach, Łódź 2013

Krajewski M., Umowa przedwstępna, Warszawa 2000

Krajewski M., Umowa ubezpieczenia. Art. 805-834 KC. Komentarz, Warszawa 2004

Krajewski M., Glosa do wyroku SN z 8.08.2003 r., V CK 169/02, OSP 2004/10, poz. 121

Krajewski M., Glosa do wyroku SN z 16.07.2004 r., I CK 11/04, OSP 2005/6, poz. 78

Krajewski M., Pojęcie odpowiedzialności odszkodowawczej (uwagi na marginesie art. 299 k.s.h.) [w:] Prawo handlowe XXI wieku. Czas stabilizacji, ewolucji czy rewolucji? Ksiegga jubileuszowa Profesora Józefa Okolskiego, red. M. Modrzejewska, Warszawa 2010

Krajewski M., Świadczenie ubezpieczyciela w umowie ubezpieczenia, PS 2011/11-12

Krajewski M., Ubezpieczenie odpowiedzialności cywilnej według kodeksu cywilnego, Warszawa 2011

Krajewski M., Glosa do uchwały SN z 13.07.2011 r., III CZP 31/2011, OSP 2012/4, poz. 43

Krajewski M., Umowa ubezpieczenia a niedozwolone postanowienia umowne [w:] Niedozwolone postanowienia umowne w umowach ubezpieczenia, red. K. Zaradkiewicz, Warszawa 2013

Krajewski M., Przydatność i treść pojęcia ochrony ubezpieczeniowej [w:] Kierunki rozwoju ubezpieczeń gospodarczych w Polsce. Wybrane zagadnienia prawne, red. B. Gnela, M. Szaraniec, Warszawa 2013

Krajewski M., Umowa ubezpieczenia. Art. 805-834 KC. Komentarz, Warszawa 2016

Krajewski M., Szkoda na mieniu wynikajaca z wypadków komunikacyjnych, raport Ministerstwa Sprawiedliwości, Warszawa 2017 
Krajewski M., Wypadek ubezpieczeniowy. Przyczyna czy skutek? [w:] Z badań nad prawem prywatnym. Ksiega pamiątkowa dedykowana Profesorowi Andrzejowi Kochowi, red. A. Olejniczak, M. Orlicki, J. Pokrzywniak, Poznań 2017

Krajewski M., Zmiany regulacji przedawnienia roszczeń, PPH 2018/12

Krupa-Lipińska K., Ubytek wartości handlowej w kontekście rodzajów szkód oraz problematyki związku przyczynowego [w:] Odszkodowanie za ubytek wartości handlowej pojazdu poddanego naprawie, red. E. Kowalewski, Toruń 2012

Kubas A., Wynagrodzenie szkody poniesionej w cudzym interesie, SC 1979, t. XXX

Kucharski B., Uwagi o nowej regulacji umowy ubezpieczenia, Pal. 2008/1-2

Kucharski B., Glosa do wyroku SN z 20.10.2006 r., IV CSK 125/06, „Glosa” 2009/1

Kucharski B., Przeniesienie praw z umowy ubezpieczenia, Warszawa 2010

Kucharski B., Powinność zabezpieczenia kluczyków i dokumentów samochodowych w ubezpieczeniu AC, PA 2010/1

Kucharski B., Odpowiedzialność ubezpieczyciela za niewykonanie umowy ubezpieczenia [w:] Ubezpieczenia gospodarcze. Wybrane zagadnienia prawne, red. B. Gnela, Warszawa 2011

Kucharski B., Termin spełnienia świadczenia przez ubezpieczyciela w orzecznictwie sądowym [w:] Kierunki rozwoju ubezpieczeń gospodarczych w Polsce. Wybrane zagadnienia prawne, red. B. Gnela, M. Szaraniec, Warszawa 2013

Kucharski B., Ubezpieczenie odpowiedzialności cywilnej członków władz spółki kapitałowej [w:] Rynek ubezpieczeniowy-nadregulacja czy niedoregulowanie, red. M. Serwach, Łódź 2014

Kucharski B., O zawiadomieniach i oświadczeniach składanych agentowi ubezpieczeniowemu [w:] Informacja w prawie ubezpieczeń gospodarczych, red. B. Gnela, M. Szaraniec, Warszawa 2015

Kucharski B., Głos w dyskusji o ochronie wierzycieli w spółkach kapitałowych, PPH 2017/12

Kucharski B., Odpowiedzialność ubezpieczycieli w ubezpieczeniu podwójnym [w:] Czynić postęp w prawie. Księga jubileuszowa dedykowana Profesor Birucie Lewaszkiewicz-Petrykowskiej, red. W. Robaczyński, Łódź 2017

Kucharski B., Between the principle of average and the principle of first risk [w:] Insurance Challenges of Anno Domini 2018, red. K. Malinowska, A. Tarasiuk, Warszawa 2018

Kunderewicz C., Rzymskie prawo prywatne, Łódź 1995

Kuropatwiński J., Ekspektatywa powstania wierzytelności w polskim prawie cywilnym, Bydgoszcz 2006

Kuropatwiński J., Umowne rozporządzenie wierzytelnością przyszłą, Toruń 2007

Kwiecień I., Czyste straty finansowe - ryzyko odpowiedzialności i zakres ochrony w ubezpieczeniach OC podmiotów gospodarczych. Zarys problematyki, WU 2009/4 
Kwieciński T., Wąsiewicz A., Glosa do wyroku SN z 20.10.1977 r., IV CR 381/77, OSPiKA 1979/6, poz. 105

Kwieciński T., Pokrzywniak J., Glosa do wyroku SN z 22.04.2003 r., II CK 144/03, „Glosa” 2006/4

Lackoroński B., Odpowiedzialność cywilna za pośrednie naruszenie dóbr, Warszawa 2013

Lackoroński B., Glosa do wyroku SN z 22.06.2012 r., V CSK 338/11, „Glosa” 2014/1

Lambert-Faivre Y., Leveneur L., Droit des assurances, Paris 2011

Lang W., O strukturze odpowiedzialności prawnej, ZNUMK 1968/31, Prawo VIII Lang W., Spór o pojęcie odpowiedzialności prawnej, ZNUMK 1969/37, Prawo IX Lang W., Wróblewski J., Zawadzki S., Teoria państwa i prawa, Warszawa 1986 Lemkowski M., Odsetki cywilnoprawne, Warszawa 2007

Lewaszkiewicz-Petrykowska B., Rembieliński A., Uwagi o zasadzie ryzyka jako podstawie odpowiedzialności z tytułu czynów niedozwolonych w kodeksie zobowiązań, NP 1959/10

Lewaszkiewicz-Petrykowska B., Odpowiedzialność cywilna prowadzącego na własny rachunek przedsiębiorstwo wprawiane $w$ ruch za pomoca sił przyrody, Warszawa 1967

Lewaszkiewicz-Petrykowska B., Odpowiedzialność na zasadzie ryzyka a ubezpieczenie, SPE 1968, t. 1

Lewaszkiewicz-Petrykowska B., Wina jako podstawa odpowiedzialności z tytułu czynów niedozwolonych, SPE 1969, t. 2

Lewaszkiewicz-Petrykowska B., Konstrukcja solidarności biernej w kodeksie cywilnym, SPE 1974/12

Lewaszkiewicz-Petrykowska B., Zobowiazanie „in solidum”, SPE 1976/17

Lewaszkiewicz-Petrykowska B., Cywilna odpowiedzialność za szkodę jądrowa w polskim prawie atomowym, $\mathrm{PiP}$ 1987/4

Lewaszkiewicz-Petrykowska B., Zasada pełnego odszkodowania (mity i rzeczywistość) [w:] Rozprawy prawnicze. Księga pamiatkowa Profesora Maksymiliana Pazdana, red. L. Ogiegło, W. Popiołek, M. Szpunar, Kraków 2005

Lichniak Z., Zastosowanie teorii zdarzeń losowych $w$ prawie o umowie ubezpieczenia, WU 1963/3

Lichniak Z., Ryzyko a niepewność, WU 1968/9

Lichniak Z., Ryzyko a wypadki i niebezpieczeństwa oraz wypadek ubezpieczeniowy, WU 1969/11

Litewski W., Rzymskie prawo prywatne, Warszawa 1990

Longchamps de Berier R., Polskie prawo cywilne. Zobowiazania, wydanie anastatyczne, Poznań 1999

Lowry J., Rawlings P., Merkin R., Insurance Law. Doctrines and Principles, Oxford and Portland, Oregon 2011 
Ludwichowska K., Odpowiedzialność cywilna i ubezpieczeniowa za wypadki samochodowe, Toruń 2008

Ludwichowska-Redo K., Odszkodowanie za ubytek wartości handlowej pojazdu po wypadku komunikacyjnym (na tle prawnoporównawczym), PiP 2012/11

Łabno Z., Prawo ubezpieczeń gospodarczych. Zarys wykładu, Katowice 1975

Ławrynowicz J., Glosa do wyroku SN z 20.10.1977 r., IV CR 381/77, OSPiKA 1979/6, poz. 105

Łazarska A., Szacowanie szkody za utratę możliwości korzystania z utraconego pojazdu, PS 2015/5

Łazowski J., Wstęp do nauki o ubezpieczeniach, adaptacja i red. W.W. Mogilski, Sopot 1998

Łopuski J., Charakter prawny odpowiedzialności z tytułu szkód atomowych, PiP 1967/4-5

Łopuski J., Kodeks cywilny [w:] Kodeks cywilny z komentarzem, t. 2, red. J. Winiarz, Warszawa 1989

Łopuski J., Podwójne ubezpieczenie [w:] Ubezpieczenia w gospodarce rynkowej, t. 3, red. A. Wąsiewicz, Bydgoszcz 1997

Łopuski J., Ubezpieczenia towarów w transporcie międzynarodowym [w:] Ubezpieczenia w gospodarce rynkowej, t. 3, red. A. Wąsiewicz, Bydgoszcz 1997

Łopuski J., W sprawie wykładni art. $827 \$ 1$ k.c. i potrzeby nowego uregulowania umowy ubezpieczenia, PA 2002/2

Łopuski J., Doktryna najwyższej dobrej wiary w anglosaskim prawie ubezpieczeniowym, jej pochodzenie, znaczenie i krytyka [w:] Szkice o ubezpieczeniach, red. M. Kuchlewska, Poznań 2006

MacGillivray on Insurance Law, red. J. Birds, B. Lynch, S. Milnes, London 2012 Machnikowski P., Uprawnienia kształtujące w zobowiązaniowych stosunkach prawnych [w:] O źródłach i elementach stosunków cywilnoprawnych. Księga pamiątkowa ku czci Prof. Alfreda Kleina, red. E. Gniewek, Kraków 2000

Machnikowski P., Struktura zobowiązania [w:] System Prawa Prywatnego, t. 5, Prawo zobowiązań - część ogólna, red. E. Łętowska, Warszawa 2012

Machnikowski P., Treść umowy [w:] System Prawa Prywatnego, red. Z. Radwański, t. 5, Prawo zobowiązań - część szczegółowa, red. E. Łętowska, Warszawa 2012 Machnikowski P., Nowelizacja przepisów Kodeksu cywilnego o przedawnieniu roszczeń, PS 2018/9

Malinowska K., Dobra wiara w ubezpieczeniach - zmiany art. 815 k.c. [w:] Umowa ubezpieczenia. Dyskusja nad forma prawna i treścia unormowań, red. A. Nowak, D. Fuchs, S. Nowak, Warszawa 2007

Malinowska K., Nowak S., Wina ubezpieczającego (ubezpieczonego) a odpowiedzialność ubezpieczyciela w umowie ubezpieczenia [w:] Umowa ubezpieczenia. 
Dyskusja nad forma prawną i treścia unormowań, red. A. Nowak, D. Fuchs, S. Nowak, Warszawa 2007

Malinowska K., Umowa ubezpieczenia w Europie bez granic, Bydgoszcz 2008

Malinowska K., Wzajemność umowy ubezpieczenia w świetle orzecznictwa ustawodawstwa i doktryny, PA 2009/3

Malinowska K., Konsekwencje niedochowania powinności ubezpieczeniowych w świetle art. 827 k.c., PA 2013/3

Malinowska K., Pojęcie zarządzania produktem ubezpieczeniowym w świetle dyrektywy o dystrybucji ubezpieczeń i przepisów implementacyjnych, WU 2017/1

Malinowska K., Space Insurance: International Legal Aspects, Kluwer Law International 2017

Malinowska K. i in., Koncepcja rynku pośrednictwa ubezpieczeniowego (projekt ustawy o pośrednictwie ubezpieczeniowym), Warszawa 2017

Marek W., Glosa do wyroku SN z 29.05.1979 r., II CR 114/79, NP 1981/2

Marek W., Glosa do uchwały SN z 31.03.1993 r., III CZP 1/93, PPH 1994/1

Maśniak D., Wybrane aspektynowego modelu ubezpieczeń ekologicznych, PA 2000/4

Maśniak D., Ubezpieczenia ekologiczne, Kraków 2003

Maśniak D., Czy test wymagań i potrzeb to wniosek ubezpieczeniowy [w:] Dystrybucja uslug ubezpieczeniowych, B. Gnela, M. Szaraniec (red.), Warszawa 2017

McGee A., The Modern Law of Insurance, London 2006

McKendrick E., Contract Law, MacMillan Press Ltd 1997

Merkin R., Steele J., Insurance and the Law of Obligations, Oxford 2013

Miaskowski J., Niezgoda K., Skawiński P., Ustawa o ubezpieczeniach obowiazkowych, Ubezpieczeniowym Funduszu Gwarancyjnym i Polskim Biurze Ubezpieczycieli Komunikacyjnych, Komentarz, Warszawa 2012

Mikołajewicz M., Problematyka pure economic loss ze szczególnym uwzględnieniem szkody wyrzadzonej przez adwokata, WU 2010/2, s. 90-91

Młynarski T., Zwrot kosztów ustanowienia pełnomocnika na etapie postępowania przedsądowego - stan sprzed uchwały i po uchwale Sądu Najwyższego $z$ dnia 13 marca 2012 r., RU 2012/2

Mogilski W.W., Charakter prawny ogólnych warunków ubezpieczeń, PA 1995/11

Mowbray A.H., Insurance. Its theory and Practice in the United States, New YorkLondon 1946

Möller H., Współczesne teorie o pojęciach ubezpieczenia i umowy ubezpieczenia, WU 1969/9

Mróz D., Kodeks cywilny. Komentarz do zmian wprowadzonych ustawa z dnia 13 kwietnia 2007 r. o zmianie ustawy - Kodeks cywilny oraz o zmianie niektórych innych ustaw, LEX/el/2008

Nawracała J., Nie tylko zapłata. Charakter prawny świadczenia zakładu ubezpieczeń w razie zajścia wypadku ubezpieczeniowego, WU 2006/9-10 
Nawracała J., Szkody częściowe w pojazdach, „Miesięcznik Ubezpieczeniowy” 2010/12

Nawracała J., Odpowiedzialność proporcjonalna ubezpieczyciela $w$ przypadku niedoubezpieczenia mienia, PA 2016/3

Nowacki J., Tobor Z., Wstęp do prawoznawstwa, Warszawa 2017

Nowakowski Z.K., Wąsiewicz A., Prawo ubezpieczeń majątkowych i osobowych, Warszawa-Poznań 1973

Ogiegło L., Pojęcie usługi i umów o świadczenie usług w ujęciu kodeksu cywilnego, SIS $1979 / 5$

Ohanowicz A., Rodzaje odpowiedzialności za szkodę, RPEiS 1962/2

Ohanowicz A., Wstapienie osoby trzeciej w prawa zaspokojonego wierzyciela, SC 1969, t. XIII-XIV

Ohanowicz A., Górski J., Zarys prawa zobowiązań, Warszawa 1970

Ohanowicz A., Rodzaje odpowiedzialności za szkodę wedle Kodeksu zobowiązań i ich wzajemny stosunek [w:] A. Ohanowicz, Wybór prac, Warszawa 2007

Ohanowicz A., Zobowiązania przemienne [w:] A. Ohanowicz, Wybór prac, Warszawa 2007

Olechowski M., O relacji między szkoda poniesioną przez spółkę akcyjnq i szkoda poniesiona przez akcjonariusza - polemika, PPH 2007/9

Olędzka H., Obniżenie wartości handlowej pojazdu po naprawie a odszkodowanie z tytułu ubezpieczenia komunikacyjnego OC, WU 2012/1

Orlicka J., Klauzula napraw a zakres obowiązku odszkodowawczego w ubezpieczeniach komunikacyjnych, RU 2007/2

Orlicki M., Instytucja kulancji w polskim prawie ubezpieczeniowym, PA 1998/4

Orlicki M., Wąsiewicz A., Koszt usługi likwidacji szkody jako element odszkodowania z tytułu ubezpieczenia odpowiedzialności cywilnej posiadaczy pojazdów mechanicznych, PA 1999/3

Orlicki M., Umowa ubezpieczenia, Warszawa 2002

Orlicki M., Kępiński M., O wykładni art. 827 kodeksu cywilnego, PS 2006/3

Orlicki M., Pokrzywniak J., Umowa ubezpieczenia. Komentarz do nowelizacji kodeksu cywilnego, Warszawa 2008

Orlicki M., Uwagi o nowelizacji przepisów dotyczących umowy ubezpieczenia na tle nowych przepisów niemieckich, PA 2008/1

Orlicki M., O łączeniu w jednej umowie różnych rodzajów ubezpieczeń, PA 2010/2

Orlicki M., O możliwości stosowania reguły proporcji przy niedoubezpieczeniu, PA 2011/2

Orlicki M., O zaliczaniu świadczeń ze środków publicznych na rzecz ofiar powodzi na poczet odszkodowań z ubezpieczeń majątkowych [w:] Ubezpieczenia gospodarcze. Wybrane zagadnienia prawne, red. B. Gnela, Warszawa 2011

Orlicki M., Ubezpieczenia obowiązkowe, Warszawa 2011 
Orlicki M., Umowa ubezpieczenia [w:] System Prawa Prywatnego, red. Z. Radwański, t. 8, Prawo zobowiązań. Część szczegółowa, red. J. Panowicz-Lipska, Warszawa 2011

Orlicki M., Regulacja umowy ubezpieczenia: imperatywna, dyspozytywna czy semiimperatywna [w:] Kierunki rozwoju ubezpieczeń gospodarczych w Polsce. Wybrane zagadnienia prawne, red. B. Gnela, M. Szaraniec, Warszawa 2013

Orlicki M., Regres między ubezpieczycielami w przypadku podwójnego ubezpieczenia OC [w:] Księga pamiattkowa dedykowana Profesorowi Andrzejowi Kochowi, red. A. Olejniczak, M. Orlicki, J. Pokrzywniak, Poznań 2017

Orlicki M., Ustandaryzowany dokument według ustawy o dystrybucji ubezpieczeń - zasady tworzenia i znaczenie prawne, PA 2017/4

Orłowski C., Dopuszczalność nałożenia na ubezpieczającego tzw. obowiązków „przedwypadkowych - prewencyjnych” w świetle art. 826 k.c., MU 2012/49

Orłowski C., Dopuszczalność stosowania zasady proporcji w sytuacji niedoubezpieczenia, MU 2012/50

Oxford Dictionary of Law, red. E. Martin, Oxford 1994

Pabiś M., Ubezpieczenie ochrony prawnej - konstrukcja produktu i likwidacja szkód w praktyce ubezpieczeniowej, WU 2016/1

Pajor T., Poland [w:] Pure Economic Loss: New Horizons in Comparative Law, red. V.V. Pamler, M. Bussani, New York 2008

Panfil B., Glosa do uchwaty SN z 17.11.2011 r., III CZP 5/11, „Glosa” 2014/2

Patterson W., Essentials of the Insurance Law. An Outline of Legal Doctrines and Their Relations to Insurance Practices, New York-Toronto-London 1957

Pawelec J.K., Odszkodowanie z ubezpieczenia AC, M. Prawn. 1999/1

Pazdan J., Glosa do uchwały SN z 7.08.1992 r., III CZP 93/92, OSP 1993/9, poz. 180

Pazdan M., Z pogranicza statusu kontraktowego i deliktowego, SIS 1984/9

Picard M., Besson A., Les assurances terrestres en droit français, t. 1, Le contrat d'assurance, Paris 1982

Piwowar M., O sposobach naprawienia szkody, PiP 2013/4

Pokrzywniak J., Regulacja prawna umowy ubezpieczenia a orzecznictwo $w$ sprawach klauzul abuzywnych [w:] Rynek ubezpieczeniowy - nadregulacja czy niedoregulowanie, red. M. Serwach, Łódź 2014

Popiołek A., Odszkodowanie z VAT czy bez? Ubezpieczyciel kontra UOKiK, „, Gazeta Wyborcza" z 3.02.2012 r., http://next.gazeta.pl/Gospodarka/1,122003,110805 50,Odszkodowanie_z_VAT_czy_bez_Ubezpieczyciel_kontra.html (dostęp: 5.11.2018 r.)

Prawo o kontraktach w ubezpieczeniach, red. Z. Brodecki, Kraków 2003

Principles of European Contract Law (PEICL), red. J. Basedow, J. Birds, M. Clarke, H. Cousy, H. Heiss in cooperation with L.D. Loacker, Munich 2009 
Prolls J., Martin A., Versicherungsvertragsgesetz. Mit Nebengesetzen, Vermittlerrecht und Allgemeinen Versicherungsbedingungen, C.H. Beck 2015

Pyziak-Szafnicka M., Glosa do uchwały SN z 26.04.1995 r., III CZP 29/95, OSP 1996/7-8

Pyziak-Szafnicka M., Wielość dłużników i wierzycieli [w:] System Prawa Prywatnego, red. z. Radwański, t. 5, Prawo zobowiq̨zań - część ogólna, red. E. Łętowska, Warszawa 2006

Pyziak-Szafnicka M., Prawo podmiotowe, SPP 2006/1

Raczyński A., Sytuacja prawna poszkodowanego w ubezpieczeniu odpowiedzialności cywilnej, Warszawa 2010

Raczyński A., Świadczenie ubezpieczyciela w ubezpieczeniu assistance [w:] Kierunki rozwoju ubezpieczeń gospodarczych w Polsce. Wybrane zagadnienia prawne, red. B. Gnela, M. Szaraniec, Warszawa 2013

Radwański Z., Teoria umów, Warszawa 1977

Radwański Z., Zawarcie umowy [w:] System Prawa Prywatnego, red. Z. Radwański, t. 2, Część ogólna. red. Z. Radwański, Warszawa 2002

Radwański Z., Olejniczak A., Zobowiązania - część ogólna, Warszawa 2016

Rajcher W., Społeczno-historyczne typy ubezpieczeń, Warszawa 1951

Rajski J., Odpowiedzialność cywilna przewoźnika lotniczego w prawie międzynarodowym i krajowym, Warszawa 1968

Rajski J., Odpowiedzialność międzynarodowa za szkody wyrządzone przez obiekty kosmiczne, Warszawa 1974

Raynes E.H., Insurance, London-New York 1960

Reps S., Reps J., Ubezpieczenia majątkowe i osobowe, Warszawa 1997

Reps S., Reps J., Ubezpieczenia majątkowe przedsiębiorców, Warszawa 2000

Reps S., Zastosowanie przepisów kodeksu cywilnego w ubezpieczeniach obowiązkowych, PA 2005/4

Robaczyński W., Kilka uwag na temat relacji art. $357^{1}$ k.c. a art. $358^{1}$ \& 3, „Rejent” 1996/11

Rott-Pietrzyk E., Klauzula generalna rozsądku de lege ferenda [w:] Europeizacja prawa prywatnego, t. 2, red. M. Pazdan i in., Warszawa 2008

Rozwadowski Z., Prawo rzymskie, Poznań 1992

Sangowski T., Regres ubezpieczeniowy, Warszawa 1977

Schimikowski P., Versicherungsvertragsrecht, München 2017

Serwach M., Wykładnia postanowień wyłączających lub ograniczających odpowiedzialność zakładu ubezpieczeń w ubezpieczeniach majątkowych [w:] Odpowiedzialność cywilna. Księga pamiątkowa ku czci Profesora Adama Szpunara, red. M. Pyziak-Szafnicka, Kraków 2004

Serwach M., Kowalewski E., Klauzula rebus sic stantibus a podwyższenie sumy gwarancyjnej w ubezpieczeniach odpowiedzialności cywilnej, RU 2006/1 
Serwach M., Ubezpieczenia odpowiedzialności cywilnej w świetle proponowanych zmian przepisów kodeksu cywilnego o umowie ubezpieczenia, PA 2006/2

Serwach M., Klauzula reprezentantów - blaski i cienie art. 827 k.c. sprzed i po nowelizacji, PA 2007/3

Serwach M., Swoboda woli stron umowy ubezpieczenia czy jej ustawowa nadregulacja? [w:] Rynek Ubezpieczeniowy. Nadregulacja czy niedoregulowanie, red. M. Serwach, Łódź 2014

Sieg K., Allgemeines Versicherungsvertragsrecht, Wiesbaden 1994

Singe Montero J., Rangel de Mesquita M.J., Insurance Law in Portugal, Kluwer Law International 2010

Sinkiewicz A., Pojęcie i rodzaje szkody w polskim prawie cywilnym, „Rejent” 1998/2 Sinkiewicz A., Miarkowanie wysokości odszkodowania w prawie cywilnym [w:] Rozprawy cywilistyczne. Ksiega pamiątkowa dedykowana Profesorowi Edwardowi Drozdowi, red. M. Pecyna, J. Pisuliński, M. Podrecka, Warszawa 2013

Skorek B., Odpowiedzialność za szkodę pośrednią wyrządzona wspólnikowi (akcjonariuszowi), PPH 2017/5

Song M., Causation in Insurance Contract Law. Informa Law from Routledge, Oxon, New York 2014

Stelmachowski A., Wstęp do teorii prawa cywilnego, Warszawa 1984

Strugała R., Szkoda czysto majątkowa - analiza prawnoporównawcza i konceptualizacyjna w prawie polskim, KPP 2017/3

Sukiennik P., Ubezpieczeniowy wymiar zasady swobody umów, PA 2000/3

Sukiennik P., Projekt ustawy $z$ dnia... o zmianie ustawy - Kodeks cywilny oraz ustawy o ubezpieczeniach obowiazkowych, Ubezpieczeniowym Funduszu Gwarancyjnym i Polskim Biurze Ubezpieczycieli Komunikacyjnych z komentarzem odzwierciedlajacym dorobek prac Sejmowej podkomisji Nadzwyczajnej do nowelizacji Kodeksu cywilnego [w:] Umowa ubezpieczenia. Dyskusja nad forma prawna i treścia unormowań, red. A. Nowak, D. Fuchs, S. Nowak, Warszawa 2007

Sumien P., Traité théorique et pratique des assurances terrestres et des operations de capitalisation et d'epargne, Paris 1948

Sury P., Świadczenie kulancyjne jako świadczenie należne, RU 2011/2

System Prawa Prywatnego, red. Z. Radwański, t. 8, Prawo zobowiąań - część szczegótowa, red. J. Panowicz-Lipska, Warszawa 2011

Szanciło T., Glosa do uchwaty SN z 17.11.2011 r., III CZP 5/11, OSP 2013/1, poz. 2 Szanciło T., Glosa do uchwaty SN z 12.04.2012 r., III CZP 80/11, M. Prawn. 2013/7 Szczepańska M., Ubezpieczenia na życie. Aspekty prawne, Warszawa 2008 Szczepańska M., Glosa do uchwaty SN z 29.06.2007 r., III CZP 62/07, LEX/el. 2009 Szczepańska M., Ubezpieczenie na życie z ubezpieczeniowym funduszem kapitałowym, Warszawa 2011 
Szczerbowski J., Szkoda czysto majątkowa w kontekście unifikacji prawa prywatnego w Europie, Olsztyn 2013

Szlęzak A., Glosa do wyroku SN z 22.04.2003 r., II CK 144/03, OSP 2004/12, poz. 159

Szmak S., Wybór prawnika w ubezpieczeniu ochrony prawnej - regulacje wybranych państw europejskich oraz orzecznictwo Trybunału Sprawiedliwości UE, PA 2012/2

Szmak S., Ubezpieczenia ochrony prawnej w systemie niemieckim - wybrane problemy, WU 2014/1

Szpunar A., O sposobach naprawienia szkody na mieniu, NP 1971/11

Szpunar A., Odpowiedzialność za szkodę przyszłą, Pal. 1973/2

Szpunar A., Ustalenie odszkodowania w prawie cywilnym, Warszawa 1975

Szpunar A., O solidarności niewłaściwej, RPEiS 1980/4

Szpunar A., Glosa do wyroku SN z 14.07.1981 r., IV CR 222/81, PiP 1983/1

Szpunar A., Restytucja naturalna jako sposób naprawienia szkody, NP 1985/1

Szpunar A., Ustalenie odszkodowania z tytułu obowiązkowego ubezpieczenia komunikacyjnego, KPP 1993/1

Szpunar A., Glosa do uchwały SN z 8.07.1993 r., III CZP 80/93, OSP 1994/3, poz. 50

Szpunar A., Przedawnienie roszczeń ubezpieczeniowych, PA 1994/1

Szpunar A., Roszczenie regresowe zakładu ubezpieczeń [w:] Ubezpieczenia w gospodarce rynkowej, t. 2, red. A. Wąsiewicz, Bydgoszcz 1994

Szpunar A., Glosa do uchwały SN z 6.09.1994 r., III CZP 105/94, PPH 1995/6

Szpunar A., Glosa do uchwały SN z 29.12.1994 r., III CZP 120/94, PiP 1995/7

Szpunar A., Glosa do wyroku SN z 6.12.1995 r., I CRN 224/95, PA 1996/3

Szpunar A., Glosa do uchwały SN z 26.09.1996 r., III CZP 108/96, OSP 1997/7-8

Szpunar A., Waloryzacja świadczeń ubezpieczeniowych [w:] Ubezpieczenia w gospodarce rynkowej, t. 3, red. A. Wąsiewicz, Bydgoszcz 1997

Szpunar A., Odszkodowanie za szkodę majątkowa. Szkoda na mieniu i osobie, Bydgoszcz 1998

Szpunar A., Glosa do uchwały SN z 12.10.2001 r., III CZP 57/01, OSP 2002/5, poz. 61

Szymański Z., O definicji umowy ubezpieczenia, WU 1963/9

Szymański Z., Typowe składniki umowy ubezpieczenia, WU 1965/9

Szymański Z., Prawo ubezpieczeniowe, Łódź 1978

Szyszka P., Analiza stosunku ubezpieczenia z punktu widzenia monistycznej koncepcji przedmiotu prawa, WU 1996/10-11

Szyszka P., Glosa do wyroku Sądu Apelacyjnego w Łodzi z 29.01.1997 r., I ACa 59/96, PS 1998/11-12

Śmieja A., Czyny niedozwolone [w:] System Prawa Prywatnego, red. Z. Radwański, t. 6, Prawo zobowiązań - część ogólna, red. A. Olejniczak, Warszawa 2014

Śmigiel M., Zasada compensatio lucri cum damno a świadczenia z ubezpieczeń gospodarczych, PUG 2001/4 
Tenenbaum M., Zobowiązania naturalne [w:] Odpowiedzialność w prawie cywilnym, red. P. Machnikowski, AUWr 2897, Wrocław 2006

Tracz G., Umowa gwarancji ze szczególnym uwzględnieniem gwarancji bankowej, Kraków 1998

Traité de Droit des Assurances, t. 3, Le Contrat d'Assurance, red. J. Bigot, Paris 2002

Trzaskowski R., Granice swobody kształtowania treści i celu umów obligacyjnych, Kraków 2005

Ubezpieczenia gospodarcze, red. T. Sangowski, Warszawa 2001

Ubezpieczenia komunikacyjne, red. S. Rogowski, Warszawa 2008

Ubezpieczenia majątkowe. Ochrona ubezpieczeniowa mienia społecznego, red. W. Warkałło, Warszawa 1971

Uruszczak W., Umowy w zakresie ubezpieczeń [w:] Prawo gospodarcze i handlowe, t. 5, Prawo umów w obrocie gospodarczym, red. S. Włodyka, Warszawa 2001 Ustawa o dystrybucji ubezpieczeń. Komentarz, red. P. Czublun, Warszawa 2017 Ustawa o działalności ubezpieczeniowej i reasekuracyjnej. Komentarz, red. M. Szczepańska, P. Wajda, Warszawa 2017

Ustawa o prawach konsumenta. Komentarz, red. D. Lubasz, M. Namysłowska, Warszawa 2015

Vassel J., Mierzejewski P., Ubezpieczenie ochrony prawnej w Europie i w Polsce, PA 2005/1

Wałachowska M., Ziemiak M., Odszkodowanie z ubezpieczenia autocasco a VAT, WU 2012/1

Wałachowska M., W sprawie stosowania przepisów kodeksu cywilnego do ubezpieczenia obowiązkowego [w:] System prawny ubezpieczeń obowiązkowych. Przesłanki i kierunki reform, red. E. Kowalewski, W.W. Mogilski, Toruń 2014

Wałachowska M., Ziemiak M., Kompensacja kosztów pomocy prawnej w postępowaniu likwidacyjnym, PiP 2014/1

Wandt M., Versicherungsrecht, München 2016

Warciński M., Miarkowanie odszkodowania (art. 440 k.c.) [w:] Prawo prywatne wobec wyzwań wspótczesności. Księga pamiątkowa dedykowana Profesorowi Leszkowi Ogiegle, red. M. Fras, P. Ślęzak, Warszawa 2017

Warkałło W., Zbieg uprawnień do świadczenia z ubezpieczenia i z tytułu odpowiedzialności za wyrządzenie szkody, RPEiS 1968/3

Warkałło W., Zasada odszkodowania w ubezpieczeniach, SC 1969, t. XIII-XIV

Warkałło W., Ubezpieczenie a odpowiedzialność odszkodowawcza, SC 1970, t. 16

Warkałło W., Odpowiedzialność odszkodowawcza. Funkcje, rodzaje, granice, Warszawa 1972

Warkałło W., Prawo ubezpieczeniowe, Warszawa 1974

Warkałło W., Ubezpieczenie utraconych korzyści, ubezpieczenie w wartości nowej i ubezpieczenie w wartości otaksowanej a zasada odszkodowania, SU 1975, t. 2 
Warkałło W., Ubezpieczenie [w:] System prawa cywilnego, t. 3, cz. 2, Prawo zobowiązań - część szczegółowa, red. S. Grzybowski, Ossolineum 1976

Warkałło W., Marek W., Mogilski W., Prawo ubezpieczeniowe, Warszawa 1983

Wawszczak P., Części zamienne - nowe, ale jakie? - wnioski i uwagi z lektury wystapienia Rzecznika Ubezpieczonych z dnia 8 listopada 2011 r. i postanowienia Sądu Najwyższego z dnia 20 czerwca 2012 r., RU 2013/1

Wąsiewicz A., Ustalenie wysokości szkody i odszkodowania w ubezpieczeniu autocasco, Pal. 1973/12

Wąsiewicz A., Odpowiedzialność odszkodowawcza z tytułu obowiązkowego ubezpieczenia OC i autocasco a ogólne zasady prawa odszkodowawczego [w:] Księga pamiątkowa ofiarowana Profesorowi Alfredowi Ohanowiczowi, red. Z. Radwański, Warszawa-Poznań 1979

Wąsiewicz A., Nowakowski Z.K., Prawo ubezpieczeń gospodarczych, Warszawa 1980

Wąsiewicz A., Uwagi na tle stosowania przepisów o udziale własnym w szkodzie w ustawowym ubezpieczeniu autocasco, Pal. 1985/11

Wąsiewicz A., Przyczynienie się ubezpieczającego do powstania szkody [w:] Ubezpieczenia w gospodarce rynkowej, t. 2, red. A. Wąsiewicz, Bydgoszcz 1994

Wąsiewicz A., Odszkodowanie ubezpieczeniowe, jego ograniczenia i wyłączenia, PA 1996/4

Wąsiewicz A., Ubezpieczenia komunikacyjne, Bydgoszcz 1996

Wąsiewicz A., Umowa ubezpieczenia [w:] Ubezpieczenia w gospodarce rynkowej, t. 3, red. A. Wąsiewicz, Bydgoszcz 1997

Wąsiewicz A., Ubezpieczenia komunikacyjne, oprac. M. Orlicki, M. Wąsiewicz, Bydgoszcz-Poznań 2001

Węgrzynowski Ł., Dopuszczalność sądowej modyfikacji sumy gwarancyjnej w ubezpieczeniu OC na żądanie poszkodowanego, PS 2009/2

Węgrzynowski Ł., Ekwiwalentność świadczeń w umowie wzajemnej, Warszawa 2011

Wiewiórowska-Domagalska A., Glosa do uchwały SN z 17.11.2011 r., III CZP 5/11, EPS 2013/3

Więcko-Tułowiecka M., Ochrona konsumentów w umowach ubezpieczenia, Warszawa 2014

Winiarz J., Obowiązek naprawienia szkody, Warszawa 1970

Wojewoda M., Robaczyński W., O odsetkach po roku obowiązywania nowych rozwiązań, M. Prawn. 2017/1

Wolter A., Ignatowicz J., Stefaniuk K., Prawo cywilne. Zarys części ogólnej, Warszawa 2017

Woronkiewicz J., Granice swobody kształtowania obowiązków prewencyjnych w umowie ubezpieczania w'świetle art. 826 i 827 k.c., PA 2016/1 
Woźnicki A., Przywrócenie pojazdu samochodowego do stanu poprzedniego wświetle przepisów o obowiązkowych ubezpieczeniach komunikacyjnych [w:] Obowiazkowe ubezpieczenia komunikacyjne w PRL. Zagadnienia wybrane, red. A. Wąsiewicz, Poznań 1979

Ziemiak M., Klauzule abuzywne w polskim obrocie ubezpieczeniowym. Ocena mechanizmów ochrony konsumenta w Polsce na tle rozwiązań niemieckich i francuskich, RU 2008/4

Ziemiak M., Klauzule abuzywne w Restatement of European Insurance Contract Law a prawo polskie, RU 2010/2

Ziemiak M., Postanowienia niedozwolone na tle umów ubezpieczenia. Studium cywilnoprawne, Toruń 2017

Zoll F., Zobowiazania w zarysie, Warszawa 1945

Zoll F., Wykonanie i skutki niewykonania zobowiązań przez spetnienie świadczenia [w:] System Prawa Prywatnego, red. Z. Radwański, t. 6, Prawo zobowiąań część ogólna, red. A. Olejniczak, Warszawa 2014

Zweigert K., Kötz H., An Introduction to Comparative Law, Oxford 1998

Żarnowiec Ł., Glosa do wyroku SN z 7.10.2010 r., IV CSK 149/10, WU 2012/4 


\section{SPIS ORZECZEŃ SĄDOWYCH}

Orzeczenie SN z 28.12.1934 r., II C 2032/34, OSNC 1935/6, poz. 252

Wyrok SN z 17.12.1935 r., III K 1681/35, LEX nr 373363

Orzeczenie SN z 24.07.1959 r., IV CR 1027/58, LEX nr 1634349

Uchwała SN (7) z 27.03.1961 r., I CO 27/60, OSNC 1962/2, poz. 40

Wyrok SN z 18.12.1968 r., II CR 409/68, OSNC 1969/11, poz. 207

Wyrok SN z 21.08.1970 r., II CR 355/70, LEX 6788

Wyrok SN z 3.02.1971 r., III CRN 450/70, OSNC 1971/11, poz. 205

Wyrok SN z 10.02.1972 r., II CR 668/71, OSP 1972/10, poz. 182

Wyrok SN z 20.10.1972 r., II CR 425/72, OSNCP 1973/6, poz. 111

Orzeczenie GKA z 5.02.1973 r., BO-13004/72, OSP 1974/2, poz. 39

Wyrok SN z 28.05.1975 r., III CRN 70/75, OSNC 1976/7-8, poz. 164

Uchwała SN z 28.10.1976 r., III CZP 46/76, LEX nr 7865

Wyrok SN z 21.03.1977 r., III CZP 9/77, OSNC 1977/10, poz. 177

Wyrok SN z 20.10.1977 r., IV CR 381/77, OSPiKA 1979/6, poz. 105

Wyrok SN z 4.11.1977 r., II CR 355/77, OSNC 1978/11, poz. 205

Wyrok SN z 19.12.1977 r., II CR 469/77, OSNC 1978/10, poz. 183

Uchwała SN z 6.04.1978 r., III CZP 19/78, OSNC 1978/12, poz. 219

Wyrok SN z 29.05.1979 r., II CR 114/79, OSNCP 1980/1-2, poz. 24

Wyrok SN z 8.10.1980 r., IV CR 382/80, OSNC 1981/5, poz. 83

Wyrok SN z 5.11.1980 r., III CRN 223/80, OSNC 1981/10, poz. 186

Wyrok SN z 20.02.1981 r., I CR 17/81, OSNC 1981/10, poz. 199

Wyrok SN z 14.07.1981 r., IV CR 222/81, OSNC 1982/2-3, poz. 32

Wyrok SN z 17.06.1983 r., I CR 189/83, OSNC 1984/4, poz. 54

Wyrok SN z 17.10.1985 r., I CR 271/85, OSNC 1986/10, poz. 156

Wyrok SN z 18.08.1986 r., II CR 187/86, OSNCP 1987/11, poz. 180

Orzeczenia GKA z 12.11.1987 r., IP-6911/87, OSP 1989/7-12, poz. 159

Wyrok SN z 27.06.1988 r., I CR 151/88, LEX nr 8894

Wyrok SN z 13.12.1988 r., I CR 280/88, LEX nr 78219

Wyrok SN z 20.07.1990 r., I CR 451/90, LEX nr 9034

Uchwała SN z 26.11.1991 r., III CZP 122/91, OSP 1992/7-8, poz. 170 
Uchwała SN z 10.04.1992 r., III CZP 126/91, OSNC 1992/7-8, poz. 121 Uchwała SN z 8.07.1992 r., III CZP 80/92, OSNC 1992/1-2, poz. 14 Uchwała SN z 7.08.1992 r., III CZP 93/92, OSP 1993/9, poz. 180 Wyrok SA w Łodzi z 11.02.1993 r., I ACr 41/93, M. Prawn. 2001/14 Uchwała SN z 18.03.1994 r., III CZP 25/94, OSNC 1994/10, poz. 188 Uchwała SN z 31.03.1993 r., III CZP 1/93, OSNC 1993/10, poz. 170 Wyrok SA w Poznaniu z 21.04.1993 r., I ACr 93/93, LEX nr 9160 Uchwała SN z 30.04.1993 r., III CZP 41/93, OSNC 1993/10, poz. 179 Uchwała SN z 8.07.1993 r., III CZP 80/93, OSP 1994/3, poz. 50 Wyrok SA w Gdańsku z 20.07.1993 r., I ACr 443/93, „Wokanda” 1994/3 Wyrok SA w Gdańsku z 27.07.1993 r., I ACr 487/93, „Wokanda” 1994/8 Uchwała SN z 31.05.1994 r., III CZP 74/94, OSNCP 1994/12, poz. 237 Uchwała SN z 6.09.1994 r., III CZP 105/94, OSNC 1995/2, poz. 26 Wyrok SA w Poznaniu z 17.11.1994 r., I ACr 377/94, „Wokanda” 1995/8 Uchwała SN (7) z 29.12.1994 r., III CZP 120/94, OSNC 1995/4, poz. 55 Uchwała SN z 26.04.1995 r., III CZP 29/95, OSP 1996/7-8 Wyrok SN z 6.12.1995 r., I CRN 224/95, OSNC 1996/4, poz. 60 Wyrok SA w Łodzi z 28.02.1996 r., I ACr 37/96, OSA 1996/9, poz. 43 Uchwała SN z 26.09.1996 r., III CZP 108/96, OSP 1997/7-8, poz. 141 Wyrok SA w Łodzi z 29.01.1997 r., I ACa 59/96, OSA 1997/6, poz. 37 Uchwała SN z 22.04.1997 r., III CZP 14/97, OSNC 1997/8, poz. 103 Wyrok SN z 27.11.1997 r., III CKN 239/97, OSNC 1998/5, poz. 98 Uchwała SN z 12.12.1997 r., III CZP 65/97, OSNC 1998/4, poz. 55 Uchwała SN z 19.03.1998 r., III CZP 72/97, OSNC 1998/9, poz. 133 Wyrok SN z 6.05.1998 r., II CKN 731/97, LEX nr 50738 Uchwała z 16.10.1998 r., III CZP 42/98, OSNC 1999/4, poz. 69 Wyrok SN z 2.12.1998 r., I CKN 278/98, LEX nr 50692 Wyrok SN z 23.06.1999 r., I CKN 57/98, OSNC 2000/1, poz. 13 Wyrok SN z 6.07.1999 r., III CKN 315/98, OSNC 2000/2, poz. 31 Wyrok SN z 27.07.1999 r., I CKN 496/99, OSNC 2000/2, poz. 39 Wyrok SN z 29.11.1999 r., III CKN 475/98, OSNC 2000/5, poz. 103 Wyrok SN z 10.01.2000 r., III CKN 1105/98, OSNC 2000/7-8, poz. 134 Wyrok SN z 13.01.2000 r., II CKN 644/98, LEX nr 51053 Wyrok SN z 15.06.2000 r., II CKN 284/00, LEX nr 52568 Wyrok SN z 19.07.2000 r., II CKN 1068/98, LEX nr 50887 Wyrok SN z 20.07.2000 r., V CKN 88/00, LEX 52586 Wyrok SN z 10.10.2000 r., V CKN 97/00, OSNC 2001/3, poz. 46 Wyrok SN z 30.11.2000 r., I CKN 970/98, OSNC 2001/6, poz. 93 Wyrok SN z 5.12.2000 r., IV CKN 185/00, LEX nr 162229 Wyrok SN z 18.01.2001 r., V CKN 193/00, LEX nr 53113 
Wyrok SN z 11.06.2001 r., V CKN 266/00, OSP 2002/3, poz. 40 Wyrok SN z 22.08.2001 r., V CKN 415/00, LEX nr 602738 Uchwała SN z 12.10.2001 r., III CZP 57/01, OSNC 2002/5, poz. 57 Uchwała SN z 15.11.2001 r., III CZP 68/01, OSNC 2002/6, poz. 74 Wyrok SN z 16.01.2002 r., IV CKN 635/00, LEX nr 78370 Wyrok SN z 29.01.2002 r., V CKN 682/00, LEX nr 54343 Wyrok SN z 20.02.2002 r., V CKN 903/00, OSNC 2003/1, poz. 15 Wyrok SN z 20.02.2002 r., V CKN 908/00, LEX nr 54365 Wyrok SN z 25.04.2002 r., I CKN 1466/99, OSNC 2003/5, poz. 64 Wyrok SN z 16.05.2002 r., V CKN 1273/00, LEX nr 55515 Wyrok SN z 4.07.2002 r., I CKN 837/00, LEX nr 5689 Wyrok SN z 22.04.2003 r., II CK 144/03, LEX nr 103201 Wyrok SN z 11.06.2003 r., V CKN 308/01, LEX nr 157324 Uchwała SN z 13.06.2003 r., III CZP 32/03, OSNC 2004/4, poz. 51 Wyrok SN z 17.07.2003 r., III CKN 17/01, LEX nr 1130166 Wyrok SN z 7.08.2003 r., IV CKN 387/01, LEX nr 141410 Wyrok SN z 8.08.2003 r., V CK 169/02, OSP 2004/10, poz. 121 Wyrok SN z 18.12.2003 r., I CK 365/02, LEX nr 599511 Wyrok SN z 20.01.2004 r., II CK 369/02, LEX nr 1129088 Wyrok SN z 12.02.2004 r., V CK 187/03, „Wokanda” 2004/7-8 Wyrok SN z 22.04.2004 r., II CK 142/03, LEX nr 484721 Wyrok SN z 7.05.2004 r., III CK 327/02, LEX nr 1125277 Wyrok SN z 13.05.2004 r., V CK 481/03, LEX nr 183801 Wyrok SN z 13.05.2004 r., V CK 489/03, LEX nr 188492 Wyrok SN z 20.05.2004 r., II CK 341/03, LEX nr 174171 Wyrok SN z 2.07.2004 r., II CK 412/03, LEX nr 121694 Wyrok SN z 15.07.2004 r., V CK 640/03, LEX nr 194105 Wyrok SN z 16.07.2004 r., I CK 11/04, OSP 2005/6, poz. 78 Wyrok SN z 8.10.2004 r., V CK 70/04, LEX nr 146334 Postanowienie SN z 6.01.2005 r., III CZP 76/04, Prok. i Pr.-wkł. 2005/11 Wyrok SN z 11.05.2005 r., III CK 522/04, LEX nr 151664 Wyrok SA w Poznaniu z 28.06.2005 r., I ACa 1938/04, LEX nr 175162 Wyrok SA w Poznaniu z 6.07.2005 r., I ACa 18/05, LEX nr 175174 Wyrok SN z 7.07.2005 r., V CK 870/04, LEX nr 152461 Wyrok SN z 11.10.2005 r., V CK 244/05, LEX nr 398447 Wyrok SN z 13.10.2005 r., I CK 185/05, OSNC 2006/7-8, poz. 133 Wyrok SN z 13.10.2005 r., IV CK 181/05, LEX nr 186907 Uchwała SN z 30.11.2005 r., III CZP 96/05, OSNCP 2006/10, poz. 164 Wyrok SN z 12.01.2006 r., II CK 327/05, LEX nr 164791 Postanowienie SN z 12.01.2006 r., III CZP 76/05, LEX nr 175463 
Wyrok SN z 26.01.2006 r., V CSK 90/05, LEX nr 195430

Wyrok SN z 2.03.2006 r., I CSK 7/05, LEX nr 179967

Wyrok SN z 26.05.2006 r., V CSK 109/06, LEX nr 200945

Wyrok SN z 14.07.2006 r., II CSK 60/06, LEX nr 450174

Wyrok SN z 20.10.2006 r., IV CSK 125/06, OSNC-ZD 2008/1, poz. 7

Wyrok SOKiK z 21.12.2006 r., XVII AmC 103/05, MSiG 2007/213, poz. 13699

Wyrok SN z 4.01.2007 r., V CSK 400/06, LEX nr 277309

Wyrok SN z 12.01.2007 r., IV CSK 307/06, LEX nr 238967

Wyrok SOKiK z 30.01.2007 r., XVII AmC 30/06, LEX nr 1724302

Uchwała SN (7) z 17.05.2007 r., III CZP 150/06, OSNC 2007/10, poz. 144

Wyrok SA w Warszawie z 23.05.2007 r., VI ACa 110/07, LEX nr 1643035

Uchwała SN z 29.06.2007 r., III CZP 62/07, OSNC 2008/7-8, poz. 87

Wyrok SOKiK z 11.10.2007 r., XVII AmC 68/06, MSiG 2008/43, poz. 2772

Wyrok SOKiK z 30.10.2007 r., XVII AmC 86/06, MSiG 2008/117, poz. 8166

Wyrok SN z 11.12.2007 r., II CSK 375/07, LEX nr 492168

Postanowienie SN z 30.01.2008 r., III CZP 140/07, LEX nr 359439

Wyrok SOKiK z 6.03.2008 r., XVII AmC 123/07, MSiG 2008/47, poz. 2969

Wyrok SN z 7.03.2008 r., III CSK 270/07, LEX nr 487542

Wyrok SN z 8.08.2008 r., V CSK 87/08, OSNC-ZD 2009/2, poz. 57

Wyrok SN z 13.08.2008 r., I CSK 114/07, LEX nr 487518

Wyrok SN z 4.12.2008 r., I CNP 72/08, LEX nr 484692

Wyrok SN z 29.01.2009 r., V CSK 291/08, LEX nr 484739

Wyrok SOKiK z 25.02.2009 r., XVII AmC 252/08, MSiG 2009/201, poz. 12815

Wyrok SOKiK z 4.05.2009 r., XVII AmC 48/08, LEX nr 519311

Wyrok SN z 7.05.2009 r., IV CSK 16/09, LEX nr 515706

Wyrok SA w Warszawie z 27.05.2009 r., VI ACa 1473/08, LEX nr 785833, Klauzule

abuzywne w działalności ubezpieczeniowej. Raport Rzecznika Ubezpieczonych, Warszawa 2012

Wyrok SOKiK z 3.08.2009 r., XVII AmC 249/08, Klauzule abuzywne w działalności ubezpieczeniowej. Raport Rzecznika Ubezpieczonych, Warszawa 2012

Wyrok SA w Warszawie z 9.02.2010 r., VI ACa 782/09, LEX nr 844686, Klauzule abuzywne w działalności ubezpieczeniowej. Raport Rzecznika Ubezpieczonych, Warszawa 2012

Wyrok SN z 18.02.2010 r., II CSK 434/2009, LEX nr 602683

Wyrok SN z 7.10.2010 r., IV CSK 149/10, LEX nr 677774

Wyrok SN z 4.11.2010 r., IV CSK 153/10, LEX nr 1232801

Wyrok SOKiK z 18.01.2011 r., XVII AmC 37/10, MSiG 2012/144, poz. 10156

Wyrok SOKiK z 7.04.2011 r., XVII AmC 1509/10, MSiG 2012/64, poz. 4267

Wyrok SOKiK z 20.05.2011 r., XVII AmC 1153/09, MSiG 2012/42, poz. 2754

Uchwała SN z 13.07.2011 r., III CZP 31/11, OSNC 2003/12, poz. 29 
Wyrok SOKiK z 19.09.2011 r., XVII AmC 145/10, MSiG 2012/167, poz. 11544 Wyrok SN z 21.09.2011 r., I CSK 727/10, LEX nr 1043967

Uchwała SN (7) z 17.11.2011 r., III CZP 5/11, OSNC 2012/3, poz. 28 Uchwała SN (7) z 13.03.2012 r., III CZP 75/11, OSNC 2012/7-8, poz. 81 Uchwała SN z 12.04.2012 r., III CZP 80/11, OSNC 2012/10, poz. 112 Postanowienie SN (7) z 20.06.2012 r., III CZP 85/11, OSNC 2013/3, poz. 37 Wyrok SN z 22.06.2012 r., V CSK 338/11, LEX nr 1228613 Wyrok SN z 17.10.2012 r., II CSK 646/11, LEX nr 1243010 Wyrok SN z 16.01.2013 r., II CSK 202/12, LEX nr 1303227 Wyrok SN z 30.01.2013 r., V CSK 75/12, LEX nr 1311857 Wyrok SA w Warszawie z 6.03.2013 r., VI ACa 1241/12, LEX nr 1322083 Wyrok SA w Warszawie z 18.09.2013 r., VI ACa 201/13, LEX nr 1392122 Wyrok SA w Łodzi z 22.12.2013 r., I ACa 494/13, LEX nr 1433807 Wyrok SN z 10.01.2014 r., I CSK 155/13, LEX nr 1523347 Wyrok SA w Łodzi z 30.04.2014 r., I ACa 1209/13, LEX nr 1496006 Wyrok SA w Krakowie z 13.05.2014 r., I ACa 319/14, LEX nr 1602917 Wyrok SN z 16.10.2014 r., III CSK 302/13, OSNC 2015/10, poz. 121 Wyrok z 23.01.2015 r., V CSK 217/14, LEX nr 1650306 Wyrok SN z 2.04.2015 r., I CSK 257/14, LEX nr 1710338 Wyrok SN z 15.05.2015 r., V CSK 470/14, OSNC 2016/4, poz. 48 Wyrok SN z 20.05.2015 r., I CSK 479/14, LEX nr 1747345 Wyrok SA w Gdańsku z 6.08.2015 r., V ACa 936/14, LEX nr 1842253 Wyrok SN z 30.09.2015 r., I CSK 800/14, OSNC 2016/9, poz. 105 Wyrok SN z 6.11.2015 r., II CSK 58/15, LEX nr 1929079 Wyrok SN z 19.11.2015 r., IV CSK 764/14, LEX nr 1962543 Wyrok SN z 27.11.2015 r., I CSK 28/15, LEX nr 1976873 Wyrok SN z 13.01.2016 r., II CSK 37/15, LEX nr 1974074 Wyrok SN z 13.05.2016 r., III CZP 16/16, OSNC 2017/3, poz. 32 Wyrok SN z 10.06.2016 r., IV CSK 624/15, LEX nr 2067079 Wyrok SN z 9.08.2016 r., II CSK 743/15, LEX nr 2095937 Wyrok SO w Łodzi z 25.08.2016 r., X GC 571/16, LEX nr 2147565 Uchwała SN z 30.11.2016 r., III CZP 74/16, OSNC 2017/7-8, poz. 82 Wyrok SOKiK z 23.01.2017 r., XVII AmC 109/15, LEX nr 2246437 Wyrok SOKiK z 4.04.2017 r., XVII AmA 107/14, LEX nr 2282539 Wyrok SN z 24.11.2017 r., I CSK 77/17, LEX nr 2473797 Wyrok SN z 14.03.2018 r., II CSK 445/17, LEX nr 2486131 



Bartosz Kucharski - adiunkt w Katedrze Prawa Gospodarczego i Handlowego Uniwersytetu Łódzkiego; adwokat specjalizujący się w prawie cywilnym i handlowym, w szczególności w prawie ubezpieczeń gospodarczych; zwycięzca konkursu „Temida” na najlepsze prace doktorskie z dziedziny prawa organizowanego przez Wolters Kluwer Polska; wykładowca na szkoleniach dla aplikantów adwokackich, adwokatów, sędziów, pracowników zakładów ubezpieczeń i pośredników ubezpieczeniowych; autor wielu publikacji i ekspertyz z dziedziny prawa ubezpieczeń gospodarczych i pośrednictwa ubezpieczeniowego.

W książce przedstawiono najbardziej kontrowersyjne oraz stanowiące przedmiot licznych sporów sądowych zagadnienia prawa ubezpieczeniowego. Wykorzystano literaturę polską i obcojęzyczną oraz omówiono dorobek polskiego orzecznictwa, co sprawia, że powinna zainteresować praktyków.

Autor udziela odpowiedzi m.in. na pytania:

- Na czym polega odpowiedzialność ubezpieczeniowa?

- Jakich świadczeń można domagać się od ubezpieczyciela?

- Jakie są przesłanki, zakres i terminy spełnienia tych świadczeń?

- W jaki sposób zakłady ubezpieczeń wyłączają i ograniczają swoją odpowiedzialność?

Książka jest przeznaczona dla adwokatów, radców prawnych, sędziów, zakładów ubezpieczeń i reasekuracji, pośredników ubezpieczeniowych oraz pracowników administracji rządowej i samorządowej, a także przedstawicieli nauki. Będzie cennym źródłem wiedzy dla studentów prawa, a także aplikantów sądowych, adwokackich i radcowskich. Może zainteresować ekonomistów, księgowych i menedżerów podejmujących decyzje dotyczące zawarcia lub wykonania umów ubezpieczenia.

„Praca stoi na bardzo wysokim poziomie naukowym. Prowadzony przez Autora wywód opiera się na doskonałej znajomości i dogłębnym zrozumieniu prezentowanych przez doktrynę i orzecznictwo poglądów naukowych dotyczących kluczowych zagadnień prawa ubezpieczeniowego. Szczególną wartością pracy jest szerokość ujęcia analizowanego zagadnienia. Krytyczna analiza dorobku prawa ubezpieczeniowego skłoniła Autora do sformułowania własnych oryginalnych wniosków i tez. Bez wątpienia są one wewnętrznie spójne, właściwie uzasadnione, dobrze osadzone w polskiej i europejskiej tradycji prawnej dotyczącej cywilistyki i ubezpieczeń. Formułowane poglądy i tezy są przy tym rozważne i ostrożne, co pozwala na stosowanie ich w praktyce sądowej i ubezpieczeniowej”.

Dr hab. Marcin Orlicki, prof. UAM

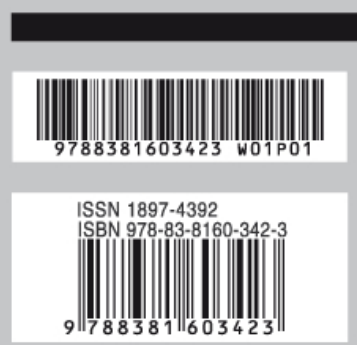

\section{ZAMÓWIENIA:}

INFOLINIA 8010445 45, FAX 225358001

ZAMOWIENIA@WOLTERSKLUWER.PL

WWW.PROFINFO.PL

ISBN WU 